\title{
ARQUITETURA RESIDENCIAL PAULISTANA DOS ANOS 1920: RESSONÂNCIAS DO ARTS AND CRAFTS?
}

\section{MARISTELA DA SILVA JANJULIO}

Dissertação apresentada à Escola de Engenharia de São Carlos da Universidade de São Paulo como parte dos requisitos para obtenção do título de Mestre em Arquitetura e Urbanismo - Área: Teoria e História da Arquitetura e do Urbanismo

Orientador: Prof. Dr. Carlos Roberto Monteiro de Andrade

São Carlos, 2009

Apoio: CNPq - Conselho Nacional de Desenvolvimento Científico e Tecnológico 
AUTORIZO A REPRODUÇÃO E DIVULGAÇ̃̃O TOTAL OU PARCIAL DESTE TRABALHO, POR QUALQUER MEIO CONVENCIONAL OU ELETRÔNICO, PARA FINS DE ESTUDO E PESQUISA. DESDE QUE CITADA A FONTE.

Ficha catalográfica preparada pela Seçāo de Tratamento da Informação do Serviço de Biblioteca - EESC/USP

Janjulio, Maristela da Silva

Arquitetura residencial paulistana dos anos 1920 : ressonäncias do Arts and Cratts? / Maristela da Silva Janjuilo $;$ orientador Carios koberto ivonteiro de Andiade. Sü Cüzồ, 2009.

Dissertação (Mestrado-Programa 'de Pós-Graduação em Arquitetura e Urbanismo e Área de Concentração em Teoria e Historia da Arquitetura e do Urbanismo .... Escola de

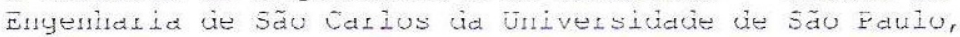
2กิ?

1. Arquitetura residencial paulistana. 2. Arts and Crafts. 3. Arquitetura anos 1920. 4. Bangalô. 5. Casa burguesa. I. Titulo. 


\section{FOLHA DE JULGAMENTO}

Candidata: Arquiteta MARISTELA DA SILVA JANJULIO

Dissertação defendida e julgada em 31/03/2009 perante a Comissão Julgadora:

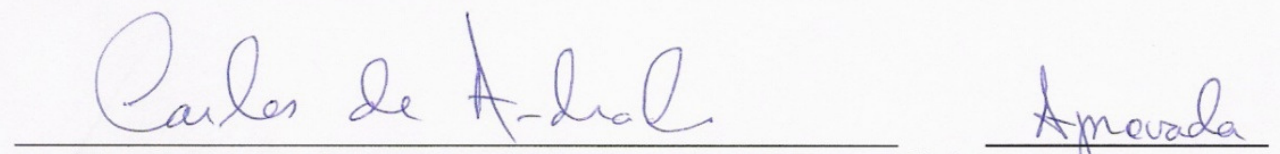

Prof. Dr. CARLOS ROBERTO MONTEIRO DE ANDRADE (Orientador)

(Escola de Engenharia de São Carlos/USP)

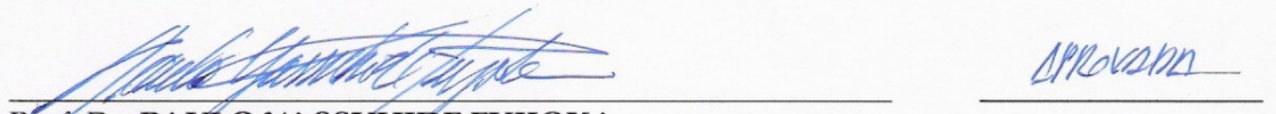

Prof. Dr. PAULO YASSUHWE FUJIOKA

(Escola de Engenharia de São Carlos/USP)

Prof ${ }^{\mathrm{a}}$. Dr ${ }^{\mathrm{a}}$. CRISTINA MENEGUELLO

APROUADA

(Universidade Estadual de Campinas/UNICAMP)

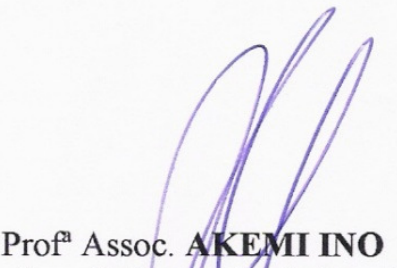

Vice-Coordenadora do Prograna de Pós-Graduação em

Arquitetura e Urbanismo

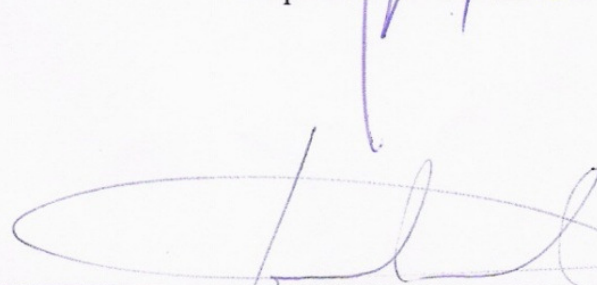

Prof. Associado GERALDO ROBERTO MARTINS DA COSTA

Presidente da Comissão da Pós-Graduação da EESC 
§XXV (...) a imperfeição é de certo modo essencial a tudo o que sabemos da vida. É o sinal de vida em um corpo mortal, isto é, de um estado de progresso e mudança. (...) Então aceite, como uma lei universal, que nem a arquitetura nem qualquer outro nobre trabalho humano possam ser bons a não ser que sejam imperfeitos. (RUSKIN, 1853).

Porque não fomos enviados para este mundo para fazer qualquer coisa onde não coloquemos nossos corações. Temos certo trabalho a fazer para conseguir nosso pão, e que deve ser feito de forma corajosa, outro trabalho a fazer para nosso deleite, e que deve ser feito com amor. (RUSKIN, 1907, p.179). 


\section{Agradecimentos}

A meu orientador, Carlos Roberto Monteiro de Andrade, meu agradecimento sincero pela amizade, pela orientação e por incentivar a procura, sempre, de novos caminhos na pesquisa. Obrigada pelo desprendimento em relação aos livros queridos.

Amigos, Fabíola Cordovil, Lucas Cestaro, Thaís Cruz, Francisco Sales Trajano, George Dantas, Luisa Videsot e Valéria Garcia, obrigada pelo apoio, amizade, contribuições. Foram muitas alegrias, preocupações, conhecimento compartilhados. Estes anos passaram muito rápido, graças a vocês

Laura, Débora e Armando, obrigada por compreenderem as ausências e impossibilidades e se alegrarem com as conquistas. Com vocês, a vida se completa.

Ruty e Antônio, queridos pais, nunca poderia agradecer o bastante por todo o apoio. .

Walquíria, Paulo, Paulinho, André, Nara, muito obrigada por sempre fazerem sentir-me em casa em São Carlos.

Aos professores Cristina Meneguello e Paulo Fujioka, obrigada pela atenção e pelas contribuições na banca de qualificação.

Aos funcionários do Departamento de Arquitetura e Urbanismo da EESC-USP, obrigada pelas gentilezas todas.

Agradeço a todas as bibliotecárias e funcionários das bibliotecas e arquivos que visitei, principalmente da Biblioteca Central da EESC-USP, da Biblioteca Central da Escola Politécnica, da Biblioteca da Câmara Municipal de São Paulo e da Biblioteca da FAUUSP. Nos solitários momentos de pesquisa, a ajuda adquire outra dimensão.

Obrigada a Vera da Cunha Pasqualin e aos funcionários que me abriram o arquivo da Companhia City e me deram seu tempo e sua atenção.

Agradeço ainda ao CNPQ - Conselho Nacional de Desenvolvimento Científico e Tecnológico, pela concessão de uma bolsa. 


\section{Arquitetura Residencial Paulistana dos anos 1920: Ressonâncias do Arts and Crafts?}

\section{Resumo}

O objetivo desta pesquisa é o estudo da arquitetura residencial que se desenvolveu na cidade de São Paulo nos anos 1920, e das influências que ajudaram a moldá-la. Entre estas, a do movimento Arts and Crafts, que revolucionou a arquitetura doméstica britânica no final do século XIX e teve repercussão internacional. Tais ressonâncias ocorreram de forma direta e também através de uma triangulação com os Estados Unidos. Ali, haverá certa popularização do movimento inglês na figura do bangalô, juntamente com o aprimoramento da cultura burguesa da habitação do Arts and Crafts. Esta nova cultura da habitação chegará ao Brasil principalmente através das revistas de decoração, trazendo uma nova maneira de morar para a classe média, que se estabelecerá principalmente nos novos subúrbios que se constituem em São Paulo nas primeiras décadas do século XX, particularmente o Jardim América, executado pela Companhia City.

Palavras-chave: arquitetura residencial paulistana, Arts and Crafts, arquitetura anos 1920, bangalô, casa burguesa.

\section{0's House Architecture of São Paulo: Resonances from Arts and Crafts?}

\section{Abstract}

The subject of this work is the domestic architecture that arises in the city of São Paulo, Brazil, in the 1920's decade and the influences it has suffered. Among them, there is the resonance from the Arts and Crafts Movement, which changed the course of the British domestic architecture in the 1890's and acquired international reputation. The influences on Brazilian architecture probably came by two ways; straight from Britain and also through the United States. In this country, there will be a mass production of a new kind of dwelling, the bungalow, which embodies the spirit of the British movement, in a more democratic way. This bourgeois housing culture, inherited from England, will arrive in Brazil mainly through domestic interior magazines. These domestic life-styles will settle in the suburbs that arise in São Paulo in the first decades of twentieth century, mainly in Jardim America from the Companhia City.

Key words: house architecture of São Paulo, Arts and Crafts, 1920's architecture, bungalow, bourgeois house. 


\section{SUMÁRIO}

INTRODUÇÃO, 1

CAPÍTULO 1 - O MOVIMENTO ARTS AND CRAFTS NA INGLATERRA

1.1 A era vitoriana, 9

1.2 A Casa Burguesa, 10

1.3 O Pinturesco, 12

$1.4 \mathrm{O}$ movimento Arts and Crafts

1.4.1 Caracterização do Movimento, 16

1.4.2 Origens: Pugin, Ruskin e Morris, 18

1.4.3 A Arquitetura Vernácula e a Revolução na Arquitetura Doméstica Inglesa, 24

1.4.4 A Revolução Industrial, as guildas e a máquina, 30

1.4.5 Revivendo e ensinando o artesanato, 33

1.4.6 Arquitetos, 35

1.4.6.1 Philip Webb, 36

1.4.6.2 William Richard Lethaby, 39

1.4.6.3 Edward Schroder Prior, 45

1.4.6.4 Charles Francis Annesley Voysey, 47

1.4.6.5 Charles Rennie Mackintosh, 63

1.4.6.6 Mackay Hugh Baillie Scott, 65

1.4.6.7 Richard Barry Parker e Raymond Unwin, 70

1.4.7 A arquitetura da cidade-jardim de Letchworh, 89

1.4.8 Momentos Finais?, 91

\section{CAPÍTULO 2 - O ARTS AND CRAFTS NOS ESTADOS UNIDOS}

2.1 Origens do movimento na América, 97

2.2 A arquitetura, 102

2.3 Gustav Stickley, 104

2.4 As novas revistas, 119

2.5 O Mission Style,121

2.6 O bangalô, 122

2.7 Uma nova forma de vida, 139 


\section{CAPÍTULO 3 - A MODERNIZAÇÃO DE SÃO PAULO NO INÍCIO DO SÉCULO XX E A PROFISSIONALIZAÇÃO DOS ARQUITETOS.}

3.1 A Modernização na América Latina, 141

3.2 A Modernização de São Paulo, 143

3.3 A cidade moderna, 146

3.4 A aceleração da vida na cidade moderna, 152

3.5 Industrialização e mudanças na estrutura social, 155

3.6 Onsino da arquitetura em São Paulo nas primeiras décadas do século XX.

3.6.1 O Liceu de Artes e Ofícios, 158

3.6.2 A Escola Politécnica

3.6.2.1 O ensino, 160

3.6.2.2 O ambiente na Escola Politécnica, 163

3.6.3 O Curso do Mackenzie, 164

3.7 Mudanças na profissão - as organizações profissionais, 167

3.8 Alguns arquitetos do início do século

3.8.1 Um professor da Politécnica: Victor Dubugras, 171

3.8.2 George Henry Krug, 183

3.8.3 Engenheiros-arquitetos da Politécnica

3.8.3.1 Augusto de Toledo, 185

3.8.3.2 Alexandre Albuquerque, 187

3.8.3.3 Hippolyto Gustavo Pujol Junior, 189

3.8.3.4 Guilherme Ernesto Winter, 190

CAPÍTULO 4 - UMA REVISTA PARA A CLASSE MÉDIA: A CASA, 191

4.1 O público alvo, 192

4.2 A família e o lar, 193

4.3 O compromisso feminino, 199

4.4 Modernização, 203

4.5 Projetos, 211

4.6 Os Bungalows, 237

4.7 O interior doméstico, 245 


\section{CAPÍTULO 5 - A ARQUITETURA EM SÃO PAULO NO PERÍODO}

5.1 A Companhia City e o Jardim América, 257

5.2 Barry Parker: as casas paulistanas, 268

5.3 O Neocolonial, 284

5.4 Além de Barry Parker, as "outras arquiteturas do Jardim América", 287.

5.5 Os arquitetos do Jardim América, 289

5.5.1 Adhemar Queiroz de Moraes, 291

5.5.2 Renato Ribeiro de Aguiar, 306

5.5.3 Olavo Soares Caiuby, 313

5.5.4 Álvaro Carlos de Arruda Botelho, 328

5.5.5 Dácio Aguiar de Moraes, 337

5.5.6 Alfredo Ernesto Becker, 345

\section{CONSIDERAÇÕES FINAIS, 350}

ANEXO 1,

Outros periódicos da época

A Revista Politécnica, 358

A Revista de Engenharia do Mackenzie, 359

A Revista Architectura e Construcções, 365

\section{ANEXO 2}

Sociedade Construtora e de Imóveis: uma importante construtora, 368

\section{ANEXO 3}

Mapa do Jardim América - casas fotografadas para o álbum Jardim América, 374.

\section{ANEXO 4}

Mapa do Jardim América com os jardins internos já loteados, 375. 
XIV 


\section{Introdução}

O estudo da arquitetura residencial paulistana dos anos 1920 e as possíveis ressonâncias provenientes da arquitetura Arts and Crafts, o tema de nossa pesquisa, exigiu, em um primeiro momento, que se analisasse o movimento inglês em seu contexto histórico, o século XIX. Assim, um recuo no tempo se fez necessário.

Ainda no Setecentos, desenvolveu-se a idéia de progresso como uma filosofia de vida: a conquista da racionalidade. Porém, tendências anti-iluministas no pensamento da época fizeram nascer a idéia de que a cultura é particular e hereditária, e não universal e racional. A história decairia, a partir de uma idade de ouro, e esta idealização do passado seria compartilhada por vários movimentos regionalistas dos séculos XIX e XX. (COLQUHOUN, 2007, p. 141)

No século XIX, com a industrialização, o progresso envolve a progressiva conquista da natureza para colocá-la a serviço do homem e da produção de riquezas. Tal conquista se daria através das ciências e da técnica, aplicadas à indústria.

A visão de mundo newtoniana e cartesiana tinha, através da industrialização, já afetado de tal maneira o mundo material que o Romantismo, a primeira interrupção nesta posição, configurou-se como uma reação apenas à medida que o século XIX avançava. (BURMAN, 1998, p.6)

"A idéia romântica do Volk e o ideal positivista do progresso material (e seu corolário, a política liberal) combateram-se por todo o século XIX. Na década de 1890, houve um renovado interesse na cultura popular, que encontrou expressão nos movimentos de reforma do crafts e no Art Nouveau. Estas tendências eram simultaneamente progressivas e regressivas. O entusiasmo pela arte primitiva, simples e popular induziu à rejeição ao classicismo e a procura por novas formas. Mas, também encorajou um retorno à tradição e à crítica da industrialização". (COLQUHOUN, 2007, p. 142)

Assim, no Novecentos, o Romantismo liderou o ataque aos princípios clássicos nas artes, que dominaram a Europa desde o Renascimento. A teoria romântica procura uma estrutura interna, orgânica e não a cópia de formas externas. A questão de como se retomar os valores eternos da arquitetura, sem a imitação de suas formas antigas foi algo com que se debateu o Romantismo e, inserido nesta tradição, também o movimento Arts and Crafts, ao tentar reviver o espírito gótico. 
Nesta dissertação, o movimento Arts and Crafts é descrito no capítulo 1, sua procura em reviver a essência do Gótico e uma tentativa de retorno à natureza, adequando o edifício ao seu entorno, usando materiais locais e naturais e técnicas construtivas tradicionais e da região. O conceito da unidade de desenho surge desta forma, a casa partindo do interior, do menor detalhe, ao exterior, ao entorno imediato e à natureza. Os limites entre as várias escalas são suavizados, não se vêem as "fronteiras". Pretende-se que o edifício confunda-se com a natureza, em uma espécie de mimetismo, uma concepção pinturesca. Compreensão do ambiente e da paisagem, em uma forma de projetar sofisticada, cheias de sutilezas, onde é respeitada a individualidade do morador, suas necessidades e desejos. Certas qualidades que hoje se buscam na arquitetura já se apresentavam no movimento inglês. A integração com a natureza e a sua preservação. Sem tabula rasa: o projeto deve se adequar a condições existentes, como a vegetação, a topografia e o clima. A preservação das tradições culturais é outro aspecto do Arts and Crafts

Ao final do século XIX, o processo de industrialização se expande de tal forma que leva a profundas alterações na conjuntura econômica internacional. A partir de 1880, acontece uma progressiva especialização na economia dos vários países, alguns se tornando fornecedores de produtos agrícolas e matérias primas, permanecendo predominantemente rurais, enquanto outros se tornaram industriais e urbanos.

Isto implicou em drásticos efeitos também na agricultura da Inglaterra. Ali, já em 1851, somente $21,7 \%$ da população ocupada trabalhavam na agricultura, silvicultura e pesca, enquanto $42,9 \%$ trabalhavam em fábricas, na mineração e em outras indústrias. ${ }^{1}$

Com o incremento dos negócios no mercado internacional, novos sistemas de produção e infra-estrutura tornaram-se necessários nas regiões fornecedoras de matérias primas, que se configuravam como novos mercados para os produtos das indústrias dos países desenvolvidos, indústrias que se especializavam a partir da década de 1880.

Não se tratavam apenas de modificações em termos econômicos, mas também culturais, sociais, políticos e espaciais, deixando sua marca nas cidades e na maneira de viver de seus habitantes. Esta economia e cultura globalizadas levam ao "trânsito" de novas idéias, por todo o mundo. Idéias no campo da arquitetura e do urbanismo inclusive o sanitarismo -; novas tecnologias sendo introduzidas, principalmente nos

\footnotetext{
${ }^{1}$ Sobre modificações na estrutura social na Inglaterra desta época, ver GRAHAM, 1973, p.16
} 
meios de transporte, e as cidades tornando-se muito semelhantes, inclusive na sua estrutura urbana. As elites locais concentram-se em áreas residenciais afastadas e reproduzem nos países em desenvolvimento o estilo de morar dos países desenvolvidos. Novos estilos de vida marcados pela domesticidade

O movimento Arts and Crafts inglês também ultrapassará os limites da Inglaterra e passará à Europa continental e aos Estados Unidos. Não se deve esquecer que a influência entre as arquiteturas inglesa e americana foi mútua, ao menos desde os 1870's.

O movimento nos Estados Unidos é o tema do capítulo 2. Ali, sofrerá transformações inevitáveis que sofrerá no novo ambiente, levando a uma ênfase na cultura material, nos objetos produzidos. Transformações em direção a uma arquitetura de classe média, onde haverá certa democratização do movimento, personificada em um novo tipo de habitação: o bangalô. Originário da Índia, na Inglaterra ele se estabelece como a segunda casa, no campo. E nos EUA, se instalará definitivamente nos subúrbios americanos, existentes desde o final do XIX e um fenômeno em expansão no início do século XX.

A influência do Arts and Crafts poderia assim ter acontecido por transferência direta da Inglaterra, ou através de uma triangulação com os EUA, devido também ao declínio da hegemonia européia, que já se anunciava e que foi precipitada pela Primeira Guerra Mundial. Simultaneamente, acontece a ascensão dos Estados Unidos como potência mundial. Sua influência sobre a América Latina, que passa a ser preponderante, foi outro fator que pesou na decisão de se estudar o Arts and Crafts americano. Tal decisão também se apoiou na observação da revista $A$ Casa - uma revista brasileira, editada no Rio de Janeiro a partir dos anos 1920 e voltada também para o público leigo - onde esta tipologia de habitação aparece repetidamente, e também devido às constantes referências ao bangalô no Brasil, particularmente em São Paulo, inclusive nas crônicas que se referem à cidade, como as de Oscar Americano.

No capítulo 3, descreve-se justamente a São Paulo moderna. Por que São Paulo? Inicialmente, pensou-se em incluir o Rio de Janeiro na delimitação geográfica, as duas maiores cidades brasileiras, onde a nova forma de vida burguesa que "transitava" pelos diversos continentes se instalaria, antes de ser irradiada para outros pontos do país. Mas, constatou-se que o excesso de informações impossibilitaria o aprofundamento do trabalho.

Nesta cidade moderna, em que a sociedade se modificou, assim como o espaço que ela habita, o crescimento, anteriormente em forma de mancha, passa a ser tentacular, 
em um processo de suburbanização, ressonância dos países desenvolvidos. Este processo de modernização da cidade de São Paulo, que envolve mudanças econômicas, sociais e culturais, se refletirá sobre a materialidade da cidade, em seu desenho - através de reformas urbanas e expansão territorial, surgindo os subúrbios e em sua arquitetura. A classe média apresentará uma nova tipologia arquitetônica. Também os cursos de arquitetura e as mudanças no ambiente profissional em São Paulo são tratados neste capítulo.

Quanto à delimitação geográfica, tentou-se explorar todos os aspectos relativos ao contexto paulistano pertinentes à pesquisa. Porém, por razões documentais, nem sempre foi possível restringir- se ao ambiente da cidade de São Paulo, quando então o campo de pesquisa foi extrapolado para um quadro mais amplo, brasileiro. Uma fonte primária importantíssima foi a já mencionada revista $A$ Casa, que apesar de editada no Rio de Janeiro, tinha alcance nacional. A fim de pesquisar esta nova arquitetura de classe média e seus bangalôs, lançou-se mão da revista. Sua análise constitui-se no capítulo 4.

E no capítulo 5, passa-se a estudar a arquitetura paulistana, agora a partir de revistas editadas na cidade e de álbuns de fotografias de duas construtoras, onde apresentam sua produção. O álbum da "Sociedade Constructora de Immoveis" (1928), uma importante construtora da época, e o álbum Jardim América, da Companhia City (1923). Ambos retratam, basicamente, casas feitas para a classe média, um mercado em expansão à época. A pesquisa no arquivo da Companhia City, outra importante fonte documental, que possui toda a informação referente a cada terreno de seus loteamentos, complementou as informações obtidas no álbum. Ali foi pesquisado o Jardim América.

As revistas paulistanas analisadas são técnicas e surgiram ou foram reformuladas nos anos 1920 - a Revista do Mackenzie, Architectura e Construcções (esta já no final da década), a Revista Politécnica.

É muito importante levantarem-se tais fontes documentais com urgência, pois além das coleções não estarem completas - ao menos nos arquivos pesquisados -, muitas vezes as revistas estão em pedaços e se desmancham em nossas mãos.

O arquivo da Companhia City é bem organizado, tem muitas informações, mas um galpão sem laje não é o local ideal para se guardar material tão precioso.

Interessante foi a descoberta da produção de profissionais esquecidos ou raramente mencionados, mas que tiveram uma atuação provavelmente marcante à época, alguns 
apenas no aspecto quantitativo, outros também no qualitativo. Sobre os arquitetos se encontram apenas informações esparsas. Quase só é possível conhecer seus projetos.

O período delimitado vai do final da Primeira Guerra Mundial, quando houve grande desenvolvimento industrial e um conjunto de reformas urbanas, na expectativa da celebração do centenário da Independência, em um ritmo acelerado de crescimento, vislumbrado alguns anos antes quando da constituição da Companhia City e da compra de grandes áreas da cidade para futura urbanização.

No início da década de 1920, o setor das construções e a indústria editorial recebem grande impulso. No caso desta, surgem revistas, jornais e livros, destinados a um público mais amplo. São Paulo, 1920's, um período em que a cidade já se modernizou e está prestes a se transformar em uma metrópole, esta é a expectativa que a imprensa reproduz e a publicidade consagra.

O período termina no limiar dos anos 1930, quando vários acontecimentos - como a crise econômica internacional de 1929 e a Revolução de 1930 no Brasil - mudarão de forma drástica o país.

Em relação à arquitetura paulistana, existe toda uma lacuna na historiografia e temos que nos apoiar na própria história urbana e tentar construir uma história de sua arquitetura baseada em fontes da época, como as revistas. De qualquer forma, evitam-se as "construções", como o relato sobre a arquitetura moderna no Brasil e os pioneiros de Pevsner. Ainda que não seja uma história completa e tenha muitas lacunas, a importância é contribuir para futuras pesquisas.

Estas arquiteturas produzidas à margem das vanguardas, com uma participação maciça na construção da cidade moderna, não podem ser entendidas apenas como uma continuidade de modos de fazer anteriores.

Que todas estas situações arquitetônicas não reúnam a limpidez das circunstâncias canônicas, mas que se trate de casos de contaminação, de híbridos entre velhos e novos modelos (...) uma situação de mudança produzida não tanto a partir das afirmações programáticas, mas a partir das condições materiais de produção e uso da arquitetura. (...) se projeta e se constrói aparentemente lançando mão dos repertórios disponíveis dentro da cultura arquitetônica estabelecida, que era - convém insistir nisto - a cultura arquitetônica mais amplamente difundida e utilizada naqueles anos na Europa e na América. (...) Por isso, estudar estas arquiteturas é 
hoje uma tarefa urgente. Porque elas são o complemento imprescindível para se entender a passagem da tradição acadêmica à nova 'tradição moderna'. (SOLÀ-MORALES, 1980, p. 105)

Qual o objetivo desta visão historiográfica livre da ilusão das vanguardas? Trata-se de entender a arquitetura relacionada a fenômenos mais gerais da produção cultural e da produção do espaço habitado, com o intuito de entender a história da arquitetura como um aspecto do processo de modernização acontecido no início do século $X X$ no mundo ocidental desenvolvido. A arquitetura, como atividade intelectual e também técnica, está profundamente imbricada neste processo.

"Dialética entre utopia e realidade construída (...) a linguagem da arquitetura é uma linguagem social; suas mudanças não são discretas, mas um constante ir e vir entre o estabelecido e o porvir" (SOLÀ-MORALES, 1980, p. 13). Ou como coloca Purdom, ao fazer um retrospecto nos dez anos da cidade-jardim.

(...) Uma cidade não é feita por um homem, nem pelas idéias de um homem. É um objeto orgânico, o produto dos esforços, objetivos e desejos de muitos homens. Nasce da forma de trabalho de sua época, e da imaginação de seus construtores. Sua arquitetura é determinada por condições naturais, pelas necessidades, reais ou supostas, pelas tradições, pelas restrições, pela cultura daqueles para os quais é construída e daqueles que a constroem. (PURDOM, 1913, p. 64)

Neste sentido, é importante conhecer-se qual a arquitetura que povoou grande parte da cidade de São Paulo nos 1920's. Desconhecida e desqualificada, seu papel no crescimento paulistano é esquecido.

$\mathrm{Na}$ época, a cidade se expandia de forma tentacular. Esta arquitetura de classe média terminou por povoar estes novos bairros paulistanos. E o modelo para muitos deles foi o Jardim América, projetado justamente pelo arquiteto do Arts and Crafts inglês, Barry Parker, que aqui esteve.

Quanto ao Arts and Crafts, ele também não mereceu a necessária atenção da historiografia de seu próprio país. Muthesius será traduzido do alemão apenas em 1979 e sofrendo uma condensação, em que parte do relato se perdeu para viabilizar sua publicação. O próprio Nikolaus Pevsner acompanhou o processo.

A compreensão da arquitetura Arts and Crafts foi dificultada devido à construção historiográfica do movimento moderno, em que Morris é colocado como o início do arco cujo final é Gropius. Provavelmente o relato sobre o Arts and Crafts foi moldado 
para a confecção deste arco. E mesmo a compreensão da figura de Morris e de seu real papel no movimento inglês torna-se muito difícil. Não é o caso de se negar seus méritos como precursor na formação e desenvolvimento das artes decorativas, mas quanto ao desenvolvimento na arquitetura necessita ser melhor investigado.

Com um exame mais crítico de seu pensamento e de sua atividade, relacionados aos processos históricos reais, Morris parecerá menos contraditório. E ficará claro que a divisão de sua personalidade em vários aspectos distintos e supervalorizados se deve substancialmente à pluralidade de intenções historiográficas. Fez-se um uso excessivamente instrumental de sua figura. (ELIA, 1977, p. 52).

A história a ser contada não mais pode ser a "dos pioneiros". Correções devem ser feitas à simplificação levada a cabo por uma historiografia pensada de antemão como justificativa de vanguardismos encadeados.

A implantação do Movimento Moderno teve que polemizar com tudo o que fosse distinto de sua doutrina. $O$ vanguardismo de suas propostas implicava na incompreensão de qualquer outra via. Neste sentido, a arquitetura estabelecida, com todas as suas variantes, deveria ser atacada, a fim de destacar com maior ênfase a nova modernidade. Uma dialética entre ruptura e construção, entre momento crítico e momento propositivo diante da realidade das arquiteturas estabelecidas.

Esta crítica se aplica tanto ao movimento em âmbito internacional quanto à sua vertente brasileira.

O formato da pesquisa, pensado ao se redigir seu plano de pesquisa, focado em dois pontos extremos, o primeiro o Arts and Crafts inglês, o irradiador, e o segundo o Brasil, o receptor, mostrou-se na prática muito mais complexo, na verdade um processo contínuo com triangulações que, no caso Inglaterra - Estados Unidos, converteu-se em via de mão dupla. Esta foi a maior dificuldade apresentada pela pesquisa, sua abrangência. Muitas frentes de trabalho foram abertas e foi necessário fechar o foco, 0 que foi particularmente difícil. Procurar uma real articulação entre tantos pontos estudados foi um desafio.

Mas, penso que não poderia ser de outra forma, pois na última década do século XIX, quando acontece o apogeu do Arts and Crafts, o mundo não era mais um local onde o isolamento era possível. As informações viajavam pelos continentes com rapidez inédita.

O início do século XX é um momento definitivo para o homem, de domínio da técnica. $\mathrm{Da}$ constituição das grandes metrópoles e da impessoalidade; do contraste entre 
público e privado; do cultivo do espaço doméstico como um mundo idealizado, auxiliado pelas novas possibilidades trazidas pela técnica. Também é um mundo que pressente e até mesmo anseia pela guerra.

É este o momento do declínio do Arts and Crafts inglês, de sua forma antiga. Momento também de importantes mudanças sociais no país e da decadência do império "onde o sol nunca se punha".

O movimento Arts and Crafts se transformaria, na própria Inglaterra e na passagem aos outros países. "Em 1914 (...), a Europa movia-se rapidamente para uma Guerra insensata e industrializada (...). A paz veio, claro, e um novo mundo nasceu. Mas com trovões no horizonte, ${ }^{2}$ imperativos sombrios, democráticos, urbanos, internacionais, contrários às maneiras aristocráticas e tolerantes da tradição do Arts and Crafts inglês." (MANDER, 1998, p. 216) Talvez o movimento tenha perdido suas maneiras aristocráticas e se popularizado, mas provavelmente manteve grande parte de seus princípios e sua simplicidade. Ele não morre com a guerra, apenas seus principais líderes saem de cena ou adotam outras estéticas.

E a mesma recusa à história do Movimento Moderno baseada apenas em pioneiros deveria ser aplicada para se relatar a história do movimento inglês, se a idéia é a construção da história da arquitetura em outras bases.

A dialética entre propostas de grupo, manifestos e teorias, e a real história da construção das cidades é o horizonte em que deve desenvolver-se a historiografia que não pretenda apenas historiar hipóteses, mas comprovar a história real das transformações físicas e visuais que nas cidades e no território se produzem, por causa daquela aplicação maciça da ciência e tecnologia em um processo de transformação das relações de produção. (SOLÀ-MORALES, 1980, p.

14)

\footnotetext{
2 “There is thunder on the horizon as well as dawn”, John Ruskin, The Lamp of Obedience, X.
} 


\section{CAPÍTULO 1}

O MOVIMENTO ARTS AND CRAFTS NA INGLATERRA

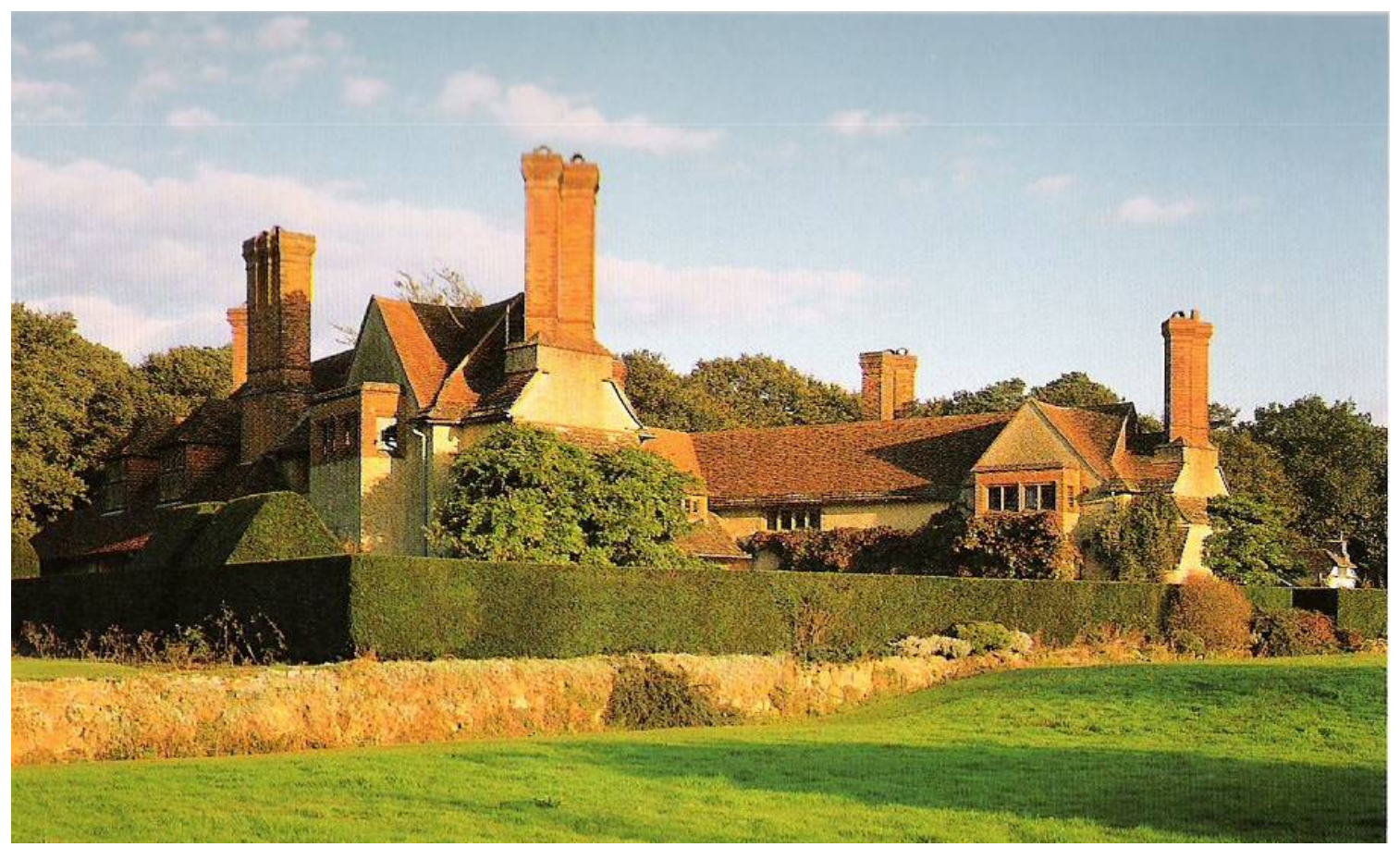

Fig.1. 1 Casa Goddards - Edwin Lutyens

\subsection{A era vitoriana}

A era vitoriana, período que compreende a segunda metade do século XIX e primeira década do século XX, é considerada o auge da Revolução Industrial inglesa e do Império Britânico. É frequentemente definida como o período entre 1837 e 1901, o reinado da Rainha Vitória

Esse período foi marcado por profundas mudanças econômicas e sociais, incluindo a migração em massa de trabalhadores do campo para as cidades. Essa movimentação populacional criou condições para o surgimento de mão-de-obra disponível para a indústria em crescimento e também para o aumento de desempregados e miseráveis, 
que povoavam bairros desprovidos de saneamento básico, iluminação e outros serviços públicos.

Apesar do materialismo, a época foi marcada pelo retorno de valores éticos, como respeitabilidade, polidez e circunspecção, consideradas as mais elevadas virtudes sociais. No entanto, muitos críticos têm uma visão amarga desse período, que consideram uma época de preconceitos, excessiva repressão moral e hipocrisia.

O espírito vitoriano marcou a literatura com refinamento e vigor, como nas obras de Charles Dickens, Emile Brontë, George Eliot e Thomas Hardy. O romance vitoriano, com ênfase no retrato da vida social, propõe reflexões sobre a extrema severidade da moral vitoriana, abordando a disciplina implacável das emoções e dos instintos, o que acaba desequilibrando a estrutura psicológica de suas vítimas.

Foi ainda uma época marcada por avanços no conhecimento científico e pela sofisticação da técnica. O processo evolutivo indiferente aos anseios sociais suscitou a necessidade de se buscar um ponto de equilíbrio entre o público e o privado, uma base que refletisse solidez e estabilidade.

Esta base, naturalmente, era o lar, e como seu representante elegeu-se alguém com as qualidades de guardião da moral e da castidade. A exigência de um anjo do lar fez nascer a mulher vitoriana. A mulher com o perfil assim delineado tinha todo o apoio da rainha Vitória, que atribuía o sucesso do seu reinado à moralidade da corte e à harmonia da vida doméstica.

\subsection{A Casa Burguesa}

No primeiro dia do século XIX, uma nuvem sombria, densa e carregada de chuva e umidade surgiu como uma capa sobre o céu da Inglaterra, exercendo sobre seus habitantes uma estranhíssima influência. Cheios de calafrios, homens e mulheres começaram a cobrir-se e o frio que sentiram, contagiou suas casas: 'os móveis foram estofados, as paredes e mesas, recobertas; não se via nada mais nu' (WOOLF, 1978, p.162 apud PONTE, 1982, p.23). A dieta se modificou, o café substituiu o porto; para bebê-lo tornaram-se necessárias as salas de estar, e com as salas de estar, os lustres, as lareiras onde pousar as flores, e depois o piano (...) e 'inumeráveis 
cãezinhos, tapetinhos, bibelôs de porcelana , (e) eis a casa - a qual adquirira extrema importância - a casa mudou completamente de aspecto'. Suas paredes recobriram-se de um sufocante verde, a luz filtrada, discretamente verde (...). Mas, não foi este o único efeito: 'a umidade invadiu o espírito. Em um esforço desesperado para aquecer seus sentimentos, os homens tentaram um recurso após outro, e uniram amorosamente o amor, o nascimento e a morte em um repertório de belas frases (PONTE, 1982, p.23)

Aqui é descrito o advento da era vitoriana, com a nuvem negra da fumaça das fábricas, das locomotivas, das máquinas a vapor e uma profunda desesperança. Neste contexto, a casa se fecha em torno da família como um ninho, um refúgio. A casa que John Ruskin, em 1865, definiria como "o lugar da Paz, o refúgio de cada injúria, terror, dúvida ou divisão", delegando à mulher a tarefa de construí-la e de defendê-la e pondo a arte a seu serviço. (RUSKIN, 1897, p.108-109 apud PONTE, 1982, p. 23).

A arte, personificada na casa, torna-se um instrumento educativo e moralizador. O belo é o que é apropriado. Segundo Christopher Dresser em Studios in Design (1879), "A arte não deve levar apenas a beleza a cada casa: sua tarefa suprema é exercer uma influência benéfica, elevando espiritualmente e moralmente aqueles que a habitam" ${ }^{3}$.

Esta operação estabelece a família como a célula base do sistema social. Em 1889, Patrick Geddes, um biólogo escocês, publica The Evolution of Sex. Geddes trata da sexualidade humana, enfatizando seus aspectos psicológicos e éticos, com ênfase na reprodução.

A sexualidade masculina e feminina, a ligação entre marido e mulher, a definição do papel de cada sexo - e a conseqüente divisão do trabalho entre ambos -, a ligação entre pais e filhos. O papel fundamental da mulher, colocando a maternidade como um dever social exercendo um controle da saúde moral e física da prole. Sentimento, economia e biologia mesclam-se nas pesquisas que pretendem analisar, sanar, controlar. A vida pode ser calculada em todos os seus aspectos e colocada a serviço do progresso individual e social. O homem tem o dever moral de usar corretamente 0 próprio corpo. É nesse contexto que deve ser entendida a obra de Geddes.

"O modelo proposto por Geddes é aquele clássico e ruskiniano das duas esferas de competência, uma doméstica e feminina, a outra pública e masculina" (PONTE, 1982, p.27). A humanidade é dividida em dois grupos: um doméstico, feminino, suburbano; o

\footnotetext{
${ }^{3}$ Citado em CALDER, Jenni The Victorian Home London, 1977, p.96, apud PONTE, 1982, p. 23
} 
outro trabalhador, masculino, urbano. À mulher cabem as tarefas da educação dos filhos e da gestão do lar, que se torna para o homem o refúgio e a salvação das tentações imorais e do frio mundo comercial.

O espaço doméstico deve seguir certas regras e ser higiênico, moral, racional.

Em um processo que parte da habitação aristocrática, passa pela de classe média e chega à das classes mais pobres, observa-se uma constante segregação. $\mathrm{Na}$ casa aristocrática, por meio de um complexo sistema de circulações, com escadas, corredores e outros percursos, separam-se os empregados domésticos dos patrões, os filhos dos pais, um sexo do outro. Na classe baixa, a casa modelo isola a família do mundo externo, garantindo ordem e tranqüilidade. Regulando ao mesmo tempo as ligações pessoais internamente ao núcleo familiar - o "dogma dos três quartos de dormir enunciado por Henry Robert" -, a casa torna-se o instrumento para se eliminar os divertimentos públicos, as ocasiões imorais que se encontram nas ruas, o tumulto, a violência , enfim, os males sociais" (PONTE, 1982, p. 30)

A suburbanização é conseqüência da cultura da descentralização. Ela é indicada como panacéia para os males da sociedade e do indivíduo, os "males urbanos". Dilatase a distância entre a casa e o local do trabalho.

Os espaços públicos terão brilho e monumentalidade. São espaços para uma nova sociabilidade. "Contrapondo-se a este imaginário coletivo, a casa burguesa aparece como espaço tipicamente de classe (...). Há de ser a reprodução do poder do Estado ou da Administração na área doméstica. $E$ isto de modo suficientemente visível para que se produza no continuum da cidade, mas também de modo suficientemente hermético para que se mantenha descontaminada a homogeneidade da família e o valor de seu espaço independente." (SOLÀ-MORALES, 1980, p.25)

Se não se pode ou não se quer transformar radicalmente a sociedade, é possível, porém, criar um mundo artificial na arquitetura do cottage. (ZUCCONI, 1982, p.40)

\subsection{O Pinturesco}

Outro conceito muito discutido no século XIX foi o do Pinturesco, fundamental para a compreensão da arquitetura Arts and Crafts. 
O Pinturesco pode ser entendido, no sentido mais amplo, como um ponto de vista, um modo ou uma intencionalidade do desenho arquitetônico, como um nível supra estilístico que transborda os limites cronológicos e geográficos, competindo com os modos acadêmicos, canônicos, clássicos ou hieráticos. (CRESPO; COVA, 1982, p.9).

O papel expressivo da cor foi bastante discutido no século XVIII. A velha polêmica entre desenho e cor (Poética de Aristóteles), que estabelecia a inferioridade desta sobre aquele, a superioridade do inteligível sobre o sensível, do objetivo sobre o subjetivo é trazida à tona pelo Neoclassicismo. Mais uma vez, a idéia do desenho como expressão da verdade e da razão; e a cor, relegada ao segundo plano, caracterizada como ambígua e ligada ao mundo dos sentidos (uma reação clássica às "transgressões" do Barroco). A arquitetura neoclássica valorizava como modelo uma arquitetura grega clássica idealizada, principalmente pela sua essencialidade formal e acromatismo (apesar de, na época, já ser um fato conhecido a policromia da arquitetura grega). A valorização da geometria. Mas, o Neoclassicismo não era a única tendência estética na cena cultural européia do Setecentos. Ele conviveria com o Pinturesco, com uma visão da cor totalmente distinta.

A revolução pinturesca iniciou-se na Inglaterra na metade do século XVIII. Na ruptura da tradição pelo lluminismo, a natureza não será mais o modelo universal, mas um estímulo para diversas reações de acordo com a individualidade do sujeito, românticas ou clássicas, passionais ou racionais. Segundo Argan (1992, p.11), as diferentes posturas frente à natureza explicam as reações - clássicas ou românticas. Ou, conforme Worringer (apud Argan, 1992, p.11), "uma distinção por áreas geográficas: o clássico seria o mundo mediterrâneo, onde a relação do homem com a natureza é clara e positiva; o romântico, o mundo nórdico, onde a natureza é uma força misteriosa, freqüentemente hostil".

O jardim pinturesco inglês certamente nasceu de condições específicas do país, como o clima e a topografia (as formas rígidas do jardim barroco não se adequavam à ondulada paisagem inglesa), mas, principalmente, de diferentes visões de mundo que contrapõem Inglaterra e França. Com risco de excessiva simplificação, o Pinturesco seria a contrapartida do lluminismo, no contexto cultural inglês. Ao racionalismo cartesiano, com sua ortodoxia, regularidade, proporção e matemática, seu mundo das formas, "reage" a arte empirista, o Pinturesco, o mundo dos sentidos e da experiência, o mundo da irregularidade, da impetuosidade e dos detalhes inesperados. ${ }^{4}$ Havia,

\footnotetext{
${ }^{4} \mathrm{O}$ empirismo sustenta que nosso conhecimento do mundo vem primeiramente da experiência, dos sentidos; e o racionalismo, que vem primeiramente da razão.
} 
inclusive, certa identificação pelos ingleses do regime absolutista da França com o desenho formal dos jardins regulares franceses: se o lluminismo francês e um estado com poderes absolutistas criam jardins que demonstram, com sua axialidade barroca a superioridade da razão sobre a ordem natural das coisas, o jardim pinturesco inglês proporciona uma nova visão da superioridade do homem sobre a natureza, melhorando-a e idealizando-a.

"A veduta do jardim pinturesco priorizando o efeito colorístico sobre a exatidão dos limites, a mancha sobre a linha, a imprecisão de contornos, a surpresa ou novidade, enfim, o 'pictórico'”. (PINHEIRO; D’AGOSTINO, 2004, pp.339).

O Pinturesco coloca a simbiose do natural - parques e jardins - e do construído. Busca-se o equilíbrio. O objetivo era quebrar a barreira entre natureza e arquitetura. Visão de John Nash, arquiteto inglês e Humprey Repton, paisagista. Juntos, pretendiam mostrar que se poderiam conceber arquitetura e paisagismo sob os mesmos princípios.

O vocábulo pitoresco, ${ }^{5}$ usual na linguagem cotidiana em inúmeras acepções tomadas por analogia de seu sentido etimológico - pittoresco, no italiano, deriva de pittura, significando 'próprio para ser pintado' - está vinculado a um conceito que, a despeito da aparente superficialidade, acarretou profundas transformações no pensamento estético ocidental, tais como a crítica à rigidez geométrica clássica (simetria, axialidade, comodulação, etc.) e ao ideal de imitação dos antigos (mímesis); a busca de coerência formal entre as qualidades materiais e as técnicas construtivas; a procura da adequação às exigências utilitárias, em suma, a concepção de arte como expressão autêntica, livre do artificialismo das convenções estilísticas. Tal concepção liga-se de modo inequívoco à assunção do pinturesco como valor artístico precípuo da arquitetura.

São características gerais do repertório pinturesco na arquitetura: a assimetria forçada, as volumetrias complexas, os recursos de cromatismo e textura e as composições aditivas, que caracterizam todas as composições análogas. A arquitetura pinturesca se expressou basicamente em matéria de residências.

Para William Kent ${ }^{6}$, as várias cenas de um jardim deveriam se relacionar de tal forma que configurassem uma totalidade, com homogeneidade de desenho, tanto quanto

\footnotetext{
5 Apesar do vocábulo pitoresco ser mais utilizado na língua portuguesa, será utilizada a forma pinturesco, derivada da palavra pintura devido à analogia com o vocábulo italiano.

${ }^{6}$ Kent (1685-1748), pintor, arquiteto, poeta e paisagista inglês, foi o primeiro a difundir os jardins chineses na Inglaterra (uma das influências na criação do jardim pinturesco inglês). Ele se preocupa

$\mathbf{1 4}$ I C a pítulo 1
} 
diversidade e naturalidade. Eram os efeitos de uma técnica calculada para criar a sensação de espaço 'real'. Ao invés do espaço baseado na perspectiva centralizada, em um eixo de simetria, onde o espectador permanecia fixo, ou seja, um esquema formal, como o dos jardins barrocos, Kent adotou uma técnica baseada no uso da perspectiva oblíqua, constituída de dois ou mais eixos, convergindo de pontos externos a cena. Isto levava o observador a procurar outros pontos de vista, independentemente ${ }^{7}$. Este arranjo cria uma transição natural de uma área à outra do jardim, e assegura que as várias características sejam reveladas aos poucos, como na natureza.

"Diferentemente da paisagem clássica, que define as distâncias com clareza, enquadrando a visão pela concordância e unidade que seus elementos guardam entre si e com o todo, a paisagem pinturesca seleciona e recorta o campo de visão pelo que nele se destaca, o inusitado da varietà (que só pode ser apreendido 'em relação a algo', ao qual se opõe como 'novidade')” (PINHEIRO; D'AGOSTINO, 2004, p.339).

Nos Estados Unidos, Andrew Jackson Downing, o paisagista do século XIX, segundo Scully (1971), faz parte da revolução pinturesca, que se iniciara na Inglaterra na metade do século XVIII. Downing rejeitava a ausência de cor. Ele achava que o branco ocultava o material e contrastava com a paisagem. Segundo ele, não haveria harmonia de cor no contraste entre o branco do edifício e o verde delicado da folhagem (SCULLY, 1971, p. XXX e XXXIII). Outro recurso empregado é desenhar cada fachada como um elemento independente. "A expressão da função de cada parte se acentua com o uso adequado de um repertório muito amplo de aberturas", que incluem janelas retangulares, bay windows e outras. "Estas foram abandonadas mais tarde pela uniforme fenêtre-en-longueur racionalista, mas, até então, atuaram como o principal vocábulo funcional da arquitetura". Ainda outro recurso é o aproveitamento das localizações privilegiadas, quase sempre de esquina, e as particularidades da topografia e da paisagem. (SCULLY, 1971, p. 21e 23).

O mais importante no Pinturesco foi sua contribuição no sentido de ensinar a olhar o edifício e seu entorno como uma seqüência de perspectivas e estimular uma nova e romântica sensibilidade visual (...). A arquitetura pinturesca não só é

também, no início dos Setecentos, com a transferência dos temas e das características formais da pintura para o paisagismo. O que tomaria o lugar, no jardim, das figuras nas pinturas históricas e dos atores no teatro? Os visitantes do jardim são chamados, assim, a atuar como atores, tanto quanto espectadores. Kent foi chamado pelo escritor britânico Horace Walpole de 'pai do jardim moderno'.

${ }^{7}$ As regras e princípios da perspectiva oblíqua foram estabelecidos e ilustrados por Ferdinando Bibiena em L'Architettura civile (Parma, 1711). Kent esteve na Itália entre 1709 e 1719 e ali teve contato com a técnica. (MOSSER e TEYSSOT, 1991, p.320). 
fundamentalmente assimétrica, mas também anti-monumental. (...) (uma) sensação geral de aparente espontaneidade, que se acentua às vezes com volumetrias não tectônicas, pela aparição de corpos salientes (...) nos pavimentos superiores (...) 0 Ecletismo oficial é eminentemente urbano, enquanto o pinturesco é suburbano e rural.“(CRESPO; COVA, 1982, p. 13-5). Uma oposição às volumetrias do clássico, tendentes à pureza prismática e à renúncia à policromia. Composição aditiva em contraposição à subtrativa. "A casa recupera seu baricentro, constituído pelo hall. Em torno deste, os tradicionais ambientes do espaço doméstico se agregam, segundo um princípio de adição" (ZUCCONI, 1982, p. 41).

\subsection{0 movimento Arts and Crafts}

\subsubsection{Caracterização do Movimento}

As formas horizontais de Perrycroft, Colwall, de Voysey contrastam com a verticalidade da Hill House, de Mackintosh, com The Barn de Prior; Cheyne Walk, de Ashbee; Melsetter House de Lethaby; White Lodge, de Bailie Scott; Orchards, de Lutyens; Stoneywell Cottage, de Gimson. Não poderia ser de outra forma, pois um dos princípios fundamentais do Arts and Crafts era o regionalismo. Aliás, este foi provavelmente o apogeu do movimento. Todas estas casas, grandes representantes do Arts and Crafts, são do período entre 1896 e 1898. Além do regionalismo, outros princípios do movimento eram: unidade de desenho, prazer no trabalho, individualidade..

Da premissa do regionalismo, fazia parte a escolha de materiais encontrados na localidade, como disse o arquiteto e escritor Halsey Ricardo (1854-1928). Haveria "cores suficientes para se destacarem e se harmonizarem com a paleta fornecida pela Natureza". Razão suficiente para que tais materiais fossem deixados ao natural, sem pinturas ou outro tipo de acabamento. Além disso, a ser levada em conta também a "verdade dos materiais", pregada por Ruskin: como seria verdadeiro algo que ao invés de sua cor e beleza naturais mostrava uma cobertura artificial? Outro objetivo era a preservação das técnicas tradicionais da construção.

A definição da arte da arquitetura (...) é independente de seus materiais: entretanto, esta arte, tendo sido, até o início do presente 
século, realizada em sua maior parte em barro, pedra, ou madeira, o resultado é que seu senso de proporção e suas leis estruturais basearam-se, esta totalmente, a outra em grande parte, nas necessidades resultantes do emprego destes materiais; e que a utilização total ou principal da estrutura metálica seria, portanto, sentida como abandono dos princípios fundamentais da arte. Apenas por si, não parece haver razão para que o ferro não devesse ser utilizado como a madeira; está provavelmente próxima a época em que um novo sistema de leis arquitetônicas será desenvolvido, totalmente adaptado à construção metálica. (...) Pelo fato da arquitetura em sua perfeição a primeira, assim como, em seus elementos ser necessariamente a arte fundamental (...) depende da utilização de materiais acessíveis em quantidade, e na superfície da terra. (RUSKIN, 1907, p. 39-40)

Preferencialmente, haveria a utilização das cores dos materiais naturais.

As verdadeiras cores da arquitetura são aquelas das pedras naturais (...) que harmonias não poderíamos conseguir? Os matizes da pedra, a quantidade é ilimitada (...) - e deixe o trabalho do pintor para a loggia sombreada e o quarto de dormir. Esta é a verdadeira e sincera maneira de construir; onde isto não puder acontecer, não se deve se envergonhar em utilizar o artifício da coloração externa; mas deve haver uma reflexão prévia(...)(RUSKIN, 1907, p. 52)

Para Walter Crane: "O Movimento (...). É um protesto contra o assim chamado progresso industrial. É um protesto contra a transformação dos homens em máquinas, contra as separações artificiais na arte" (CRANE, 1893, p. 12, apud DAVEY, pp. 60). “(...) um artista ou artesão impessoal tentando produzir coisas bonitas para um público impessoal e desconhecido." (CRANE, 1893, p. 10, apud DAVEY, pp. 60). A individualidade do cliente, o conhecimento e a satisfação de suas necessidades pessoais são de suma importância. Assim, a relação entre o artista e o cliente é fundamental para o Arts and Crafts.

O Movimento Arts and Crafts foi inspirado por uma crise de consciência. Suas motivações foram sociais e morais, e seus valores estéticos se desenvolveram a partir de uma conviç̧ão de que a sociedade produz a arte e a arquitetura que merece. Foi, originalmente, um movimento inglês; (...) a percepção de que o progresso tecnológico não coincide necessariamente com 0 aperfeiçoamento da sorte do homem trouxe consigo a longa campanha pela reforma social, industrial, moral e estética, ainda sem 
solução hoje. O Movimento Arts and Crafts representa uma faceta desta campanha... Posições similares foram observadas nos países da Europa, à medida que se industrializaram, e nos Estados Unidos. (NAYLOR, 1971, p.7)

O Movimento representou um retorno à natureza - particularmente na adequação de um edifício ao seu entorno, no uso de técnicas de construção tradicionais e de materiais locais e naturais. Desta aspiração surge o conceito da unidade de desenho. A casa deveria surgir do entorno e seus jardins e interior também fariam parte desta unidade. Um continuum, do menor detalhe interno aos jardins e à natureza. Limites suavizados entre as várias escalas, entre jardim e natureza selvagem. E a utilização das cores e materiais da natureza favoreceria este efeito.

Mas o centro era o homem. Sua vida deveria ser a mais completa possível, vivida em comunhão com a natureza, neste ambiente idílico. Distante da cidade industrial.

O trabalho humano deveria ser valorizado e equiparado à obra de arte, como concepção total, indivisível. Ele fora totalmente desfigurado e desprovido da alegria e do prazer pela divisão do trabalho que a industrialização trouxera. Cada homem era apenas uma etapa na produção de um objeto, não tinha acesso à sua totalidade. $O$ artesanato era visto como uma possível solução para este dilema e como uma ferramenta educativa.

O novo desenho do Arts and Crafts implicava em liberdade: novas proporções formais e experimentações com os materiais a serem utilizados. As características estruturais eram destacadas, para enfatizar como o edifício havia sido construído. Sugeriam uma forma orgânica emergindo da paisagem.

O arquiteto não é obrigado a mostrar a estrutura; (...), entretanto, aquele edifício será geralmente o mais nobre, um olho inteligente descobrirá os grandes segredos da sua estrutura. (RUSKIN, 1907, p. 35)

\subsubsection{Origens: Pugin, Ruskin e Morris}


Já no início do século XIX, a Inglaterra tivera Turner $^{8}$ (1775-1851), um pintor que olhara a natureza como nunca fora olhada antes. E, na metade do século, surgem os Pré-Rafaelitas e se deu uma verdadeira revolução na arte. Este movimento representava o primeiro rompimento bem sucedido com a arte acadêmica que dominava na época, mas também apontou o caminho para o cultivo de valores inteiramente novos: o estudo da natureza em todos os seus detalhes e "uma espiritualidade invocando um mundo de idéias mais profundas. Um verdadeiro produto do Romantismo, a arte Pré-Rafaelita foi direto ao coração do que se pode descrever como a visão alemã da arte, em contraste ao clássico representado pela arte acadêmica". (MUTHESIUS, 1987, p. 13).

Claramente, este movimento estava destinado a se mesclar ao revival gótico, já que seus conceitos eram similares. Mas, possuía uma visão mais ampla e diferia do revival gótico por ser mais progressista que arcaico: não queriam apenas reproduzir as formas dos estilos antigos. Devotavam-se às novas idéias, sentindo-se personificações dessa nova maneira de ver a arte como um todo. Uma tentativa de se reviver o espírito da época medieval.

Um marco das origens do Arts and Crafts é a Grande Exposição, no Palácio de Cristal, em 1851, em Londres. Em meio à grande quantidade de produtos da indústria inglesa, de péssima qualidade, "encontra-se uma área dedicada, com firmes princípios, aos séculos XIII e XIV". Fora totalmente desenhada por Augustus Welby Northmore Pugin (1812-1852). Em pleno revival gótico, este era o estilo considerado apropriado para igrejas e largamente utilizado para outros tipos de edifícios.

Pugin, um arquiteto que projetou vários tipos de edifícios, principalmente igrejas, não só defendeu a causa do Gótico, mas da reinterpretação da vida medieval, de forma idealizada. Acreditava que o Gótico refletia a ordem e estabilidade do Cristianismo. Adotou a assimetria da arquitetura gótica. Em seu livro, True Principles of Pointed or Christian Architecture (1841), ele estabelece as suas duas regras para o desenho: "Primeira, não deve haver características em um edifício, que não são necessárias por

\footnotetext{
${ }^{8}$ Joseph Mallord William Turner é considerado por alguns como um dos precursores do Impressionismo, em função dos seus estudos sobre cor e luz. Dedicou-se à pintura da paisagem com paixão, energia, força, interpretando seus temas de forma épica. Seus trabalhos transmitiam uma emoção extrema e foi considerado o ponto culminante da paisagem romântica. Uma de suas preocupações principais foi a aplicação da luz e sua incidência sobre as cores da maneira mais natural possível. Para tanto, dedicou-se intensamente ao estudo dos paisagistas holandeses do século XVIII, muito em voga naquela época na Europa. Em sua obra os motivos eram em geral paisagens, e o mar era uma constante. (http://pt.wikipedia.org/wiki/William_Turner)
} 
conveniência, construção ou propriedade; segunda, todo ornamento deveria constituirse de parte essencial do edifício". Estes dois princípios influenciariam todo o movimento Arts and Crafts. Ainda segundo Pugin, um edifício deveria refletir suas funções - uma planta baixa obedecendo a estas funções determinaria o aspecto externo do edifício - e o material que o constituía - sempre que possível encontrado no local e utilizando-se de técnicas tradicionais.

$\mathrm{Na}$ década de 1840, surgira um escritor cuja extraordinária eloqüência e entusiasmo pela arte contagiariam o grande público. Era John Ruskin (1819-1900). Hoje é difícil entender toda a sua importância, que só pode ser medida no ambiente de sua época.

Para a Inglaterra de sua época, ele foi o profeta de uma nova cultura artística. Ele não foi apenas o primeiro a apontar a importância de Turner, o primeiro a aceitar os Pré-Rafaelitas, apesar do desprezo e do ridículo que despertaram os primeiros esforços do movimento. Ele foi também o primeiro a defender os ideais que se tornariam os princípios a guiar o novo Movimento Arts and Crafts: simplicidade e naturalidade na arte, honestidade no design da forma, (...), observação da natureza. Mas, acima de tudo, ele procurou no design da forma: o bom, respeitável e sólido trabalho como o dos antigos objetos feitos à mão. Esta preocupação surge antes na Inglaterra do que no continente, pois a cultura antiga com base nas guildas de trabalhadores desaparecera na Inglaterra cerca de cinqüenta anos antes, e na metade do século XIX a máquina havia destruído completamente a velha tradição do artesanato. (MUTHESIUS, 1987, p. 13).

Como coloca Selwyn Image ${ }^{9}$, na introdução às Sete Lâmpadas da Arquitetura, edição de 1907:

Para os homens de sua própria geração representou primeiramente 0 grande mestre da arte. Para os homens de nossa geração representa preeminentemente 0 grande mestre dos princípios fundamentais, eternos, de economia social, um pregador ou profeta da honra - ou, como ele mesmo teria dito, de justiça. (IMAGE in RUSKIN, 1907, p. IX)

\footnotetext{
9 Selwyn Image (1849-1930) Artista, ilustrador e membro da Century Guild. Criou vitrais, bordados e capas de livros. Foi eleito Master da Art Workers' Guild em 1900 e foi membro fundador da Design and Industries Association (D.I.A.)
} 
A segunda geração são os arquitetos e artistas do Arts and Crafts, a quem Ruskin ensinará preceitos éticos rigorosíssimos. Pode-se dizer que os princípios do movimento fundamentam-se em seus ensinamentos.

Ruskin foi um grande defensor do Gótico. Ele segue a crença de Pugin na utilidade do desenho gótico no capítulo "On the Nature of Gothic". O gótico era absolutamente racional, característica que passará à arquitetura Arts and Crafts.

$\S X X X V I I I$ Desses usos gerais da variedade na economia do mundo, haveremos de entender imediatamente o seu uso e abuso na arquitetura. A variedade das escolas góticas é tanto mais bela e saudável porque em muitos casos ela é inteiramente impensada e resulta não do mero amor da mudança mas de necessidades práticas. Pois de um certo ponto de vista, o gótico não é apenas a melhor, mas a única arquitetura racional, na medida em que é aquela que pode se ajustar mais facilmente a todos os serviços, nobres ou vulgares (...) E tal é uma das virtudes principais dos construtores góticos que eles jamais permitiram que idéias de conformidade ou simetria exterior interferissem nos reais uso e valor do que faziam. Se queriam uma janela, eles a abriam; um cômodo, acrescentavam-no; um contraforte, construíam (...). (RUSKIN, 1853)

O gótico era imperfeito, como deveria ser uma arquitetura feita por homens livres, pensantes, criativos - era a selvatiqueza ${ }^{10}$ ou rudeza (savageness).

§VIII (...) E erraríamos severamente se recusássemos reconhecer como um caráter essencial da arquitetura existente no Norte, assim como admiti-la como um caráter desejável naquilo que ainda há de ser, esta rebeldia de pensamento e aspereza no trabalho (...)

§IX (...) a selvatiqueza da arquitetura gótica (...) pode ser de alguma maneira considerada como um caráter nobre, ela ainda possui uma nobreza superior quando considerada como um indício, não do clima, mas de um princípio religioso. (RUSKIN, 1853)

\footnotetext{
${ }^{10}$ Savageness pertence a uma família semântica muito cara a Ruskin: Ferocity, Rudeness, Fierce, Wild, são termos nem sempre referidos ao gótico, mas a um aspecto da paisagem, condições atmosféricas ou atitude de um animal, aqui respectivamente traduzidos por Ferocidade, Rudeza, Feroz e Selvagem. Optou-se pela tradução de Savageness por Selvatiqueza, e não por selvagismo ou selvageria, que no uso corrente em português parecem tender a brutalidade, fúria, bestialidade. A sugestão veio de uma passagem do livro de Euclides da Cunha, Os Sertões (1902), em que o aspecto intratável e aridez da terra era como que antropogeograficamente salientado ante a ameaça iminente do jagunço feroz: "Deslembravam-se do inimigo. A ferocidade do jagunço era balanceada pela selvatiqueza da terra." (Os Sertões, 29a ed., Rio de Janeiro, Francisco Alves; Brasília, INL, 1979, p. 318). (nota do tradutor- Tradução no site www.eesc.sc.usp.br/babel).
} 
A mente inglesa teria um desejo extremado de perfeição, de um acabamento primoroso em todas as coisas. Para Ruskin (1853, §XI), de forma abstrata, tal caráter é nobre, porém é ignóbil quando preferimos a perfeição da natureza menor à imperfeição da mais elevada. Porém, à perfeição é preferível um ser pensante:

§XI E é isso que devemos fazer com todos os nossos operários: procurar a sua parte pensante e fazê-la desabrochar não importando o que se perca com isso, nem com que faltas e erros sejamos obrigados a arcar. (...) você pode ensinar um homem a desenhar uma linha reta e a cortar outra, perfurar uma linha curva e cinzelá-la e a copiar e cinzelar qualquer número de linhas e formas dadas com rapidez admirável e perfeita precisão, e você achará o seu trabalho perfeito em sua espécie. Mas, se pedir-lhe que pense a respeito de qualquer uma dessas formas, (...) ele simplesmente irá parar, a sua execução se tornará hesitante, ele pensará e aposto que pensará errado; aposto que cometerá um erro no primeiro toque que aplicar sobre o seu trabalho como ser pensante. E, apesar de tudo, você terá feito dele um homem, Até então era apenas uma máquina, uma ferramenta animada. (RUSKIN, 1853).

John Ruskin insistia em que os objetos deveriam revelar sua origem, ou seja, revelar que são feitos pelo homem e refletir sua essencial humanidade em sua imperfeição a rudeza (savageness) - e individualidade. A rudeza contrapunha-se à perfeição, que ele associava à arquitetura clássica, segundo ele, uma arquitetura de escravos.

§XXV (...) a imperfeição é de certo modo essencial a tudo o que sabemos da vida. É o sinal de vida em um corpo mortal, isto é, de um estado de progresso e mudança. (...) Todos admitem irregularidade à medida que supõem mudança; e banir a imperfeição é destruir a expressão, impedir a manifestação, paralisar a vitalidade. (...) Então aceite, como uma lei universal, que nem a arquitetura nem qualquer outro nobre trabalho humano possam ser bons a não ser que sejam imperfeitos. (RUSKIN, 1853).

Outra característica da arquitetura gótica, analisada por Ruskin, era a mutabilidade ou variedade (changefulness):

$\S X X I X$ Compreendamos então de uma vez por todas que a mudança ou a variedade é para o coração e o cérebro humanos uma necessidade tanto das construções como dos livros; que não há 
qualquer mérito, apesar de haver algum uso ocasional, na monotonia. (...)

§XXXIII Acredito que as verdadeiras relações entre mudança e monotonia podem ser mais facilmente compreendidas quando observadas na música. Podemos nela notar primeiramente que há algo de sublime e majestoso na monotonia, inexistente na rápida e freqüente variação. Isto é verdadeiro em toda a natureza(...)

§XXXIV Ainda assim a monotonia depois de certo tempo, ou além de certo grau torna-se desinteressante ou intolerável, e o músico se vê obrigado a interrompê-la de uma ou duas maneiras.(RUSKIN, 1853)

A verdade era um dos princípios que Ruskin levava às últimas conseqüências:

Quando, devido a estrutura de um edifício, algumas partes estão ocultas aos olhos, e que são a continuação de outras partes que ostentam um ornamento harmonioso, não é bom que o ornamento seja interrompido nas partes escondidas (...) deixe-os terminar atrevidamente e marcadamente, em algum evidente ornamento final, e nunca se supor que exista onde não existe. (RUSKIN, 1907, p. 23)

Eu teria o Espírito da Lâmpada da Verdade claro nos corações dos artistas e dos artesãos, não porque a prática verdadeira do artesanato poderia contribuir para a causa da verdade, mas porque eu veria satisfeito o próprio artesanato impelido pelas esporas da honra. (RUSKIN, 1907, p. 32)

O grande seguidor das idéias de Pugin e Ruskin seria William Morris (1834-1896). Poeta, artista-artesão, reformista social e depois socialista, em torno de Morris se desenvolveria todo o movimento Arts and Crafts. Sua contribuição é extremamente importante, não apenas como teórico, mas também pela sua experiência pessoal. A partir destes ensaios e conferências, que começaram a aparecer no final da década de 1870, a filosofia de projeto do Arts and Crafts se desenvolveria.

À estatura de sua figura corresponde uma grande polêmica sobre sua personalidade: "Morris era um capitalista que pregava o comunismo; um designer de arte produzida em massa que acreditava na liberdade de cada artesão; um fabricante de ornamentos feitos à máquina que preferia a mais absoluta simplicidade". (DAVEY, 1999, p.36). Dizia que no interesse de sua firma, ele não diria o que ele realmente preferia paredes brancas, sem pinturas ou cortinas sufocantes: "Papéis de parede são um medíocre paliativo" (MORRIS, May, 1935, p.616, apud DAVEY, 1995, p. 36). 
Isto reforça a opinião que alguns contemporâneos, como Norman Shaw, tinham sobre ele: um hipócrita avarento. Para Shaw, Morris era "apenas um comerciante, cujo único objetivo era ganhar dinheiro" e quanto a seu Socialismo, que era apenas pose. "Morris, como socialista, deveria dedicar-se a produzir cômodas e papéis de parede baratos". (SHAW, citado por BLOMFIELD, 1940, p.12 apud DAVEY, 1999, p. 66) ${ }^{11}$

\subsubsection{A Arquitetura Vernácula e a Revolução na Arquitetura Doméstica Inglesa}

A arquitetura doméstica necessitava ser reorganizada como as outras artes. A casa ainda estava sob o domínio do classicismo e sua simetria arbitrária. Eram caixas, conhecidas como "vilas italianas", rebocadas e pintadas a óleo. As grandes casas resultavam de uma mistura de estilos antigos, adaptados a partir de formas eclesiásticas.

A mudança veio na década de 1860, efetuada por três arquitetos. Eles procuraram projetar mais livremente, preocupando-se com a utilidade, o material e outras considerações puramente práticas, indo além da imitação das formas dos grandes edifícios - castelos, palácios e catedrais -, como acontecia até então. Ao mesmo tempo, eles observaram as casas simples do campo e das pequenas cidades e vilas, construídas na tradição das velhas guildas de pedreiros. Estes três homens eram Phillip Webb (1831-1915), Eden Nesfield (1835 -1888) e Richard Norman Shaw (18311912).

No passado, houve sempre um grande número de edificações com as quais os arquitetos não se envolviam. O trabalho era responsabilidade dos mestres-pedreiros que pertenciam às guildas e representavam as tradições locais, passadas de geração a geração. As mudanças de estilo da arquitetura refinada não tinham influência sobre esta arquitetura popular. A situação se alteraria, no século XIX, com 0 desaparecimento das guildas. Neste século, o mestre-pedreiro desapareceu, marcando o início da perda da tradição como um todo.

Nesta época houve um aumento no número de arquitetos, por um lado, e uma ascensão da classe média, por outro. $O$ arquiteto era cada vez mais solicitado para pequenos encargos. Ele trouxe consigo uma ambição arquitetônica que o fez

\footnotetext{
${ }^{11}$ Blomfield está aqui parafraseando anotações de Robert Shaw, filho de Norman. 
experimentar com a arquitetura monumental nestes pequenos projetos - esta foi a falha fundamental do arquiteto no século XIX.

Foi a Inglaterra que primeiro encontrou um caminho. Consistiu na recuperação pelos arquitetos das tradições do velho mestre-pedreiro das guildas, construindo racionalmente e de maneira simples. Parece natural hoje, mas na época era quase uma revolução.

No começo, porém, os arquitetos não estavam totalmente seguros sobre quais aspectos considerar para restabelecer um estilo de edifício mais honesto. Pensou-se, no começo, que as casas construídas no período da Rainha Anne (1702-1714), seriam a resposta. Assim, a denominação "Queen Anne" veio descrever o novo movimento, que manteve este rótulo por décadas. O que estava realmente sendo descrito era a casa menor dos séculos XVII e XVIII. Um grande número delas havia sobrevivido por todo o país e haviam sido negligenciadas devido a sua aparência simples.

Ao redor de Londres, existiam muitas casas que eram simples construções em tijolos, com telhados vermelhos de várias águas, janelas em madeira - divididas em pequenos panos de vidro, pequenas e baixas, em faixas ou projetando-se da superfície da parede. Grandes chaminés, quase torres. A madeira era pintada de branco. Estrutura de madeira e estuque também eram comuns. Uma espécie de telha cerâmica revestindo as paredes era quase típica, enquanto algumas vezes o pavimento superior ficava em balanço. O interior era extremamente simples, apesar de quase sempre apresentar uma lareira que se projetava para o exterior. De cada lado da lareira, uma janela pequena iluminava os assentos. A lareira e o espaço ao seu redor (ingle-nook) tornaram-se o motivo favorito da arquitetura doméstica nas décadas seguintes.

Não havia nada de particularmente surpreendente nestas casas de trabalhadores, apesar da sua redescoberta ter tido tanta influência na arquitetura inglesa.

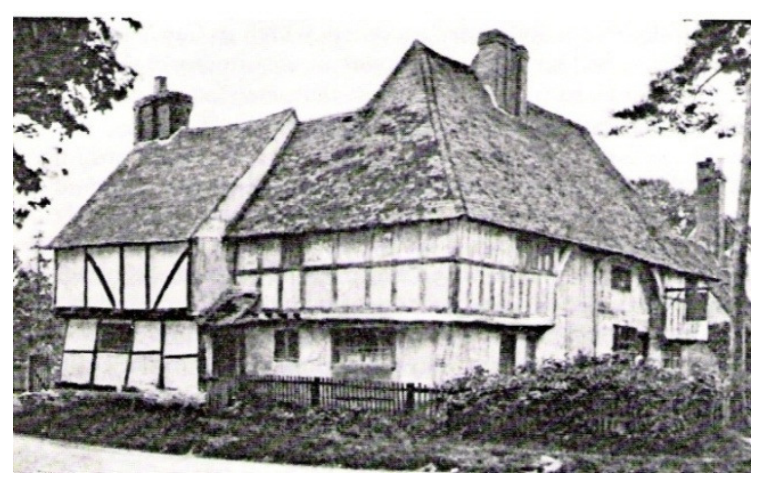

Fig.1.2 Velha casa de fazenda com estrutura de madeira, Kent. 


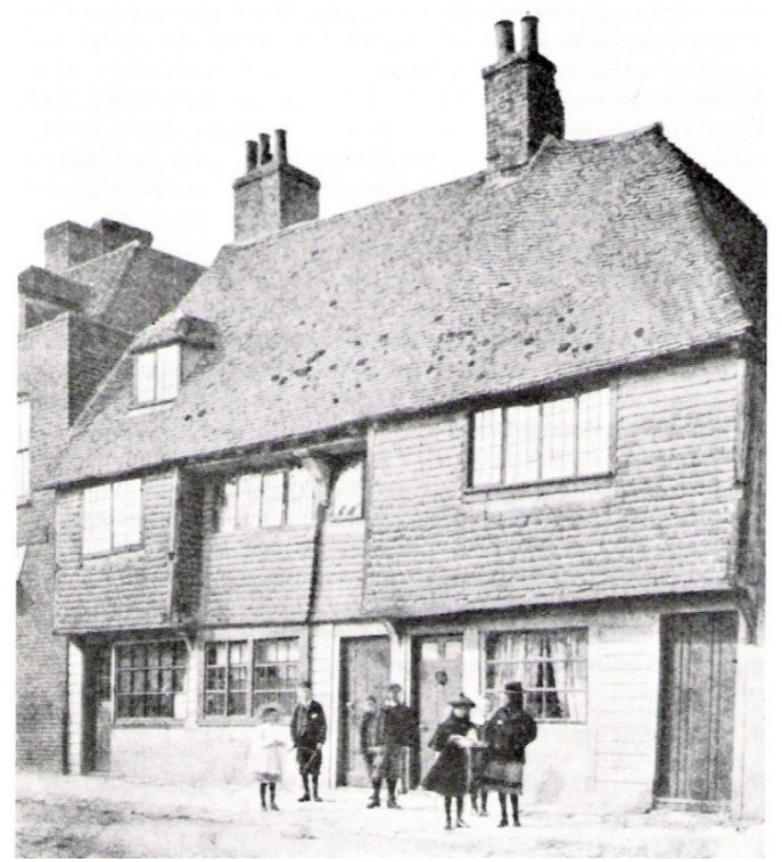

Fig. 1.3 Velha casa de fazenda com cerâmica nas paredes do segundo pavimento.

Com certeza, o número de formas arquitetônicas usadas nestas habitações do campo era extremamente pequeno e ainda que molduras, cornijas, suportes, etc. pertencessem ao estilo renascentista, seu caráter como um todo, sua simplicidade, sua praticidade poderiam também ser chamados góticos. (MUTHESIUS, 1987, p.17).

Ambos os movimentos, o Arts and Crafts e aquele associado à redescoberta dos edifícios vernáculos, nasceram simultaneamente sem terem muitos pontos em comum. Assim, no começo, os dois movimentos que iriam fundir-se mais tarde, para formar a moderna arquitetura doméstica inglesa, prosseguiriam independentemente.

Além do mais, poucos haviam compreendido o conceito da unidade artística entre a casa e seu conteúdo, assim, o arquiteto e o "decorador" eram pessoas diferentes que pouco tinham em comum. Seus partidários estavam, no entanto, lutando contra a proliferação de formas e a compreensão artificial dos estilos históricos. Colocavam-se não apenas contra um estilo em particular, mas contra todos, porém, não ao ponto de desprezar a tradição.

Assim, o período viu uma ruptura com os estilos da arquitetura refinada, um passo da maior importância na história da arquitetura.

Dos três arquitetos mencionados, Shaw foi o mais influente. Muitos dos arquitetos da nova geração, que fundariam o movimento Arts and Crafts na arquitetura, como 
William Richard Lethaby, Edward Prior, Mervyn Macartney, trabalharam em seu escritório.

Shaw tinha um vocabulário bastante eclético: no segundo pavimento de suas casas utilizava estrutura de madeira aparente ou um revestimento cerâmico semelhante à telha (tile-hung) e no térreo, pedras ou tijolos. Janelas seccionadas e altas chaminés completavam seu assimétrico "Old English" (características presentes naquelas casas pequenas e simples que o inspiraram). Com seu "deliberadamente assimétrico" Old English, ao contrário dos arquitetos do Arts and Crafts, Shaw muitas vezes explorava a paisagem de forma teatral. (CUMMING; KAPLAN, 1993, p. 34-35).

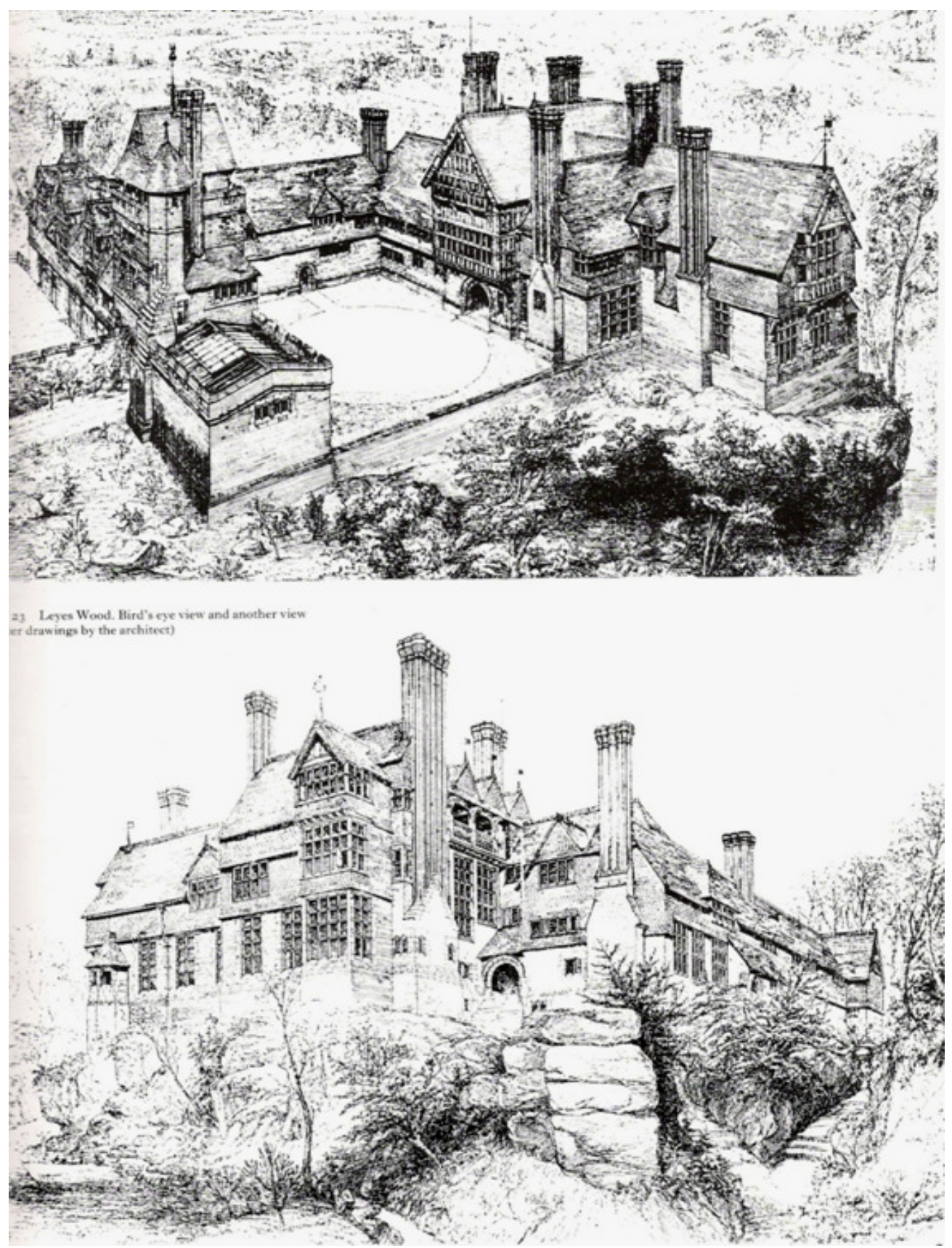

Fig.1. 2 Leyes Wood- Norman Shaw- Desenhos do arquiteto. 
Selvagem e variado no sentido atribuído por Ruskin, Shaw levava tais características á exacerbação:

$\S X X X I I$ (...) Por último: se o prazer da mudança for repetido com muita freqüência, deixará de ser prazeroso, pois desse modo a mudança, ela mesma se torna monótona e somos impelidos a procurar deleite nos seus mais extremos e fantásticos graus. Tal é o amor doentio da mudança, de que falamos acima. (RUSKIN, 1853)

Seu trabalho era tributário de dois grandes mestres do pinturesco: William Burn e Anthony Salvin, com os quais trabalhara antes de chefiar o escritório de George Edmund Street, que projetara várias igrejas.

Mesmo como mestre de muitos arquitetos do Arts and Crafts, Shaw, permaneceria uma figura conservadora, mantendo a concepção do arquiteto como grande mestre, sem ligação com o artesanato.

Contemporâneo de Webb, mas sem seu puritanismo e sua aversão à publicidade, suas criações eram constantemente divulgadas pelas revistas da época. Apresenta uma obra bastante extensa, com adaptações sucessivas ao gosto dos nouveaux riches.

Uma importante fase da arquitetura inglesa termina com os arquitetos referidos. Até então, o movimento Arts and Crafts (que começara na pintura) e o movimento na arquitetura tinham pouco em comum. Apenas Webb esteve envolvido em ambos. A nova geração de arquitetos teve uma relação diferente com o Arts and Crafts: foi bastante influenciada pelo movimento, que já tinha grande importância e era mais conhecido:

As primeiras conseqüências deste movimento para a arquitetura não foram uma imediata disposição por parte dos arquitetos em pensar o desenho do interior doméstico como um todo, mas primeiramente uma forte evolução purista na própria arquitetura. Os arquitetos agora almejavam um máximo de discrição formal e a simplicidade mais rigorosa (...). Na verdade, certos méritos, não belezas, começam a ser reconhecidos em tais edifícios (...). Há algo austero, sombrio, quase triste no todo. Porém, também há algo surpreendentemente poderoso e seguro. (MUTHESIUS, 1987, p. 37-8). 
Por volta de 1900, percebe-se uma polarização na arquitetura Arts and Crafts: uma corrente, movendo-se em direção a um estilo clássico, simétrico e disciplinado. Outra corrente, dando prioridade a questões funcionais, sociais e econômicas.

Nesta época, houve a tendência entre vários arquitetos de abandonar as formas históricas na arquitetura e trabalhar com as assim chamadas novas formas. Adotaram uma atitude similar à do novo movimento no continente, que começou por "jogar a tradição ao vento". Deve ser dito que tal grupo é pequeno na Inglaterra, incluindo o grupo escocês. Em Londres, eles pertencem à Art Workers Guild, como o grupo de Shaw - que não adotou as "novas formas". (MUTHESIUS, 1987, p. 41)

Ao examinar este novo vocabulário, fica claro que, do ponto de vista formal, era extremamente simples, beirando o primitivismo. Mas, as inovações não estavam apenas nas formas, mas também nas superfícies, "a relação entre áreas decoradas e não decoradas" e na cor. Este grupo também sentia que a casa e todo seu conteúdo deveriam ser considerados como uma unidade. O trabalho de Voysey, particularmente, entre os membros do movimento londrino foi extremamente influente. Ele foi o primeiro a conseguir uma síntese completa entre o trabalho que fora a seara de Morris e aquele que até então pertencera aos arquitetos. Esta síntese entre a casa e o interior foi o segundo passo no desenvolvimento da casa inglesa, segundo Muthesius. Agora o mesmo designer era responsável por ambos. (MUTHESIUS, 1987, p. 41)

Muthesius se refere a Voysey, e neste grupo pode ser incluído Baillie Scott e Parker e Unwin entre outros, não apenas na utilização do conceito da unidade de desenho, mas também pelo tratamento das superfícies e pelo contraste entre elas.

O trabalho que Parker, Baillie Scott e Voysey faziam na arquitetura doméstica, pouco antes da Primeira Guerra Mundial, eram muito próximos em caráter. Simplicidade e "limpeza" nas casas.

Ainda segundo Muthesius, Baillie Scott foi o primeiro a realizar a idéia do interior como obra de arte. Tal idéia aparece então em vários locais, inclusive no continente. Londres e mesmo a Inglaterra como um todo permaneceram estacionados no ponto em que Morris os levou. A Escócia, no entanto tomou esta nova direção ao mesmo tempo que o continente, ainda que com as cores locais, místicas e poéticas, que sempre marcaram o trabalho escocês. (MUTHESIUS,1987, p. 51) 


\subsubsection{A Revolução Industrial, as guildas e a máquina}

A escala da produção industrial aumentava e a cada dia isolava mais o designer do objeto de quem a executava. $O$ ideal anti-industrial - apenas uma pessoa criando e executando o objeto do início ao fim - foi raramente alcançado e, apenas de forma elitista, como fez Morris. Para Ruskin (1853, §XVI), a divisão do trabalho que acompanhou a revolução industrial tem um nome falso. Ele diz em $A$ Natureza do Gótico, capítulo de As Pedras de Veneza: "verdadeiramente falando, não é o trabalho, mas os homens que são divididos (...)" Ruskin ataca o espírito dos tempos modernos, "que deseja produzir o máximo ao menor custo" em The Seven Lamps of Architecture (RUSKIN, 1907, p.10).

Ruskin dizia que a civilização da máquina fez do homem também uma máquina, já que o forçou a passar toda a vida fazendo apenas uma operação mecânica e isto era realmente a morte para a felicidade material e espiritual do trabalhador. Acreditava que 0 trabalhador deveria tornar-se novamente um ser pensante, capaz de desfrutar da criação independente de suas mãos: isto, ele acreditava, era o pré-requisito da existência humana. (MUTHESIUS, 1987, p. 13).

Ele desejava reviver o ambiente medieval de produção das guildas onde, acreditava, existiam cooperação e prazer no trabalho. Estas eram suas principais reivindicações: 0 prazer e a honestidade no trabalho. Opôs-se a todo trabalho feito à máquina, pois seria desonesto. "(...) todo molde e todo trabalho feito à máquina é inferior, como trabalho; (...) é desonesto".(RUSKIN, 1907, p. 53).

Para Ruskin, realizar com verdade era realizar manualmente e realizar manualmente era realizar com alegria.

Porque não fomos enviados para este mundo para fazer qualquer coisa onde não coloquemos nossos corações. Temos certo trabalho a fazer para conseguir nosso pão, e que deve ser feito de forma corajosa, outro trabalho a fazer para nosso deleite, e que deve ser feito com amor. (RUSKIN, 1907, p. 179).

O trabalho humano era de importância tão fundamental que, comparando-se um diamante a um ornamento, que está impregnado do esforço do homem, o valor deste é muito maior que o daquele:

(...) O ornamento tem duas fontes distintas de prazer: Uma, a da beleza abstrata de suas formas, (...); a outra, a percepção do trabalho humano e esmero utilizada nele. (...), além disso, (o 
ornamento) tem um valor intrínseco, que o diamante não tem; (pois um diamante não tem mais beleza autêntica que um pedaço de vidro). (...) Pois não é o material, mas a ausência do trabalho humano que deixa o objeto sem valor; e um pedaço de terracota ou de ou de reboco de Paris, que foi trabalhado pela mão humana, é preferível à pedra de Carrara, cortada à máquina. (RUSKIN, 1907, p. 53)

Pugin não era tão radical, admitindo para a máquina um papel limitado. Porém, esta nunca deveria imitar o trabalho feito à mão.

Morris aceitava o trabalho à máquina, com reservas: "se o necessário trabalho racional for do tipo mecânico, devo ser auxiliado pela máquina, não para baratear meu trabalho, mas para que o mínimo tempo possível seja gasto nele e eu possa ser capaz de pensar em outras coisas enquanto conduzo a máquina." 12

Provavelmente, o arquiteto que mais se aproximou dos ideais de Ruskin e de Morris sobre o trabalho foi C.R. Ashbee. Em 1888, ele criou uma escola, associada a uma oficina. Os alunos freqüentavam ambas, em uma antecipação da filosofia da Bauhaus. Era a Guild of Handicraft, que inicialmente funcionou em Londres, transferindo-se para as Costwolds em 1902. A guilda teria influência internacional, como tivera a firma de Morris. Pretendia "um padrão melhor para o artesanato, mas ao mesmo tempo(...) protegia o status do artesão". (CUMMING; KAPLAN, 1993, p.28)

Nas Costwolds, forma-se uma comunidade de mais de 150 membros - homens, mulheres e crianças - procurando uma vida simples e comunitária; a ética e o prazer no trabalho. Para Ashbee, como para Ruskin e Morris, a qualidade do design dependia de boas condições sociais.

Ashbee nunca se opôs a utilização da máquina no artesanato. A serra circular poderia ser usada para serrar a madeira, mas esta jamais deveria ser entalhada pela máquina. Desta forma, o trabalho artesanal seria capaz de competir com aquele feito à máquina, em igualdade de condições, para que os produtos artesanais não se tornassem apenas um luxo feito para os ricos, mas pudessem ser livremente escolhidos. A atitude de Ashbee em relação à máquina tornou-se menos radical com o tempo. Ele continuava a achar imoral executar-se mobília ou trabalho em metal com a máquina, porém, "era tão imoral quanto manter homens fazendo coisas mecânicas à mão". (ASHBEE, 1911, p.13, apud DAVEY, 1995, p. 158)

\footnotetext{
${ }^{12}$ MORRIS, William. How We Live and How We Might Live (1885). In: MORRIS, May Works of William Morris, Vol.XXIII, p.20, apud DAVEY, 1995, p. 35.
} 
As máquinas teriam um papel crescente - mas, certas máquinas: "A tendência que é conhecida na América como 'fine machine tool production', depende da habilidade pessoal na utilização da ferramenta pelo indivíduo, e a força da máquina necessita estar sob seu controle direto. Todo mecanismo que auxilia o indivíduo pode também ajudar as Artes." (ASHBEE, 1911, p.98, apud DAVEY, 1995, p. 160)

Ashbee foi amigo de Frank Lloyd Wright. Este, em sua defesa da máquina, acreditava que o artista criativo a controlaria, "Wright estava, de fato, transpondo o abismo entre os séculos XIX e XX (...) e abrindo caminho para os dilemas doutrinários do Movimento Moderno" (NAYLOR, 1971, p.174). Ashbee, de certa forma, concordava com Wright, mas reafirmando suas preocupações com o bem estar do trabalhador diz que: "a personalidade da média deve ser considerada, além daquela do próprio artista criador." (ASHBEE , 1938, Vol. I, p.242 apud NAYLOR, p. 174).

Sua compreensão do papel da máquina era muito maior que a de seus contemporâneos: "há uma maneira de se distinguir entre o bom e o ruim na produção mecânica" (ASHBEE, 1911, p.115, apud DAVEY, 1999, p. 160).

Ao mesmo tempo, um grupo similar ao de Ashbee se instalara no sul do país, liderados por Ernest (1861-1926) e Sidney (1863-1926) Barnsley e Ernest Gimson (1864-1919). Em 1893, procurando a integração com a natureza, pregada pelo movimento, unindo vida e trabalho, deixaram Londres. Nesta época, os três estavam envolvidos na produção de mobília em uma oficina que operavam juntos.

Ernest Barnsley produziu uma das últimas e maiores casas de campo do Arts and Crafts, Rodmarton Manor em Gloucestershire, entre 1909 e 1926. A construção, interrompida apenas no período da guerra, foi executada na tradição das Cotswolds. Toda a madeira e a pedra foram retiradas do local e ali mesmo trabalhadas. A casa foi toda construída à mão - mesmo a serra circular não foi utilizada. Obediência estrita aos princípios de Ruskin. "Também mostra o pior lado da aversão do Arts and Crafts à máquina," a recusa em poupar os trabalhadores do trabalho exaustivo e repetitivo através do uso de novos equipamentos, "Enquanto Gimson e os Barnsleys passavam um período idílico combinando trabalho criativo e contato direto com o campo, dois homens, pai e filho, consumiram grande parte de suas vidas na opressiva e repetitiva tarefa de serrar madeira à mão. O serviço teria sido executado de forma muito mais fácil e menos degradante com uma serra circular, como arquitetos como Voysey e Ashbee compreenderam." (DAVEY, 1999, p. 165). 


\subsubsection{Revivendo e ensinando o artesanato}

Em 1886, surge a Art Worker's Guild, uma estrutura hierárquica bastante fechada. Seus membros eram eleitos e presididos por um Master. Em 1886, um grupo de designers, a maioria membros da guilda, sentiu a necessidade de um maior contato com o público e liderados por Walter Crane $^{13}$ (1845-1915) e W.A.S. Benson(18541924), arquiteto que também trabalhava com metal, propuseram em 1887 uma exposição pública anual de Combined Arts (Artes Associadas) que CobdenSanderson (1840-1922), designer e encadernador de livros, pela primeira vez denominou Arts and Crafts. O objetivo, estabelecer certo status para os artistas e artesãos e colocá-los em contato com a indústria e os consumidores de seus produtos.

Outras organizações por toda a Bretanha pretendiam manter ou reviver as técnicas regionais de artesanato. A utilização do artesanato como uma ferramenta na reforma moral tornou-se lugar comum em toda a Grã-Bretanha. O objetivo era ocupar as horas de lazer dos trabalhadores, que os reformadores temiam fossem gastas bebendo e jogando. Aulas de artesanato para homens e mulheres, envolvendo: trabalho em metal, escultura em madeira, fiação, tecelagem, tricô, renda, bordado.

Selwyn Image coloca como a idéia, tão presente no Arts and Crafts, da educação pela arte foi inspirada por Ruskin.

Ele criou ao redor de todo o tema da arte, em todas as suas ramificações, uma nova atmosfera. (...) arte não era apenas uma questão de simples bom gosto, para o luxo de especialistas, mas realmente uma questão de profundo e amplo interesse humano pela sociedade como um todo. Não mais deveria ser olhada como um adorno para a vida, mas algo necessário para resgatar a vida da brutalidade, para literalmente fazê-la vida humana. (IMAGE, 1907, p. $\mathrm{X})$

Escolas de artesanato foram fundadas por todo o país, a partir de um plano conjunto sob a direção de uma autoridade central, estabelecida com este propósito e ligada ao Museu South Kensington. O plano foi estabelecido após a Grande Exposição de

\footnotetext{
${ }^{13}$ Walter Crane era ilustrador de livros infantis, com os quais ele alcançou os mais distantes setores da população e também tornou-se o primeiro canal a transmitir as idéias amadurecidas na Inglaterra para o mundo não inglês. A inspiração para suas inovadoras ilustrações coloridas veio principalmente das gravuras coloridas japonesas com as quais a Europa recentemente tivera contato, já que, artisticamente, o Japão foi uma descoberta deste período. (MUTHESIUS, 1987, p.14)
} 
Londres, em 1851. Foi essencialmente o trabalho de Albert, o Príncipe Consorte, após prévia consulta com Gottfried Semper (o arquiteto alemão que era refugiado político na Inglaterra na época). Por muito tempo, tais escolas foram dirigidas como as da Alemanha: o estudo da arte baseado nas suas formas tradicionais. Mas, à medida que um novo desenho, baseado em um cuidadoso estudo da natureza, se desenvolveu no círculo de Morris foi também adotado nas escolas. O ensino não se basearia mais na cópia de formas antigas, mas no estudo da natureza. (MUTHESIUS, 1987, p. 14).

Por muitos anos, centenas de desenhistas, modeladores, arquitetos, professores de desenho e artesãos de todos os tipos surgiram nestas escolas, trabalhando e criando desta nova maneira.

Dentre as escolas mais importantes, a Central School of Arts and Crafts em Londres, aberta em 1896 e a Glasgow School of Arts. Os alunos eram encorajados a inspirar-se na vida moderna e a resolver seus problemas práticos e estéticos. Os estudantes deveriam desenvolver suas idéias manipulando os materiais ao invés de aterem-se à disciplina restritiva da prancheta. (CUMMING; KAPLAN, 1993 p.106).

"Por volta de 1900, quatro anos após a morte de Morris, o movimento inglês tornara o artesanato uma profissão multidisciplinar muito difundida. As cidades associavam-se através de suas escolas de arte, cada qual com suas atividades particulares - bordado e trabalho em metal, por exemplo, em Glasgow." (CUMMING; KAPLAN, 1993, p.88)

O mercado consumidor da classe média crescia e se estendia além dos objetos artesanais. Incluía a mobília para a casa, disponível em grandes lojas de departamentos nas grandes cidades inglesas. A mais importante delas, a Liberty em Londres, que vendia tanto produtos exclusivos, feitos à mão, quanto artigos saídos das fábricas.

Ligações surgiam com as indústrias locais, por todo o país. Alguns designers do movimento, como Gimson, colocavam-se totalmente contra o envolvimento com a indústria, enquanto outros, como Lethaby, foram aos poucos aceitando tal condição e implicitamente o trabalho feito pela máquina. Porém, tal trabalho não deveria imitar aquele feito pelas próprias mãos do artista, o que deveria ficar absolutamente claro.

A aceitação por Lethaby do status quo da indústria no início do século $X X$ foi uma inversão de seus ideais anteriores. (DAVEY, 1995, p. 74). Afinal, ele fora um dos líderes do movimento, um dos continuadores das idéias de Ruskin e Morris.

A admiração na Inglaterra pelo trabalho da Deutsche Werkbund, fundada na Alemanha em 1907, somada à competição pelo mercado internacional, levou à formação do 
Design Club em 1909 e da DIA (Design and Industries Association), em 1915. Como a Werkbund, "aceitava a máquina no seu devido lugar, como um invento que deve ser guiado e controlado, e não simplesmente posto de lado". ${ }^{14}$

Lethaby foi uma das principais figuras do Arts and Crafts, junto com Benson e Image, que aderiram à DIA e à aceitação do trabalho feito pela máquina. De forma mais limitada, Ashbee. Gimson, nunca:

Lethaby tentou persuadir Gimson, um de seus mais antigos amigos, a juntar-se à associação:

A questão parece ser (para ir direto ao assunto) quem se interessa pelo artesanato? (grifo de Lethaby) (...) Suponho que todos os designers que possuem oficinas tiveram, em tempos difíceis, que encarar o problema da máquina. Afrontei o problema freqüentemente - algumas vezes parece ser um dilema entre a mecanização ou não se conseguir manter o próprio negócio e tenho hesitado, mas sempre termino sabendo que, das duas alternativas, eu preferiria não manter meu negócio. E eu gostaria que você pensasse bem no assunto - $\underline{\text { do }}$ ponto de vista do artesão (grifo de Lethaby). Se o interesse de alguém pelo trabalho fosse apenas sobre desenho e utilidade, seria diferente, mas o interesse é também nos homens e nas suas condições de trabalho e, através disso, em muitas outras coisas na vida, como você sabe.

Inclusive, eu reconheceria os méritos das nossas grandes obras de engenharia em nossas cidades como sendo freqüentemente de real beleza e alguma (grifo de Lethaby) arte. De fato, devemos todos reconhecer que há e haverá um grande campo para motores e máquinas. (...). Mas, um dos objetivos da D\&l é mecanizar (...) este campo. (...) Porque sem o movimento do Crafts teriam eles esta necessidade de um aspecto melhor e mais vivo para os objetos ou usariam seu próprio julgamento sobre o bom e o mau desenho ${ }^{15}$

\subsubsection{Arquitetos}

\footnotetext{
${ }^{14}$ The Beginnings of a journal of the D.I.A., 1916, p.6 apud PEVSNER, 2002, p.23.

${ }^{15}$ LETHABY, carta a Ernest Gimson, 18 de Abril de 1916, de uma cópia nos arquivos Burrough, CAGM. In: GREENSTED, 2005, p.70-1.
} 


\subsubsection{Philip Speakman Webb (1831-1915)}

Philip Webb fez casas mais simples e modestas que as de Shaw, mas, procurando as melhores técnicas construtivas e os materiais mais refinados. Ao contrário de Shaw, ele não se preocupava em evitar deliberadamente a simetria externa. Nos anos 1870, Webb utilizou-se da simetria em várias obras, como na Lincoln's Inn Fields em Londres e em outras casas desta década. Em Standen, Sussex, de1891, ao contrário, estarão presentes o princípio da variedade (changefulness) de Ruskin, e o mandamento de Pugin, de que um edifício deveria refletir suas funções. As aberturas são diferenciadas: janelas fixas (leaded lights) para locais de circulação e grandes janelas guilhotina para dormitórios. O princípio de Pugin de fidelidade ao local é seguido através do uso de diferentes materiais - madeira, pedra e tijolo - e técnicas construtivas locais.

Nos anos 1880's, vários assistentes de Norman Shaw se voltaram para Webb por uma inspiração diferente daquela do Old English de Shaw e por uma abordagem diferente para o projeto arquitetônico.

"Webb discordava de Ruskin sobre o fato de uma grande arquitetura poder desenvolver-se a partir do revival do estilo Gótico. Webb considerava que os revivals de estilos passados degradavam a arquitetura." (KIRK, 1998, p.146). Porém, os fundamentos da arquitetura estariam no passado; assim um estilo completamente novo seria impossível.

Longe das perspectivas pinturescas e dos livros que serviam de modelo de estilos, ele decidiu procurar a experiência dos construtores e as características do local, adequando-se ao clima e à paisagem do país.

Desde a Red House, de 1859, ele começara a desenvolver sua própria maneira de projetar, partindo de uma planta bem resolvida, de acordo com as necessidades e os desejos do cliente. Uma construção sólida e durável, com os confortos da vida moderna. Em suas composições, contrastes entre luz e sombra, entre linhas e planos diagonais, verticais e horizontais. 


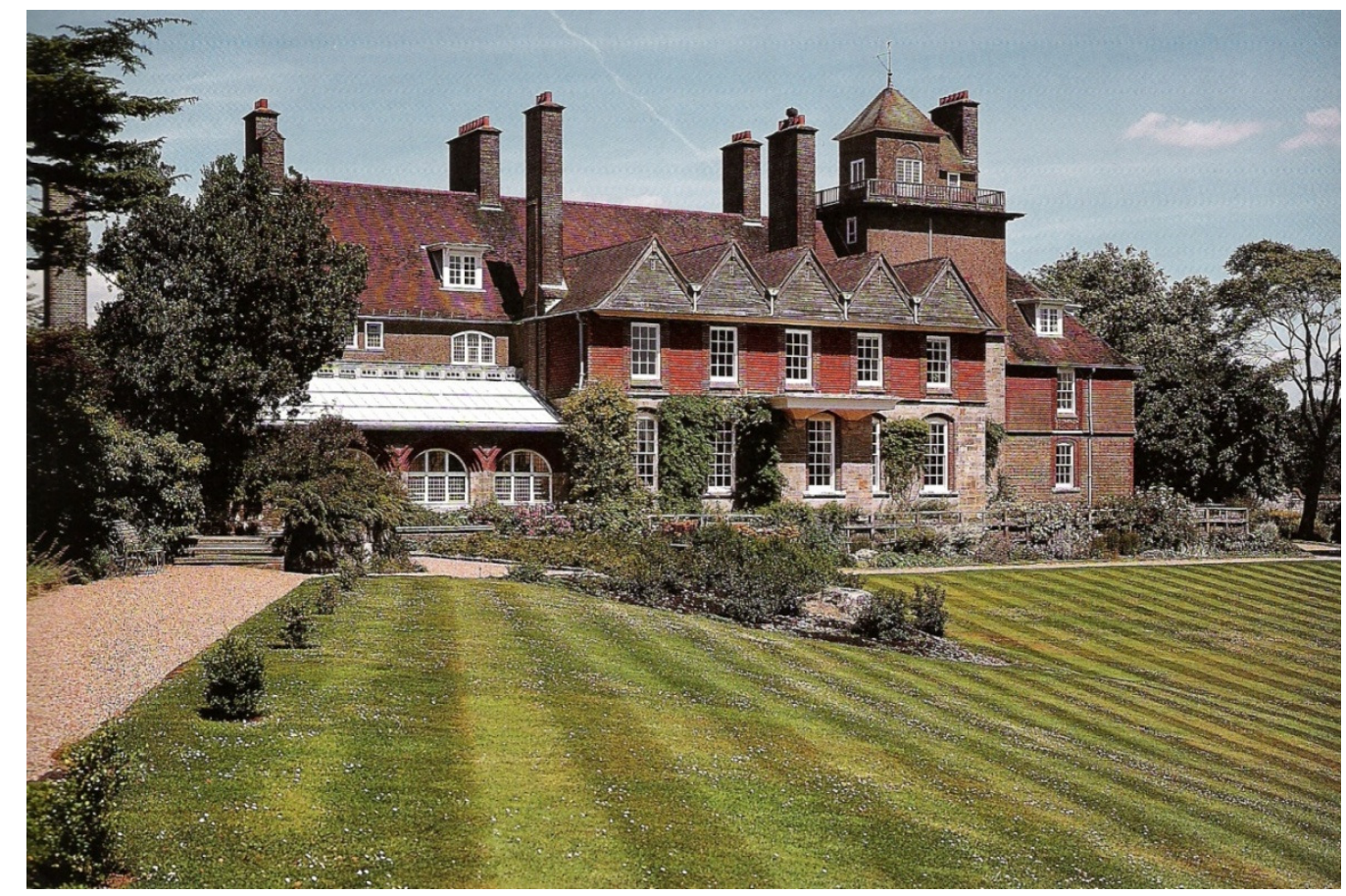

Fig.1. 3 Standen.

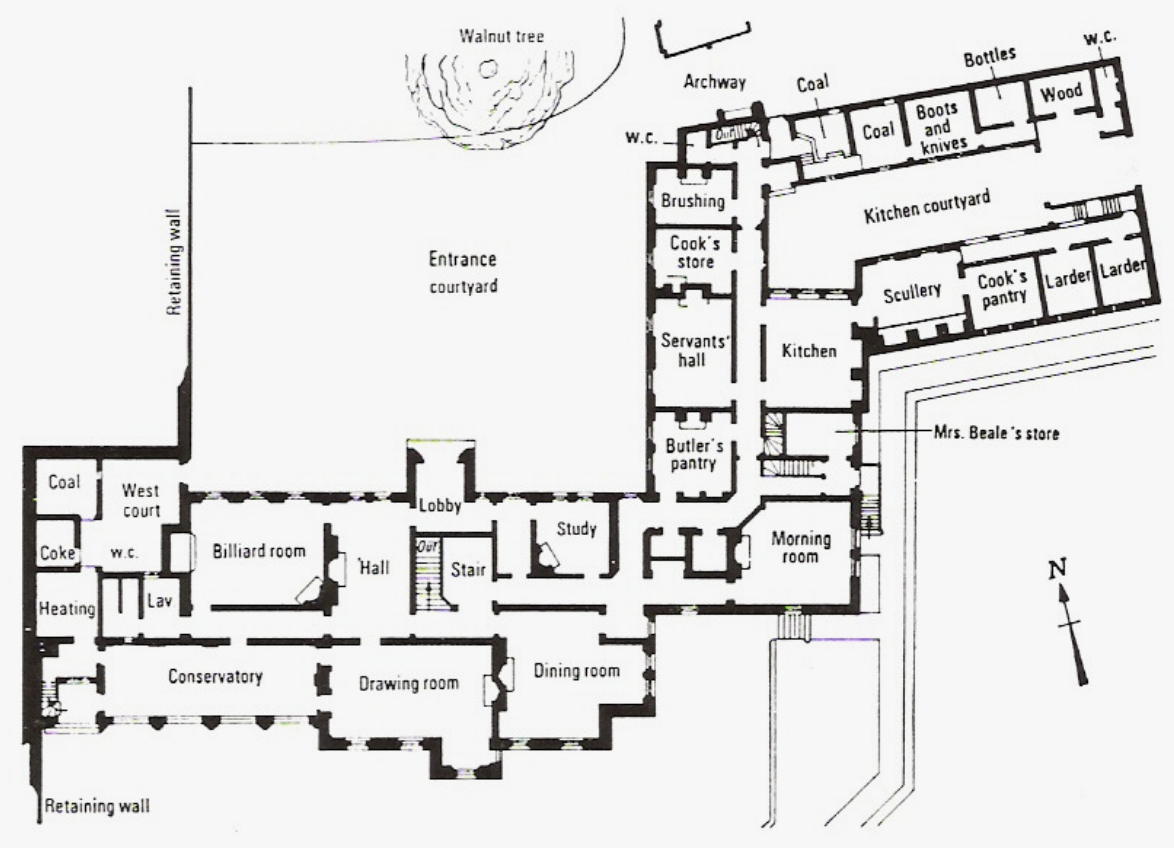

Fig.1. 4 Standen - planta baixa do pavimento térreo. 


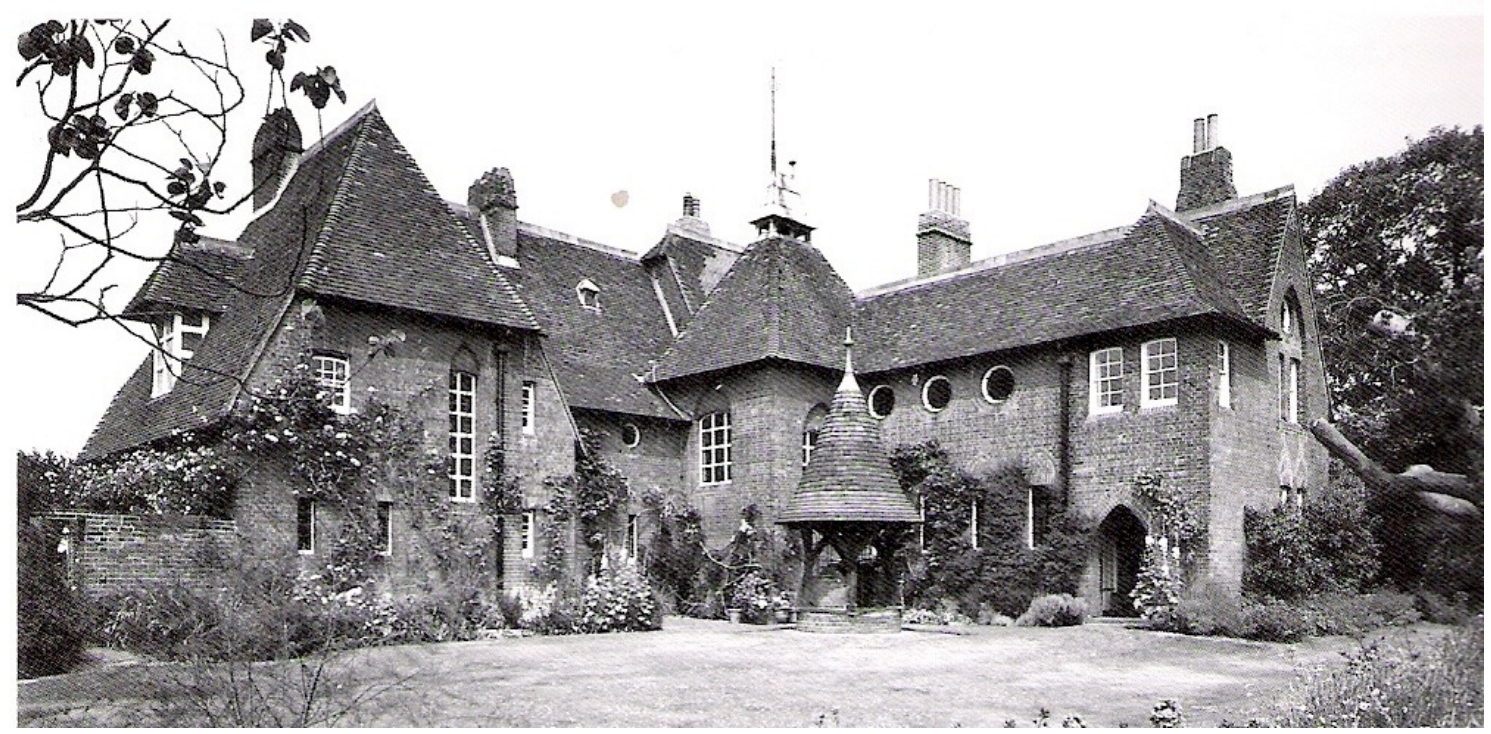

Fig.1. 5 A Red House- "Fachada do poço".

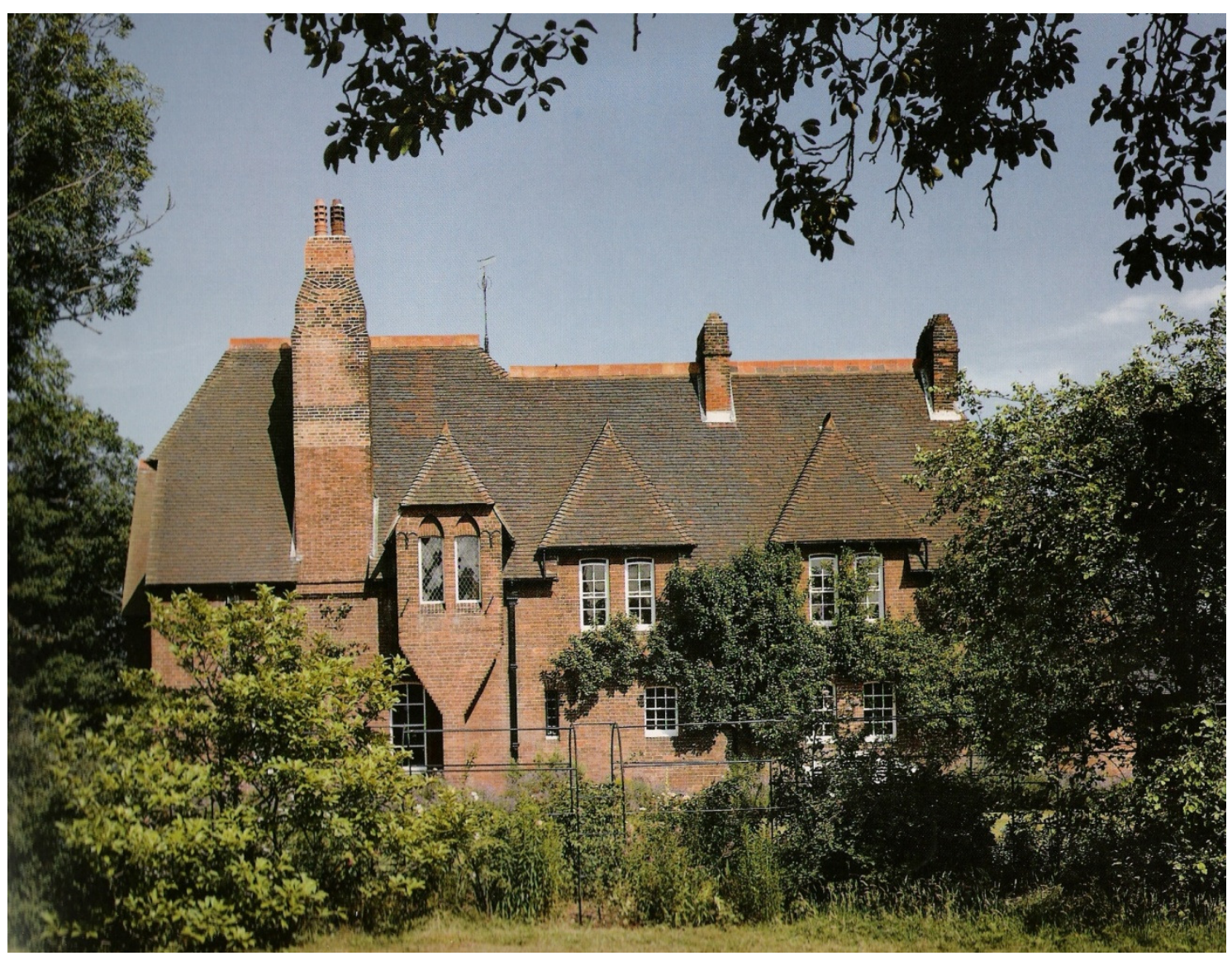

Fig.1. 6 Red House - outro ângulo.

"Webb raramente usava ornamentos entalhados. A seu ver, a afirmação de Ruskin de que um edifício sem ornamentos não poderia ser arquitetura era um engano. Para Webb, arquitetura significava construção, não construção decorada" (KIRK, 1998, 
p.147). Seus edifícios eram valorizados, por exemplo, pela textura e cores dos materiais utilizados, não por uma policromia arbitrária.

Webb só discutia um projeto com um cliente após cuidadoso levantamento do local, no qual passava várias horas, às vezes dias, examinando o terreno, a região e os prédios existentes em detalhe, para que pudesse "desfigurar a paisagem o mínimo possível com os edifícios a serem construídos". ${ }^{16}$ Assim, procurando harmonizar o edifício com a paisagem, Webb utilizava os mesmos materiais e formas dos edifícios ali existentes, mas não copiava seus detalhes. Assim, em determinada região ele utilizava os materiais locais, tanto pela facilidade de obtenção quanto pela harmonia com a paisagem. Pedras deveriam ser encontradas no local e trabalhadas conforme 0 costume, com as mesmas ferramentas. Evitando todo tipo de imitação, Webb construía acréscimos a prédios antigos que pareciam modernos.

Webb também utilizava novos materiais e tecnologias, se estivesse convencido de que eram aperfeiçoamentos funcionais e visuais de materiais antigos, como colunas de ferro fundido, vigas de ferro, fundações e vergas em concreto. Apesar disso, ele disse a George Jack que um edifício completo em concreto não seria arquitetura. ${ }^{17}$ Consultava especialistas em abastecimento de água, drenagem, aquecimento, mas ele mesmo sempre se manteve informado sobre as novas tecnologias necessárias ao conforto moderno. Aprovava o uso de máquinas para reduzir o trabalho humano mais cansativo, mas não deixava de acreditar que a máquina encorajava o descuido e a desatenção.

Todos os elementos em seus edifícios eram funcionais: chaminés, por exemplo, eram usadas como pontuação visual, como âncoras ou pivôs, mas seu propósito primordial era a funcionalidade. (KIRK, 1998, p.149)

Webb mostrou que era possível a um edifício moderno mostrar suas características locais e nacionais, sem cópias de estilos passados. Sua abordagem ao regionalismo pode se repetir em qualquer local, a qualquer tempo. Ele foi o grande mestre para os arquitetos do Arts and Crafts.

\subsubsection{William Richard Lethaby (1857-1931)}

\footnotetext{
${ }^{16}$ Carta de Webb para G.P. Boyce, 26 de Setembro de 1883, British Library Add., MS 45354 apud KIRK, 1998, p. 148.

17 JACK, George. An Appreciation of Philip Webb, Architectural Review, 38, Julho de 1915, p.5 apud KIRK, 1998, p. 153.
} 
Lethaby chefiou o escritório de Shaw por doze anos. Com ele, desenvolveu novas idéias sobre racionalidade na construção e sobre o ajuste às necessidades. Outra grande influência nesta fase foi a de Phillip Webb. Ambas as influências podem ser vistas em um mesmo projeto: AvonTyrrell, com as janelas com pequenos panos de vidro e as bay windows, típicas do Queen Anne de Shaw. E, no topo da fachada, os quatro espigões que lembram Standen, de Webb, da mesma época.

Lethaby, a partir de 1896, passa a dedicar-se também ao ensino, inicialmente como diretor da London County Council's Central School of Art and Crafts

Também foi professor de design no Royal College of Art. Alfred Powell, arquiteto e artesão, seu biógrafo, comenta que Lethaby “(...) nos mostrou os esforços dos homens para se ligar ao Universo, através de sua arte (crafts) e assim assegurar estabilidade em um mundo efêmero". (Burman, 1998, p. 110).

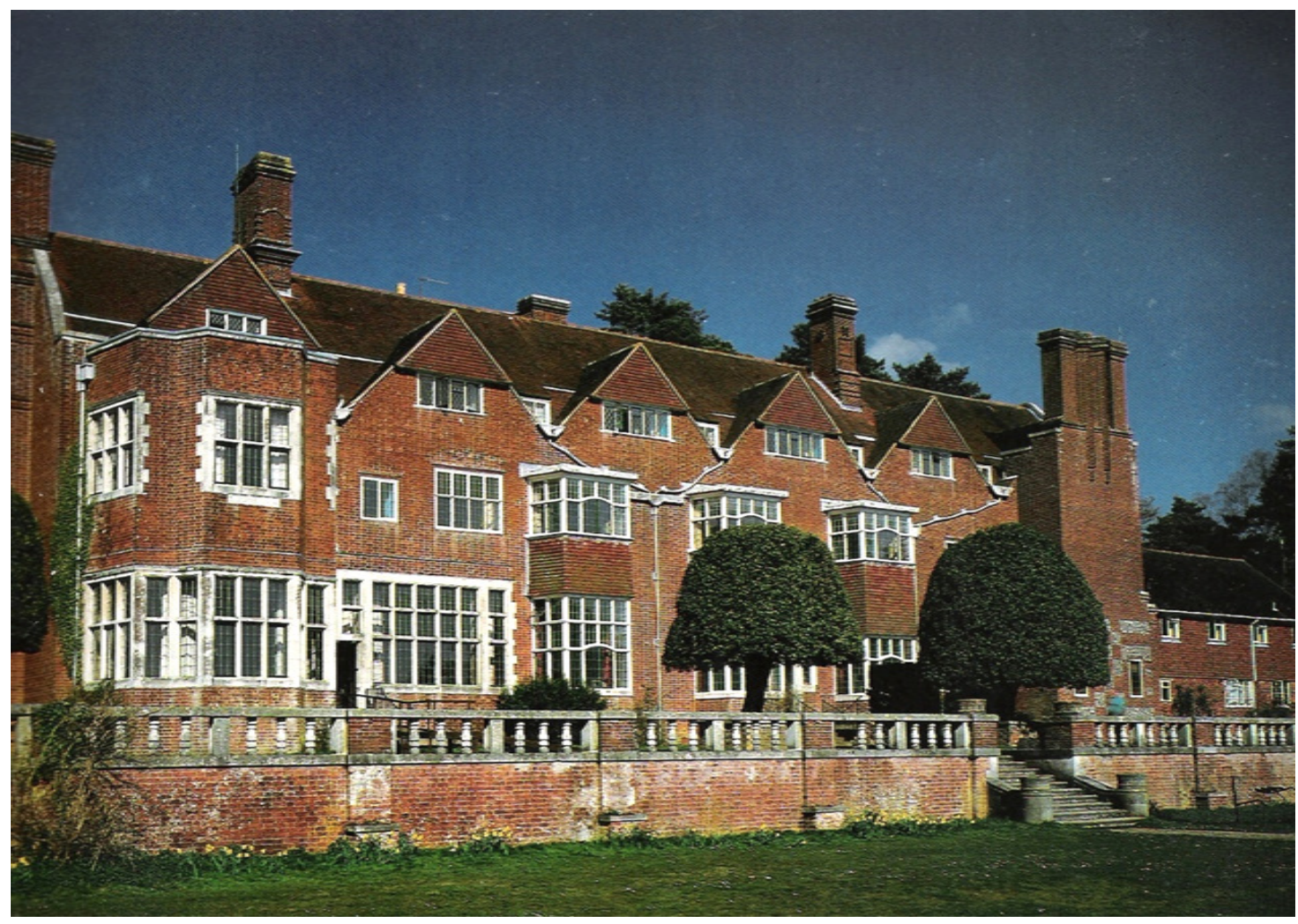

Fig.1. 7 AvonTyrrell - fachada principal.

Lethaby tornou- se um dos mais influentes arquitetos do início do século $\mathrm{XX}$, o grande teórico do movimento Arts and Crafts. Falando sobre a arquitetura do futuro, coloca:

Como será, então, esta arte do futuro? A mensagem ainda será sobre a natureza e o homem, sobre ordem e beleza, mas tudo será 
delicadeza, simplicidade, liberdade, confiança, e luz; a outra é passado, e é desejável que seja, pois seu objetivo era subjugar a vida; a nova, do futuro, é para amparar a vida e educá-la, 'para que a beleza possa fluir pela alma como uma brisa'. (LETHABY, 2004, p.8)

Quando Lethaby se refere assim à arquitetura do futuro, ele a contrapõe àquela do passado que, para ele, apesar das construções estupendas, como as pirâmides do Egito, teve "cada pedra cimentada com o sangue de uma criatura humana". (LETHABY, 2004, p.8)

O que quero então perguntar, quais são os fatos básicos por trás de toda arquitetura que Ihes deu sua forma? Principalmente três: primeiro necessidades e desejos similares do homem; segunda sobre a estrutura, as necessidades impostas pelos materiais, e as leis físicas (...); e terceiro (...) natureza. É sobre esta última que me proponho falar; a influência dos fatos conhecidos e imaginados do universo sobre a arquitetura. (LETHABY, 2004, p.3).

Tudo tinha como referência o ritual e a pompa da natureza; assim o homem se uniria a ela e partilharia de sua força.
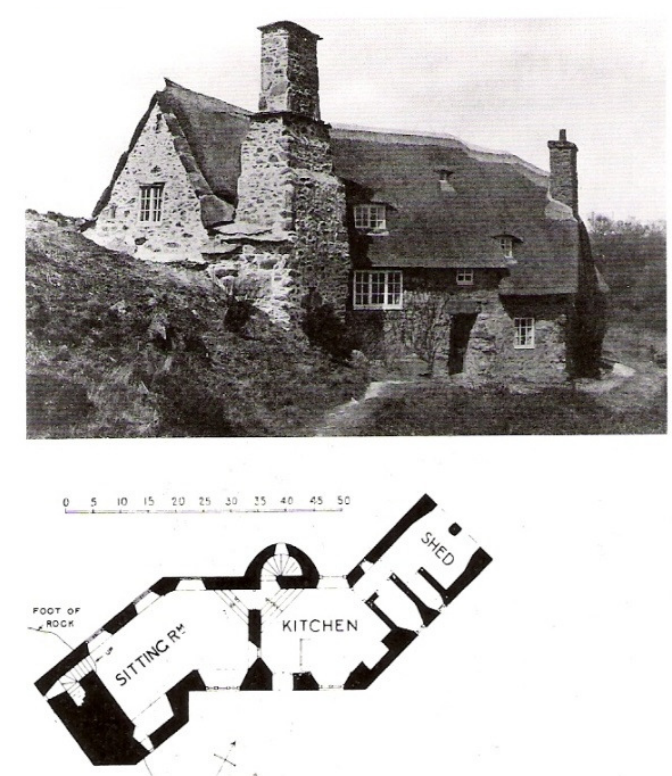

Fig.1. 8 Stoneywell Cottage- Ernest Gimson

Neste trecho citado, Lethaby coloca alguns postulados do Arts and Crafts: o atendimento das necessidades e desejos do homem; a adaptação à paisagem, seguindo o princípio da fidelidade ao local de Pugin. Esta fidelidade chega a extremos em que o edifício parece ter brotado da terra, como no Stoneywell Cottage de Ernest Gimson (1898). 
Como teórico, Lethaby escreve sobre o Gótico, e é possível estabelecer paralelos entre seu relato e o próprio movimento Arts and Crafts:

A forma da sociedade medieval na Cristandade Ocidental foi aperfeiçoada no século treze. Esta foi a grande era da filosofia teológica, da expansão monástica, da organização de comunidades urbanas, guildas de artesanato e universidades, assim como de fruição artística. Pouco antes, a sociedade era violenta e a arquitetura rudimentar, pouco depois, as forças da ruptura apareceram e o Gótico romântico abriria caminho para o Gótico comercial. (LETHABY, 1937 (1911), p.197)

Quando se fala em idealização da vida medieval, trata-se especificamente do século XIII, e da maneira como a arte era produzida e fruída, como se desenvolvia a vida em comunidade. Este contraponto torna-se mais claro com a descrição das cidades inglesas em plena revolução industrial: desumanas, cinzentas, caóticas.

É impossível explicar em palavras o conteúdo da perfeita arte gótica. É franca, clara, alegre; é apaixonada, mística e sensível; é vigorosa, luminosa, penetrante, forte e sã. Nasceu da terra e das pessoasuma arte do povo. Tentar defini-la apenas baseado na forma seria um erro; ela personificou um espírito, um anseio, uma era. Os ideais da época, de força e ordem, produziram um tipo de edifício de grande intensidade. Todo o supérfluo foi banido e o trabalho em pedra concentrado em partes funcionais ativas. Estas nervuras, barras e colunas estão todas tensionadas. Um pedreiro baterá levemente em um pilar para fazer sua força audível; podemos considerar uma catedral como tão 'sensível' que se tocada, uma nota musical seria ouvida.

(...) uma grande igreja não era um ensaio em design para a satisfação do gosto; foi desenvolvida organicamente, e outrora, particularmente, o organismo era perfeito. (LETHABY, 1937, (1911) p.200)

Definir a arquitetura Arts and Crafts pela forma ou por um estilo seria impossível. Ela deve ser caracterizada pelo espírito do Gótico, reavivado, em sua ordem, clareza e racionalidade. A simplicidade é almejada e o supérfluo deve ser esquecido. O edifício é um organismo, suas partes estão conectadas entre si e com o todo.

O desenho da superestrutura de uma grande igreja foi concebido como um problema de equilíbrio. (...) A estrutura, como Morris bem 
colocou, tornou-se orgânica. Esta foi a lei do desenvolvimento da arquitetura gótica. (LETHABY, 1937 (1911), p.201)

A planta baixa de uma catedral foi lentamente desenvolvida por experimentos contínuos no ajuste das partes para obter máxima eficiência (...). Uma planta é a base e a chave para a totalidade da construção. (LETHABY, 1937 (1911), p.198)

O 'estilo' Gótico não foi, claro, uma forma de construir apenas igrejas. Os castelos, muralhas e portões, pontes e casas, eram não menos góticos; escultura, pintura, vitrais, eram todos partes de uma arte. (LETHABY, 1937 (1911), p.205)

O organismo deve estar em equilíbrio, assim como o edifício, desenvolvido a partir da planta baixa, com vistas ao melhor desempenho.

A totalidade do ambiente construído era gótica. Da totalidade do edifício Arts and Crafts faz parte seu interior e seu exterior, tudo uma grande obra de arte.

Outro ponto do qual Lethaby sempre fala é o trabalho, inspirado no modelo das guildas e das comunidades medievais. Powell cita o artigo de Lethaby sobre 'Labour' (Trabalho), publicado no Hibbert Journal em 1921, onde diz: "O trabalho é o tema por nós mais conhecido, o grande alicerce de nossas vidas" e a Arte "corpo e mente personificados no trabalho digno." (Burman, 1998, p.111). Um legítimo discípulo de Ruskin e Morris. Ainda sobre arte, Lethaby coloca: "Toda arte é sentimento incorporado à forma. Para encontrar a beleza, devemos refletir sobre o que realmente nos dá prazer - prazer, não orgulho - e demonstrar nosso verdadeiro deleite." (ensaio sobre Carpenter's furniture apud Burman, 1998, p. 118).

Lethaby escreveu uma biografia de Philip Webb, Philip Webb and his work, onde coloca que a arte era uma palavra chave para Morris e Webb, encarada não como um luxo, mas como trabalho executado com prazer.

No mesmo livro, Lethaby fala da importância da experiência prática para os arquitetos: "o início do aprendizado de construção e projeto deve ser no trabalho nas oficinas. A arquitetura é um trabalho de responsabilidade, como comandar um navio. A construção é a arte do fazer." (Burman, 1998, p. 120). Sobre Webb, Lethaby, diz: "a melhor parte do que Webb aprendeu sobre construção ele diria que foi obtido em discussões com trabalhadores". (Burman, 1998, p. 120). A importância do saber fazer para a qualidade do projeto é crucial para Lethaby: "(o) desenho correto é indispensável à boa qualidade e envolve a escolha de materiais bons e adequados, percepção do propósito, habilidade no trabalho, acabamento adequado, e assim, muito 
mais que simples ornamento; e na verdade, a decoração era antes uma exuberância do trabalho refinado do que uma questão de meras linha abstratas". (prefácio da coleção The Artistic Crafts Series of Technical Handbooks, editada por Lethaby, apud BURMAN, 1998, p. 122).

Importante também para ele era a noção de arte em nosso trabalho diário: "A beleza só pode ser trazida de volta à vida diária quando fizermos nosso simples trabalho de forma interessante". (LETHABY, 1957, p.162 apud DAVEY, 1995, p. 70).

Lethaby era extraordinário na mescla de técnicas de construção antigas com novas tecnologias, como prova a cobertura de sua igreja All Saints Church em Brockhampton: concreto coberto com colmo ${ }^{18}$ (thatch), um material tradicional de Herefordshire. Esta mistura parece, à primeira vista, apenas algo pitoresco. Mas na verdade, o colmo é um material isolante térmico e impermeabilizante. Mostra o refinamento de Lethaby, mesclando uma técnica moderna, o concreto, com um material tradicional do local - que não apenas "lembra" os edifícios locais, mas porque é uma boa solução técnica. Aliás, falando sobre o concreto, Lethaby, diz que:

O concreto armado moderno é apenas uma forma mais eficaz do sistema romano de construção. Se pudermos acabar com nosso medo de que seja um material sem arte, e corajosamente construirmos uma estação de trem, um museu, uma catedral, ampla e simples, plenamente iluminada e convocarmos nossos pintores para completar as paredes, poderemos nos interessar novamente em edificar quase imediatamente. (LETHABY, 1937 (1911), p. 245).

Porém, ele não fala em residências. E frisa que devemos convocar nossos pintores para completar as paredes. E a verdade dos materiais?

A igreja em Brockhampton é um dos maiores monumentos do Arts and Crafts, combinando variedade, rudeza (savageness) - os artesãos tiveram liberdade na criação da decoração-, fidelidade ao local. (DAVEY, 1995, p. 69). Lethaby acreditava que a boa arquitetura era, antes de tudo, "uma estrutura perfeita com adequado acabamento." (CUMMING; KAPLAN, 1993, p. 39).

\footnotetext{
${ }^{18}$ Espécie de fibra vegetal.
} 


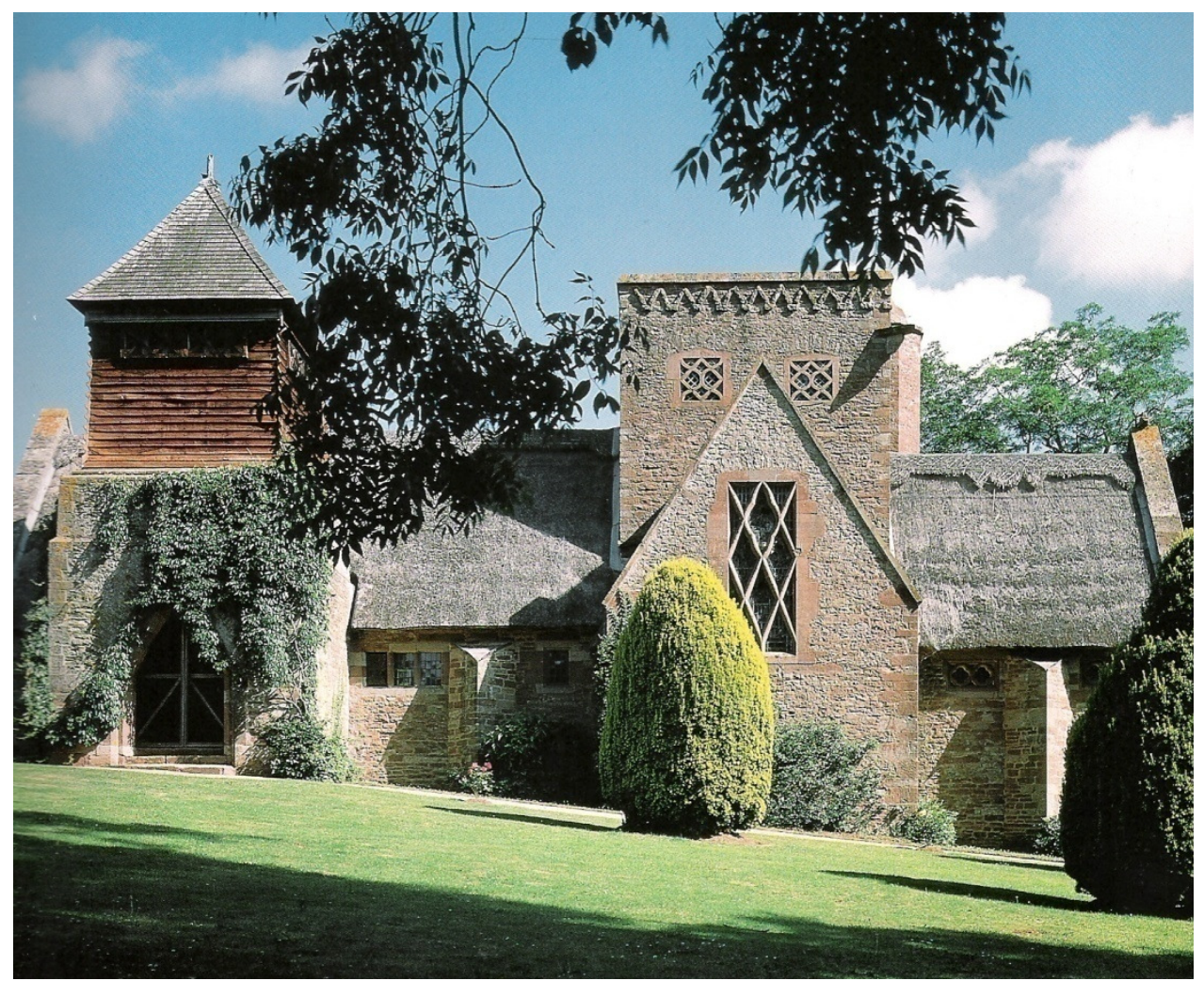

Fig.1.9 All Saints Church, Brockhampton.

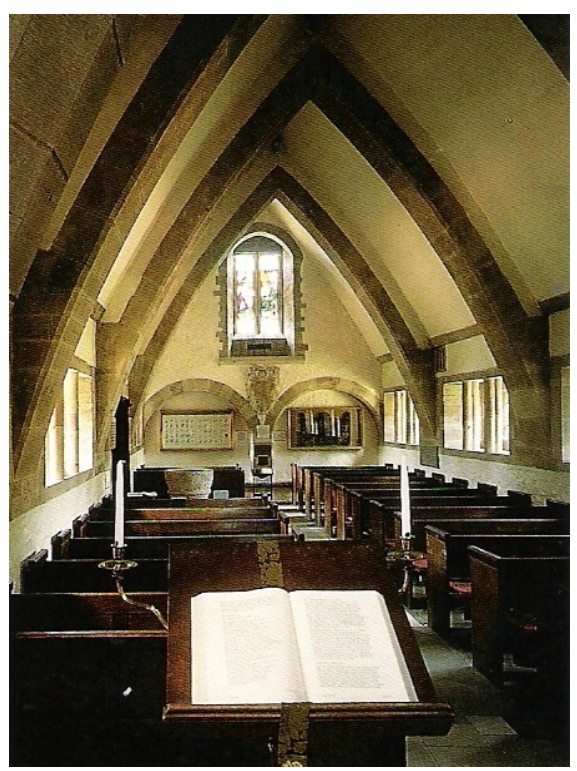

Fig.1.10 All Saints Church, Brockhampton - interior.

\subsubsection{Edward Schroder Prior (1852-1932)}

Prior, outro pupilo de Shaw, criava plantas notáveis, que enfatizavam o papel da casa como abrigo, como a planta butterfly (borboleta), uma alternativa às plantas em L, 
muito utilizadas pelos arquitetos Arts and Crafts.Os dois 'braços' da planta curvam-se, a dar as boas vindas aos visitantes.

Foi, porém, nas técnicas de construção que Prior mais se aproximou dos ideais de Ruskin, utilizando materiais encontrados no local. Ele leva esta idéia tão longe, que os agregados para o concreto em Kelling Place e os seixos para a fachada foram retirados do próprio solo, cavando-se um enorme buraco em frente à casa.

Como Lethaby, Prior se interessava muito pela utilização do concreto. Os arquitetos do Arts and Crafts tinham uma atitude ambígua em relação a este material. $\mathrm{Na}$ St. Andrews Church, Prior utiliza arcos executados em concreto armado, com revestimento em pedra. Randall Wells, o encarregado da obra, respondeu às críticas sobre a falta de honestidade dos materiais dizendo que grandes volumes de pedra necessitam um suporte e a opção mais econômica seria o concreto.

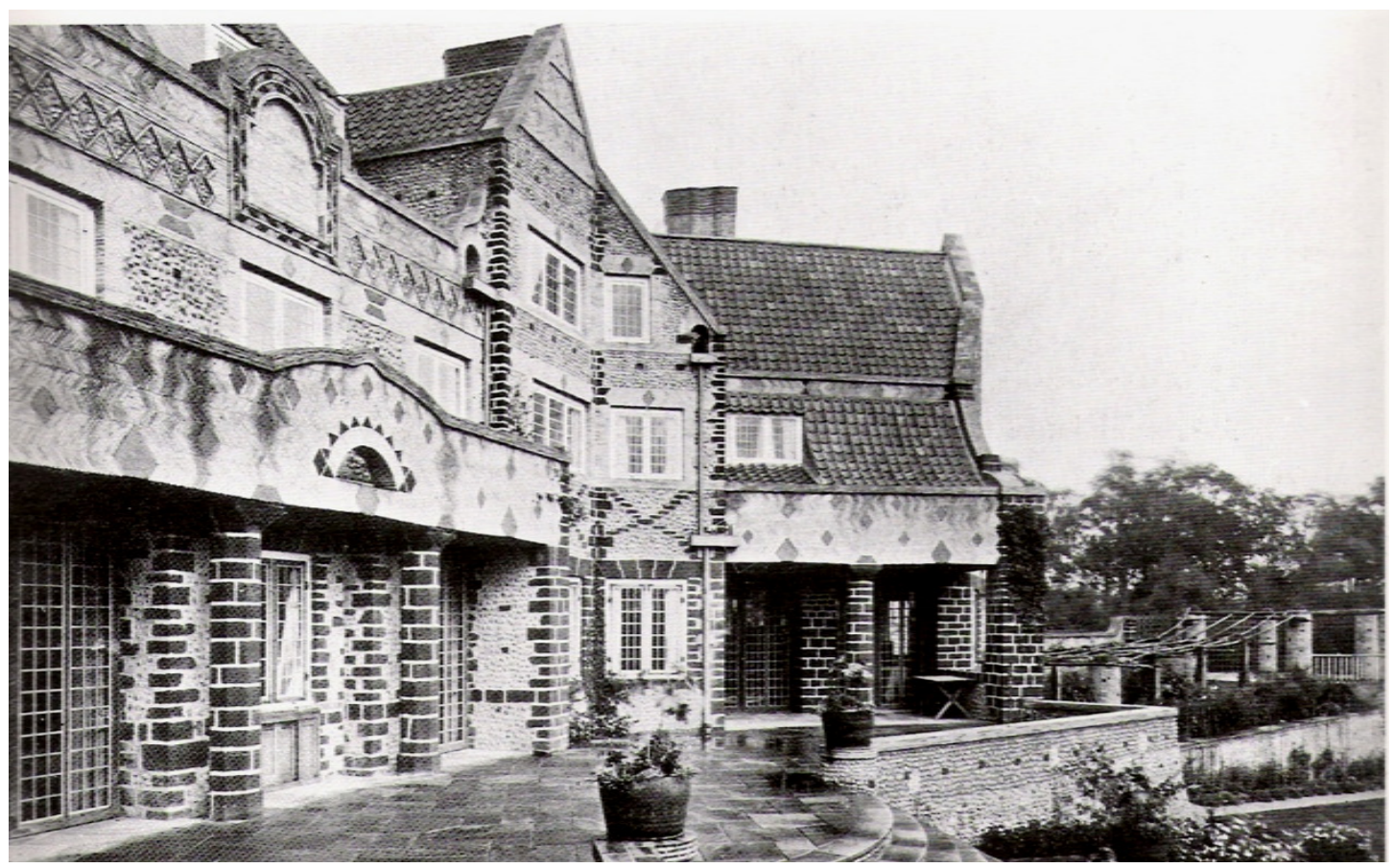

Fig.1. 11 Home Place, fachada principal. 


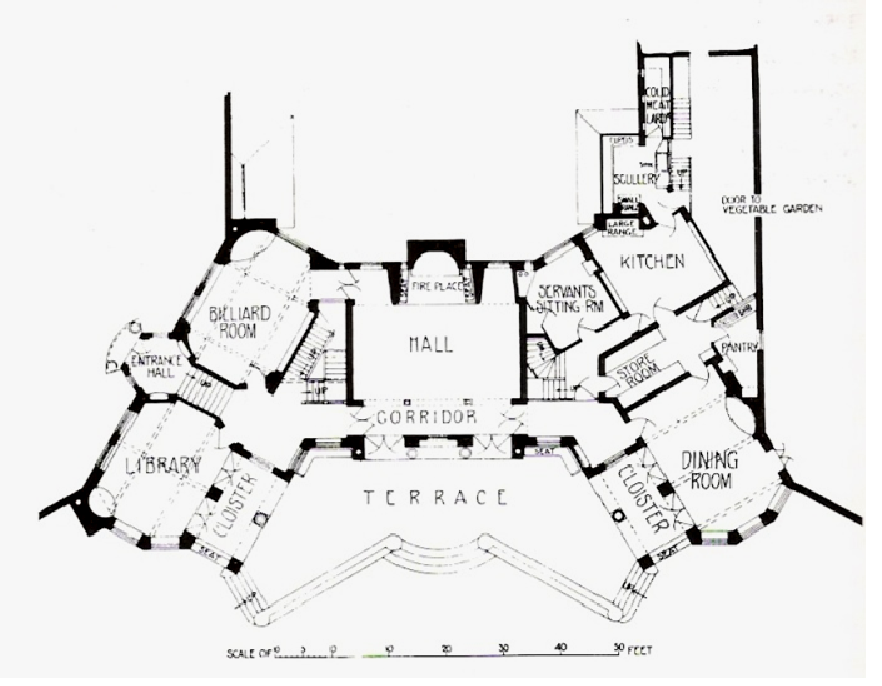

Fig.1. 12 Home Place, Norfolk (1903-1905), planta baixa.

\subsubsection{Charles Francis Annesley Voysey (1857-1941)}

Nenhum arquiteto inglês era mais retraído e insular que Voysey. Provavelmente só fez uma única viagem ao Continente, aos países baixos, em 1906. Não gostava de influências estrangeiras. Em uma palestra dada a estudantes de arquitetura na University College em Londres (não se sabe a data exata, em seus papéis foi anotada no dia 10 de março de 1934), ele diz: "A melhor arquitetura no passado sempre foi natural de seu país e originou-se do conhecimento das necessidades e condições locais. Necessidades incluíam as do corpo, da mente e do espírito; condições, clima e características nacionais". (Burman, 1998, p. 95)

Por que (...) deveria a Inglaterra virar as costas a seu próprio território e fingir que nasceu tão híbrida que não pode ter uma verdadeira arquitetura nacional? Ela não tem um clima nacional? As suas condições geológicas e geográficas são as mesmas de todos os outros países? Não há diferenças entre homens ingleses e homens italianos? (...) Por que, então, nós tentamos insistentemente imitar os modos estrangeiros? (VOYSEY, 1911, p.60 apud DAVEY, 1995, p.97)

Apesar disso, Voysey desenvolveu um estilo que, apesar de possíveis variações locais era aplicável a muitos lugares. (DAVEY, 1995, p. 89). Talvez este seja um dos motivos, obviamente além da qualidade de sua arquitetura, da grande influência 
exercida sobre seus contemporâneos, não apenas na Inglaterra, mas também nos Estados Unidos e na Europa Continental.

Era conservador em muitas de suas opiniões, talvez resultado de sua educação. Foi educado por seu pai - um pastor - em casa e dele herdou "um amável puritanismo que permeou sua vida." Sua fé era fundamental para seu trabalho e para sua vida. De acordo com os ensinamentos do pai, sua crença era simples e direta sem rituais intervenientes. Seu individualismo era conseqüência da crença de que o propósito de nossa existência seria o incremento de nossas qualidades individuais, oferecidas por Deus.

Para Voysey o coração - figura que pode ser vista em várias de suas casas - era um símbolo para o amor de Deus. Ele escreveu sobre a importância do simbolismo na arte.

Voysey sempre se considerou um individualista. Segundo ele, "Coletivismo, convenção e moda tiram sua força da supressão da personalidade, forçando mentes e corpos a certas rotinas (...) coletivismo é uma forma de compulsão e assim não pode ter o mesmo valor ético e efeito no caráter que a livre escolha individual deve ter. Pouco esforço é necessário para nadar a favor da corrente."19 "Acreditava que a felicidade só poderia ser alcançada quando homens de todas as classes aprendessem a aceitar sem questionamentos as posições e responsabilidades para as quais haviam nascido".( BRANDON-JONES, 1998, p. 98) Apesar de admirar os desenhos de Morris, Voysey não tinha nenhuma simpatia pelo socialismo.

Iniciou sua carreira com desenhos para The British Architect. Os primeiros, publicados nos 1880's, eram românticos, pinturescos, devido à influência exercida por George Devey, em cujo escritório trabalhara. Devey, em suas casas de campo e seus cottages, desenvolve uma espécie de Old English, com profusão de materiais, volumes que se projetam e desenho pinturesco.

Nestes primeiros projetos de Voysey, a preocupação com o aspecto econômico ainda não está presente. Isto acontecerá nos anos 1890's, através, por exemplo, do uso do roughcast ${ }^{20}$. Com uma parede não tão grossa com este revestimento, seriam possíveis conforto térmico e proteção contra as intempéries equivalentes a uma parede mais espessa. Contrafortes eram introduzidos para restituir à parede a firmeza

\footnotetext{
${ }^{19}$ VOYSEY, notas autobiográficas não publicadas, 1931 apud BRANDON-JONES, 1998, p. 96.

${ }^{20}$ Roughcast seria a primeira camada de reboco. Um material irregular como cascalho, pedra triturada ou areia grossa é misturado ao reboco, resultando em uma massa grossa e jogada sobre uma base enquanto está flexível. (WARE; BEATTY, 1952, p. 103-4).
} 
perdida - provavelmente eram muito mais uma expressão da solidez que pedia o senso estético do arquiteto do que uma necessidade construtiva real. (ANON.,1927, p. 315 apud HITCHMOUGH, 1995, p. 35). A racionalidade e a independência de Voysey Ihe permitiam mesmo a utilização do revestimento na parede externa, algo desaconselhado por Ruskin.

Em seu primeiro projeto construído, em 1888, um cottage em Bishop's Itchington, Voysey utilizou telhas de cimento como cobertura, provavelmente em colaboração com seu cliente, um fabricante do material. O objetivo era explorar o potencial do cimento na indústria da construção.

A ênfase nas linhas horizontais da sucessão de telhados desta casa e as mullioned windows ${ }^{21}$ tornaram-se, junto com o roughcast, marcas de seu trabalho posterior.

Porém nesta época ainda publica projetos com composições ecléticas como The Veranda House (The British Architect, fevereiro, 1889), com paredes em pedra, uma grande chaminé e empena com uma cruz como detalhe. O ecletismo fica patente no fato de Voysey apresentar dois desenhos alternativos para o tratamento da fachada.

À medida que Voysey torna-se mais experiente, as últimas lembranças do Old English são deixadas de lado.

Outra marca de Voysey seriam os tetos baixos, que aparecem na Tower House, de 1889, em Bedford Park, juntamente com a preocupação com a ventilação adequada. Voysey acreditava que cômodos altos destruíam o efeito da horizontalidade e repouso. Cômodos com pé direito mais baixo seriam melhores para ventilar, iluminar e aquecer. A horizontalidade de grande parte de seu trabalho deriva de sua crença no simbolismo das linhas retas, baixas, alongadas. (DAVEY, 1995, p. 92):

Quando o sol se põe, a horizontalidade prevalece, quando estamos cansados, nos reclinamos, e a escuridão oculta as diferenças e esconde todos os detalhes sob um véu harmonioso, enquanto nós, também, fechamos nossos olhos para descansar. O que, então, é evidentemente necessário para se ter a impressão de repouso em nossas casas (é) evitar angulosidades e complexidades na cor, forma ou textura, e fazermos as linhas dominantes horizontais, ao invés de verticais. (VOYSEY, 1915, p.111 apud DAVEY, 1995, p. 92).

\footnotetext{
${ }^{21}$ Os mullions são peças verticais em pedra, madeira ou ferro, no montante de uma janela, separando os caixilhos ou os panos de vidro. (WARE; BEATTY, 1952, p. 78) Este tipo de janela é associado ao gótico e ao romantismo. (Nota do autor)
} 

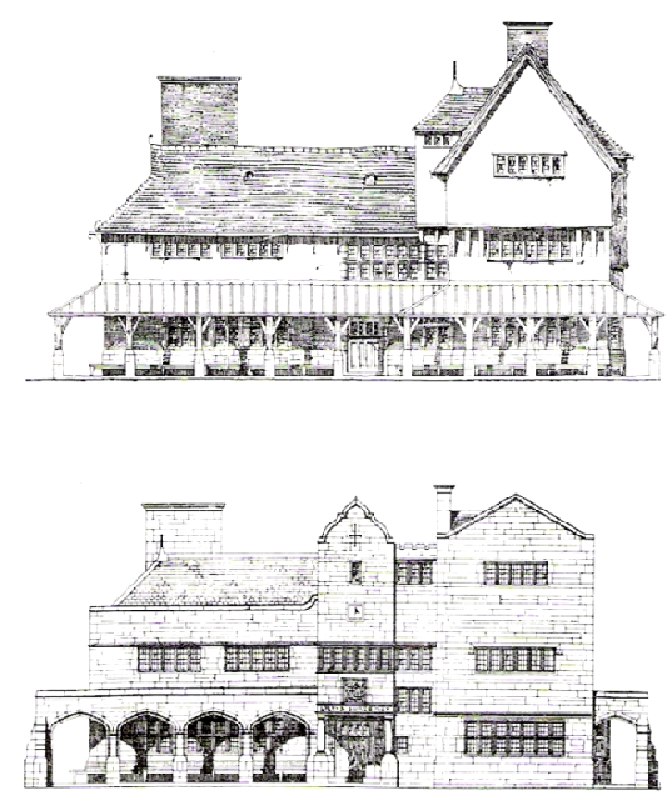

Fig.1. 13 Veranda House - alternativas para a fachada

Na Tower House, outra característica de Voysey já aparece: a planta é compacta, as paredes do térreo e do segundo pavimento coincidem quando possível, em outra consideração pela economia na construção. Voysey não gostava das plantas abertas. Primeiro por questões estruturais e econômicas, depois porque ele preferia a privacidade e tranqüilidade.

A insistência de Voysey na simplicidade e ausência de decoração o levou a preparar um contrato com 18 folhas desenhadas para o projeto (1888-1891) da Foster House, para que o construtor não se 'aventurasse' pelas decorações usuais: faixas, molduras, chanfros.

Fiel seguidor de Pugin e de seus princípios, de que não deve haver características em um edifício não necessárias por conveniência, construção ou propriedade e de que todo ornamento deveria constituir-se em parte essencial do edifício. Estes dogmas 0 levaram a amadurecer sua maneira de projetar.

Paralelamente a esta, Voysey projetava outra casa, Walnut Tree Farm. Nesta, a localização e o orçamento eram muito mais interessantes. "A casa foi desenhada com uma exuberância juvenil e um caráter experimental que significou uma crescente autoconfiança no trabalho de Voysey (...). Walnut Tree Farm era uma casa de Voysey na adolescência". (HITCHMOUGH, 1995, p. 39) 


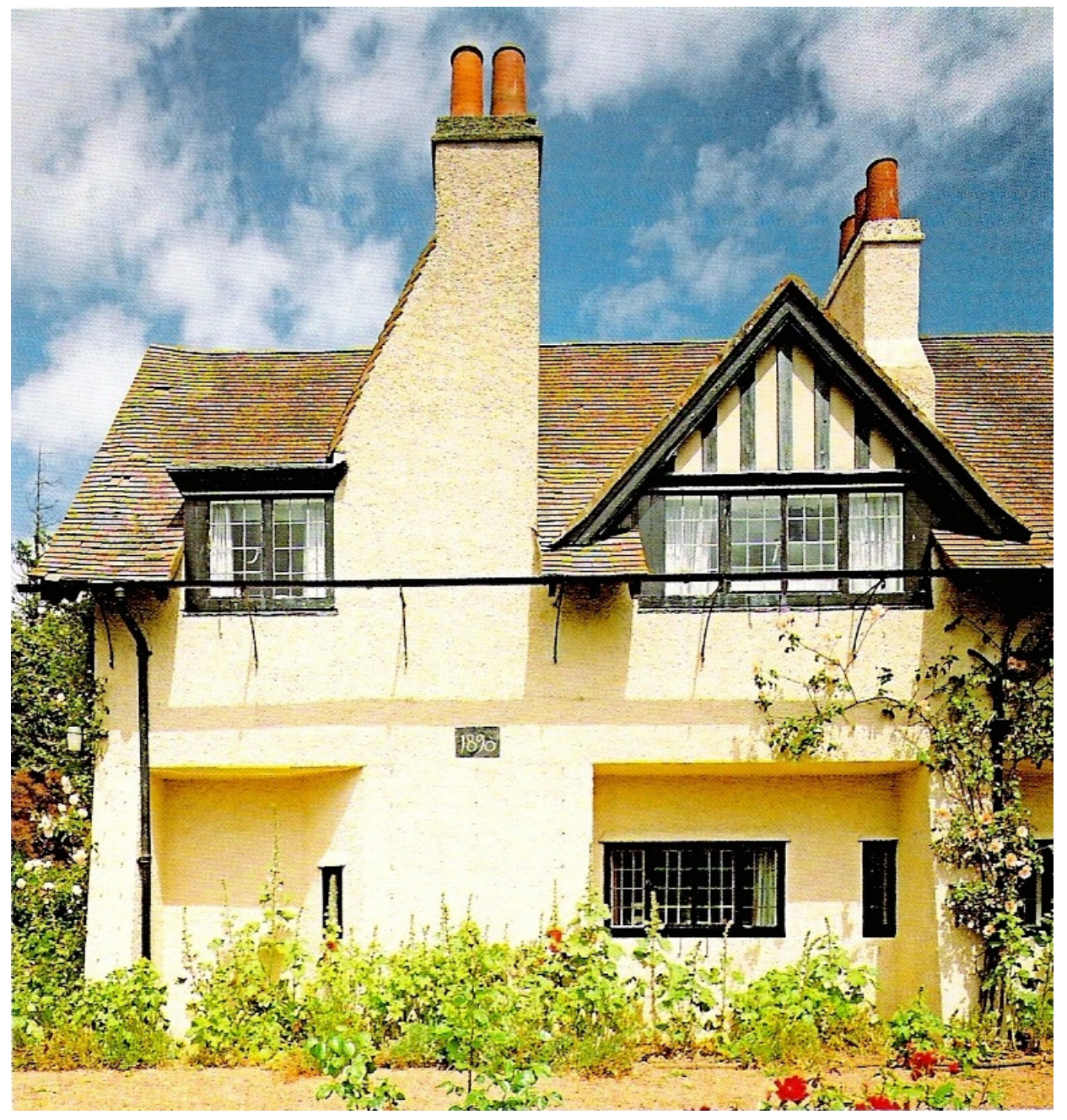

Fig.1. 14 Walnut Tree Farm.

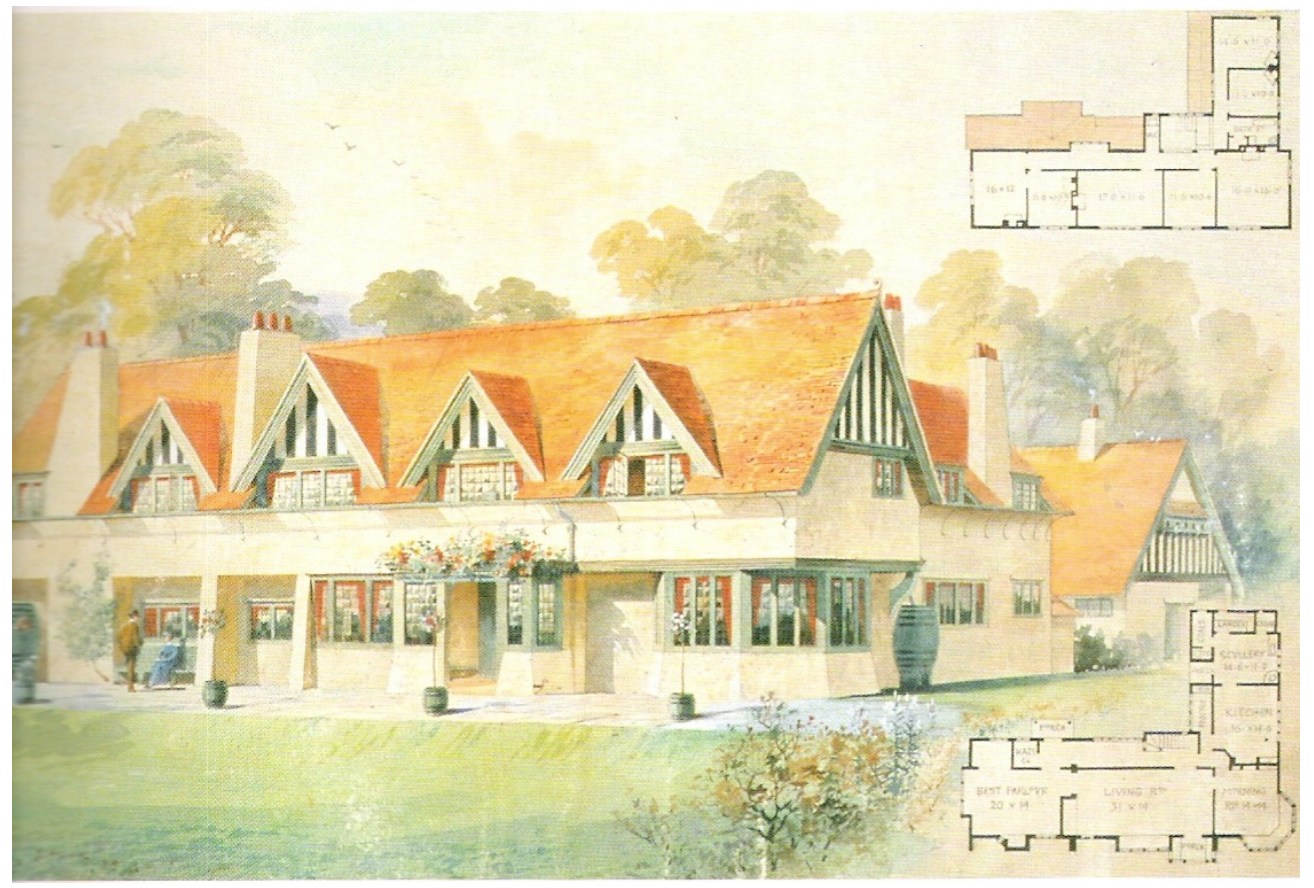

Fig.1. 15 Walnut Tree Farm 
Seus clientes eram membros da classe média, em boa situação econômica, entre eles o escritor H.G.Wells. Este, em 1899, escolheu Voysey como "o pioneiro na libertação da pequena e afetada vila para o luminoso e confortável pseudo cottage" ${ }^{\text {"22 }}$. As casas de campo menores de Voysey foram desenhadas para uma nova classe de proprietários rurais, assim definidos por Country Life em 1899:

A vida urbana prolongada torna-se mais intolerável a cada ano, e homens de recursos moderados, que sempre quiseram uma pequena casa de campo, começam a realizar seu desejo. Em alguns casos, possuem família e se satisfazem em fazer de sua pequena casa de campo seu lar, mantendo apenas alguns aposentos em Londres (...) para a semana de trabalho, (...) (eles) descobriram finalmente ser mais barato, mais saudável e muito mais agradável possuir uma casa acessível que podem freqüentar nos feriados e férias. ${ }^{23}$

Desde o início, os projetos de Voysey foram publicados nas revistas mais influentes: The British Architect, The American Architect \& Building News (1890), The Studio e Country Life. Desta forma, teve excelente reputação como arquiteto entre seus colegas de profissão, mas foi com The Studio, lançada em 1893, que sua doutrina artística tornou-se acessível a um público - inglês e estrangeiro - muito maior. Tal doutrina envolvia a crença na honestidade e na simplicidade e a atenção aos mínimos detalhes. E o menor elemento deveria ser coerente com o todo para que este se tornasse harmonioso.

Em Perrycroft (1893-4), Voysey não conseguiu envolver a casa com seu entorno, através do desenho ou do uso de materiais locais. Estava desassociada das colinas Malvern, uma construção branca e retangular em uma plataforma nivelada.

Em Lowicks, ele introduz o living hall, ligado a outro hall, com as funções de circulação vertical e acesso à casa. Ali, pela primeira vez, ele desenhou também os jardins, típicos do Arts and Crafts, em sua combinação de racionalidade no desenho e um plantio mais natural. Caminhos retos e alinhamentos geométricos conferiam severidade em planta. Porém "a vegetação era abundante e indisciplinada, com arbustos nativos, plantas perenes e trepadeiras crescendo pelas paredes e pendendo

\footnotetext{
22 WELLS, H.G. Experiment in Autobiography Londres: Victor Gollancz,republicada em 1966, p. 638 apud DAVEY, 1995, p. 96.

${ }^{23}$ Houses for people with hobbies, Walnut Tree Farm, Castle-morten, Country Life, 28 de outubro de 1899, p.525 apud HITCHMOUGH, 1995, p. 40.
} 
sobre os contornos rígidos dos caminhos e dos canteiros, e a mata nativa ao redor do jardim formal". (HITCHMOUGH, 1995, p. 91).

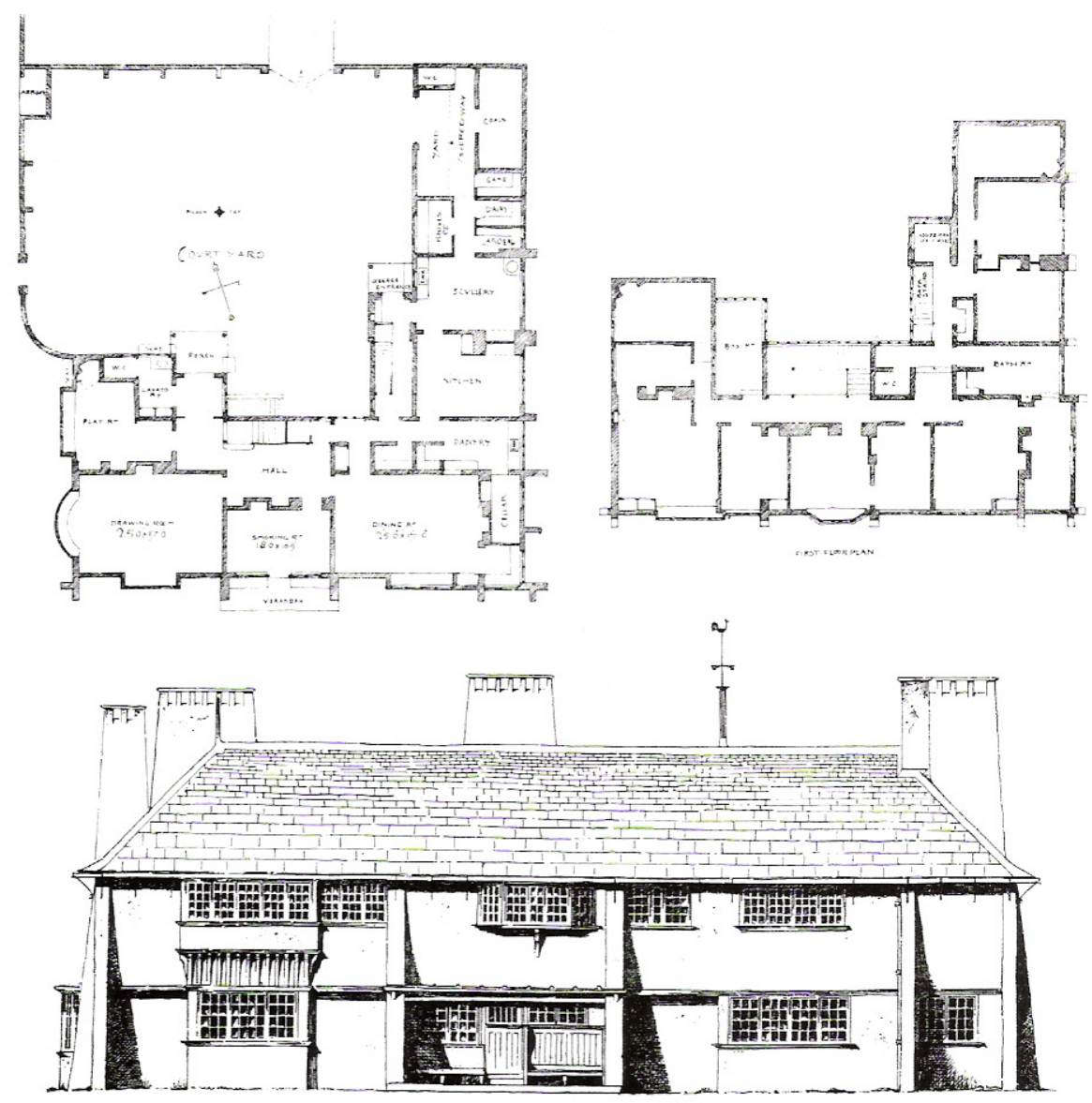

Fig.1. 16 e Fig.1. 17 Perrycroft

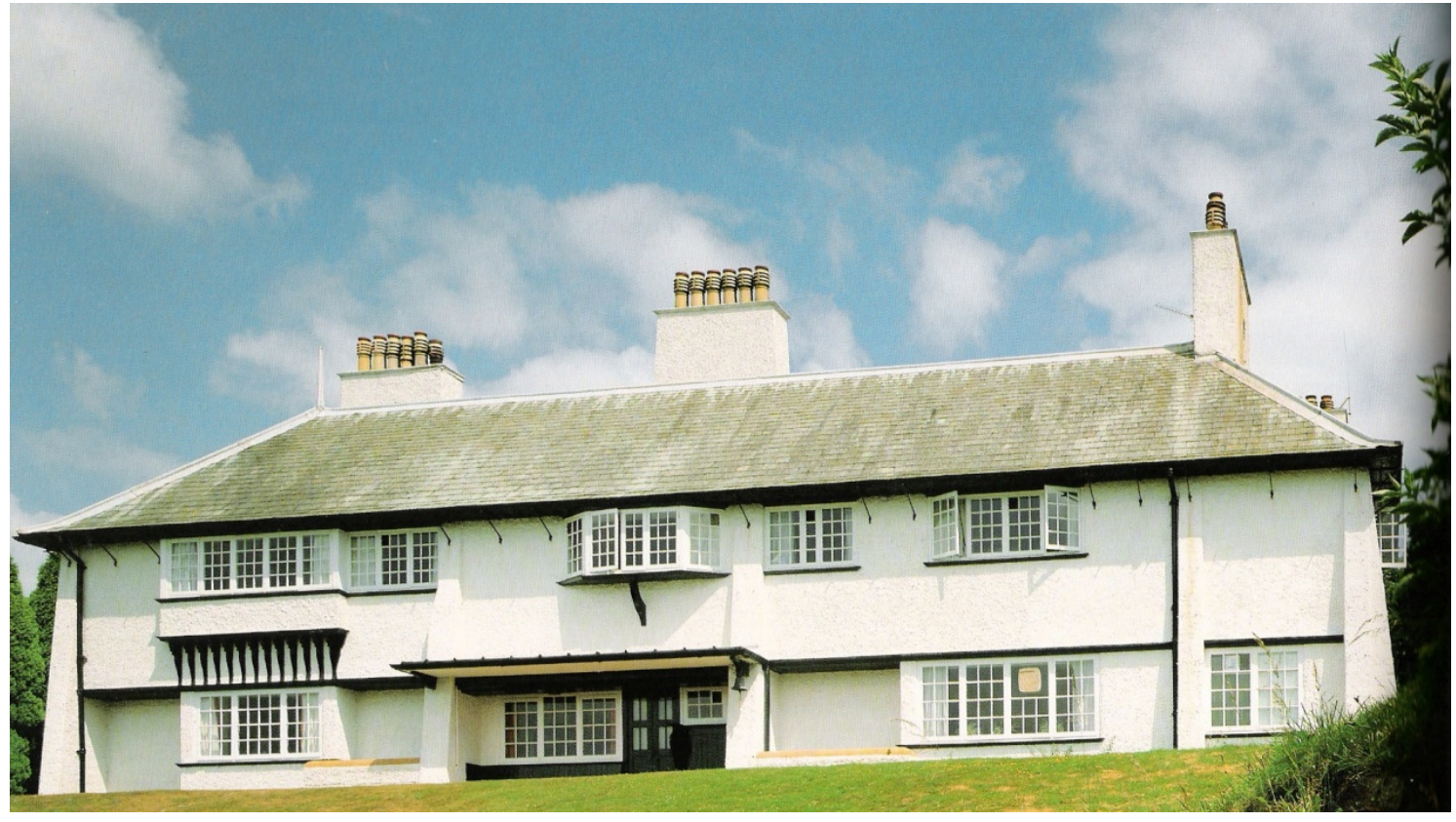

53 I C a pítulo 1 


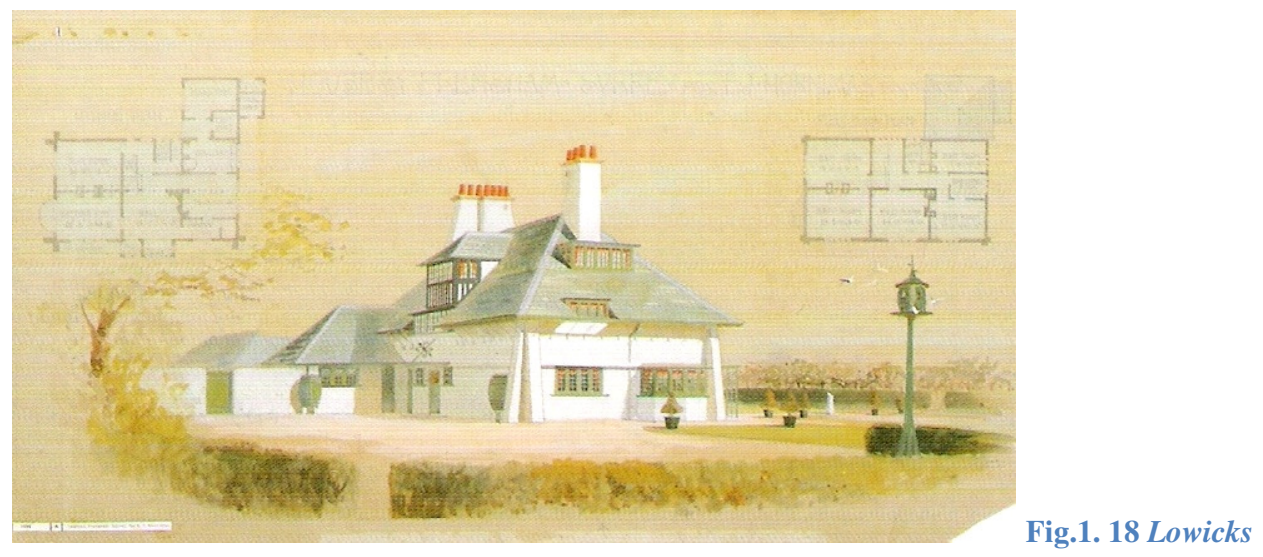

Voysey desenhava pérgulas e quiosques para seus jardins, que eram equipados com bancos também desenhados por ele. Relógios de sol eram colocados estrategicamente para criar vistas interessantes. $O$ acesso aos jardins era feito por um portão também criado pelo arquiteto.

Trabalhando em colaboração com um paisagista, já que ele não era um conhecedor de plantas, ele conseguiu que casa e jardim estivessem ligados, em harmonia. Nesta casa, por volta de 1894, ele aprendera a manejar a sucessão de espaços a partir da casa, através do jardim, e entorno.

Esta maestria, ele demonstrará também em Broadleys, de 1898.

Voysey nega alguns dos princípios do Arts and Crafts, ao rejeitar a construção com materiais locais e técnicas tradicionais, quando utiliza, por exemplo, o roughcast e ardósia verde na cobertura:

(...) mostrar meu respeito pelas condições locais de clima e solo, mas, não ignorando as facilidades modernas de trânsito, quando possível, selecionar seu material para que harmonize com o caráter local em cor e textura. Por exemplo, pode haver algum mal em usar ardósia verde de Wales ou Cumberland em lugares onde esta não seja produzida, considerando que a ardósia verde se harmoniza muito mais com a natureza (...) (VOYSEY, 1909 apud HITCHMOUGH, 1995, p. 83)

O caráter do sítio irá propor muitas restrições e condições tanto para a aparência da casa quanto para a perspectiva que se tem dela. $O$ contorno do terreno obviamente controla a organização; a cor, forma e textura dos morros e árvores sugerem a cor, forma e textura de 
nosso edifício. Isto é, desde que não tenhamos idéias pré-concebidas de fachadas (itálico de Voysey) Clássicas ou uma preferência muito arraigada por um estilo particular de arquitetura. (VOYSEY, 1906, p. 11 apud DAVEY, 1995, p. 94)

Outra casa de Voysey, Norney, de 1897, tem "uma qualidade barroca de grandeza e monumentalidade" (HITCHMOUGH, 1995, p. 84). O arco em pedra da entrada com uma janela circular não é encontrado na arquitetura medieval inglesa, é uma composição clássica. Porém:

Formalmente, um homem seria ou totalmente gótico ou totalmente clássico, e não poderia ser ambos; o Sr. Voysey não se liga a nenhum estilo. Os princípios fundamentais do Desenho, que ele defende, são as condições e as exigências do trabalho a ser executado - na Inglaterra, as condições climáticas do país e as necessidades nacionais da vida familiar que the são peculiares. (ANON., 1896, p.68 apud HITCHMOUGH, 1995, p. 85).

Aliás, a citação anterior se aplica à arquitetura Arts and Crafts em geral. A própria trajetória de Voysey é emblemática do próprio movimento: do deliberadamente pinturesco Old English à racionalidade e à pureza de formas, observada por Muthesius.

Fig.1. 19 Norney

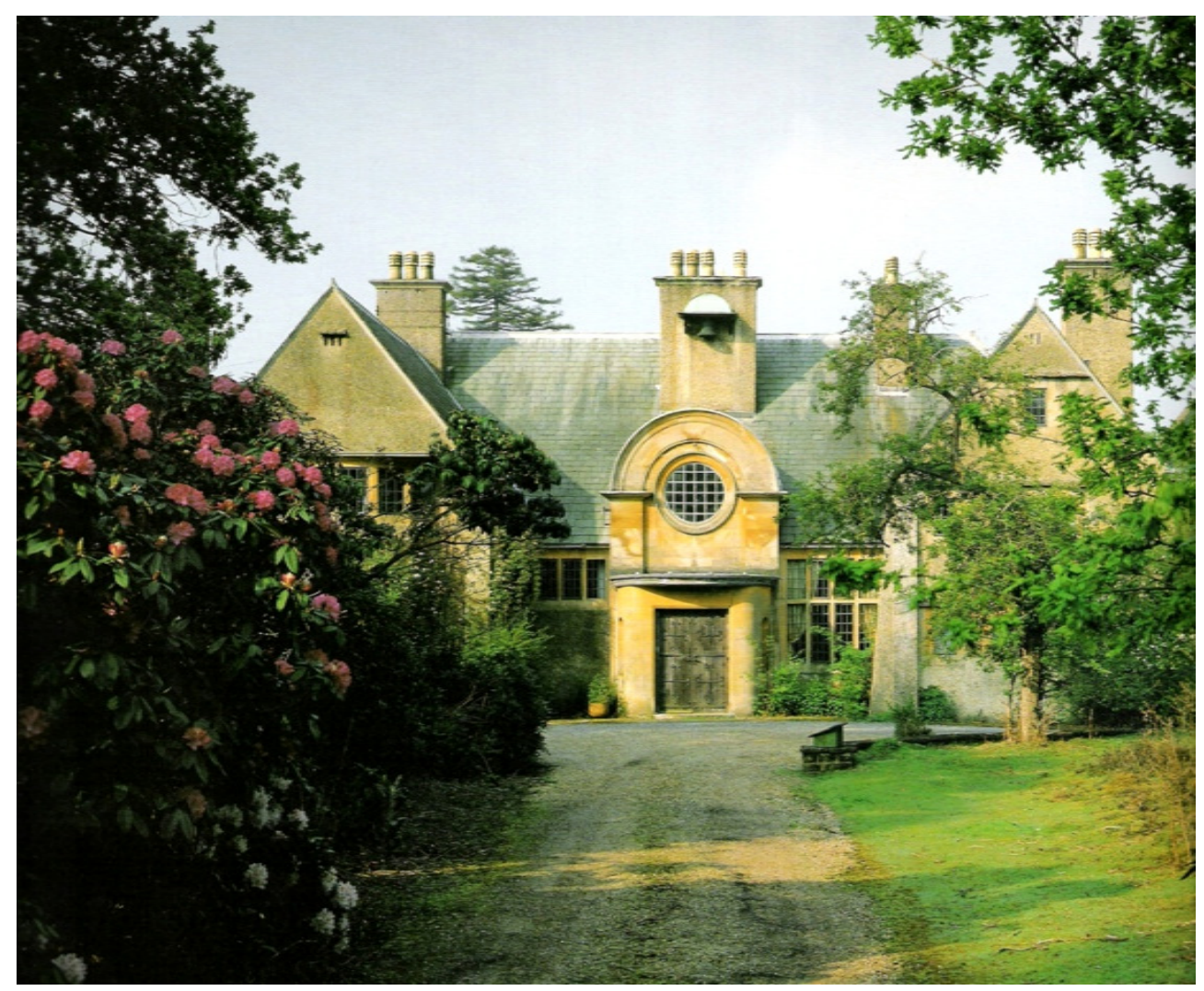




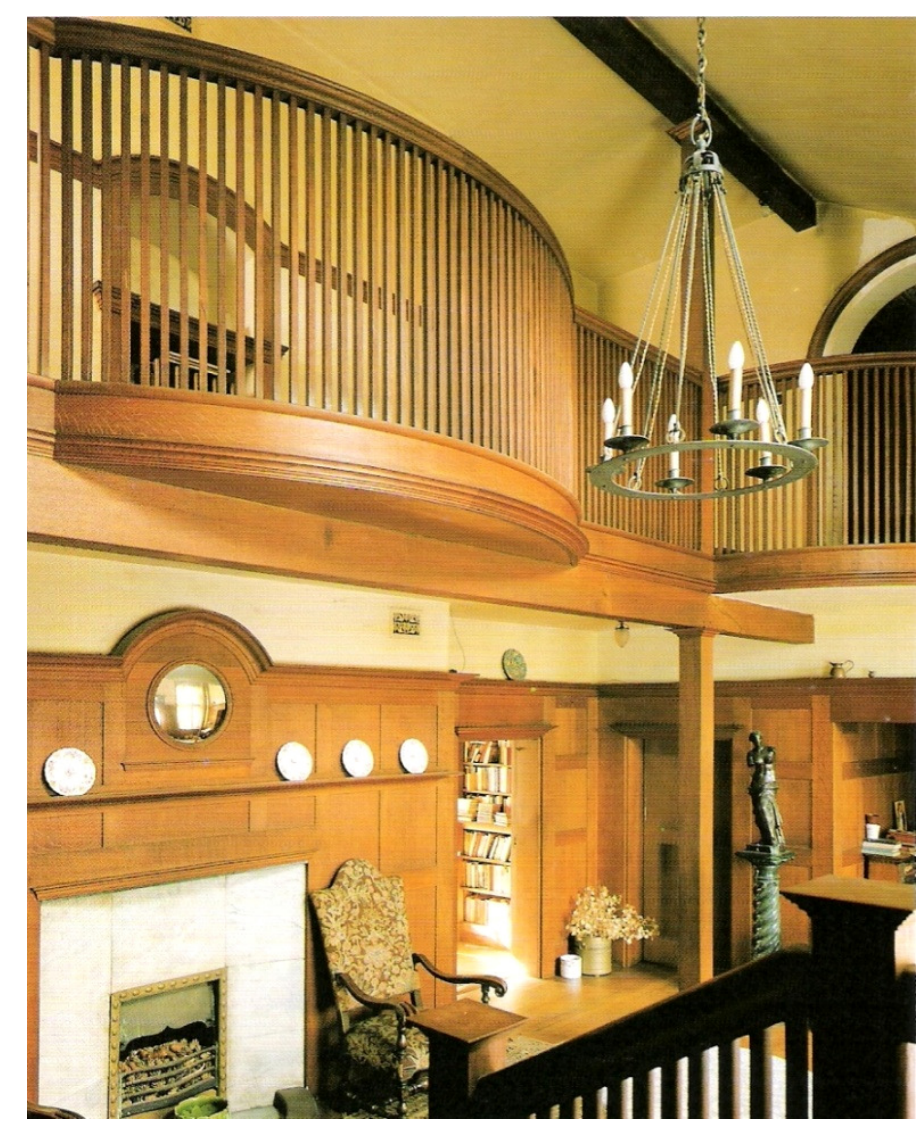

Fig.1.20 Norney - interior.

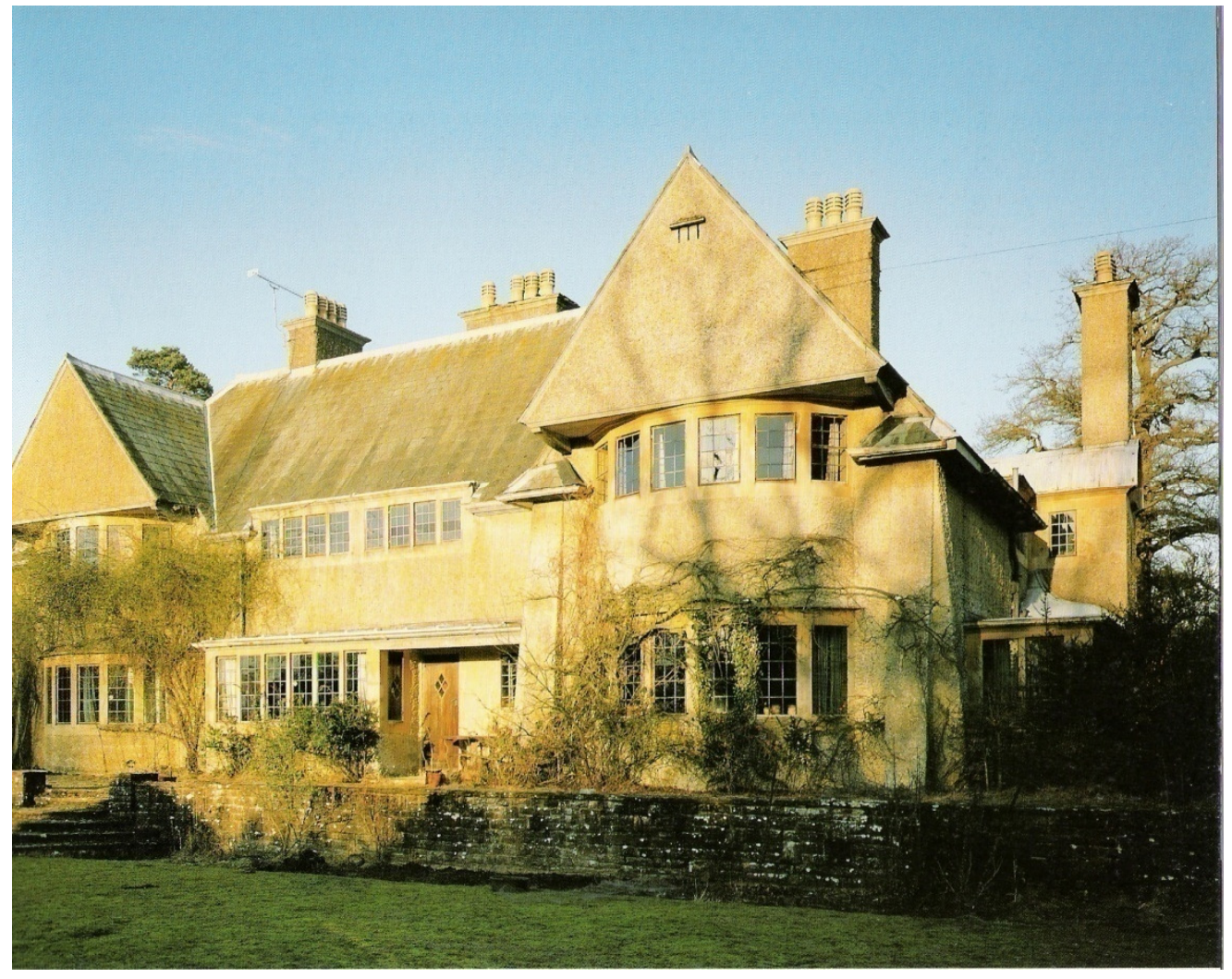

Fig.1. 21 Norney

56 I C a pítulo 1 
Em Norney, segundo HITCHMOUGH (1995, p. 87), há uma "tensão romântica", que voltaria a aparecer novamente nas melhores casas de Voysey.

Certa estranha tensão entre o pinturesco e o clássico. Ao se aproximar da casa, a entrada com seu arco e sua janela redonda são absolutamente clássicos. Porém, seu conjunto é pinturesco com suas diferentes fachadas guardando surpresas para o observador a cada mudança de direção: apesar de diferentes em caráter, uma elevação flui naturalmente a outra. As diversas atividades desenvolvidas no interior são estampadas nos volumes e nas aberturas.

Esta característica está muito clara também em Broadleys. Nos volumes em forma de cilindro que se projetam na fachada do lago, com múltiplas aberturas, a intenção é admirar o lago Windermere. Na ala de serviço, um longo corredor é percebido de fora; e na entrada, uma varanda baixa com porta ampla dá as boas vindas.

É um elemento que caracteriza sua arquitetura: a porta de acesso mais larga em relação à altura, geralmente recuada em relação a um arco. Para Voysey, este detalhe acolhia o visitante.

Voysey percebera o potencial expressivo dos telhados desde suas casas iniciais. Em suas casas de campo, fez grandes planos de cobertura bastante inclinados, descendo quase até ao chão, sugerindo abrigo e intimidade, geralmente reproduzindo o desenho das colinas próximas.

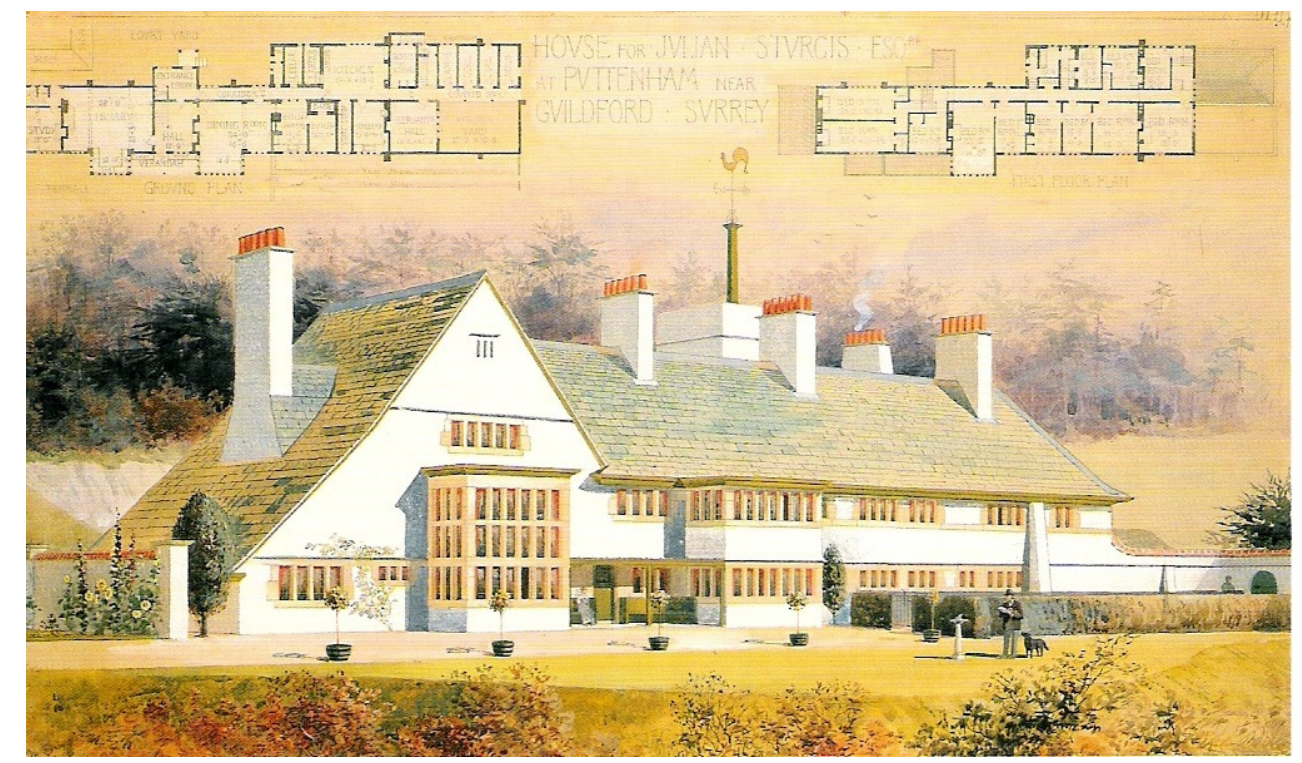

Fig.1. 22 Greyfriars 
"Voysey estava fascinado pela interação de formas geométricas simples em três dimensões, da mesma maneira que Wren e Hawksmoor estiveram antes dele" (HITCHMOUGH, 1995, p. 85). Em Greyfriars, de 1897 um longo volume horizontal cruza uma empena que com seu telhado, que quase toca o chão, forma um grande prisma, ambos interrompidos pelo ritmo das grandes chaminés. Esta transição verticalhorizontal também é vista em New Place (1897), onde a adaptação ao terreno está cada vez mais precisa. Ali, Voysey trabalha com meios níveis, aproveitando a declividade do local.

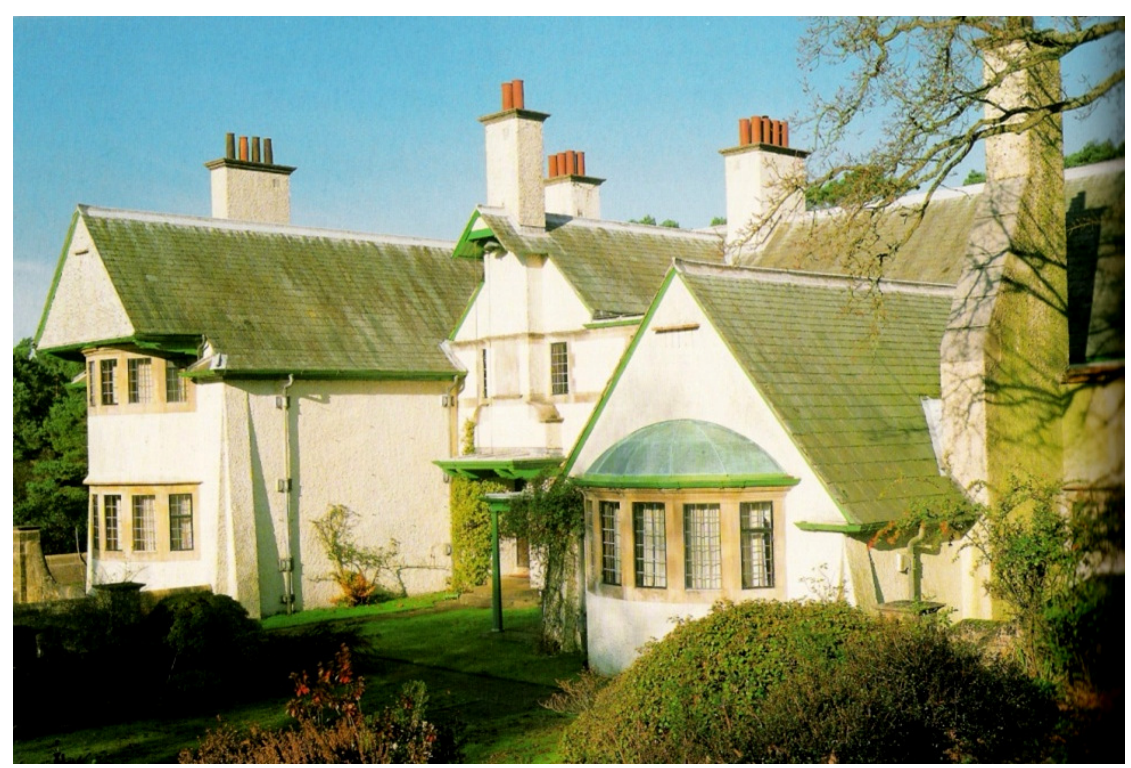

Fig.1. 23 New place

Da adaptação ao entorno fazia parte a criação de vistas expressivas, que focavam a casa. Mas também, a partir da casa, os olhos eram guiados e os "pés desafiados" (HITCHMOUGH, 1995, p. 90), através dos jardins formais para contemplar e conhecer o cenário de fundo, a natureza deixada intocada.

Em Broadleys, o que se percebe é um arquiteto completamente maduro, totalmente seguro de seu próprio estilo. (HITCHMOUGH, 1995, p. 94). O terreno, à margem do lago sobe abruptamente e a casa foi localizada no topo e sendo o acesso principal pelo lago, ela é desvendada aos poucos. A inclinação do telhado repete a do próprio terreno e a ardósia verde da cobertura junto com o terraço com pedras locais também verdes, liga a casa à sua localização. (HITCHMOUGH, 1995, p. 94). 


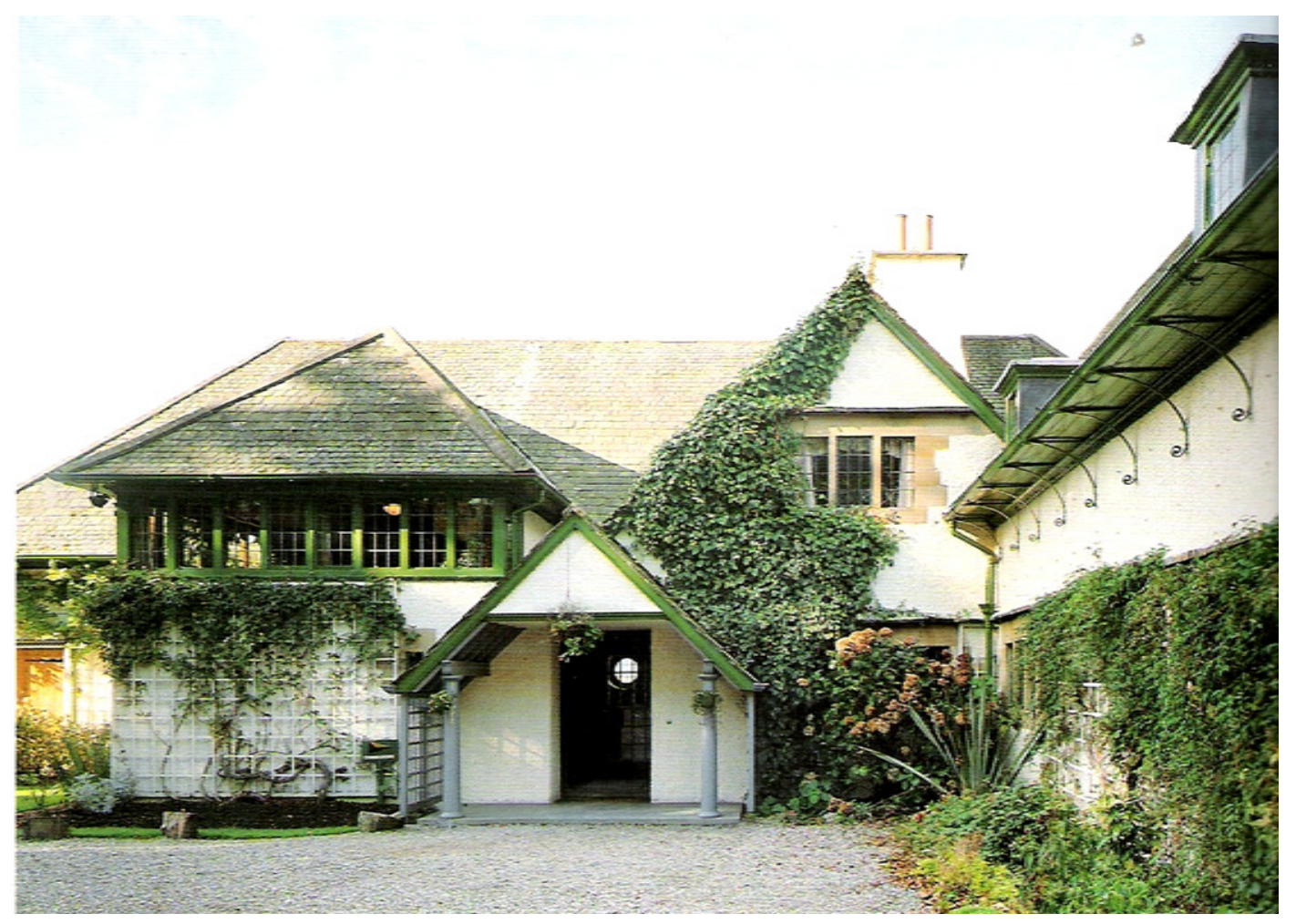

Fig.1. 24 Broadleys, entrada

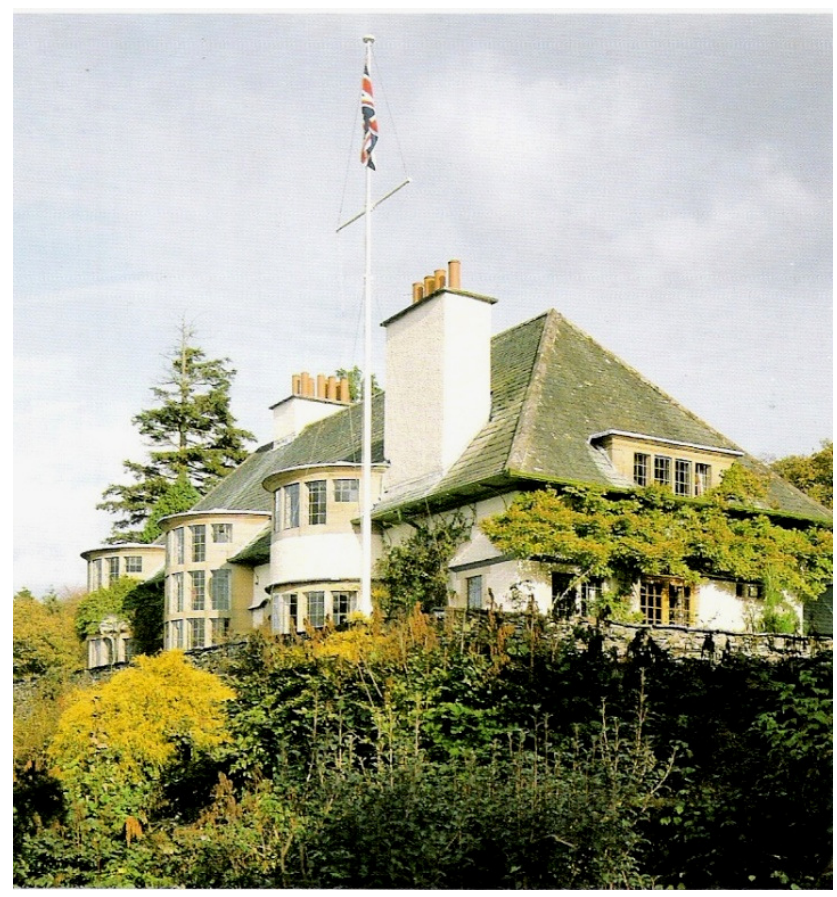

Fig.1. 25 Broadleys, vista a partir do lago - 
Voysey desenhava todos os detalhes da casa até as dobradiças das portas. Considerava que "tudo dentro de uma casa (deve ser) da alçada do arquiteto, desde utensílios e mobília até as escovas de dente." (ANON., 1896, p.67 apud HITCHMOUGH, 1995, p. 59). E na metade dos 1890's, ele estava publicando desenhos para tapetes, cerâmicas, bordados, lareiras, caligrafia e mobília. (HITCHMOUGH, 1995, p. 59)

Reconhecia-se a mobília de Voysey como excepcional para o período, por sua simplicidade, suas proporções, a ausência de ornamentos inúteis e as linhas originais. (HITCHMOUGH, 1995, p. 129). Características eram repetidas em várias peças, como as curvas no topo do encosto das cadeiras e os motivos de coração.

Também executou design de papéis de parede. Nestes, rejeitava o realismo, a ilusão de profundidade. Seguia o princípio de Pugin, de que o designer deveria ser autêntico no uso dos materiais. Para isto, ele deveria conhecê-los profundamente, além das técnicas para trabalhá-los. Um papel de parede deveria ser essencialmente um modelo plano a ser repetido.

A utilização de cores incomuns era outra característica do arquiteto expressa em seus interiores, sua mobília e até mesmo em suas roupas que ele próprio desenhava: púrpura, azul pavão, verde escuro, vermelho. Para ele, as cores encontradas na natureza eram fontes de inspiração.

O paradoxo Ruskiniano foi resolvido por Voysey em favor do designer e não do craftsman. Ele estava preparado para aceitar a máquina, como uma possibilidade, como Pugin mesmo a aceitara. (DAVEY, 1995, p. 95-6):

O caráter humano em objetos familiares tem sido tirado em muitos casos pela máquina. Apesar disto, a máquina veio para liberar a mente humana para mais trabalho intelectual do que a serra manual fizera. (VOYSEY, 1909, p.107 apud DAVEY, 1995, p. 96)

Ecos da savageness de Ruskin:

(...) nós estamos ávidos em demasia pela perfeição mecânica. Este amor pelas superfícies polidas, lisas é muito materialista; podem ser produzidas sem o intelecto e em muitos casos somente podem ser produzidas através da eliminação de toda reflexão e sentimento humanos. (VOYSEY, 1909, p.107 apud DAVEY, 1995, p. 96) 


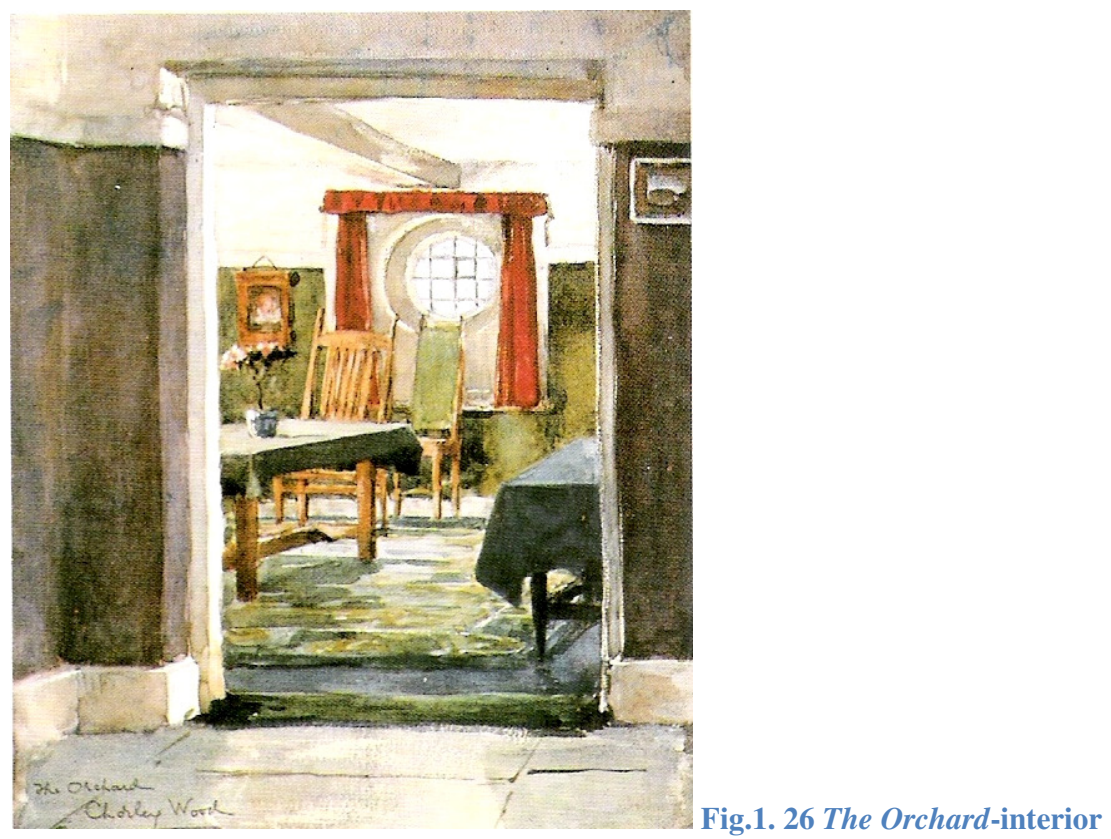

Mas, à medida que envelheceu, Voysey tornou-se incrivelmente hostil à produção da máquina. (DAVEY, 1995, p. 96)

Sobre o método de trabalho de Voysey, disse Baillie Scott:

O público em geral pouco sabe sobre os métodos através dos quais um arquiteto atinge suas metas. $O$ esquema que se inicia na sala de fumar do hotel, ou do clube, é depois desenvolvido pelo assistentes no escritório, enquanto muito é deixado para o construtor. De tais métodos, o trabalho de Mr. Voysey está realmente distante. Examinar uma série de desenhos preparados por ele para uma casa é reconhecer, em cada folha, como todas as possibilidades de erro são eliminadas pela mais cuidadosa e consciente previsão. O projeto é desenvolvido de forma tão completa no papel, que se esclarece completamente. Apenas uma devoção verdadeira ao trabalho inspiraria tão infatigável trabalho: e isto é, basicamente, a causa do sucesso do Sr, Voysey. ${ }^{24}$

Sugere ao menos certa proximidade entre ambos, para que Baillie Scott tivesse examinado um projeto completo de Voysey.

${ }^{24}$ BAILLIE SCOTT, M.H On the characteristics of Mr. C.F.A.Voysey's architecture, The Studio, Vol. XLII, Outubro de 1907, p. 19-24 apud HITCHMOUGH, 1995, p. 124. 
A imagem idealizada do cottage no campo - paredes brancas, rosas ao redor da porta - representando a estabilidade e a continuidade, em um século de profundas mudanças, tornou-se recorrente perto do final do oitocentos. Para Country Life, a fim de se evitar o alto custo da reforma de um autêntico cottage antigo, a solução seria encomendar um novo e a pessoa indicada era Voysey:

O melhor método é prevenir-se contra toda pretensão de antiguidade, e ter uma casa que é moderna em todos os aspectos (...) foi construída para durar, e é confortável, tanto quanto pinturesca. Aqui entra o Sr. Voysey, e apenas ele, pois nenhum arquiteto nos dias de hoje experimentou o que ele tem feito muitas e muitas vezes. ${ }^{25}$

As restrições destes cottages situados no campo eram o veículo perfeito para a contenção e a atenção aos detalhes de Voysey. Não eram realmente cottages, mas atendiam às necessidades de uma habitação relativamente modesta e funcional no campo, mas com acomodações para empregados. Eram geralmente a segunda casa e assim precisavam ter ligações com a cidade, localizando-se próximas às ferrovias. Fundamentava-se na idéia de uma vida "simples" no campo, onde se passavam os feriados e finais de semana. Poderia ainda funcionar como residência permanente. Neste caso, o chefe da família mantinha uma casa menor na cidade. Era um ideal muito presente na época, este do abandono da vida urbana - ao menos temporário - e de comunhão com a natureza.

Em Homestead, a lareira profunda, chanfrada nos lados, é o ponto focal do ambiente. Janelas de ambos os lados, para que o sol e a luz para leitura penetrassem. Um arco, como aqueles da entrada de suas casas, também no inglenook. Nestas casas menores, a lareira é ainda mais valorizada e ali se concentram os poucos ornamentos que Voysey permite. À lareira sempre foi dado muito valor pelos arquitetos do Arts and Crafts, mas em Voysey ela será particularmente elaborada. Característica que Parker e Unwin levarão muito à frente.

\footnotetext{
${ }^{25}$ E.B.S. Country Cottages, Country Life, Vol. III, 19 de fevereiro de 1898, p. 195-7 apud HITCHMOUGH,
} 1995, p. 115. 


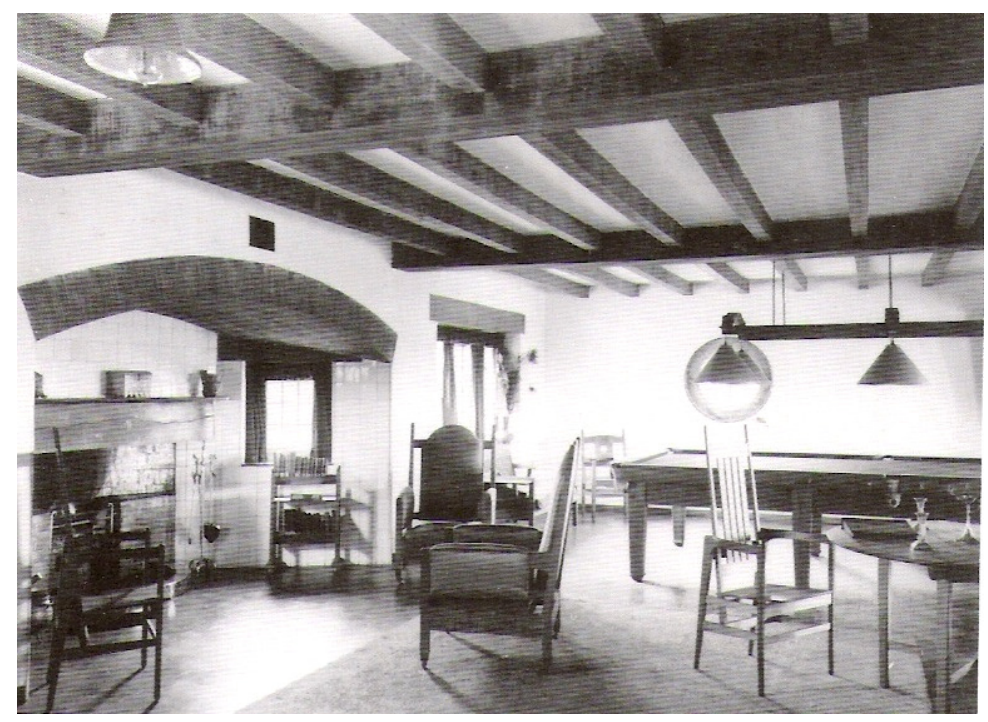

Fig.1. 27 The Homestead - inglenook

\subsubsection{Charles Rennie Mackintosh (1868-1928)}

As novas idéias tomaram forma na Escócia através de um pequeno grupo de jovens na metade dos 1890's. O público inglês travou contato com o grupo na Exposição do Arts and Crafts de 1896, onde não foram compreendidos e mesmo ridicularizados (MUTHESIUS, 1987, p. 51), com seus painéis de cobre forjado e as austeras formas do mobiliário. Na exposição de 1899, suas peças foram recusadas. O reconhecimento veio, porém, do continente e tiveram uma influência seminal no movimento nascente, principalmente em Viena.

O Arts and Crafts em Londres parou na época de Morris. Como relata Muthesius, um ambiente completo todo decorado não fora ainda mostrado na época, nas exposições de Londres. Contentavam-se em mostrar caixas, bordados, desenhos para papéis de parede e mobília, como antes.

A grande força do movimento escocês é Mackintosh. Seu principal objetivo era que o ambiente fosse um trabalho de arte como "um conjunto orgânico envolvendo cor, forma e atmosfera. (MUTHESIUS, 1987, p. 51).

A essência do grupo de Glasgow é a sua qualidade emocional e poética fundamental. A procura por uma atmosfera mística, simbólica. Ambientes refinados, delicados e austeros.

Existia um grande contraste entre o grupo londrino trabalhando com novas formas, entre eles Voysey, e o grupo ao redor de Mackintosh. Enquanto o grupo londrino 
procurava uma extrema simplicidade, na qual a imaginação era suprimida, o grupo escocês é virtualmente levado por ela.

Em ambos, porém, está presente a valorização das qualidades do material e da construção, nunca denotando algo artificial.

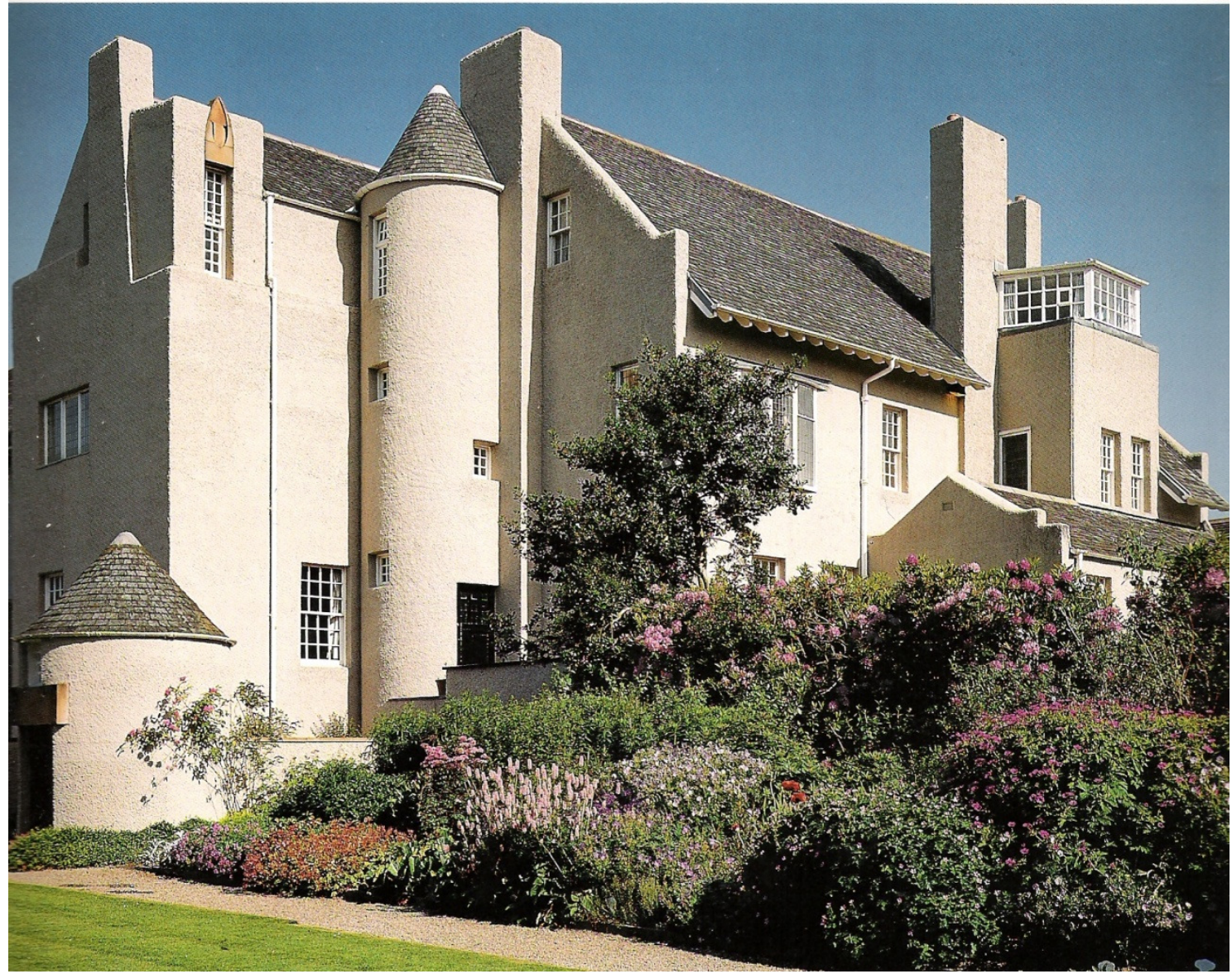

Fig.1. 28 Hill House

Construiu duas casas de campo marcantes: Windyhill (1899-1901) e a Hill House (1902-4). Ambas inspiradas em modelos escoceses do século XVIII, com telhados de ardósia, paredes brancas, janelas guilhotina e torres cilíndricas. As duas incorporam detalhes voysyanos, como as altas chaminés e as bay windows

Ali, apresenta-se muito mais variedade do que Voysey jamais quis alcançar. A Hill House, particularmente, tem uma grandeza vertical que é muito escocesa, e completamente original. Outra obra importante foi a Glasgow School of Art com grandes inovações técnicas, entre elas um sistema de ar condicionado pioneiro. 


\subsubsection{Mackay Hugh Baillie Scott (1865-1945)}

A maneira como Muthesius se refere a Baillie Scott é sugestiva - o poeta entre os arquitetos domésticos.(MUTHESIUS, 1987, p. 47). Sobre ele:

Toda a frieza e crua racionalidade que distingue o sul anglo-saxão parece já ter desaparecido. Parece já termos adentrado um mundo de fantasia e romance. (...) Ele reveste todos os seus ambientes com o mais profundo, poético e concentrado sentimento (...) nunca considera cômodos sem mobília, mas (...) sempre imagina como será o ambiente quando estiver totalmente equipado e ocupado. Assim, cada pedaço de espaço é considerado por sua adequação para ali viver: nenhuma porta é posicionada arbitrariamente e toda janela está na correta relação com o quarto que deverá iluminar. (MUTHESIUS, 1987, p. 47-9)

Durante sua vida profissional, Baillie Scott nunca deixou de praticar uma arquitetura voltada ao artesanato e aos ensinamentos de Ruskin e Morris. Iniciou seu aprendizado em 1886, com o Major Charles Davis, arquiteto da cidade de Bath e se estabeleceria na Isle of Man em 1889.

Seus primeiros edifícios eram variações do Old English, sem muita ligação com seu entorno, influenciado por Shaw e por Ernest George (DAVEY, 1995, p. 174). Os interiores já eram mais inovadores.

A maior realização de Scott seria o planejamento dos interiores domésticos, que começaram a tomar forma em uma série de casas na Isle of Man nos 1880's. Porém, seria na própria casa, de 1892, que Baillie Scott inovaria o interior, separando o hall e as salas de estar e de jantar através de portas de correr e permitindo a constituição de um espaço único ou de espaços individualizados, de acordo com as funções a serem desempenhadas. Este hall, que ele denominou "houseplace", é derivado do hall medieval.

A atmosfera da obra de Baillie Scott é delicada e íntima, com uma agradável poesia idílica. (MUTHESIUS, 1987, p. 49)

A possível influência do Shingle Style americano sobre o desenvolvimento da planta aberta pode ser mapeada desde o inicio dos 1880's. Mesmo a preocupação que se passa a ter com a pequena casa, com o cottage, marca uma mudança do interesse 
anterior pelas grandes casas e é outra possível influência americana. Na América, a casa da classe média foi levada em consideração muito mais cedo.

Baillie Scott fala sobre o interior subdividido em cômodos mínimos e inúteis:

Todo o interior está apertado e a família passa seu tempo em casa presa entre uma mesa e uma lareira moderna, e toda polegada de chão é disputada por mobília inútil e "ornamentos" que não ornamentam ${ }^{26}$.

No hall, com pé direto duplo, Scott costumava colocar uma galeria no segundo pavimento, para que músicos tocassem para entreter a família. Este artifício está presente em Blackwell (1898-99), uma grande casa de campo na Cumbria. Ali, a estrutura de madeira encaixada na parede foi trazida para o interior, para a galeria que se localiza sobre uma enorme lareira.

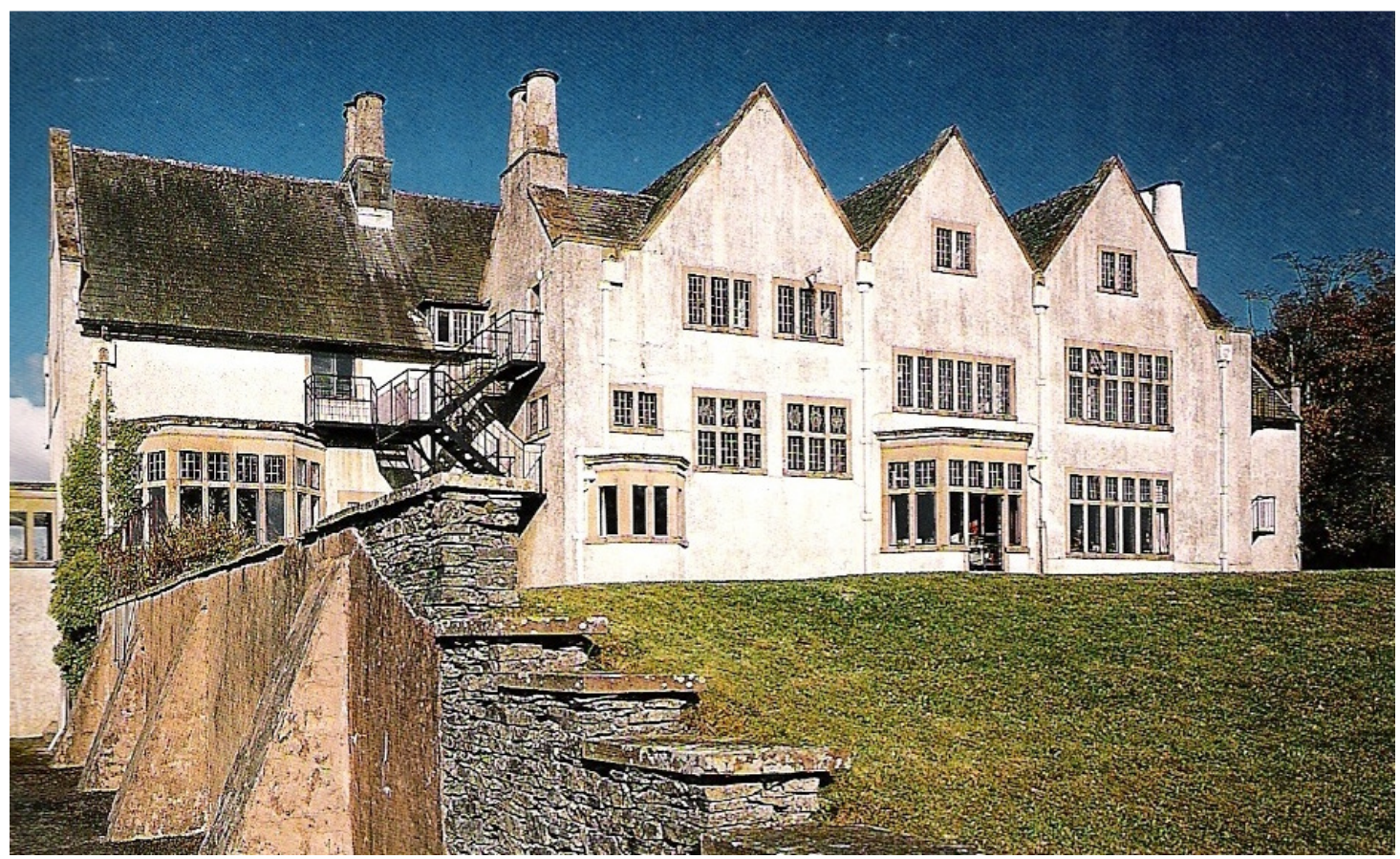

Fig.1.29 Blackwell

${ }^{26}$ BAILLIE SCOTT, M.H. The House As It Is and Might Be apud UNWIN, Raymond Garden Suburbs, Town Planning and Modern Architecture. Londres, 1910, p. 84 apud CREESE, 1992, p. 291.

66 I C a pítulo 1 


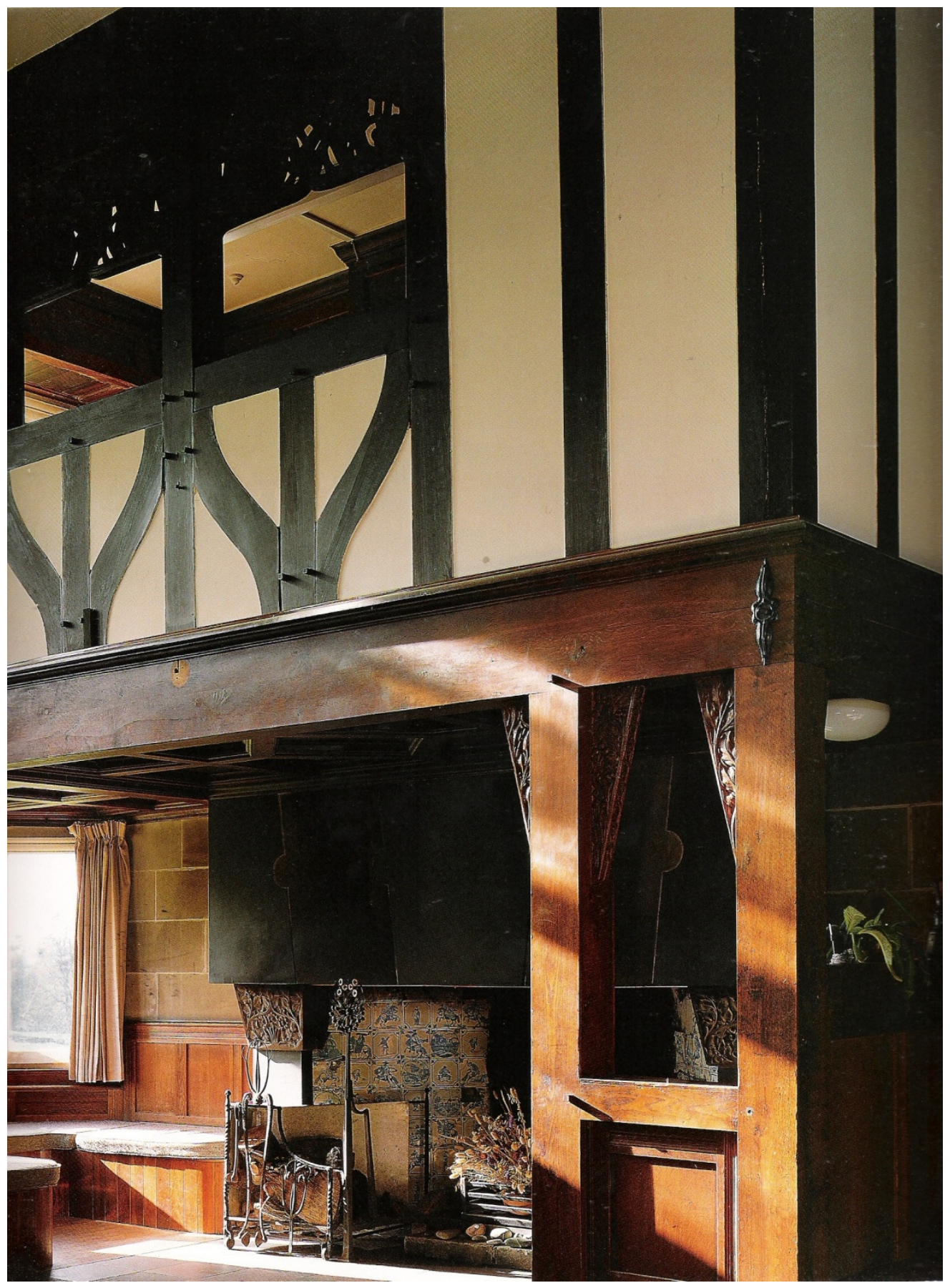

Fig.1. 30 Blackwell, lareira e galeria do hall.

Muthesius (1987, p.51) diz que o conceito de Baillie Scott da casa é de um todo orgânico, a ser pensado com coerência entre o interior e o exterior. Arquiteto e designer de interiores fundem-se. Isto seria um avanço em relação ao movimento em Londres. Apesar de Voysey trabalhar de forma similar, traços sentimentais não são tão enfatizados em seu trabalho. Porém, no trabalho de Baillie Scott, cada ambiente é uma criação individual, os elementos emergem da idéia do todo. 
No primeiro dos muitos artigos escritos por Scott para The Studio - um veículo para suas idéias e projetos -, ele enfatiza o que Muthesius coloca: cada ambiente é pensado individualmente, com suas próprias cores e acabamentos, porém nunca se perde a idéia do todo, que ele chama de efeito final. Cada elemento deve ter relação com a totalidade, refletindo a idéia da obra de arte total, tão cara ao Arts and Crafts. E tais relações se estabelecem entre elementos que não são apenas os sólidos, mas também os vazios. Quando fala sobre o que não escolher, ele se refere também ao vazio que não deve ser preenchido.

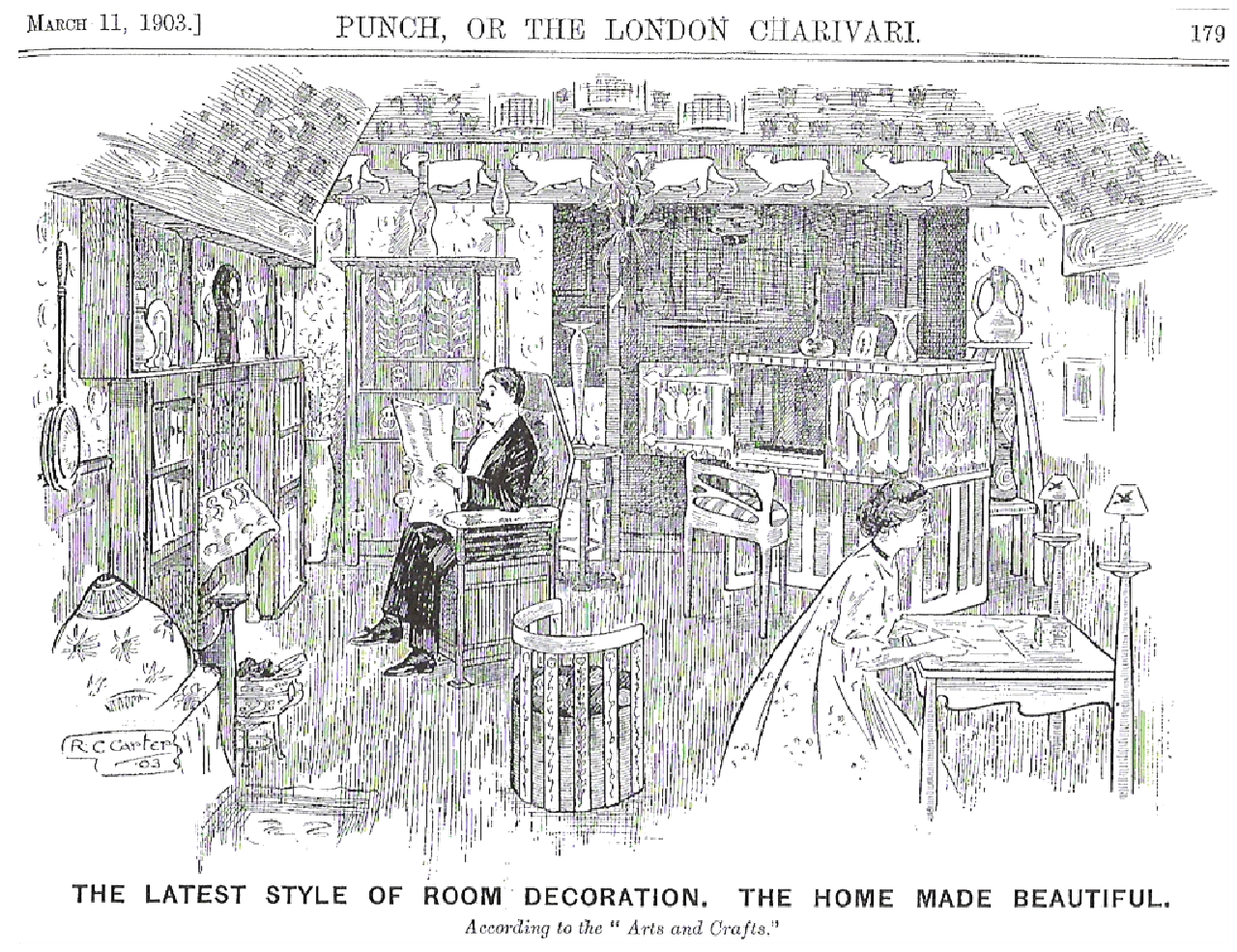

Fig.1. 31 Caricatura mostrando o interior doméstico ${ }^{27}$

Finalmente, a idéia de não se separar a casa e seu interior, o que só pode ser obtido quando a mesma pessoa se responsabiliza pela totalidade, que inclui os jardins.

No tratamento dos dormitórios (...) sugere-se que tanta variedade quanto possível deva ser utilizada. Um dormitório pode ter acabamento em esmalte branco, talvez com papel de parede azul. Outro pode ser trabalhado em tons amarelos dourados ou brilhantes; enquanto um terceiro pode sugerir a simplicidade do hall. De qualquer

\footnotetext{
${ }^{27}$ Bailie Scott é o homem sentado. R.C. Carter, 11 de Março de 1903.
} 
forma, deve-se ter em mente que um efeito final exato deve ser o objetivo, e o cômodo não deve apresentar o costumeiro amontoado de peças, que, ainda que sejam bonitas, não têm uma relação efetiva com um plano pré-concebido. Ao escolher os móveis, é mais fácil indicar o que evitar ao invés do que escolher. (...) É difícil para o arquiteto fixar uma linha entre a arquitetura da casa e o mobiliário. A concepção de um interior deve necessariamente incluir a mobília a ser usada ali, e disto naturalmente se conclui que o arquiteto deve desenhar as cadeiras e mesas, tanto quanto a casa em si. ${ }^{28}$

A importância da cor no trabalho de Scott já foi assinalada por Muthesius. Ele pensava nas cores a serem utilizadas desde o início. (MUTHESIUS, 1987, p. 49)

Em 1898, O Grão-Duque de Hesse, fundando uma colônia de artistas em Darmstadt, encomendou a mobília a Baillie Scott e a Ashbee, para decorar seu palácio. Baillie Scott desenhou as salas de jantar com painéis brancos, enriquecidos com frisos de couro em alto relevo de flores e pássaros voyseyanos executados pela guilda de Ashbee. Darmstadt foi o início de várias encomendas executadas por ele no continente, incluindo várias mansões aristocráticas na Alemanha.

Abandonando os motivos históricos iniciais, ele passa a projetar exteriores brancos, muito simples, contrastando com interiores em cores variadas. Influência de Voysey. Em 1901, muda-se para Bedford, onde seu estilo Voyseyano continua. Ele falava sobre seu entusiasmo pelo arquiteto, mais velho:

Se for pedido a alguém para resumir em poucas palavras o alcance e o propósito do trabalho do Sr. Voysey, deve dizer que consiste principalmente na aplicação de idéias rigorosamente sensatas, práticas e racionais à criação da casa ${ }^{29}$.

Um dos maiores edifícios de Scott foi Waterlow Court, uma associação para senhoras necessitadas, no subúrbio-jardim de Hampstead. Trata-se de um grande pátio cercado por apartamentos, caiados em branco. Grandes arcos arredondados compõem o claustro. O exterior é menos severo com estrutura de madeira aparente sobre térreo com tijolos vermelhos.

\footnotetext{
${ }^{28}$ BAILLIE SCOTT, M.H. An Ideal suburban House, The Studio, Vol. V, 1894, p. 127, 130-1 in GREENSTED, 2005, p.40-1

${ }^{29}$ BAILLIE SCOTT, M.H. On the Characteristics of Mr. C.F.A.Voysey's Architecture, The Studio, Vol. XLII, 1908, p.19 apud DAVEY, 1995, P. 176.
} 


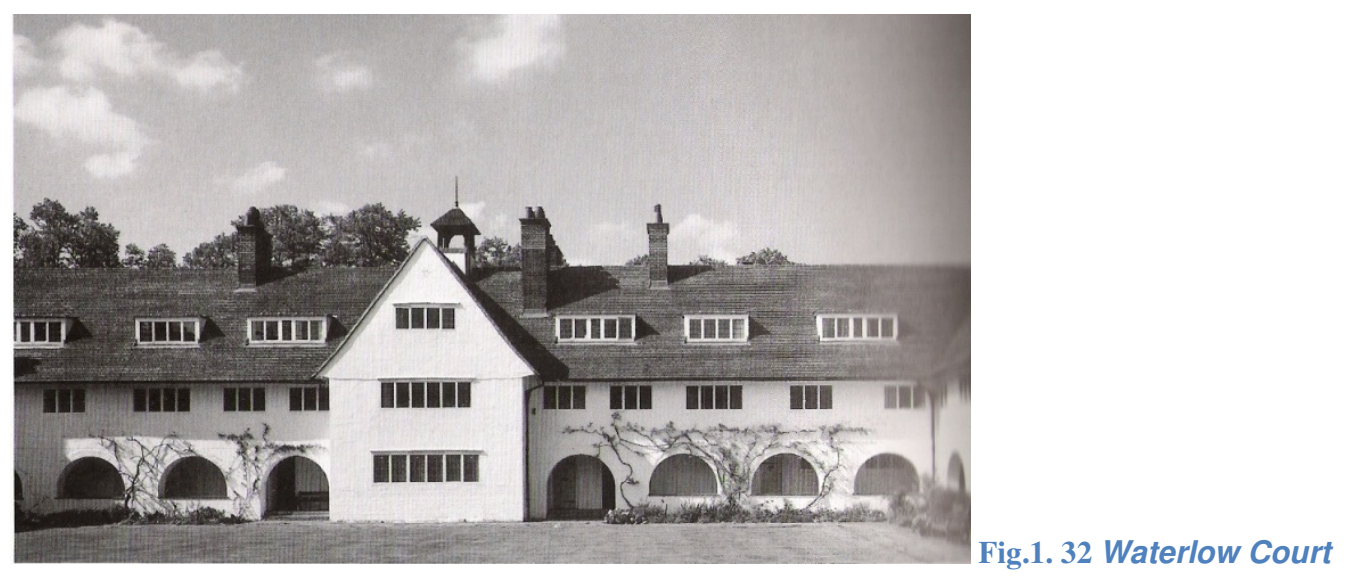

Em 1914, Scott desenha sua primeira casa Neo-Georgiana, e isto implicava em simetria e na "domesticação" da planta para se adequar a fachadas pré-concebidas a procura por ordem, que mudara totalmente o gosto do público. Segundo DAVEY (1995, p. 179) era a antítese de tudo o que ele fizera até então.

Sobre a máquina:

Aqui, como em outros lugares, temos que discutir a idealização do que é feito à máquina, que é a marca de quase todo o trabalho moderno, e que não leva em conta as texturas e superfícies, mas torna tudo monótono e apático. Aqueles que já perceberam a beleza de uma velha viga, com sua superfície trabalhada a mão, serão capazes de avaliar como isto se perdeu com a plaina do marceneiro, e este é apenas um dos exemplos da degradação do trabalho moderno. $^{30}$

\subsubsection{Richard Barry Parker (1867-1947) e Raymond Unwin (1863-1940)}

Os arquitetos situam-se no final de um arco que, partindo de Webb, passa por Voysey e chega a eles. Outra grande influência seria de Baillie Scott.

Thoreau foi uma referência para Parker. Em um artigo de 1895 (CREESE, 1992, p.284), ele diz "Thoreau, vocês se lembrarão, jogou o fóssil fora, o único ornamento da sala, porque necessitava de limpeza (...) e acredito que, geralmente, quanto mais algo é adaptado ao uso, mais elegante será sua forma."

\footnotetext{
${ }^{30}$ BAILLIE SCOTT, M.H The Fireplace of the Suburban House, Studio 6 (1895-6), p. 104-5 apud CREESE, 1992, p. 287.
} 
Unwin assistiu às conferências de Ruskin em Oxford e era amigo de Edward Carpenter $^{31}$. Provavelmente através dele conheceu William Morris. Tornou-se socialista e escrevia para o Commonweal de Morris.

Em 1887, Parker tornou-se aprendiz de G. Faulkner Armitage, que tinha um escritório de projetos e uma oficina próximos a Manchester. Um esboço de uma sala feita por ele sugere o "calor" e a preocupação com a utilidade presentes nos interiores de Parker. Ele coloca uma lareira, bancos, um guarda-louça embutido e objetos utilitários usados como ornamentação.

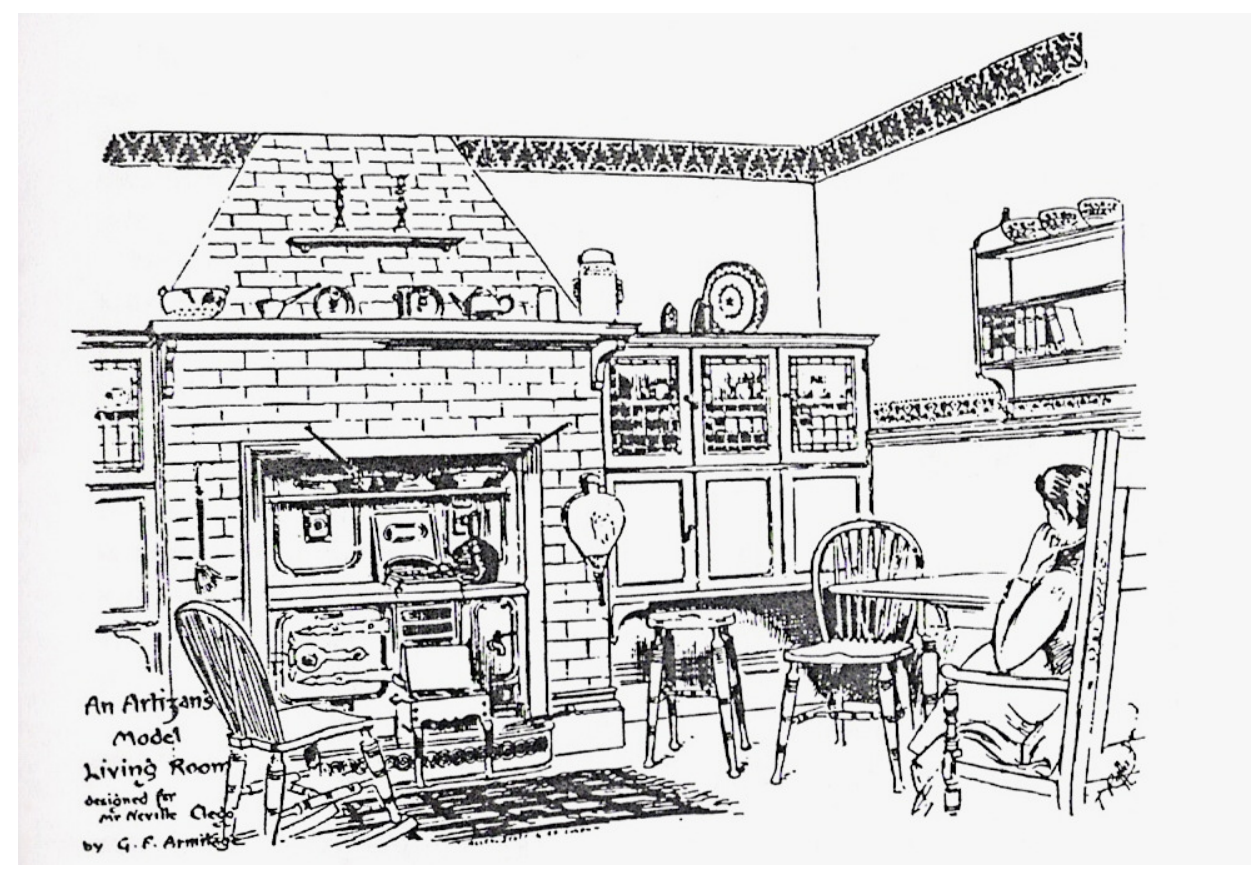

Fig.1. 33 Desenho de Armitage - Exposição do Jubileu de Manchester.

No início de sua carreira, Parker desenhou papéis de parede, têxteis e mobília.

Parker diz, em seus artigos escritos para The Building News, 'Our Homes', em 1895, ligando forma, função e beleza: "Queremos cômodos onde se possa viver livremente e com prazer (...) singelos, simples, sem decoração (...) mas sinceros (...). Deixemos o

31 Edward Carpenter (1844-1929) foi ordenado, mas rompeu com a Igreja, para passar a vida trabalhando com os pobres. Tornou-se uma figura influente nos círculos socialistas nos anos 1880's e 1890's. (DAVEY, 1995, p. 181) 
piso sem tapetes, e a madeira sem pintura, para que possamos ter tempo para pensar e os recursos para educar nossas crianças para também aprenderem a pensar."32 Esta atitude despojada pode ser encontrada no ensaio escrito por Baillie Scott na mesma época: Ideal Suburban House. "Pode-se dizer que a tônica do desenho seja simplicidade e conforto rústico, e a beleza de casa de bonecas da assim chamada residência Queen Anne tem sido considerada tão indesejável quanto a feiúra apática da caixa de tijolos da casa suburbana." ${ }^{33}$

Predispostos a expressarem em seu trabalho as idéias de Morris, em 1901, Parker e Unwin fizeram juntos uma série de conferências sob o título de The Art of Building a Home. A dimensão social de seu pensamento reflete-se em alguns títulos, como "Sobre a pequena casa da classe média". Foi publicado como livro neste mesmo ano e suas idéias provavelmente encontraram repercussão, pois uma segunda edição apareceu ainda em 1901.

Resumindo os princípios de seu livro The Art of Building a Home, Parker coloca:

Percebo agora que o livro poderia ser resumido como um apelo por honestidade, e perceber também que ele resultou de uma convicção de que uma mentalidade diferente era necessária na prática da arquitetura doméstica antes que esta pudesse tornar-se uma cultura vivificante. Sabemos que só pode haver um modo verdadeiro de se trabalhar, que é construir da forma mais simples e mais direta possível, apenas assim serão as funções e necessidades melhor atendidas. (PARKER, 1986, p. 37)

Parker não se refere apenas a uma reforma do ambiente físico. Ele pede uma reforma na maneira vitoriana de se viver: casas divididas em pequenos ambientes enclausurados, cheias de objetos inúteis, com as crianças afastadas de seus pais. Todos vivendo vidas vazias. "(...) a unidade familiar como o ponto de partida do projeto iria tornar-se essencial nas iniciativas de Parker e Unwin” (CREESE, 1992, p. 276)

E assim, o mais importante era a função de cada parte da habitação, não um padrão de planta, onde "o tamanho dos cômodos variasse de acordo com o status do morador" (MILLER, 1998, p. 182). Ele lamenta a existência de salas de visitas: "uma

\footnotetext{
32 PARKER, Barry Our Homes, artigo para The Building News, 26 de Julho de 1895, p. 108 apud MILLER, 1998, p. 181.

33 BAILLIE SCOTT, M.H. An Ideal suburban House, The Studio, Vol. V, 1894-5, p. 127 apud CREESE, 1992, p. 282.
} 
pequena sala frontal aonde ninguém vai, exceto para limpá-la" ${ }^{34}$, e pede uma grande sala, onde áreas de estar e trabalho se sobreponham, refletindo as necessidades complexas da vida familiar. Como a oficina do carpinteiro onde a beleza se origina do trabalho que ali é feito. Esta grande sala reviveria a houseplace das casas medievais. Prevenindo-se contra o costume de se projetar um cômodo para cada função, estas grandes salas seriam multifuncionais, seguindo o costume japonês, onde não existia nem mesmo um cômodo exclusivo para dormir.

Honestidade na admissão do que realmente se necessita para viver uma vida verdadeira:

(...) aqueles prestes a construir suas casas raramente parecem avaliar suas necessidades e exigências reais e legítimas, ou considerar o que Ihes permitiria viver uma vida mais plena, ou mesmo o que melhor expressaria suas personalidades, individualidades e desejos. (...) Talvez pensassem qual impressão a casa proposta causaria nos visitantes, o que seus amigos, vizinhos e parentes esperariam que tivessem; o que era habitual na classe social a que pertenciam (...). Julgamos ser tarefa do arquiteto utilizar qualquer influência que tenha com seus clientes para fazê-los considerar suas necessidades reais e não se aterem a meras convenções. (PARKER, 1986, p. 37)

Havia uma unidade de pensamento entre suas idéias sobre arquitetura e seu pensamento social. Para os sócios, a dimensão social do Arts and Crafts aplicada às casas deveria ser estendida à vida comunitária. E esta era a tarefa de Unwin.

Seus princípios poderiam ser aplicados a diferentes escalas, desde o planejamento urbano até os menores detalhes da habitação. E o funcionalismo do Arts and Crafts aparece como ponto de partida para o projeto em todas estas escalas. Na casa, como a função preponderava, esta deveria determinar o desenho da planta, do interior para o exterior. $O$ fundamento é a racionalidade com certa inspiração na tradição vernácula.

Em 1903, Parker e Unwin envolvem-se com a Northern Arts Workers Guild, fundada em Manchester, em 1896, por Walter Crane, discípulo de Morris. O objetivo da guilda era "unir em suas fileiras artistas e artesãos de todo tipo, com o desejo e o propósito de quebrar as barreiras que (os) têm separado. (...) A verdade que tal grupo deve manter é a unidade essencial de todas as artes, e seu verdadeiro fundamento deve

\footnotetext{
${ }^{34}$ PARKER, Barry Our Homes, op.cit., p. 98 apud MILLER, 1998, p. 182.
} 
ser o artesanato vivo." (CREESE, 1992, p. 274-5). Na exposição de 1903, da qual participaram Parker e Unwin, havia uma alusão a obrigações morais e também estéticas.

No mesmo ano, Parker e Unwin foram convidados a participar de um concurso para o plano da primeira cidade-jardim, Letchworth. Venceram e tornaram-se os principais intérpretes do novo movimento. Em 1905, Unwin desenha o subúrbio-jardim de Hampstead. De certa forma, a atividade dos sócios como planejadores ofuscou sua prática arquitetônica.

A honestidade de que falam em The Art of Building a Home mostra-se também na forma com que trabalham o material utilizado, não desconsiderando as qualidades decorativas inerentes a ele, ou seja, não o cobrindo com outro material. Um bom exemplo é o tijolo aparente: economiza-se em seu acabamento, expondo a beleza própria do material, presente em sua textura e em sua cor.

Nossa esperança repousa na revelação das belezas próprias da construção e dos materiais utilizados, também se espera que façamos as coisas úteis e necessárias da casa bonitas, ao invés de desconsiderá-las ou cobri-las com o que julgamos belo. (...) Sabemos que a escolha dos materiais corretos para se construir deve vir antes e que quase com certeza se provará serem os materiais disponíveis no local; uma lição a ser aprendida do trabalho de épocas passadas era a probabilidade de que os materiais de construção encontrados na localidade fossem, artisticamente e na prática, os melhores para serem utilizados naquele local, que se harmonizariam mais com o entorno, e que conceber formas adequadas a eles provavelmente resultaria em um todo perfeito a que devemos almejar. (PARKER, 1986, p. 38)

Seguindo Ruskin, mais uma vez:

A falsidade na arquitetura é plenamente considerada sob três tópicos: 1- A sugestão da estrutura ou suporte, que não seja a verdadeira; como nos pendentes dos últimos telhados góticos; 2- A pintura de superfícies que representam outro material que não aquele realmente utilizado (como na marmorização da madeira). 3- O uso de ornamentos moldados ou feitos à máquina de quaisquer tipos. (RUSKIN, 1907, p. 34-5)

O pensamento Ruskiniano é sempre aludido como autoridade. Unwin diz que, sem dúvida, a maioria dos homens aceitaria o ideal de Ruskin para uma casa: 
Não um cômodo em um alojamento, não o número tal da Rua Paraíso, mas um cottage seu, com seu pequeno jardim, o ar saudável, sua cozinha limpa, sala de estar e dormitórios ${ }^{35}$.

Quando Ruskin se refere ao nome da rua, row não significa apenas rua, mas também uma fila de casas, todas iguais, como se pensava a habitação operária na época. Ele nos convida a pensar sobre a necessidade da personalização da habitação de número tal - the number so and so - e sobre a própria individualização do homem. Ainda a idéia da casa como o "ninho", onde o homem encontrará a felicidade, não esquecendo os preceitos higiênicos: o ar saudável e a cozinha limpa. Evitando a promiscuidade de um cômodo em um alojamento, a casa com suas funções definidas, com as separações necessárias à vida familiar.

Parker estampava a personalidade do cliente na casa. Tal efeito não poderia ser obtido se a casa e seus elementos - mobília e decoração - fossem obtidos de diferentes fontes. Como os artigos desenhados de forma impessoal, apenas para serem colocados no mercado e vendidos.

Um bom exemplo desta "casa feita sob medida" é a Hilltop, cujo proprietário, praticante de jiu-jitsu, havia incorporado a filosofia de vida japonesa, após muitos estudos e viagens para a região. Um ginásio para tal prática com pé direito duplo, onde 0 proprietário passava grande parte de seu tempo, ocupa lugar central na casa, quase como um houseplace das demais casas de Parker e Unwin. Ou a casa do médico, que ali também mantém seu consultório, em Minehead. Para Parker, deve-se, antes de se projetar, fazer uma lista das necessidades e questioná-las uma a uma. Se é necessária para satisfazer certas funções, para manter a resistência, a estabilidade, impermeabilidade ou durabilidade da casa. Finalmente, "não se deve permitir que nada seja adicionado que não apresente um incontestável direito de existir, porque é bonito e coloca a beleza como a razão para sua existência" (PARKER, 1986, p. 74)

\footnotetext{
35 "Not a compartment of a model lodging house, not the number so and so of Paradise Row but a cottage all of our own, with its little garden, its healthy air, its clean kitchen, parlour and bedrooms". (RUSKIN, John apud UNWIN, Raymond Cottage Plans and Common Sense, Buxton.: s.n.,1902, p.4 apud CREESE, 1992, p. 276)
} 


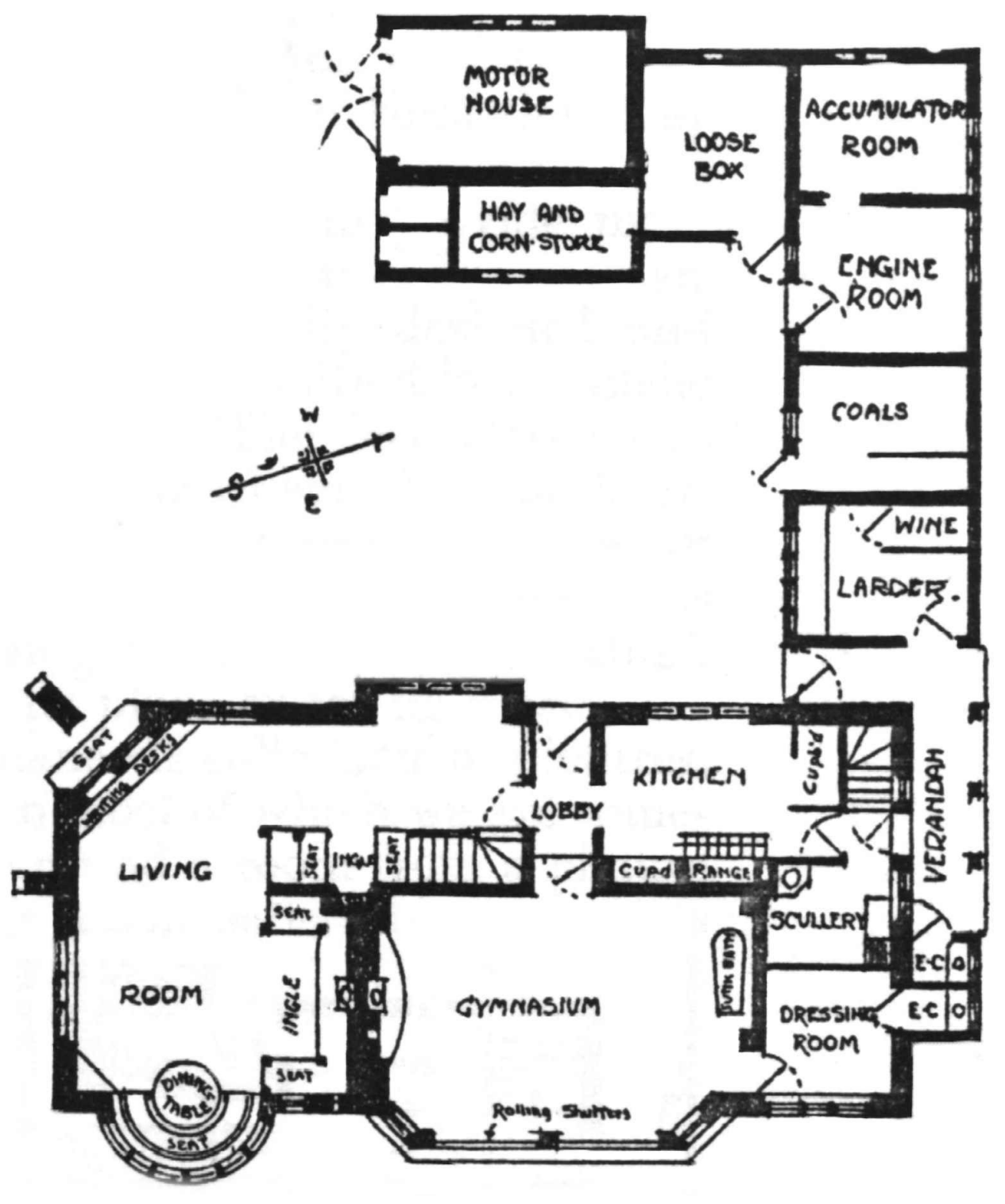

Fig.1. 34 Hilltop, planta baixa - térreo. 


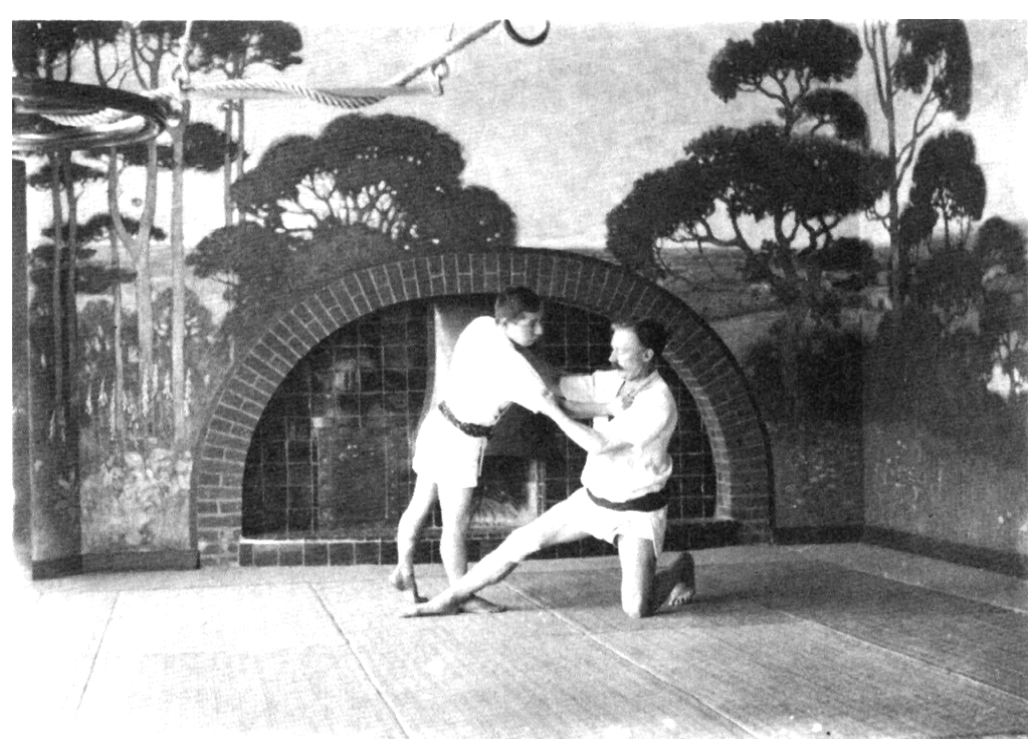

Fig.1. 35 Hilltop, ginásio- interior.

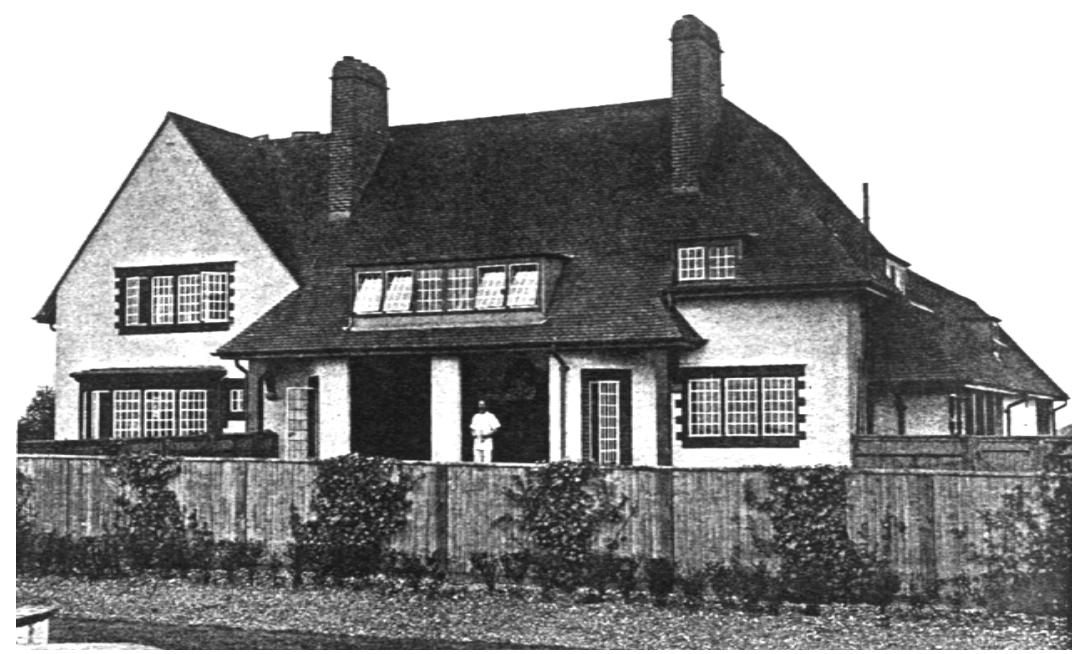

Fig.1. 36 Hilltop, entrada do ginásio.

O efeito do contraste entre o pé direito duplo e os espaços adjacentes - geralmente de altura reduzida -, com as vigas de madeira aparentes em uma exposição da estrutura do edifício, foi explorado muitas vezes. Este cômodo mais alto era geralmente o hall, contrastando com uma série de ambientes, tanto no térreo quanto no segundo pavimento, separados em algumas situações por portas de correr. O efeito é de sofisticação espacial, em que se vêem diferentes combinações volumétricas. Às vezes é percebida uma relação entre a lareira e a bay window, às vezes se impõe a verticalidade do pé direito duplo. Mas, tudo permanece sob controle das linhas horizontais do friso que percorre a parte superior das paredes internas. 


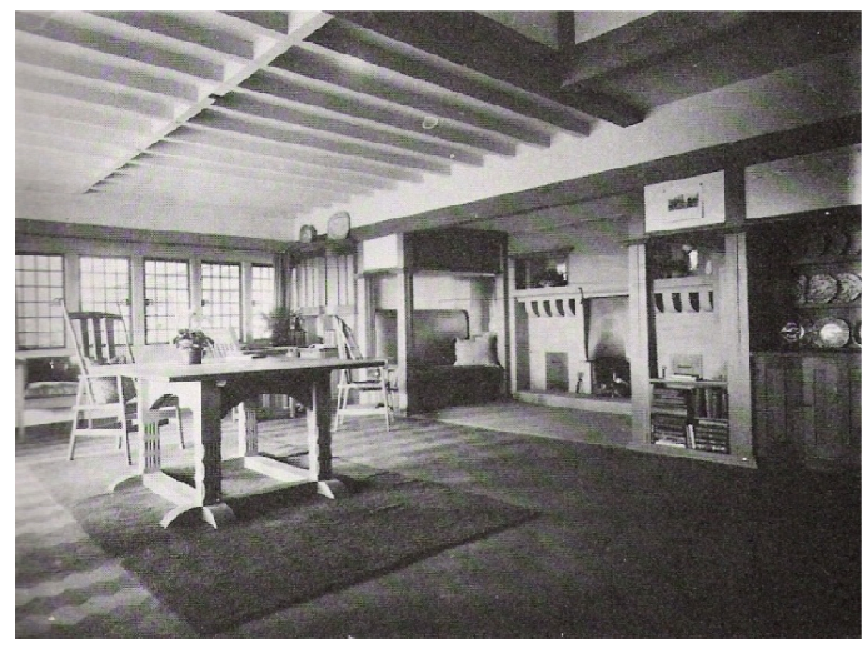

Fig.1.37 Whirriestone, houseplace

Como o próprio Voysey já dissera, com exceção do hall, a altura muito elevada para ambientes, principalmente para casas menores, traria uma percepção não muito agradável de um cômodo muito elevado em relação ao comprimento e à largura..

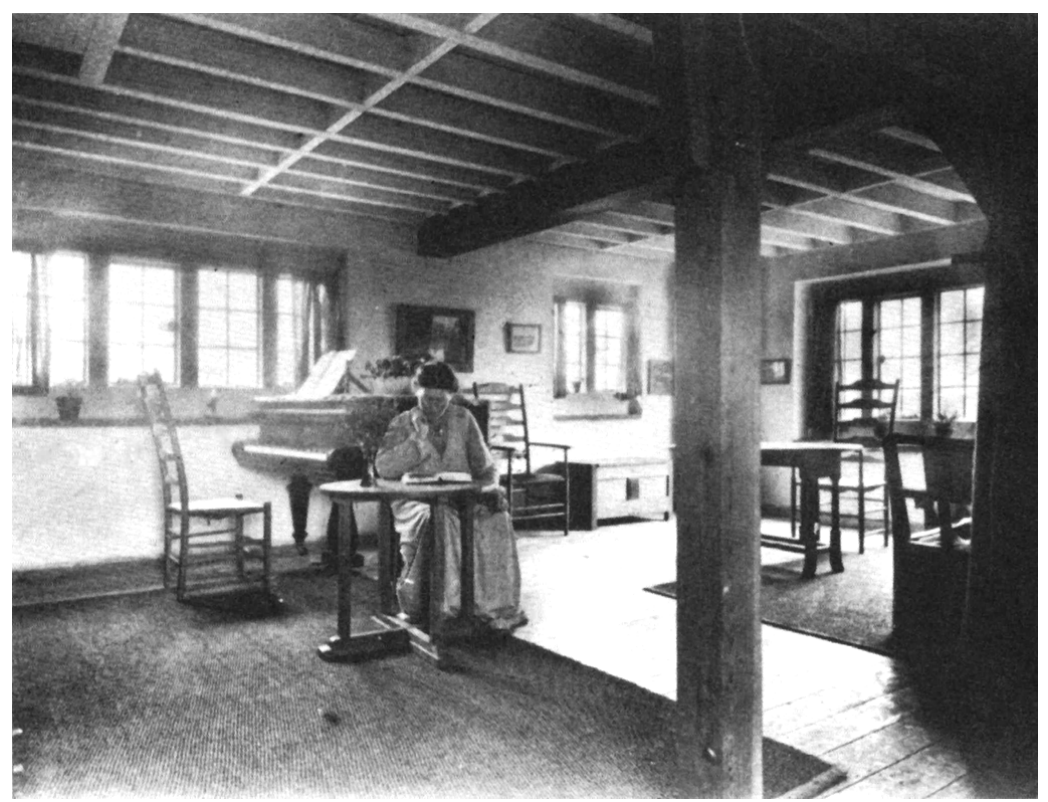

Fig.1. 38 Casa de Stanley Parker, houseplace

Localizado geralmente no hall, havia o ingle-nook - uma área que contém a lareira e o espaço circundante, geralmente equipada com bancos. Concebido por Parker e Unwin como centro da vida familiar nos meses de inverno, era sempre pensado com muito cuidado. 
A sofisticação espacial incluía espaços que eram desvendados aos poucos, por ângulos inusitados, como na Hilltop a lareira sob a escada. Algo essencialmente pinturesco, no sentido de não permitir a visão da totalidade.

Há um grande encanto em uma sala de formato irregular, onde existe aquela leve sensação de mistério que surge quando não se pode ver toda a área de qualquer ponto onde se sentar; onde há sempre algo próximo à esquina. (itálico de Parker) ${ }^{36}$

Outra característica do houseplace: era um espaço onde se valorizavam as atividades artísticas como a música. Nichos para piano ou órgão e galerias no mezanino, que Parker chamava de "galeria do menestrel" - referindo-se aos trovadores da Idade Média - e aparece em The Homestead. E as artes visuais eram utilizadas na decoração das paredes.

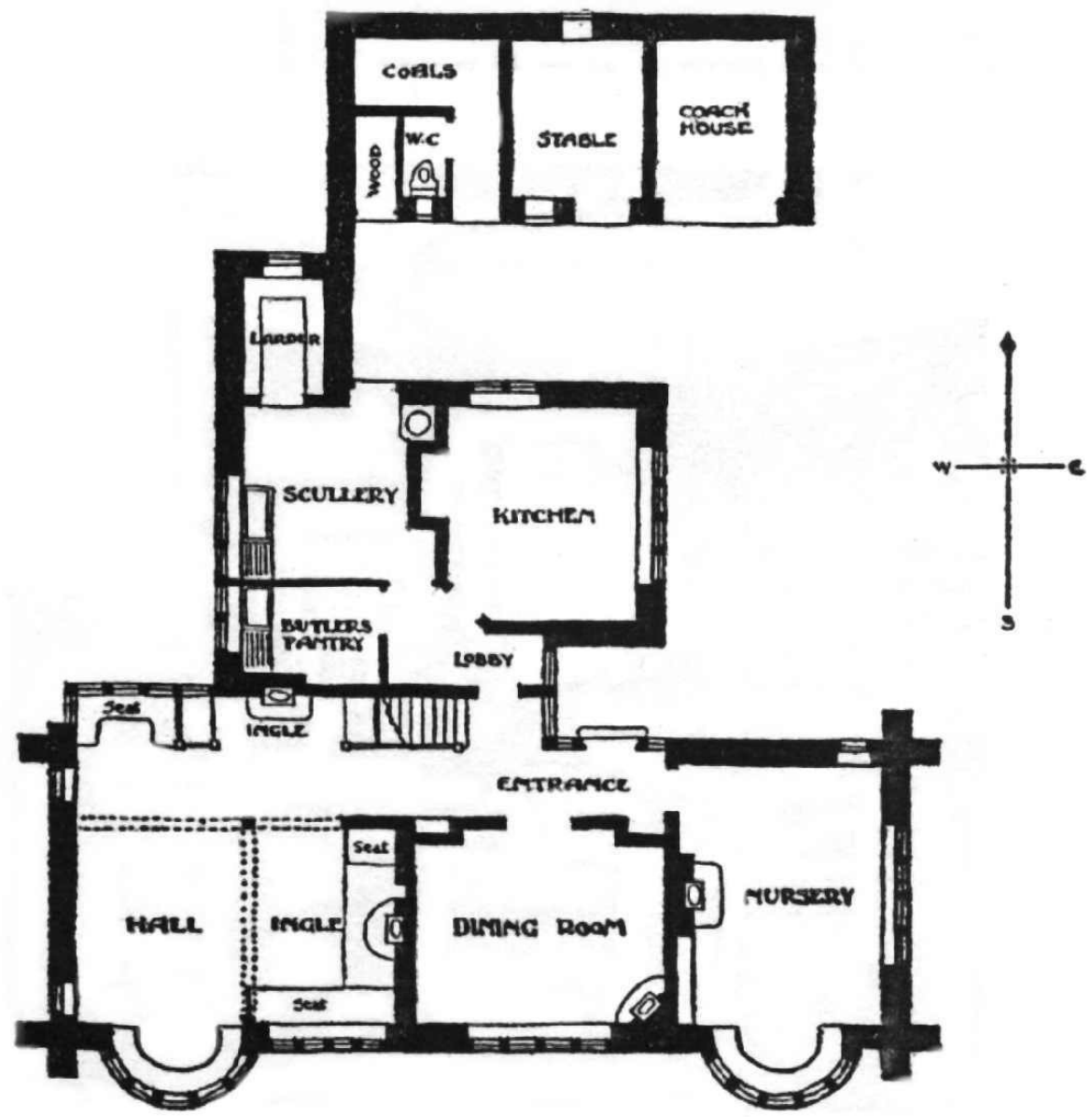

Fig.1. 39 Homestead, planta baixa - térreo.

36 PARKER, Barry The Smaller Middle Class House, conferência dirigida a uma platéia de arquitetos, 1895, in PARKER e UNWIN, 1901, p.3 apud DAVEY, 1995, p. 186 


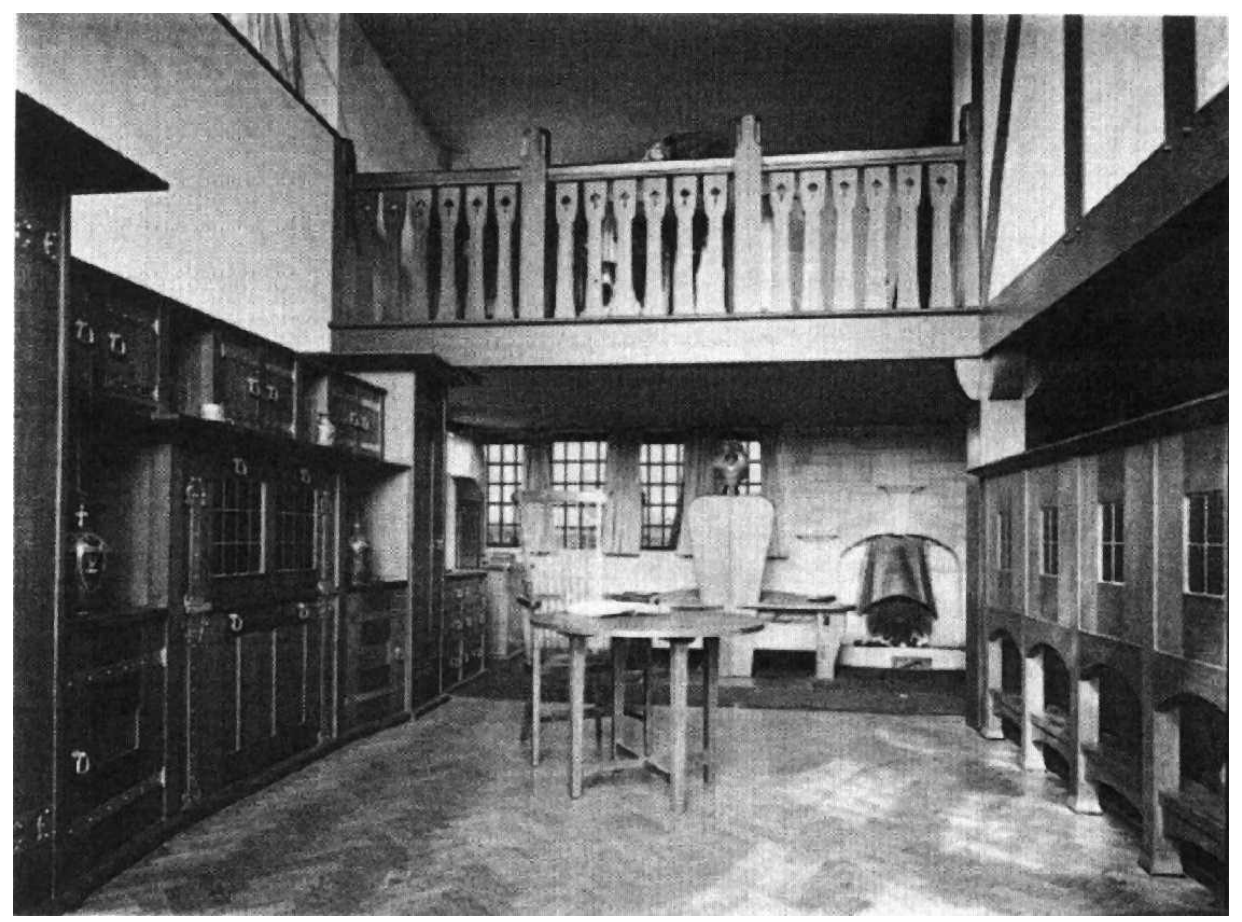

Fig.1. 40 Homestead, hall e galeria.

Interessante notar como a própria estrutura das casas e a mobília fixa são interdependentes, particularmente a lareira e as escadas. O espaço sob estas foi utilizado, muitas vezes, para localizar assentos para a lareira ou armários. Na Homestead, a estrutura da construção e os móveis proporcionam a decoração da sala. A pedra na lareira e nos parapeitos das janelas e a estrutura em madeira da parede que divide o dormitório do pavimento superior do hall são deixadas sem acabamento. Nesta casa, Parker desenhou todo o mobiliário, os tapetes, até as peças metálicas das portas. A mobília embutida implicaria em facilidade de limpeza e economia nos custos. O proprietário teria apenas o necessário, desenhado segundo suas necessidades. Não teria que ir às lojas comprar o que estivesse disponível, quando certamente elementos supérfluos seriam também adquiridos.

Em Glaed Home, hall, sala de jantar e de estar podem ser convertidas em um espaço único, através da abertura de portas de correr, utilizado para recepções maiores, sem resultar em um grande espaço inutilizado pela maior parte do tempo. A influência de Baillie Scott aparece aqui, na idéia da concepção do interior como uma unidade. As cores são variadas, como aquelas utilizadas por Voysey e o próprio Baillie Scott: azul pavão, verde e púrpura em tapetes e cortinas e o tom escuro do carvalho. 


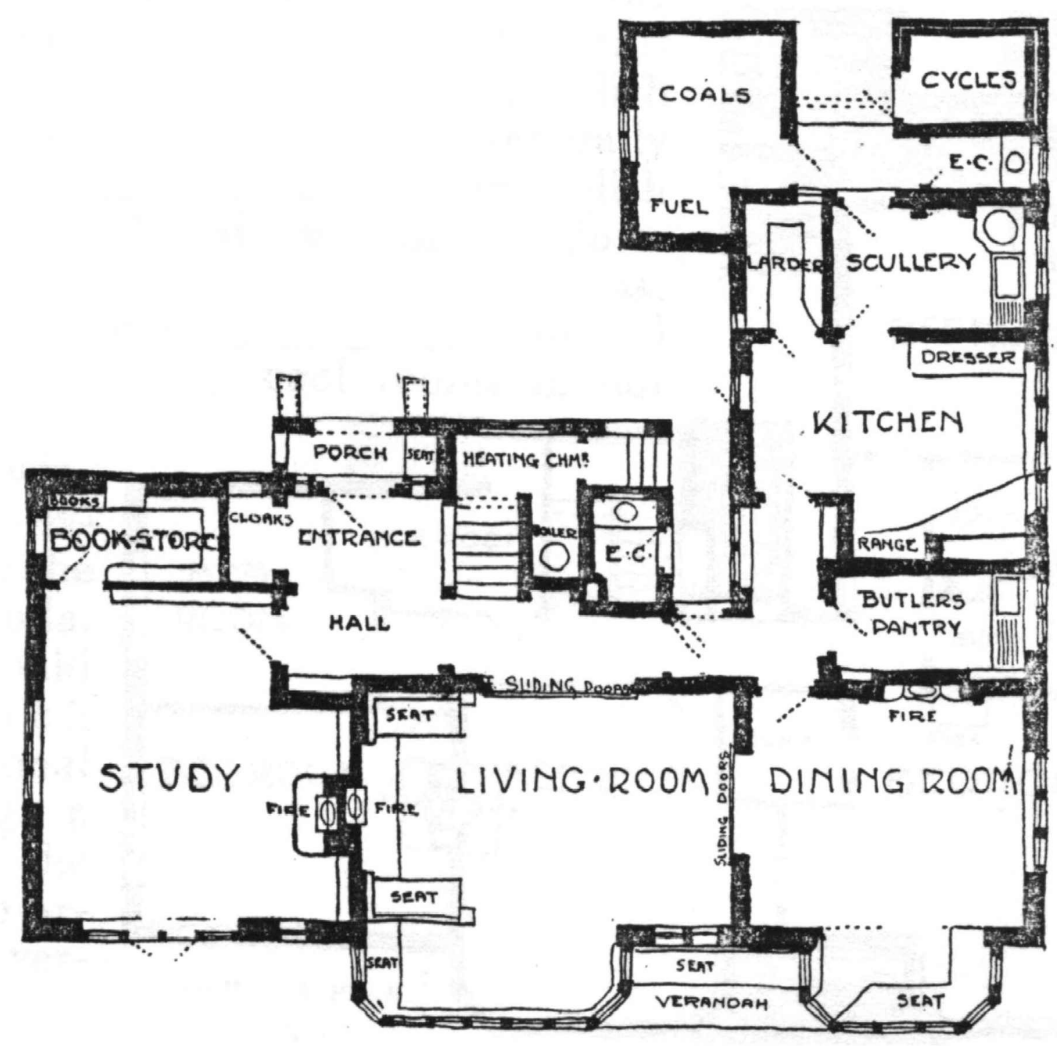

Fig.1. 41 Glaed Home, planta baixa- térreo

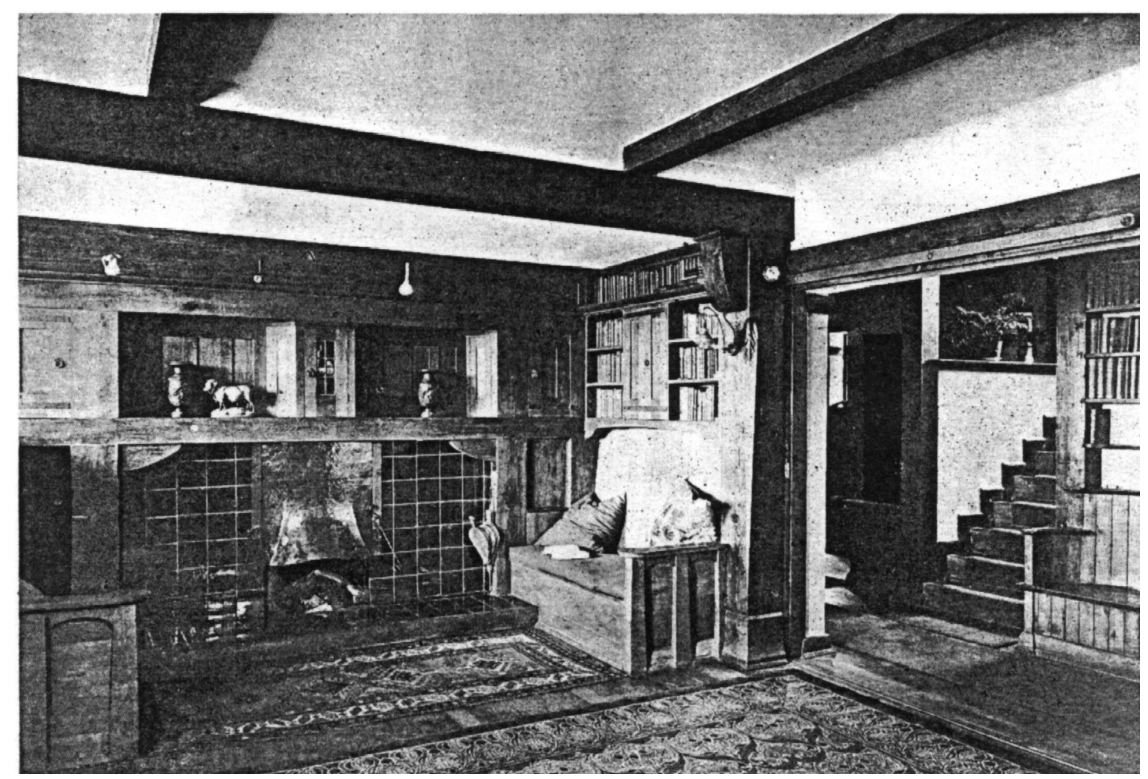

Fig.1. 42 Glaed Home, sala de estar

Formas geométricas básicas muitas vezes sustentam a composição de projetos sofisticados. Geralmente um volume retangular central é trabalhado, com a adição de 
uma série de espaços menores, associados a uma função específica. Não se consegue perceber esta geometria básica, devido às várias inflexões e ajustes.

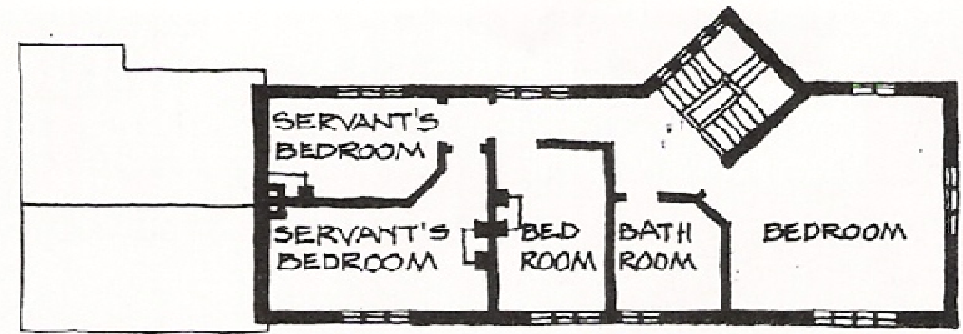

FIRST FLOOR PLAN

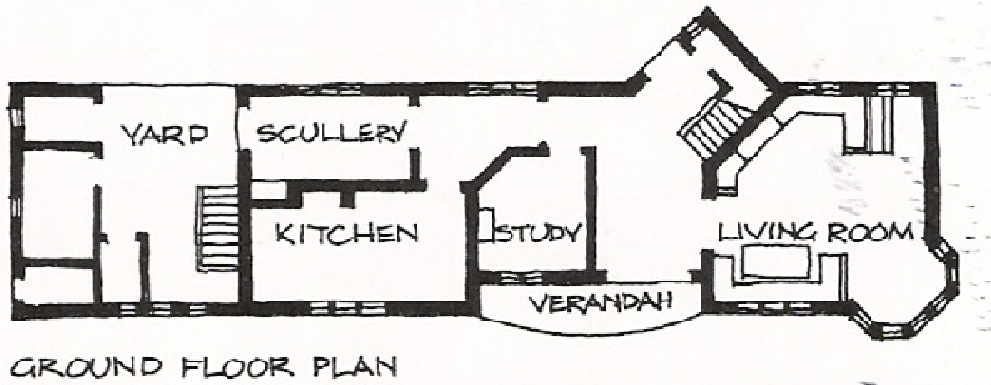

Fig.1. 43 The Cottagge, Newton

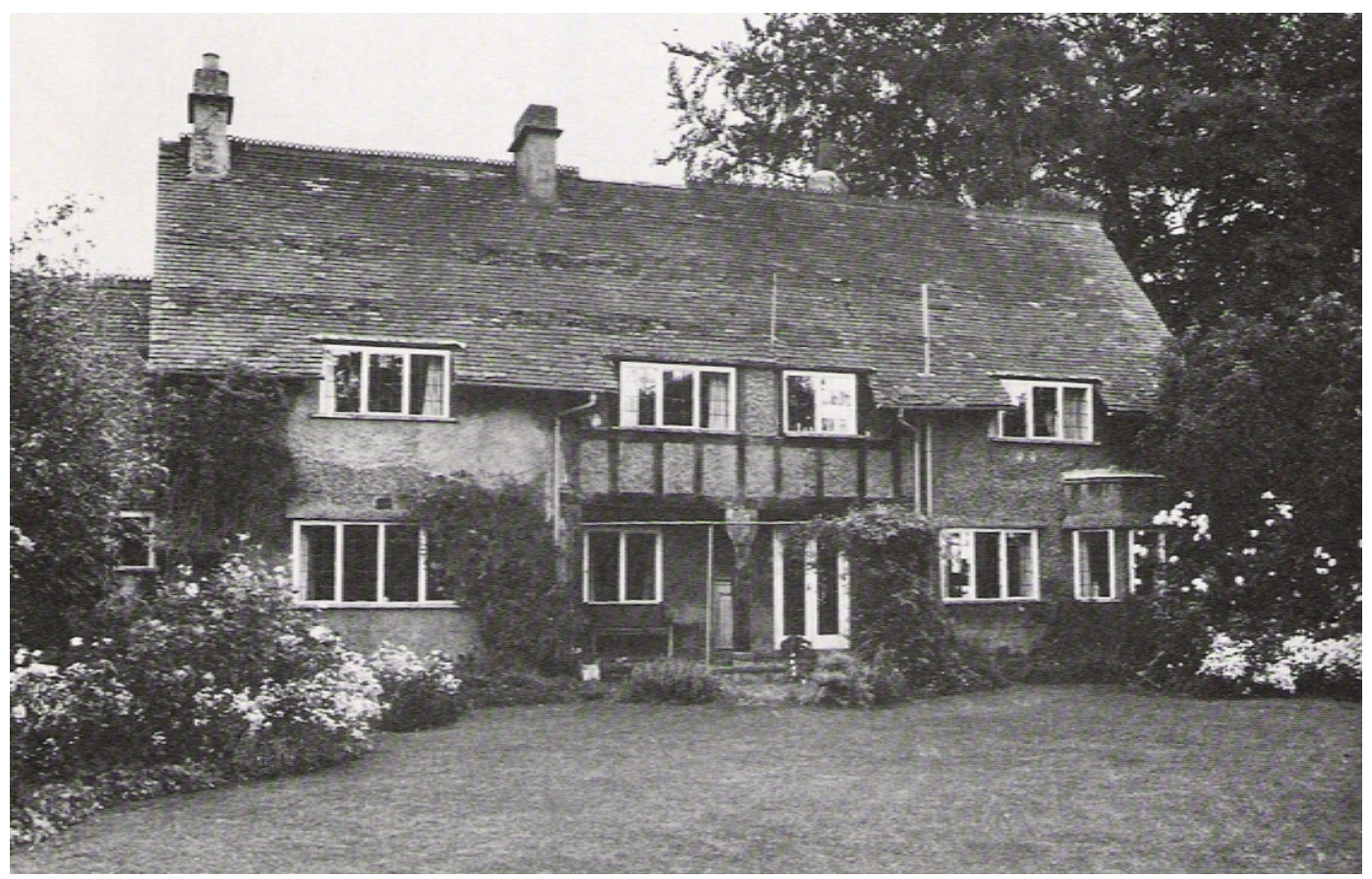

Fig.1. 44 The Cottagge, Newton

As necessidades de cada cliente seriam consideradas para se produzir uma planta racional com complexos zoneamentos. A planta borboleta aparece menos do que se espera.

82 I C a pítulo 1 
A racionalidade da planta era estendida aos menores detalhes. A circulação era algo muito importante. Por exemplo, se o hall fosse utilizado como sala de estar, a circulação entre os demais espaços não deveria atravessá-lo. Correntes de ar deveriam ser evitadas sobre os ocupantes da sala, particularmente se estivessem próximos à lareira. Isto era de suma importância devido à falta de aquecimento central na Inglaterra, na época. (CREESE, 1992, p. 277) A ventilação cruzada deveria ser permitida, através do posicionamento das aberturas para a eliminação do "ar viciado". Deveriam ser previstas janelas para iluminar 0 espaço onde as pessoas desenvolveriam determinadas atividades, como ler, conversar, desenhar, comer. $O$ sol, com todos os benefícios intensamente louvados na época, deveria penetrar a casa pelas aberturas na direção sul. A tendência a associar a luz solar com uma vida saudável é muito presente no início do século XX, mas potencializa-se na Grã Bretanha, devido à localização do país bem ao norte, implicando em escassa irradiação solar. Segundo Unwin: "Em grande parte de nosso país (...) a importância do planejamento para os poucos dias com excesso de sol é pequena, se comparada aos arranjos para se adaptar aos muitos dias em que cada hora de luz solar é preciosa". (UNWIN, 1901, p.113 apud CREESE, 1992, p. 278).

Nas casas pequenas deveriam ser evitados corredores e outras áreas de circulação. Tais espaços poderiam ser incorporados a cômodos adjacentes.

Parker se interessava pelo uso da simetria nos edifícios e se opunha ao uso arbitrário da variedade. Mas, não a simetria clássica, mas antes uma conciliação de ambas as linguagens, clássica e pinturesca, como Voysey fizera antes. Isto é observado nas fachadas simétricas que escondem uma planta assimétrica ou exteriores inicialmente simétricos tornados assimétricos por um detalhe a mais, produzindo certa tensão.

Porém, existem uma ou duas regras gerais que podem ser ditas: (...) das quais a primeira é que, onde quer que a Proporção exista, uma parte da composição deve ser maior ou menor que o restante. Não há proporção entre coisas iguais. Elas podem ter apenas simetria, e simetria sem proporção não é composição. (RUSKIN, 1907, p. 126-7).

Parker (1986, p.98) diz que "temos um instinto de que há algo inerentemente correto no arranjo simétrico de edifícios" e, citando Alfred Gotch, que no livro "The Growth of the English House" explica que anacronismos impressionantes foram produzidos no século XVIII, desenhando fachadas formais de acordo com regras de proporção e fazendo então as acomodações necessárias na planta. Isto produziu resultados quase tão inadequados quanto as tentativas de se obter algo pinturesco em épocas posteriores. 
Somando-se à procura intuitiva pela simetria existe um instinto por uniformidade, onde é lógica e natural. A introdução da variedade gratuitamente seria tão desastrosa quanto, por exemplo, a procura da uniformidade adequando as aberturas de um edifício a arranjos prévios da fachada a que pertencem. "(..) a variedade que nasce da faculdade criativa e da imaginação, (...) é uma expressão espontânea de deleite na beleza" (PARKER, 1986, p. 99)

$\S X X X I I$ Entretanto, deveremos reparar aqui, cuidadosamente, na distinção entre o saudável e o doentio no amor da mudança; pois se foi no amor saudável da mudança que a arquitetura gótica se elevou em parte foi em conseqüência do amor doentio da mudança que ela foi destruída. No sentido de compreender isto claramente, será necessário considerar as diferentes maneiras pelas quais mudança $e$ monotonia se nos apresentam na natureza, cada qual com o seu uso, como a escuridão e a luz, uma incapaz de ser desfrutada sem a outra.(...) (RUSKIN, 1853)

(...) Entre todos os avisos que daria ao projetista de pequenas casas, viria um, contra o esforço consciente de se fazer algo pinturesco. Deixemos o exterior ser o resultado e a expressão de um arranjo interno bem estudado. (...) talvez os mais importantes fatores para o sucesso ou fracasso artístico no desenho de pequenas casas seja a relação entre sólidos e vazios, entre o espaço das janelas e o das paredes e na proporção e distribuição destes. (PARKER, 1986, p. 42)

Os exteriores são normalmente francos, simples, tentando "construir da maneira mais simples e direta possível", mas escondem interiores ricos e complexos. As fachadas, despretensiosas, chegam a ser desapontadoras. Apesar de Voysey ser a principal influência, a dupla raramente alcançou sua serenidade. (DAVEY, 1995, p. 187). Uma das melhores casas da primeira década do século XX é a de Stanley Parker, irmão de Barry. Certa confiança foi adquirida, à medida que se dirigiam a uma concepção mais purista, com grandes volumes pintados em branco, claramente identificados. Este cottage lembra claramente Tilehurst, de Voysey. Apesar do medievalismo do início, Parker e Unwin moveram-se para uma simplificação volumétrica, que também se encontrará em Baillie Scott. 


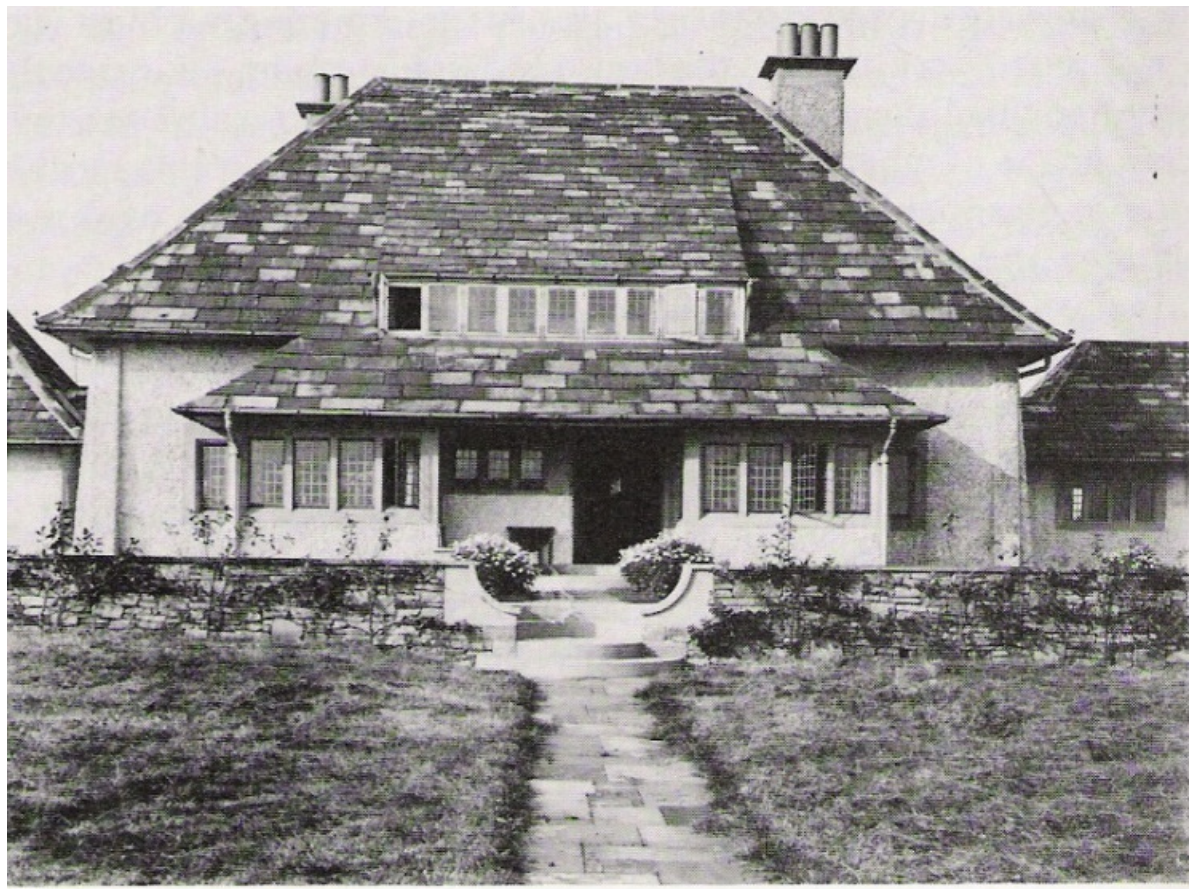

Fig.1.45 Whirriestone - Fachada principal.

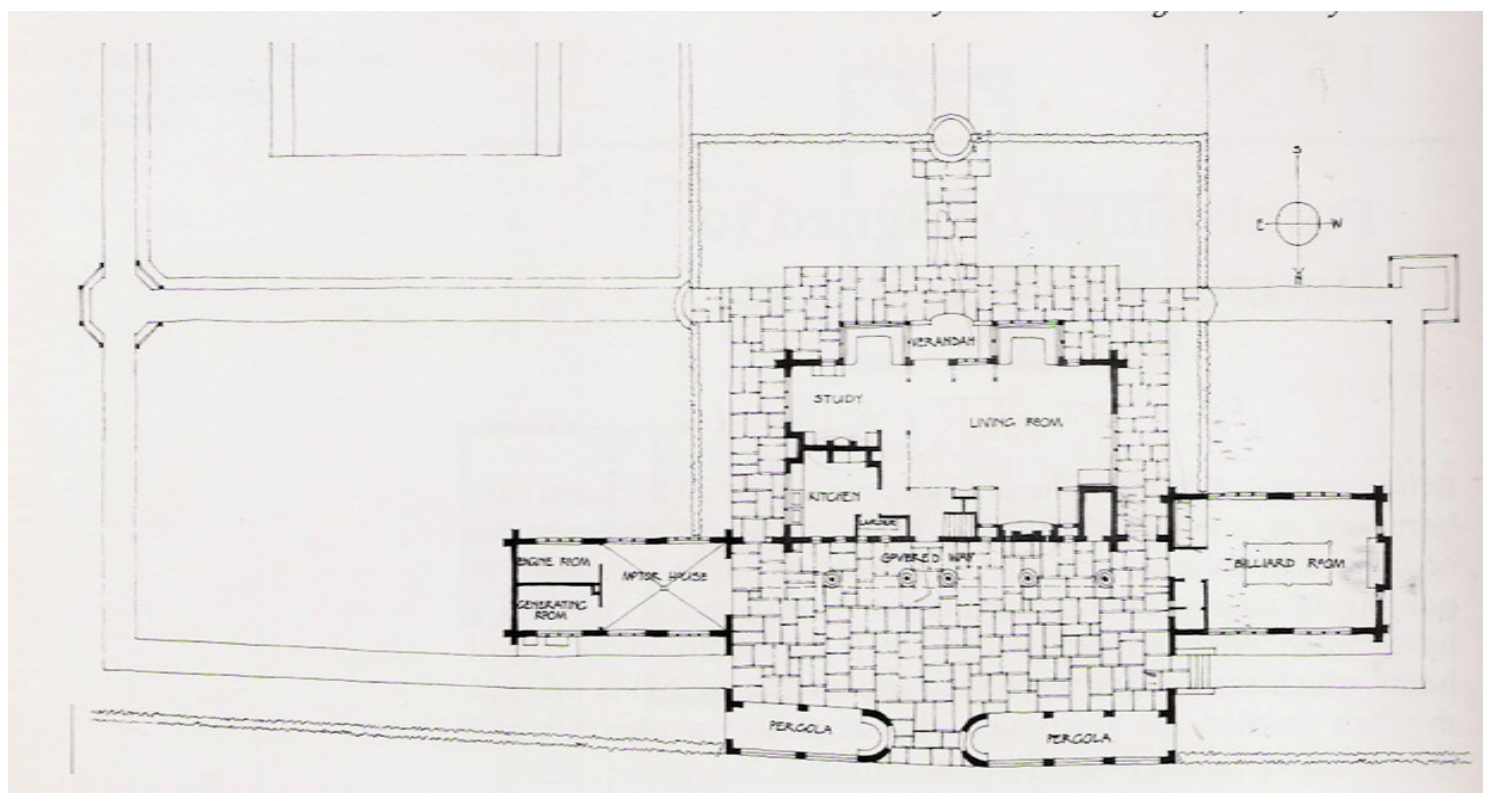

Fig.1. 48 Whirriestone - Planta baixa térreo.

Nas pequenas casas, os cottages, a função do houseplace muitas vezes cabia à sala de estar, que ocupava toda a lateral da casa, da frente aos fundos, arranjo já presente nas casas de New Earswick. Assim era possível que janelas fossem colocadas em ambas as paredes externas. Para proteção da entrada, uma pequena varanda. Outra novidade, já presente em New Earswick, era o banheiro no segundo pavimento dos 
cottages. A intenção de Parker e Unwin era afastar o banho da área onde se lavava a louça.

As fachadas não seriam hierarquizadas, "todos os lados de uma casa são igualmente satisfatórios para se olhar" (PARKER, 1986, p. 80). A frente de uma casa não deveria ser supervalorizada à custa das laterais e do fundo. Todos os ambientes deveriam estar sob o mesmo telhado, sem edículas de serviço e outros tipos de construção, que acabariam desfigurando as vistas e elevando o custo da construção.

O interior total: Parker enfatizava a importância da unidade total e em completa harmonia, que só poderiam ser obtidas se a casa e seu interior fossem concebidos por apenas uma pessoa, que desenhasse até os menores detalhes:

(...) sua influência (do arquiteto) deveria estender-se ao menor detalhe da decoração e mobília; pois é essencial que ele esteja em posição de conceber cada casa como um todo, tão completo como nenhuma outra obra de arte poderia ser. (PARKER, 1986, p.38)

E isto incluía também o jardim, com terraços, pérgulas, sacadas, varandas e pequenos riachos, lembrando os projetos da dupla Lutyens-Jekyll. Parker trata o jardim de forma totalmente coerente com os princípios do Arts and Crafts. A natureza não deveria ser imitada e o jardim deveria ser também um trabalho de arte. Assim como na natureza não se vêem linhas sem sentido, um jardim planejado deveria ter contornos expressivos, sem curvas desnecessárias. Ele deveria ser dividido em seções, em "cômodos ao ar livre". Como no desenho da casa, o terreno deve "sugerir" a forma do jardim. Deve-se então fazer um zoneamento: aqui uma quadra de tênis, ali um local para horta, um canteiro de flores, locais para se sentar e apreciar as vistas, que deveriam ser previstas. Sempre colocando cada elemento onde se mostrasse mais conveniente. Porém, nunca perdendo a noção da unidade, da obra de arte que deve ser o jardim, onde as partes devem guardar relação entre si e com o todo.

O ajuste de um elemento a todos os outros circundantes, no mesmo ambiente. Fosse um sólido, como um móvel, uma árvore, um edifício; ou um vazio, como uma lareira, uma sala com pé direito duplo, uma rua. Nenhum elemento poderia ignorar a presença de outros e assim relações seriam estabelecidas entre eles.

Mas, a racionalidade sempre estaria presente: não se deveria conceber um "efeito" para o jardim, e então adequar e sacrificar seus vários elementos. Não deveriam ser criadas formas arbitrárias, mas seguir o zoneamento feito de antemão. 
O jardim deveria ser uma extensão do pavimento térreo da casa. Casa e jardim como partes de uma mesma concepção, pensados como um todo. "Uma importante função do jardim é colocar a casa em harmonia com seus arredores, para suavizar o contraste entre os rígidos e precisos limites da casa e a suave e fluida liberdade dos limites da natureza". (PARKER, 1986, p. 113)

A casa deveria se harmonizar com seu entorno.

O projetista deve ir ao sítio e deixá-lo ditar como deveria ser o arranjo interno da casa, e, em grande medida, como deveria ser seu aspecto externo. (...) porque os contornos e a inclinação da terra devem influenciar o desenho, ou a casa nunca poderia parecer ter surgido naturalmente, como uma agradável parte de seu entorno, e não um "corpo estranho". (PARKER, 1986, p. 43)

Como Webb já fizera em seus levantamentos exaustivos do sítio.

Nos melhores edifícios, sempre parece que houve uma concepção completa. Sua planta e suas elevações parecem inseparáveis, (...) (ou quando) é mais satisfatório começar-se a partir das plantas (...) deixe-se o exterior ser o resultado lógico e a expressão de um bem pensado arranjo interno. (PARKER, 1986, p. 44)

A arquitetura, como uma arte viva deveria expressar o "espírito da época como razão fundamental para sua existência" (PARKER, 1986, p. 152, itálico de Parker) "A arte do século XIX expressou inequivocamente seu característico materialismo e o progresso mecânico e comercial”. (PARKER, 1986, p. 153) Por isso, não se deveria copiar a arquitetura de épocas passadas, pois o espírito da época a que pertencem - a mitologia dos gregos, o fervor religioso da Idade Média - não poderia ser revivido. Do contrário, haverá revival após revival, e o gosto do público será conduzido desta forma. $E$ os olhos se fecham à destruição das obras de outras épocas. O gosto pela simetria alterna-se com a paixão do pinturesco, sem consideração pelo que realmente deve ser a arquitetura. (PARKER, discurso em abril de 1916 apud CREESE, 1992, p.280).

Quanto ao uso dos materiais, Unwin diz, no início do século XX, que "devemos nos preparar para a utilização de novos materiais, como concreto armado e blocos de concreto". (UNWIN, 1911, p.400 apud CREESE, 1992, p. 280).

Sobre a questão da utilização da máquina, Unwin e Parker questionavam mais as origens da revolução tecnológica do que suas últimas tendências. Procuravam enfrentar as crescentes e complexas necessidades sociais e psicológicas resultantes 
de um ambiente físico alterado (...). Depois da guerra, eles não mais contestaram o trabalho feito à máquina. (CREESE, 1992, p. 286). Em uma palestra em 1925, em Oxford, Parker disse que: "A máquina veio para ficar, devemos aceitá-la." A partir de então, o critério seria se o objeto adaptava-se a suas necessidades, fosse feito à mão ou à máquina.

As influências sobre Parker e Unwin são inúmeras, das mais citadas, como Voysey e Baillie Scott, até Lutyens. Na Rotherwick House em Hampstead (1908-10) a feição das casas georgianas de Lutyens é reconhecível, com sua simetria (facilitada pelo fato das residências serem geminadas), a procura pela ordem, a utilização do tijolo aparente e as grandes chaminés. Lutyens projetara algumas casas na praça central de Hampstead, além das duas igrejas.

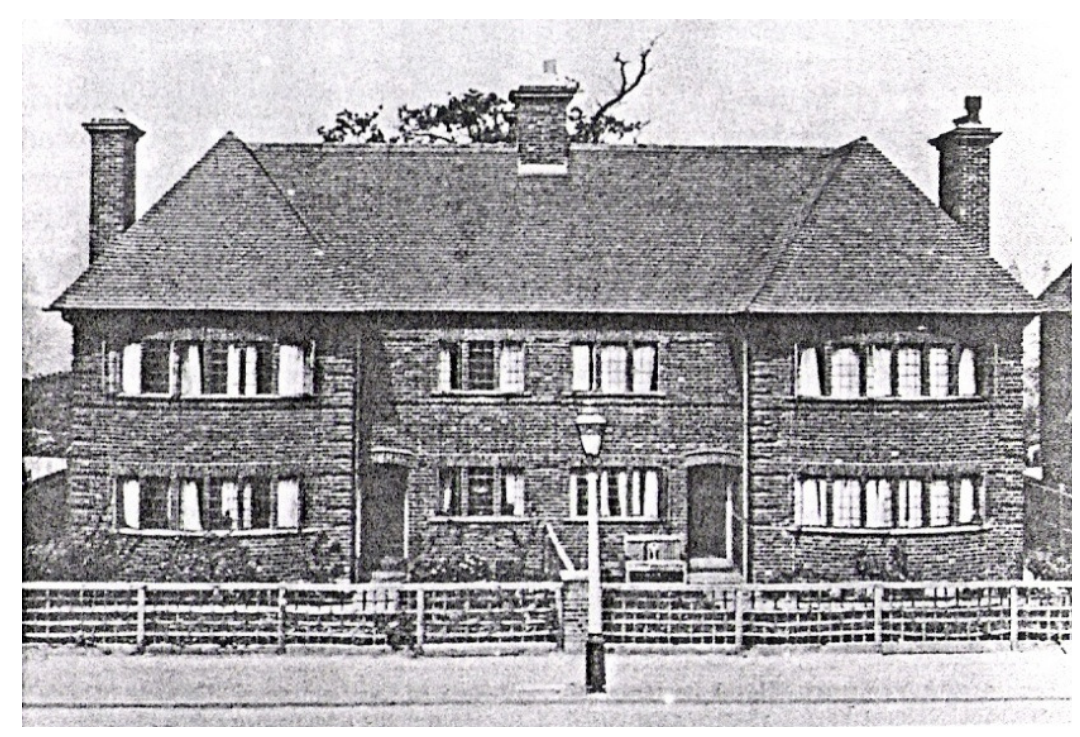

Fig.1. 46 Casas geminadas - Hampstead

Outra influência é a japonesa, através das gravuras. As vigas do teto expostas acentuam a horizontalidade, como na arquitetura japonesa, assim como os painéis e a mobília com delgados elementos verticais.

Na comparação entre Voysey, Baillie Scott e Parker e Unwin, as residências puristas dos primeiros são bastante complexas, mas não tão minuciosamente estudadas ou tão conscientemente racionais em cada detalhe como as dos sócios. Assim, Voysey e Baillie Scott apresentam um ritmo mais relaxado, mais lírico. (CREESE, 1967, p. 19). 


\subsubsection{A arquitetura da cidade-jardim de Letchworh}

No livro de Purdom sobre os dez anos da fundação de Letchworth - The Garden City: a study in the development of a modern town ${ }^{37}$ a denominação Arts and Crafts não é mencionada, porém sua arquitetura filia-se ao movimento. O que é confirmado por esta passagem: "Todos conhecem o 'cottage da Garden City', apesar de ter sido inventado muito antes da cidade-jardim - um edifício Tudor, com reboco grosso, branco, com telhado vermelho, empenas, pintura verde, calhas e condutores, e janelas com caixilhos (...). Cada pequeno espaço deveria ser utilizado, inclusive o espaço sob o telhado." (PURDOM, 1913, p. 83) Tais casas teriam sido construídas para atender às necessidades de seus moradores, não eram casas para exposição pública.

Porém, como a própria arquitetura inglesa da época, as edificações de Letchworth não se resumiam a cottages e, no futuro, ainda segundo Purdom, seria feita uma tentativa para estabelecer um padrão a que os edifícios em certas áreas da cidade deveriam se conformar. As primeiras regras já haviam sido elaboradas e os prédios na Rua Broadway, uma rua no centro, teriam um "caráter Georgiano" - para assegurar, nesta parte da cidade, um tratamento formal dos prédios, contrastando com o restante da cidade. Mas, estilos não seriam considerados entre os princípios a serem atendidos nestas construções, talvez critérios como altura, alinhamento e materiais a serem utilizados. (PURDOM, 1913, p.69-70)

A qualidade da arquitetura da cidade-jardim pode ser conferida pelas fotos. A evolução do Arts and Crafts na arquitetura para as formas simples e claras, grandes volumes que se juntam para dar origem às casas e cottages, faz-se presente aqui.

Os próprios edifícios mostrariam não ser obra de especuladores, que constroem casas não adaptadas a ninguém. Todas as casas seriam o produto do gosto individual - bom ou mau - mas interessante e vivo.

${ }^{37}$ O livro de C. B. Purdom, de 1913, pertence ao acervo da Biblioteca Central da Politécnica. 


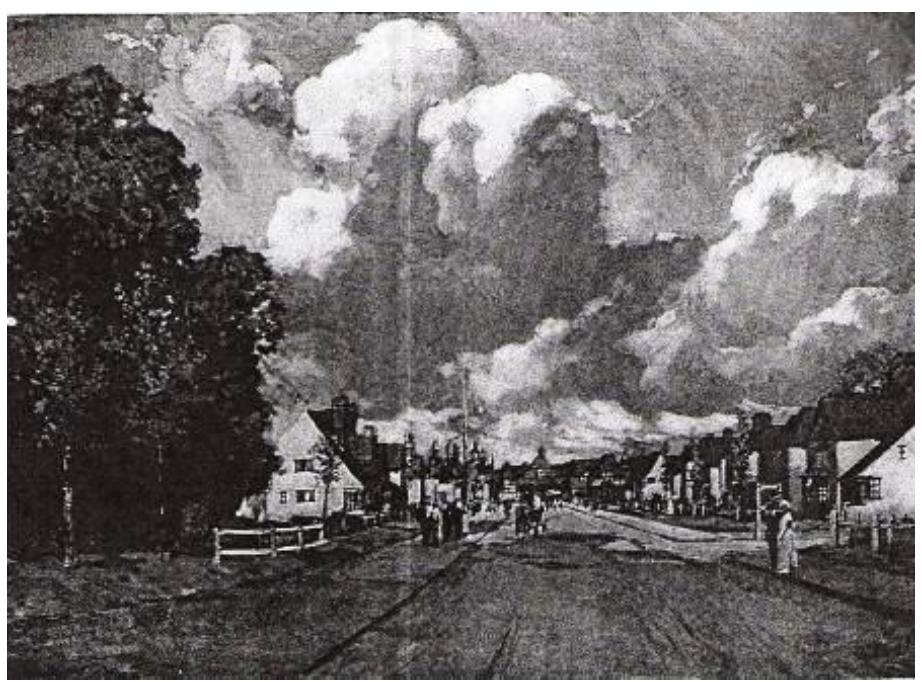

Fig. 1.50 Rua com pequenas casas em Letchworth

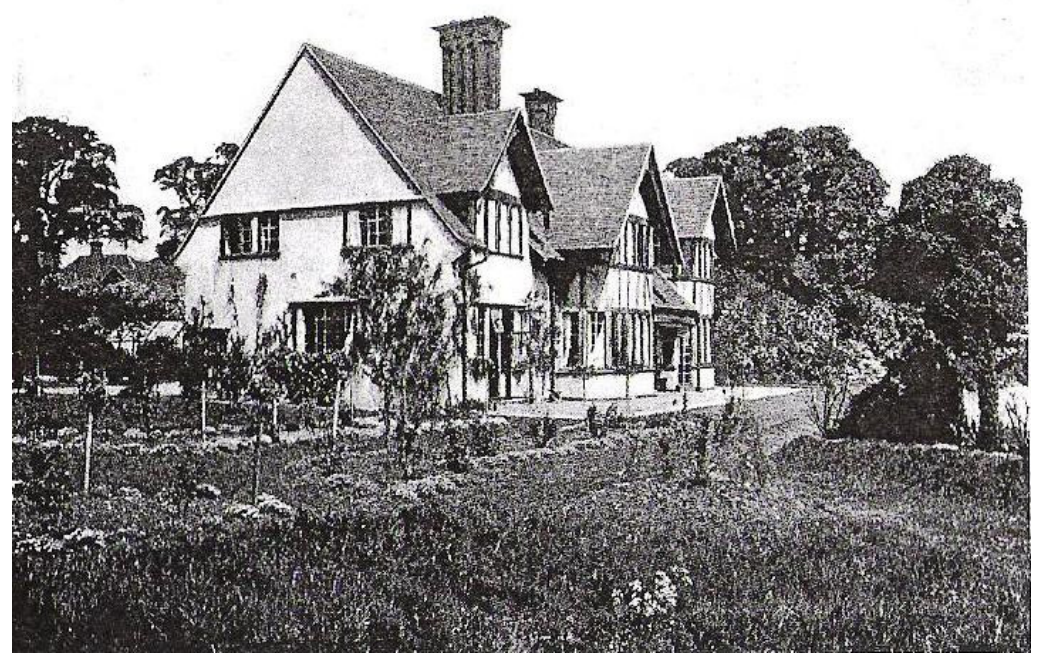

Fig. 1.51 Casa em Letchworth

A casa típica da cidade-jardim era pequena. Bons e confortáveis cottages teriam sido destinados às classes trabalhadoras, e a parte industrial da cidade não diferia em caráter do resto do lugar. Mesmo os cottages mais baratos tinham elementos atrativos, e se harmonizavam com seu entorno. Eram também o trabalho de arquitetos.

Não sem razão, Muthesius, ao término do relato sobre a arquitetura inglesa, menciona Letchworth, ainda sem mostrar fotos das casas, pois a época era ainda do início do empreendimento. Antes, ele descrevera as vilas de trabalhadores de Port Sunlight e Bournville. Sobre Port Sunlight, ele diz que ali estavam as novas conquistas dos arquitetos ingleses, que conteriam todo o repertório de meios contemporâneos de 
expressão, de forma tão perfeita que o empreendimento poderia ser considerado "a flor da pequena casa moderna em um pequeno espaço." (MUTHESIUS, 1987, p. 58)

Em Letchworth, ficava claro nos regulamentos sobre a cidade a idéia de que a arquitetura ali se pautaria pelos princípios do Arts and Crafts.

"Os diretores da First Garden City, Ltd., estão convencidos de que o alto padrão de beleza, que desejam alcançar na cidade-jardim, apenas pode ser o resultado de edificações simples, honestas, e do uso de bons e harmoniosos materiais. Eles desejam, tanto quanto possível, desencorajar ornamentos inúteis, e assegurar que os edifícios deverão adaptar-se a seu propósito e localização", ${ }^{38}$

Ou seja, simplicidade, adaptação às necessidades do morador e às características do sítio. As casas deveriam ter amplas frentes para que não fossem construídas as filas estreitas de casas dos especuladores. Todos os ambientes deveriam estar sob o mesmo telhado. Raymond Unwin, Barry Parker - os autores do plano para a cidade e Baillie Scott, entre outros, projetaram casas para a cidade-jardim. No início, Parker e Unwin, consultores da companhia, tentaram manter algum controle sobre o projeto das casas para assegurar os aspectos estéticos dos regulamentos de construção, mas tais tentativas logo enfraqueceram, devido às objeções colocadas a elas. (PURDOM, 1913, p. 69)

A questão mais relevante não era a estética, mas o aperfeiçoamento da moradia individual. Seus fundadores eram reformadores, homens e mulheres que desejavam um local limpo, saudável e higiênico, onde os homens poderiam viver e trabalhar em condições apropriadas - uma vida regrada, sem os tumultos, a violência e os divertimentos públicos encontrados nas grandes cidades.

\subsubsection{Momentos Finais?}

Se entre 1900 e 1910, alguém sobrevoasse de balão Brighton em direção ao noroeste da Inglaterra, veria, edifício após edifício, infindáveis exemplos do Arts and Crafts. Mais ao norte, outro fenômeno: cada grande cidade tinha um número crescente de subúrbios, possibilitados pelo transporte público, localizados normalmente na direção

\footnotetext{
38 "Sugestões e Instruções Gerais em relação aos Edifícios exceto Fábricas na Propriedade da CidadeJardim" apud PURDOM, 1913, p. 66.
} 
sudoeste-norte para que os ventos predominantes afastassem para o leste a fumaça que vinha da cidade. (DAVEY, 1995, p.104).

As ferrovias teciam uma rede pelo interior. Entre as cidades maiores, próximas às estações ferroviárias, estavam as maiores casas de campo. Davey (1995, p. 101), relata que era raro que as casas Arts and Crafts se situassem a mais que poucas milhas de uma estação. Quando Holmes e Watson não estavam chegando a uma legítima casa medieval nas franjas da estação, eles estavam se aproximando de uma versão do Arts and Crafts.

Abandonado pelos arquitetos e pelos formadores de opinião, o Arts and Crafts foi adotado pelos especuladores e autoridades locais, multiplicando-se em infindáveis telhados recortados, estruturas em madeira e bay windows, nos subúrbios do entre guerras. De certa forma, ele agora estava acessível a uma parcela maior da população, algo que Morris e seus interiores elitizados não haviam conseguido.

Esta interpretação desta fase do Arts and Crafts é aprofundada por Zucconi (1982, p. 39). Para ele, qualquer continuidade é negada entre os cottages pré-bélicos e aquelas filas de cottages públicos e privados que no primeiro pós-guerra invadem a periferia inglesa. Da fase heróica, "da poética pessoal dos protagonistas" à outra fase, de uma produção impessoal, marcada em termos quantitativos, fazendo parte de uma política de habitação. Para Zucconi, é possível estabelecer uma continuidade entre as duas fases. Devem ser levadas em conta a mudança no quadro de profissionais e a política de descentralização após 1905 e tentar-se uma sistematização que passe ao largo da falência pessoal de alguns dos protagonistas. Ainda segundo Zucconi, aquelas qualidades exemplares da casa inglesa que Muthesius apontara, aqueles "valores de modernidade e reprodutibilidade", não aparecem como o epílogo do caso, mas como a promessa de um desenvolvimento posterior. E a própria arquitetura das cidadesjardins confirma esta argumentação.

$\mathrm{Na}$ interpretação de Pevsner, seus pioneiros, "incapazes de traduzir em teoria orgânica as conquistas individuais", passam a liderança moderna à Alemanha de Behrens e Gropius. O final de The English House não contradiz tal afirmação. Desta forma, torna-se difícil fugir à interpretação de que o Arts and Crafts realmente acabou próximo à primeira guerra. $\mathrm{O}$ relato de Pevsner contagiará a crítica inglesa no entre guerras e a levará a esta interpretação nostálgica de um movimento terminado, de "uma fratura exata e dolorosa na arquitetura da casa". (ZUCCONI, 1982, p. 39)

Para Davey, a guerra virtualmente matou o Arts and Crafts, apesar de a agonia já se prolongar há uns dez anos. Sem uma mudança radical na sociedade, era impossível 92 I C a pítulo 1 
para o movimento apresentar outro fundamento que a produção de artigos de luxo para os ricos (DAVEY, 1995, p. 167). Quando o gosto da classe média alta começou a mudar, o arquiteto também mudou. Alguns como Shaw, Lutyens e mesmo Baillie Scott voltaram-se para a simetria clássica. Outros resistiram, como Voysey que adotou detalhes francamente góticos, mas pouco trabalharam.

As mudanças na arquitetura pertencem a um quadro maior, de decadência do Império Britânico, com sua hegemonia sendo progressivamente diminuída. Às portas da Primeira Guerra Mundial, os Estados Unidos emergem como a grande potência mundial.

A próspera classe média inglesa, da qual o movimento tanto dependera, teve "a manteiga tirada de seu pão" (DAVEY, 1995, p. 167), particularmente após as reformas implementadas pelo governo liberal em 1906, para aliviar a carga sobre a classe trabalhadora.

A procura pela disciplina, pela ordem e pelo já estabelecido acontece neste contexto. As antiguidades substituem o artesanato no gosto do público. (DAVEY, 1995, p. 168).

Devem-se assinalar alguns momentos importantes da "involução inglesa". Dois deles acontecem no ano de 1905: a direção da Architectural Review passa a Mervyn Macartney $^{39}$, o que supõe para a revista "o abandono das posições lethabianas"; e o outro momento é a inauguração de várias obras acadêmicas, como o Hotel Ritz, a nova ala do Museu Britânico e o Central Hall de Westminster.

Em 1915, a publicação da Architecture of Humanism de Scott (que ocorrera em 1914) é rápida e entusiasticamente recebida pela The Review. (ELIA, 1977, p. 94)

A linha que triunfa na Inglaterra a partir de 1915 é completamente distinta. É a linha de Geoffrey Scott, que se converte em guia teórico de uma recuperação neoclássica à maneira das Belas Artes. Porém, não podemos nos limitar a falar em involução academicista ao nos referirmos a Scott. Seu pensamento é muito mais rico e sua opção pelo clássico baseia-se na teorização sobre a disciplina na arquitetura. Remetendo-se à tradição acadêmica, determina os elementos da linguagem arquitetônica: o volume, o espaço, a linha e a coerência. (ELIA, 1977, p. 97) "A

\footnotetext{
39 Macartney (1853-1932), arquiteto, foi um dos ex-pupilos de Norman Shaw que fundaram a Art Workers' Guild. Em 1906, começa sua guinada em direção ao classicismo, movimento do qual se tornou uma das maiores forças.
} 
arquitetura é uma combinação de espaços, volumes e linhas que se expressam com luz e sombra" ${ }^{40}$, diz Scott.

O quadro da arquitetura da época pode ser traçado a partir do número especial da Architectural Review ${ }^{41}$.

O cottage, entretanto, apesar de bastante pinturesco e encantadoramente apropriado a seu ambiente original, não se pode dizer que represente o real espírito da nossa época. Por essa razão, muitos indícios podem ser percebidos de um retorno ao estilo de se construir em sintonia com o requinte e o modo de viver dos dias atuais (...). Felizmente, já se foi o tempo em que do detalhe se fazia um estudo absorvente, e forma e proporção eram consideradas questões totalmente secundárias. ${ }^{42}$

Purdom (1913, p. 69) assim se refere à arquitetura inglesa da época: “(...) quando se considera as condições da arquitetura no país, a separação em relação à vida comum, sua falta de recursos, sua distância dos primeiros princípios, suas idéias confusas, e a geral incompetência dos que a praticam."

Mas, o quadro não é assim tão simples e esquemático. Neste número da Architectural Review, é vista a diversidade que tomara conta da arquitetura inglesa: existem casas tratadas de modo pinturesco, arbitrariamente, sem a racionalidade do Arts and Crafts com detalhes, como as chaminés, colocados sem nenhum critério. Vêem-se também projetos clássicos, com ou sem detalhes do antigo movimento. Mas, ainda existem projetos bem resolvidos. Alguns mais pinturescos e outros que revelam a arquitetura purista para a qual parte do Arts and Crafts evoluíra.

A verdade dos materiais é questionável ao nos depararmos com alguns anúncios da revista, como o de um revestimento assim definido: imitation stone applied to brickwork in plastic form and can be carved (imitação de pedra aplicada ao tijolo em forma maleável que pode ser entalhada). Carved é um termo geralmente usado com a palavra ornament. Ruskin, nesta época já morto, provavelmente teria ataques de fúria.

40 SCOTT, Geoffrey, Architecture of Humanism, 1914; versão em castelhano: Arquitectura del Humanismo. Um estudio sobre la historia del gusto. Barcelona, Barral Editores, 1970, apud ELIA, 1977, p. 97.

${ }^{41}$ Recent English Domestic Architecture. O editor da revista ainda era Mervyn Macartney. Acervo da FAUUSP.

42 MACARTNEY, Mervyn Recent English Domestic Architecture, número especial da Architectural Review, s.d., prefácio.

94 I C a pítulo 1 


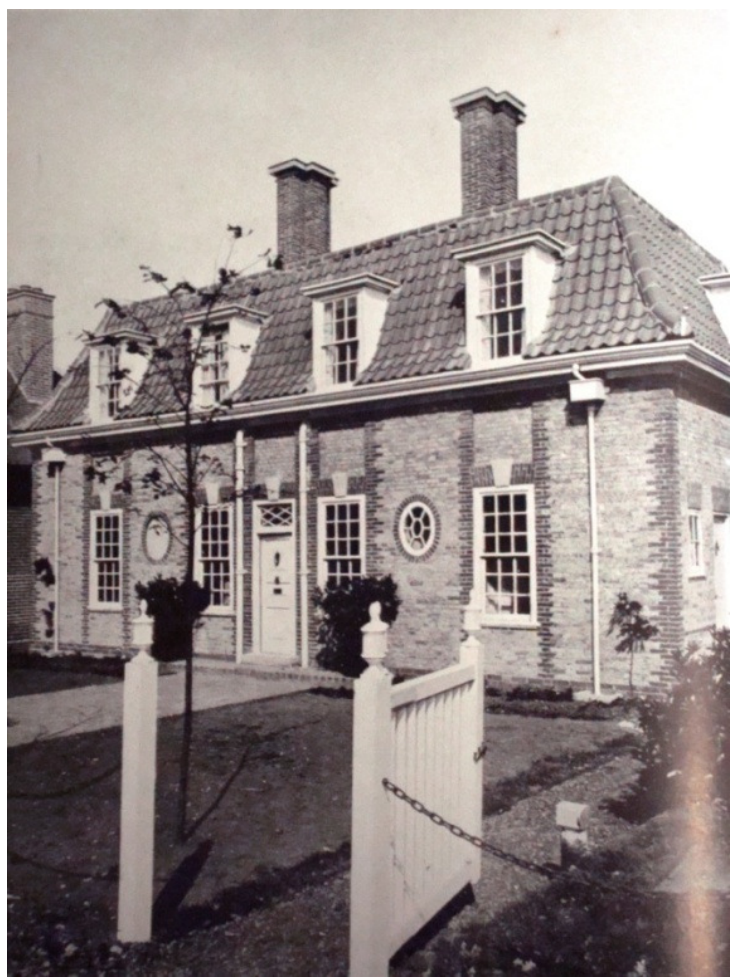

Fig. 1.52 Casa clássica com detalhes pinturescos, Essex - Arquiteto Clough Williams-Ellis

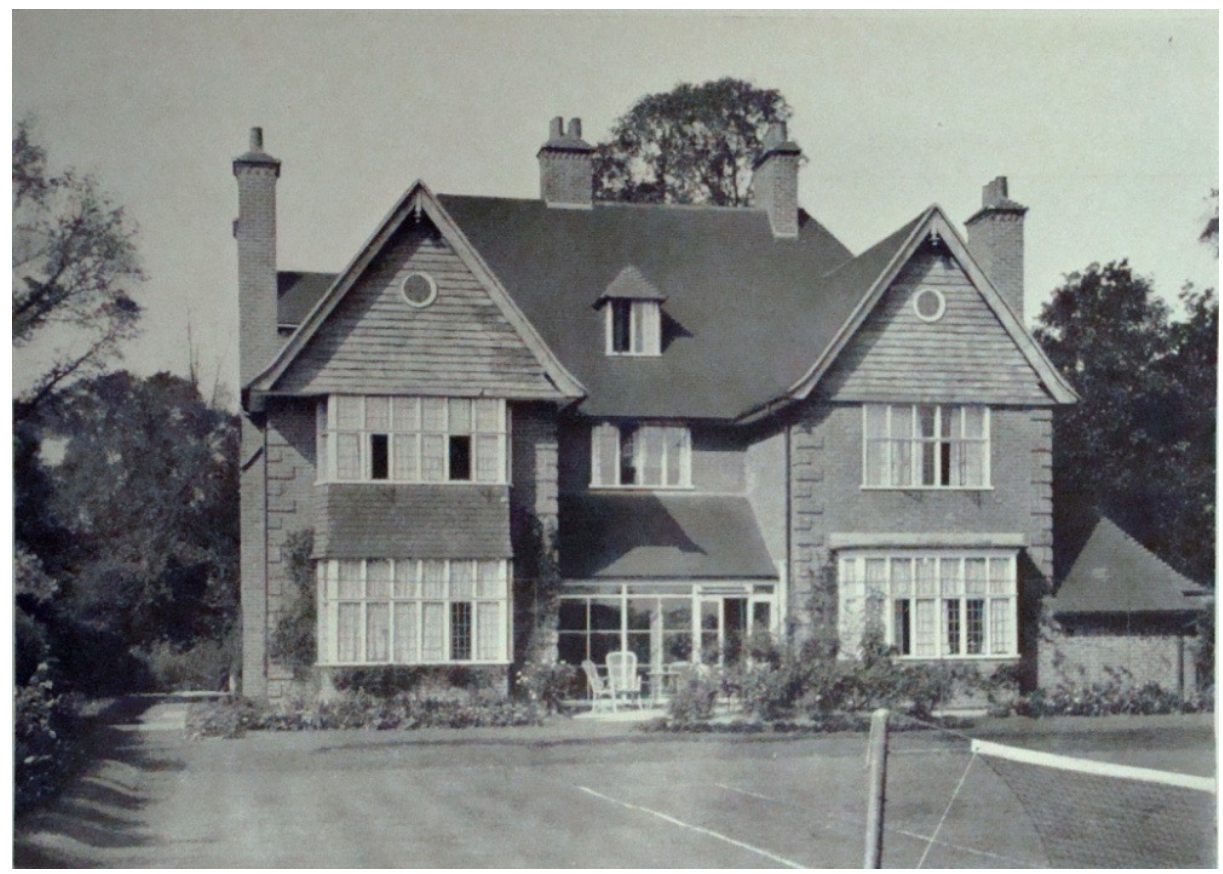

Fig. 1.53 Casa de composição clássica, com materiais que realçam os detalhes pinturescos, Chislehurst Arquiteto E. J. May. 


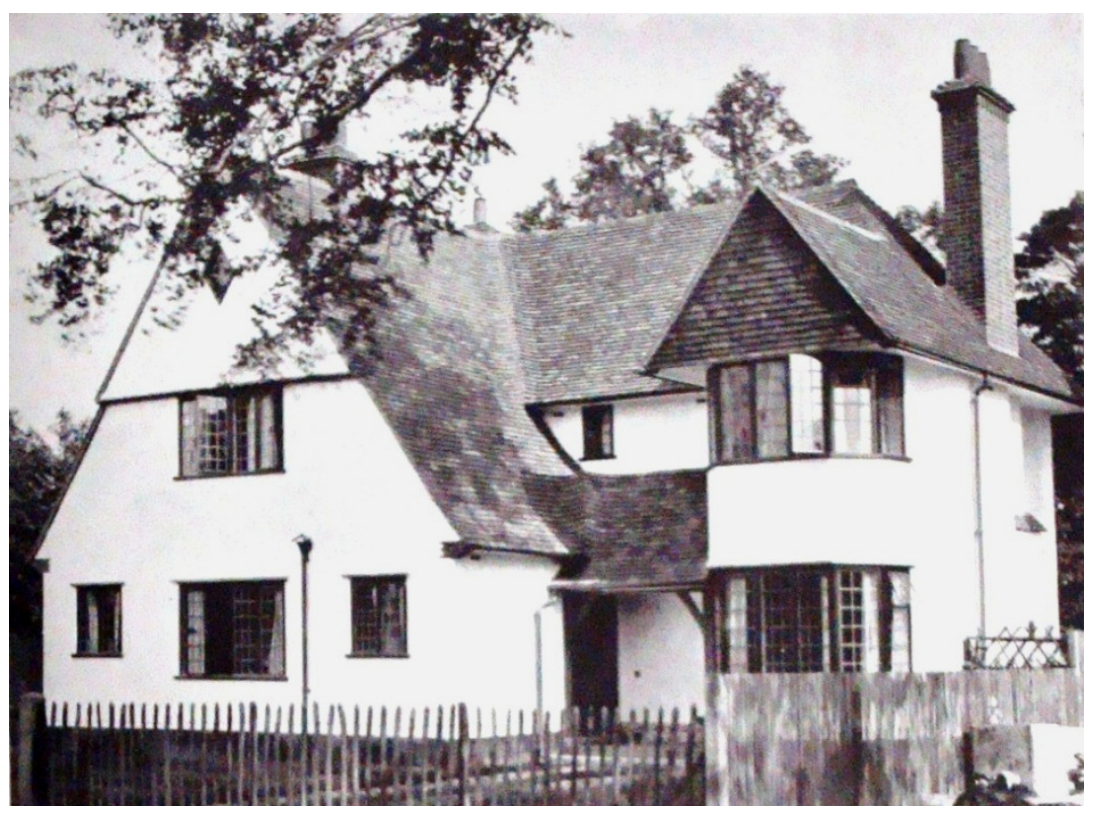

Fig. 1.54 The Homestead, casa "purista”, Chislehurst - Arquiteto E. J. May.

O Arts and Crafts foi visto, por muitos anos após a Primeira Guerra Mundial, de forma caricatural. O Arty Crafty, como era chamado, significando um requinte exagerado e afetado, uma beleza exageradamente sentimental.

Quando as luzes se acendem, e se vislumbram as sombras, e uma perfumada brisa da Noruega,

Se esquiva do biombo que você construiu entre a lareira e a porta de entrada,

Quando a chuva e o granizo irrompem através de cada fenda do caixilho,

E o gesso cai das paredes emboloradas, e a umidade brota do porão,

Talvez você conclua que seu arquiteto foi Arts-and-Crafty demais,

E desejaria que seu terreno ao vento não o expusesse mais. ${ }^{43}$

Apesar desta imagem contraditória, o Arts and Crafts foi muito influente entre a classe média alta inglesa e também no exterior. Nos Estados Unidos, as grandes cidades tinham seus subúrbios Arts and Crafts.(DAVEY, 1995, p. 102).

\footnotetext{
${ }^{43}$ Canção da pantomima da Garden City, citada por Purdom (1913, p. 70), ao comentar que o grande risco da arquitetura da cidade-jardim não se referia ao conflito de estilos, mas às deficiências em termos de construção. Que ele assinala ser um problema comum nas construções da época.
}

96 I C a pít u 1 o 1 


\section{CAPÍTULO 2}

\section{O ARTS AND CRAFTS NOS ESTADOS UNIDOS}

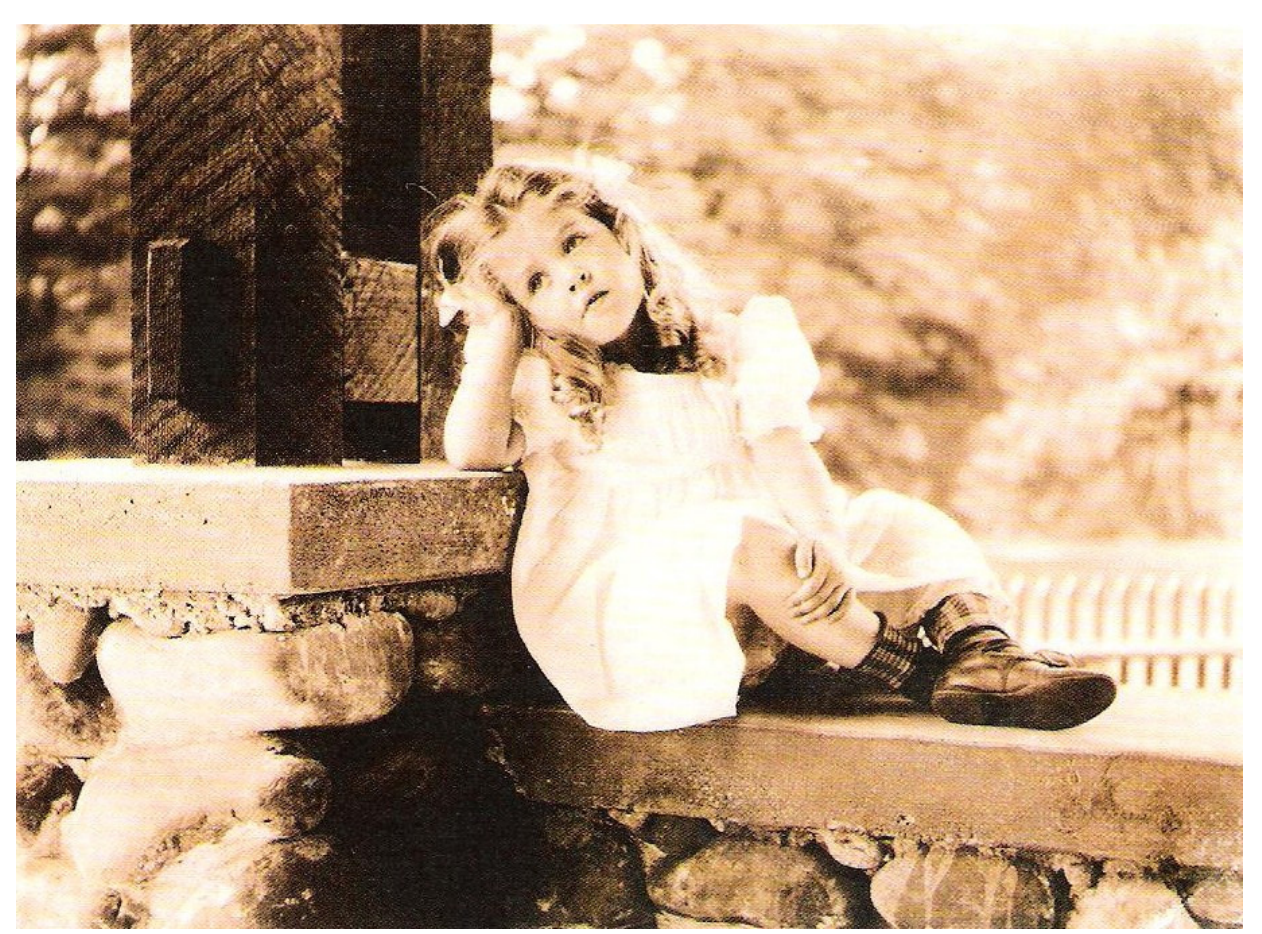

Fig. 2.1 A varanda do Arts and Crafts, com base em pedra e pilares em madeira, simbolizando a domesticidade na figura desta criança do Oregon.

\subsection{Origens do movimento na América}

John Ruskin nem William Morris jamais estiveram nos Estados Unidos, que consideravam uma terra de competição desenfreada e de implacável feiúra, mas ambos tiveram um profundo impacto na cultura americana entre a Exposição do Centenário de 1876 e a Primeira Guerra Mundial. "Ruskin e Morris inspiraram um movimento organizado, dedicado à produção do artesanato e de trabalhos manuais refinados com integridade artística: uma reunificação da arte e do trabalho, de artista e artesão. O interesse pelo trabalho artístico cresceu na América durante os anos 1890, principalmente entre as mulheres da elite e profissionais ligados à arte, e se espalhou entre a classe média durante a próxima década." (BORIS, 1980, p. XIV). 
Apesar de Ruskin e Morris nunca terem visitado os EUA, houve outros embaixadores do Arts and Crafts, como C.R. Ashbee, Walter Crane e May Morris. Ashbee visitou os Estados Unidos vários vezes, a primeira em 1896, expondo, dando conferências sobre educação e socialismo e conhecendo o país. Retornou em 1900, 1908 e em 1915. Resumindo sua série de visitas:

Não podemos mensurar a produção destas pequenas oficinas pelos elevados padrões daqueles que são os melhores. Isto é o que temos feito na Inglaterra (...) e assim transformamos um grande movimento social em uma cansativa e limitada classe que trabalha com grande habilidade para os muito ricos. ${ }^{1}$

Sua esposa conheceu Elbert Hubbard (1896-1915), que criara uma comunidade dedicada ao artesanato em 1900, em East Aurora, Nova York. Inicialmente produzia peças em cobre, depois teve uma linha de móveis com certa inspiração em Mackmurdo. Hubbard depois visitaria os Ashbees em Chipping Campden. $\mathrm{Na}$ Inglaterra, também conheceria a Kelmscott Press de William Morris em 1894. Em 1895, ele fundaria as Roycroft Shops, que faziam livros manualmente. Depois, criaria Philistine, publicação mensal. (SMITH, 1992, p. xiii-xiv)

Walter Crane, socialista, ilustrador e amigo de William Morris, fez conferências e exposições em Chicago em 1891 e 1892. May, a filha de Morris, também visitou os Estados Unidos. Outro propagador dos novos ideais foi Oscar Wilde, que fez uma viagem para conferências em 1882.

Publicações também fizeram esta ligação entre os países. A revista inglesa The Studio era publicada nos EUA como International Studio.

Entre 1896 e 1915, formaram-se muitos grupos de artesãos e admiradores do artesanato nos Estados Unidos, que chegavam a ter centenas de membros. Procurando moldar o gosto americano, juntavam artistas e clientes em aulas, palestras e exposições. Vinte e três destes grupos formaram a Liga Nacional do Artesanato em 1908.

Os líderes destes grupos americanos estavam em contato direto com a Arts Workers'Guild e a Arts and Crafts Exhibition Society na Inglaterra. Artesãos americanos foram à Inglaterra aprender sobre artesanato, artes decorativas e sobre as guildas.

\footnotetext{
1 "The Ashbee Memoirs" (manuscritos na biblioteca do Victoria and Albert Museum, junho de 1915, p.201 apud Kaplan, 2004, p. 247).
} 
Nos anos 1880, Morris tornou-se moda nos EUA. Já em 1871, seus papéis de parede, tecidos e tapetes eram vendidos em Boston. Com a Exposição da Filadélfia, em 1876, um número muito maior de pessoas tivera a oportunidade de conhecer seu trabalho.

A influência pessoal do arquiteto Henry Hobson Richardson, admirador pessoal do inglês, que o visitara na Inglaterra em 1882, também foi importante. Incorporando motivos Pré-Rafaelitas em suas obras, ele ensinou a uma geração de arquitetos o valor da arte decorativa.

Podem-se identificar duas correntes principais do movimento Arts and Crafts nos Estados Unidos: a primeira propunha um sistema alternativo de produção no qual tanto os interesses das classes consumidoras quanto os das classes produtoras seriam resguardados. Permitindo a expressão individual do trabalhador, o trabalho traria satisfação pessoal. E o consumidor teria acesso a produtos de qualidade. A arte se tornaria democrática.

A outra corrente do movimento tentaria mudar os objetos, e não a natureza do trabalho.

As associações que se formaram em Chicago e Boston são representativas das direções que seguiram o movimento na América: a Chicago Society of Arts and Crafts e a Society of Arts and Crafts, Boston (BSAC). A BSAC, fundada em 1897 foi o modelo para a maioria dos grupos por todo o país.

A primeira exposição do grupo de Boston acontece ainda em 1897 e teve grande repercussão. A loja de artesanato da BSAC permaneceu por mais de uma década como a experiência de maior sucesso do grupo, tornando-se depois independente da sociedade. Com propósitos educativos, Arthur Astor Carey, presidente desde 1900, fundou Handicraft, uma revista mensal sobre arts and crafts, iniciada em abril de 1901. Carey e Mary Ware Dennett, designer e professora de artes, outro importante membro da sociedade, defenderam melhores condições para o trabalhador, ética no trabalho, próximos ao espírito de Ruskin e Morris. Apesar disto, o conselho da BSAC em 1904 definiu o Arts and Crafts como "essencialmente um movimento por uma arte melhor, através do revival do artesanato, que outrora era praticado como meio de subsistência; mas que vinha até poucos anos atrás se deteriorando." ${ }^{2}$ A beleza tornou-se um fim em si e não uma maneira de se humanizar e alegrar o trabalho. $O$ foco eram objetos únicos, preciosos, puramente decorativos. "A sociedade começou a se voltar para o consumo, ao invés da produção da arte, uma prática simbolizada pela emergência da

\footnotetext{
2 “I. The Problem: 1904" Autos do BSAC, Atam 300, p. 170-72, rascunho apud BORIS, 1980, p. 42.
} 
loja e não da oficina cooperativa como seu espaço característico - deste modo rompendo a ligação entre 'arte' e 'trabalho', tão fundamental ao ideal do craftsman”. (BORIS, 1980, p. 44-5).

A Easter Art Exhibit de 1897 levou à fundação da Chicago Society of Arts and Crafts (CSAC) poucos meses depois, pedindo um “'justo' senso de beleza” (BORIS, 1980, p. 46). Era apoiada por mulheres abastadas e por professores da Universidade de Chicago - cujos cursos de extensão espalharam a mensagem de Ruskin e Morris. Apesar de compartilhar objetivos educativos e princípios estéticos com o grupo de Boston, a CSAC via o Arts and Crafts como "parte de um programa de aprimoramento cívico, (...) e reorganização da indústria; propunha confrontar as condições sociais, incluindo a tecnologia da máquina, que afetava a produção da arte." (BORIS, 1980, p. 46).

$\mathrm{Na}$ conferencia de 1901 à CSAC, "The Art and Craft of the Machine", Frank Lloyd Wright, um de seus membros, diz que a máquina iria se tornar uma força que redefiniria a natureza da arte e assim faria o artesanato passar "de uma expressão pessoal a uma expressão social". O artista deveria tornar-se o "líder de uma orquestra, onde antes era um grande artista" (BORIS, 1980, p. 47). Esta posição de Wright refletia a opinião de parte do mundo intelectual e cultural de Chicago. Produtores começaram a investir em educação para os trabalhadores da indústria. Em 1900 é fundado o Art Craft Institute.

Em Chicago e Boston, o objetivo de se unir arte e trabalho, tão caro ao movimento na Inglaterra, acabou por restringir-se aos desejos do consumidor e do artesão amador, deixando em segundo plano o artesão profissional. Estes grupos ligados ao artesanato acabaram por difundir um novo ideal de beleza e um novo estilo de vida assimilado facilmente pela classe média.

Em busca do espírito do Arts and Crafts, houve uma revalorização dos objetos feitos artesanalmente pelos índios americanos, junto a uma percepção da possível perda da cultura indígena. Isto aconteceu particularmente no noroeste do Pacífico. Mulheres indígenas que viviam nas reservas dirigiam-se às cidades para vender seus cestos. $\mathrm{A}$ tecelagem com palha de milho, bolsas e tapetes navajos foi muito procurada. Assim, enquanto a política governamental e religiosa aconselhava que os indígenas abandonassem sua maneira tradicional de viver e fossem confinados em reservas, 0 forte interesse em sua arte ajudou a manter vivas muitas tradições das tribos de várias regiões do país. (KREISMAN e MASON, 2007, p. 28) 
“'Desenho democrático' era um termo comumente usado em torno de 1900 para se designar objetos simples, de qualidade, feitos para um público amplo. Era o que os europeus percebiam como a contribuição da América ao movimento Arts and Crafts. Aqueles que pretendiam reformular o desenho em ambos os lados do Atlântico viam a inovação tecnológica e o uso racional da máquina como o trunfo dos EUA". (KAPLAN, 2004, p. 247).

Assim, o movimento atingiu sua maior popularidade aqui, de forma mais pragmática, sem a carga ideológica da Inglaterra. O país diluiu os ideais do movimento ao deixar de ser fiel às suas mais profundas aspirações.

Não houve hesitação por parte dos americanos: eles foram mais empresariais, mais abertos à utilização da máquina e de métodos eficientes de produção. Assim, a mobília, a cerâmica, o trabalho em metal do Arts and Crafts floresceram e tornaram-se acessíveis a um público mais amplo, ao contrário do que aconteceu na Inglaterra. (KREISMAN e MASON, 2007, p. 18)

Estes objetos passam a ter seu design alterado. A aparência passa a preponderar sobre a função. Os cestos, por exemplo, não serviam mais para transportar alimentos, mas eram utilizados na decoração, junto com a mobília Mission, em bangalôs Arts and Crafts ou casas Craftsman. (KREISMAN e MASON, 2007, p. 31)

Nos Estados Unidos, os líderes do movimento acabaram sendo empresários, que propagaram os ideais de Morris, se não em profundidade, ao menos de forma ampla entre a classe média. É o caso de Gustav Stickley.

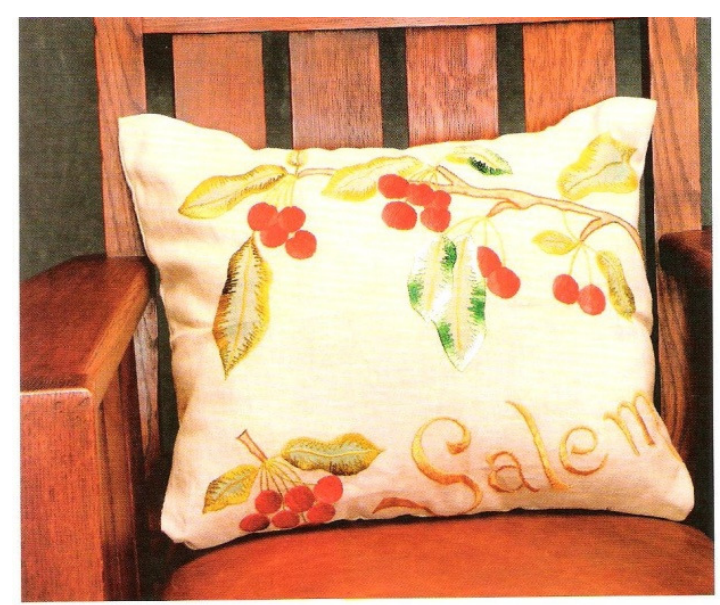

Fig. 2.2 e Fig. 2.3 Capas de almofadas e outros trabalhos manuais com motivos do Arts and Crafts tornaram-se populares nos anos 1910. Geralmente não havia indicação do autor. 


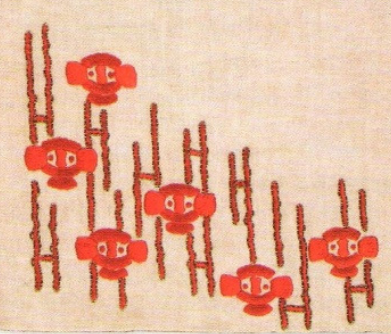

Os Estados Unidos tinham uma classe média numerosa, e assim, as condições para o "faça-você-mesmo" do Arts and Crafts prosperar. Os americanos tinham o tempo livre suficiente para tal hobby doméstico. Kits para bordado e outros tipos de trabalhos manuais, aulas e mesmo livros que ensinavam as técnicas estavam à disposição.

Alguns dos ideais fundamentais podem ter se diluído, mas os produtos alcançaram um público muito maior nos Estados Unidos do que em qualquer outro país. Os objetos podiam ser produzidos em casa, adquiridos através de catálogos das lojas de departamentos, nas exposições ou nas pequenas oficinas - com custos bastante diferentes, tornando-se viáveis para aquisição por pessoas de diferentes classes.

Se a afirmação de Morris "não quero arte, educação ou liberdade para uns poucos" era o grande objetivo, então a história americana de democratização do design pode ser vista como um sucesso sem precedentes. ${ }^{3}$

\subsection{A arquitetura}

Se a ideologia do Arts and Crafts americano caracterizou-se pelos esforços em fazer o design mais democrático, sua estética é caracterizada pela expressão regional na arquitetura e artes decorativas.

Esta nova arquitetura criou raízes no Meio Oeste e na Califórnia. Seus maiores representantes, Frank Lloyd Wright, Charles e Henry Greene, William Purcell, Irving Gill e Bernard Maybeck, apresentavam grande diversidade, mas tinham um mesmo

\footnotetext{
${ }^{3}$ Citação de Morris, de sua primeira conferência, "The Lesser Arts" (1877). In: MORRIS, William Selected Writings. Londres: Nonesuch Press, 1948, p. 514 apud KAPLAN, 2004, p. 282.
} 
enfoque em relação aos materiais, ao artesanato e à totalidade artística, comuns ao Arts and Crafts. A totalidade artística envolvia a unidade entre o edifício e o entorno, entre o interior e o exterior.

No Meio Oeste, a Prairie School, com Louis Sullivan e Frank Lloyd Wright como líderes, "carregava a convicção de que um edifício deveria dialogar com seu entorno: ser horizontal como a pradaria e ligar-se a terra através de seus telhados pouco inclinados com amplos beirais e de seus prolongamentos - varandas, terraços e pérgulas." (KAPLAN, 2004, p. 259).

Também a Califórnia era uma região que apresentava características de design particulares. Varandas para dormir, pérgulas e pátios (espaços praticamente inexistentes no clima inclemente da Grã-Bretanha) foram usadas por todo o país, mas nunca como na Califórnia, onde o clima quente e a vegetação abundante tornavam possível o ideal do Arts and Crafts de vida em comunhão com a natureza. A Califórnia proporcionou ao movimento o maior símbolo da democratização da arte: o bangalô.

$\mathrm{Na}$ virada do século, arquitetos regionalistas encontram uma clientela pronta para o Arts and Crafts, principalmente nos enclaves residenciais para a elite e nos subúrbios da classe média.

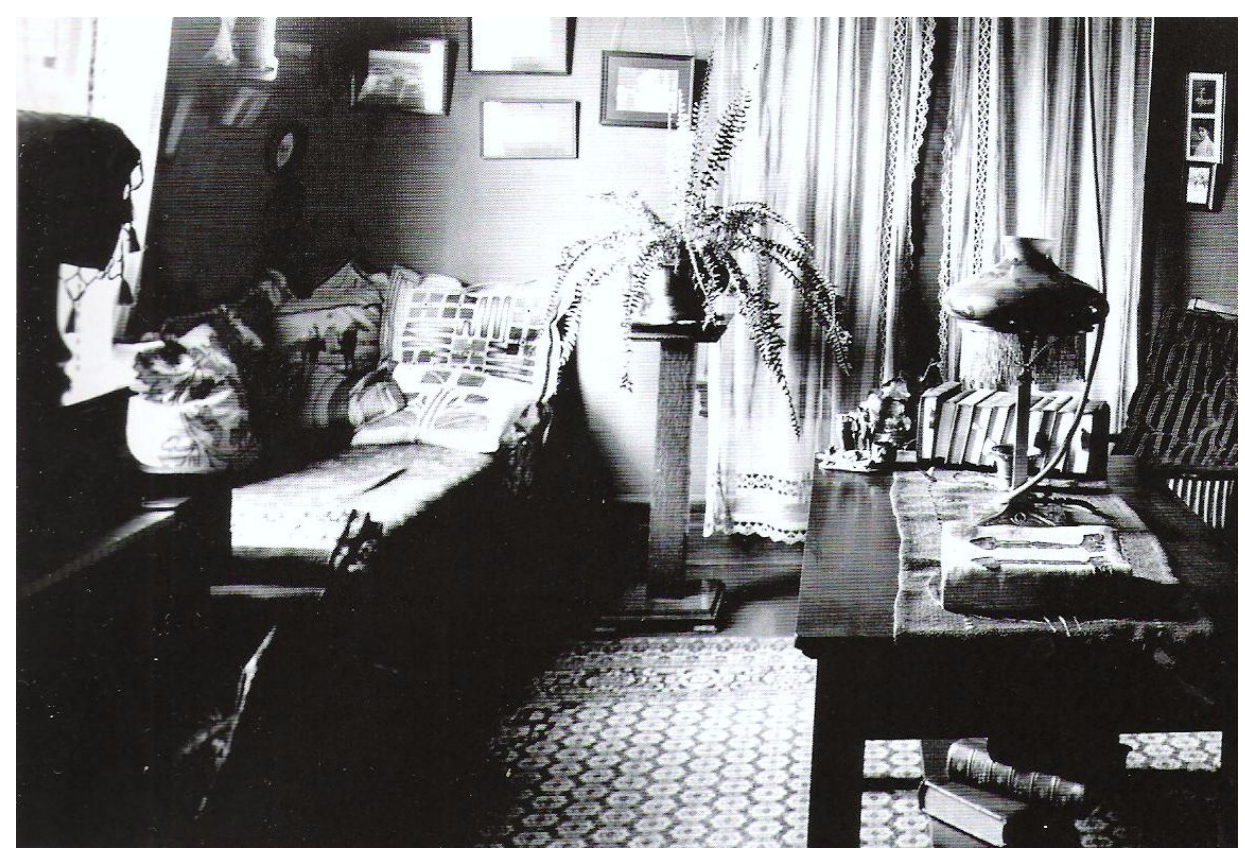

Fig. 2.4 O uso dos têxteis do Arts and Crafts se popularizou como uma maneira de decorar os bangalôs e casas Craftsman do período. Plantas, almofadas, abajures e cortinas também seriam utilizados na decoração das casas de classe média no Brasil, nos anos 1910 e 1920.

Para ricos e pobres, uma nova arquitetura doméstica surge para responder à questão: o que é 'lar'? Os bondes tornaram possível o afastamento entre as áreas residenciais 
e as áreas industriais e comerciais. Nestes novos subúrbios, o bangalô encontrou seu lugar. Ali, ao lado das casas Craftsman, ele aparece em grande número. Mobília embutida, móveis Mission, estênceis nas paredes, bordados pela casa: o sonho americano passa a ser representado pelo bangalô do Arts and Crafts. (KREISMAN e MASON, 2007, p. 37-8)

"Coincidindo com o período de expansão da construção de casas, a decoração dos interiores legitima-se como a atividade onde a ciência doméstica e a estética se encontram." (KREISMAN e MASON, 2007, p. 38)

\subsection{Gustav Stickley}

Gustav Stickley compartilhava com o movimento Arts and Crafts a utopia anti-urbana e uma atitude moralista em relação ao trabalho, tributária de Ruskin e Morris. Esta maneira de ver o trabalho talvez seja herança do duro ofício de pedreiro em que se iniciou aos 12 anos.

Um tio que possuía uma pequena fábrica de cadeiras na Pensilvânia ofereceu-Ihe um trabalho, que Ihe deu a primeira chance de trabalhar com madeira, por volta dos dezessete anos.

Até o final dos 1890's, quando fez sua primeira viagem à Europa, Gustav Stickley foi o típico fabricante americano de móveis. Envolvera-se em uma série de empresas, geralmente com membros de sua família. Estas sociedades geralmente duraram pouco.

$\mathrm{Na}$ Europa, conheceu a Inglaterra e o continente. Especula-se que teria conhecido grandes figuras do Arts and Crafts como T.J. Cobden-Sanderson, William Richard Lethaby, Barry Parker, Raymond Unwin, Charles Robert Ashbee. (SMITH, 1992, p.9). Provavelmente conheceu a Morris and Company onde era produzida a poltrona Morris ${ }^{4}$, muito confortável, com o encosto regulável. Stickley produziria depois várias versões desta mesma poltrona.

Era admirador do trabalho de John Ruskin e William Morris desde a infância - tinha acesso na época a uma pequena biblioteca que possuía livros de Ruskin. Apesar disto, a posição de Stickley em relação ao uso da máquina não coincidia com a de

\footnotetext{
${ }^{4}$ Existem referências à poltrona Morris até mesmo em anúncios da loja de Departamentos Mappin, em São Paulo, nos anos 1920.
} 
Ruskin. Nas várias empresas que possuiu, as máquinas foram utilizadas na produção dos móveis.

Esta admiração por Ruskin e Morris transparece nos primeiros números de The Craftsman. Os dois primeiros artigos da revista, publicada a partir de 1901, são devotados a eles. A filosofia de ambos seria de grande importância como base do que Stickley viria a realizar. Na revista, editada em Nova York onde ficava a empresa de Stickley, ele viria a tratar dos vários assuntos de seu interesse, em artigos escritos por ele ou por terceiros e teria a chance de propagar as idéias do movimento inglês e suas próprias realizações - como o mobiliário e as casas.

Os tópicos incluíam socialismo, artes manuais, jardins, o Japão (incluindo os jardins, a arte, a arquitetura e vários outros aspectos da vida no país), indígenas americanos. Assuntos tão diversos quanto os interesses do próprio Stickley. Porém, um dos temas fundamentais era realmente o trabalho, feito com prazer pelo artesão, e que alegraria também o consumidor.

No início, ele teve a colaboração de Irene Sargent - professora da Universidade de Syracuse, que depois ensinaria estética e história da arte.

Stickley defendia que os trabalhos manuais executados em vários materiais, como madeira e metal, fossem ensinados nas escolas. O intuito não era preparar as crianças para serem bons trabalhadores nas fábricas, mas fazer com que experimentassem o trabalho feito com suas próprias mãos, transmitindo-lhes a idéia de sua dignidade.

Os arquitetos do Arts and Crafts que mais tiveram influência nas casas Craftsman de Stickley foram Baillie Scott, Voysey e Barry Parker, que também se dedicaram ao projeto dos cottages. A principal influência não se deu nas plantas ou no aspecto geral do projeto, mas no desenho do seu interior, no conceito de obra de arte total, uma premissa do movimento inglês. Devido a seu trabalho com mobiliário, Stickley sempre estivera mais interessado no interior do que na casa como um todo. Apesar disto, por volta de 1902, ele passa a se interessar por arquitetura.

No início do século $X X$, os principais periódicos de arquitetura publicados no leste dos EUA eram American Architecture and Building News e Architectural Record. Nestes, quase não se discutia a casa de classe média. Eram mostrados principalmente edifícios públicos e comerciais inspirados no desenho clássico das Beaux Arts, como os de McKim, Mead e White. A revista House Beautiful, pelo contrário, dedicaria muitos de seus artigos às casas de tamanho médio e ao movimento Arts and Crafts. Ali, Stickley encontraria inspiração para os projetos que publicaria em sua revista. 
Uma das marcas destas casas publicadas na The Craftsman seria o grande hall, utilizado como espaço de estar, herança do Queen Anne inglês, via Shingle Style americano, adaptado por H.H.Richardson. (SCULLY JR., 1971, p.4)

(...) a casa americana passara então por uma série de mudanças, adaptando-se às condições locais, às necessidades funcionais e aos materiais, o que lhe emprestará um estilo original, independente do Queen Anne de Norman Shaw. A abertura do interior e o fluxo do espaço são americanos. (...) (SCULLY JR., 1971, p. 88) ${ }^{5}$

As casas de Stickley não apresentavam salas formais para visitas. O espaço de estar substituía a antiga sala de visitas e também funcionava como biblioteca. Ele acreditava que a casa deveria ser utilizada principalmente pela família, sem a perda de espaço apenas para recepção de visitas. "Uma lareira - essencial às casas Craftsman, mesmo no sul da Califórnia - reuniria a família e era uma espécie de centro da vida social de toda residência Craftsman." (WEISSMAN, 1988, p.vi) Estas lareiras simples, apenas com revestimento em cerâmica, lembravam aquelas das casas de Voysey.

O espaço interior do pavimento térreo era integrado. Os vários ambientes eram demarcados apenas pela estrutura de sustentação das vigas de madeira, que ficavam aparentes. Com freqüência, uma faixa horizontal na altura das portas era colocada, percorrendo todas as paredes desta área, unificando visualmente os vários ambientes, como já acontecia nos interiores de Barry Parker. Em artigo de janeiro de 1906, sobre halls e escadas: Halls and Stairways: their importance in the general scheme of a Craftsman house, Stickley diz:

Ao invés da pequena e escura galeria com espaço suficiente apenas para o chapeleiro e as escadas, (...), temos agora o grande hall para recepção, com sua lareira acolhedora e a mobília confortável (...). Existe mesmo uma sugestão do "grande hall do castelo", onde antigamente toda a vida se concentrava, na planta, cada dia mais popular, que junta hall, sala de estar e de jantar em apenas um cômodo grande e irregular, divididos apenas por painéis (...) ou por biombos que servem temporariamente para isolar uma parte da outra se é necessária privacidade. (STICKLEY, 2002, p. 125). ${ }^{6}$

\footnotetext{
${ }^{5}$ Após 1880, as casas americanas começaram a aparecer freqüentemente nas publicações inglesas. Sua possível influência sobre Voysey e outros não foi ainda adequadamente estudada. (SCULLY JR., 1971, nota 63, p. 112)

${ }^{6}$ Craftsman Homes é uma compilação do próprio Stickley dos melhores projetos publicados na revista. São mais de 40 desenhos de cottages, bangalôs e cabanas. Apresenta ainda interiores, detalhes para decoração, jardins e outros elementos externos a casa. Publicada originalmente em 1909 e novamente em 2002.
} 


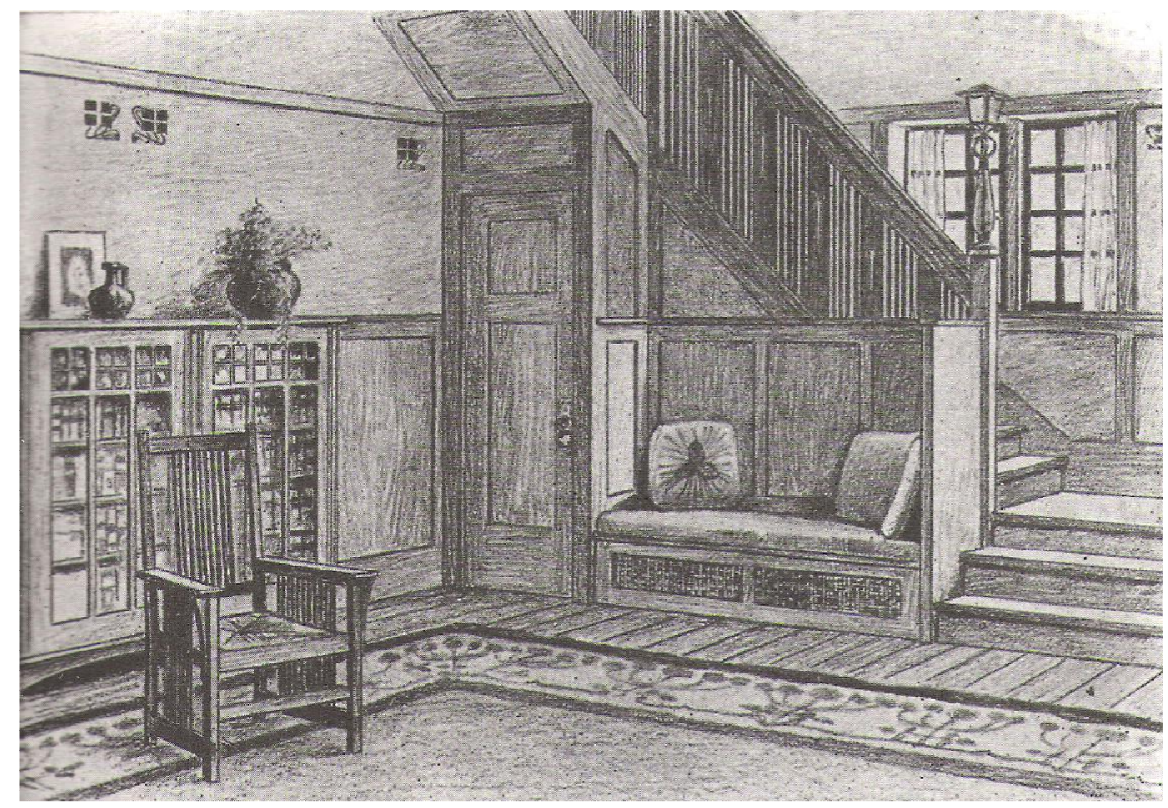

Fig.2.5 Hall com escadaria e mobília encaixada.

As casas Craftsman mais bem sucedidas apresentavam uma fluidez de espaço do interior ao exterior, porém o volume era o de uma caixa, apesar do acréscimo de terraços e varandas.

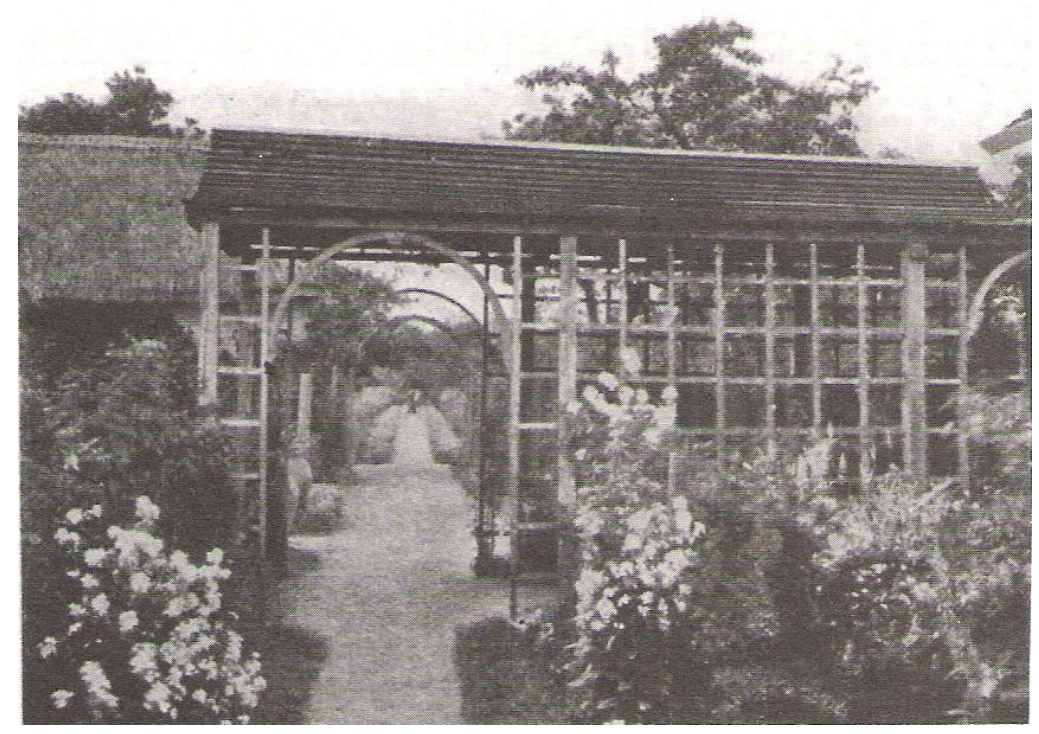

Fig.2.6 Caramanchão, de onde se desfruta de belas vistas.

Aliás, a integração do espaço interno e externo é algo que já estava presente na arquitetura doméstica americana desde o século XIX: "a casa alcança o espaço externo e o espaço externo a penetra. Uma característica peculiarmente americana: a expansão e integração da varanda, um espaço meio fechado, meio aberto, que se torna parte da casa". (SCULLY JR., 1971, p.54-55)

A maior parte da mobília era embutida e desenhada especialmente para a casa. 


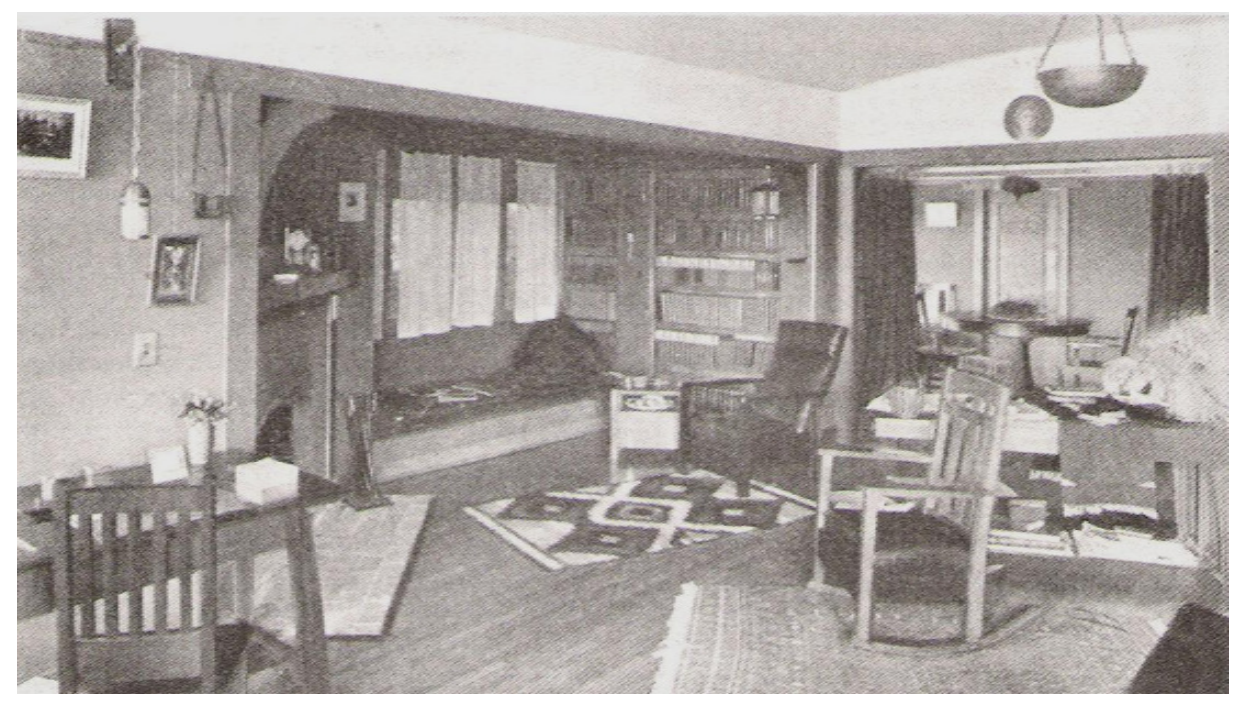

Fig.2.7 Interior de um bangalô

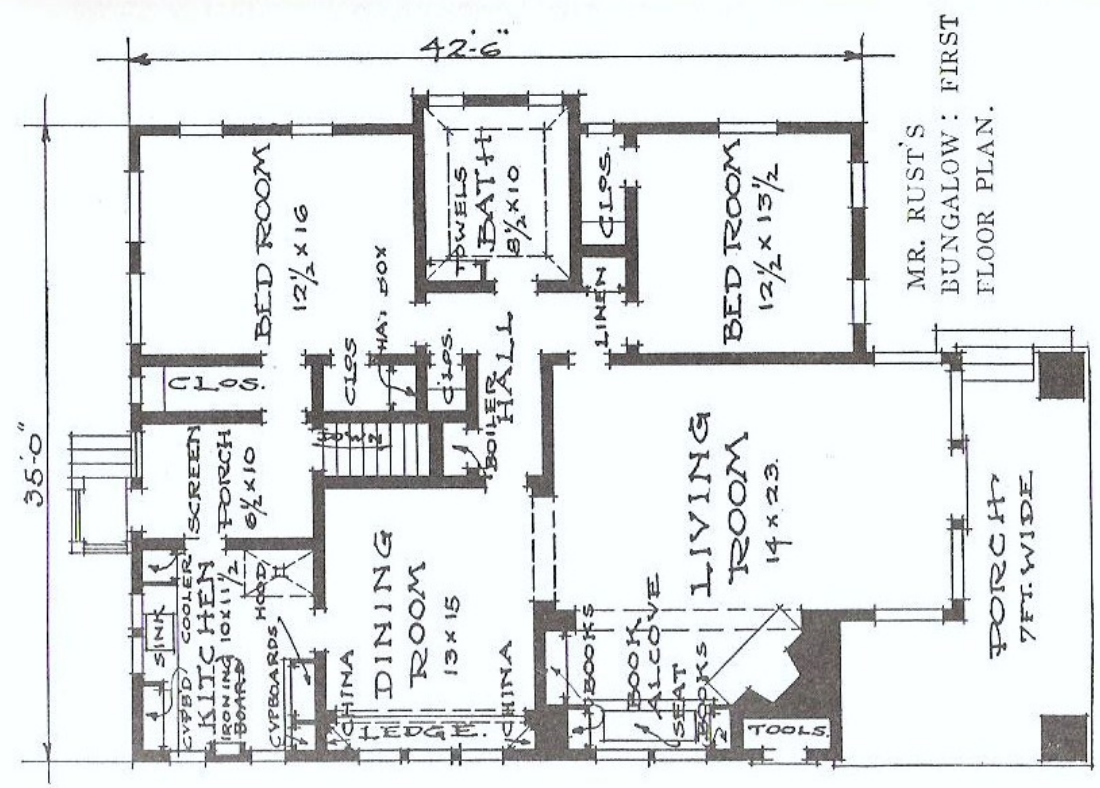

Fig.2.8 Planta do mesmo bangalô (observar recanto da lareira)

Stickley fez ainda grandes cozinhas, confortáveis, ventiladas e banhadas pela luz do sol. E modernas, para facilitar a vida da dona de casa ou dos empregados, sempre mais raros.

A primeira casa aparece na The Craftsman em 1903 e apresenta detalhada descrição do interior. Por um pequeno período, entre 1903 e 1904, Stickley contaria com a preciosa colaboração do arquiteto Harvey Ellis (1852-1904), que passara vários anos 
na Europa, retornando aos EUA por volta de 1877 para se juntar ao escritório de Henry Hobson Richardson por curto período de tempo, trabalhando depois com vários outros arquitetos. Ellis traria sua sólida experiência arquitetônica para a The Craftsman. Durante o período em que trabalhou na revista, esta apresentou um projeto seu em quase todos os números.

Além das casas e dos artigos, Ellis também projetou móveis para The Craftsman seus desenhos eram mais delicados e suaves que os tradicionalmente fabricados por Stickley. Ellis inspirara-se nas peças criadas por Voysey, Baillie Scott e Mackintosh. Ele permaneceu na revista até sua morte, no início de 1905.

Em novembro de 1903, a revista anuncia a formação de um "Clube de Construtores de Casas". Era permitido a qualquer assinante solicitar o projeto de uma casa que houvesse sido publicada, gratuitamente. O número de projetos que poderiam ser solicitados chegou a mais de 200 até 1916, quando a revista deixou de ser publicada. Os projetos enviados continham elevações, plantas, cortes e detalhes interiores. Móveis e outros acessórios poderiam ser encomendados. Os interessados também poderiam ter os projetos publicados adaptados às suas necessidades pela equipe do The Crafsman. Os proprietários muitas vezes se envolviam na construção e na decoração de suas casas: os homens projetavam ou executavam a mobília e as mulheres, os têxteis.

O primeiro destes projetos era uma casa inspirada no Mission style californiano. Neste mesmo ano - 1904 - Stickley visita o oeste americano, que Ellis já conhecia, quando também visitara as antigas missões espanholas. Sobre este primeiro projeto:

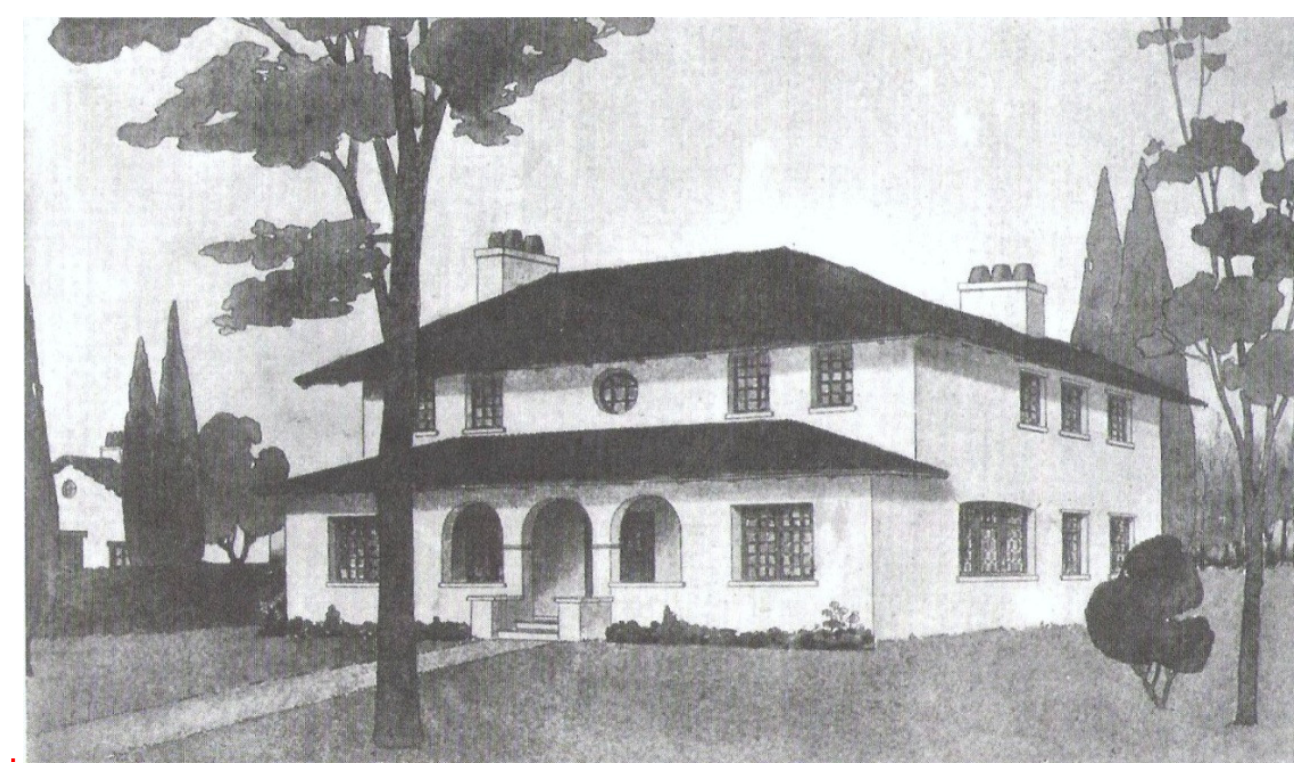

Fig.2.9 Casa californiana, no Mission Style 
É natural que a primeira expressão desta idéia seja uma casa, que mesmo não sendo inspirada totalmente na arquitetura Mission, tão usada na Califórnia, é similar àquele estilo, através das dimensões amplas e baixas da construção e do uso dos arcos (...). O telhado pouco inclinado e que tem uma grande projeção utiliza telhas espanholas vermelhas (...). Tal casa é um bom exemplo de como a questão do exterior foi solucionada através da combinação de três fatores: simplicidade nos materiais construtivos, utilização apenas das características construtivas como ornamento e o reconhecimento de que a cor é extremamente necessária à harmonia entre a casa e seu entorno. Neste caso, nas paredes foi utilizado um pigmento com um tom creme quente, quase um marrom e o telhado é vermelho desbotado, que se adapta à cor predominante na Califórnia ou no Sul, onde abundam amarelos, marrons e violetas. Para as colorações mais frias das paisagens do norte e do leste, as paredes de argamassa deveriam ser mantidas em um cinza natural, ou dar-lhes um tom verde apagado (...) (The Craftsman, janeiro de 1904 apud STICKLEY, 2002, p. 9-11)

O público de Stickley era a classe média com renda anual de 1.200 a 2000 dólares. Muitas casas Craftsman tinham o preço estimado entre 2000 e 6000 dólares e pequenos cottages a 1000 dólares. Stickley alegava que em 1915, mais de vinte milhões de dólares teriam sido investidos na construção de casas tipo Craftsman por todo o país. ${ }^{7}$

Além de publicar desenhos próprios, a revista também apresentou projetos e artigos de outros arquitetos. Muitas vezes, a The Craftsman reconheceu o talento de arquitetos que apenas mais tarde se tornariam conhecidos do grande público. Alguns, como Bertran C. Goodhue (1869-1924) e Louis Sullivan (1856-1924), escreveram artigos. Apesar disto, Stickley ignorou a Escola de Chicago, inclusive Frank Lloyd Wright - é surpreendente, já que as Prairie Houses eram também tributárias dos princípios Arts and Crafts. Mas, aos arquitetos da Califórnia ele dedicou muitas páginas. Ele admirava a adaptação ao clima - com varandas e pérgulas -, o uso honesto dos materiais e a simplicidade das casas daquela região. Se não encontrou os irmãos Charles Sumner Greene (1868-1957) e Henry Mather Greene (1870-1954) em sua viagem à região, ao menos conheceu algumas de suas obras, pois uma casa publicada em julho de 1904 em The Craftstman, tem um pátio semelhante ao da casa Hollister, dos Greene.

\footnotetext{
7 SANDERS, Barry (ed.) The Best of Craftsman Homes Santa Bárbara e Salt Lake City: Peregrine Smith, 1979, p. vii apud SMITH, 1992, p. 77.
} 
O trabalho dos irmãos foi mostrado em vários artigos. Eles apresentavam todas as qualidades admiradas por Stickley em suas obras, entre elas o apreço pelo artesanato, pelo trabalho em madeira e a preocupação com todos os detalhes da construção, mesmo os menores. Em um artigo de agosto de 1912, elogiam-se "o telhado amplo e pouco inclinado, as paredes sólidas, mas pinturescas, o uso claro de vigas estruturais, o espaço exuberante das varandas e balcões e a calma e o encanto do interior. E ainda, tão vasta é a imaginação dos arquitetos, e tão diverso o tratamento em cada caso particular, que se tem a impressão de que cada casa possui uma personalidade definida, certa singularidade de conceito e expressão." ${ }^{8}$ Eles uniam interior e exterior através de pérgulas, terraços, balcões e grandes beirais com o madeiramento em balanço.

A obra dos irmãos Greene simboliza os mais elevados ideais do movimento Arts and Crafts na arquitetura. Ashbee admirava seu trabalho, considerando-os entre os melhores do país.

As influências recebidas pelos Greene incluíam seu aprendizado do artesanato na escola secundária em St.Louis e a arquitetura japonesa.

Comentando uma de suas casas, Henry M. Greene - com a racionalidade e a procura da simplicidade e beleza, típicas do Arts and Crafts - diz:

(...) o edifício todo foi cuidadosamente pensado e houve uma razão para cada detalhe. A idéia foi eliminar tudo que fosse desnecessário, para fazer o conjunto o mais claro e simples possível, mas sempre com a beleza como o objetivo final.

Em uma casa publicada na The Craftsman em janeiro de 1909, a influência dos Greene pode ser vista principalmente nos detalhes das pérgulas, no trabalho em madeira aparente, nos grandes beirais, no segundo pavimento em balanço e no pátio. As paredes do segundo pavimento utilizam shingles ${ }^{9}$, telhas vermelhas na cobertura e a fundação e os parapeitos são executados em pedra. É assinalado que "como em todas estas casas, no entanto, os materiais utilizados são opcionais e podem ser alterados de acordo com o gosto do proprietário, as condições da paisagem ou as limitações do orçamento." (STICKLEY, 2002, p.42) Sobre o projeto:

\footnotetext{
8 "California's Contribution to a National Architecture; its significance and beauty as shown in the work of Greene and Greene, architects", The Craftsman, Vol. XXII, n.5, Agosto de 1912, p.533.

9 Os shingles são telhas finas de madeira, normalmente retangulares, colocadas parcialmente sobrepostas umas às outras, utilizadas na cobertura, mas também como fechamento lateral. Também podem ser executadas em outros materiais como ardósia, fibrocimento ou cerâmica. (http://en.wikipedia.org/wiki/Roof_shingle)
} 
A vida em uma região quente, onde o sol sempre brilha e é possível ficar ao ar livre na maior parte do tempo, foi especialmente considerada no desenho desta casa, pois a planta aproveita ao máximo os terraços, as varandas e o pátio aberto calçado, tanto quanto os ambientes internos. Tal projeto é totalmente apropriado para uma residência na Califórnia ou nos estados do Sul, mas seria recomendável apenas para locais mais favorecidos no Norte e Leste, já que seu conforto e encanto dependem em grande parte da possibilidade da vida ao ar livre. (STICKLEY, 2002, p.42)

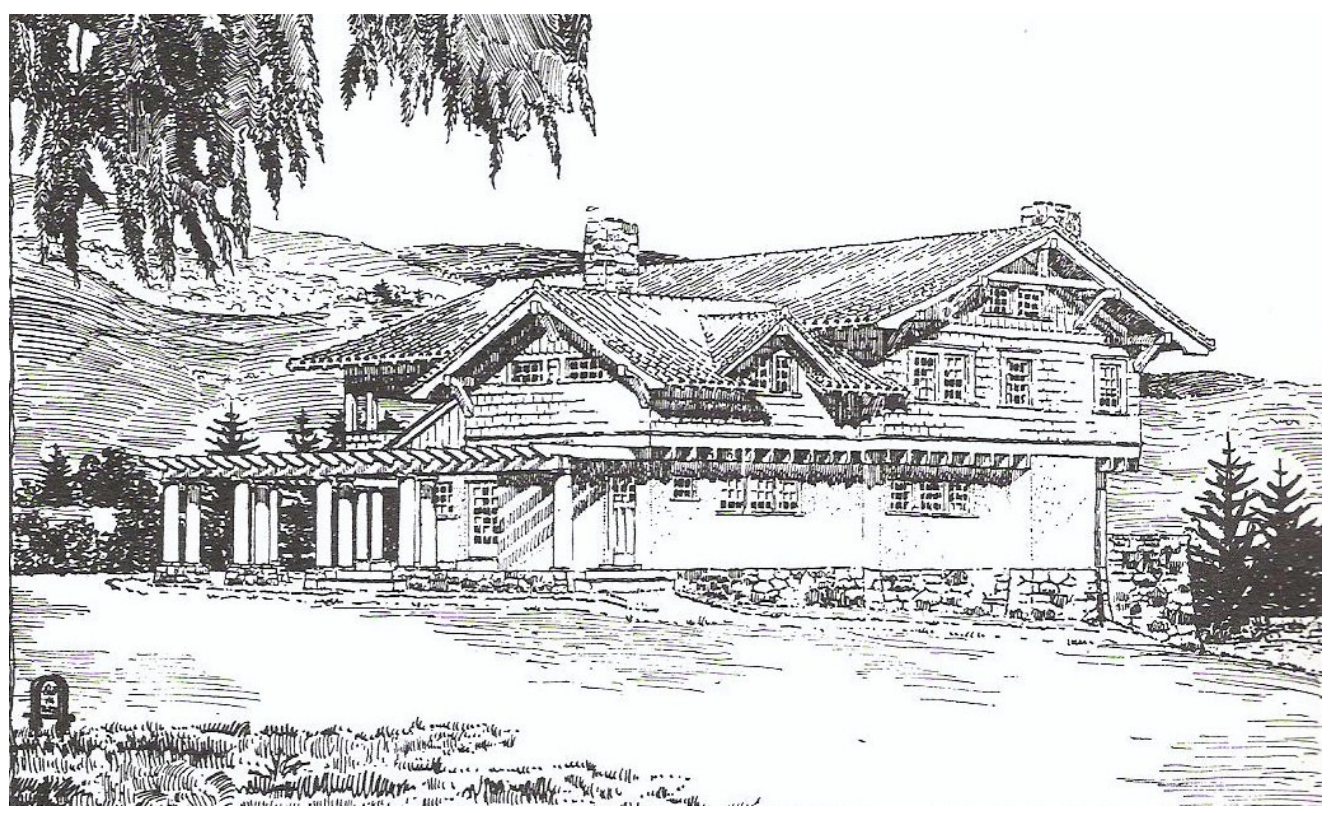

Fig.2.10 Casa publicada em The Craftsman, janeiro de 1909

A influência californiana foi muitas vezes demonstrada:

O tipo de casa que hoje existe em grande número na Califórnia - na qual conforto e arte estão habilmente conectados - não supõe uma atitude deliberada, um estilo temporário. É um produto de sua época, lugar e de seu povo, com profundas raízes nas necessidades geográficas e humanas. Tem uma relação precisa com o tipo de clima e solo, com os hábitos das pessoas e sua maneira de encarar a civilização e a natureza. É igualmente rica em tradições históricas. ${ }^{10}$

A admiração de Stickley por Irving Gill (1870-1936), outro arquiteto da Califórnia, fica clara nos vários artigos dedicados a ele na revista. Gill escreve, na The Craftsman:

${ }^{10}$ The Craftsman, Vol. XXII, n.5, Agosto de 1912, p.532. 
Deveríamos construir nossa casa simples, sincera e sólida como uma rocha e depois deixar a ornamentação à natureza, que a enfeitará com liquens, a trabalhará com o cinzel das tormentas, a fará graciosa e agradável com a sombra de parreiras e flores, como faz com a pedra do prado. Creio também que as casas deveriam ser construídas com mais solidez e que deveriam ser absolutamente higiênicas. Se o custo da decoração desnecessária fosse aplicado à construção, teríamos uma casa mais digna e resistente. ${ }^{11}$

O material usado por Gill era bem diferente daquele dos Greene. Ao invés da madeira, concreto. O exterior das casas de Gill, com seus arcos, balcões e tetos planos evoca as missões espanholas da Califórnia. Gill extrai a essência das formas arquitetônicas históricas para criar o novo. (SMITH, 1992, p.141).

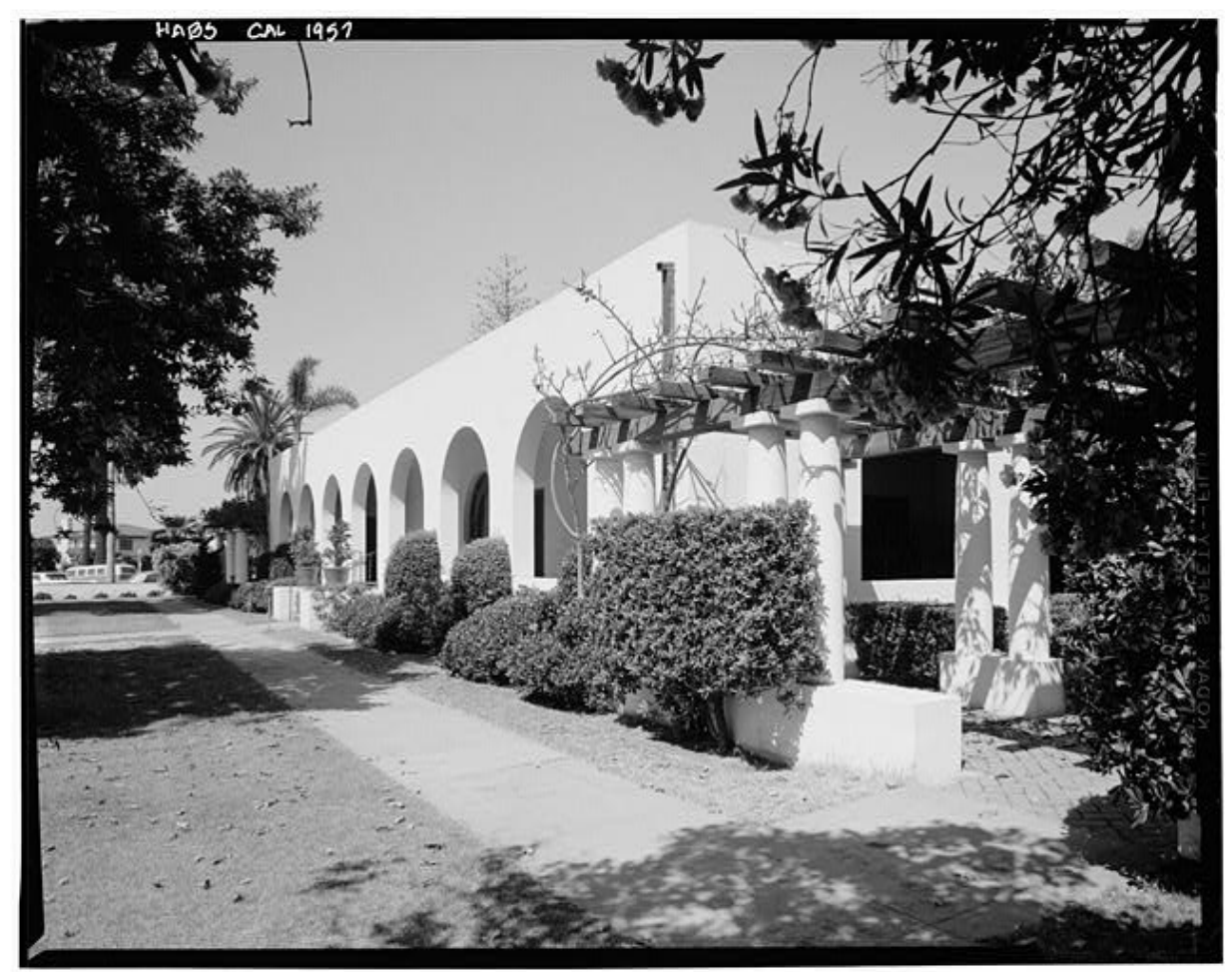

Fig.2.11 La Jolla Women's Club, San Diego, Irving Gill

Outro arquiteto que escreveu para a revista foi Barry Parker, com uma série de 28 artigos entre 1910 e 1912. Através dos artigos de Parker, foram apresentados conselhos práticos e bons exemplos da arquitetura Arts and Crafts inglesa para os leitores. O sócio de Parker, Raymond Unwin também escreveu na The Craftsman sobre desenho urbano, enquanto ele e Parker projetavam Letchworth. O livro dos

\footnotetext{
${ }^{11}$ The Craftsman, Vol. XXX, n.5, Maio de 1916, p.142 apud POTES; PAZ; ARBOLEDA, 2000, p.28.
} 
arquitetos The Art of Building a Home teve uma resenha na revista ${ }^{12}$, que dizia: "Somos uma nação de homens e mulheres auto-suficientes e não podemos esperar que se desenvolva uma arquitetura genuína e expressiva até que construamos casas simples, mas também bonitas (...) e que sejam apropriadas para pessoas ocupadas e inteligentes. Que o mesmo estado de ânimo prevaleça em outras terras (ainda que em nenhum outro lugar tenha a mesma intensidade que na América) podemos perceber pelos escritos de dois arquitetos ingleses muito conhecidos, Barry Parker e Raymond Unwin, que em uma série de conferências publicadas sob o título de The Art of Building a Home fazem um apelo por maior honestidade na arquitetura e sinceridade na decoração." (STICKLEY, 2002, p.6)

"O conceito do The Craftsman era amplo o bastante para incluir casas de fazenda, no subúrbio, cabanas na montanha e casas urbanas geminadas. Havia mansões Craftsman e cottages Craftsman. O ponto importante era a adequação da casa aos moradores e ao seu entorno. No entanto, durante os dezesseis anos de existência da The Craftsman, um tipo de habitação realmente recebeu maior atenção: o bangalô." (WEISSMAN, 1988, p. vi)

Se as casas da The Craftsman podem ser ou não chamadas de bangalôs depende da definição que se atribui a eles. Algumas das casas efetivamente tinham tal denominação. Como aquele publicado em abril de 1907: A bungalow of irregular form and unusually interesting construction.

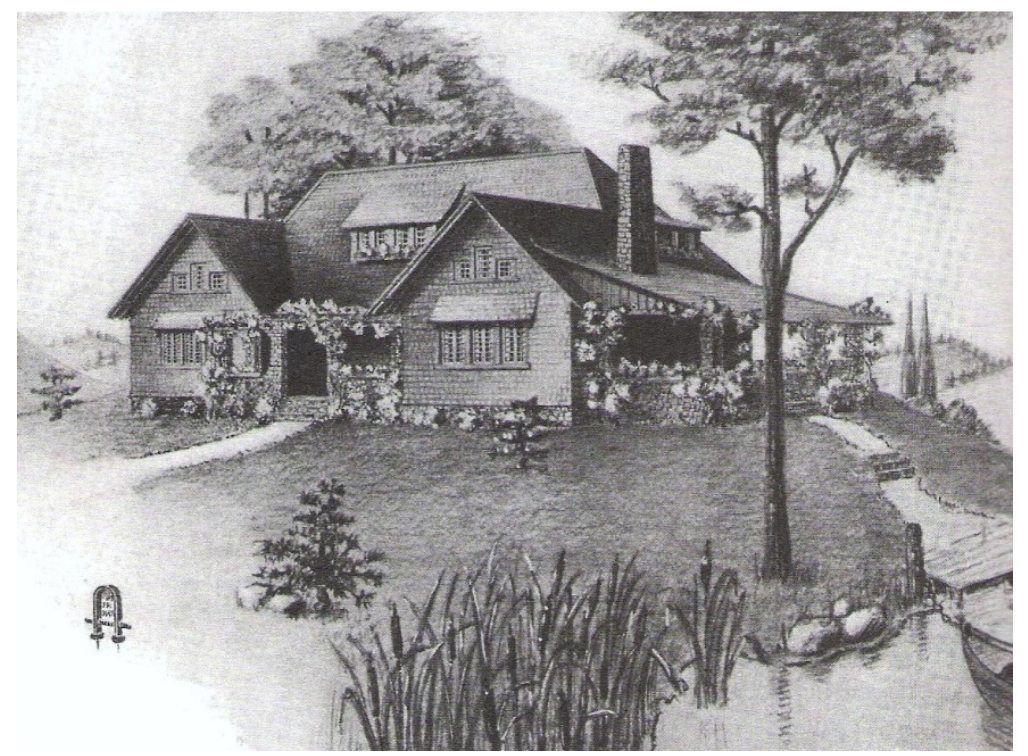

Fig.2.12 Bangalô publicado em The Craftsman em abril de 1907

\footnotetext{
12 O livro de Parker e Unwin também foi resenhado pelo The New York Times, em 16 de novembro de 1901, recomendando-o tanto para os arquitetos quanto para aqueles leigos que procuravam por uma casa.
} 


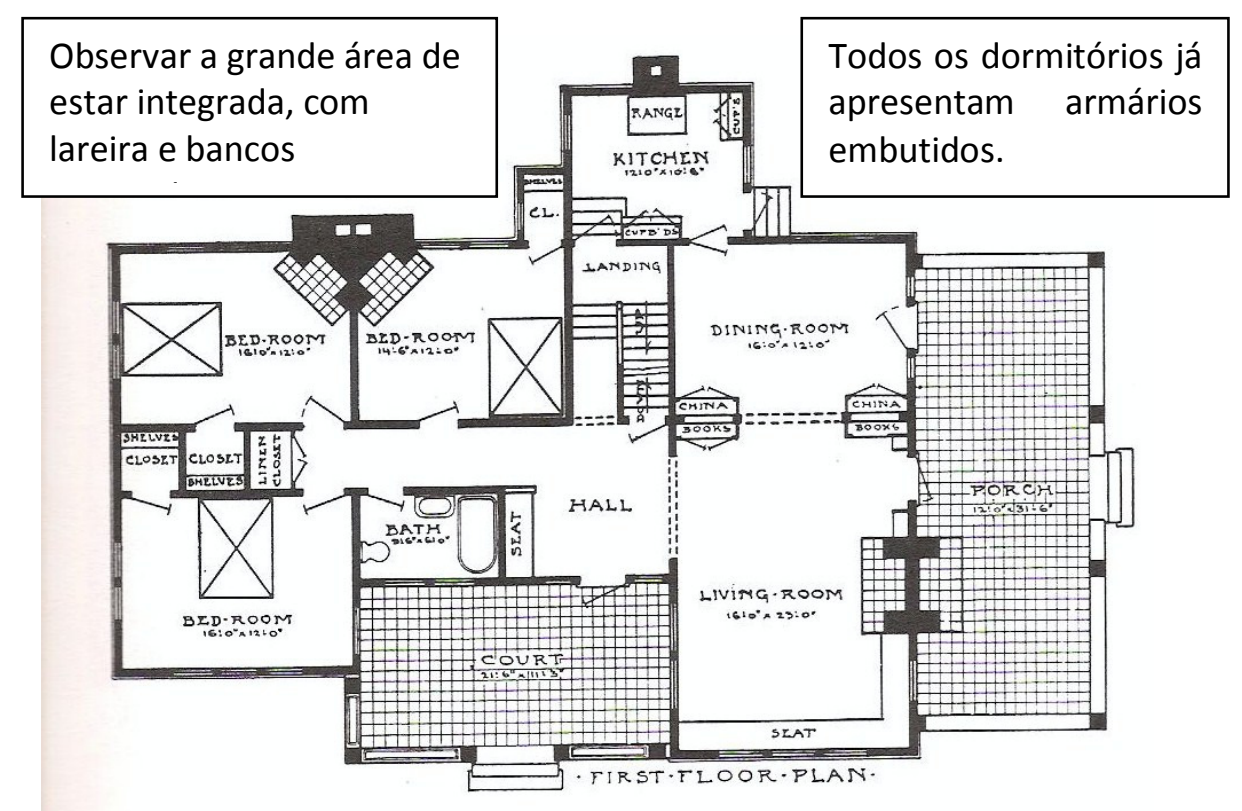

Fig.2.13 Planta do pavimento térreo do mesmo bangalô.

A casa é algo irregular no desenho, mas é tão bem planejada e tão proporcional, que suas linhas impressionam como as que se vêem em uma velha casa inglesa que adquiriu sua forma atual depois de séculos de alterações que responderam às mudanças de necessidades. Parece, acima de tudo, uma casa capaz de coroar o cume de uma colina no campo. (STICKLEY, 2002, p. 62)

Cottages também aparecem nas páginas da The Craftsman: A Pleasant and Homelike Cottage designed for a small family, publicado em fevereiro de 1905 seria adequado para os subúrbios ou para uma vila. (STICKLEY, 2002, p.77)

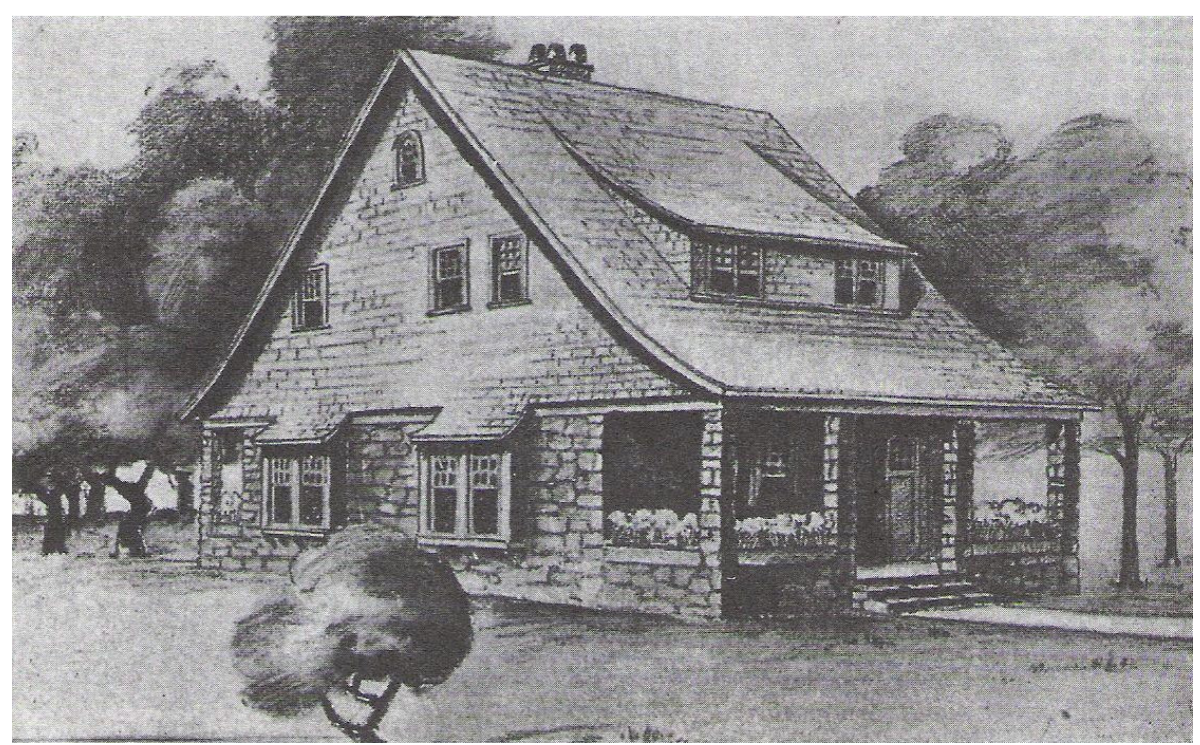




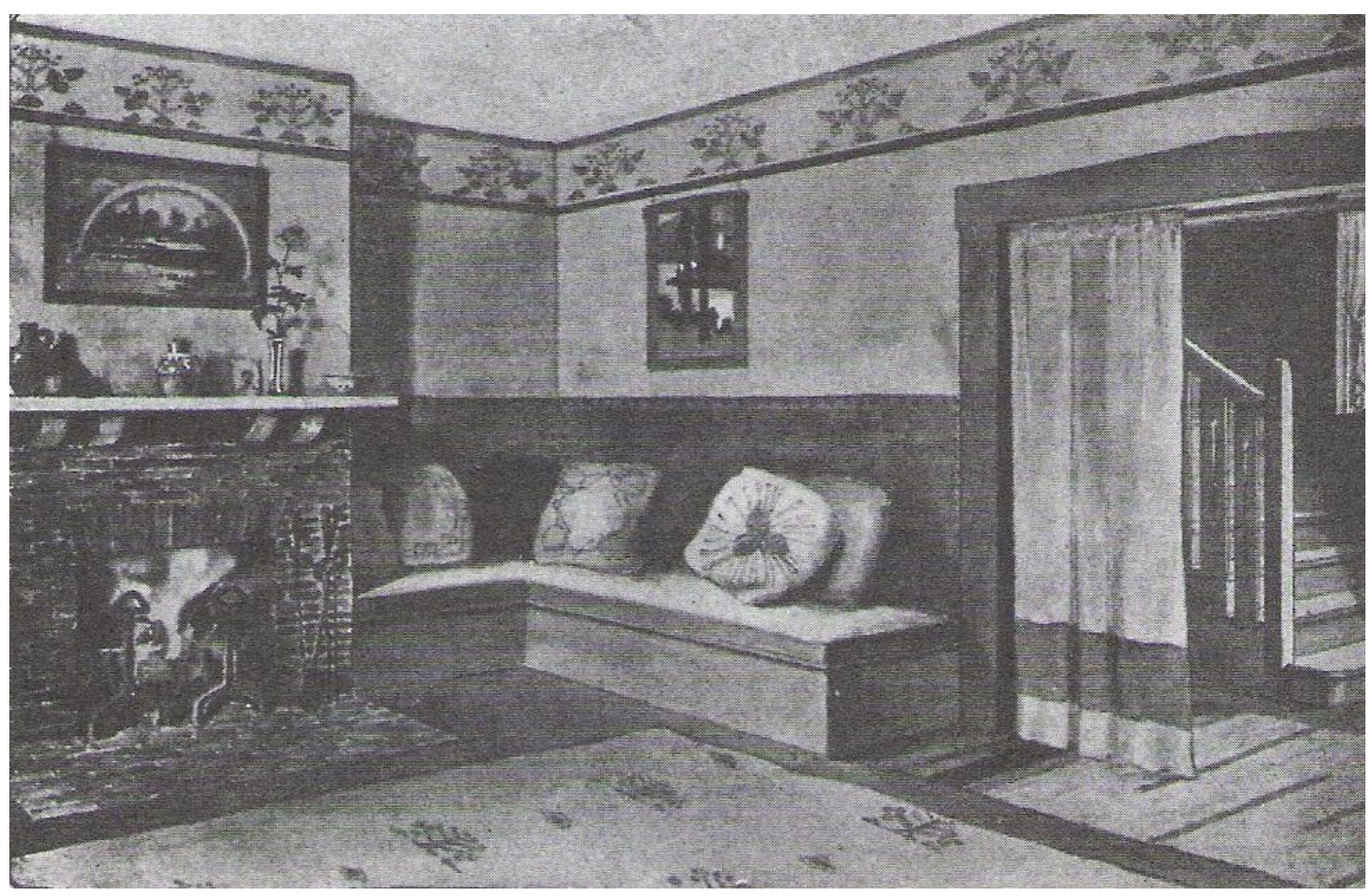

Havia ainda o bungalow-cottage, como no artigo publicado em julho de 1910, A charming and inexpensive cottage in the bungalow style (STICKLEY, 1988, p. 48) ou no artigo de novembro de 1914, Cottage Bungalow: a new development in intimate home architecture. (STICKLEY, 1988, p. 121), em que o cottage-bungalow é definido como o mais novo passo na evolução da pequena casa americana e combinaria "os melhores aspectos do simples e antiquado cottage com o mais elaborado e moderno conceito do bangalô". O arquiteto, Sylvanus B. Marston, teria:

(...) preservado o aspecto simples, firme e democrático do cottage, que sugere verdadeiro conforto interno e vida saudável; ao mesmo tempo ele utilizou as varandas arejadas, as amplas salas de estar, lareiras agradáveis, o trabalho em madeira e a mobília embutida do bangalô. (...) uma palavra apenas não o descreveria; suas qualidades podem ser expressas apenas utilizando-se de ambas. As linhas longas e baixas do telhado, os grandes beirais, a localização dos principais cômodos no térreo, colocaria as casas na categoria do bangalô. Ainda, a conformação das paredes, os pilares da varanda e a pérgula sugerem os cottages coloniais. (...) são 'híbridos' satisfatórios. (STICKLEY, 1988, p. 121-122) 


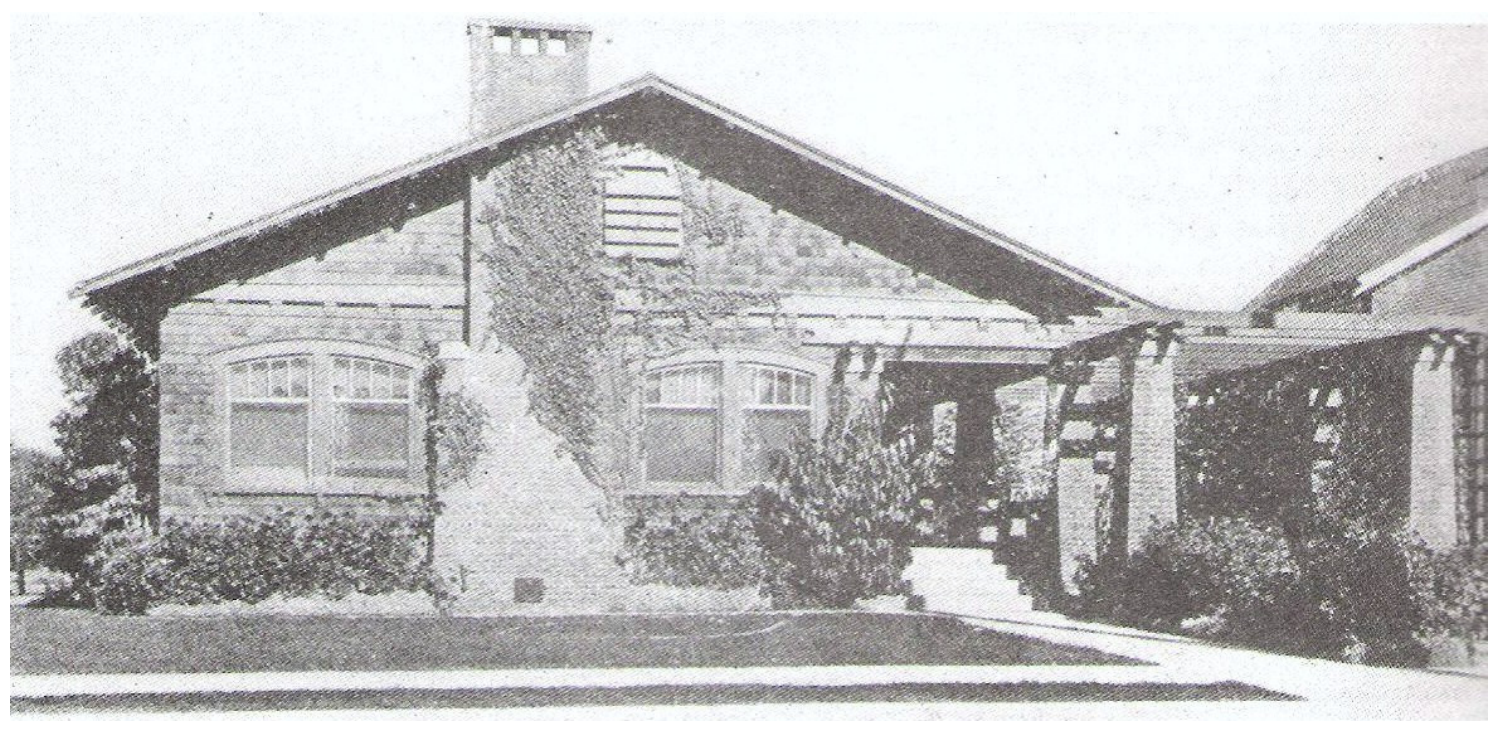

Fig.2.16 Cottage no "estilo bangalô"

A casa Craftsman era um verdadeiro lar. Aqueles que nelas moram, mesmo anos depois de construídas, sentem que suas casas são lares, no melhor sentido da palavra. (SMITH, 1992, p. 94). Dizia-se que estas casas, com sua aparência acolhedora, trariam descanso e alívio após o convívio no mundo tumultuado do trabalho.

Não tinham um custo baixo. O próprio Stickley avisava que elas poderiam custar mais do que uma casa comum com a mesma área, devido aos materiais especiais e ao trabalho manual a ser executado para se obter um todo harmonioso. Sempre que possível eram utilizados materiais encontrados na localidade, como madeiras, argila e pedras, shingles, blocos cobertos com cimento, tijolos, permitindo que a casa fosse reconhecida como um produto daquela região. Comentando o custo das casas dos Greene, Stickley diz:

(...) a qualidade dos materiais e do artesanato presentes nas casas construídas pelos senhores Greene e Greene as torna realmente caras. A construção é sempre da melhor qualidade e inclui muito trabalho manual - que naturalmente não pode competir com 0 trabalho feito à máquina em termos de custo, no entanto, os resultados suplantam aqueles da máquina, tanto em durabilidade

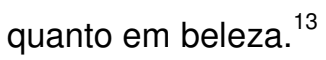

Stickley sempre insistiu em chamar sua mobília de Craftsman, apesar de algumas vezes a ela ter se referido como Mission. O nome Craftsman refletia várias de suas

${ }^{13}$ The Craftsman, Vol. XXII, n.5, Agosto de 1912, p.547. 
preocupações: em primeiro lugar, sua mobília era produzida por artesãos, manualmente. As máquinas não estavam excluídas do processo, porém o acabamento era feito à mão. Outro motivo para tal denominação era o interesse de Stickley pelo sistema de produção das guildas medievais. Houve mesmo uma distribuição de lucros entre seus trabalhadores, no início da empresa.

Gustav Stickley fala à: "numerosa classe média, possuidora de uma cultura média, de recursos materiais moderados, modesta em seus projetos e ações, mediana em tudo, menos na virtude (...) uma arte democrática e simples deve proporcionar-lhes um ambiente útil a uma vida simples (...) e uma domesticidade refinada"14.

A cultura material determinaria comportamentos e transmitiria valores acreditava Stickley e outros seguidores de Ruskin. A reforma moral através do design era a intenção colocada no embelezamento do lar da classe média. Se o lar é o centro da vida, então devemos trazer a arte ao nosso lar.

Que a influência da casa seja de fundamental importância na formação do caráter é um fato já bastante reconhecido e admitido para ser aqui colocado como uma nova idéia. (...) sem exceções, as pessoas que levam uma vida com simplicidade e de maneira saudável e ao ar livre, e que percebem a importância do lar, são as pessoas que fizeram os maiores progressos no desenvolvimento da raça humana. Quando a luxúria ali penetra e milhares de necessidades falsas parecem reais, a raça está a caminho da degeneração. (STICKLEY, 2002, p. 194)

Através das revistas de decoração, os ideais do Arts and Crafts migraram das casas da elite e dos intelectuais avant-gardes para aquelas da classe média. As casas da The Crafsman e de outras companhias como a Sears - pré-fabricadas -, junto com os numerosos livros de bangalôs, finalmente propagaram o legado do Arts and Crafts. Uma arquitetura mais democrática se concretizaria com o movimento do bangalô na América (CUMMING; KAPLAN, 1991, p.7).

O "estilo" Craftsman na arquitetura residencial do início do século XX foi o resultado de vários fatores: a ascensão da classe média, um incremento na propriedade individual da casa, um crescente interesse na vida junto à natureza e o movimento Arts and Crafts americano.

\footnotetext{
14 STICKLEY, Gustav Thoughts Occasioned by an Anniversary: a Plea for a Democratic Art, The Craftsman,Vol. VII, outubro de 1904, p.53 apud BORIS, 1986, p. 62.
} 


\subsection{As novas revistas}

Revistas de decoração da casa vinham de encontro a um grande interesse das mulheres de classe média por informações e conselhos. Como a House Beautiful, fundada em 1896, em Chicago e que em 1906 chega à circulação de 40.000 exemplares e a Ladie's Home Journal que declarava ter mais de um milhão de assinantes. (BORIS, 1980, p.54) Em 1901, Gustav Stickley lança The Craftsman. O Arts and Crafts tornara-se um estilo de vida associado à classe média.

Com tal circulação, provavelmente a Ladie's Home Journal teve muito mais influência do que The Craftsman. Mesmo a House Beautiful, uma revista de qualidade, fundada por arquitetos e voltada ao público leigo, tinha o triplo da circulação da revista de Stickley. (KREISMAN e MASON, 2007, p. 158) "Produzidas em papel de qualidade, distinguiam-se por seu visual surpreendente e, em certos casos, a capa era usada para assinalar a originalidade de determinado assunto ao invés da periodicidade do título." (AYNSLEY, 2005, p.45) Jennifer Scanlon mostrou como tais artigos eram escritos por mulheres que viviam vidas bem diferentes daquelas que aconselhavam às leitoras. No âmbito da domesticidade, o que Scanlon chamou de filosofia da 'vida simples' é significativo: ater-se a modas simples, mobiliar e viver em pequenas casas e manter relações descomplicadas em casa e na comunidade. ${ }^{15}$

Somando-se às revistas, os livros com modelos de projetos tornam-se uma verdadeira indústria. As casas construídas sob sua inspiração compartilham características como linhas retas e simples, acabamentos despretensiosos, plantas informais e o uso de materiais locais.

De 1908 a 1912, ${ }^{16}$ Henry L. Wilson publicou a Bungalow Magazine em Los Angeles, mostrando os mais novos e interessantes bangalôs californianos. Ele publicava também livros de modelos. Em todos os projetos constava o custo aproximado para a construção do bangalô mostrado. Os projetos poderiam ser solicitados através do correio. Um projeto completo com plantas da fundação, porão e dos pavimentos, quatro elevações, detalhes e especificações custaria dez dólares. (WILSON, 2006, p. 5)

\footnotetext{
${ }^{15}$ SCANLON, Jennifer Inarticulate Longings: the Ladies' Home Journal, Gender and the Promises of Consumer Culture. Routledge, 1995, p. 53 apud AYNSLEY, 2005, p.52

${ }^{16}$ De 1912 a 1918, Jud Yoho, um empresário de Seattle, publicou a revista na cidade, quando então esta foi encerrada.
} 


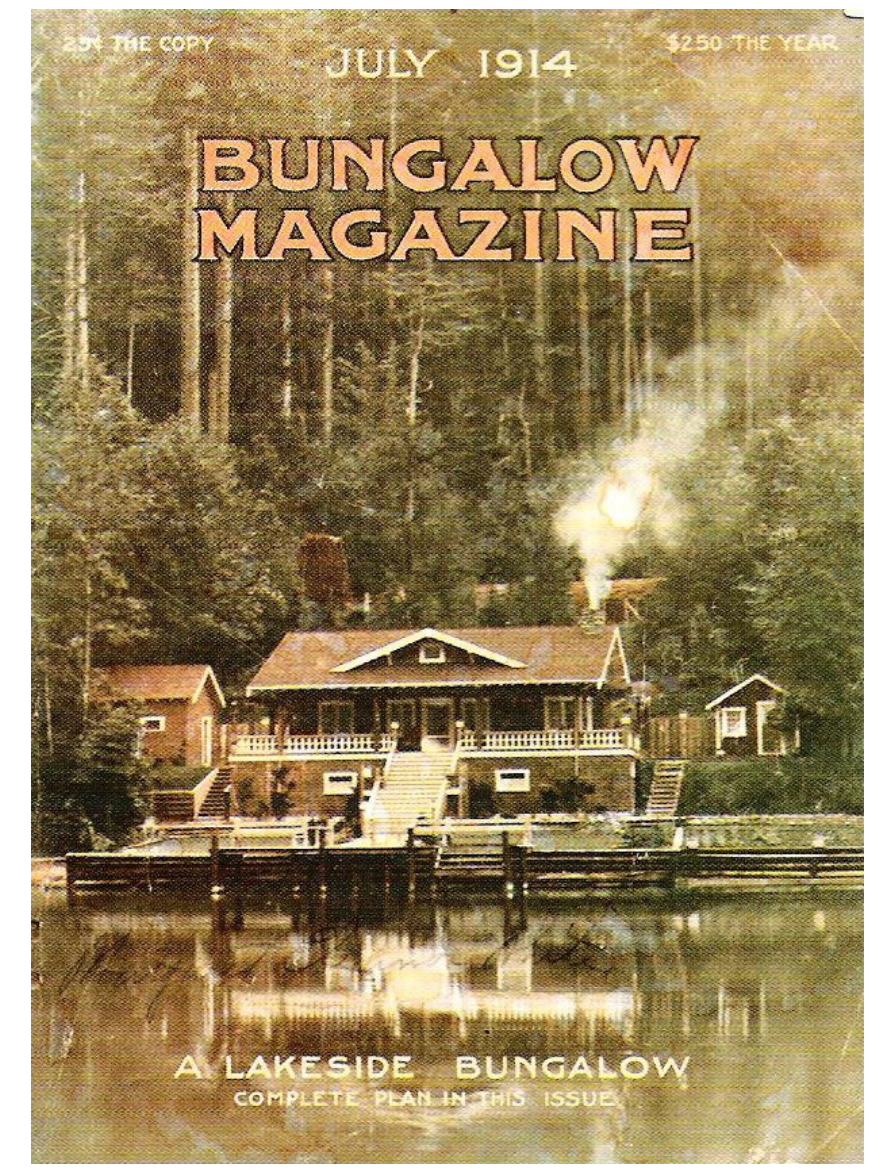

Fig. 2.17 Bangalô no Lake Crescent, que incorpora seus aspectos rústicos e sofisticados e também seu conforto.

A revista Pacific Builder and Engineer publicava periodicamente reportagens sobre 0 assunto. Em outubro de 1910, apresentando um bangalô, o exterior é descrito como modesto. Grande parte do artigo fala sobre o interior, com salas de estar, jantar e escritório integrados, onde se poderiam receber muitos convidados nas ocasiões festivas. ${ }^{17}$

Havia um grande contraste entre as residências encomendadas a arquitetos e os bangalôs inspirados nos livros de modelos, para a classe média ou para trabalhadores. Em alguns casos, estes últimos, que muitas vezes tinham os proprietários como construtores, apresentavam detalhes mais interessantes $\mathrm{e}$ requintados que as grandes mansões do Arts and Crafts, onde havia grande número de pessoas envolvidas na construção. (KREISMAN e MASON, 2007, p. 127)

\footnotetext{
${ }^{17}$ Pacific Builder and Engineer 10, n.17, 22 de Outubro de 1910, p. 160-1 apud KREISMAN e MASON, 2007, p. 165.
} 


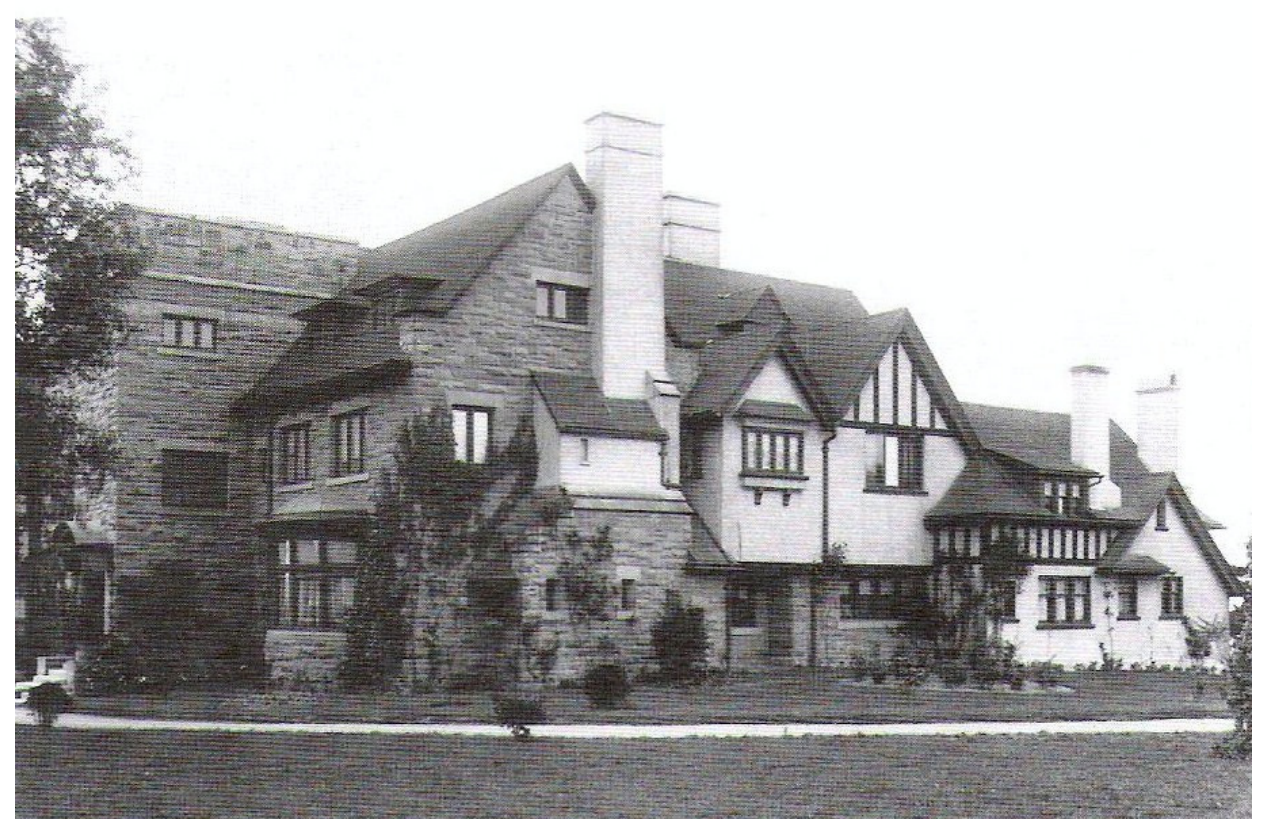

Fig. 2.18 Residência da primeira década do século XX, em Seattle, assimétrica e variada, como as casas do Arts and Crafts inglês.

\subsection{Mission Style}

Outras formas históricas foram utilizadas na arquitetura, como no Mission Style, exploradas na Califórnia Midwinter International Exposition em 1894, em São Francisco.

"A evolução do termo Mission - denominação dada a algumas cadeiras executadas para uma igreja de São Francisco ${ }^{18}$, que se torna um nome genérico, ainda em uso hoje, para referir-se a todo tipo de mobília Arts and Crafts - é um exemplo do conceito do historiador Eric Hobsbawn da 'invenção da tradição"'. (KAPLAN, 2004, p. 270). A "invenção da tradição" descrevia como, na virada do século XX, o passado foi manipulado, reconstruído e atualizado para instituir ou reforçar identidades nacionais. ${ }^{19}$

\footnotetext{
${ }^{18}$ A Swedenborgian Church, em São Francisco foi construída em 1894 por A.C. Schweinfurth e Bernard Maybeck que trabalhavam no escritório de A.Page Brown. A mobília foi desenhada neste escritório, mas não se sabe ao certo a autoria. A cadeira viria a ser conhecida como "Mission chair". (KAPLAN, 2004, p. 271)

${ }^{19}$ HOBSBAWN, Eric Introduction: Inventing Traditions In: HOBSBAWN, Eric e RANGER, Terence (ed.) The invention of Tradition Cambridge: Cambridge University Press, 1988, p.1-15 apud KAPLAN, 2004, p. 270.
} 


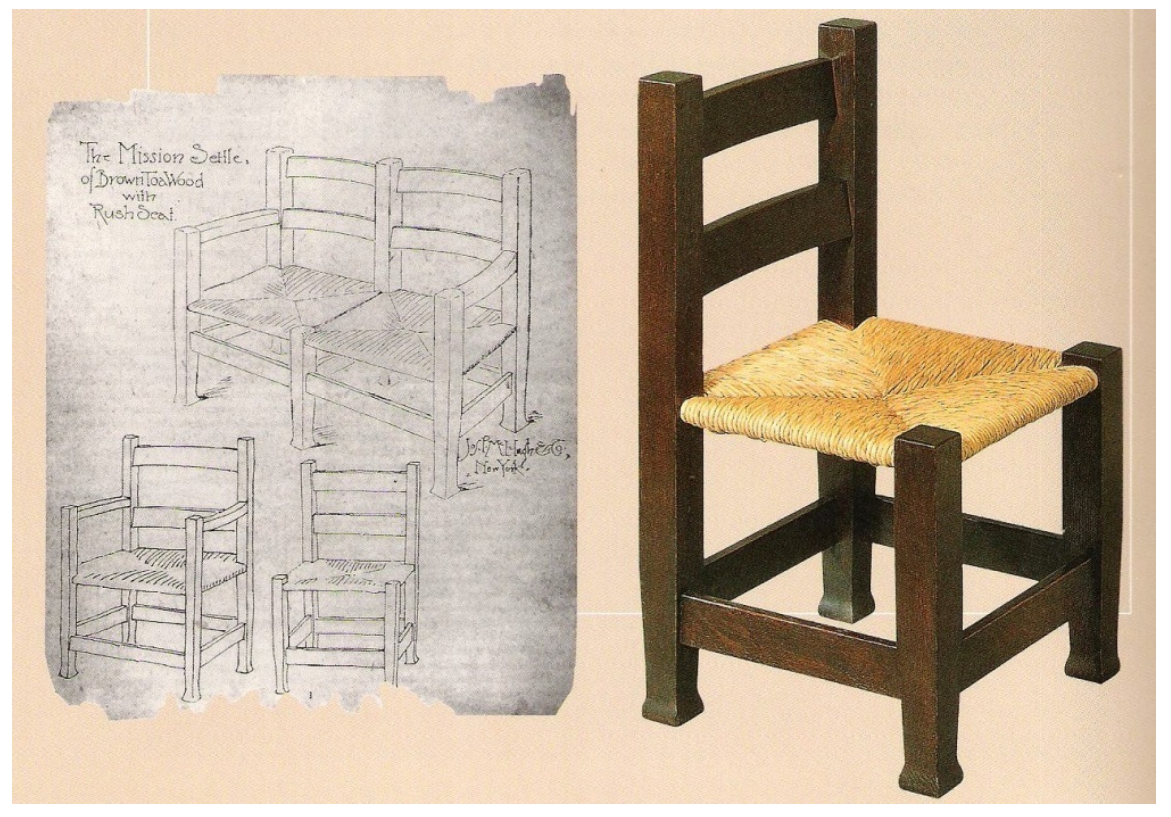

Fig. 2.19 Cadeiras Mission Style

O termo Mission tem profundas ressonâncias. Ele sustenta o mito de que as missões espanholas foram um grande capítulo na história da colonização americana, ao invés da exploração vergonhosa e dizimação de uma população nativa. Importante também era a maneira como o termo nitidamente se encaixava com a ideologia do movimento Arts and Crafts. Esta combinação de moralidade e marketing foi capitalizada por jornais e revistas (KAPLAN, 2004, p. 273)

Mission tornou-se sinônimo do "estilo" Arts and Crafts, especialmente na Califórnia apesar dos conhecedores da arquitetura das missões saberem que não havia tal coisa como mobília Mission.

Os interiores rústicos do Mission teriam grande influência nos círculos do Arts and Crafts. Suas cadeiras despretensiosas tornaram-se o protótipo da onipresente mobília Mission das décadas seguintes. (KREISMAN e MASON, 2007, p. 35)

\subsection{0 bangalô}

Entre os arbustos e árvores frondosas

Fica o pequeno e alegre bangalô

Seu portão branco balança e nos dá as boas vindas

Enquanto sua porta nos convida a entrar. 
Suas janelas claras e cintilantes

Olham-nos com orgulho

As limpas e sorridentes paredes de madeira

Fazem-nos adivinhar quão aconchegante é seu interior.

Aqui espíritos amáveis brilham intensamente

E a vida da família está protegida

Da fumaça das chaminés

Pelas cortinas esvoaçantes.

A casa da bravura americana

Independência e verdade em sua vida

Chama os vizinhos e amigos

Para com a família confraternizar ${ }^{20}$

O bangalô foi tema de muitas canções nas primeiras décadas do século $X X$. Foi festejado, mas também ridicularizado. Na canção anterior, ele é apresentado como parte da família.

A palavra "bungalow", do híndi banglã, ou casa no estilo de Bengala originalmente se referia a um tipo de habitação colonial do leste da Índia. Era uma casa térrea cujos cômodos bem ventilados abriam-se para um hall central arejado, e que tinha um telhado pouco inclinado e varandas em todas as fachadas. Por algum tempo, certo tipo de bangalô tornou-se moda na Inglaterra. No início do século $\mathrm{XX}, 0$ movimento Arts and Crafts americano de maneira informal o adotou como a casa Craftsman ideal. Na prática, o bangalô Craftsman é muito diferente do modelo original da Índia. Havia mesmo bangalôs de dois pavimentos. (WEISSMAN, 1988, p. vi)

A primeira construção denominada bangalô na Inglaterra data de 1869. Era uma habitação grande e baixa em um resort à beira-mar, próximo à Vila de Birchington. Outros bangalôs foram construídos ali e um dos moradores era o poeta e pintor Dante Gabriel Rossetti. (LANCASTER, 1985, p.34-5)

\footnotetext{
20 'The Bungalow', Keith's Magazine on Home Building, 33, Abril de 1915, p.246 apud R. Winter, The Californian Bungalow, 1980, p.18 apud KING, 1995, 9. 137.
} 


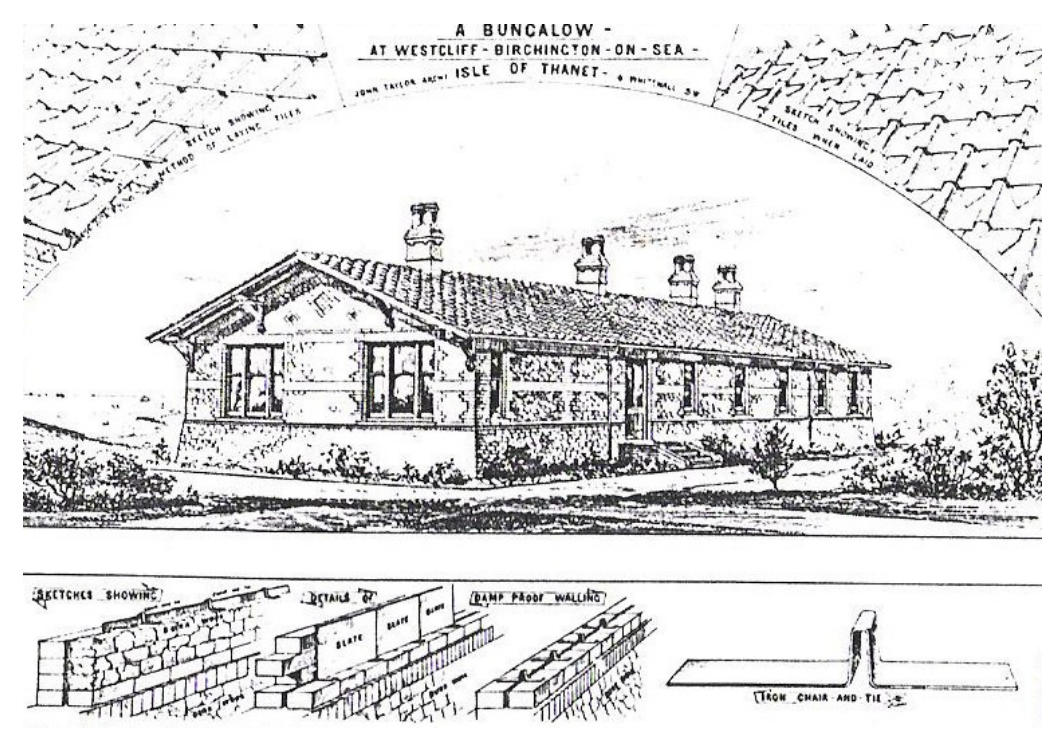

Fig. 1.20 Primeiro bangalô construído na Inglaterra.

Até aproximadamente 1914, na Inglaterra, o bangalô ${ }^{21}$ situava-se na área rural. Representava a "fuga da cidade" e o ideal da "simplificação da vida". Tomando a aristocracia como exemplo, as classes urbanas, média e alta, começaram a procurar por um refúgio no campo. Com a possibilidade de transporte - representada pelas ferrovias e depois de 1900 também pelo automóvel - esta burguesia enriquecida pelo desenvolvimento industrial e comercial, com o auxílio crescente dos arquitetos, passa a almejar uma segunda casa, no campo. Significava fugir não apenas do ar poluído e das condições degradadas das cidades, mas também do stress, da rotina e das convenções da vida urbana. Inicialmente para uso temporário no verão, e, a partir dos anos 1880, também para o "weekend". "Ter um cottage no campo ou, ainda melhor, um bangalô, significava fugir temporariamente da cidade". (KING, 1995, p. 93)

O movimento pela simplificação da vida estava basicamente ligado à classe média, pregando o valor da vida no campo, do trabalho na terra, luz e ar livre. E o bangalô

\footnotetext{
${ }^{21}$ A palavra bungalow (ou banggolo, com várias pronúncias) tem sido definida a partir de vários critérios, desde suas origens na Índia. Ali, para defini-la como habitação para os colonizadores europeus, utilizaram-se critérios raciais, culturais e implicitamente políticos. Quando se transfere à Inglaterra, na segunda metade do século XIX, o bangalô foi definido de diversas maneiras. A noção que prevalece hoje, de que o termo se refere a uma habitação térrea isolada é muito simplificada. Inicialmente quando foi introduzido, distinguia-se pela sua função, como uma casa para lazer e férias ou, algumas vezes, pelo seu tipo de construção (pré-fabricada ou não) e algumas vezes pelo seu desenho. Também pela sua localização - era uma casa para um local em particular: no campo, à beira-mar. Estabelecer uma simples definição, indicando o que o termo significa não é fácil. Na prática, na Europa e Estados Unidos referiase a uma habitação isolada, às vezes com varanda, geralmente habitada por apenas uma família e locada em seu próprio terreno. Não era necessariamente térrea, no início. (KING, 1995, p.90-1)
} 
torna-se o símbolo deste movimento, sua habitação característica. Definido mais em termos de uso de que de outros critérios como características construtivas.

Os ensinamentos de Ruskin e Morris apareciam constantemente nas páginas da revista The Bungalow. Para Morris: "Simplicidade na vida, mesmo a mais frugal, não é miséria, mas o verdadeiro princípio do requinte." 22

O arquiteto R.A. Briggs publica o primeiro livro de projetos para bangalôs na Inglaterra, Bungalows and Country Residences, que tem cinco edições entre 1891 e 1901, contribuindo bastante na sua difusão em ambos os lados do Atlântico. Conforto e baixo custo eram fundamentais. Os bangalôs de Briggs eram todos pinturescos. (LANCASTER, 1985, p.38) Neste livro, Briggs tenta diferenciar o bangalô do velho cottage:

Um Bangalô (...) não é necessariamente uma construção térrea, nem um cottage do campo. Um Bangalô é essencialmente um pequeno "recanto" ou "refúgio". Um cottage é uma pequena casa no campo, mas um Bangalô é uma pequena casa de campo - um lugar agradável e acolhedor, com varanda e balcões e uma planta pensada para assegurar conforto total, com caráter rústico e uma sensação de despreocupação. (...) (LANCASTER, 1985, p. 39)

Na primeira década do século XX, muitas áreas do campo se tornaram subúrbios das cidades. Os moradores locomoviam-se diariamente para o trabalho. E o bangalô fazia parte deste contexto, tornando-se a habitação de famílias cada vez menores, resultantes de uma impressionante queda na taxa de natalidade na Grã-Bretanha no período 1890-1910. (KING, 1995, p. 126)

Se as origens do bangalô moderno estão na Inglaterra, ele desenvolveu-se plenamente nos Estados Unidos. O bangalô chegou à América através de conexões que incluíam livros, jornais e revistas, inclusive The Studio, que publicou um artigo de R.A. Briggs em 1894.

Em 1890, Nova York com mais de dois milhões e meio de habitantes se transformara em uma metrópole. Ali, como também na costa oeste, o "voltar à natureza" e a segunda casa estavam em voga desde os anos 1880, após a Guerra Civil, quando começa a procura pelos refúgios à beira-mar.

O movimento de retorno à Natureza estava ligado à outra ideologia que influenciava os círculos intelectuais da época, o movimento social

\footnotetext{
${ }^{22}$ MORRIS, William The Prospects of Architecture, conferência no London Institute, 1881. In: MORRIS, May Works of William Morris, Vol. XXII, p.149 apud DAVEY, Peter Arts and Crafts Architecture. Londres: Phaidon Press, 1995.
} 
e estético Arts and Crafts, que se desenvolvera na Inglaterra a partir dos anos 1880. Rejeitando a sociedade de consumo, era um ataque moral e humanista à civilização burguesa e ao materialismo. Sua crença na 'unidade com a natureza', sua busca pela simplicidade e seu interesse pelo artesanato eram a fonte das mudanças que depois teriam lugar nas artes." (KING, 1995, p. 133)

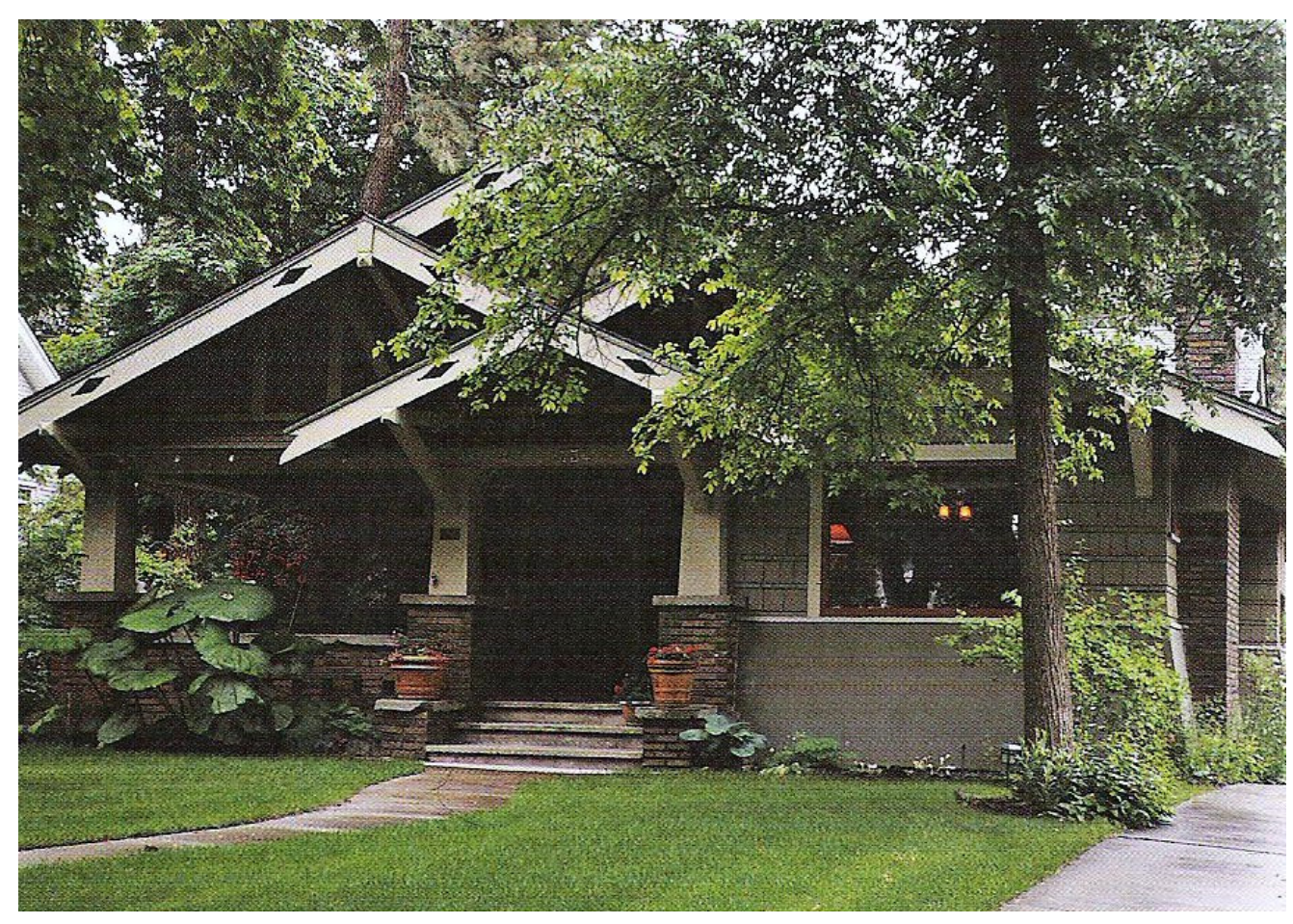

Fig. 2.21 A imagem eternizada do bangalô: telhados baixos, base dos pilares em pedra, situado em meio à vegetação.

A revista The Craftsman foi, com certeza, uma das mais importantes na divulgação desta ideologia da simplificação da vida e do bangalô. Estava implícito no próprio subtítulo da revista: "uma revista mensal ilustrada para a Simplificação da Vida."

(...) para qualquer lugar, montanha ou vale, que seja realmente "campo", o melhor tipo de casa de veraneio é o bangalô. (...) uma casa reduzida à sua forma mais simples, onde a vida pode ser vivida com o máximo de liberdade; nunca deixa de se harmonizar com seu entorno (...) nunca é cara porque construída com materiais e mão de obra locais. (The Craftsman, 1906 apud KING, 1995, p. 134)

A ênfase na horizontalidade dos bangalôs, térreos e com amplos telhados pouco inclinados, "era algo a ser festejado, já que o campo não mais seria afrontado por sobrados estreitos" (The Craftsman, 1903 apud KING, 1995, p. 134). 
O ambiente não deveria ser "perturbado", árvores seriam preservadas e os materiais escolhidos para assegurar a relação íntima entre a casa e seus arredores. Uma casa pinturesca e informal.

Uma habitação que incorporava o espírito do Arts and Crafts. Até mesmo pelo fato do bangalô ser "uma casa que parece ter custado menos do que realmente custou." ${ }^{23}$

Nos Estados Unidos, a presença do bangalô também é marcante no desenvolvimento do subúrbio moderno. E a partir do início do século XX, principalmente após 1905, o bangalô torna-se um fenômeno, com a proliferação de livros e revistas sobre o assunto. (KING, 1995, p. 132)

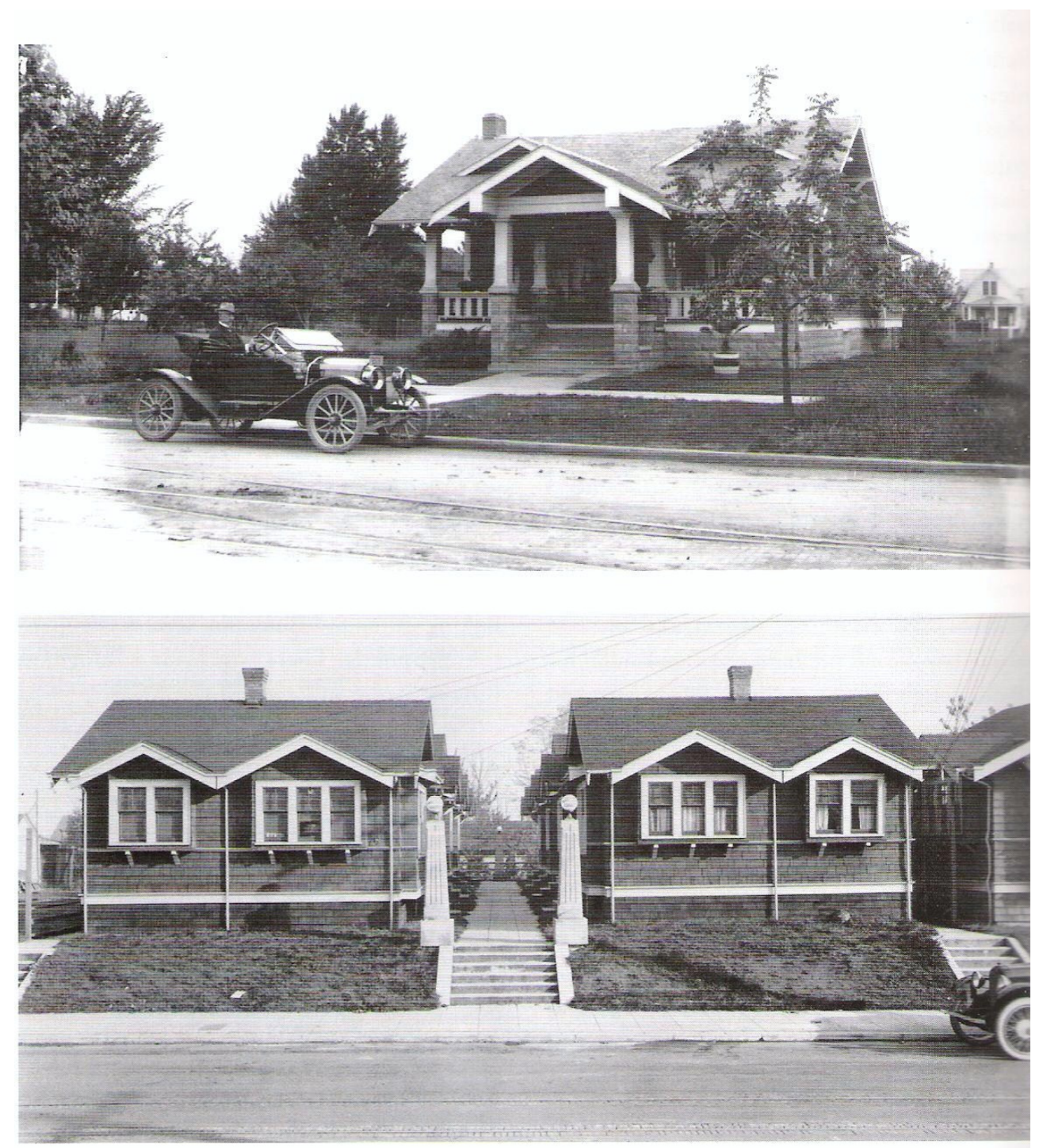

Fig. 2.22 Na primeira foto, o binômio bangalô-automóvel, já presente em 1912. Na segunda foto, de 1915, um conjunto habitacional composto por numerosos pequenos bangalôs, feitos em shingles.

\footnotetext{
23 SAYLOR, H.H. Bungalows. Their Design, Construction and Furnishing. Nova York: Grant Richards, 1911, p. 1 apud KING, 1995, p. 135.
} 
A introdução do bonde elétrico no final dos anos 1880 foi um das razões para o surgimento dos subúrbios, e muito importante no seu crescimento. Anteriormente acessíveis apenas às classes de maior poder aquisitivo, os subúrbios tornam-se uma realidade também para a classe média, com grandes e lucrativos investimentos na sua criação. A seguir, a produção em massa do automóvel tornaria estes locais ainda mais atraentes. Apesar de existirem em grande número também na costa leste e no meio oeste, sua explosão acontece na Califórnia. Los Angeles torna-se o protótipo da metrópole fragmentada, de baixa densidade, com milhares de habitações unifamiliares espalhadas por seus subúrbios. Assim, não é surpreendente que uma nova forma de morar ali se desenvolvesse no início do século XX: o bangalô californiano.

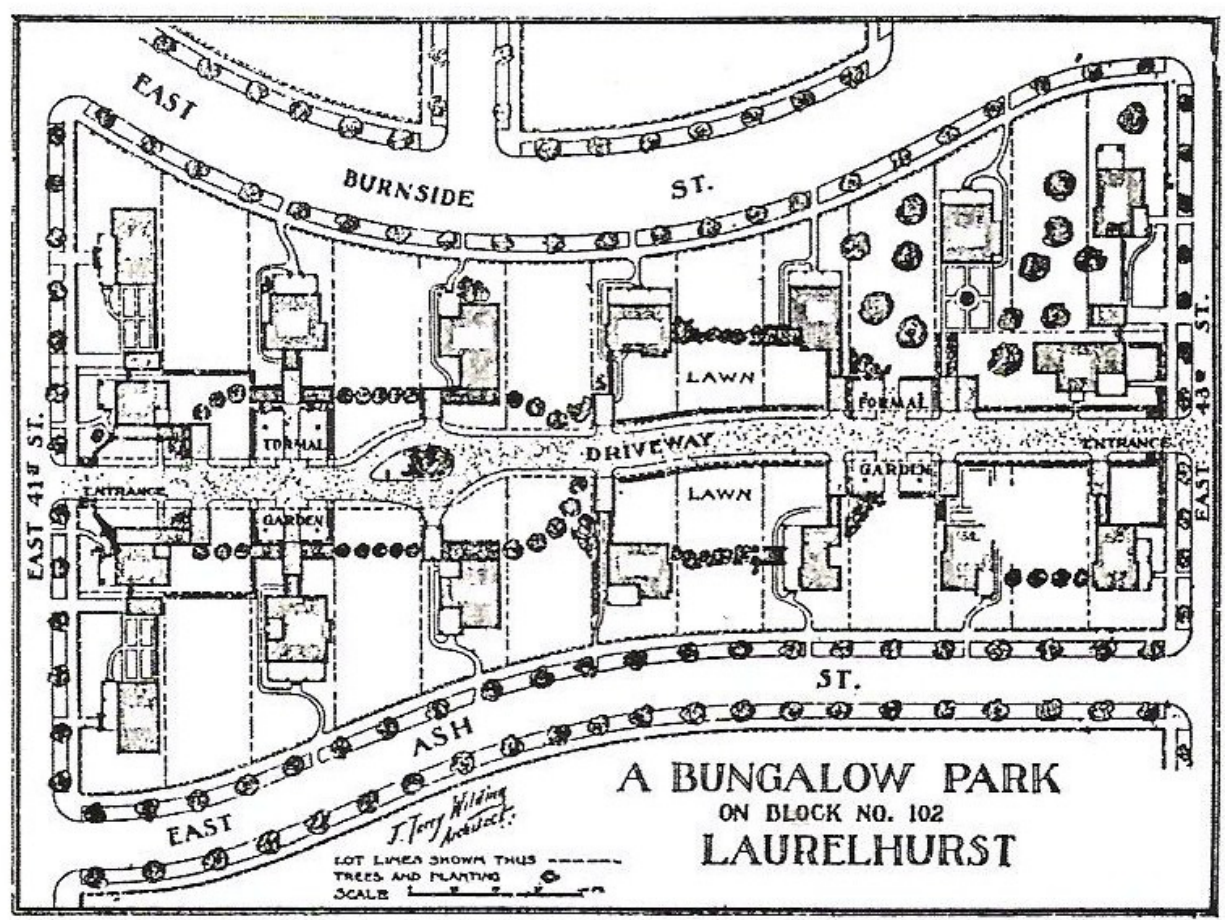

Fig. 2.23 Um "Bungalow Park", Portland, 1916.

Apesar de construído por todo o país, o bangalô sempre esteve associado à Califórnia: térreo, com o interior integrado, varandas, telhados baixos com grandes beirais, oferecendo ventilação e proteção contra o sol. Sua informalidade o fez perfeito para uma sociedade com a mobilidade da californiana.

Com a ferrovia transcontinental, inaugurada em 1885, ligando a Califórnia ao leste, iniciou-se a migração em massa. Na virada do século, estes migrantes eram predominantemente indivíduos brancos, de classe média, vindos do meio oeste. Ao 
contrário da típica metrópole americana, Los Angeles não teve um vasto grupo de imigrantes europeus. (KING, 1995, p.140) A motivação para emigrar não era apenas econômica, mas muitos foram viver ali após a aposentadoria, atraídos pelo clima quente e seco e pela possibilidade de viver nos subúrbios.

(...) o verdadeiro habitante do oeste, é uma pessoa prática e sempre aberta a sugestões de qualquer procedência, desde que contribuam para aumentar seu conforto e satisfazer seu senso de beleza. (The Craftsman, junho de 1910 apud STICKLEY, 1988, p. 44)

Além disto, a Califórnia oferecia o cenário perfeito. Seus recursos, além do clima, incluíam uma provisão enorme de terra barata, acessível graças ao bonde elétrico. Um arquiteto de Milwaukee, radicado em Los Angeles no início do século XX, em um artigo publicado na The Craftsman em outubro de 1907, diz:

"Muitas pessoas do leste pensam que temos um estilo diferente aqui. Se tal qualidade realmente existe na arquitetura da Califórnia, não é porque nossos arquitetos tenham se esforçado para serem únicos em seus projetos, mas porque eles tentaram eliminar todas as características que não condizem com o clima e condições locais, porque eles tentaram ser apenas naturais. $O$ arquiteto californiano não está cercado, como aquele do leste, por uma grande massa de edifícios pré-existentes, que constituem um ônus, uma tradição da qual é difícil fugir. (STICKLEY, 1988, p. 17)

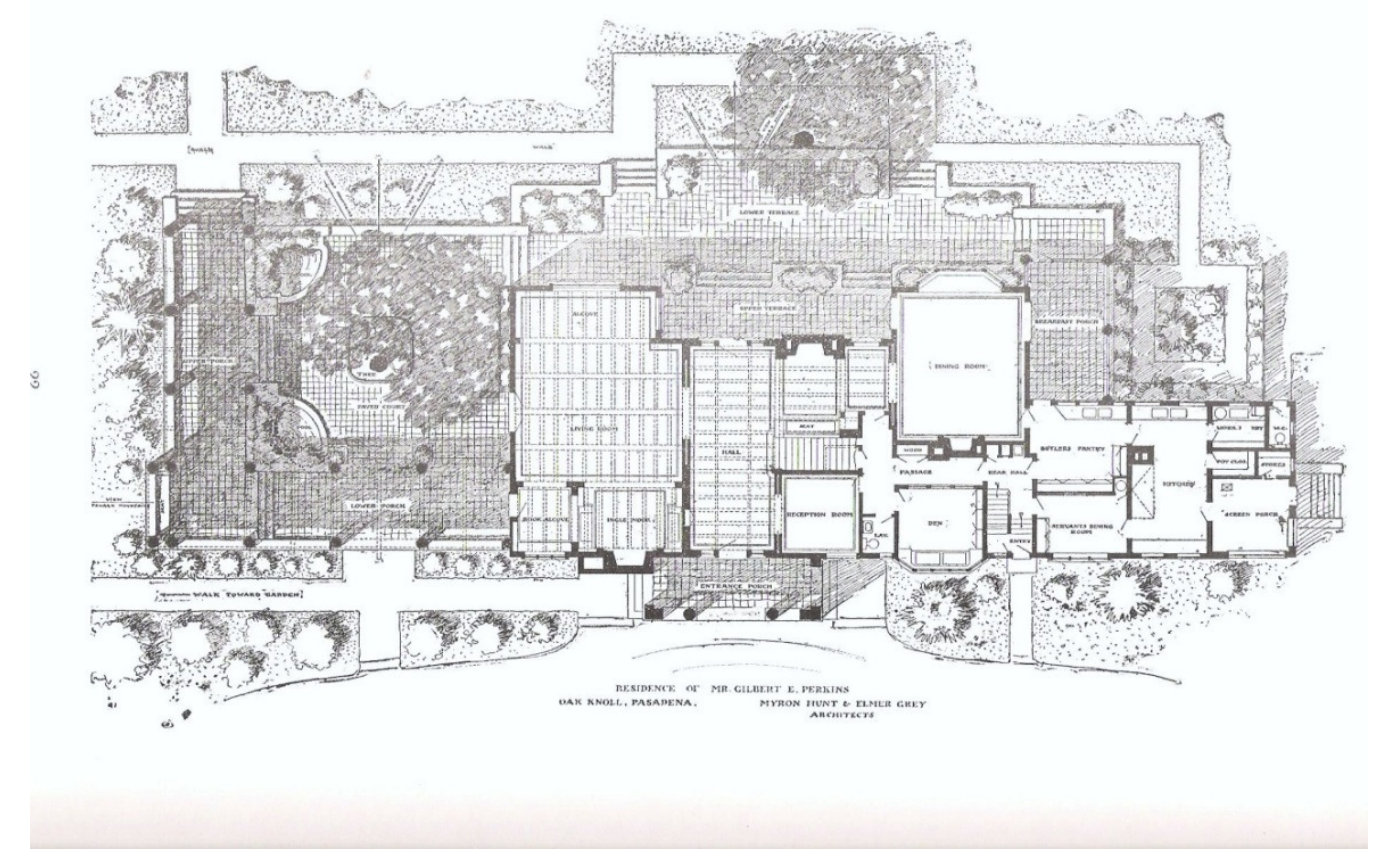

Fig. 2.24 O bangalô californiano, uma grande casa, com amplos ambientes, construída em meio a pátios e à vegetação. 
Na metamorfose do bangalô, de casa de veraneio a residência fixa, o desejo de viver próximo à natureza transforma-se na procura por uma "casa simples, porém artística". Era a síndrome da "volta à natureza" aplicada à casa do subúrbio de onde se ia e voltava todos os dias do trabalho:

Em vários aspectos, a residência de verão (...) nada mais é que uma casa suburbana mal projetada, copiada freqüentemente de livros de modelos arquitetônicos. (STICKLEY, 1988, p. 1)

O bangalô com estrutura em madeira utilizava-se da arquitetura vernácula da Califórnia, com inspiração nas tradições espanholas, mexicanas e indígenas.
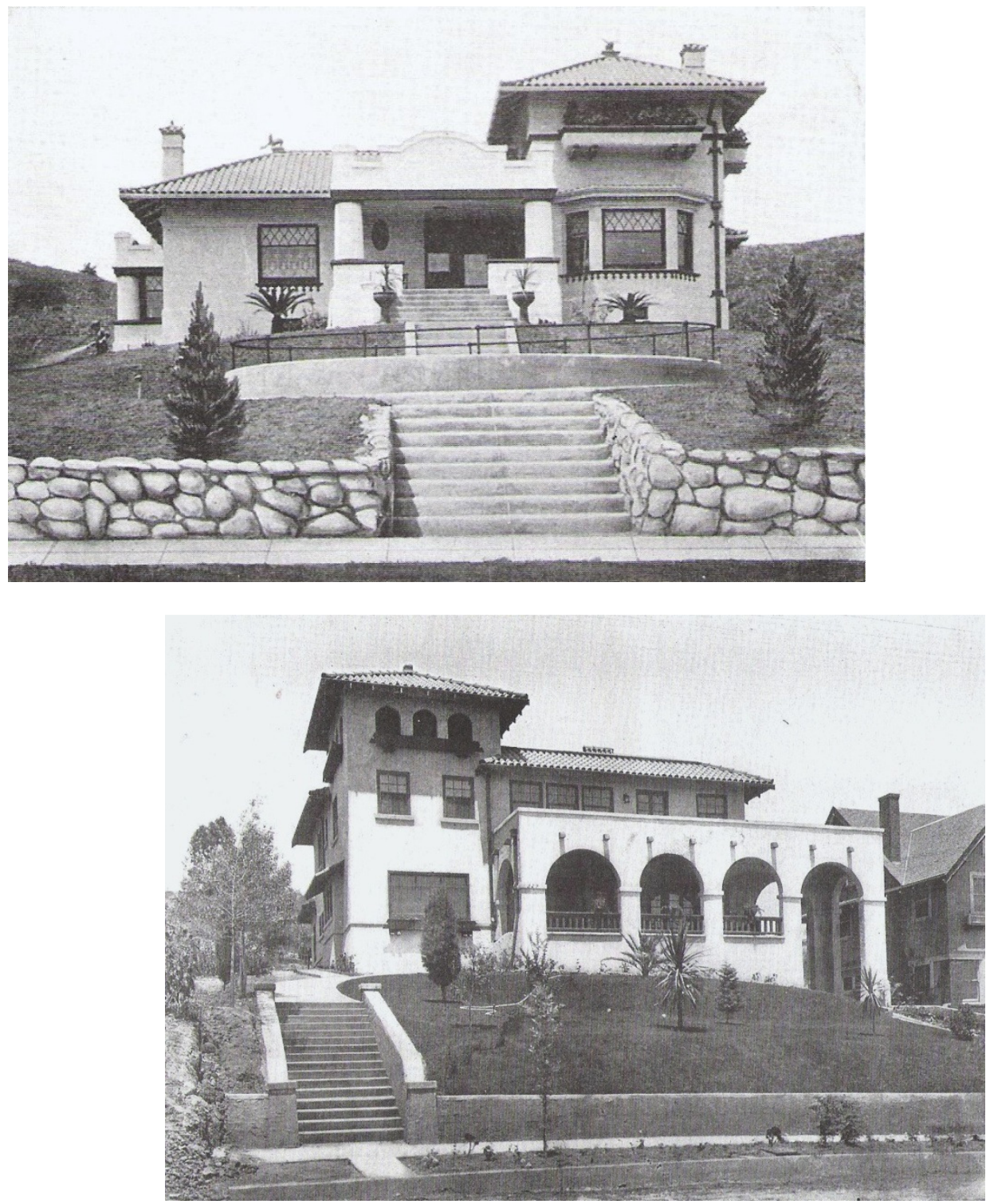

Fig. 2.25 Bangalôs construídos no "Spanish Mission Style". Estes tipos de bangalôs aparecem no Jardim América em São Paulo, nos anos 1920. 
$\mathrm{Na}$ costa oeste, o passado colonial espanhol era idealizado de maneira análoga à que era percebido o passado colonial inglês na costa leste: uma época mais simples, quando o espírito comunitário prevalecia, as pessoas viviam em harmonia com a natureza e orgulhavam-se do trabalho feito com as próprias mãos.

O bangalô californiano (...) é um descendente direto das experiências originais em arquitetura na Califórnia. Podem-se buscar suas linhas artísticas simples diretamente nas velhas missões dos padres espanhóis - com seus beirais baixos e amplos, grandes varandas, aparência hospitaleira e aconchegante - e nas casas de adobe dos pioneiros. Destas "cabanas de adobe" aos graciosos bangalôs hoje conhecidos, parece um grande período de tempo, mas aconteceu uma evolução constante. (WILSON, 2006, p. 3)

Aconselhava-se que estes Spanish Mission style bungalows fossem feitos em estuque, que "se bem executado não deixaria nada a desejar quanto à durabilidade, cor e textura". Haveria inclusive diferentes maneiras de se aplicar o material, obtendo-se diferentes acabamentos "artísticos" nas paredes externas. (WILSON, 2006, p.98)

Vários materiais eram utilizados: shingles, madeira, pedras, o estuque e mesmo blocos de terracota feitos à máquina. "São ocos, assegurando calor no inverno e frescor no verão, e uma casa sempre seca e saudável." Produzidos em várias cores, não requeria pintura e seria mais barato que os tijolos. (WILSON, 2006, p. 67)

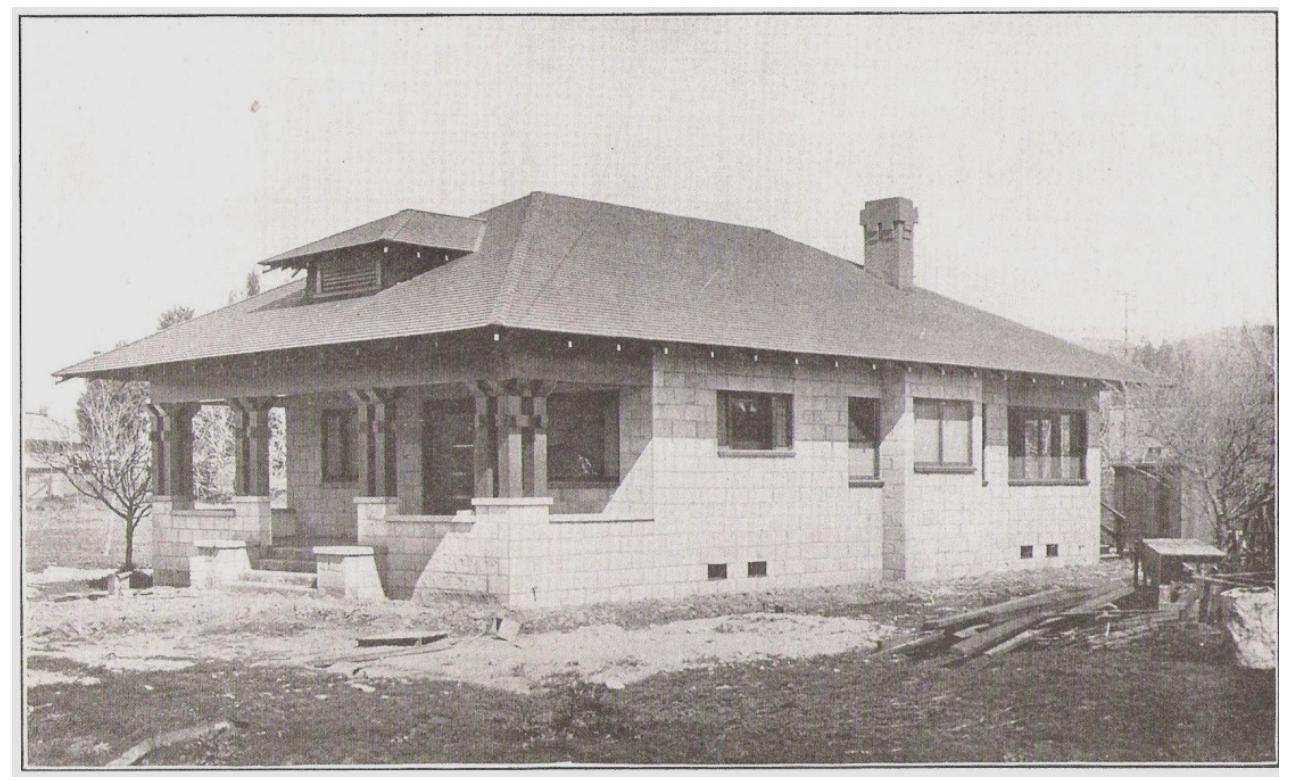

Fig. 2.26 Bangalô construído com blocos de terracota feitos à máquina. 
No livro de Wilson havia mesmo um "Colonial cottage", "sem as características externas do bangalô" (WILSON, 2002, p. 36), o que confirma o fato deste tipo de habitação não constituir-se em um "estilo", com determinados estilemas ${ }^{24}$ a serem copiados, mas tratava-se de uma maneira de morar, que teria diferentes conformações externas, de acordo com o local a ser construído, procurando inspiração na arquitetura vernácula ali encontrada, ou em apenas uma tradição criada, um passado reinventado. O que sempre estava presente eram as exigências de conforto e de adequação ao morador e ao entorno. Definitivamente, uma maneira moderna de se viver no início do século XX.
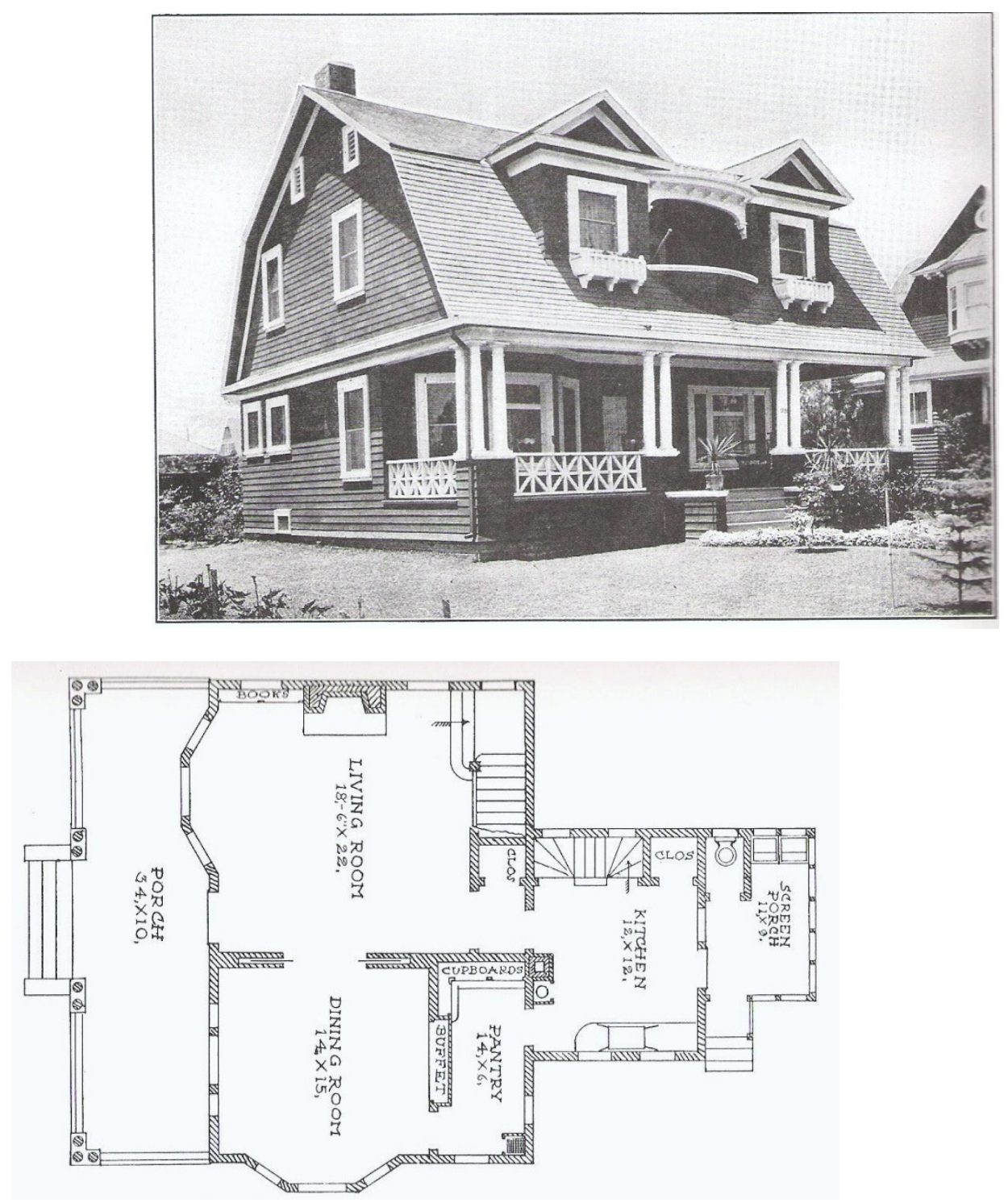

\footnotetext{
${ }^{24}$ Estilema é uma palavra usada para designar as partes constitutivas de um estilo, as características imprescindíveis para sua exata classificação. Sem um mínimo de estilemas, a obra assume uma nova configuração, às vezes migrando para outro estilo que não aquele desejado. Em certos casos, estilemas de diversos estilos se fundem, impossibilitando a classificação, dando origem ao que se chama de eclético propriamente dito. (ATIQUE, 2007, p. 298)
} 
Fig. 2.27 Um "Colonial cottage" e sua planta, onde estar, jantar e varanda se convertem em um grande espaço para a reunião da família. Na sala de jantar, a utilização de portas de correr, que se recolhem dentro das paredes.

A inspiração inglesa, sempre presente, é vista em um bangalô chamado "Los Anglicized". A estrutura em madeira aparente ${ }^{25}$ nos frontões e as bay-windows confirmam a influência da arquitetura inglesa. (WILSON, 2006, p. 86)

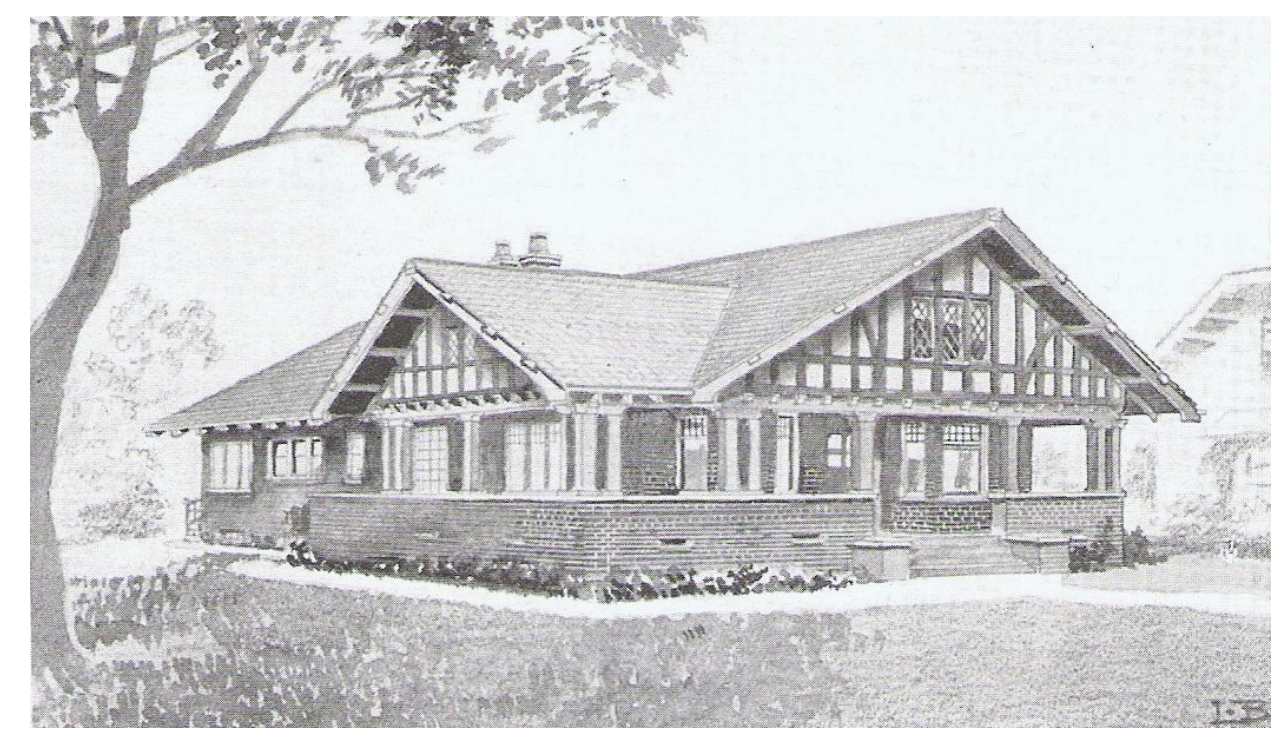

Fig. 2.28 Bangalô "Los Anglicized"-características inglesas e americanas.

Grandes transformações ocorreram, não apenas com o bangalô, mas com a casa de classe média americana em geral, no período 1873-1913.

(...) de um exuberante e personalizado desfile de formas irregulares, contrastes pinturescos e variedade de ornamentos, supostamente simbolizando a singularidade da família, a uma residência contida e simples, com interesse focado na cozinha cientificamente planejada. ${ }^{26}$

Houve dezenas de livros de bangalôs publicados nas duas primeiras décadas do século. Artigos sobre o assunto proliferavam, não apenas nos periódicos dedicados à construção e à arquitetura, mas também nas novas revistas dedicadas a casa, como House and Garden, House Beautiful, Ladie's Home Journal ou Keith's Beautilful Homes Magazine.

\footnotetext{
${ }^{25}$ Half timber

${ }^{26}$ WRIGHT, Gwen W. Moralism and the Model Home. Domestic Architecture and Culture Conflict in Chicago, 1873-1913 Chicago: University of Chicago Press, p.3 apud KING, 1995, p. 143.
} 
Enquanto alguns arquitetos não gostariam de ser conhecidos como arquitetos de bangalôs, outros ali enxergavam uma oportunidade de trabalho e de sustento. $O$ próprio Wilson anunciava ao final de seu livro que ele não se limitava à venda das plantas apresentadas, "estava preparado para incorporar suas idéias (do cliente) em um trabalho especial." (WILSON, 2006, p. 158) Apenas era necessário que fosse informado o local onde seria construída a casa e o programa, com número de cômodos e a forma de organizá-los. Estudos preliminares seriam enviados para possíveis alterações e a finalização dos desenhos dependeria da aprovação destes estudos pelo cliente. O preço era de cinco dólares por cômodo para uma casa que não custasse mais que cinco mil dólares. Banheiros, varandas, closets e halls não seriam contados como cômodos.

Para cada casa Arts and Crafts projetada por uma firma de arquitetura que fazia projetos diversos como edifícios comerciais e institucionais, havia milhares de casas da autoria de arquitetos cuja clientela principal era a classe média procurando residências unifamiliares em novos bairros das cidades. (KREISMAN e MASON, 2007, p. 156)

Como moradia mais popular, especialmente criada para os subúrbios, o bangalô estabeleceu-se na América uma geração antes da Inglaterra. Neste caso, foi feito o caminho inverso. No processo de difusão, o Building News colaborou: em maio de 1912, o periódico inglês publicava um entusiasmado relato sobre o bangalô americano sugerindo as razões para seu sucesso:

Para os habitantes do centro da cidade ou dos subúrbios ao seu redor, nos quais as habitações de três ou mais pavimentos, encostadas umas às outras, parecem ser predominantes, as delícias do bangalô, existente em lugares agradáveis nos EUA, particularmente em um paraíso como Pasadena, parecem um sonho. Para aqueles que amam a vida simples, com conforto sem formalidades, onde vaidades e futilidades não têm lugar, não existe habitação tão apropriada e tranqüila quanto o bangalô, térreo, amplo e bem planejado. (apud KING, 1995, p. 145).

Baixo e espaçoso, simples para ser construído e a um baixo custo, o bangalô térreo apresentava grandes beirais, varandas e pedras não aparelhadas para fundações e chaminés. E a principal característica: deveria haver o mínimo de distinção entre o exterior e o interior.

(...) o bangalô, se desenhado de maneira apropriada, combina graça, beleza e conforto a um custo mínimo. Em seu desenho, como foi 
colocado neste livro, o problema da organização e manutenção da casa é reduzido quase a uma ciência exata. (...) No bangalô, existe a possibilidade de se combinar economia nos custos com a beleza artística em um grau quase ilimitado. (...) uma característica notável de todos os meus projetos é a quase simétrica relação entre exteriores e interiores, combinando linhas elegantes com um interior conveniente e confortável. Penso ser um erro adotar uma planta e então empenhar-se em desenhar um exterior que se adapte a ela. (...) Devem ser feitas concessões, e tanto detalhes internos quanto externos devem ser modificados para se conseguir aquela atmosfera de aconchegante elegância tão admirada em todos os meus projetos. (WILSON, 2006, p.3-4)

O bangalô californiano era feito em madeira, pintada em verde, marrom ou cinza. Internamente, uma das características mais marcantes era a planta aberta. A sala de estar, ligada por um arco à sala de jantar torna-se o centro da vida familiar. "Se a sala de estar informal não se originou com o bangalô, ali ao menos desenvolveu todo seu potencial,(...) tornou-se o núcleo, o coração da casa, ordenando sua pulsação e o fluxo de vida que a animava.(...) O estar normalmente se abria para a varanda ou terraço, para onde suas funções eram transferidas quando o tempo permitia" . (LANCASTER, 1985, p. 241)

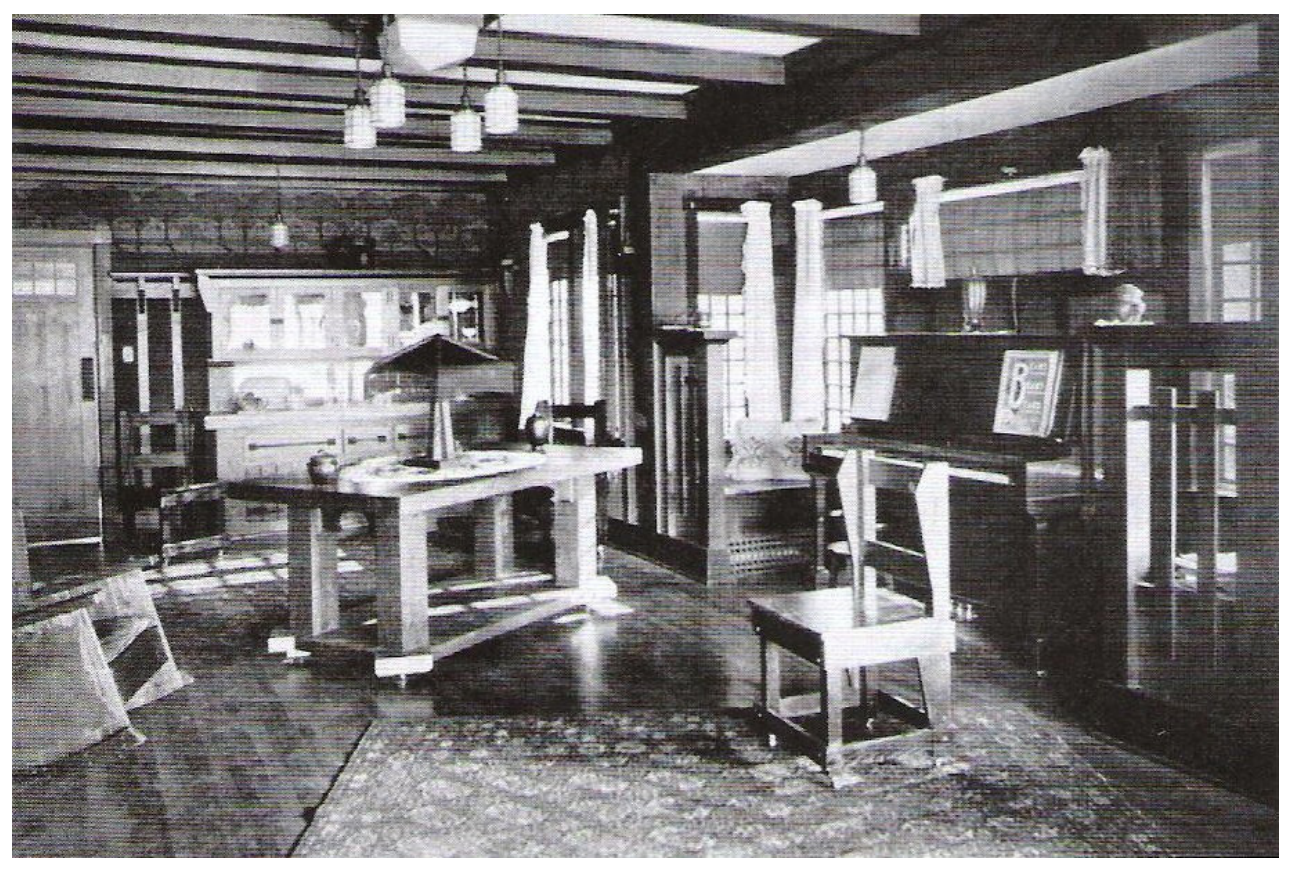

Fig. 2.290 interior de um bangalô, um verdadeiro ambiente Arts and Crafts, assemelhando-se aos cottages de Barry Parker (1912). 
A mobília embutida torna-se uma opção a cada dia mais procurada. A casa poderia ser equipada com prateleiras, aparadores, bancos, mesas e camas dobráveis, que poderiam ser guardadas quando não estivessem em uso, permitindo um melhor aproveitamento do espaço. Outras peças embutidas, como estantes, bancos para lareira, armários de cozinha eliminavam a necessidade de móveis caros. 0 acabamento da madeira era rústico, resistente ao uso e dando boas vindas às crianças. (LANCASTER, 1985, p. 220) A facilidade de limpeza também era outro atrativo para as donas de casa. Porém o que é visto muitas vezes nas fotos são interiores repletos de objetos decorativos ou revestimentos de gosto duvidoso, como a lareira mostrada.
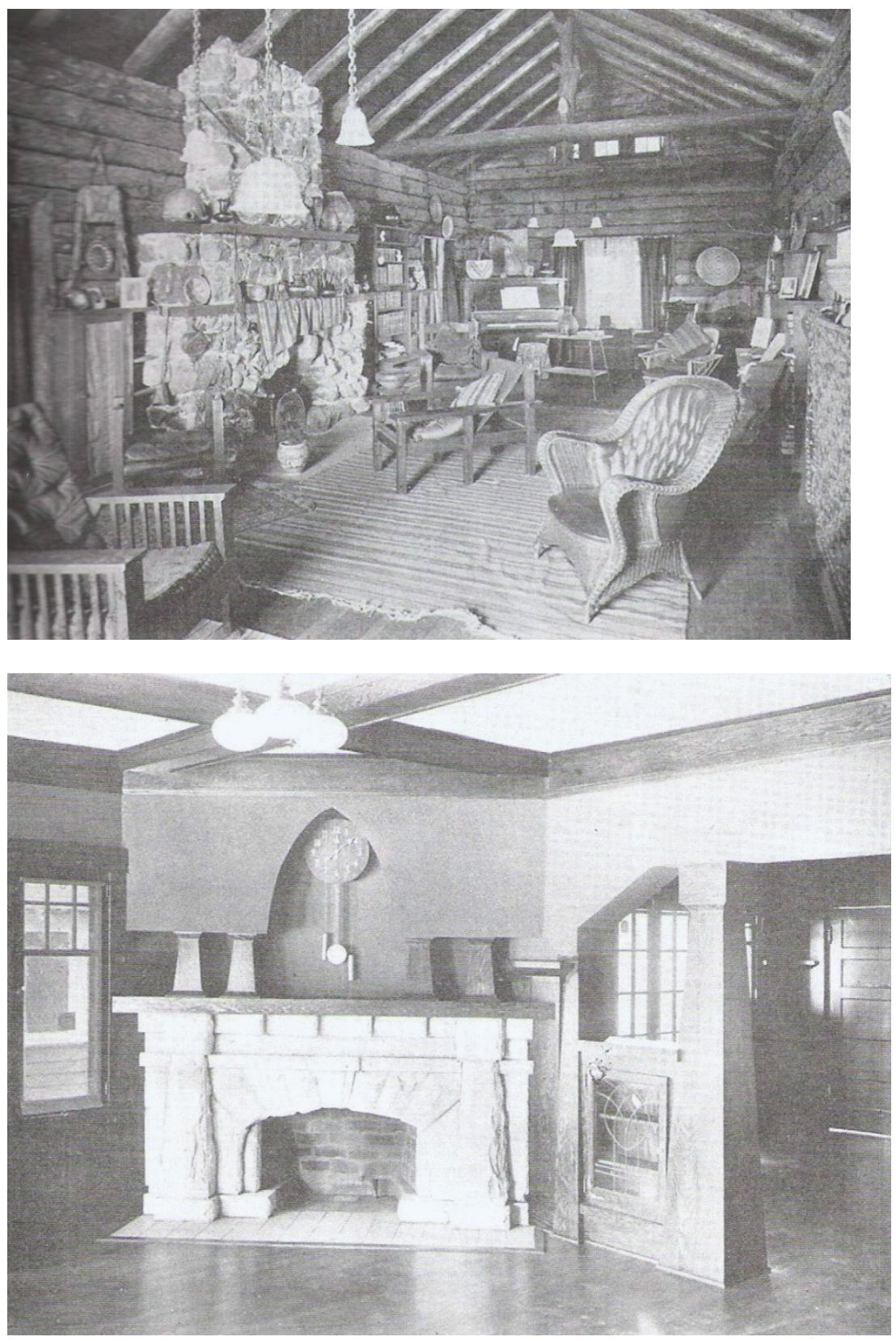

Fig. 2.30 Interiores de bangalôs 
A lareira era outro atributo fundamental, revestida com cerâmicas decorativas e apresentando cornijas onde eram colocadas peças em cerâmica ou vidro e cestos indígenas. Ou ainda feita com pedras ou tijolos, a importância da lareira correspondia ao papel que o Arts and Crafts havia atribuído ao ambiente em torno dela, de coração do lar.

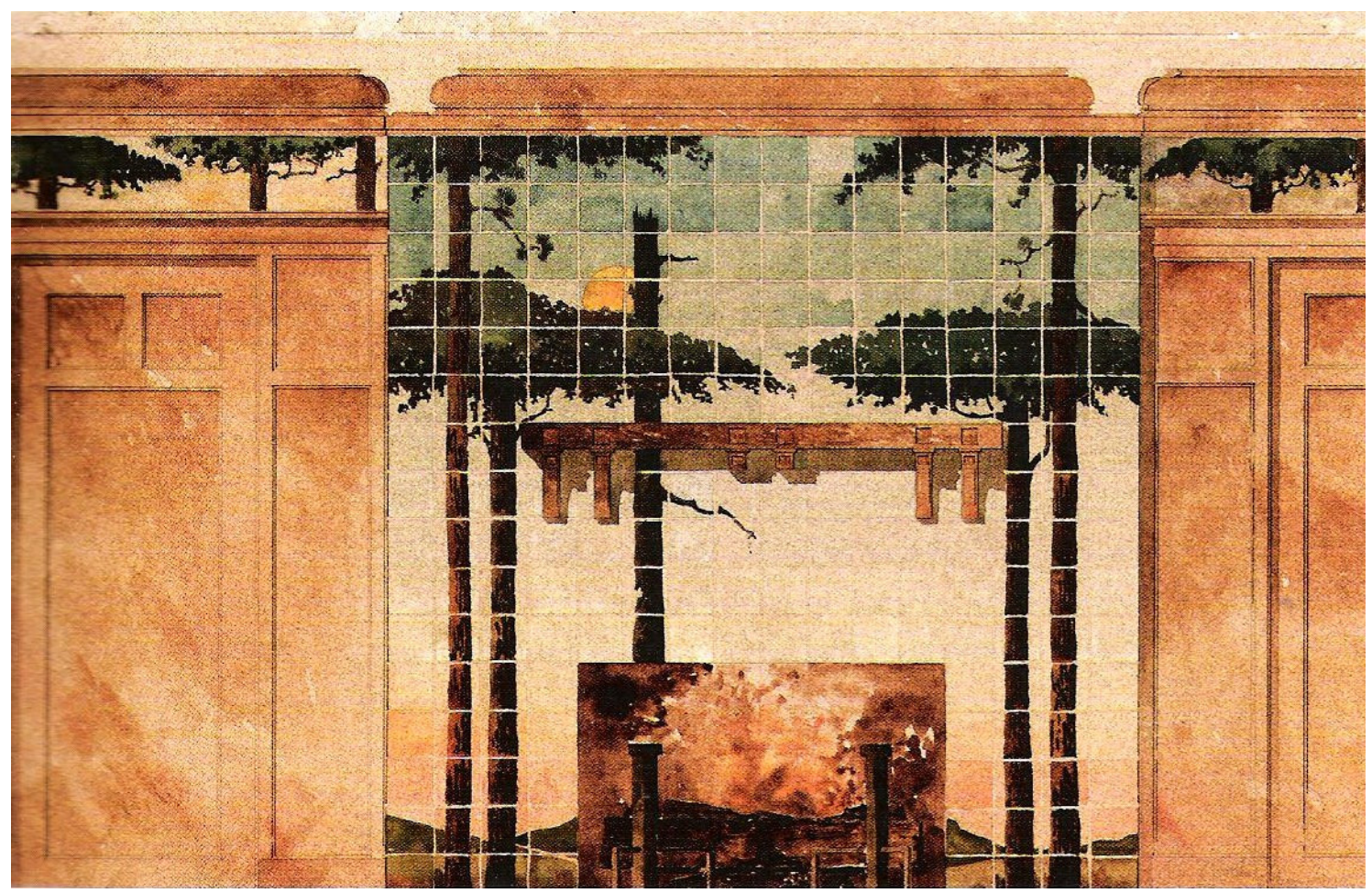

Fig. 2.31 Cerâmica pintada (1910)

E uma cozinha cheia de dispositivos que poupavam trabalho. Ali ocorreu a maior racionalização do espaço. Não havia mais empregados. Não se tratava apenas de falta de mão-de-obra, mas da rejeição da presença da relação patrão-empregado na casa. (KING, 1995, p. 146).

Estou inclinado a pensar que toda dona de casa que planeja uma casa começa pela cozinha, e estou ainda mais tentado a achar que ela esteja certa. É o cômodo mais importante, e deveria ser feito o mais agradável e prático possível. Poupar movimentos significa economia de energia e saúde, e assim promove o bem estar de toda a família. (...) Aqui, também, os lambris pintados ou laqueados são importantes do ponto de vista do saneamento, já que são facilmente laváveis e não absorvem poeira. (WILSON, 2006, p. 4) 
Um menor número de horas passadas na cozinha, pela dona de casa de poucos recursos, assegura tempo livre para o aprimoramento da própria cultura e para o auxílio aos outros, na biblioteca, na sala de música, no quarto das crianças. (WILSON, 2006, p. 140)

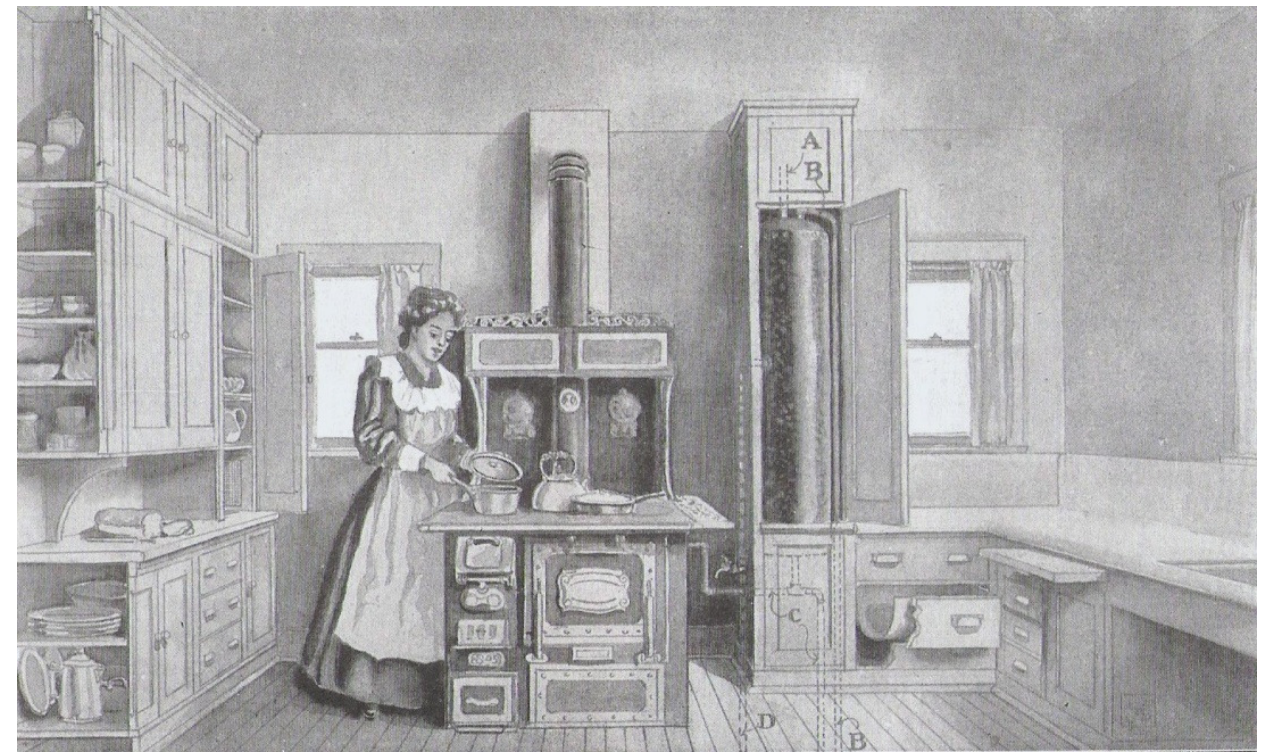

Fig. 2.32 A cozinha "Wilson".

Mais tarde, a eletricidade influenciaria o desenho da cozinha, através dos eletrodomésticos: fogão, forno, cafeteira, geladeira, máquinas de lavar. O telefone, permitindo comunicação rápida com as lojas, torna o espaço de armazenamento menos necessário.
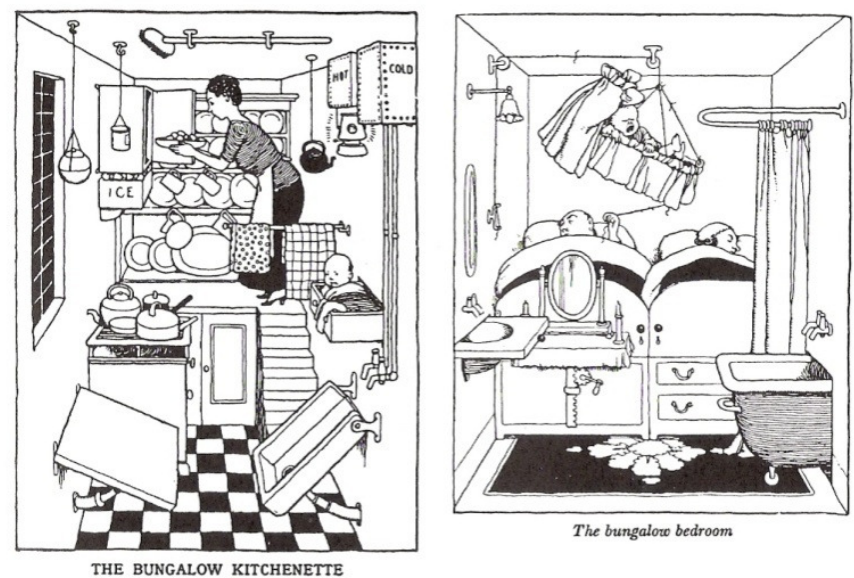

Fig. 2.33 e Fig.2.34 Redução de espaço: o "bangalô compacto" (1936) 

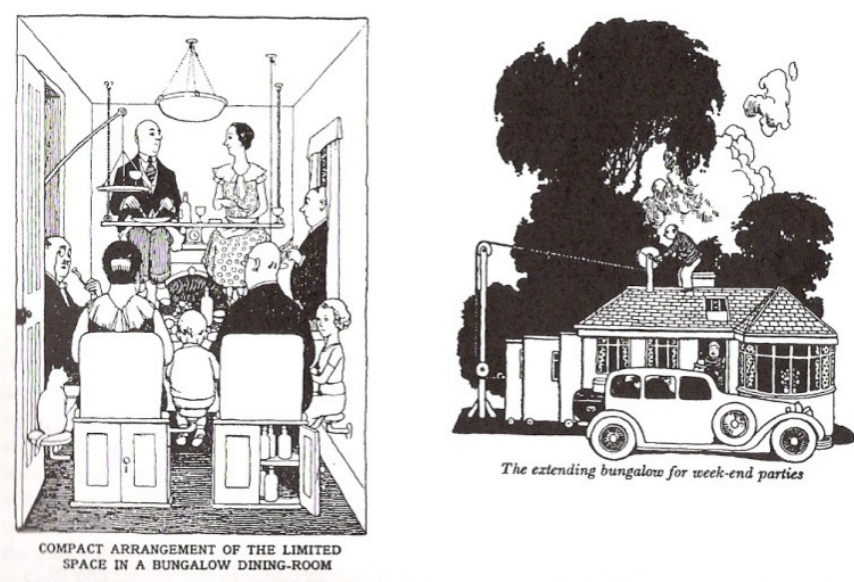

Desde o final do século XIX, várias atividades começaram a ser executadas fora da casa, como o pão, e a preparação de vários tipos de alimentos, com o aparecimento dos enlatados. Roupas prontas e lavanderias dispensavam a casa de outras tarefas. Tudo isto leva a uma mudança para casas menores, mais eficientes e mais simples de serem mantidas.

\subsection{Uma nova forma de vida}

O subúrbio torna-se a realização do sonho americano, um estilo de vida da classe média, centrado na família nuclear. E o bangalô era seu tipo de habitação. Apesar de não ter uma aparência uniforme, ele é considerado uma unidade, uma forma de habitação informal, simples e individual.

Introduzido como um fenômeno de massa, o bangalô baseou-se em uma imagem burguesa do mundo - um ambiente separado, privatizado. Como parte da reação à cidade, houve a mudança para casas unifamiliares, predominantemente térreas, no subúrbio (...) é o que o bangalô representa nos países ricos, industrializados, capitalistas do 'Norte'. Simultaneamente, no assim chamado mundo em desenvolvimento do 'Sul', na Ásia, África e América Latina, a introdução do 'moderno' bangalô resultou da penetração nestes países da economia de mercado e de gostos, estilos e padrões de vida 'ocidentais' ou 'burgueses'. A forma moderna de se morar, da qual o 'bangalô europeu' foi uma forma preliminar e os subúrbios, o 
cenário, com o consumo de bens em uma economia em expansão, contrasta com o ambiente tradicional que gradualmente substitui. (KING, 1995, p. 260)

Para se entender estes estilos de vida, esta domesticidade que se impõe, é necessário compreender a emergência de uma economia e uma cultura globalizadas. Com a expansão da indústria e da revolução tecnológica, particularmente nos meio de transporte, as cidades tornam-se muito semelhantes. Cidades onde as elites locais concentram-se em áreas residenciais afastadas e reproduzem nos países em desenvolvimento a estrutura urbana e o estilo de morar dos países desenvolvidos.

As principais condições para a criação desta cultura urbana já surgiam nas três décadas anteriores a 1914. Por todo o mundo, as novas tecnologias estavam sendo introduzidas. Idéias sobre sanitarismo, habitação, planejamento e saúde circulavam. Uma nova cultura, que se expressava não apenas em termos econômicos, sociais e políticos, mas também espaciais, deixando sua marca nas cidades e na maneira de viver de seus habitantes. 


\section{CAPÍTULO 3}

\section{A MODERNIZAÇÃO DE SÃO PAULO NO INÍCIO DO SÉCULO XX E A PROFISSIONALIZAÇÃO DOS ARQUITETOS.}

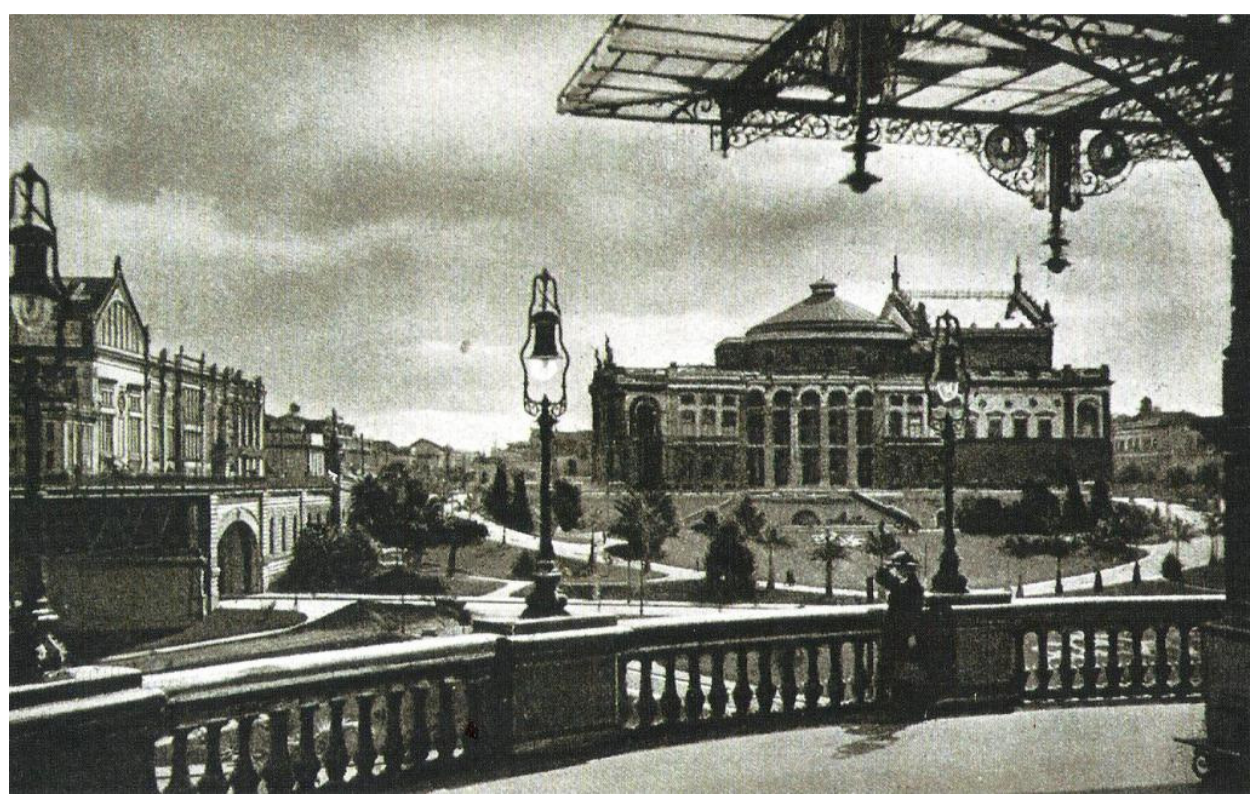

Fig.3. 1 Vista do Anhangabaú reurbanizado, tendo ao fundo o Teatro Municipal.

\subsection{A Modernização na América Latina}

A partir de 1880, muitas cidades latino-americanas sofreram grandes transformações: econômicas, sociais, na paisagem urbana e na forma de pensar.

Haviam se estreitado os laços entre a economia latino-americana e os grandes países industrializados. Nesta época, colocar a América latina sob sua influência era uma das metas dos centros de poder. Porém é necessário esclarecer que a dependência consistia em uma correspondência entre os interesses das elites locais e as necessidades dos grupos estrangeiros, não uma situação de antagonismo ou dominação. Não implicava em uma atitude passiva por parte da sociedade dependente, mas sim uma aceitação consciente. ${ }^{27}$

\footnotetext{
${ }^{27}$ Sobre a noção de dependência ver ALMANDOZ, 2002, p. 23-4.
} 
O comércio internacional de produtos agrícolas levara a uma extrema especialização e até mesmo à monocultura nas regiões exportadoras.

A especialização acontecia em uma escala global: alguns países tornaram-se fornecedores de produtos agrícolas e matérias primas, permanecendo predominantemente rurais, enquanto outros se tornaram industriais e urbanos.

Multiplicavam-se as demandas do mercado internacional e assim multiplicavam-se também os negócios. Novos sistemas de produção e infra-estrutura tornavam-se necessários nas regiões provedoras de matérias primas. Novos mercados eram necessários para os produtos das indústrias que se sofisticavam a partir da década de 1880.

Investimentos estrangeiros, principalmente britânicos, deveriam prover a infraestrutura administrativa e econômica para a exportação. No investimento em capital e tecnologia - principalmente maquinário para mineração, máquinas a vapor e ferrovias - o papel da Inglaterra foi predominante de 1850 a 1900, depois, a hegemonia passaria aos Estados Unidos.

A antiga estrutura demográfica não se alterou apenas quantitativamente, mas também qualitativamente. Novas possibilidades de ascensão social, das quais o 'novo-rico' e o pequeno comerciante próspero são exemplos. O fenômeno social mais marcante e significativo destas cidades foi o crescimento e transformação das classes médias. Ocorreu mesmo a passagem das classes populares para as classes médias. Certa mobilidade, inexistente até então. Foi na classe média que se operou a renovação das formas de vida nas cidades: elas liam jornais, movimentavam o comércio, e formaram as fileiras dos novos partidos políticos.

Os membros das novas burguesias, principalmente nas capitais, passaram a controlar ao mesmo tempo o mundo dos negócios e o da política. O poder político era exercido indiretamente muitas vezes. As leis e os decretos eram estudados e redigidos pelos mesmos grupos que delas tirariam proveito. Em São Paulo, ainda bem mais tarde, no final da década de 1910, isto se torna claro, quando a Companhia City irá sugerir alterações nas leis e fornecer parâmetros para o zoneamento municipal.

Isto demonstra a coesão interna que tais burguesias alcançavam. Coesão que correspondia a uma resposta ao projeto proposto pela conjuntura econômica internacional. Constituía-se em uma classe sem vínculos internos, diferentemente do antigo patriarcado. 


\subsection{A Modernização ${ }^{28}$ de São Paulo}

Vários fatores sócio-econômicos, que já se estabeleciam desde o último quartel do século XIX, contribuíram para o rápido crescimento e modernização de São Paulo. Entre estes, o fato da vasta rede de estradas de ferro do estado e de outras regiões se articularem na cidade, para partir em direção a Santos, que escoava a produção de café. Este foi o primeiro porto moderno do Brasil, construído na última década do século XIX

O processo de modernização em São Paulo envolveu inovações, como um novo Código de Posturas (1875) com as alterações determinadas pela Resolução n.134 de 1886. Já estabelecia, por exemplo, que as novas ruas teriam a largura de dezesseis metros e dez centímetros. Para as ruas já existentes, foram elaborados planos de alinhamento nos novos edifícios. Além dos aspectos relativos à construção da cidade, definia a maneira dos cidadãos se comportarem nos espaços públicos. Tratava também de questões relativas à higiene e salubridade pública, como plantio de árvores, combate a moléstias contagiosas, polícia sanitária, cemitérios e diversas outras normas sobre a segurança e a moral públicas. ${ }^{29}$

Em 1893, estabelece-se a necessidade de aprovação legal pelo município das plantas de novas edificações, que passam a ser regulamentadas em 1894 pelo decreto estadual 235 que criava o Código Sanitário. ${ }^{30}$

Em 1896, criou-se uma comissão técnica na intendência de obras municipais a qual cabia: "(...) a organização do plano ou projeto geral da cidade, fazendo para esse fim os serviços necessários e confeccionando os planos técnicos gerais, parciais e detalhes para o conjunto das obras ou edificações a executar, para retificações, melhoramentos, embelezamentos e tudo o que (fosse) necessário para que a cidade (fosse) colocada em condições estéticas e confortáveis." ${ }^{31}$

\footnotetext{
${ }^{28}$ O termo 'modernização' aplica-se às vezes a casos nos quais a urbanização ocorre apenas com uma leve industrialização, isto é, nos quais os estímulos do mundo industrial exterior provocam mudanças no estilo de vida e nos níveis de aspiração, sem provocar mudanças estruturais no sistema econômico. (MORSE, 1970, p. 391). Foi o que ocorreu em São Paulo.

${ }^{29}$ Sobre o Código de Posturas do município de São Paulo, ver BARBUY, 2006, p. 44 e ANDRADE, 1998, p. 145-6.

${ }^{30}$ Sobre esta nova legislação, ver WOLFF, 2000, p.59 a 62.

${ }^{31}$ Lei n.264/1896, art.1ํ. apud BARBUY, 2006, p.44.
} 
Para a garantia da modernização da cidade, eram proibidas reformas que contribuíssem para o aumento da vida útil do edifício condenando-se assim as velhas construções em taipa.

Desta época -1875 - é também a iluminação e pavimentação de ruas e a instalação de um serviço de bondes movidos a cavalo.

A Avenida Paulista é aberta em 1891. No ano seguinte, a inauguração do Viaduto do Chá seria um marco na história da cidade e um incentivo à subdivisão em lotes das chácaras situadas nas colinas além do triângulo.

Em 1885, a população de São Paulo já atingira 47.000 habitantes. Nesta época, as famílias dos fazendeiros de café se estabelecem na cidade. Ainda no início da gestão do prefeito António Prado é inaugurado o bonde elétrico ${ }^{32}$.

O conselheiro Prado, além das reformas que executou na cidade, assumia uma atitude pedagógica de freqüentar, só ou com sua família, os mais variados espaços públicos, mostrando a nova sociabilidade possível nesta cidade remodelada e modernizada, como fruí-la com elegância. O prestígio de sua figura era notável. (SEVCENKO, 1992, p. 121)

"Como se sabe, espaço público é uma categoria que carrega uma ambigüidade radical: designa lugares materiais e remete a esferas da ação humana no mesmo conceito; fala da forma e fala da política, de um modo análogo ao da palavra polis." (GORELIK, 1998, p. 19). Implícita na forma destes espaços públicos está esta nova forma de sociabilidade.

Porém, naturalmente, o Conselheiro Prado não era uma unanimidade. Havia divergências sobre sua atuação frente à prefeitura da capital, como mostra este artigo publicado no jornal operário A Terra Livre ${ }^{33}$ (13/06/1906 apud ANDRADE, 1998, p. 149-50), comentando a greve nas linhas da Paulista, que ocorrera entre 15 e 30 de maio, encerrada com extrema violência pela polícia, mandada pelo prefeito. "O presidente da Companhia é o velho áulico da monarquia, conselheiro Antônio Prado, (...) é prefeito da Paulicéia, deu o seu nome ao largo mais central que ele ... perdão! Os pedreiros e engenheiros transformaram, e tem fama entre a alta casta e os engrossadores da imprensa, só porque, no seu reinado, tendo São Paulo absoluta

\footnotetext{
${ }^{32}$ Com grande espírito modernizador, Prado, foi fazendeiro de café e político. A importância de suas três gestões consecutivas (1898-1910) está principalmente na profunda alteração da fisionomia da cidade que suas obras e melhoramentos provocaram. Remodelou a cidade através da abertura de avenidas, sendo ainda serviços seus as concessões de luz, força e viação e o Teatro Municipal. A respeito da atuação de Antônio Prado como prefeito de São Paulo ver: ANDRADE, 1998, p.147-150.

${ }^{33}$ Publicado 13/06/1906 apud ANDRADE, 1998, p. 149-50 apud CARONE, Edgard Movimento Operário no Brasil (1877-1904). São Paulo e Rio de Janeiro: DIFEL, 1979, p. 93.
} 
necessidade de atrair gente e capitais, de se embelezar, os vereadores decretaram e os contribuintes pagaram os melhoramentos realizados em certos bairros felizes, e ainda porque prestou mão-forte a certas empresas, como a Light, que pode e manda nesta terra." O entendimento dos operários quanto ao fato dos bairros "felizes" receberem recursos em detrimento dos bairros operários é claro.

O final da década, com a proclamação da República em 1889, marcara o início de uma nova era com novas perspectivas. Depois de 1890, o ritmo das transformações no país se acelerou para o estabelecimento de uma economia industrial, um estado secularizado e uma flexibilidade maior na estrutura social. (GRAHAM, 1973, p. 31).

Em São Paulo, por volta de 1902, começam a se intensificar as demolições e construções de prédios novos e não mais apenas reformas, já que neste ano começaria a diminuir a crise causada pela superprodução de café em 1898 e pela política deflacionária de Campos Salles. A presença de arquitetos e engenheiros como autores de projetos é cada vez mais constante. Aos poucos, os velhos armazéns de secos e molhados, as lojas de panos de algodão e as hospedarias rústicas dão lugar às importadoras, às casas de modas e aos hotéis sofisticados.

Todas as semanas, navios descarregavam artigos europeus em Santos, grande parte para a cidade de São Paulo. O consumo era parte importante desta forma de vida moderna. Um símbolo desta nova era do comércio é a vitrine, convidativa, mostrando as novidades. Tudo anunciado pelos jornais e pelas novas revistas, que nesta época já apresentavam fotografias impressas, e por letreiros luminosos.

Para uma sociedade em transformação era necessário um novo habitat: as cidades deveriam ser reformadas seguindo o modelo das grandes cidades européias, remodeladas no final do século XIX e início do XX.

A obtenção de uma linguagem que dê forma às esperanças de progresso material. "Uma linguagem ideológica que consolide o poder desta nova burguesia com as imagens da representação de seu próprio poder. Na medida em que este processo é de reestruturação física, mas também social, o resultado será a expressão de uma vontade hegemônica. (...) a exemplificação do poder através da hierarquia do espaço, da modificação arquitetônica dos lugares emergentes como núcleos de articulação da nova ordem." (RUBIÓ, 1980, p. 22)

As novas burguesias almejavam um estilo de vida que expressasse de modo inequívoco sua condição de classe superior, através da exibição de sua riqueza e de um comportamento sofisticadamente ostensivo. Pessoas, de diferentes nações, formando uma comunidade internacional com valores, crenças e idéias análogas, com 
modelos de consumo e de comportamento semelhantes. Com formas de vida similares.

\subsection{A cidade moderna}

Desde a última década do século, aparecem inúmeros projetos para a cidade, como o do Engenheiro José Antônio Fonseca Rodrigues de 1893 propondo a regularização do Rio Tietê e, em fins do século, um projeto de um sistema de transportes à tração elétrica para o conjunto da cidade, do Eng. Phelippe Gonçalvez. Apesar de não se constituírem em planos para a totalidade da cidade são tentativas de apresentação de uma nova imagem para São Paulo.

Nesta época, enormes áreas de terreno eram ainda compradas por preço baixo ou simplesmente tomadas pela grilagem. As áreas - com ruas dispostas segundo "tabuleiro de xadrez", sem qualquer relação com a topografia, como Ipiranga, Perdizes, Vilas Cerqueira César, Gomes Cardim, e outras - eram divididas no maior número possível de lotes e vendidas. Os lotes, vagos ou com uma casa semi construída eram abandonados, à espera da valorização. Quando vendidos, grande parte destes terrenos ainda estava sem infra-estrutura e sem ligação adequada com o restante da cidade.

"Um dos mais expressivos aspectos do desenvolvimento foi a ocupação progressiva do maciço pela alta burguesia; avanço que começou em 1890 através de Higienópolis ${ }^{34}$ até a Avenida Paulista no espigão, para prosseguir depois pelas vertentes a sudoeste até os 'Jardins'.

Este movimento corresponde à ascensão de uma elite imigrante, industrial e comercial, destituída de tradições, fato que se reflete na transição das moradias de tipo fazenda dos barões do café, para a miscelânea ostentosa de estilos - clássico, florentino, inglês, oriental, neocolonial, etc. - da Avenida Paulista. "Ilustra também como o ideal de uma classe de lazer tranqüila, culta, afrancesada, implícito no nome 'Campos Elíseos', cedia o lugar à imagem anglo-saxônica de uma plutocracia dinâmica, trabalhadora, endinheirada, dedicada ao lar, e dada aos esportes e ao

\footnotetext{
${ }^{34}$ Data de 1893 , a criação do primeiro cottage square paulistano, o bairro de Higienópolis.
} 
confôrto - imagem popularizada pelo urbanismo de Barry Parker". (MORSE, 1970, p. 357)

Os problemas que a capital apresentava eram muitos, entre eles o abastecimento de água - dificultado pela topografia de vales e espigões -, que nunca foi suficiente para a população. Em apenas dois anos (1892-94), o fornecimento de água diário passou de 6.000.000 para 27.000.000 litros. Mas, durante o decênio seguinte, constatou-se que os diâmetros dos canos eram inadequados e que o sistema era todo dividido, não levando em conta as diferenças de nível da cidade. Além disso, os condutores eram colocados próximos aos canos de esgotos, a água não só mudava de cor, como se contaminava com o tifo.

Em 1907, o vereador Augusto da Silva Telles publica "Melhoramentos de São Paulo", onde elogia as obras realizadas por Antônio Prado, porém critica a falta de um plano de conjunto, que permitia a abertura de ruas em pontos pitorescos da cidade, apenas para a valorização de terrenos particulares. Ele pede ainda que o centro seja desafogado, que seja criada uma Avenida Central, construídas vilas operárias e o Parque da Várzea do Carmo, para atender aos operários do Brás.

Entre 1911 e 1913, São Paulo discutia seu mais importante projeto urbano: o Vale do Anhangabaú, próximo ao Teatro Municipal.

Comentando a visita do engenheiro-chefe de Reims, cidade francesa, a São Paulo, Victor da Silva Freire, o diretor de Obras da Prefeitura paulistana ${ }^{35}$ diz: "isso não o impediu de ficar extasiado ao visitar o nosso Theatro, diante do espetáculo natural que tão levianamente se quer hoje destruir por completo" ${ }^{\text {"36, }}$, referindo-se ao Vale do Anhangabaú. "Buenos Aires entregou o seu problema a Bouvard (...). Será vergonha de irmos aprender com os que melhor conhecem o terreno?" ${ }^{37}$

O urbanista francês Joseph Antoine Bouvard, que fora diretor do Serviço de Arquitetura, Passeios e Plantações da Cidade de Paris, e que era plenamente reconhecido nos meio profissionais, é então chamado para arbitrar as discussões que envolviam três projetos para a área. Ele propõe grandes parques, jardins, lugares para

\footnotetext{
${ }^{35}$ Na gestão Antônio Prado, Freire foi convidado para trabalhar como engenheiro-chefe da Prefeitura pelo conselheiro, um mês após este tomar posse. Permaneceria na Prefeitura paulistana até janeiro de 1926, quando se aposentou, sendo que de 1899 a 1924 foi seu diretor de Obras Públicas. (ANDRADE, 1998, p. 147).

${ }^{36}$ FREIRE, Victor da Silva, "Melhoramentos de São Paulo", conferência do então professor, no Grêmio Politécnico, 15 de fevereiro de 1911, publicada na Revista Polytechnica, n³3, VI volume, fevereiromarço de 1911, páginas 91-145, p. 125.

37 Na mesma conferência, Freire comenta que Bouvard se encontra em Buenos Aires.
} 
se visitar "ilhas de saúde e bem-estar, necessárias tanto para a saúde física quanto para a saúde moral do publico". (TOLEDO, 1989, p.23 apud PEREIRA, 2002, p.93).

Victor da Silva Freire assume então a direção das obras e desenvolve um quarto projeto, incorporando as propostas de Bouvard sem, no entanto, abandonar totalmente a primeira versão, que era da Diretoria de Obras. ${ }^{38} \mathrm{Em}$ sua proposta, Freire articulará em um único plano geral, os melhoramentos a serem implantados na área central que tinha seu eixo deslocado para o Anhangabaú, dirigindo-se a expansão da cidade para oeste, ultrapassando os limites históricos do Triângulo. (ANDRADE, 1998, p. 156).

Victor da Silva Freire, referindo-se à importância das áreas verdes, comenta: "(os) 'systemas de parques', denominação technica já consagrada e que exprime para cada cidade, a forma por que ella satisfaz a necessidade da distribuição de ar puro, luz, repouso e recreio ao melhor das suas forças vivas, às suas crianças. E não é só. É a salubridade moral que se procura também obter." 39

Os higienistas acreditavam na influência terapêutica da circulação do ar: o movimento se opõe à estagnação, elimina os miasmas

Em seu Relatório de 1918, o prefeito Washington Luís informa que haviam sido construídos "muitos parques e jardins na cidade, assegurando a conservação dos espaços livres, aumentando a capacidade de seus pulmões, na frase já consagrada, para melhor oxigenação da vida e garantia da saúde pública, procurando-se com a realização dessas obras úteis, que fossem elas formosas." 40 Obras como o Parque do Anhangabaú, de Bouvard, o Parque da Avenida Paulista, remodelado pelo arquiteto Barry Parker, o Parque da Várzea do Carmo e a conclusão da Praça Buenos Aires.

Mas, o relatório mostra também um quadro não tão promissor em relação às obras realizadas, devido à situação financeira. Além disto, 1918 fora um ano complicado para a cidade, com a ocorrência de greves de operários - por aumento de salários e redução das horas de trabalho - e epidemias - a gripe. Apesar disto, no período 19141918, em que Washington Luís fora prefeito de São Paulo, mais de um terço da

\footnotetext{
${ }^{38}$ O primeiro projeto era de Alexandre Albuquerque, o segundo era o da Diretoria de Obras e o terceiro da Secretaria da Agricultura do Estado, formulado pelo Engenheiro Samuel das Neves, todos elaborados entre o final de 1910 e início de 1911.

${ }^{39}$ FREIRE, Victor da Silva, conferência citada, publicada na Revista Polytechnica, n³3, p. 132.

40 Relatório de 1918, apresentado à Câmara Municipal de São Paulo pelo prefeito Washington Luís Pereira de Souza. São Paulo, Casa Vanorden, 2 v., 1919, v.1, p.XVII apud ANDRADE, 1998, p. 203-4.
} 
superfície pavimentada da cidade -2 milhões e trezentos mil metros quadrados de ruas e avenidas - fora executada. ${ }^{41}$.

No ano anterior já haviam acontecido várias greves, inclusive uma geral no mês de julho, que durara uma semana e envolvera o transporte, comércio e obras públicas além da distribuição de gás ${ }^{42}$.

Duas grandes companhias privadas de capital estrangeiro tiveram papel importantíssimo no processo de crescimento de São Paulo: a São Paulo Tramway Light and Power e a City of São Paulo Improvements and Freehold Land Company, o que demonstra a forte participação do capital privado no desenvolvimento de São Paulo. $^{43}$

A Light ${ }^{44}$ teve o monopólio de vários serviços públicos, tornando-se a companhia um "Estado dentro do Estado". ${ }^{45}$ O maior agente especulador que comprometeu o desenvolvimento da cidade, criando partes desconexas foi o monopólio do fornecimento de gás, eletricidade e transporte urbano, obtido pela Light and Power.

Por meio dos equipamentos domésticos, deu-se uma nova relação entre o espaço doméstico e o espaço urbano na cidade. A comercialização do gás para o consumo doméstico nos novos fogões, distribuído em redes, tornou a casa dependente de novos agentes para novas formas de abastecimento.

A Light tinha o poder de manipular a valorização do solo urbano, em associações com particulares, manobrando e especulando. (SEVCENKO, 1992, p. 122). Tais associações aconteciam com grande parcela da elite paulista, baseada na capital, que detinha o poder no estado. Atuava no setor imobiliário e possuía negócios relacionados à cultura cafeeira. A articulação política era feita em grande parte através do Partido Republicano Paulista.

\footnotetext{
${ }^{41}$ Op. cit, v.1, p.XIV.apud ANDRADE, 1998, p. 159.

$42 \mathrm{O}$ ano de 1919 foi particularmente comemorado na cidade de São Paulo: era o fim dos flagelos que haviam atingido São Paulo: os cinco Gês: A gripe espanhola, a geada e os gafanhotos, a Guerra e as greves. (SEVCENKO, 1992, p. 24)

${ }^{43}$ Sobre a participação da Companhia City e da Light no desenvolvimento de São Paulo, ver: ANDRADE, 1998, Cap. 2.1 e 2.2 .

${ }^{44}$ Sobre a Light, ver o artigo escrito por Victor da Silva Freire "O Futuro Regimen das Concessões Municipaes na Cidade de São Paulo", publicado na Revista Polytechnica, n60, $X^{\circ}$ volume, outubro de 1919 , p. 259-334, onde ele coloca que: "Graças à superioridade do seu jogo em relação ao meio, mercê do valor das suas cartas sobre o daquellas que a Prefeitura podia ter em mãos, conseguia a 'Light' ganhar a partida no momento em que se estabelecia em São Paulo (...) não sabermos, nem mesmo approximadamente, a que serviço, a que conforto e commodidades nos dão direito, os preços que lhes estamos pagando", nas páginas 314-315, referindo-se ao Contrato de 1899 para distribuição de energia e iluminação.

45 Eletropaulo, A cidade da Light 1899-1930. São Paulo: Superintendência de Comunicação/Depto do Patrimônio Histórico, 1990, 2 vols., p.13 apud PEREIRA, 2002, p.92.
} 
O transporte público era um grande problema, A cidade, circular tinha linhas radiais de trânsito, que era assim mal distribuído, fraco na periferia e excessivo no centro. (...) Ligações entre bairros de periferias inexistiam. Depois de 1926, aos bondes juntam-se os ônibus, mas as pequenas empresas proprietárias eram desorganizadas e não faziam manutenção adequada. (...). (MORSE, 1970, p. 371).

Houve alguns contatos entre as duas companhias, City e Light, em 1914. Tratava-se da extensão de linhas de bonde para as áreas que a City pretendia lotear. O negócio se concretizou em 1915 com a assinatura do contrato que previa um total de 15,2 km de novas linhas, com a Light recebendo 760 contos por ano.

Quanto à constituição da Companhia City, ${ }^{46}$ inicialmente Bouvard viera ao Brasil, como consultor de um banqueiro belga, Fontaine de Laveleye, interessado em negócios imobiliários no Paraná, em janeiro de 1911.

Em depoimento dado no início dos anos 1930, como testemunha em um processo envolvendo a Companhia City e a Sra. Laveleye, Victor da Silva Freire, então diretor da Escola Politécnica relata o episódio: "Antigo Diretor da Seção de Obras da Prefeitura desta Capital, o depoente teve ocasião, nessa qualidade, de se aproximar do engenheiro francês Sr. Bouvard, o qual em 1911, a convite da municipalidade desta capital veio a São Paulo examinar os planos de melhoramentos urbanos que, então, se debatiam. Permanecendo algumas semanas nesta capital, aquele engenheiro francês teve ocasião de examinar detidamente as condições de vida da cidade, convencendo-se de que seu desenvolvimento seria extraordinário. O Sr. Bouvard comunicou essa impressão, entre outras pessoas, ao Sr. Fontaine de Laveleye que, com ele, viera da Europa e que o havia levado ao Estado do Paraná para inspecionar empresa que ali explorava. Entusiasmado com as impressões do Sr. Bouvard o Sr. Fontaine de Laveleye perguntou a ele, depoente, se não conhecia, aqui, em São Paulo, alguém que dispusesse de grandes áreas de terreno para vender, pois desejava organizar uma companhia para explorar esse ramo de negócio. O depoente, amigo íntimo do Dr. Cincinato Braga, o qual, nessa ocasião, estava com outros amigos adquirindo grandes quantidades de terrenos nesta capital com o mesmo intuito manifestado pelo Sr. Laveleye, aproximou um do outro. Dessa aproximação resultava, meses depois, a criação de uma grande Companhia Imobiliária." ${ }^{47}$

\footnotetext{
${ }^{46}$ Sobre a constituição da Companhia City, ver ANDRADE, 1998, cap2, p.179 a 188.

47 BARRETO, Plínio Uma temerária aventura forense (A questão entre D. Amália de Moreira Keating e a City of San Paulo Improvements \& Freehold Land Co.Ltd.)Allegações finaes do advogado desta última. São Paulo, E.G. “Revista dos Tribunaes”, p. 24 apud Andrade, 1998, p.183-4.
} 
Cincinato Braga $^{48}$ teria formado um consórcio que adquirira aos poucos as glebas de terreno ${ }^{49}$ que viriam a compor o patrimônio da Companhia City.

Bouvard foi sócio de Laveleye no empreendimento e vice-presidente do primeiro conselho diretor da City. Seu apoio ao projeto, junto aos meio financeiros ingleses, foi fundamental devido à sua reputação profissional. A companhia foi organizada em Londres com um corpo de catorze diretores. (MORSE, 1970, p. 367).

Apoiando e aproveitando o grande negócio, associam-se grandes personalidades nacionais e internacionais, como Lord Balfour of Burleigh, Governador Geral do Banco da Escócia, presidente da San Paulo Railway Co., que viria a ser Ministro do Exterior da Inglaterra, e tornou-se o Presidente do Conselho Diretor da nova companhia.

Faziam ainda parte da primeira diretoria nomes como o do ex-presidente da República, Campos Salles, Cincinato Braga, à época deputado federal pelo PRP por São Paulo, e Horácio Sabino, advogado com negócios imobiliários que já loteara a "Vila America".

Contratado justamente pela City $^{50}$, o arquiteto Barry Parker esteve em São Paulo entre 1917 e 1919. Trazendo o ideário da cidade-jardim, projetou entre outros, o bairro do Jardim América, o Alto da Lapa e o Pacaembu (embora neste caso não tenham sido realizados todos os aspectos de seu projeto). Parker sugeriu alterações na legislação urbanística de São Paulo, chegando a interferir junto ao poder público para modificála, tornando viável a construção de projetos da City que não seriam aprovados pela legislação em vigor.

Os bondes e as avenidas haviam diminuído as distâncias. As famílias de classe alta abandonaram os centros tradicionais, saturados desde o final do século XIX com atividades comerciais e administrativas. Aparecem novos bairros elegantes para a elite, afastados do centro, em locais altos, resultantes da subdivisão das antigas chácaras. E loteamentos para compradores de condição econômica humilde, mais

\footnotetext{
${ }^{48}$ Cincinato César da Silva Braga (1864 - 1953) começou sua carreira política elegendo-se deputado estadual e depois federal em sucessivos mandatos pelo Partido Republicano Paulista. Apoiou a campanha civilista de Rui Barbosa. Durante o governo de Artur Bernardes foi presidente do Banco do Brasil. Escreveu importantes obras sobre a economia paulista e brasileira, entre elas: "Magnos Problemas de São Paulo". (http://pt.wikipedia.org/wiki/Cincinato_Braga)

49 Mais de 12.000 .000 de metros quadrados de terrenos na zona oeste da cidade, os quais foram vendidos em 1912 por $£ 930.000$ à City of San Paulo Improvements and Freehold Land Co., Ltd. (MORSE, 1970, p. 367).

${ }^{50}$ Inicialmente Raymond Unwin, o sócio de Parker foi encarregado do plano do Jardim América, através de recomendação de Bouvard, e provavelmente também de Victor da Silva Freire. Freire conhecia bem os avanços da urbanística européia e visitara a cidade-jardim de Letchworth e o subúrbio de Hampstead, na Inglaterra, em companhia de Mr. Gurd, Managing Director da City no Brasil. (ANDRADE, 1998, p. 186).
} 
afastados. O Código de Posturas de São Paulo e o Padrão Municipal tentam controlar

a expansão urbana. É proibida, por exemplo, a construção de habitação pública de baixa renda no "triângulo central". A carência de habitações era atendida de forma precária naqueles bairros afastados ou em zonas alagadiças e vales, às vezes nas proximidades das novas fábricas, principalmente nas direções norte e leste.

"Como parte desta política sanitarista de purificação da cidade, a ação dos higienistas sociais incide também sobre a moradia dos pobres, de acordo com o desejo de constituir a esfera do privado, tornar a casa um espaço da felicidade confortável, afastada dos perigos ameaçadores das ruas e bares. Mas também a partir da intenção de demarcação precisa dos espaços de circulação dos diferentes grupos sociais." (RAGO, 1985, p. 164)

\subsection{A aceleração da vida na cidade moderna}

O teatro era um dos locais para ver e ser visto. O Teatro Municipal se tornaria um dos símbolos do progresso material e cultural da cidade. O centro da vida social.

Nos parques e jardins recém-criados, os restaurantes ao ar livre, como nos jardins do Museu do Ipiranga. Para as férias, as estações de águas e os novos balneários a beira-mar começam a entrar na moda. Nesta época inicia-se o hábito de se freqüentar as praias. "(...) o fim de semana em um chalé ou bangalô suburbano, assim como as férias no Guarujá, Campos do Jordão ou Poços de Caldas, tornou-se uma instituição fixa para aqueles que se podem permitir tal. Originalmente uma simples mania, que Hollywood muito contribuiu para popularizar, o 'fim de semana' vem se tornando cada vez mais uma fuga necessária do torvelinho e das tensões da existência na cidade". (MORSE, 1970, p. 358-9)

Faz parte também deste novo conceito de vida saudável a prática dos esportes. Nos anúncios publicitários para a venda de lotes do recém-lançado loteamento Jardim América da Companhia City (1918), desenhos apresentam pessoas praticando esportes e a conhecida frase: "Mens sana in corpore sano"

O automóvel virá acrescentar mais um elemento a esta nova concepção de vida, já no pós-guerra. Muito mais que um simples meio de transporte, o automóvel já nasce como símbolo de status e de bom gosto. Devido a seus custos de importação e 
manutenção era visto como sinal de ostentação e exclusividade. A prova de que se pertencia à "aristocracia" - termo usado constantemente na publicidade referindo-se à elite. Os anúncios de automóveis eram os mais associados ao "moderno", com tudo o que a fortuna e o prestígio social poderiam proporcionar. Ele também facilitava 0 turismo interno, bastante impulsionado pela guerra e a dificuldade de acesso à Europa.

Porém, o abuso da velocidade e do uso da buzina era constante. Não havia regulamentação de trânsito e, com o automóvel associado aos poderosos, os inúmeros atropelamentos ficavam impunes, implicando apenas em uma pequena multa. (SEVCENKO, 1992, p. 74)

Em relação aos bondes elétricos, da imagem inicial de mistério, curiosidade e receio, passou-se ao entusiasmo e ao reconhecimento do potencial do novo meio de transporte. A demanda cresceu mais rápido que a oferta. "Receber ou não energia elétrica e ter ou não acesso fácil à rede de bondes passou a ser não apenas o principal referencial da especulação imobiliária, mas também um dos mais distintivos símbolos de status. (...) De via sinistra, a eletricidade se tornou logo a vedete cobiçada do espetáculo urbano." (SEVCENKO, 2001, p. 548)

Travava-se uma batalha diária entre os pedestres e os novos veículos - bondes e automóveis; e os atropelamentos tornaram-se constantes.

Sair à rua era perigoso, confuso, desnorteante. Os nervos eram solicitados ao máximo. A nova percepção necessária aos novos tempos recomendava a precaução, pois certa sensação de perigo estava sempre presente. As condições de vida alteravam a sensibilidade e o comportamento.

A imprensa passa por grandes transformações, em conseqüência do processo de metropolização da cidade. Houve um grande crescimento na indústria editorial paulista no início dos anos 1920; revistas, livros, jornais - O Estado torna-se o jornal de maior tiragem do país.

O novo tipo de vida, mais mundana, e as novas formas de sociabilidade que se apresentam no cotidiano das pessoas fazem com que aumente o público das novas revistas de variedades que surgem nos anos 1920, como A Cigarra e Ariel. Reportagens sobre moda, decoração, arte, etiqueta forneciam modelos para todos os aspectos da vida da elite. "A syntese, porem, do desenvolvimento paulista realizou-se na capital. A velha cidade de estudantes, com suas viellas tortuosas, suas praças de chão batido, seus casarões de largo beiral foi desapparecendo rapidamente. 
Rasgaram-se largas avenidas; abriram-se formosos parques e jardins; ergueram-se monumentos (...)." (Ariel, n.34, abril de 1926 apud PADILHA, 2001, p. 64).

Os apelos da publicidade, cada vez mais eficazes estimulam o consumo. A vida se torna vertiginosa, principalmente fora do lar, nas ruas - com seus cafés, restaurantes, teatros, cinemas, escritórios, clubes. A industrialização; a intensificação do comércio e das possibilidades de lazer e serviços; o afluxo populacional. Alterações em um ritmo acelerado suscitando as mais diversas reações: medo, entusiasmo, estranhamento. Os modismos marcavam esta sociedade em constante mutação. Tentativas do paulistano de desfrutar o sonho das grandes metrópoles mundiais.

Um relatório de 1924 mostra certo complexo de inferioridade; a procura de uma cidade para ser exibida e não para atender às necessidades de seus habitantes: “(...) de que nós, paulistas, possamos orgulhar-nos, exhibindo-a ufanos aos extrangeiros que nos visitem. E S. Paulo actualmente tem muito pouca cousa digna de ser vista pelo extrangeiro, offerecendo, mesmo, muito aspecto deplorável e lamentável", 51

As imagens da cidade apresentadas pela publicidade, ainda que não fossem reais, davam vazão às expectativas de seus cidadãos.

A publicidade acabou familiarizando o homem urbano com as novas formas de reprodutibilidade. Os anúncios tornaram-se um dos principais difusores das fotografias impressas. Estes se espalhavam por toda a cidade, inclusive no interior dos bondes, tentando captar a atenção das pessoas, a cada dia mais dispersas.

O cinema já exercitara o homem em um novo tipo de percepção e nas novas atitudes que a técnica, cada vez mais presente em seu cotidiano, exigia. "O cinema é a forma de arte correspondente aos perigos existenciais mais intensos com os quais se confronta o homem contemporâneo. Ele corresponde a metamorfoses profundas do aparelho perceptivo" (BENJAMIN, 1987, p.192).

E o cinema americano marcará também algo que já começara a acontecer: a influência preponderante dos EUA, e não mais da Europa sobre os modos de vida nos países latino-americanos.

\footnotetext{
${ }^{51}$ Relatório de 1924, sobre implantação do plano de Victor da Silva Freire que consistiu na ampliação do Triângulo, alargamento de algumas de suas ruas e modificações nas linhas de bonde, iniciado por volta de 1912. (Morse, 1970, p. 372).
} 


\subsection{Industrialização e mudanças na estrutura social}

A estrutura social mostra-se cada vez mais diversificada. "O Rio de janeiro foi talvez a primeira cidade brasileira a criar uma camada social média mais extensa; além de ser o principal entreposto comercial do país (...), como capital do Império constituía o núcleo do aparelho burocrático e militar. (...). Contudo, é na região cafeeira de São Paulo, em fins do século XIX, que as cidades tomarão maior impulso e se desenvolverá um setor médio citadino. Isto se explica pelo fato de que, ao contrário das economias primário-exportadoras, o setor cafeeiro paulista converteu as cidades num seu apêndice (...)." (SAES, 1973, p. 25-6) "O complexo cafeeiro provocou a construção de uma infra-estrutura de serviços indispensáveis ao setor exportador. Também houve a absorção de grupos decadentes, de antigos proprietários, descendentes de famílias paulistas antigas, empobrecidos e expelidos para a cidade, onde irão ocupar altos cargos no aparelho do Estado e se localizarão nas profissões liberais". Ou ainda nos circuitos comercial e financeiro. Os imigrantes também terão um peso específico. (PINHEIRO, 1985, p. 20-1)

O desenvolvimento urbano, acelerado após a guerra, provocará a expansão do pequeno comércio nos centros mais importantes do país, assim como de pequenas indústrias. Há o aumento das antigas classes médias - pequenos comerciantes, artesãos, pequenos industriais, alfaiates, carpinteiros e sapateiros - e das novas classes médias - funcionários públicos, assalariados. A urbanização ocorrerá simultaneamente ao crescimento da burocracia dos serviços públicos. (PINHEIRO, 1985, p.16).

As camadas médias urbanas ${ }^{52}$ eram insignificantes numericamente e se constituíam em um aglomerado heterogêneo ${ }^{53}$, quanto à origem profissional e racial. - em 1920,

\footnotetext{
${ }^{52}$ Utiliza-se no texto a denominação corrente "classes médias". Mas, deve ser feita uma ressalva quanto a seu sentido, que é o mesmo de "camadas médias urbanas" que designa aqueles setores da população urbana que, não sendo detentores do capital, realizam trabalho predominantemente não-manual, quer trabalhando por conta própria, quer vendendo a sua capacidade de trabalho a terceiros. Semelhante agregado não poderia ser confundido com uma classe social, já que reúne grupos sociais sem participação direta no processo da produção (profissionais liberais, funcionários públicos) e aquelas parcelas dos trabalhadores da indústria, comércio e bancos que realizam serviços de escritório e que não se consideram "proletários", recusando tal identificação. A expressão "camadas médias urbanas" é mantida no plural porque tais grupos são bastante heterogêneos dos pontos de vista social, cultural e ideológico. (SAES, 1973, p.19-20).

Segundo a teoria das classes sociais elas são consideradas como: "grupos sociais antagônicos em que um se apropria do trabalho do outro por causa do lugar diferente que ocupam na estrutura econômica de um modo de produção determinado, lugar que está determinado fundamentalmente pela forma específica através da qual de relaciona com os meios de produção" (HARNECKER, Marta Los conceptos
} 
dois terços da população da cidade de São Paulo, 580.000 habitantes, eram estrangeiros ou descendentes de estrangeiros.

Estas camadas apresentavam uma forte dependência econômica, social e ideológica em relação aos grupos oligárquicos. (SAES, 1973, p. 34-5 e p.75) O fato de realizarem um trabalho predominantemente não-manual confere a estas pessoas uma posição intermediária (embora com gradações), posição esta valorizada por seus ocupantes. Situados entre os grandes proprietários rurais e os trabalhadores braçais, os setores médios urbanos apresentam o desejo comum de fugirem das atividades manuais, sobre as quais paira o preconceito desenvolvido ao longo dos séculos de escravidão.

Estudos a respeito dos imigrantes italianos em São Paulo mostram que sua cultura Ihes dava motivação para a mobilidade ascendente, em comparação com os brasileiros natos ${ }^{54}$. Porém, o novo ambiente os leva a abandonar sua própria ética do trabalho que assegurara seu progresso inicial e a adotar a busca do status. Neste contexto de preconceito contra o trabalho manual e contra o comércio miúdo, esta nova classe média, composta também pelos imigrantes, contribui para um aumento artificial das profissões tradicionais, que se não mantêm a predominância econômica, conservam o prestígio social - muitos imigrantes enriquecidos sem terem recebido instrução, conseguem proporcioná-la a seus filhos, o que terá principalmente valor simbólico. Aqueles que ascendiam socialmente tendiam a adotar a aparência da elite, e a educação funcionava mais para perpetuar os privilégios do que para reconhecer novos talentos e treiná-los.

Essas classes médias aceitavam os ideais e valores de classe da elite. Copiavam - da maneira como permitiam suas posses - seu modo de vida. Seu projeto não era que seus ideais e valores fossem aceitos, pois não os tinham, mas sim participar dos privilégios da classe superior. (PINHEIRO, 1985, p. 34)

$\mathrm{Na}$ fase que vai de 1889 a 1930, o maior anseio das camadas médias urbanas seria o crescimento e a sofisticação do setor terciário, com o conseqüente aumento de oportunidades e o surgimento de novas modalidades de trabalho não-manual. Um

elementares del materialismo histórico. México: Siglo Veintiuno Editores S.A., 1970, 3ạ edição, p. 116 apud SAES, 1973, p. 15-6).

Alguns setores sociais, por não estarem diretamente ligados à produção (na acepção marxista da palavra), não fazem parte de nenhuma classe social. É o caso dos funcionários públicos, advogados, professores, etc.(SAES, 1973, p. 16)

${ }^{53}$ Segundo Pinheiro, 1985, p. 16, a população ativa não manual em 1920, no estado de São Paulo era de 74.015 pessoas, em um total de 4.592.188 habitantes. Estas atividades não manuais incluíam a Força Pública, a administração pública, a administração particular e as profissões liberais.

54 HUTCHINSON, Bertram et al., Mobilidade e trabalho, um estudo na cidade de São Paulo. Rio de Janeiro, 1960 apud MORSE, 1970, p. 390. 
terciário amplo e mais novo seria viável apenas com o processo de industrialização em ritmo acelerado, já que isto demandaria serviços específicos, além de burocratas e técnicos. (SAES, 1973, p. 22) A evolução social das camadas médias urbanas só se faria através dos processos de industrialização.

O setor industrial nasceu no bojo da economia agrícola-exportadora, com os capitais gerados por esta. A aceleração no crescimento industrial no Brasil deu-se na década de 1910. Essa expansão provocará uma ampliação e diversificação do setor terciário urbano e haverá assim, na década seguinte um setor intermediário mais expressivo numérica, econômica e socialmente.

Porém Cardoso alerta contra a tendência de se atribuir a industrialização paulista simplesmente ao acúmulo de capital produzido pelo boom do café, pois este dinheiro poderia ter sido aplicado em outro lugar. Importância maior teria tido o deslocamento das fazendas para o Oeste paulista, tornando Santos o principal porto exportador de café, o crescimento no interior paulista das cidades e de uma pequena burguesia urbana, fornecendo mercado para a indústria nacional ${ }^{55}$.

O êxito dos fazendeiros paulistas que se dedicaram a empresas urbanas segundo Dean pode ser atribuído a fatores históricos e econômicos, como a própria natureza da agricultura cafeeira - propícia aos fazendeiros, "capitalistas que reinvestiam os lucros". 56

Os industriais paulistas foram relativamente acanhados até a década de $1950 ;{ }^{57}$ na escolha de modalidades tradicionais de negócios e na incapacidade de exercer pressão política efetiva sobre os dirigentes. Entre as causas, o fato da elite industrial ser bastante heterogênea. Seus membros enxergavam-se sob critérios pessoais de status e apenas secundariamente como um grupo empresarial. Assim, Cardoso acha que o empresariado paulista era mais acomodatício que inovador. Contesta-se desta forma a tese amplamente aceita de que "a burguesia empresarial constitui a mola propulsora inicial do desenvolvimento e da modernização do Brasil."

O crescimento de São Paulo não se aceleraria enquanto ele apenas exportasse produtos agrícolas não beneficiados, assim, seria decisivo o desenvolvimento industrial baseado em matéria prima regional. $\mathrm{O}$ momento decisivo se deu quando $\mathrm{o}$

\footnotetext{
${ }^{55}$ CARDOSO, Fernando Henrique $\mathbf{O}$ café e a industrialização da cidade de São Paulo, Revista de História, XX, 42 (abril-junho 1960), p. 471-75 apud MORSE, 1970, p. 383.

${ }^{56}$ DEAN, Warren The Planter as Enterpreneuer: the Case of São Paulo, The Hispanic American Historical Review, XLVI, 2 (maio 1966), p. 138-52 apud MORSE, 1970, p. 387.

${ }^{57}$ CARDOSO, Fernando Henrique Empresário industrial e desenvolvimento econômico. São Paulo, 1964 apud MORSE, 1970, p. 388-89.
} 
volume do intercâmbio entre São Paulo e o interior superou o intercâmbio com Santos. (MORSE, 1970, p. 384).

\subsection{O ensino da arquitetura em São Paulo nas primeiras décadas do século $\mathrm{XX}$.}

Para analisarmos a arquitetura em São Paulo nos anos 1920, é necessário que se conheça o ensino a que tinham acesso os profissionais da época.

Entre os cursos de engenheiro-arquiteto, o primeiro foi o da Escola Politécnica ${ }^{58}$, que funcionou de 1894 a 1954. Existiam ainda o curso de engenheiro-arquiteto do Mackenzie, oferecido entre 1917 e 1946, e o curso de arquiteto da escola de Belas Artes de São Paulo, criado por volta de 1928, existindo até 1934. (FICHER, 2005, p. 17).

$\mathrm{Na}$ época, a atividade conhecida como arquitetura era a construção do edifício, o projeto arquitetônico constituía-se em apenas uma etapa. Seu valor comercial praticamente inexistia. E sua autoria era um aspecto secundário. Seu autor poderia ser um projetista contratado pela firma de arquitetura. Este funcionário especializado podia ser diplomado por uma escola superior ou técnica ou ter tido outra forma de aprendizado, junto a uma empresa ou a outro projetista mais experiente. Mais secundário ainda era o "estilo" do projeto, geralmente determinado pelo cliente. $\mathrm{O}$ projetista deveria dominar o repertório da época.

\subsubsection{O Liceu de Artes e Ofícios ${ }^{59}$}

O Liceu de Artes e Ofícios de São Paulo foi fundado em 14 de dezembro de 1873. Para Ricardo Severo, que foi seu diretor geral, o Liceu significava:

(...) um ideal de cultura geral e popular, segundo um método de ensino básico, livre das peias escolásticas que se propunha levantar

\footnotetext{
58 A Escola Politécnica foi fundada em 1894 e dois anos depois começa a funcionar a Escola de Engenharia do Mackenzie College. O Liceu começa a ser reorganizado em 1895.

${ }^{59}$ Os cursos do Liceu era profissionalizantes, mas como formavam a mão-de-obra qualificada utilizada na construção civil são aqui mencionados.
} 
o nível moral e intelectual das classes laboriosas. Denuncia-se nos fundadores deste Liceu esse espírito liberal e douto que vê na cultura o potencial da civilização e do progresso do país, e que a fundamenta na educação profissional como base imediata da série ascendente da cultura nacional. (SEVERO, 1934, p. 14).

Ainda segundo Severo, a educação profissional fora sempre vista sob o ponto de vista moral e intelectual e, assim, o Liceu teria sempre atuado como uma verdadeira corporação de artes e ofícios, mantida por uma tradição de espírito patriarcal, "mas como laço de íntima compreensão entre mestres e aprendizes, sob o livre reconhecimento do direito igual aos proventos espirituais e temporais da civilização e da cultura; todavia, sem as peias do juramento confessional ou político, que foi de uso nas corporações de caráter medieval e está a modo de reeditar-se nas ultramodernas". (SEVERO, 1934, p. 23)

Ramos de Azevedo, outro diretor em discurso ufanista, escreveria: "O que me enche a alma de satisfação é que o Liceu é uma escola magnífica de trabalho. Não de trabalho obrigatório, forçado, constrangido, mas o trabalho-virtude, que é muito raro mas do trabalho prazer, no qual o aprendiz ou o operário encontra, a todos os instantes, novos motivos de satisfação e entusiasmo." (LEMOS, 1993, p. 54) As concepções de Ruskin, através de uma moral de culto ao trabalho executado de forma cooperativa. A qualificação humana através do trabalho.

A idéia da oficina-escola é transmitir o conhecimento durante a prática profissional: se instrui fazendo. Entre 1873 e 1933, por ali passaram mais de quarenta e sete mil futuros profissionais. (SEVERO, 1934, p.221) Sua produção não podia ser considerada homogênea. Havia encomendas - projetos elaborados por arquitetos, engenheiros e desenhistas, às vezes com a participação dos clientes -, mas também havia a produção de manufaturados para o comércio. As oficinas do Liceu estavam aptas a atender à indústria da construção, em todas as suas etapas - instalações hidráulicas, elétricas, telhas de ardósia, esquadrias, grades, portões e peças em madeira.

As obras de marcenaria e serralheria conquistaram o mercado e em 1903, passam a funcionar as oficinas de ebanesteria e escultura em madeira, de caldeiraria e forja artística, de fundição de bronze e metais finos. Mas, nenhuma oficina tinha clientela numerosa como a de marcenaria, tanto que, em 1904, o Liceu recebe prêmio na Exposição Industrial de St. Louis. (BELLUZZO, 1988, p. 123) Outros prêmios internacionais seriam obtidos, entre eles os das Exposições Internacionais de Bruxelas, em 1910, e de Turim, em 1911. 
Para Motta (1957, p.48), O Liceu perderia todo sentido renovador, não conseguindo um entrosamento maior com a indústria e, em conseqüência, seus produtos se tornariam muito caros, devido também à inegável qualidade da mão de obra: "mas sem significação como produto de uma mentalidade moderna, a história do Liceu, como organização, mostra que, no início, os propósitos eram bem outros". Como acontecera antes na Inglaterra, os produtos artesanais tornaram-se um luxo para poucos. A elite em São Paulo se utilizaria dos serviços do Liceu em suas residências.

Ainda segundo Motta (1957, p. 49), ao contrário da visão romântica, idealista da industrialização do Brasil, a realidade era bem diferente, havia:

o impacto do novo, com a vinda do imigrante, com a instalação de vias-férreas, empresas hidro-elétricas, enfim tôda uma série de fôrças elaboradas num meio estranho ao nosso. Deveríamos buscar em William Morris um pensamento artístico que refletisse esse processo de continuidade dos liberais. Mas, se na Inglaterra, o ideal de uma restauração do artesanato levara a um conflito com a crescente industrialização, que se dirá, do Brasil, onde, além de um choque nos métodos de produção, tínhamos choques de culturas, de mentalidades, na complexa mescla de tendências as mais contraditórias! Assim, todo o trabalho do Liceu se reduziu a um pequeno campo de aperfeiçoamento e educação profissional, para mais tarde assistir, inerte, ao segundo e maior domínio do progresso industrial, amparado em organizações semi-oficiais e um ensino profissional de caráter mecanicista." (MOTTA, 1957, p.49)

\subsubsection{A Escola Politécnica}

\subsubsection{O ensino}

Ao contrário de Paris ou do Rio de janeiro, onde a formação dos arquitetos dava-se em uma escola ligada ao ensino artístico, em São Paulo a arquitetura era estudada como uma especialidade da engenharia, na Escola Politécnica. (FICHER, 2005, p. 26).

$\mathrm{Na}$ Politécnica, os cursos especiais, dependentes do curso fundamental eram os de engenheiro-arquiteto $^{60}$, engenheiro civil e engenheiro industrial. Os alunos de

\footnotetext{
${ }^{60}$ A procura pelo curso de engenheiro-arquiteto da Politécnica sempre foi pequena, no período 18991915, formaram-se 18 profissionais; entre 1915 e 1930, formaram-se apenas quinze. Isto se alteraria por
} 
arquitetura e de civil assistiam juntos às cadeiras em comum. Em alguns anos, as disciplinas específicas arquitetônicas, reunidas na 4aㅗ Seção de Artes, deixaram de ser dadas, o que demonstra a pouca procura pelo curso de engenheiro-arquiteto. (FICHER, 2005, p. 46).

O curso fundamental da Politécnica, criado em 1894, era constituído por um curso preliminar, com um ano de duração e um curso geral, com dois anos. Tinha como função o estabelecimento de um repertório de noções sobre as ciências exatas e o domínio do desenho técnico e artístico, exigência que se estendia a todas as especializações.

A preocupação em garantir a todos os estudantes o ensino do desenho transparecia não só nos regulamentos, mas também nos relatórios anuais do diretor da Politécnica. Paula Souza, em 1904, expôs o seu objetivo: estimular "o gosto pelas artes gráficas, que constituem um dos maiores cabedais de que pode dispor o engenheiro no exercício da profissão". (FICHER, 2005, p. 44).

A responsabilidade pela qualidade do ensino do desenho recaía sobre os professores. Esses foram, de 1894 em diante, Domiziano Rossi e Victor Dubugras, ambos não diplomados em escolas de engenharia, mas destacados pela sua habilidade como desenhistas e projetistas. As aulas de desenho, mais orientadas para a arquitetura, eram comuns a todos os estudantes. Os programas incluíam desenho ornamental a base geométrica, desenho de sólidos, desenho de molduras greco-romanas, desenho de perspectiva convencional, desenho arquitetônico ornamental a simples contorno e sombreado. (FICHER, 2005, p. 45).

A área ficou completamente imobilizada por muito tempo, já que Dubugras nunca alterou os exercícios de que se utilizava para suas aulas. E no conjunto da escola, o ensino do desenho perdia importância para as cadeiras técnicas e para as atividades nos gabinetes experimentais. As péssimas condições dos locais onde eram oferecidas as aulas de desenho atestam seu caráter secundário - em um relatório de 1929, Prestes Maia, que ensinava Desenho de Perspectiva no $1^{\circ}$ ano do curso especial de engenheiro-arquiteto, descreve o espaço, sem piso, sem luz, sujo, apertado e com goteiras. Foi nesse período que o curso de engenheiro-arquiteto teve seu mais baixo índice de procura: entre 1918 e 1931, diplomaram-se apenas catorze profissionais, distribuídos em oito turmas. (FICHER, 2005, p. 192)

volta de 1932, com a cassação dos direitos de funcionamento da Escola de Engenharia do Mackenzie, quando muitos mackenzistas transferiram-se para a Politécnica. 
Foi intensa a importação de aparelhos e máquinas para os demais gabinetes e laboratórios, pelo menos até 1923, porém, apesar do discurso oficial valorizar o ensino de desenho, não há qualquer menção à aquisição de material para o Gabinete de Arquitetura, responsável pelo ensino do desenho. (FICHER, 2005, p. 45).

Ficher (2005, p. 175) estabelece um primeiro período, de consolidação do curso de engenheiro-arquiteto da Politécnica, que vai de sua instalação, em 1894 até 1916.

O curso de engenheiro arquiteto não foi afetado de modo expressivo até 1918, quando foi baixado $06^{\circ}$ Regulamento. A Politécnica passaria por uma importante reforma. Não foi modificado apenas o currículo do curso, mas também a composição do corpo docente. Nesta época, começam a voltar para o curso os seus diplomados, agora como professores. O primeiro foi Alexandre Albuquerque em 1917. (FICHER, 2005, p. 27). O segundo período iria até 1933, um momento atribulado, com muitas transformações políticas, econômicas e sociais no estado e no país, desencadeadas pela crise econômica internacional de 1929 e pela revolução de 1930 .

Em 1925, entra em vigor o $7^{\circ}$ Regulamento. Entre outras modificações, a cadeira de História de Arquitetura, do terceiro ano, regida por Alexandre Albuquerque, acrescenta seções sobre arte jesuítica, arte colonial brasileira e arquitetura pré-colombiana. Este fato, associado às viagens organizadas por Albuquerque com os alunos, mostra o interesse pelos estilos Neocolonial e Missões no ambiente da Politécnica.

A biblioteca da Escola Politécnica foi dirigida entre 1917 e 1937 por Alexandre Albuquerque. Várias revistas procedentes de vários países eram assinadas, entre elas as americanas The Architectural Review, Pacific Coast Architect and Building Review $^{61}$, The Architectural Record; as germânicas, as francesas, as inglesas. Muitos outros títulos de procedência norte americana, inglesa, francesa e alemã, das áreas de engenharia e de história da arquitetura, faziam parte do acervo.

O acervo histórico da Politécnica se encontra hoje na Biblioteca Central da Escola Politécnica (EPBC). Uma parte dos títulos da EPBC pertenceu a antigos professores, entre ele Ramos de Azevedo, co-fundador da instituição. Após sua morte em 1928, por desejo seu, pouco mais de 400 de seus livros foram doados à biblioteca. Entre eles a coleção da revista The Craftsman, desde seu início.

Grande parte da pesquisa em fontes primárias para esta dissertação foi feita na EPBC, que tem em seu acervo vários periódicos brasileiros do início do século $X X$, entre os

\footnotetext{
${ }^{61}$ Teve início em 1924, depois se transformou em California: Arts and Architecture (1929-1944).
} 
quais a própria Revista Politécnica, a Revista de Engenharia do Mackenzie e alguns números de A Casa.

\subsubsection{O ambiente na Escola Politécnica}

Para compreender a renovação arquitetônica que se desenvolvia no âmbito da Escola Politécnica de São Paulo, com grande participação de Victor Dubugras é importante conhecer o contexto em que ela se desenvolve. No início do século $\mathrm{XX}$, adota-se no Brasil o ideário do Art Nouveau, que pretendia ser a arquitetura da sociedade industrial, com a procura de novos padrões visando adequar a arquitetura à sua época.

Desde a segunda metade do século XIX, várias correntes com sentido racionalista definiram-se, opondo-se ao academicismo, buscando a atualização e modernização das linguagens. Uma volta às origens vernáculas, em países como a Inglaterra, França e Alemanha. (REIS FILHO, 1997, p. 31) Pode-se dizer que o Arts and Crafts deu início a esse processo.

Já no início do século $X X$, é possível falar-se em uma corrente racionalista na Politécnica e na prática de uma arquitetura de caráter construtivo, na qual as formas decorrem do modo de construir - materiais e técnicas construtivas -, considerada moderna à época. Ao longo dos anos 1920, o racionalismo apareceria como novidade no movimento moderno, esquecendo-se as realizações anteriores de uma arquitetura de base racional. "As mudanças passaram a ser vistas como frutos das ações de heróis, esquecendo-se o sentido coletivo do processo de mudança." (REIS FILHO, 2005, p. 54)

Faz parte deste quadro da Politécnica, o desenvolvimento de novos laboratórios e o trabalho do engenheiro-arquiteto Pujol Júnior no Gabinete de Resistência dos Materiais. A primeira publicação da Escola Politécnica foi o "Manual de Resistência dos Materiais", a partir de ensaios realizados por uma equipe da qual participou Pujol Júnior ${ }^{62}$.

\footnotetext{
${ }^{62}$ A orientação que seguiu a escola Politécnica em sua origem ligava-se à formação de Antônio Francisco de Paula Souza (1843-1917), seu fundador. Educador, esteve ligado à Politécnica por 25 anos. Seu desejo era introduzir no Brasil um ensino técnico voltado à formação de profissionais dinâmicos, que não estivessem envolvidos apenas em discussões acadêmicas. Criou um conceito novo de ensino, convidou especialistas europeus e americanos para lecionar na instituição, à frente da qual esteve como primeiro diretor, de 24 de novembro de 1894 a abril de 1917, quando faleceu em São Paulo. Formado
} 
Segundo Reis Filho (2005, p. 56), as pesquisas de caráter tecnológico dos engenheiros-arquitetos da Politécnica foram tão importantes quanto as pesquisas sobre linguagem, de caráter estético. Entre 1915 e 1930, houve continuidade nas preocupações racionalistas no plano técnico, ao contrário do que ocorreu no plano estético.

A própria orientação da Revista Politécnica prova tal hipótese: por volta de 1916, os artigos sobre estética, realizações no âmbito da arquitetura e as discussões sobre a cidade tornam-se raras, ao menos até o fim do período abarcado por esta pesquisa 1930. Passam a predominar os artigos técnicos - novas tecnologias e métodos de cálculo de estruturas, incluindo anotações de aula.

As pesquisas de caráter estético envolviam a experimentação, por parte dos arquitetos, com várias linguagens, nenhuma hegemônica, de forma a atender a critérios como a demonstração de como funcionava determinado sistema estrutural e a exposição dos materiais. A modernização incluía também as pesquisas sobre novos materiais estruturais como o concreto e o aço. Por outro lado, como na obra de Victor Dubugras, as técnicas tradicionais eram utilizadas de forma moderna, com critérios racionais.

Quando o Neocolonial ganhou força, quase todos adotaram a linguagem, mas sem abandonar as preocupações com a racionalidade construtiva.

Assim, o ambiente na Politécnica, no início do século $X X$, estava sintonizado com o que se fazia na Europa e nos Estados Unidos, pois além das revistas estrangeiras a que tinham acesso, os alunos empreendiam viagens. ${ }^{63} \mathrm{E}$ existia ainda a presença de grande número de professores estrangeiros.

\subsubsection{O Curso do Mackenzie}

\footnotetext{
na Suíça e na Alemanha, ele incorporou à Politécnica aspectos ligados aos padrões alemães e da Europa Central, e não à tradição acadêmica das escolas de belas artes existentes na Europa Ocidental.

Seu dinamismo contrastava com o conservadorismo de Ramos de Azevedo, que o substituiu à frente da Politécnica, formado na Bélgica, de tradição acadêmica.

$\mathrm{Na}$ tradição alemã, existiam engenheiros de edificações (obras acima do solo) e de infra-estrutura (obras abaixo do solo). Os engenheiros de edificações deveriam desenvolver os projetos arquitetônicos e os problemas referentes aos seus aspectos técnicos. Isto explica o fato das normas técnicas da construção civil serem de origem alemã. Os alemães eram arquitetos, mas eram também engenheiros.

${ }^{63}$ Tais viagens eram depois relatadas, como a de Alexandre Albuquerque em 1905, que fora premiado quando de sua formatura com uma viagem à Europa. Ele assina um longo artigo na Revista Politécnica sobre suas impressões do velho continente.
} 
A formação dos cursos superiores do Mackenzie College ${ }^{64}$ inicia- se em 1896. O curso de Engenharia Civil é deste mesmo ano ${ }^{65}$. Havia um acordo com a Universidade de Nova York (USNY), que conferia os diplomas ${ }^{66}$.

Em 1923, o governo brasileiro implantou uma reforma no ensino superior, conhecida como "Reforma Carlos Maximiliano". Esta reforma referendou a Lei Rivadávia de 1911, que requeria uma atitude mais rígida quanto à validação de diplomas de universidades estrangeiras. Apesar de, na prática, o egresso do Mackenzie apenas apresentar seu diploma expedido em inglês pela USNY, com a tradução juramentada, para registro na Diretoria Geral de Educação, desde a reforma houve certo incômodo da sociedade culta do país, que via o Mackenzie como uma instituição de ensino que não se subordinava às leis brasileiras.

Em 1923, o Mackenzie altera seu projeto pedagógico, principalmente do curso de Engenharia, para atender ao Decreto-Lei n. 4569-A, que estabelecia a equiparação dos cursos de orientação estrangeira aos estabelecimentos oficiais ${ }^{67}$.

Como parte das reformas na Universidade, o cargo de fiscal residente da USNY ${ }^{68}$ foi extinto em 30 de julho de 1927. A Revista de Engenharia do Mackenzie (junho 1928, n.47, p.108) noticia que "A Universidade de New York conferiu autonomia à Escola de Engenharia Mackenzie".

Assim, a Escola de Engenharia do Mackenzie teria passado a um regime autônomo, ao invés do inspecionado. A obrigatoriedade de conservação dos padrões e das tradições da Universidade de Nova York não seriam mais obrigações legais, mas morais, assinala o mesmo artigo.

A escola paulistana passou praticamente a ministrar dois cursos paralelos, para que pudesse continuar expedindo diplomas válidos tanto nos Estados Unidos, quanto no Brasil: o "Curso Americano" e o "Curso Nacional", conforme os alunos desejassem freqüentar instituições americanas ou atuar no Brasil. Os diplomas conferidos pelo Mackenzie seriam registráveis no Brasil e aqueles conferidos pela Universidade de

\footnotetext{
${ }^{64}$ Sobre os cursos de engenharia e arquitetura do Mackenzie, ver Atique, 2007, p. 150-178.

65 Como já foi mencionado, o curso de engenheiro-arquiteto da Escola de Engenharia do Mackenzie College foi criado em 1917.

66 Porém, mesmo antes da criação dos cursos superiores, o Mackenzie encaminhava ex-alunos da instituição brasileira para prosseguir os estudos nas universidades americanas.

67 Em anúncio do Mackenzie College na Revista de Engenharia do Mackenzie (março 1927, n.41), a escola é apresentada como: “Academia equiparada pela lei n. 4659-A de 19 de Janeiro de 1923, reconhecida pela Universidade de Nova York (...)".

${ }^{68}$ A USNY exigia a fiscalização das instituições chanceladas por ela, como era o caso do Mackenzie. A tarefa do fiscal era inspecionar o estabelecimento, as teses dos formandos e garantir que o programa dos cursos fosse cumprido. (ATIQUE, 2007, P.174)
} 
Nova York seriam válidos nos Estados Unidos e revalidáveis em quase todos os países $^{69}$.

Houve tanta polêmica que até mesmo editoriais de jornais nacionais foram dedicados ao tema. O certo é que a questão não ficou resolvida, ainda mais com o fervor nacionalista que marcou a época no Brasil - na política, na arquitetura e nas artes.

Revelador deste fato é o artigo publicado na Revista de Engenharia do Mackenzie (junho de 1928, n.47, p.106), noticiando a entrega da medalha de ouro e o diploma conferidos ao Mackenzie, no III Congresso Pan-Americano de Arquitetura, acontecido em Buenos Aires, em 1928: "É doloroso registrar que um memorável congresso de architectura distingue a nossa Escola de Engenharia reconhecendo a excellência dos methodos de ensino, a competência dos cathedráticos, a dedicação de seus alumnos, emquanto brasileiros não só negam essas mesmas qualidades como procuram apagal-as por uma campanha infeliz".

A própria diretoria do Mackenzie fazia comentários desabonadores às autoridades brasileiras - descritas como políticos corruptos - em seus relatórios enviados à Nova York.

Apesar das mudanças, que incluíram a criação do Conselho do Mackenzie College, o projeto educacional da escola não era visto com bons olhos pelo Governo Federal que, em 1932, caçou os direitos de funcionamento da Escola de Engenharia do Mackenzie, através do Decreto $n^{\circ} 21.519 / 32$. Os diplomas expedidos pelo Mackenzie não seriam mais reconhecidos ${ }^{70}$. Em conseqüência houve grande número de transferências de alunos para os cursos da Politécnica. A reversão da cassação aconteceria em 1938.

Alguns autores argumentam que a cassação aconteceu porque o Mackenzie seria visto como reduto do PRP (Partido Republicano Paulista), participante ativo da Revolução de 1932. A justificativa do decreto era a falta de adequação às normas educacionais - a falta de um sistema de carreira por cátedras. (ATIQUE, 2007, p. 178)

Ficher (2005, p. 175-6) coloca que a cassação se deveu a perseguições do governo federal. Os motivos seriam mesmo de ordem política, mas também pessoais: uma

\footnotetext{
69 Porém, as vinculações com os Estados Unidos ainda continuariam fortes porque, entre outros motivos, Christiano Stockler das Neves, egresso da Universidade da Pensilvânia continuou a dirigir o curso de engenheiro-arquiteto do Mackenzie.

${ }^{70}$ O ministério dos Negócios da Educação e Saúde Pública fora criado em 1930 e seu Conselho Nacional de Educação em 1931. Assim, foram estabelecidas legislações federais mais estritas, de controle do ensino superior. A cassação do Mackenzie insere-se neste quadro.
} 
vingança de Getúlio Vargas contra Washington Luiz, cujo filho formara-se em engenharia civil pelo Mackenzie, em 1927.

De qualquer forma, uma indireta retaliação aos paulistas pela oposição ao governo provisório e um gesto nacionalista contra uma instituição americana sediada no Brasil.

$\mathrm{Na}$ biblioteca da Escola de Engenharia do Mackenzie, como esperado, eram encontrados muitos títulos de procedência americana, como as revistas Architectural Record e Pencil Points ${ }^{71}$.

\subsection{Mudanças na profissão - as organizações profissionais}

Após quase vinte anos de funcionamento de dois cursos de engenharia na cidade de São Paulo, o aumento no número de profissionais diplomados leva à sua organização em torno de entidades de classe.

A Sociedade dos Arquitetos de São Paulo foi fundada em 1911. Segundo a Revista de Engenharia, "em um país como o nosso, sem tradições artísticas, recebendo a influência de civilizações diferentes, aberto a elementos adventícios e heterogêneos, as agremiações como essa representam um fator importante na educação artística do povo, concorrendo para a adaptação conveniente das idéias estrangeiras e para estimular o desenvolvimento da arte local." (Revista de Engenharia, julho 1911, n.2, p.89 apud ANDRADE, 1998, p. 182) Pouco depois foi permitida a participação de engenheiros e engenheiros-construtores na entidade. Não há notícias a respeito da Sociedade dos Arquitetos a partir de fevereiro de 1912, quando seus estatutos são publicados na Revista de Engenharia (p. 263 e p. 266-7 apud FICHER, 2005, p. 30).

Em 13 de maio de 1916 acontece a criação do Instituto de Engenharia (FICHER, 2005, p. 30$)^{72}$, que viria a ser um órgão de grande importância na política profissional. Em sua fundação, a participação dos professores e engenheiros politécnicos foi significativa. "Os Mackenzistas não participaram do evento e só passaram a freqüentar a instituição de modo expressivo após o movimento constitucionalista de 1932." (FICHER, 2005, nota 23, p. 168).

\footnotetext{
${ }^{71}$ Nascida da revista The Architectural Review, a Pencil Points, surgida em 1920, tornou-se pioneira na divulgação do Movimento Moderno em Arquitetura.

72 A fundação do Instituto de Engenharia foi noticiada pelo jornal O Estado de São Paulo no dia 16 de fevereiro de 1917, na p.5, como tendo acontecido na véspera.
} 
O Instituto de Engenharia tinha entre seus objetivos, definidos em seu primeiro estatuto: "A regulamentação do exercício da profissão por meio de leis, avisos ou instruções, no sentido de ser assegurado, tanto quanto possível, aos engenheiros diplomados pelas escolas reconhecidas oficialmente do país ou do estrangeiro o exercício da profissão (...) (FICHER, 2005, p. 178).

A importância do Instituto era tão grande que ele chegou a se posicionar em questões como a entrada do Brasil na Primeira Guerra Mundial e sobre a participação na Revolução Constitucionalista de 1932.

Bem mais tarde, em 13 de maio de 1930, seria formado, o Instituto Paulista de Arquitetos (IPA) ${ }^{73}$, em atendimento à resolução do $3^{\circ}$ Congresso Pan-Americano de Arquitetos, que acontecera em 1927 em Buenos Aires, segundo a qual "os arquitetos de cada país (deveriam) (...) agrupar-se em uma única sociedade nacional”, com as "filiais necessárias". O Instituto Paulista foi idealizado para associar-se ao Instituto Central. ${ }^{74}$ Desapareceria em 1937, mas no início foi bastante dinâmico, sob inspiração de Christiano Stockler das Neves, o que acabou por imprimir maior ênfase ao aspecto artístico da atividade de arquiteto à entidade.

No Instituto de Engenharia também existia uma Divisão de Arquitetura. Assim, no final dos anos 1920, havia em São Paulo dois grupos de arquitetos diplomados, que também tinham atuação política: o da Divisão de Arquitetura do Instituto de Engenharia, liderado por Alexandre Albuquerque e formado predominantemente por politécnicos, e aquele do IPA, de composição mais heterogênea, com grande número de egressos do Mackenzie e seguindo as orientações de Stockler das Neves.

Stockler das Neves, então diretor do curso de engenheiro-arquiteto da Escola de Engenharia do Mackenzie, preconizava o projeto arquitetônico como a única atividade a que os arquitetos deveriam se dedicar, talvez pelo fato de haver estudado nos Estados Unidos, onde já estavam separadas as atividades de construção e de projeto. Ele era contrário a que arquitetos e engenheiros tivessem as mesmas competências e mesmo contra o emprego do título composto de "engenheiro-arquiteto": "Nós, architectos, que já não toleramos que o engenheiro civil faça architectura, apezar de conhecer um dos seus ramos - a construcção (...) "(Revista Architectura e Construcções, set. 1929, p.15). Ele considerava a arquitetura não um ramo da engenharia, mas como arte, superior às demais. $E$ aconselhava que seu ensino se

\footnotetext{
${ }^{73}$ Sobre o ensino da arquitetura e a organização profissional, ver Ficher, 2005, p.175-199.

${ }^{74}$ Os arquitetos do Rio de Janeiro fundaram, em janeiro de 1921, o Instituto Brasileiro de Arquitetos. Em 1922, uma dissidência formou a Sociedade Central de Arquitetos. Em 1924, as duas foram unificadas no Instituto Central de Arquitetos, ICA, renomeado Instituto de Arquitetos do Brasil - IAB - em 1935. (FICHER, 2005, p. 181).
} 
desse nas escolas de belas artes e não nos institutos politécnicos. (FICHER, 2005, p. 243) Ele coloca:

Effectivamente, pretender tornar a arte scientifica ou industrialisal-a, com a estandardização, fazel-a apenas utilitária, é uma cousa tão absurda que só pode occorrer aos que não estimam, não sentem a sua belleza, não possuem emotividade, revelando ausência de alma. (...) Ruskin dizia que não há normas e modelos para as producções de uma grande arte porque assim, esta deixaria de existir para se tornar uma manufactura. (...) Quer esse revolucionário da arte "scientífica" que o architecto seja ainda mais scientífico do que o engenheiro, para poder recuperar seu importante papel no mundo. Não nos consta que o architecto, nos grandes paizes, tivesse, jamais, perdido sua autoridade profissional. Pelo contrário, vemol-o cada vez mais prestigiado nas nações que estimam, de facto, a arte. (...) No Brasil, os architectos não perderam aquella autoridade por uma razão muito simples: ainda não a ganharam. (...) Jamais acceitaremos aqui o absurdo de se transformar a architectura em sciencia. (Revista Architectura e Construcções, agosto de 1930, p.5-6)

Porém, onde Stockler das Neves "via nobreza, o senso comum da época via apenas um plebeu bem convencional; mesmo que diplomado, o portador do título de arquiteto continuava identificado com um desenhista de fachadas e plantas (...) sem a deferência social outorgada aos engenheiros por seu alegado domínio da técnica." (FICHER, 2005, p. 243-4). Não poderia ser de outra forma, já que era a época da valorização do saber técnico e a arquitetura poderia ter várias formas, seguir vários estilos, desde que adaptada às novas tecnologias. A ênfase era na técnica utilizada.

O pioneiro na dedicação exclusiva a projetos seria Rino Levi, que se diplomara em Roma em 1926 e desde 1928 possuía uma pequena construtora em São Paulo. Em meados da década de 1930, passou a se dedicar exclusivamente a projetos completos de execução e à fiscalização dos mesmos, tornando-se um profissional liberal. Serviria de modelo aos jovens arquitetos. O modo de atuação preconizado por Stockler das Neves viria através de um arquiteto modernista.

Por volta de 1928 , seguindo as resoluções do $3^{\circ}$ Congresso Pan-Americano de Arquitetos, e sob a influência da Escola Nacional de Belas Artes - ENBA - do Rio de Janeiro, os arquitetos da Divisão de Arquitetura do Instituto de Engenharia criaram o curso de arquitetura da Escola de Belas Artes de São Paulo.

Havia vários temas polêmicos em discussão, entre eles a questão da obrigatoriedade do diploma para o exercício da profissão e a do predomínio dos politécnicos em 
determinadas áreas do mercado de trabalho. Realmente, comparando-se os engenheiros-arquitetos da Politécnica e os do Mackenzie, os politécnicos compareciam com as obras de vulto, públicas ou privadas, os cargos públicos, estando sempre em maior evidência que os mackenzistas. Havia ainda a questão das atribuições profissionais de arquitetos e engenheiros civis e a procura por um ensino autônomo de arquitetura.

"Do ponto de vista do prestígio social, os graduados da Politécnica, a escola oficial, iriam sempre desfrutar de preeminência em relação aos do Mackenzie, a escola confessional." (FICHER, 2005, nota 18, p. 168).

Quanto à hegemonia dos politécnicos, houve mesmo uma moção do IPA "contra a exclusiva nomeação de ex-alunos da Escola Politécnica de São Paulo para cargos públicos", aprovada em assembléia geral em 28 de julho de 1931 (Instituto Paulista de Arquitetos, 1930/1933, p.54-56 apud FICHER, 2005, p. 183) ${ }^{75}$.

Porém, quanto à regulamentação, ambas as entidades defendiam a obrigatoriedade do diploma para o exercício da profissão e a diferenciação legal entre as atribuições dos arquitetos e dos engenheiros. Tal distinção levaria, ao final, no entender das entidades, à separação entre projeto e construção e à atividade estritamente liberal do arquiteto.

Aliás, tais discussões não aconteciam apenas a nível nacional: no número 12 da revista Architectura e Construcções (julho de 1930, p. 3-7), aparece um artigo sobre o IV Congresso Pan-Americano de Arquitetos que se realizara no Rio de Janeiro em junho de 1930. Um das teses discutidas foi sobre a regulamentação profissional, para que os poderes públicos dos diversos países sancionassem leis para regulamentar a profissão e definir as atribuições. E ainda garantir os direitos autorais nas obras de arquitetura.

Foi muito grande o engajamento de engenheiros e arquitetos, tanto do IPA quanto do Instituto de Engenharia na Revolução de 1932. Após a revolução, houve união inédita da classe. Significativo deste aspecto foi a incorporação dos mackenzistas ao Instituto de Engenharia e o progressivo desaparecimento do IPA. (FICHER, 2005, p. 188) Esta

\footnotetext{
${ }^{75}$ Mas, provavelmente não havia tanta polarização, já que a Revista Architectura e Construcções tinha, ao menos desde seu sexto número (jan. 1930), entre seus colaboradores Alexandre Albuquerque, do Instituto de Engenharia e professor da Politécnica e outros professores da mesma escola, como Augusto de Toledo e Antônio Ippolito; e, ao mesmo tempo, Christiano Stockler das Neves, do Instituto Central de Arquitetos e outros professores da Universidade Mackenzie, como Francisco Kosuta. Aliás, ambos, Albuquerque e Stockler das Neves, foram retratados em caricaturas na "Galeria dos nossos Engenheiros e Architectos", publicada na revista.
} 
união propiciou um avanço na luta pela regulamentação profissional a nível federal. Em dezembro de 1933, o Decreto Federal n.23.569 definiria a doutrina de proteção ao título acadêmico, tornando o exercício da profissão restrito aos diplomados, mas deixava indefinida a diferenciação entre as atribuições de engenheiros civis e arquitetos.

\subsection{Alguns arquitetos do início do século}

\subsubsection{Um professor da Politécnica: Victor Dubugras}

Nascido em Sarthe, na França, Victor Dubugras (1868-1933) foi criado na Argentina, onde começou a prática arquitetônica no escritório de Francisco Tamburini. Chegou a São Paulo provavelmente em 1891.

Ligou-se à Politécnica já no ano de sua fundação, com um trabalho relacionado às correntes mais renovadoras da época. Ali lecionou até 1926. Victor Dubugras proporcionou a toda uma geração de engenheiros e arquitetos os elementos básicos de estética e composição arquitetônica, além das técnicas de desenho e aquarela. Entre 1894 e 1926, quase todos os estudantes da Politécnica, qualquer que tenha sido a especialização posterior, passaram por suas aulas: desenho de arquitetura fachadas e plantas -, perspectiva e o traçado de sombras. (FICHER, 2005, p. 82)

Dubugras recebeu a medalha de prata na Exposição de Saint Louis em 1904, entre outros vários prêmios. Foi um dos fundadores da Sociedade dos Arquitetos e Engenheiros de São Paulo e do Instituto de Engenharia. (FICHER, 2005, p. 83)

Trabalhou no escritório de Ramos de Azevedo e depois no Departamento de Viação e Obras Públicas (D.O.P.), no período de 1896 a 1902. São Paulo vivia uma época de impulso ao ensino primário, sendo aplicadas as recomendações de Rui Barbosa. Além das escolas, outro elemento considerado indispensável à ordem pública era a cadeia. "Dir-se-ia que vivíamos sob o signo café-escolas-justiça, tantas foram as residências de fazendeiros, os edifícios para escolas e as cadeias que Dubugras construiu." (MOTTA, 1957, p. 50) Entre as escolas e cadeias, estão as de Botucatu, Amparo, Espírito Santo do Pinhal, Itapira, Piracicaba, Mogi Mirim, São Manoel e São Carlos.

Em algumas casas de câmara, como a de Santa Bárbara, a solução adotada estava próxima dos padrões ingleses do Movimento Arts and Crafts, seguindo os preceitos de 
Ruskin e William Morris sobre a verdade construtiva. (REIS FILHO, 2005, p. 19-20). Utilizava o tijolo aparente com técnicas refinadas, similares às britânicas. Este material seria bastante utilizado na arquitetura paulistana do início do século aos anos 1920. Nestas casas de câmara, o destaque era o grande salão do júri, que se localizava no pavimento superior, em local de destaque, geralmente com um grande balcão para 0 exterior. Pé direito alto, com certa monumentalidade, a atração era o madeiramento do telhado, bastante elaborado, com o tirante metálico exposto. O destaque é a Câmara de São Carlos. Para Toledo (1985, v.1, p.46), o que caracterizaria estes edifícios seria sua funcionalidade, o aproveitamento integral do espaço edificado.

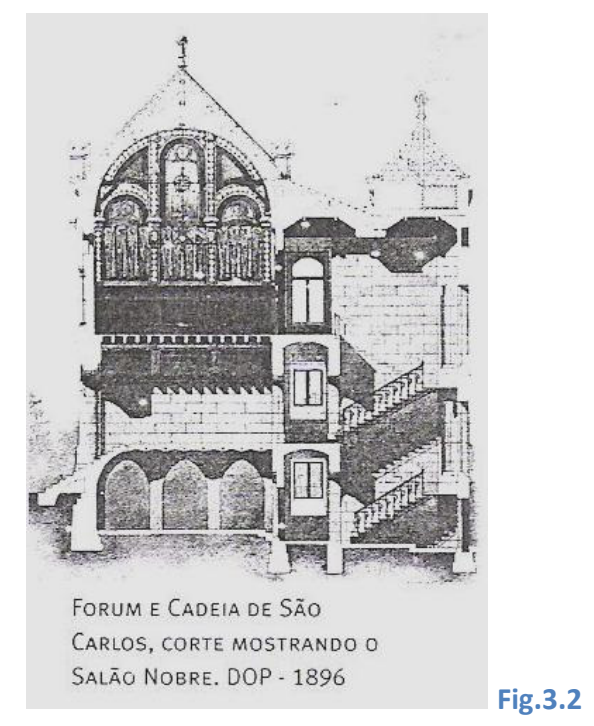

Ainda para Toledo (1985, v.3, p.5-6), estas obras públicas, inserem-se num movimento que alguns críticos chamariam medievalismo ou "gothic revival", que segundo ele teria se caracterizado por uma revisão dos processos construtivos e revalorização dos materiais. Na verdade, ele se refere ao movimento Arts and Crafts, pois faz uma distinção entre estas obras e aquelas do Neogótico, que ele associa ao ecletismo, e se caracterizaria pela gratuidade de formas e artificialismo dos materiais, muitas vezes com sacrifício do programa.

Este "medievalismo" de Dubugras procuraria a revalorização dos aspectos "tectônicos" do edifício, em oposição ao mascaramento das estruturas, em voga no século XIX. Tais obras públicas formariam um conjunto coerente e facilmente identificável. (Toledo, 1985, v.3, p.5-6)

Neste aspecto, Dubugras filia-se totalmente ao Arts and Crafts, não apenas por se utilizar com maestria de uma técnica - o tijolo aparente - tradicional do movimento, 
mas por fazer uma arquitetura orgânica, onde os vários elementos se relacionam, são interdependentes, para se obter a máxima eficiência. Como na arquitetura gótica. A "verdade construtiva" nada mais é que demonstrar claramente como um edifício foi pensado e executado. Como no Gótico, o projeto inicia-se na planta, e a volumetria é concebida a partir dela. Os aspectos estruturais devem ser ressaltados e uma máxima simplicidade é almejada, todo o supérfluo deve ser eliminado, apenas o essencial mantido. E para cada técnica, existe sua linguagem específica; para cada material, a melhor forma: "(...) Sabemos que a escolha dos materiais corretos para se construir deve vir antes e que quase com certeza se provará serem os materiais disponíveis no local (...) e que conceber formas adequadas a eles provavelmente resultará em um todo perfeito a que devemos almejar." (PARKER, 1986, p. 38)

Esta honestidade no trato com as diversas técnicas construtivas é demonstrada mais uma vez na Estação de Mayrink onde, segundo Pujol Júnior (Revista Politécnica, julho-agosto de 1908, n.22, p. 186-190), Dubugras consegue "convencer da possibilidade de fazer bella uma obra de cimento armado os descrentes da esthetica do novo systema de construcção, os que acreditam que o único meio de tornar attrahente uma obra executada com esse material é esconder a natural rigidez geométrica das fórmas que decorrem da construcção mesma, fazendo-a desapparecer sob successivas camadas de emboço e reboco (...). É que é effectivamente difficil escapar à insensível repetição das velhas normas de composição, adaptar-se a um material inteiramente novo, seguindo unicamente as indicações do bom senso, procurar uma composição geral e uma decoração inspiradas na própria construcção (...).

Além do contato com as correntes britânicas através das revistas, Dubugras casou-se com uma jovem escocesa. Sua própria residência à Alameda Joaquim Eugênio de Lima, construída em 1896, é uma construção surpreendentemente austera para um arquiteto que faria residências contidas, mas muito mais refinadas. Ele a classificava como cottage. A casa apresentava apenas dois elementos ornamentais decorativos próximos ao telhado. Todas as outras eram soluções derivadas de elementos construtivos. Lembra muito a Red House, a residência de William Morris, com os tijolos aparentes, a grande chaminé e as janelas com arcos abatidos colocadas livremente. As fachadas diferem entre si. 


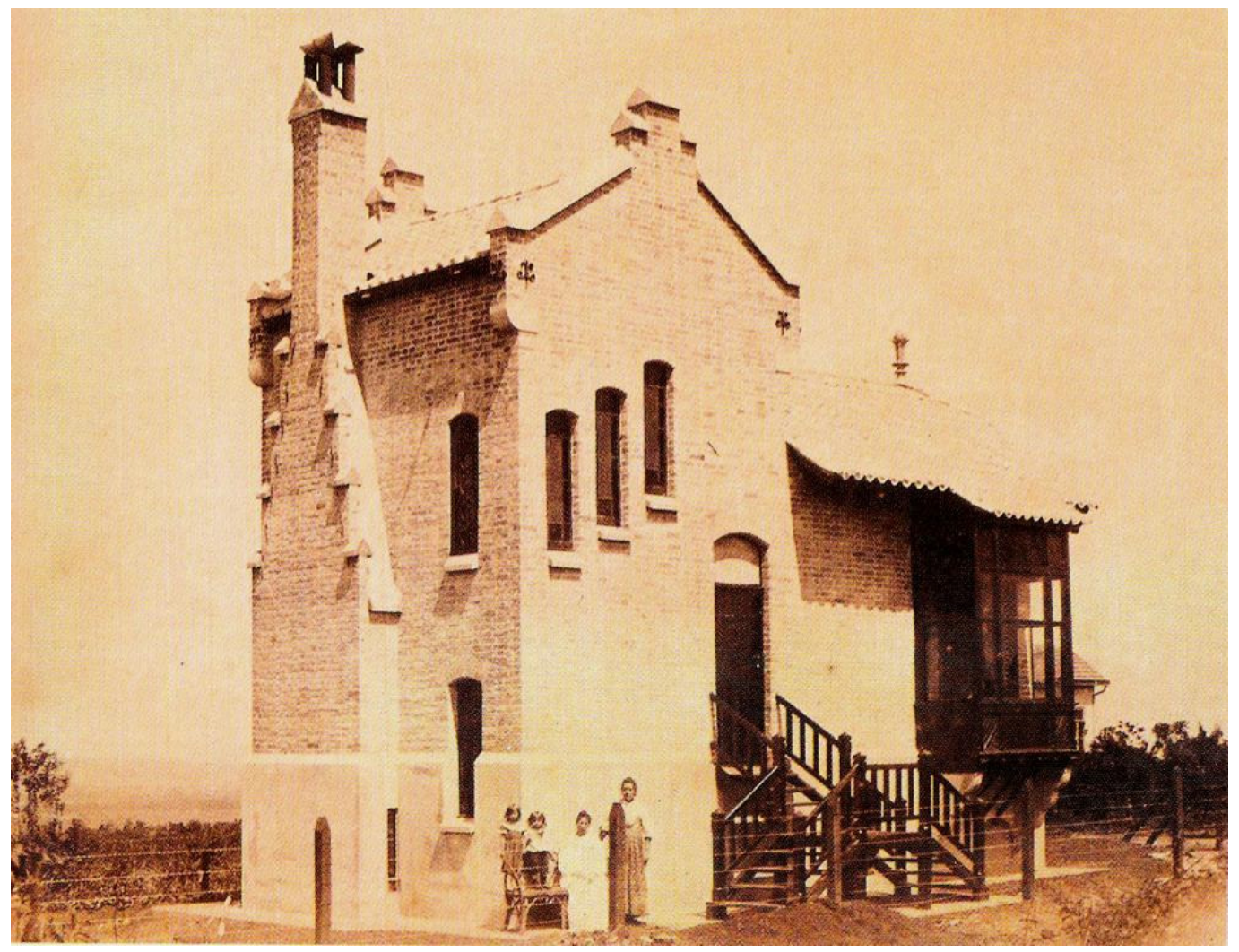

Fig.3.3 Casa do arquiteto

Victor Dubugras adotou o Art Nouveau por volta de 1902 , na Vila Uchoa, na Rua Caio Prado esquina com Rua Augusta. Alguns detalhes ainda eram do Arts and Crafts, como a balaustrada da varanda sobre a porta de entrada e a decoração do saguão. Mas, outros detalhes são claramente Art Nouveau. Esta linguagem foi utilizada com algumas descontinuidades até por volta de 1914. (REIS FILHO, 2005, p. 53)

$\mathrm{Na}$ Vila Uchoa, as curvas da rampa de acesso e a cobertura do automóvel modificavam o edifício e estabeleciam uma transição entre a casa e o jardim. No interior, ele criou e supervisionou a pintura mural, o desenho dos caixilhos, dos móveis, vitrais e a iluminação natural e artificial. Dubugras, sempre que possível, projetava todos os detalhes da casa, desenvolvendo o conceito da obra de arte total. $\mathrm{Na}$ Vila Uchoa, o grande hall unifica os dois pavimentos, através do trabalho em madeira da escada e galeria, das pinturas murais e da iluminação. Ele mostra elegância na utilização dos materiais e nos detalhes construtivos e domínio do espaço.

Existe um artigo de Augusto de Toledo na Revista Politécnica (jan. 1905, n.2, p. 75-7), sobre a Vila Uchoa, em que ele descreve a casa:

(...) conjuncto (...) agrada sobretudo pela harmonia do membramento. E apezar do movimento produzido pelos corpos avançados, torreão, bow-windows não fica destruída nem prejudicada a bella simplicidade 
que reina em toda obra. (...) Todo o edifício dá a quem se vae approximando a boa impressão de paz acolhedora, de alegria tranquilla que são os verdadeiros caracteres das casas de moradas. (...) Interiormente um grande hall pavimentado de mosaico veneziano, com decorações de pinturas que symbolisam as differentes épocas da arte, abrangendo dois pavimentos e formando uma bonita galeria na altura do primeiro andar, constitue a peça dominante e nobre da moradia. (...) As pinturas deccorativas, arte nova, em grande parte inspiradas na flora brasileira, forma executadas sob croquis do próprio architecto. (...) Em toda a construcção o Sr. Dubugras deu inteira preferência às fórmas de instructura real. As disposições constructivas e a natureza dos materiaes são francamente accusadas, lealmente postas em evidência: o que é supporte está effectivamente caracterisado como supporte; o que parece parte supportada funcciona verdadeiramente como tal; o granito é granito mesmo; os revestimentos de argamassa não illudem; e toda peça de madeira lá está com sua cor própria, tendo apenas uma camada protectora de verniz transparente. Applaudimos convicto esta maneira de construir tão honesta e racional. $O$ architecto tem de cingir-se aos recursos de que dispõe, e às fórmas impostas pela estabilidade e resistência dos materiaes. Ladear difficuldades ou simular riquezas com fingimentos e artifícios é, a nosso ver, cair em uma arte viciada e mentirosa.

A descrição de Toledo está impregnada dos princípios de Ruskin, para quem, a falsidade na arquitetura seria considerada sob alguns aspectos: o primeiro, a sugestão da estrutura ou suporte que não fosse verdadeira e, segundo, a pintura de superfícies que representassem outro material que não aquele realmente utilizado. (RUSKIN, 1907, p. 34-5)

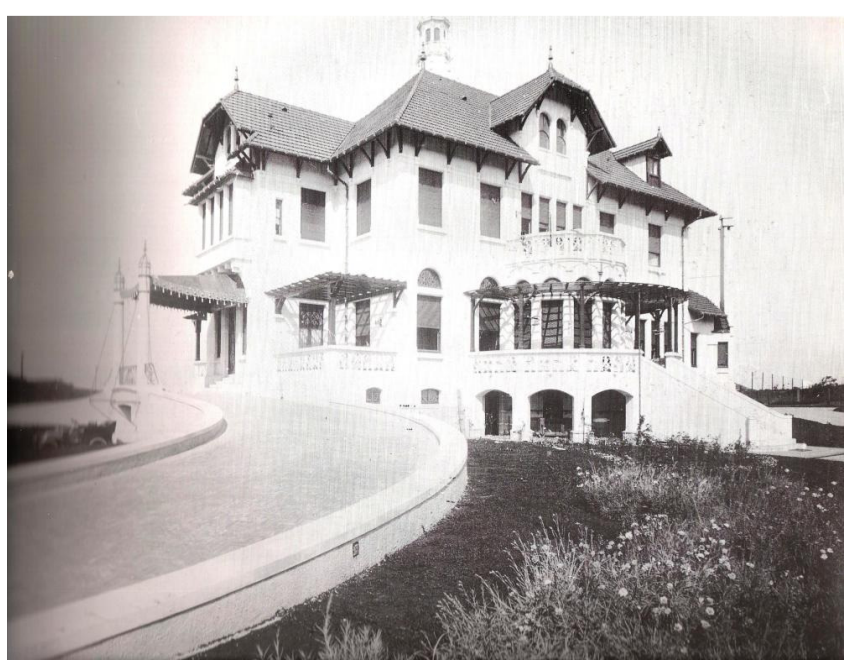




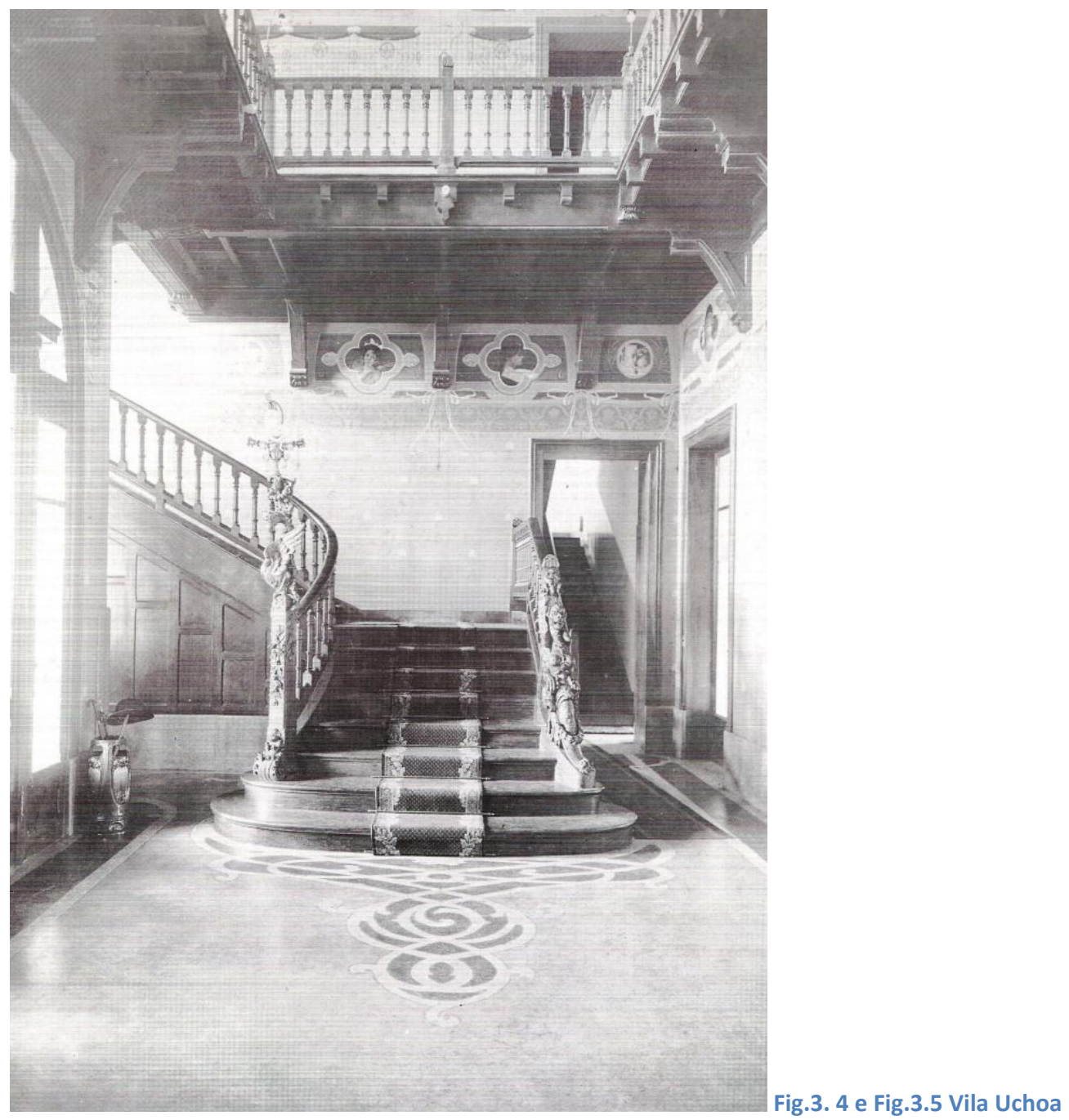

E a simplicidade, o despojamento e o sentido de unidade das obras de Dubugras ficam claros neste interior da Vila Nenê (1910).

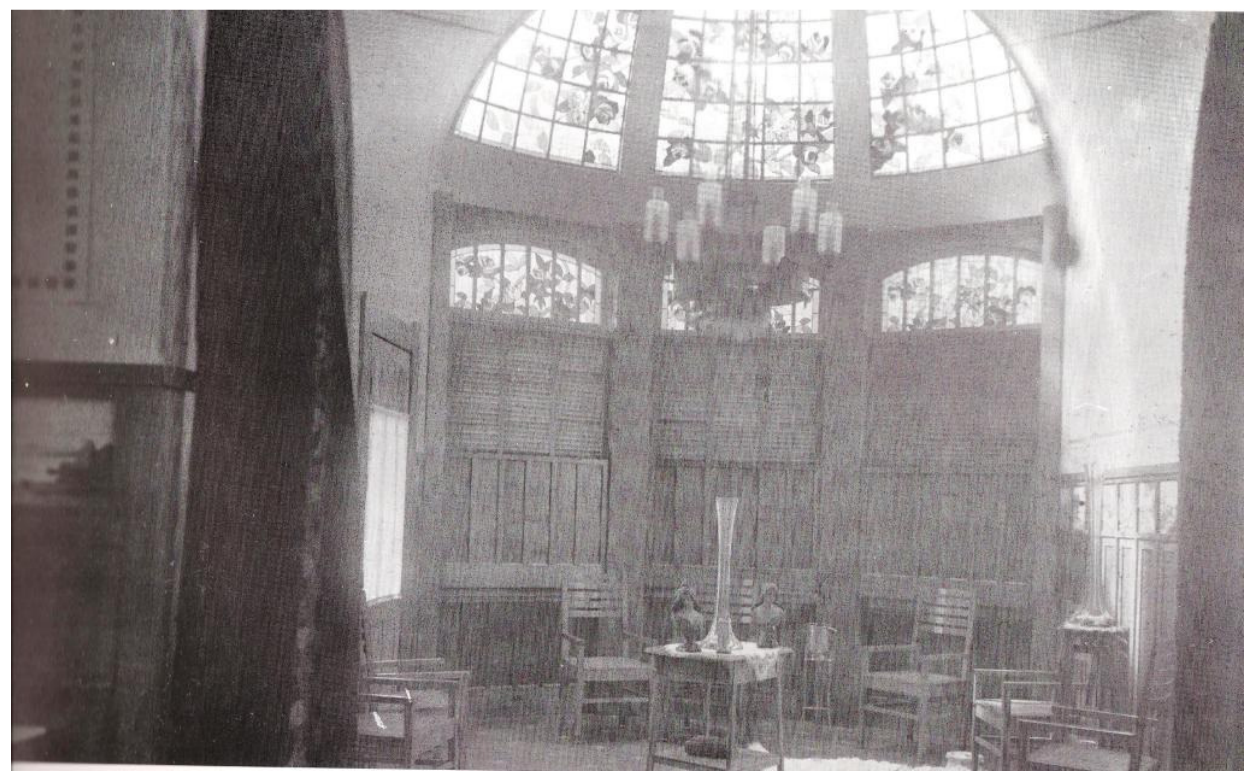


Esta racionalidade na utilização dos materiais é salientada em outro artigo - sem autoria definida - da Revista Politécnica (março 1905, n.3, p. 155-9), em que se descreve a Vila $M$. de Medeiros: "uma composição inteiramente livre, rebelde às normas estylísticas. (...) a decoração baseia-se única e exclusivamente numa combinação racional de materiaes de tons differentes. Desapparecem todos os ornatos supérfluos, para que o membramento mais se accentuasse, para que toda a serenidade da estructura se manifestasse vivamente accusada, e servindo de pretexto a uma decoração simples e racional". As cores, na medida do possível, deveriam ser aquelas dos materiais, deixados sem acabamento - tijolo, pedra, madeira. Os materiais da natureza. A estrutura se "impunha" e os ornamentos utilizados eram poucos e sempre coerentes com os outros elementos. A utilização apenas do acabamento e das cores inerentes aos materiais no tratamento exterior dos edifícios era outra característica dos projetos do Arts and Crafs.

Na residência Horácio Sabino, por volta de 1903, a "casa confundia-se com o parque e a luz penetrava por grandes vitrais, ornamentados com desenhos de rosas, dando a impressão de que o jardim penetrava no interior" (MOTTA, 1957, p. 51) Havia continuidade entre a casa e seu entorno.

Às vezes, Dubugras sacrificava a lógica construtiva em favor da solução plástica, como nesta residência, em que uma coluna é colocada no meio de um arco.

A obra de Dubugras é racionalista porque procura sempre a objetividade nas soluções adotadas. A técnica moderna é vista como algo a ser destacado e as técnicas tradicionais a serem revistas sob novos critérios.

Ele utiliza poucos ornamentos, sempre integrados à composição, quase sempre decorrentes do processo construtivo. Os estilos eram secundários. O mais importante era a técnica construtiva e a maneira de se projetar. O projeto decorria das necessidades relativas às novas maneiras de se viver, de novas noções de conforto. Estas eram as questões relevantes.

A partir de 1914, Dubugras passa a praticar o Neocolonial. Algumas casas de 1915, em Santos, seguem a estética, como a de Saturnino de Brito. 


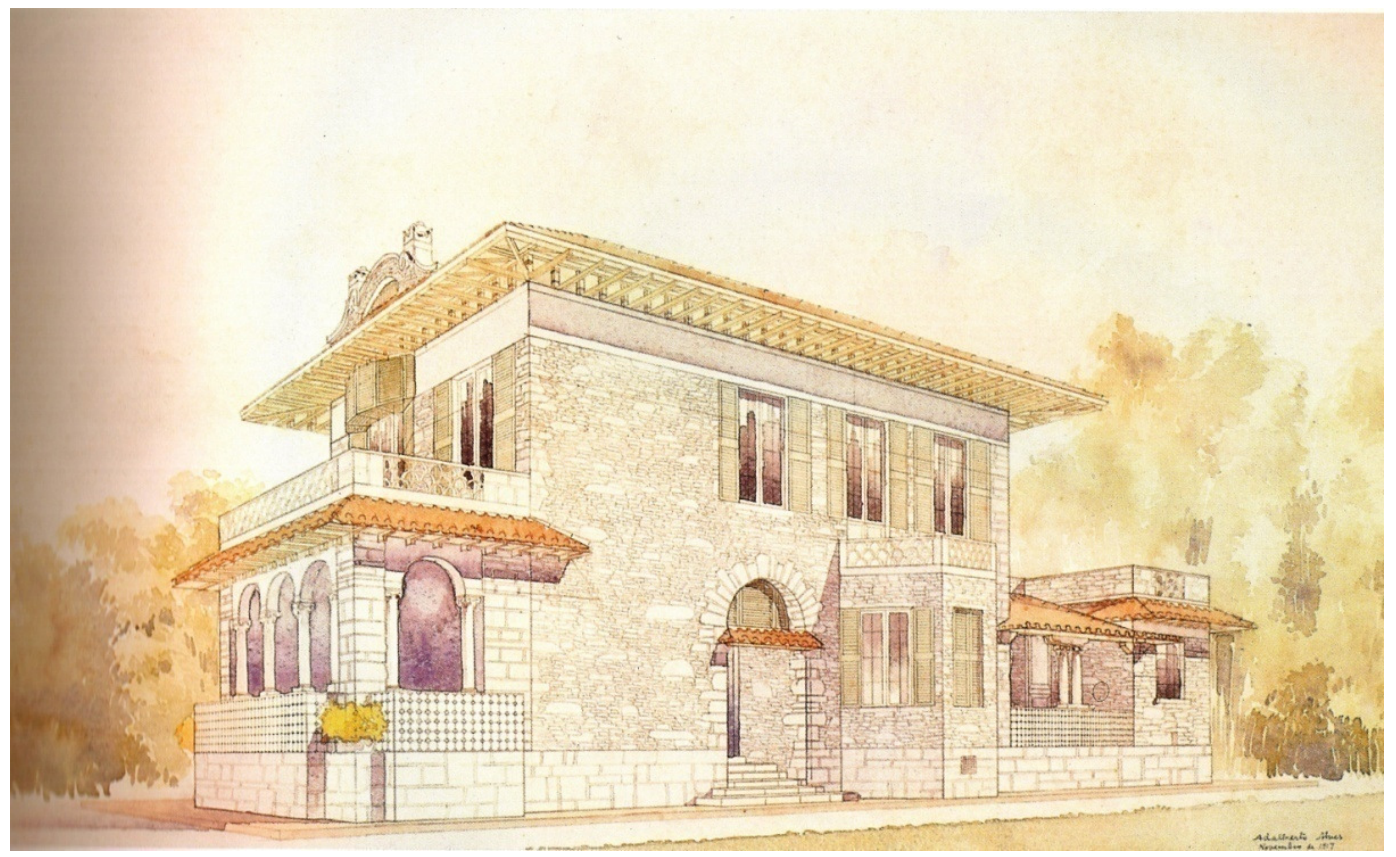

Fig.3. 7 Casa de Saturnino de Brito

E ainda, vinculada ao Neocolonial, a casa da Baronesa de Arari.

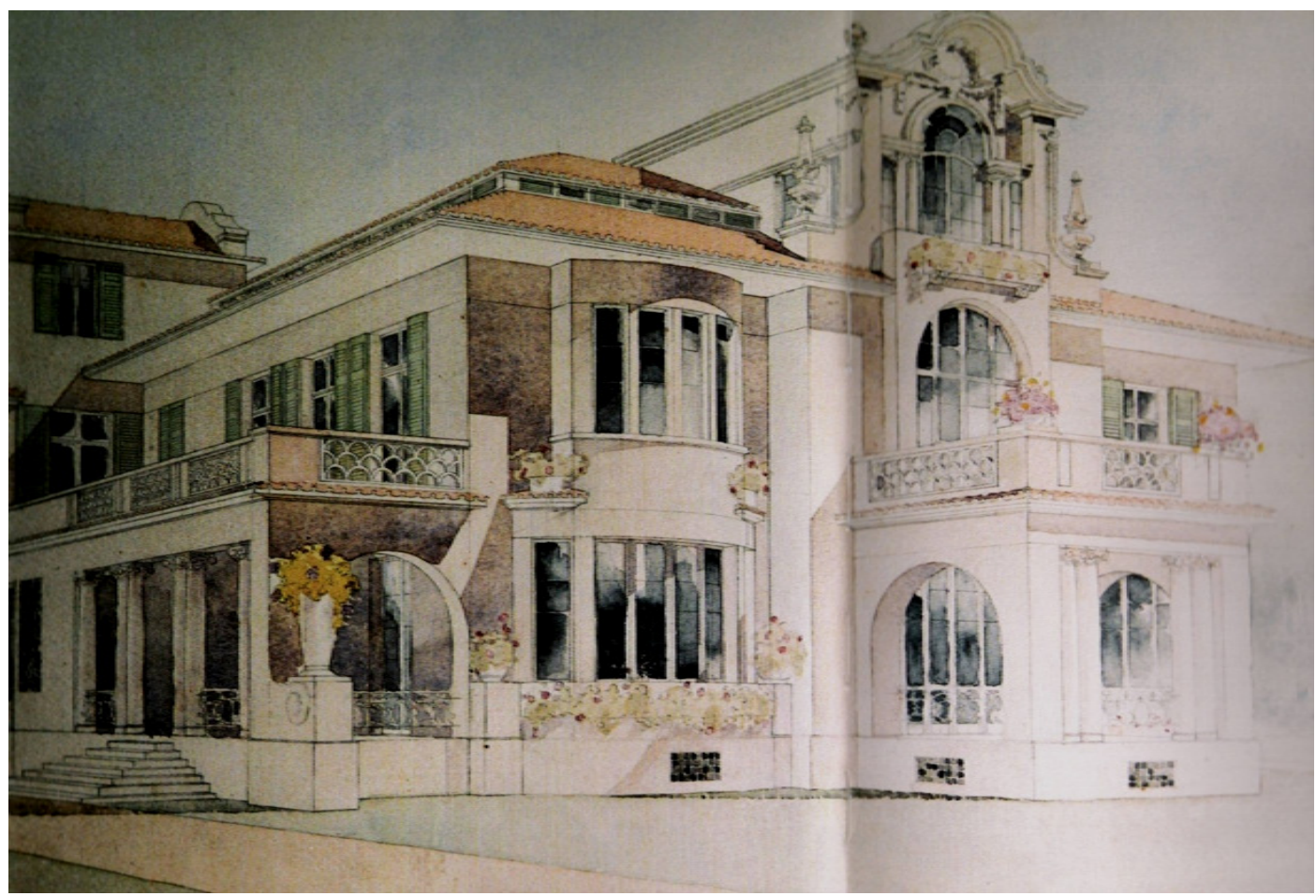

Fig.3.8 Casa da Baronesa de Arari

O Neocolonial de Dubugras não se fazia apenas com volutas e frontões. Apesar de existirem, eles não pareciam ter sido adicionados simplesmente para a utilização dos 
estilemas da nova linguagem. Faziam parte da composição. Seu Neocolonial não era simplesmente uma busca pelas formas da arquitetura tradicional. Era feito de paredes em tijolo aparente, de excelente acabamento, assentadas sobre embasamento em pedra, que não tinham correspondência na arquitetura do período colonial.

A versão muito pessoal de Dubugras foi difundida entre os arquitetos e popularizada em São Paulo: as "casas de tijolinhos". Tais casas não existiam na arquitetura colonial brasileira. Eram comuns na Inglaterra, foram muito utilizadas pelos arquitetos do Arts and Crafts e passaram aos Estados Unidos.

Como os melhores arquitetos do Arts and Crafts, Dubugras não transpunha simplesmente a arquitetura vernácula para suas obras. Ela servia de inspiração, mas era recriada.

Dubugras é mestre na adaptação dos edifícios ao local em que são implantados, através das formas e dos materiais. Como os pousos da Serra do Mar, que parecem sempre ter estado ali, tal a maneira como se integram à natureza circundante.

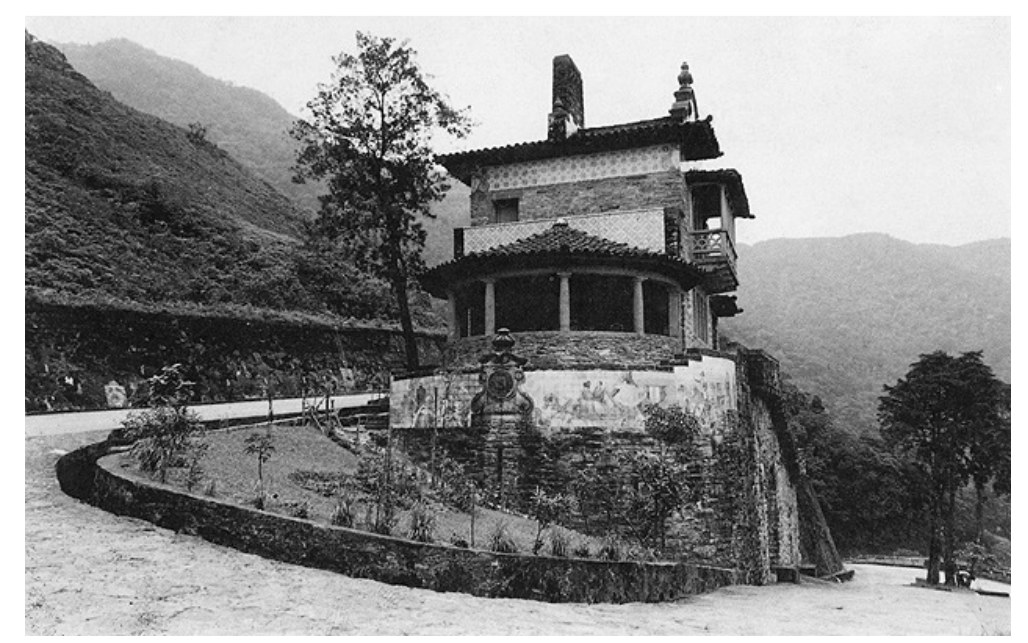

Fig. 3.9 Rancho da Maioridade (azulejos de José Wasth Rodrigues)

Nos anos 1920, Dubugras projetou duas residências para terrenos contíguos na Alameda Joaquim Eugênio de Lima. Uma das casas era construída em alvenaria de pedra e a outra em tijolos aparentes. Os fundos do terreno foram liberados para jardins - algo incomum à época - com a colocação dos serviços no porão, que aproveitava a declividade do terreno. Os detalhes eram resolvidos de acordo com a técnica construtiva escolhida, tijolo ou pedra. Neste caso, é possível constatar-se como as opções projetuais dependiam da técnica construtiva escolhida. 

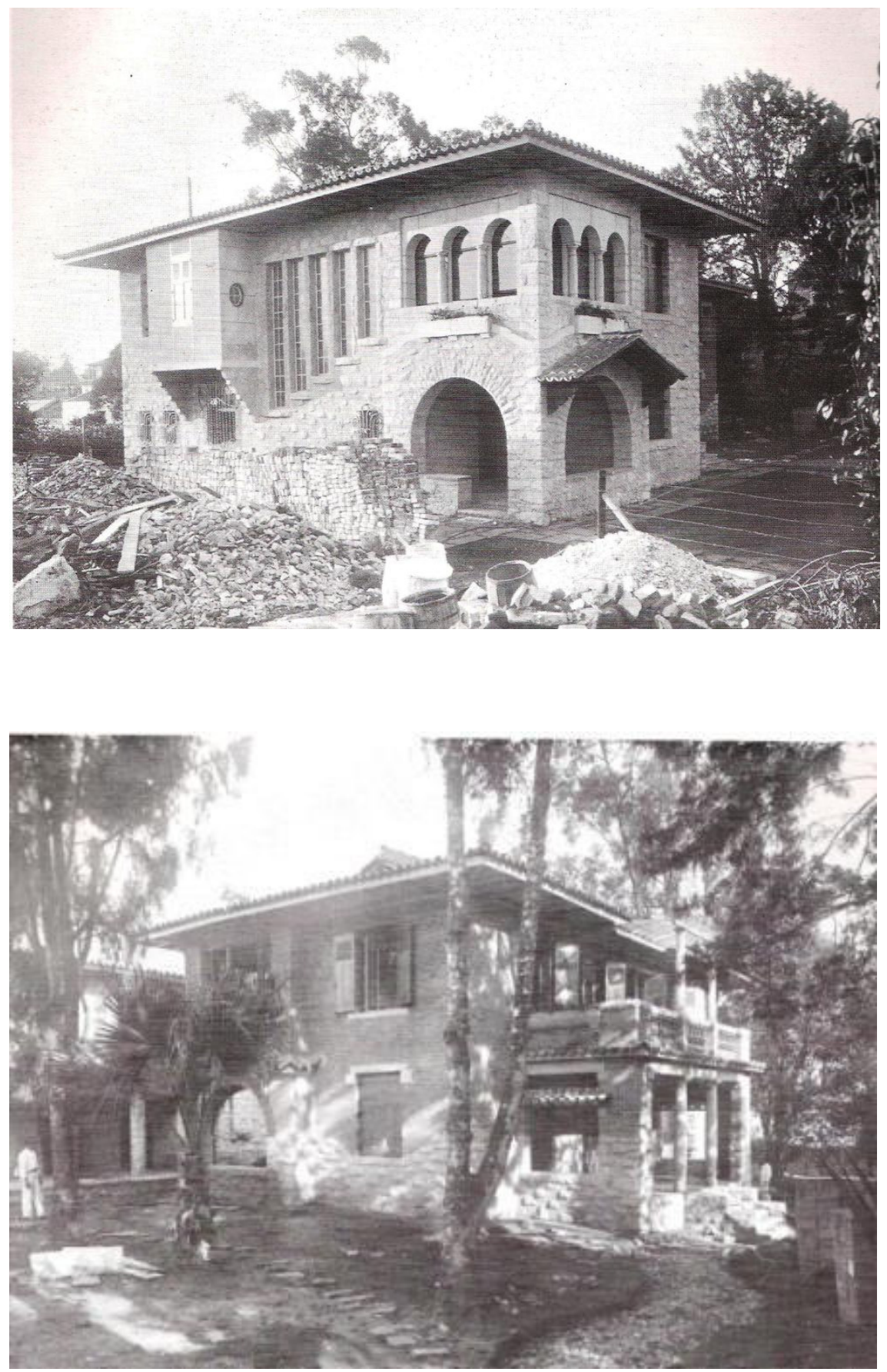

Fig.3.10 e Fig. 3.11 Residências na Alameda Joaquim Eugênio de Lima

Outra residência, em São José dos Campos, de 1921, assemelha-se muito a um bangalô, talvez porque seja uma das únicas residências térreas mostradas, com telhados não muito inclinados, chaminés, tijolos aparentes e arcos na varanda. 


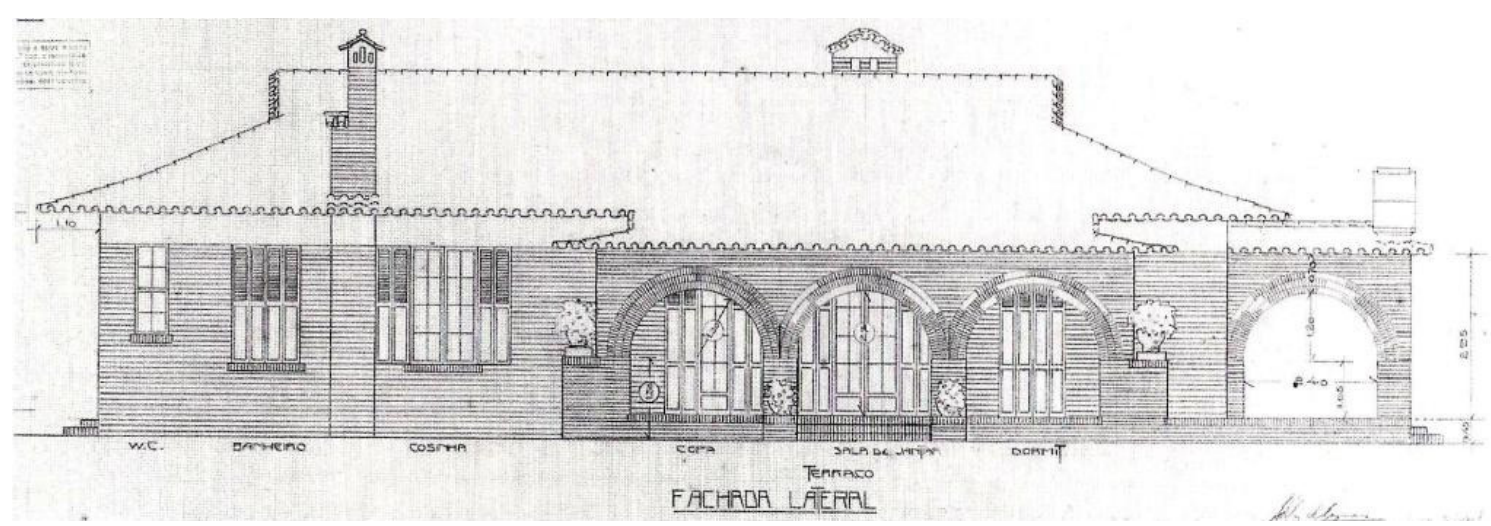

Fig.3. 12 Residência em São José dos Campos

A preocupação de Dubugras com o conforto, ao desenhar um fechamento para as empenas que possibilitasse a ventilação do telhado, pode ser vista em outra residência na mesma linha, um sobrado, com embasamento em pedra, sem data e sem localização, com detalhes muito bonitos, como a floreira e o guarda corpo da sacada.

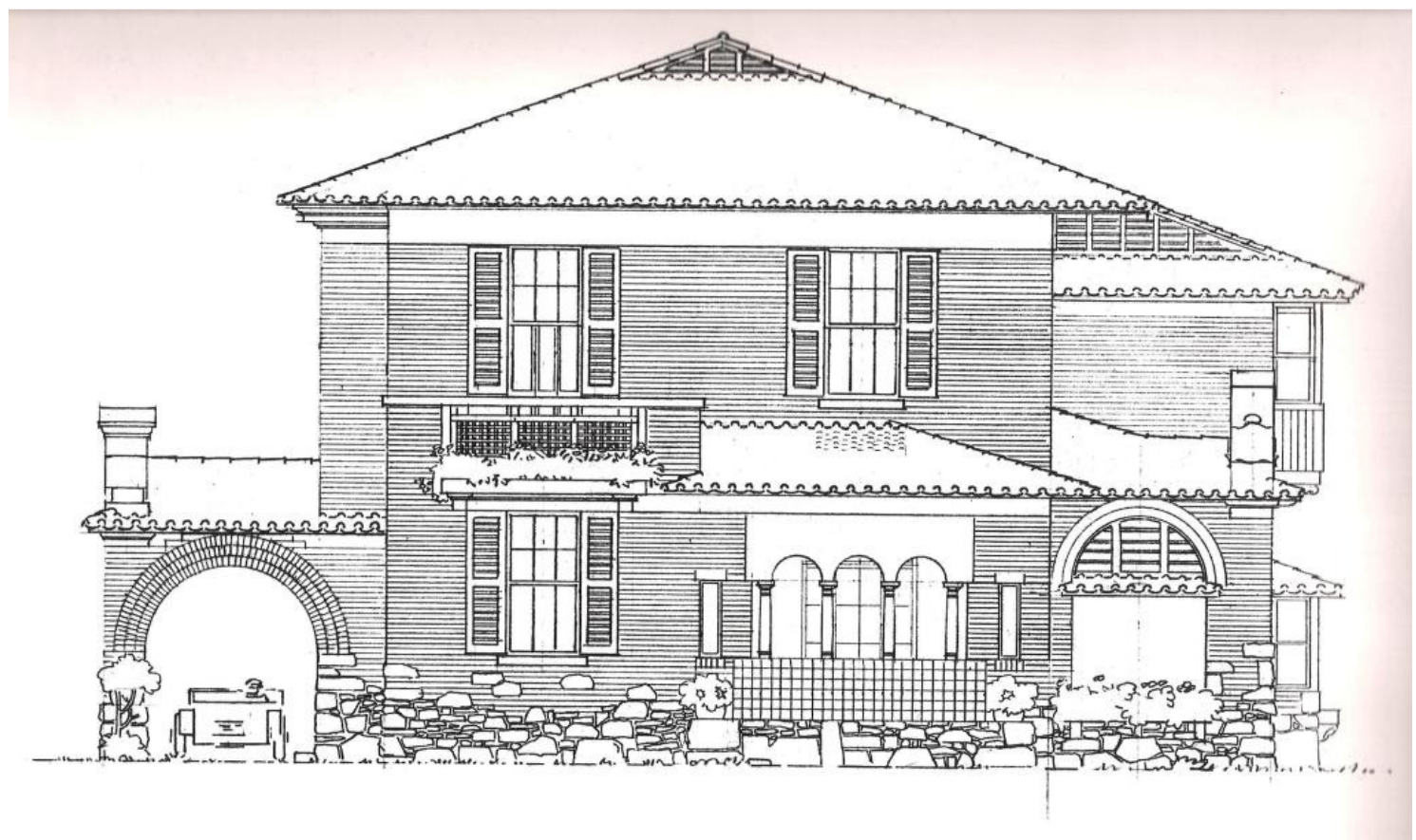

Fig.3. 13 Sobrado sem referências

As experiências anteriores de Dubugras com o uso do concreto em residências tiveram problemas de conservação no clima chuvoso de São Paulo. As estruturas de concreto e os revestimentos de argamassa sofreram fissuras e infiltrações. As casas em tijolos aparentes ou alvenaria de pedras e amplos beirais, pelo contrário, tiveram 
excelente conservação. As cintas de amarração em cimento, revestidas de argamassa, ficavam apenas no alto sob os beirais e assim estavam protegidas. (REIS FILHO, 1997, p. 81) O arquiteto utilizou não a técnica mais moderna, que na época ainda não estava desenvolvida o suficiente para ser utilizada no clima de São Paulo, mas aquela mais adequada à situação - a que estava disponível e se adaptava às condições existentes ${ }^{76}$.

$\mathrm{Na}$ época, a utilização de lajes de concreto em residências limitava-se ao piso dos banheiros do pavimento superior. Assim, não havia, mesmo nos sobrados, a necessidade de peças estruturais de concreto, como vigas e pilares. Eram utilizadas apenas as cintas de amarração. E as vigas, quando utilizadas, eram metálicas.

Os pisos do pavimento térreo eram executados quase sempre em madeira, e havia a necessidade de porões para evitar a umidade. Os pisos do pavimento superior e as escadas eram também executados em madeira e, assim, Dubugras criava grandes espaços com pé direito duplo e detalhes em madeira, como os parapeitos, os lambris nas paredes, os forros e até mesmo móveis. Formavam um conjunto bastante refinado. Nas casas mais sofisticadas, as características incluíam telhados com amplos beirais, chaminés, grandes vitrais junto às escadas e balcões em que o acabamento dos peitoris tinha pequenos arcos sobrepostos - com os eixos desencontrados -, detalhe provavelmente criado por Dubugras e que se tornou marca do Neocolonial. E alguns ornamentos barrocos que faziam referência à arquitetura tradicional. Dubugras construiu casas na Avenida Paulista, na Vila América e pelo menos uma casa no Jardim América.

No Jardim América, o projeto número 24.02.122/23.252, encontrado nos arquivos da Companhia City, de fevereiro de 1922, que consta como sendo de Mário Whately, é apontado como sendo de Dubugras (MOTTA, 1957, p. 53): uma casa em tijolos aparentes, grandes beirais, um grande balcão, o Neocolonial característico do arquiteto.

\footnotetext{
${ }^{76}$ Estes sistemas estruturais foram observados também em nossa pesquisa no arquivo da Companhia City.
} 


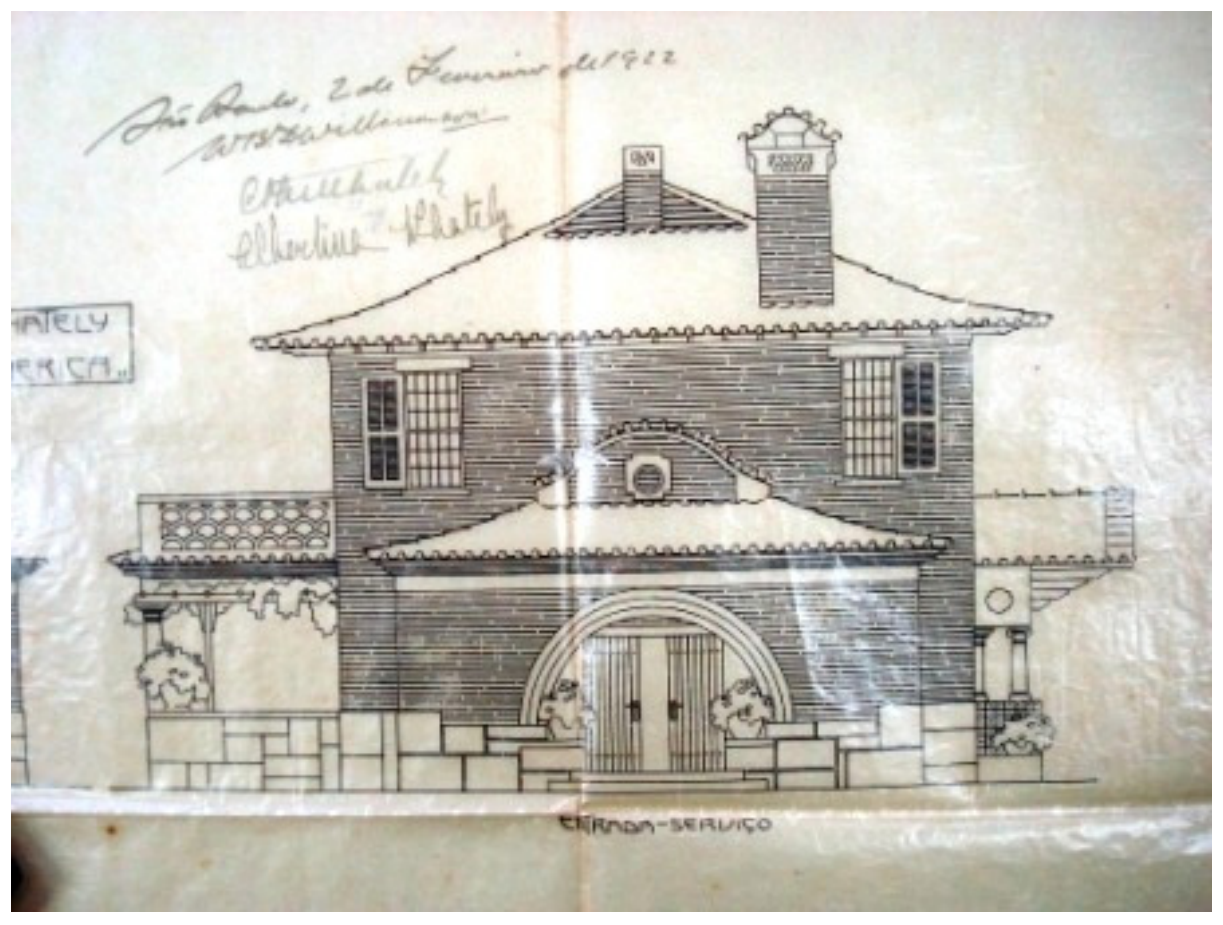

Fig.3.14 e Fig. 3.15 Residência no Jardim América

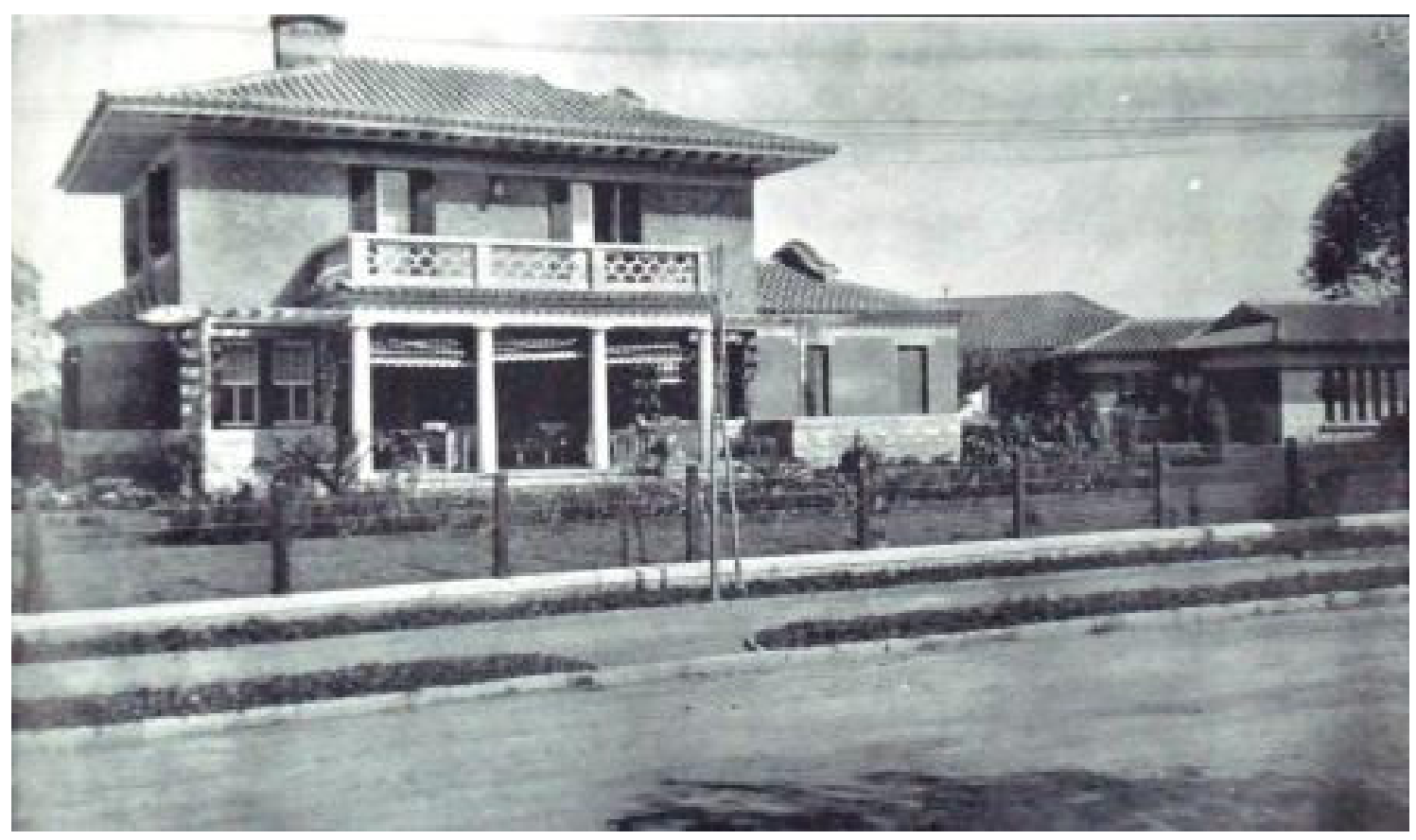

\subsubsection{George Henry Krug}

George $\mathrm{Krug}^{77}$ (1860-1919), filho de um alemão e de uma americana, nasceu em Campinas. Estudou na University of Pennsylvania entre 1883 e 1885, onde freqüentou

${ }^{77}$ Sobre George Krug, ver Ficher, 2005, p. 87-8 e Atique, 2007, p. 212-220. 
um curso especial de curta duração, não a graduação convencional da instituição, provavelmente porque já atuava com seu pai como construtor. Continuaria a trabalhar com ele, depois do retorno ao Brasil. Atuavam em São Paulo e construíram residências e outros edifícios como o Hospital Samaritano. Segundo Atique (2007, p. 217), a produção de Krug vinculava-se ao Queen Anne inglês, via Estados Unidos. Foi com um armazém inspirado nesta estética que Krug e seu pai receberam a medalha de prata na Exposição Internacional de Saint Louis, nos Estados Unidos em 1904.

Foi professor da Escola de Engenharia do Mackenzie College, função que deixou após ter ingressado na Escola Politécnica em 1904, como lente substituto. Após sua saída do corpo docente do Mackenzie, exerceu a função de fiscal residente da Universidade de Nova York junto ao Mackenzie até sua morte.

Trabalhou para o arquiteto Ramos de Azevedo, antes mesmo que este abrisse seu escritório e, provavelmente, Krug recebeu o apoio de Ramos para entrar na Politécnica.

Paralelamente à docência, Krug manteve a firma criada por seu pai, e após a morte deste associou-se a Antônio Garcia Moya, antigo colega no escritório de Ramos de Azevedo.

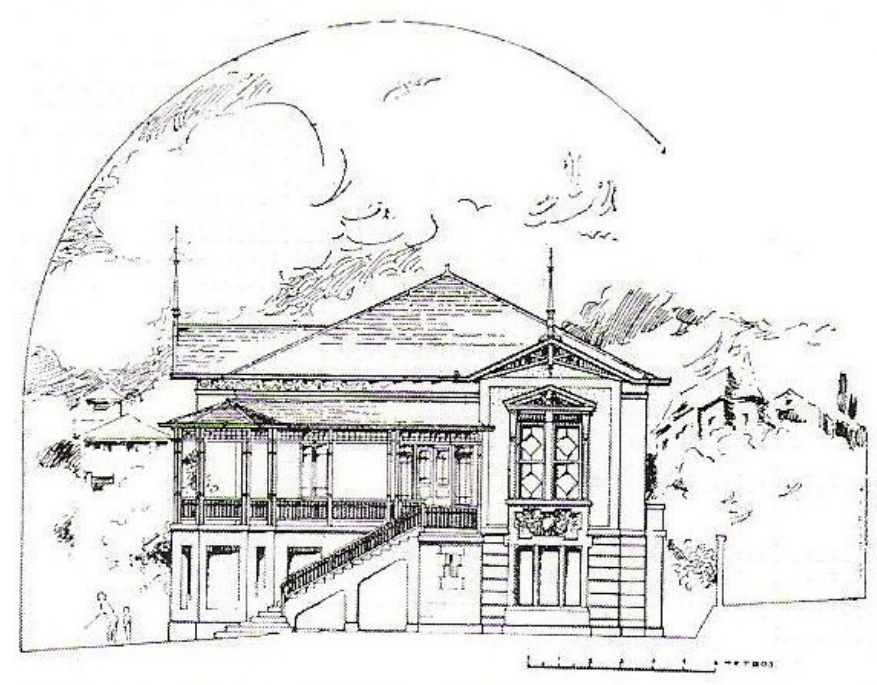

Fig.3.16 Projeto Vila Rogério Dauntre - Rua Maranhão - São Paulo, autor George Krug, publicada em 1911 na Revista de Engenharia.

A partir de 1916, quando tornou- se catedrático da Politécnica, Krug assumiu a direção das obras da nova catedral de São Paulo, função até então exercida por seu colega Maximiliano Hehl. Permaneceu nas obras da catedral até sua morte em 1919. 
Hehl fez parte da Sociedade de Arquitetos de São Paulo, fundada em 1911 e foi um dos fundadores do Instituto de Engenharia.

\subsubsection{Engenheiros-arquitetos da Politécnica}

Grande parte dos engenheiros-arquitetos formados pela Escola Politécnica teve destaque nos meio profissionais e acadêmicos paulistanos nas primeiras décadas do século XX. Como já foi dito, eles tinham proeminência na ocupação dos cargos públicos e na obtenção de grandes obras, em relação aos mackenzistas. A seguir, alguns dos que sobressaíram.

\subsubsection{Augusto de Toledo}

Augusto de Toledo (1877 ou 1880-?) formou-se engenheiro-arquiteto em 1903, pela Politécnica, onde colaborou na Revista Politécnica - um de seus artigos foi aquele citado, sobre a Vila Uchoa, de Dubugras.

Foi sócio de Hippolyto Gustavo Pujol Júnior em uma firma de projetos e construção. Da parceria, um dos projetos mais conhecidos é a Vila Zenny à Avenida Paulista. Também executaram projetos de Victor Dubugras.

Em 1919, Toledo foi contratado como professor do curso de engenheiro-arquiteto da Politécnica. Foi um dos fundadores da Sociedade dos Arquitetos de São Paulo, em 1911, e também sócio fundador do Instituto de Engenharia de São Paulo. Colaborava regularmente na revista Architectura e Construcções .

Foi encontrado um projeto - código 51.05.471.263 - seu no arquivo da Companhia City, de setembro de 1928: um pequeno cottage, como a Vila Gama Jr., publicada em 1912 na Revista de Engenharia, quando Toledo ainda era sócio de Pujol Júnior. 


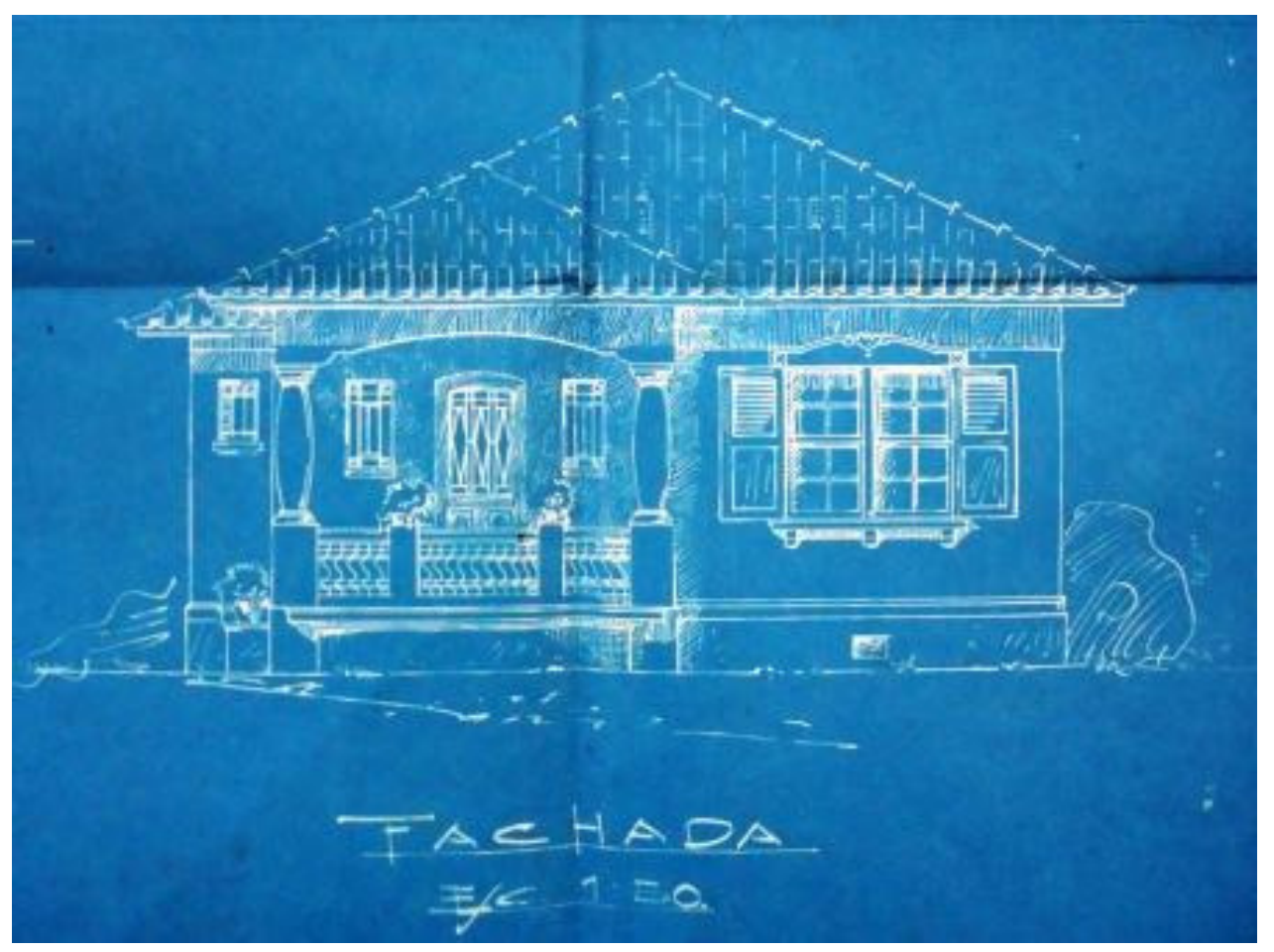

Fig.3. 17 e Flg. 3.18 Projeto no Jardim América

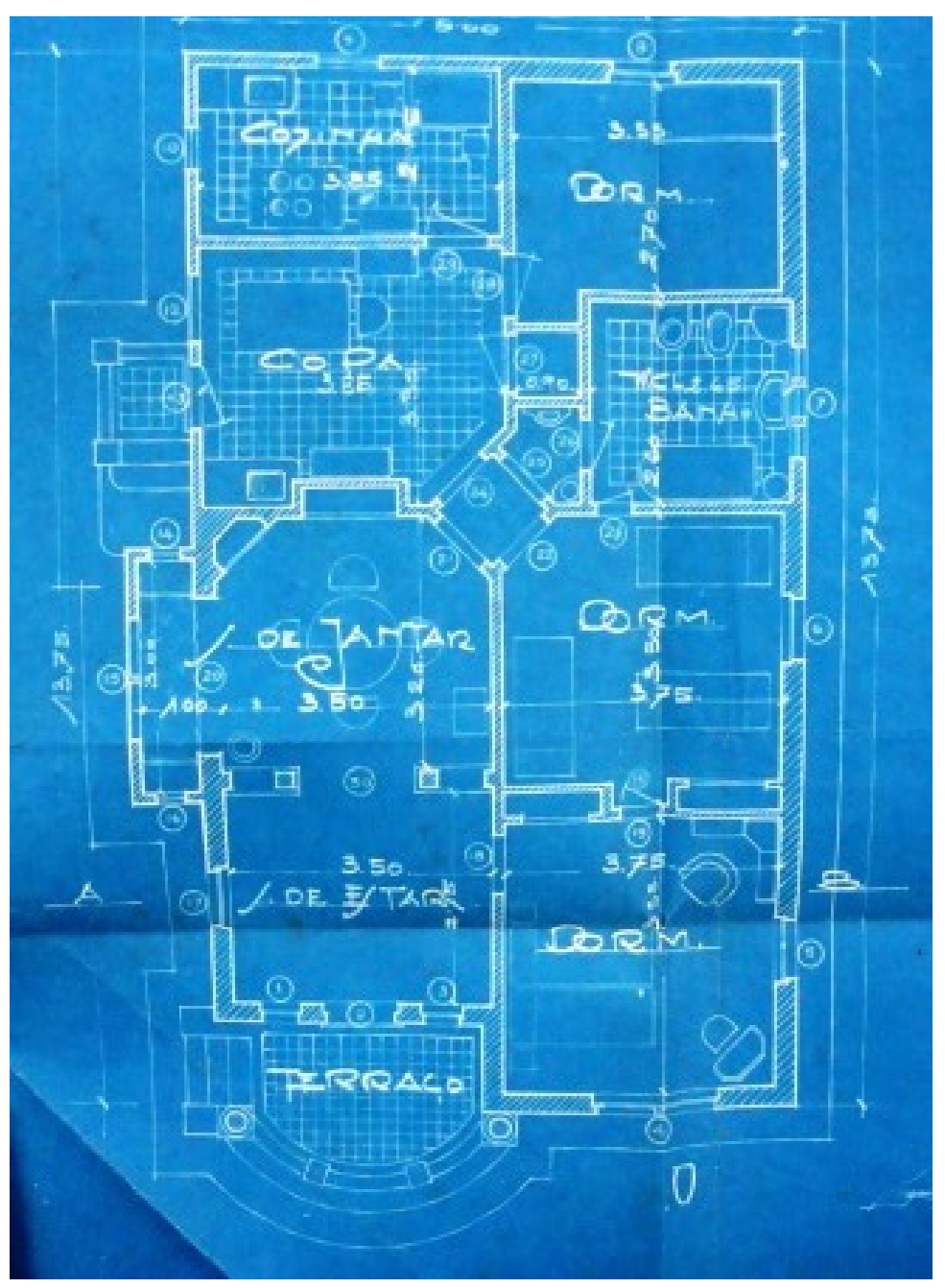

$\mathbf{1 8 6}$ I C a pítulo 3 
O projeto citado apresenta salas de estar e jantar integradas. No jantar, uma lareira e um volume que se destaca, onde provavelmente existia um banco e outro espaço para a colocação de um móvel embutido. É um ambiente que lembra, em seu aconchego e preocupação com os detalhes, os cottages de Barry Parker. Existem armários embutidos nos dormitórios também. A disposição da mobília na planta mostra a preocupação com o aproveitamento máximo do espaço. A geometria utilizada, com a circulação em diagonal, mostra-se uma solução inteligente e confere certa movimentação e racionalidade à planta, permitindo ainda que haja espaço para um pequeno lavatório. À primeira vista, a disposição dos dormitórios, sem circulação exclusiva, parece um retrocesso a formas mais antigas, mas, na verdade, o primeiro dormitório é utilizado como um escritório e assim tem acesso pelo estar. Provavelmente o último era uma acomodação para empregados, e por isso era alcançado pela copa.

\subsubsection{Alexandre Albuquerque}

Alexandre Albuquerque (1880-1940) ${ }^{78}$ foi professor de construção da Politécnica, e transitava entre a arquitetura e a engenharia. Quando estudante, já havia sido professor do Liceu de Artes e Ofícios. Albuquerque foi o primeiro professor concursado do curso de engenheiro-arquiteto da Politécnica diplomado na própria escola.

Formou-se engenheiro-arquiteto e engenheiro civil com distinção em 1905 e, como orador da turma, seu discurso foi marcante no início da luta pela regulamentação profissional. (FICHER, 2005, p.99)

Começou sua carreira no Escritório Técnico Ramos de Azevedo, mas depois teria seu próprio escritório, cujo último endereço foi a Catedral da Sé, onde foi arquitetoconstrutor por 21 anos até sua morte. Além do escritório, em que projetou e construiu muitas residências e edifícios, desenvolveu várias atividades paralelas, como a política profissional, o ensino e os trabalhos técnicos.

Em 1916, Albuquerque publicou "Insolação", sobre a necessidade da penetração do sol para a "higiene das habitações" e "higiene pública". Sistematizou as informações sobre o assunto e preparou os gráficos necessários para os cálculos de insolação na

\footnotetext{
${ }^{78}$ Sobre Alexandre Albuquerque, ver Ficher, 2005, p. 99-113.
} 
cidade e no estado de São Paulo. Seus estudos deram base científica ao Código de Obras de São Paulo, para que fossem asseguradas a insolação correta nas dependências de uso diurno e noturno das habitações.

Com o falecimento de George Krug, em 1919, substitui-o na Politécnica e também nas obras da Catedral de São Paulo. ${ }^{79}$. Hehl, Krug e Albuquerque trabalhavam diretamente no canteiro desta obra de dimensões impressionantes, erguida em alvenaria de pedra e tijolos. Uma forma de trabalho como o da construção das catedrais medievais, em que $\mathrm{o}$ arquiteto era responsável pela concepção e execução da obra. E com paralelos com a Igreja da Sagrada Família em Barcelona, de Gaudí.

Alexandre Albuquerque foi o responsável pela divulgação da arquitetura neocolonial entre os estudantes da Politécnica, nos anos 1920. Com eles, costumava visitar as cidades históricas de Minas Gerais, para fazer levantamentos arquitetônicos. Dizia que "as soluções importadas não deveriam contrariar a nossa natureza, nem os programas de necessidades sintonizados com a tradição". (LEMOS, 1994, p. 154). Propôs a realização de um inventário exaustivo de nossa arquitetura vernácula, pois apenas ela seria válida para a renovação, e não a portuguesa.

Realizou algumas obras de inspiração neocolonial em São Paulo, como o Convento de Santa Teresa, atual sede da Pontifícia Universidade Católica de São Paulo, além de várias residências. (ATIQUE, 2007, p. 320)

Dedicou-se à política de classe. Em 1911, foi um dos fundadores da primeira agremiação da classe em São Paulo, a Sociedade dos Arquitetos e Engenheiros. Foi também um dos fundadores do Instituto de Engenharia, do qual foi presidente no biênio 1923-24. Quando vereador, encaminhou à Câmara Municipal um projeto de lei para a regulamentação do exercício profissional a nível municipal, resultando na Lei $n{ }^{\circ} 2.986$, de julho de 1926, que foi um dos precedentes para a legislação profissional a nível federal.

Albuquerque foi também um dos fundadores, em setembro de 1925, da Academia de Belas Artes de São Paulo. Quando assumiu interinamente sua presidência, em 1928, foi o organizador de seu curso de arquitetura, onde também lecionou.

Presidiu ainda a comissão executiva do Congresso da Habitação, que aconteceu em 1931, e foi um de seus conferencistas. Logo depois, participou ativamente da Revolução Constitucionalista de 1932.

\footnotetext{
79 As obras da catedral de São Paulo começaram em julho de 1913, seguindo projeto em estilo neogótico, de 1912, de Max Hehl - diplomado engenheiro-arquiteto em Hanover. Veio para o Brasil em 1888 e em 1896 começou a dar aulas na Politécnica.
} 


\subsubsection{Hippolyto Gustavo Pujol Junior}

Pujol Junior $^{80}$ (1880-1952) entrou na Politécnica em 1899 e formou-se engenheiroarquiteto e engenheiro civil em 1905. Foi um dos fundadores da Revista Politécnica. Ainda estudante, começou a trabalhar no Gabinete de Resistência dos Materiais, do qual seria diretor. Foi encarregado por Antônio Francisco de Paula Souza de estudar a organização de laboratórios semelhantes na Europa. Dedicou-se depois à organização do gabinete, a fim de transformá-lo em um centro de pesquisas e de prestação de serviços. Em 1909, passou também a lecionar.

Sua atividade profissional fora da Politécnica foi também muito intensa. Da sociedade com Augusto de Toledo, foi publicada a Vila Zenny à Avenida Paulista.

Também com Toledo, projetou o Edifício Guinle, em 1912, o primeiro a ser objeto de cálculos completos e provas de carga, realizadas no Laboratório de Resistência dos Materiais da Politécnica. Foi utilizada uma linguagem arquitetônica decorrente do uso do concreto. Não há paredes externas, os vãos deixados pela estrutura são preenchidos com vidros.

No final da década de 1910, dirigia, com seu irmão Ernesto Pujol, a Empresa Imobilária de São Bernardo, que fazia loteamentos e construía casas operárias. Em 1925, como diretor presidente da Cia. Imobiliária Nacional participou da comissão julgadora do concurso de projetos de casas econômicas da revista $A$ Casa, no Rio de Janeiro.

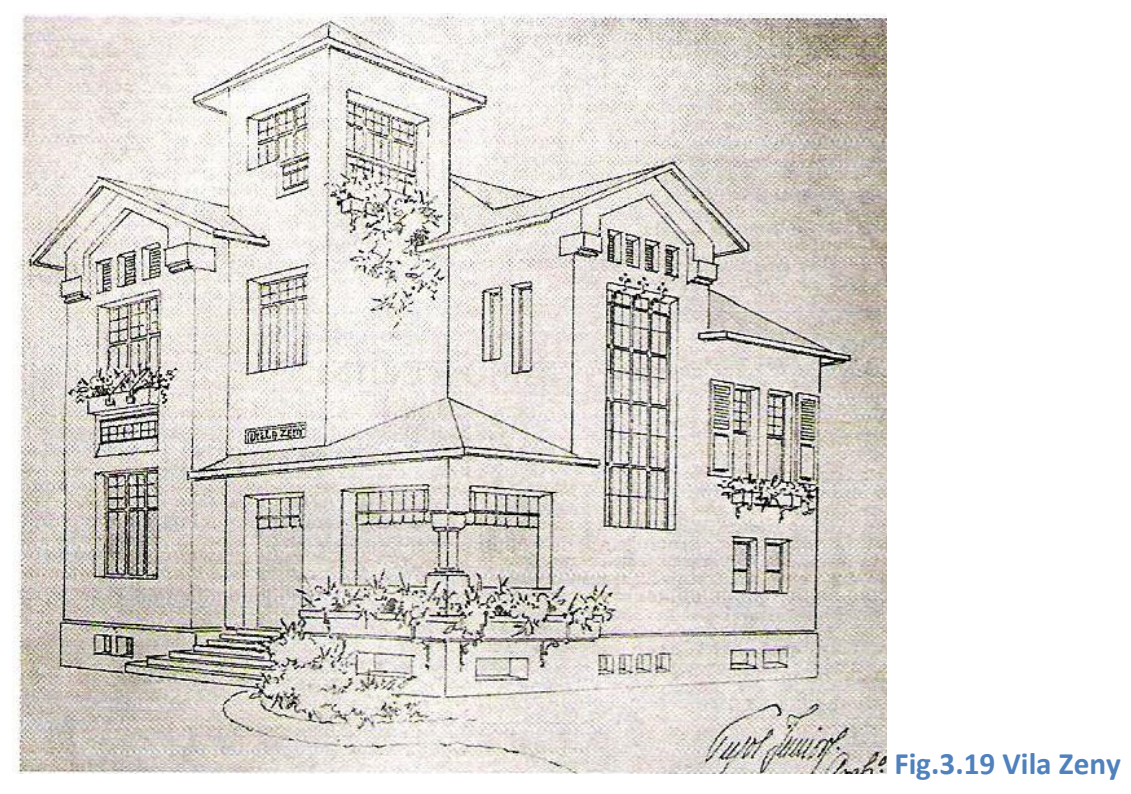

${ }^{80}$ Sobre Pujol Junior, ver Ficher, 2005, p.119-126. 


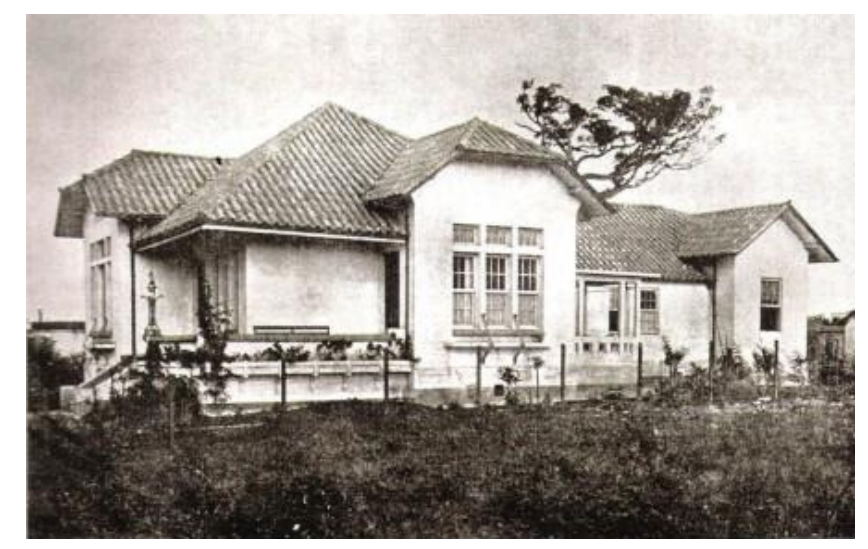

Fig.3.20 Vila Gama Júnior

Participou ainda da construção de grandes obras, como o Pavilhão de São Paulo na Exposição do Centenário e o estádio do Fluminense Futebol Club.

Foi um dos fundadores da Sociedade dos Arquitetos de São Paulo em 1911 e do Instituto de Engenharia em 1916, onde participou da mobilização em apoio às forças constitucionalistas na revolução de 1932 - realizou o plano de defesa militar da entrada do porto de Santos.

\subsubsection{Guilherme Ernesto Winter}

Guilherme Ernesto Winter ${ }^{81}$ (1884-1961) foi admitido na Politécnica em 1901, e em 1907 formou-se engenheiro-arquiteto e engenheiro civil. Em 1915, seria contratado como lente substituto na instituição. Sócio de Dácio de Moraes, a partir de 1918, em uma firma de projetos e construções que realizava residências e obras públicas. Pouco antes de 1930, desfez a sociedade e associou-se a Mário Whately ${ }^{82}$ (Engenheiro Civil Poli, 1911). Foi secretário de Viação e Obras Públicas do Estado onde, entre várias realizações, planejou o Aeroporto de Congonhas, além de outros no interior do estado. Fez planos para hidrelétricas e vários edifícios públicos como o Hospital das Clínicas e o Instituto Adolpho Lutz.

Winter foi um dos fundadores do Instituto de Engenharia e participou de sua primeira diretoria.

\footnotetext{
${ }^{81}$ Sobre Guilherme Winter, ver Ficher, 2005, p.130-3.

82 Mário Whately foi professor da Politécnica - a partir de 1923 - de Resistência dos Materiais e Estabilidade das Construções. Estudou na Politécnica de 1905 a 1910, quando se diplomou. (Revista Politécnica, n.70, abril/maio de 1923, p. 274). Consta como sócio do Instituto de Engenharia (Revista do Instituto de Engenharia, 1926, n. 31).
} 


\section{CAPÍTULO 4}

\section{UMA REVISTA PARA A CLASSE MÉDIA: A CASA}

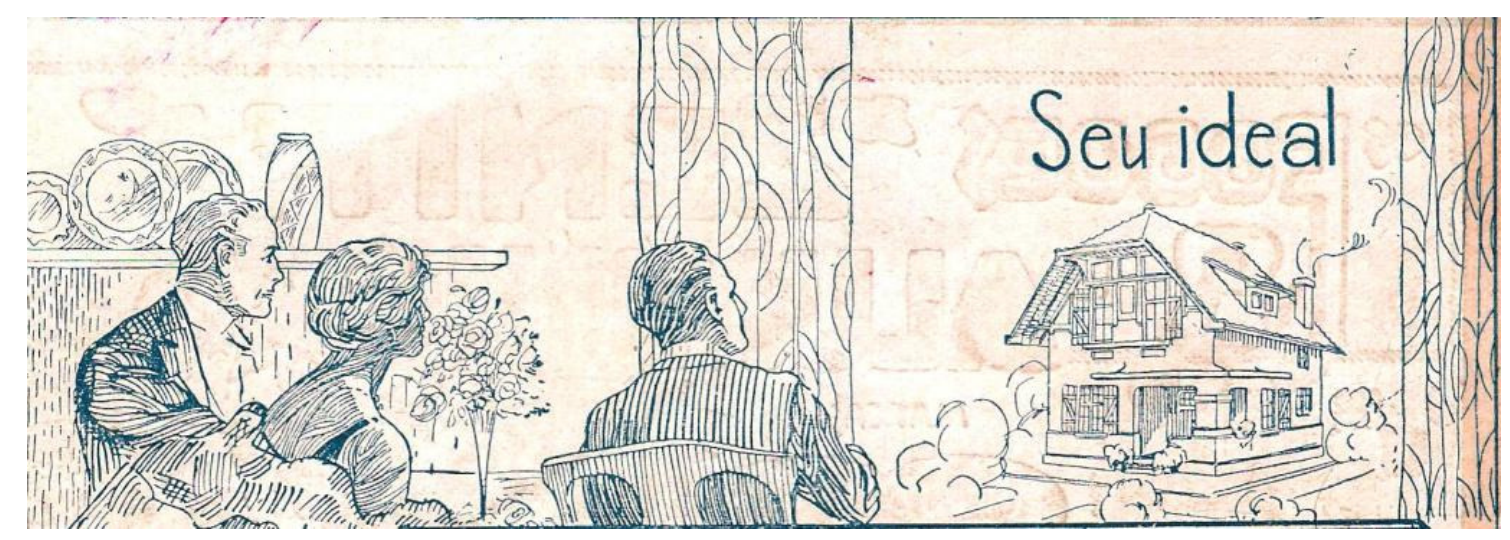

Fig. 4.1-a

No boom das novas publicações dos anos 1920, surge a revista $A$ Casa'. Sua análise é importante, pois se trata da primeira revista destinada ao público leigo de classe média, e não apenas aos profissionais. Isto fica claro nas casas mostradas - de tamanhos pequeno ou médio -, sem a sofisticação dos palacetes das classes mais abastadas. Apesar de a revista ser publicada no Rio de Janeiro, esta é uma das situações em que o campo de pesquisa foi extrapolado até o nível nacional. Isto não invalida tal fonte documental, já que o alcance da publicação não ficava circunscrito à capital do país - A Casa era vendida em São Paulo e a cidade é objeto de vários artigos.

Assim, ela faz parte das transformações que ocorrem na cena paulistana após a Primeira Guerra Mundial e até o início dos anos 1930.

A importância da revista não se deve tanto aos edifícios e projetos mostrados enquanto produção vinculada a determinados arquitetos, mas como modelo para a moradia de classe média. Em grande parte dos projetos a autoria não é nem mesmo explicitada.

\footnotetext{
${ }^{1}$ A Revista A Casa foi fundada em 1923, pelo arquiteto Ricardo Wriedt. Em 1924, tornou-se propriedade de Segadas \&Cordeiro - sociedade formada pelo engenheiro civil A. Segadas Vianna e pelo arquiteto J. Cordeiro de Azeredo. A periodicidade era mensal e as tiragens, a princípio de 4 mil exemplares, em 1940 atingiriam 8 mil exemplares. Publicada no Rio de Janeiro, a revista recebia contribuições de vários estados e chegou a ter representação própria em São Paulo. Em suas páginas era possível encontrar projetos de arquitetos conhecidos e de anônimos.

No número 61 de maio de 1929, constam como redatores os engenheiros civis A.Segadas Vianna e Braz Jordão. Foi publicada ao menos até 1945, já que constam números publicados neste ano na biblioteca da EESC-USP.
} 
Apesar de o Arts and Crafts não se configurar em um estilo, foram utilizadas características visuais para análise dos projetos, além da leitura dos textos que os acompanham, onde é possível detectarem-se mudanças na maneira de morar, totalmente modernizada à época. São apontadas prováveis influências aos projetos mostrados, porém tal análise não pretende ser definitiva, pois houve muitas trocas entre as arquiteturas inglesa e americana a partir de meados do século XIX e início do $X X$, que ainda necessitam ser melhor analisadas. Determinada característica pode advir da arquitetura desenvolvida na Inglaterra, porém pode também estar presente na americana.

\subsection{O público alvo}

A revista se dirige, no editorial do número 4 (1924, p.9) a seus "amáveis clientes", bastante diversos, já que, ela "é destinada a todos, isto é, architectos, engenheiros, pessoas desejosas de construir e ao público em geral." ( $A C A S A, 1924$, n. 4, p.32) "Lembre-se de que $A$ Casa é a única revista no gênero que se publica no Brasil. É a revista por excellencia dos constructores e pessoas que desejam construir." (A CASA, 1925 , n. 9 , p. 35)

O alcance da revista era nacional, pois na seção "Correspondência " (n.74, junho 1930), são respondidas cartas de Penápolis - no interior de São Paulo -, Natal e da cidade de São Paulo, além, do Rio de Janeiro.

Era até possível se estudar engenharia por correspondência, como preconizava o anúncio presente no número 9 (1925, p. 41).

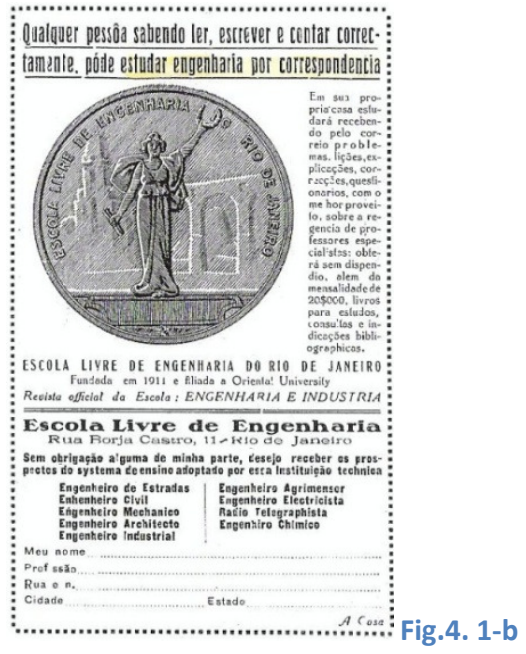


Estão presentes na revista matérias dirigidas aos técnicos, que tratam, por exemplo, de infra-estrutura - como o artigo sobre a Companhia Paulista de Estrada de Ferro, a primeira estrada de ferro eletrificada do Brasil, que estava em expansão. ( $A C A S A$, 1924, n. 4, p.32) Ou artigos com o público leigo como alvo - como aquele sobre o concreto, onde se definem as características do material e se explicam suas origens, de maneira bastante didática. São ressaltadas suas qualidades higiênicas, "o concreto armado, graças a sua compactez, não permite o desenvolvimento desses vehículos de infecção nem, tampouco, o accumulo de poeira. (...) o estylo que irá marcar a época atual será o do concreto armado". (A CASA, 1924, n. 8, p.7)

A Casa trazia ainda, ao final de cada número, os preços de materiais de construção, como areia, cal, cimento, ferro, azulejos, telhas (de cerâmica e vidro), tijolos, gesso.

O intuito era colecioná-la: os profissionais poderiam sempre recorrer a ela para a execução de seus projetos ou aqueles que procurassem idéias para a própria casa iriam folheá-la em busca de novidades. A revista "ao contrário das outras não é jogada à cesta de papéis, é guardada cuidadosamente para consulta, devido aos projetos que publica." ( $A$ CASA, 1924, n. 8, p.3)

Projetos estes que poderiam ser solicitados pelo correio: "aos que desejarem construir segundo os modelos apresentados, remettendo copias de projectos com detalhes tal como são exigidos pela Prefeitura do Districto Federal, mediante a quantia de $50 \$ 000$ (cincoenta mil reis)." (A CASA, 1924, n. 8, p. 36)

Ou ainda, na compra de uma assinatura, o brinde seria "um projecto completo em papel ferro-prussiato, prompto para construir do 'bungalow' publicado à página 23 do número de Agosto." (A CASA, 1925, n. 16, p. III).

\subsection{A família e o lar}

Em $A$ Casa, o lar é apresentado como o local ideal para a existência: um refúgio na cidade. A mesma concepção da casa formulada na época vitoriana, de local de salvação contra as tentações e imoralidades do mundo urbano. O lar torna-se, principalmente para o homem, a oportunidade de se proteger contra os divertimentos públicos, o tumulto, a violência e os males sociais encontrados nas ruas. 
Esta concepção da habitação é inerente ao movimento Arts and Crafts inglês, que se desenvolve na época vitoriana, e também ao movimento na América.

O desenvolvimento de uma nova cultura ligada à moradia. A casa, e tudo o que está dentro dela, passa a ser objeto do seu interesse. O espaço da sociabilidade em pequenos grupos. O habitante da grande cidade, submetido a choques constantes, ali se recolhe.

De forma mais ampla, é algo que pertence à cultura burguesa da habitação. Nascido na burguesia e difundido entre as classes trabalhadoras e outros grupos sociais, o lar vitoriano significava estabilidade, ordem e paz, o contraponto às incertezas do mundo exterior em constante transformação, um ponto de equilíbrio possível, entre as esferas pública e privada.

A divisão em dois grupos, um doméstico, suburbano e feminino, o outro urbano, masculino, trabalhador é um arranjo presente nos subúrbios americanos e ingleses, vinculado à cultura da descentralização.

A "carga" imposta ao homem deveria ser suavizada quando este retornasse ao lar. As diferenças de gênero na família sustentavam o discurso que via a casa em posição diametralmente oposta ao mundo exterior - um campo de batalha, o habitat masculino. Esta é uma idéia sempre muito presente também no Brasil, à época, inclusive nos anúncios, como neste do Mappin Stores, que vendia móveis, tapetes e objetos decorativos para a casa:

No nosso clima vive-se muito fôra de casa. A maior parte do tempo corre fora do lar, na rua, no escriptorio, no armazém, no theatro, no cinema. Há pouca vida de família. Porisso laxam-se os vínculos de intimidade que devem apertar os membros dessa pequena unidade celular que é a base de todas as outras. (...) É lastimável porque denota a falta de vida de família e sem a vida de família não há sociedade e não há pátria. ${ }^{2}$

A família era vista como a base do sistema social, como sua instituição mais importante, e como tal, fonte e solução da maioria de seus problemas.

Um estilo de vida centrado na família nuclear, que será adotado pela classe média ${ }^{3}$. "Os segmentos médios foram, em São Paulo, o público-alvo predileto dos conselhos e campanhas publicitárias que previam o enfraquecimento da sala de visitas como zona

\footnotetext{
2 "A intimidade do Lar", Revista Feminina, julho de 1918, p.16 apud CARVALHO, 2008, p. 312.

${ }^{3}$ Havia a predominância da organização do tipo nuclear nas famílias paulistanas à época, reforçada pelo fato dos filhos deixarem a casa da família para constituírem um domicílio independente. (CARVALHO, 2008, p. 309)
} 
de representação social e o seu fortalecimento como área de convívio familiar, íntimo e confortável, segundo o modelo inglês do living room"(CARVALHO, 2008, p. 165-6)

No lar, com a família fixada, deveria ser priorizado o conforto de seus habitantes e não a exibição de um suposto luxo para pessoas estranhas à família:

A casa em que moramos é justamente aquella que nos deve merecer o maior cuidado, não pela vaidade de apresentarmos a quem nos visita instalações bizarras ou luxuosas, demonstrando preocccupações exibicionistas, senão porque o arranjo cuidadoso, quer exterior, quer interior da nossa habitação, tem uma justificativa imperiosa no facto de ser ali que vivemos dois terços da existência (...).(A CASA, 1928, n.56, p. 17)

Este, segundo o próprio Barry Parker, quando esteve em São Paulo, era seu maior temor no Jardim América - que os proprietários tivessem a idéia de fazer um 'show', para impressionar os que passassem. Ou quando, ainda na Inglaterra, ele pedia que apenas as legítimas necessidades do homem fossem atendidas no desenho da casa"a casa" para viver uma vida plena, preservando a individualidade do morador e refletindo sua personalidade. Fugir às convenções sociais, que determinavam o que era necessário à determinada classe social.

Em artigo intitulado "O Lar" (A CASA, 1929, n.63, p.37-8), é dito que:

"Por vaidade muito natural e plenamente justificável, todos pretendem que a sua casa se destaque das outras, quer em originalidade, quer por uma esquisitice qualquer. $O$ que se tem em mira, geralmente, é uma casa que desperte attenção.(...) Ora, uma casa barata, apresentando exteriormente certas sunptuosidades, torna-se ridícula, porquanto o interior não se poderá harmonizar com o exterior, e uma coisa deve ser funcção da outra.(...). Somos de opinião que a nobreza de uma casa está em se deixar transparecer por fora aquillo que existe por dentro (...). Faça de sua casa um castello que preencha o seu ideal e não um castello de sua casa, se os seus recursos não lhe permittirem."

Implícita nesta citação também está a premissa do Arts and Crafts de que a concepção de um edifício deve ser completa, planta e fachadas, interior e exterior inseparáveis.

Em um anúncio da Casa Nunes que vendia móveis, tapeçarias e objetos decorativos, comenta-se que: "A felicidade consiste no conforto e na alegria em que vivemos." ( $A$ 
CASA, 1924, n. 4, p.2) A busca do conforto também está presente na ilustração de $\mathrm{A}$ Casa Alemã, mostrando um homem que se abandona totalmente em uma poltrona.

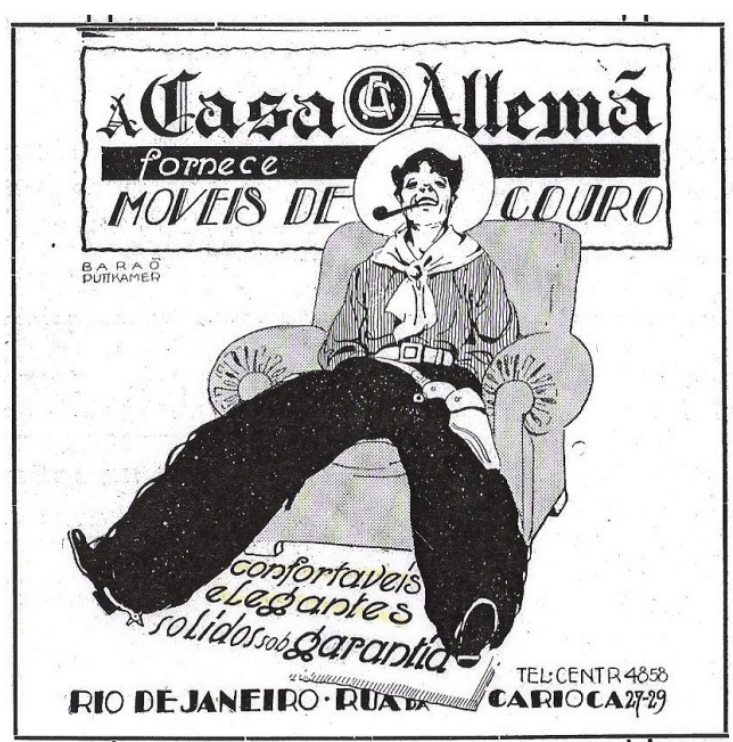

Fig.4. 2

O conforto está associado à idéia de descanso masculino simbolizado pelo relaxamento físico proporcionado pela confortável poltrona de couro estofado. Porém, a idéia de conforto não se restringe ao descanso físico, mas estende-se à dimensão psíquica. Acreditava-se que esta dimensão só seria alcançada em um espaço contraposto àquele do trabalho produtivo e que um ambiente "artístico" seria a melhor opção.

(...) o bem estar é proporcionado pelo modo de dispôr o mobiliário e os objectos de ornamento, pelo concurso da boa disposição da luz directa e da luz electrica coada atravez de lâmpadas opacas e 'abatjours' de gosto; pelo colorido e aroma das flôres, pelo canto melodioso de pássaros ou o som de victrolas e alto falantes. ( $A$ CASA, 1928, n.56, p. 17).

As cortinas faziam uma espécie de transição entre o interior e o exterior. Não apenas a entrada de luz e a visão do ambiente externo eram filtradas, mas sua própria agitação. As almofadas serviriam para atenuar a rigidez dos móveis em madeira, bastante desconfortáveis, que ainda não haviam se modernizado.

Uma casa ricamente mobiliada e cheia de mil alfaias, (...) mas que não disponha desses pequenos lavores femininos, assemelha-se a um hotel - como elle, incaracterístico e impessoal - porque é naqueles delicados mimos da alma da mulher que se adivinha o affecto, 0 carinho, o ar de amistosa intimidade que devem caracterisar o lar. 
Entre elles as almofadas de todos os feitios e de todos os tamanhos, desde logo destacam-se. E destacam-se porque parecem preoccupadas com o maior conforto dos da casa e de seus hóspedes, alcochoando os móveis, dando-Ihes uma macieza e uma carícia fofa que convida a ficar. ${ }^{4}$

Reforçavam ainda mais a idéia de conforto e repouso a contemplação dos jardins. As plantas eram colocadas em vários pontos da casa, até em treliças de madeira. Eram "ornamentos dos mais modernos bungalow.(...) Qualquer velho prédio feitio de caixão, paredes lisas, sem o menor vislumbre de gosto, fica completamente transformado pelo uso de algumas treliças de madeira, devidamente collocadas, onde se vejam roseiras em flor". Ela deveria ser colocada ligeiramente afastada da parede, além de ser benéfico para a planta, "maior realce é assim obtido devido ao contraste entre as partes de luz e sombra a que dá logar tal disposição." ( $A$ CASA, 1924, n. 8, p.10)
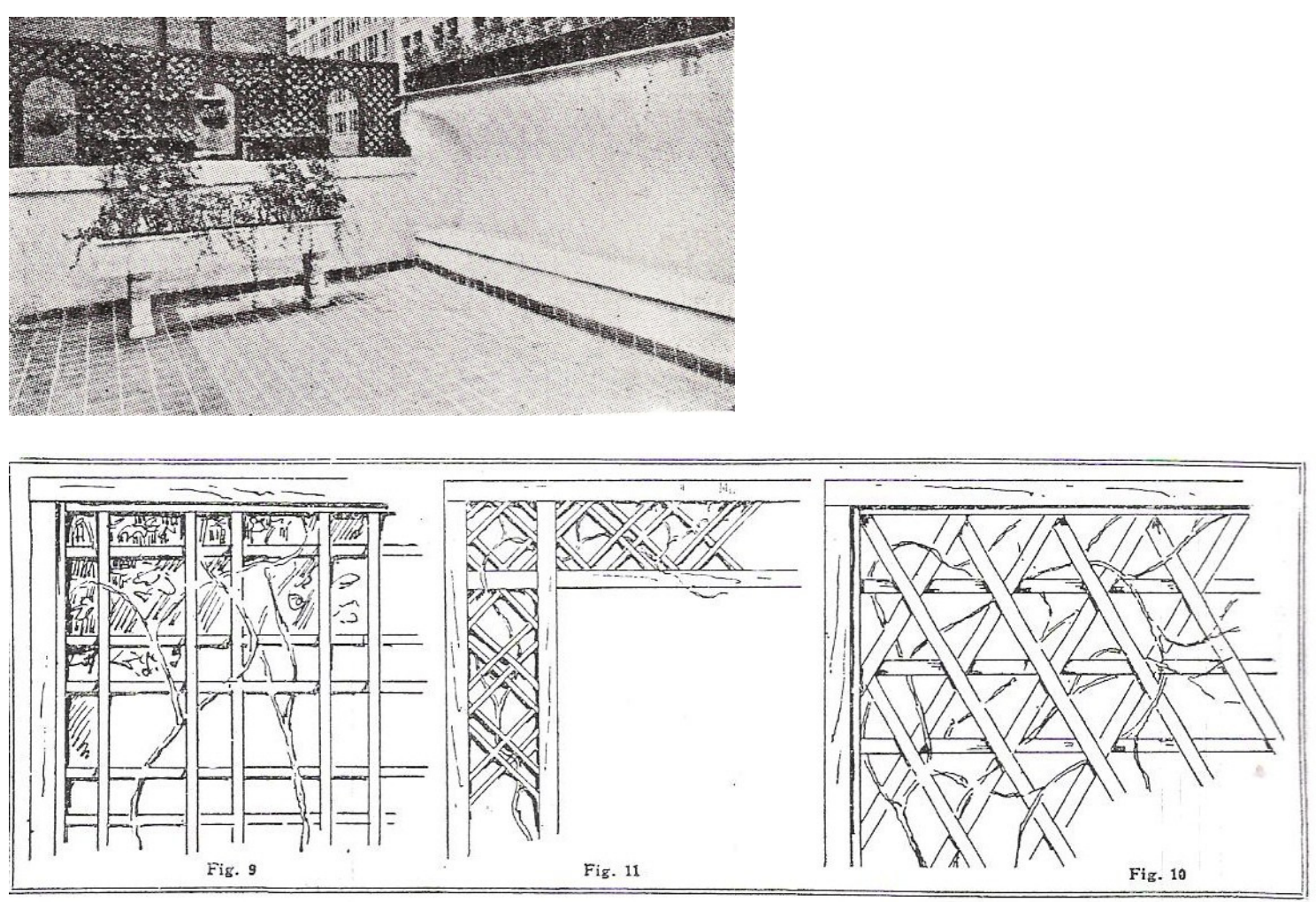

Fig. 4. 3 Treliças de madeira

São apresentados em A Casa (1928, n.56, p. 17-9) vários ambientes externos: “(..) bem se vê que se trata de um trecho de jardim de casa de família de tratamento, mas que póde servir de modelo para proporções modestas. (...) Por mais modesta, porém, que seja a habitação, ella precisa ter um ponto pittoresco, onde a vista descanse da

\footnotetext{
4 "Trabalhos Femininos", Revista Feminina, jan.1919, p.13 apud CARVALHO, 2008, p. 99.
} 
monotonia dos demais pontos da casa, tanto no interior como no exterior". Estes espaços, que fazem a transição entre o interior da casa e mundo exterior, apresentam pequenos gramados, comparados a tapetes aveludados, ou pisos de pedra; grades de madeira e pérgulas cobertas com vegetação; canteiros de flores, lagos; mobiliário mesas, cadeiras, balanços, bancos, com proteção contra o sol; plantas pendentes, jarros de flores e viveiros de pássaros completam a moldura para esta vida familiar ao ar livre, porém protegida. Lê-se, estuda-se, repousa-se, fazem-se as refeições ali. Nas fotos aparecem livros, almofadas, revistas, para garantir verdadeiro conforto. Neste arranjo perfeito que favorece a perfeita convivência familiar deve haver harmonia nas cores e texturas: "O tecido de linho foi empregado em harmonia com os tons da mobília, que se casam com o colorido das flôres e folhagens do jardim. (...) Uns, obra prima sahida das mãos do homem, a outra, dádiva da natureza, brotando por toda a parte!"
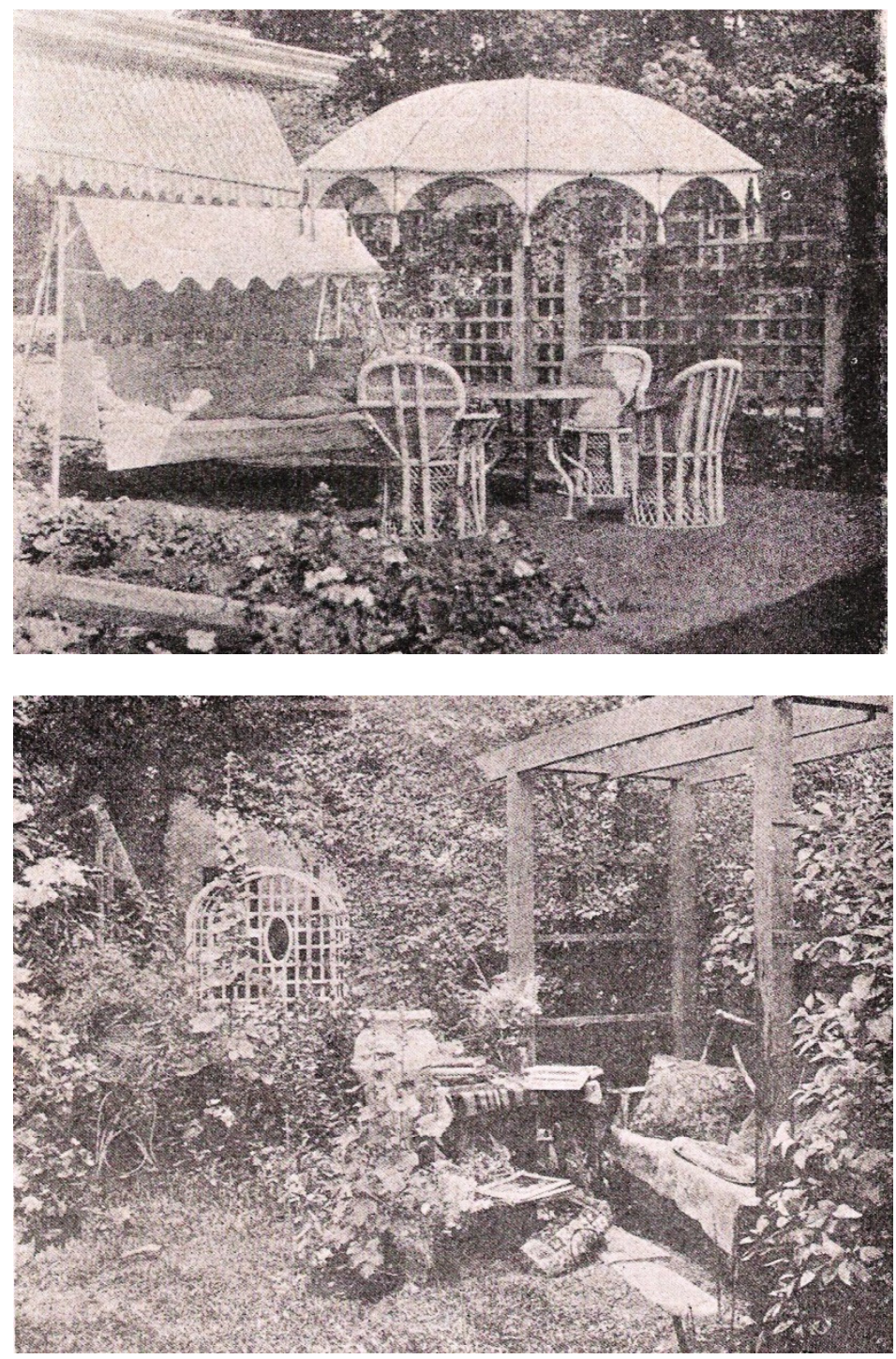

Fig. 4.4 - Jardins mostrados em A Casa 
A importância dos jardins é colocada ainda na seção "Notas e Recortes" de A Casa (1924, n. 8, p. 14) onde se diz que em muitas residências cariocas "as árvores e as flôres são amadas com esse desejável carinho esthetico. Mas as casas inimigas de árvores e de flôres também são innumeras (...) em bairros onde cada residência devia ser o centro de um pequeno jardim." Em contraponto, "São Paulo é o grande exemplo neste e em casos mil de progresso e de arte. São Paulo é hoje a cidade dos jardins. (...) trepadeiras que sobem pelos terraços até o telhado, jarras e canteiros especiaes, elegantíssimos, suspensos, à margem das janellas, tudo isso embelezza as construccções de São Paulo desde muito dando à cidade o encanto característico do trópico." Provavelmente, com a natureza tão exuberante e próxima no Rio de Janeiro, seus moradores não sentissem a necessidade de trazê-la para sua casa, no formato de jardim. Apesar de que, em São Paulo, nesta época, ainda existiam grandes áreas de mata, principalmente nos fundos de vale ainda não ocupados, que encantaram o arquiteto Barry Parker quando de sua visita à cidade nos anos 1910.

Esta aproximação com a natureza através dos jardins domésticos que chegavam quase a penetrar a casa, com as floreiras e trepadeiras que cresciam pelas paredes é muito presente no Arts and Crafts inglês e americano, particularmente nos bangalôs. $\mathrm{E}$ transferiu-se ao Brasil. Nas casas do Jardim América, é presença constante, onde os jardins chegam a ser "cômodos" ao ar livre, sob a proteção das pérgulas, como no movimento inglês.

Existe ainda a questão da importância dada às áreas verdes pelos higienistas, como garantia de saúde mental e física. Era muito moderna, esta preocupação em se ter a natureza próxima, presente no cotidiano das pessoas; natureza domada, como nas pinturas. Havia mesmo uma moldura para tal quadro, na forma dos caminhos e equipamentos como bancos, quiosques e fontes.

A dimensão educativa desta casa unifamiliar, cercada pelo verde, está patente neste trecho: "Haverá espaço sufficiente para jardim e horta que só podem, com residências, ter o destino de embelllezar a casa, divertir os moradores e proporcionar às creanças pratica de jardinagem.”. (A CASA, 1926, n.25, p. 8).

\subsection{O compromisso feminino}


No lar vitoriano, à mulher caberia a tarefa de construir "o lar". A maternidade era o papel fundamental da mulher, algo que se dará também no contexto brasileiro. Um dever social que incluía o controle sobre a saúde física e moral dos membros da família. Envolvia a higiene do lar em um momento em que cresce a obsessão contra os micróbios, a poeira, tudo o que possa facilitar a propagação das doenças.

"Em São Paulo, a crença no poder da ordenação do espaço doméstico fará com que a mulher seja alvo de expectativas quanto ao cuidado com os filhos, mas também quanto à alteração dos hábitos do marido. Fora do âmbito da elite, o homem de outros segmentos sociais, muitas vezes é compreendido com as mesmas ferramentas que se usa para entender as crianças. (CARVALHO, 2008, p. 315)

O título do anúncio publicado em $A$ Casa (1929, n.68, p.7), do isolante térmico Celotex, é "A felicidade da mulher em sua casa depende de... conforto". "A casa para offerecer conforto à mulher - para dar prazer durante todas as estações, deve estar protegida das condições do tempo (...). Celotex é hoje indicado pelas esposas ciosas de conforto, aos seus maridos (...)."

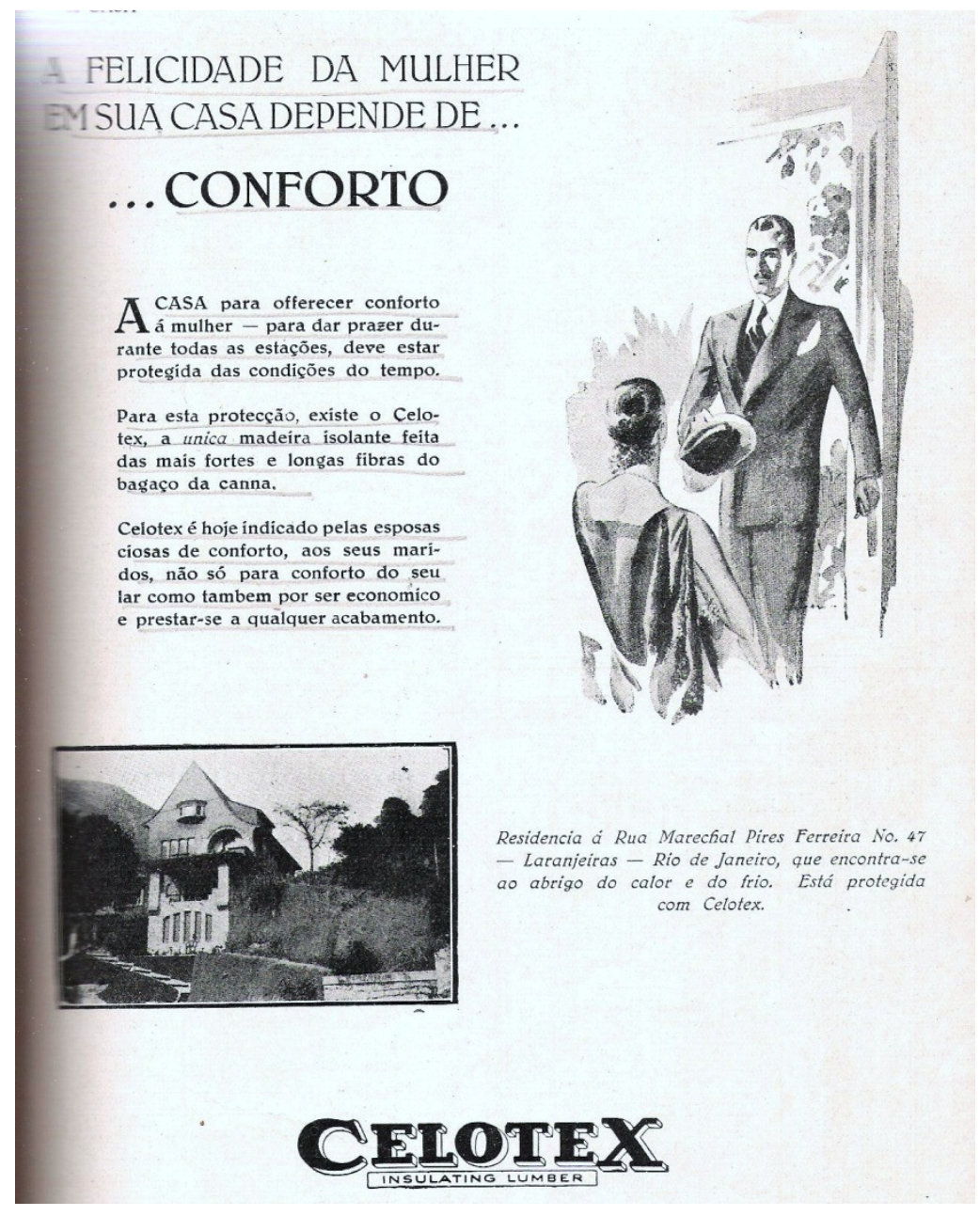


Um novo modelo de feminilidade, a esposa - dona-de-casa - mãe -de- família, e uma preocupação especial com a infância - o potencial da nação - estabeleciam novas relações intra-familiares, relações estáveis e assépticas, onde os vínculos poderiam ser estreitados. A mulher deveria se preocupar com os detalhes da vida cotidiana de cada um dos membros da família, vigiar seus horários, prevenir doenças ou desvios. (RAGO, 1997, p.62)

(...) devemos fazer-Ihes compreender que o seu lugar é em casa, a tratar e educar seus filhos (...); oxalá que elas saibam compreender seu papel de educadoras daqueles que amanhã serão os nossos substitutos na luta do pão e da conquista do bem-estar da humanidade, pois, assim, demonstrarão à sociedade serem as verdadeiras rainhas do lar; o papel de uma mãe não consiste em abandonar seus filhos em casa e ir para a fábrica trabalhar, pois tal abandono origina muitas vezes conseqüências lamentáveis, quando melhor seria que somente o homem procurasse produzir de forma a prover as necessidades do lar. (A Razão, 29-7-1919 apud RAGO, 1997, p. 69)

A casa era considerada como o lugar onde se forma o caráter das crianças, a futura força de trabalho do país.

Para o conjunto da tradição do Arts and Crafts, a casa familiar era o veículo social básico a partir do qual os valores da sociedade poderiam ser gradualmente transformados. A reforma moral através embelezamento do lar, também está presente em A Casa.

Nessas condições, a nossa transitória morada precisa ter o conforto necessário para que não a aborreçamos, passando a viver mais na rua do que em casa. (...) O lar tem de ser, portanto, um ponto de atracção, onde o carinho affectuoso da família encontra a moldura natural de encantadores ambientes preparados pelo gosto artístico das creaturas que o formam (...) tudo isso fórma o conjunto que attrahe, que prende ao lar os membros da família. (A CASA, 1928, n.56, p. 17) 
Organizações inglesas, ainda no século XIX, tentaram resgatar as antigas técnicas regionais de artesanato e utilizá-las como ferramenta educativa na reforma moral, na tentativa de que o lazer dos trabalhadores não consistisse em bebida e jogos ${ }^{5}$.

No ensino do artesanato, no contexto americano, os homens são incentivados a fazer seus próprios móveis e as mulheres, os têxteis e outros trabalhos, como a cerâmica. No Brasil, como o trabalho manual sempre foi visto sob a lente do preconceito e associado à escravidão, o maior incentivo se dava em relação às mulheres. Os trabalhos manuais permitiriam que se individualizasse a casa. $O$ trabalho era valorizado e, através dele, a própria pessoa que o executava. O prazer que poderia trazer mesmo um pequeno trabalho "de agulha", em que planejamento e execução, do início ao fim estão nas mesmas mãos. A alegria de um trabalho terminado, de uma habilidade adquirida.

A participação da mulher na organização deste novo lar no Brasil é clara.

(...) no intuito de orientar os nossos leitores no que de moderno, confortável e agradável, se está creando para o lar não poupamos sacrifícios (...). A coadjuvação das Exmas. Snras., é nesta tarefa de um valor indiscriptivel, pois, uma mão feminina sabe sempre que, uma almofada bordada ou pintada com arte, uma cortina escolhida com acerto, o tom da cor de um tapete, um vaso de flores distinctamente collocado em seu devido logar, são de uma importância capital no conjunto a formar. Compete a todos collaborar efficazmente e proprocionar a nossa família todo o bem estar e alegria para o interior do nosso lar, tornando-o assim, sempre e inconfundivelmente, o lugar mais desejado. (A CASA, 1924, n. 4, p.24)

"A habitação torna-se mais attrahente pelo bem estar que proporciona, interna e externamente. Além dos cuidados hygiênicos, do asseio, que deve ser a preoccupação de toda a dona de casa (...)". (A CASA, 1928, n.56, p. 17)

A figura feminina confunde-se com a da casa, em anúncio publicado em $A$ Casa (1925, n. 16, p. 40). As curvas aparecem nas flores, na luminária, nos cabelos e nas

\footnotetext{
${ }^{5}$ No limite desta preocupação com o lazer do trabalhador, as vilas operárias no Brasil controlarão totalmente este aspecto de sua vida. Em 1916, o industrial Jorge Street, que construiu a vila Maria Zélia ao redor de sua fábrica de tecidos, diz: “(...) depois um grande parque com coreto para concertos, salão para representações e baile; escola de canto coral e música, um campo de football (...) proporcionando, também, aos operários, distração gratuita dentro do estabelecimento, evitar que freqüentem bares, botequins e outros lugares de vício, afastando-os especialmente do álcool e do jogo. (RAGO, 1997, p. 178)
} 
roupas da mulher. "Flores e rendas estão presentes nos vestidos, acessórios e mesa. O conjunto harmonioso inclui sempre a protagonista que se funde ao cenário." (CARVALHO, 2008, p. 80) E supõe-se que seu talento para os trabalhos manuais tenham sido utilizados na decoração da sala - na luminária e nas almofadas.

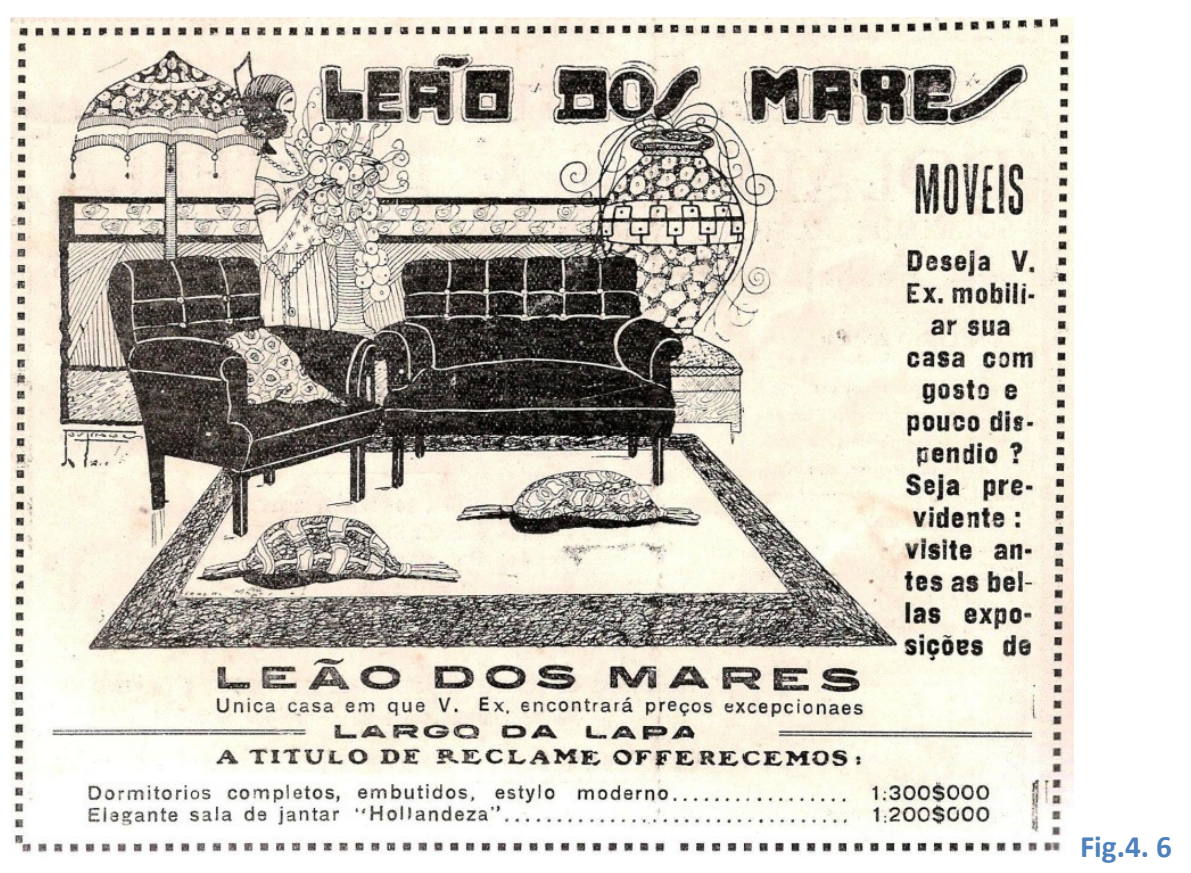

Bordados e rendas legítimas poderiam ser mescladas a partes já produzidas pela indústria inglesa e francesa, que permitiriam que famílias de baixa renda decorassem suas casas por meio de um sistema de coberturas que substituía a ausência de móveis caros. A criatividade e o talento femininos poderiam fazer com que todo lar, independente de suas posses, se vinculasse aos valores caros ao ideário burguês. (CARVALHO, 2008, p. 75)

\subsection{Modernização}

Os anos 1920 são um período de grandes modificações nas grandes cidades brasileiras, particularmente em São Paulo. Em artigo de $A$ Casa (1924, n. 4, p.28), dizse que "continua intensa a febre de edificações em São Paulo. Em Janeiro foram construídos 234 prédios, número que, em Fevereiro, ascendeu a 343. Destes, 246 são casas térreas e 97 sobrados". 
Porém, é um momento de transição, quando o arquiteto Eduardo Walsh ainda anuncia seus projetos "obedecendo rigorosamente às leis da esthetica." ( $A C A S A, 1924$, n. 4, p.5)

Acontecem várias discussões sobre a cidade: "A cidade moderna é um organismo bem complicado, cujo estudo se vem fazendo ha poucos annos com grande empenho e methodo, por engenheiros do valor de Stübben, Sitti (grafia da revista) (...) e outros. Pôde ser comparada a um ser vivo pela grande solidariedade entre os seus differentes órgãos e partes, a qual se torna cada vez maior, à medida que a civilização progride." No artigo, transcrito do jornal $A$ Noite e publicado em $A$ Casa (1925, n. 9, p. 13-15), coloca-se, mais uma vez, a metáfora do organismo aplicada à cidade. $E$ a influência ainda presente de Stübben e Sitte, desde o final do $\mathrm{XIX}^{6}$.

No mesmo artigo é discutido o modo de crescimento da cidade: "Citando as questões que, por serem mais urgentes, pediam mais prompta solução, em benefício da cidade, O Dr. Armando Godoy, engenheiro da Diretoria de Obras Públicas da Prefeitura assignalou que um dos defeitos maiores de nossa capital é ser ella muito espalhada, ocupar uma área sem correspondência com o número de habitantes, o que encarece e difficulta os serviços públicos dos vários abastecimentos". Algo que também acontecia em São Paulo, onde a expansão das linhas de bonde da Light levava a um crescimento tentacular da cidade com a constituição de inúmeros subúrbios sem ligação entre si. O resultado era a criação de grandes vazios na trama urbana.

A discussão no artigo acontecia porque fora nomeada uma comissão de engenheiros e arquitetos para estudar o aproveitamento das áreas conquistadas ao mar, enquadrando-as num plano geral de melhoramentos urbanos.

Tal comissão reduzira a três metros o pé direito nos pavimentos habitáveis, pois se constatara, após "innumeras observações de rigoroso cunho scientifico, o que tem importância não é o volume do aposento, mas a descarga da corrente de entrada e saída do ar, isto é, a ventilação." A comissão ainda "diminuira as exigências relativas às pequenas habitações sem sacrificar as condições hygiênicas." ( $A C A S A, 1925$, n. 9 , p. 15) ${ }^{7}$.

\footnotetext{
${ }^{6}$ A polêmica entre Stübben e Sitte refletiu a aspereza do debate entre arquitetos e engenheiros sobre morfologia urbana. É a polêmica entre artistas e técnicos, entre historicistas e funcionalistas: a separação entre ciência e técnica de um lado e as belas artes de outro.

${ }^{7}$ Victor Freire empreenderá grandes esforços para alterar essas posturas em São Paulo, através de sua intensa participação no debate em torno da elaboração do código de obras, a partir de 1918 (consolidado em 1920 com o nome de Padrão Municipal), quando é adotada a redução do pé-direito para 3,00 m. e eliminado o conceito de cubagem, utilizado anteriormente.
} 
Alíás, as qualidades higiênicas são sempre ressaltadas, como no anúncio da tela "Clain Link", que seria a "melhor e mais higiênica". (A CASA, 1924, n. 8, p.2)

Em artigo de A Casa, (1927, n.35, p. 9-10), sobre a habitação higiênica, a localização é apontada como o elemento primordial para a salubridade da habitação. Deveriam ser evitados os terrenos baixos e úmidos e os retangulares e alongados, "afim de não prejudicar a insolação e, ao mesmo tempo, não impedir a livre circulação do ar nas áreas lateraes do edifício." A questão da insolação era colocada ressaltando-se a importância dos dormitórios localizarem-se no lado leste da habitação, para receberem o sol da manhã.

"A abordagem higienista atingiu todos os cômodos da casa (...) as janelas deviam ser abertas para a troca freqüente de ar; as paredes deveriam receber o óleo que era lavável, etc." (CARVALHO, 2008, p. 250)

A idéia de lar é representada em uma ilustração de $A$ Casa (1924, n. 8, p. 4) de um anúncio de lotes que poderiam ser pagos em prestações mensais, em até cinco anos, no "aprazível bairro do Andarahy". A figura mostra uma casa que evoca a imagem do Arts and Crafts, com sua chaminé em destaque, esquadrias com vidros quadriculados, volumetria e telhado movimentados, em meio a um jardim, onde brinca uma criança. Uma imagem idílica atribuída ao subúrbio, como uma forma de morar moderna e paradisíaca.

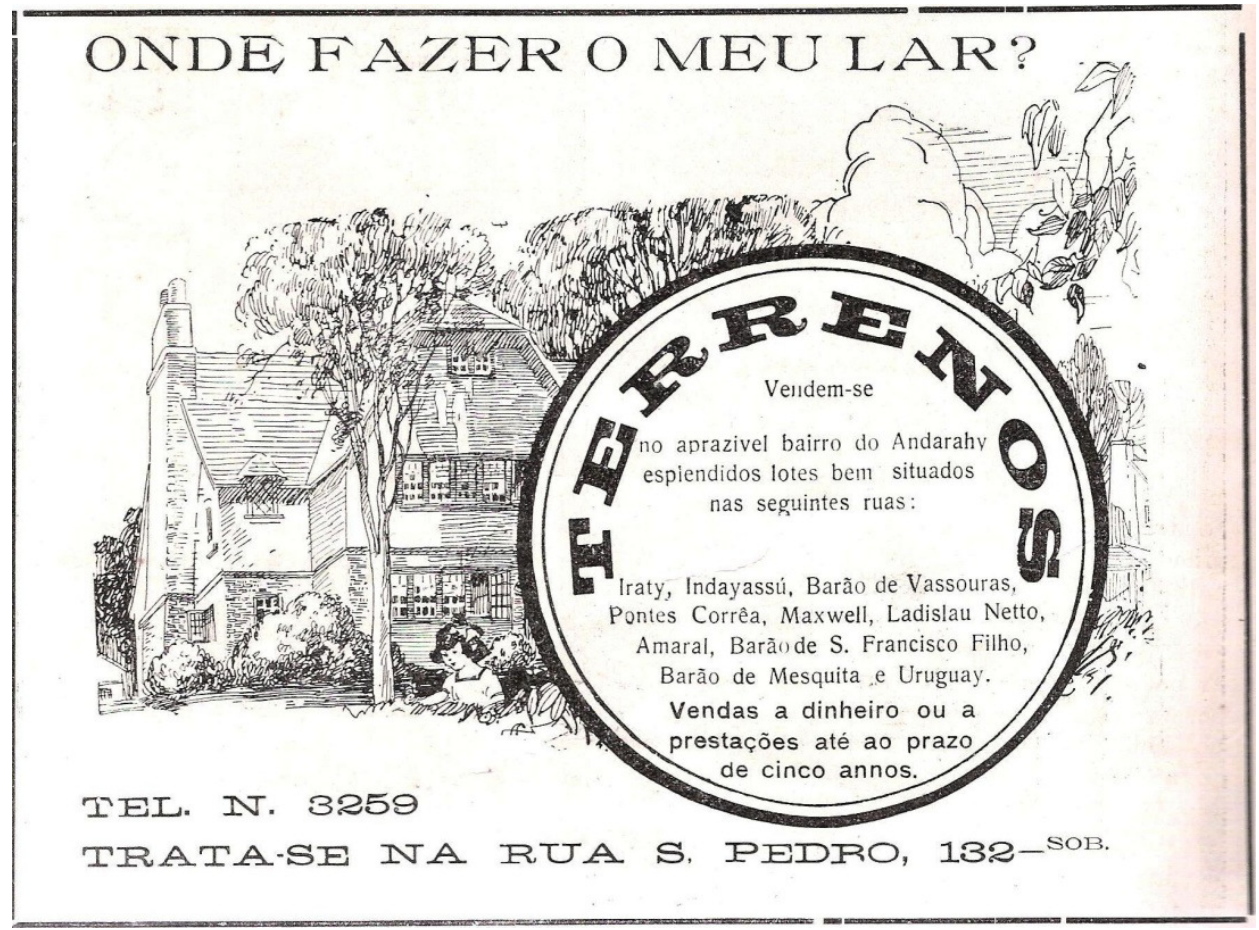


A ideologia do subúrbio constitui-se no final do século XIX, na Inglaterra e nos Estados Unidos. Com a urbanização e o crescimento acelerado das cidades do Rio de Janeiro e de São Paulo, nas primeiras décadas do século XX, os subúrbios também aparecem como uma solução para a localização da moradia, basicamente unifamiliar. Em São Paulo, serão criados, entre outros, o Jardim América e outros loteamentos da Companhia City.

A ligação entre a pequena moradia e o subúrbio é mostrada em um artigo sobre casas econômicas - onde se diz que estas não precisariam "ser feias". A localização nos subúrbios seria vantajosa, entre outros motivos, porque ali existiria um tijolo de boa qualidade que poderia ser deixado aparente e havia muitos terrenos de grande frente, plantados com árvores. (A Casa, nov.1924, n.7, p.17-9)

"O mesmo modelo, ao lado, transportado para qualquer rua sem vegetação, ou collocado em um terreno árido, perderia toda a graça." O tijolo aparente, além da evidente economia no acabamento, tornaria o aspecto externo interessante e estaria "em harmonia com o conjuncto de um terreno arborisado." (p. 18). E o artigo termina elogiando a varanda de descanso e leitura. Os modelos mostrados são os do cottage em tijolinhos do Arts and Crafts - com bay window, chaminé e telhados inclinados. A planta é racionalizada até nos pequenos detalhes, a cozinha planejada e os ambientes sociais conjugados. É o processo de projeto do Arts and Crafts, pensado dos detalhes da planta até a interação com a natureza, através da varanda de leitura. A preocupação com lotes de grande frente mostra a influência do desenho urbano de Unwin e Parker. O pequeno cottage e os subúrbios são vistos como interdependentes, na concepção da unidade de desenho do Arts and Crafts e, por extensão, da cidade-jardim.

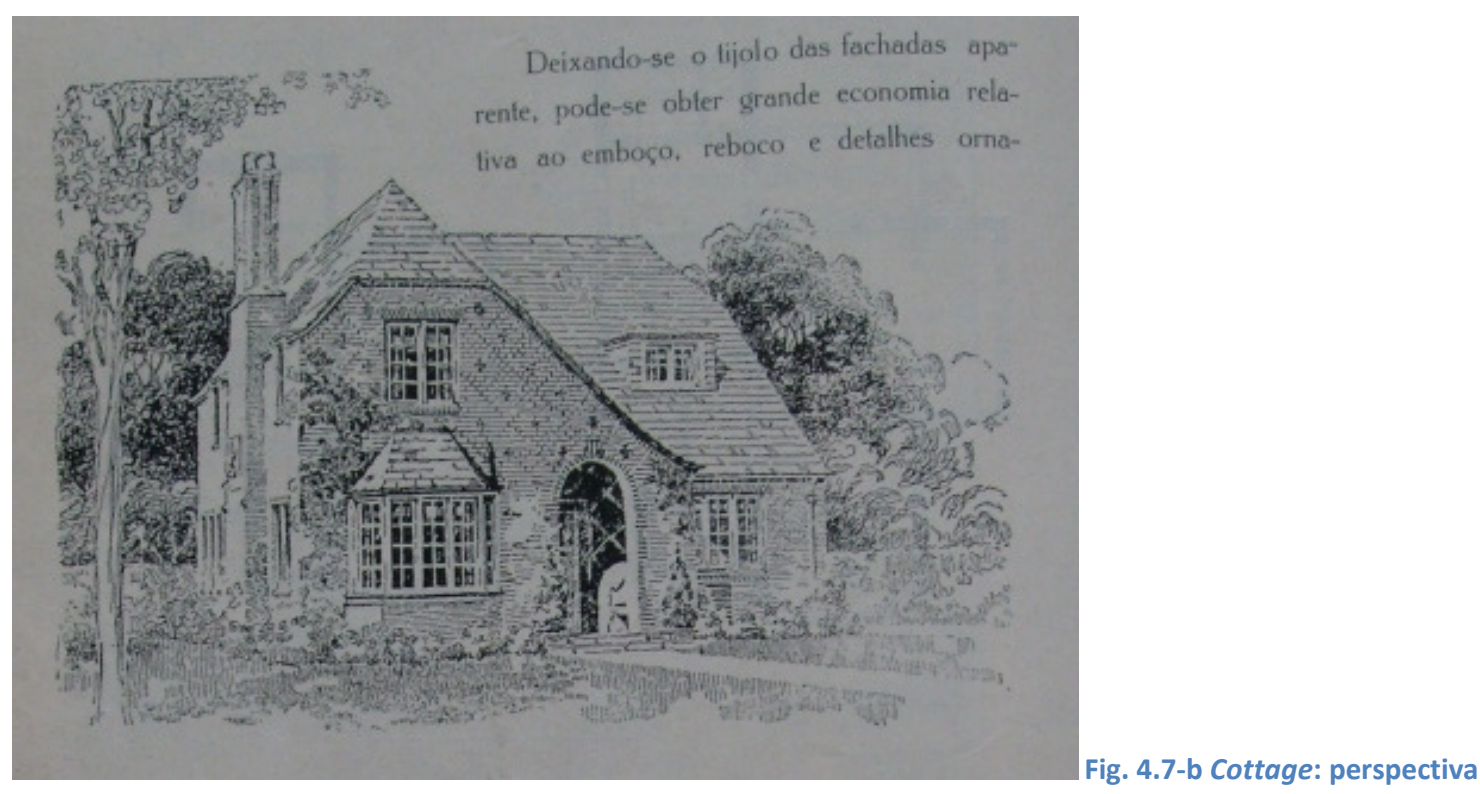




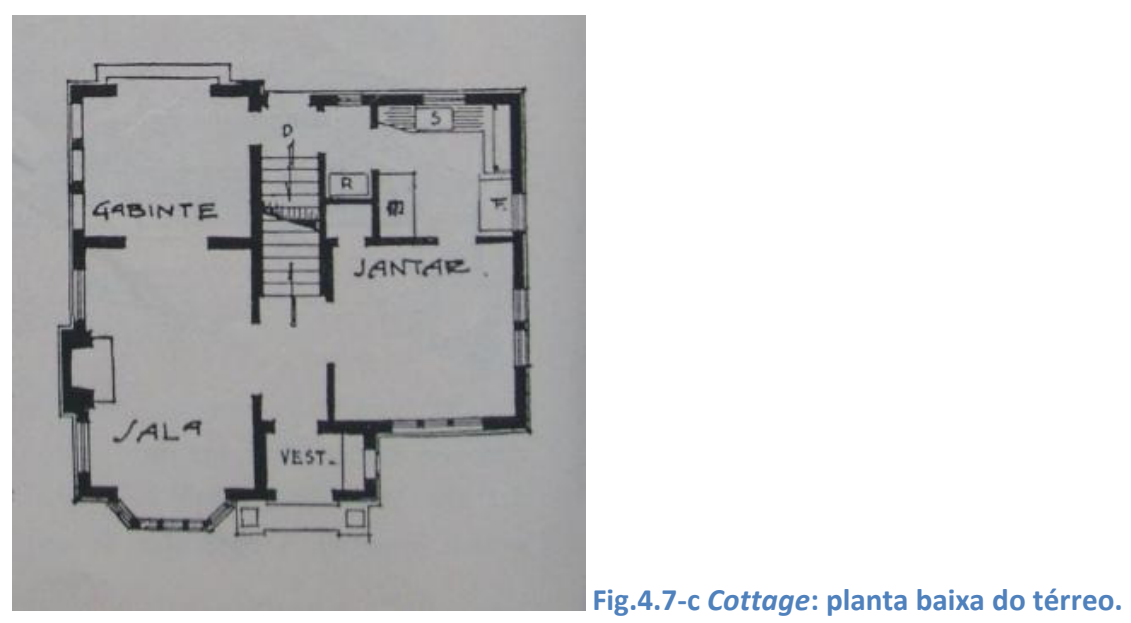

A Companhia Immobiliaria Nacional, grande construtora existente na época, havia projetado um bairro jardim na Avenida Suburbana, "cujo plano de arruamento, divisões de lótes e de melhoramento geraes, obedeceu a todas as exigências dos traçados modernos." (A CASA, 1925, n. 9, p. 20). A cidade jardim era a forma da cidade moderna.

Ainda em A Casa (1925, n. 16, p. 40), anuncia-se um "Bungalow" de 18 a 24 contos de réis em Côrreas, em uma fazenda a 20 minutos de Petrópolis. O acesso estava garantido já que havia "serviço de auto-omnibus em correspondências com todos os trens."

A modernização das cidades aparece também sob a forma dos arranha-céus. Por volta de 1929, começam a aparecer referências a eles nas páginas de $A$ Casa. No artigo de 1929, (n.61, p.13), apesar das vantagens, dizia-se que o arranha-céu estava sendo severamente criticado devido a seus excessos.

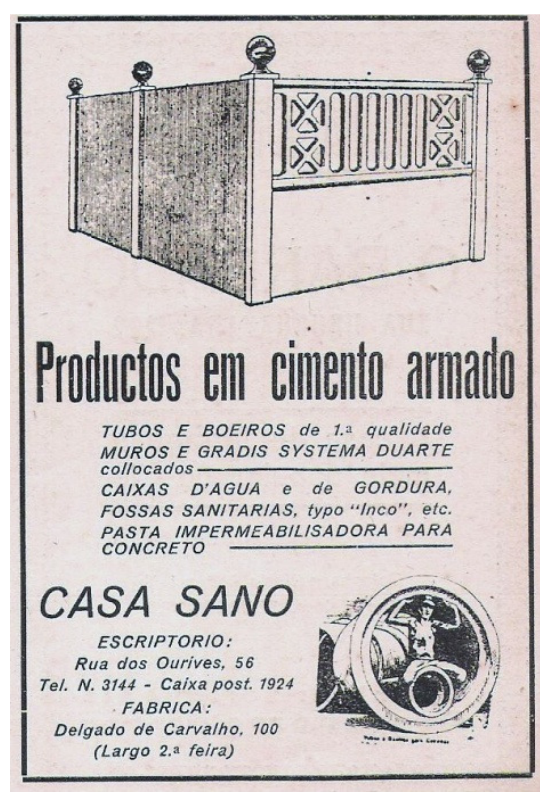


Novos materiais continuam a ser anunciados, como "productos em cimento armado, para infra-estrutura, como tubos, bueiros e fossas, mas também muros, gradis" e provavelmente alguns tipos de ornamentos para a utilização com a linguagem do Neocolonial. (A CASA, 1929, n.62, página 5)

Outro material recorrente nos anúncios é o isolante térmico Celotex - ilustrado na fig. 4.5 -, feito das fibras do bagaço da cana de açúcar. ( $A$ CASA, 1930, n.69, p.1).

No número 35 de A Casa (1927, p. 8) é anunciado um piso de linóleo mais moderno, "os padrões não seriam pintados, mas embutidos (inlaid)", seria "confortável, higiênico e muito durável", o Belflor Inlaid Linoleum.

Os novos materiais de acabamento tornam-se acessíveis à classe média. Em anúncio de "A Sanitária", é mostrado um banheiro completo, com revestimento em azulejos: "Esta casa dispõe do maior e mais variado sortimento em Ladrilhos, Azulejos, Fogões, Aquecedores a Gaz, Louça Sanitária e Mármores."

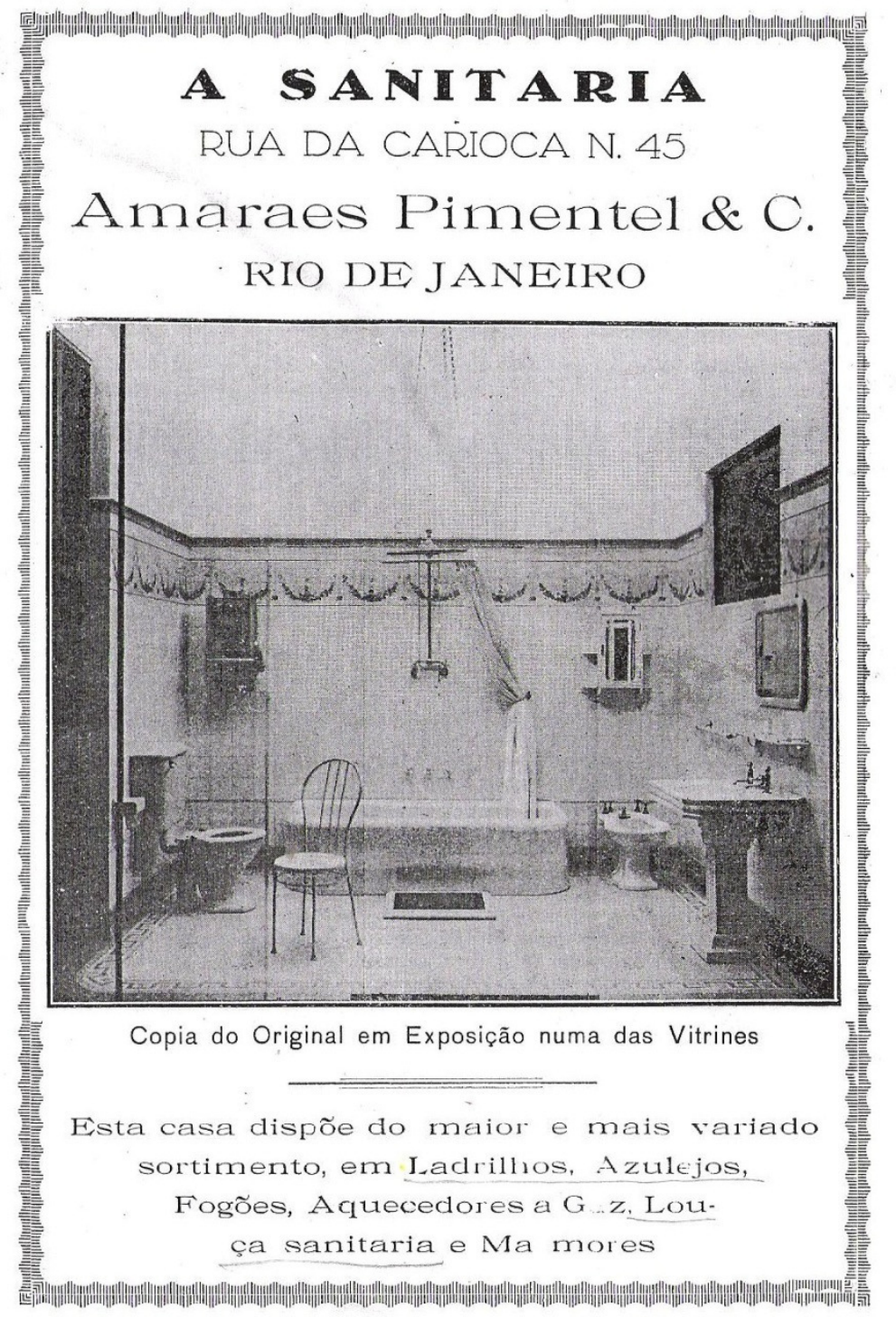


Outro anúncio é o de "J. M. Mello \& Cia., uma grande fábrica de ladrilhos hidráulicos e importadores de louças, cerâmicas, azulejos e outros materiais de construção".

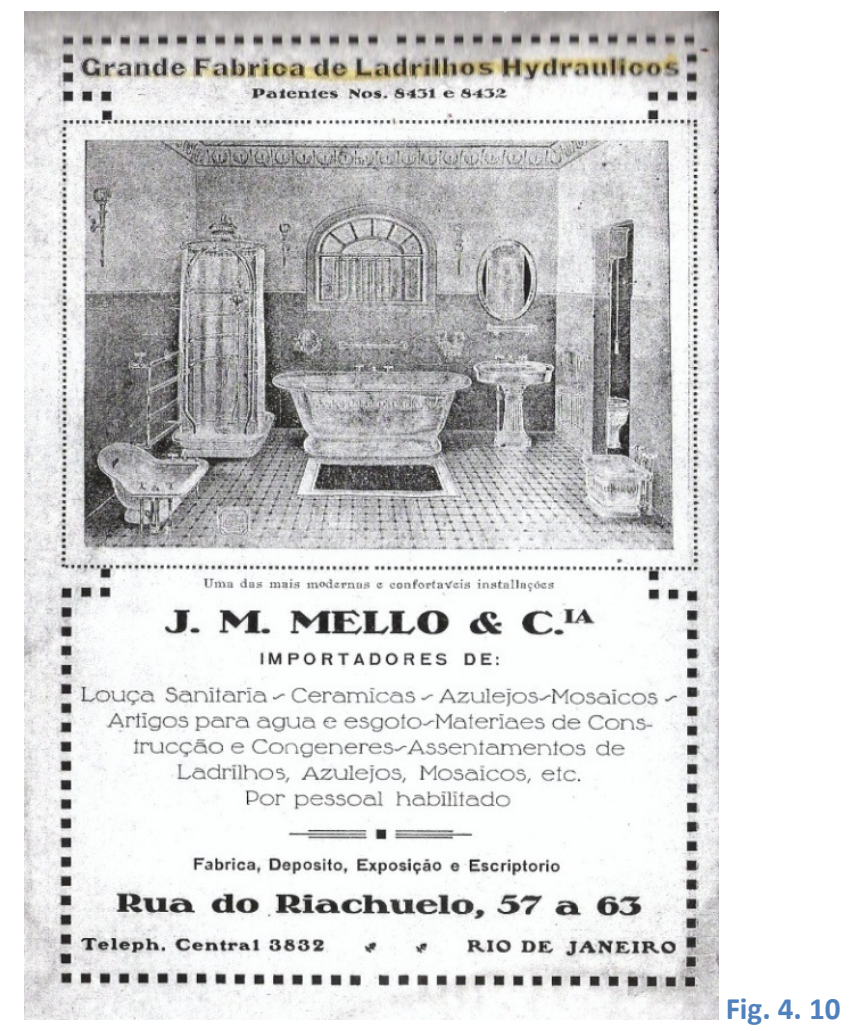

Em um artigo sobre o arranjo dos banheiros é possível conferir sua modernização:

"Realmente, quem vê os actuaes banheiros e passa uma vista d'olhos sobre os velhos quartos de banho, sente a mesma impressão de quem compara um primitivo automóvel com um modelo de 1929 (...) O banheiro, como a cosinha ou outra qualquer dependência da casa, deve ser intelligentemente planejado e disposto.(...) A introducção do colorido é, sem dúvida, a maior revolução havida nos banheiros de hoje. (...) Actualmente, para dar um effeito colorido ao banheiro, dispomos dos mármores de cor, do esmalte, do 'lap', dos mosaicos e dos vários typos de reboco decorativo. O colorido do chão se consegue por meio do azulejo, linoleum, cimento ou composição, de que egualmente dispomos em qualquer matiz que se desejar. Um dos processos freqüentes na remodelação da casa é procurar espaço para um segundo banheiro, utilizando qualquer quarto desoccupado ou mesmo um pouco de espaço da sala, recesso desnecessário ou socavão.(...) É de grande vantagem ter dois banheiros, principalmente nos prédios de dois pavimentos. Na América do Norte, 
até nas menores casa, estão sendo installados dois banheiros." ( $A$ CASA, 1929, n.61, p. 33, 35-6)

No número especial da revista americana House \& Garden (HOUSE \& GARDEN, $1925)^{8}$, de 1925 , dos sobrados mostrados, $89 \%$ possuem ao menos dois banheiros no pavimento superior.

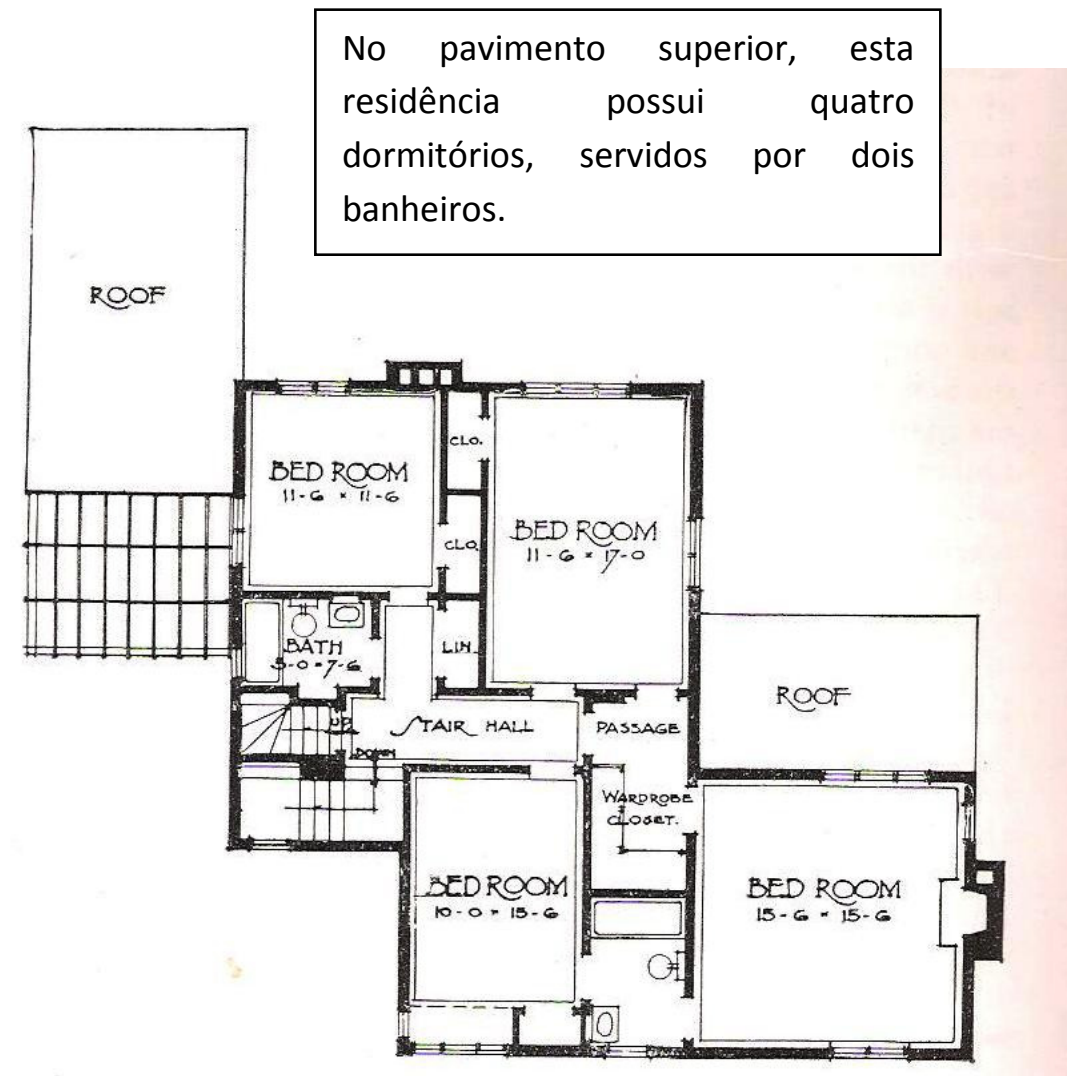

No Brasil, pelo contrário, os dormitórios, que eram dois, três ou mais, eram servidos por apenas um banheiro completo. Apenas no final da década de 1930, começam a aparecer, aos poucos, nas casas maiores, um banheiro privativo para o quarto principal ${ }^{9}$. Esta circunstância pôde ser observada na pesquisa nos arquivos da Companhia City, em que o segundo banheiro no pavimento superior aparece raras vezes na segunda metade da década de 1920.

\footnotetext{
${ }^{8}$ A revista foi fundada em 1901, por Herbert C. Wise, Wilson Eyre, and Frank Miles Day, todos arquitetos da Filadélfia. Um de seus editores foi Richardson Wright, entre 1914 e 1946, período em que foi publicado este número especial, de 1925, que faz parte do acervo da EPBC (Biblioteca Central da Escola Politécnica).

${ }^{9}$ Sobre estas modificações dos programas residenciais no período 1910-1930, ver WOLFF, 2000, p. 1857.
} 


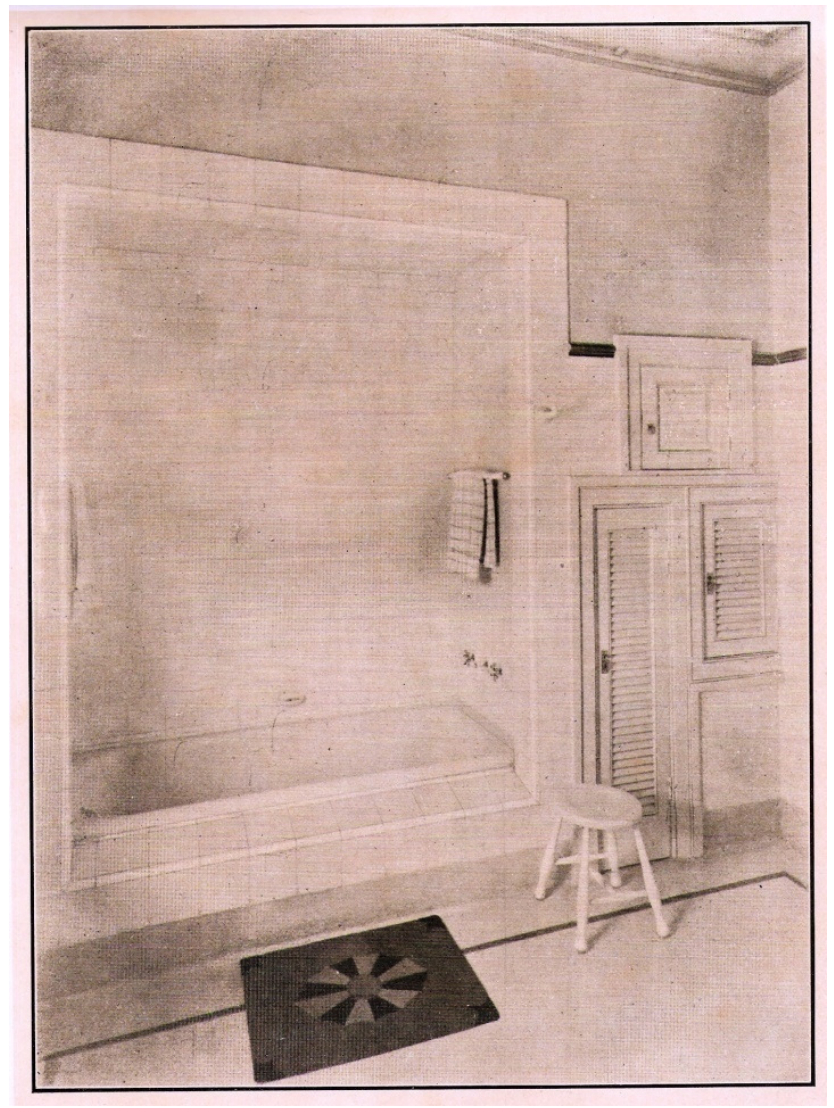

Fig. 4. 11 Banheiro de casa paulistana, mostrado no álbum de 1928 da Sociedade Construtora e de Imóveis.

\subsection{Projetos}

A Casa trazia sempre muitas fotos de casas construídas e projetos. Suas filiações podem ser estabelecidas visualmente e através dos textos que os acompanham ou dos artigos publicados pela revista.

A aproximação às casas da cidade-jardim é clara e, através delas ou diretamente, com o próprio movimento Arts and Crafts.

A arquitetura da cidade-jardim seria a arquitetura Arts and Crafts, como já foi dito no capítulo 1. Cottages para atender às necessidades de seus moradores, não para exposição a outras pessoas. "Casas para se viver uma vida plena e verdadeira", comentário tantas vezes repetido pelos arquitetos filiados ao Arts and Crafts, principalmente Barry Parker.

Como é colocado no artigo de $A$ Casa (março 1930, n.71, p.5-6), que fala da verdade na arquitetura como primeiro princípio a ser observado: a aparência deveria corresponder exatamente à realidade. 
De facto, os ornamentos não são condemnáveis; ao contrário, quando empregados com propriedade, realçam extraordinariamente a construcção. (...) No conjunto, desde que se considere a estructura do edifício, nada deve produzir uma illusão falsa; nos detalhes, não dissimular uma funcção qualquer da construcção sob outros aspectos. (...) Emfim, todo edifício deve apresentar o caracter architectonico indicado ao seu destino. (...) Todo o falso effeito em architectura denota absoluto desconhecimento destes importantes princípios. A observação da verdade se manifesta pelo emprego apropriado dos materiaes de construcção. (p.5)

Segundo o artigo, os materiais mais robustos serviriam como base dos demais materiais, mais leves e menos resistentes. Assim, a pedra seria o material adequado aos alicerces.

Percebe-se que, como no Arts and Crafts, cada parte da construção, inclusive através de seus materiais, denotaria sua função. Para Pugin, um edifício deveria refletir suas funções. E o edifício como um todo, o seu caráter

O trecho fala por si, na filiação aos princípios da verdade de Ruskin: verdade dos materiais; verdade das partes componentes do edifício - não deveriam ser criadas ilusões, como um falso suporte.

A presença de Barry Parker em São Paulo também indica o interesse despertado pelas experiências urbanísticas das cidades-jardins. A cidade-jardim inglesa fazia parte da cultura urbanística da época e era vista como a configuração moderna para a cidade, a nova maneira de se viver. $\mathrm{E}$ assim, era esperado que sua arquitetura também tivesse influência internacional. E é o que se pode constatar através das páginas de $A$ Casa.

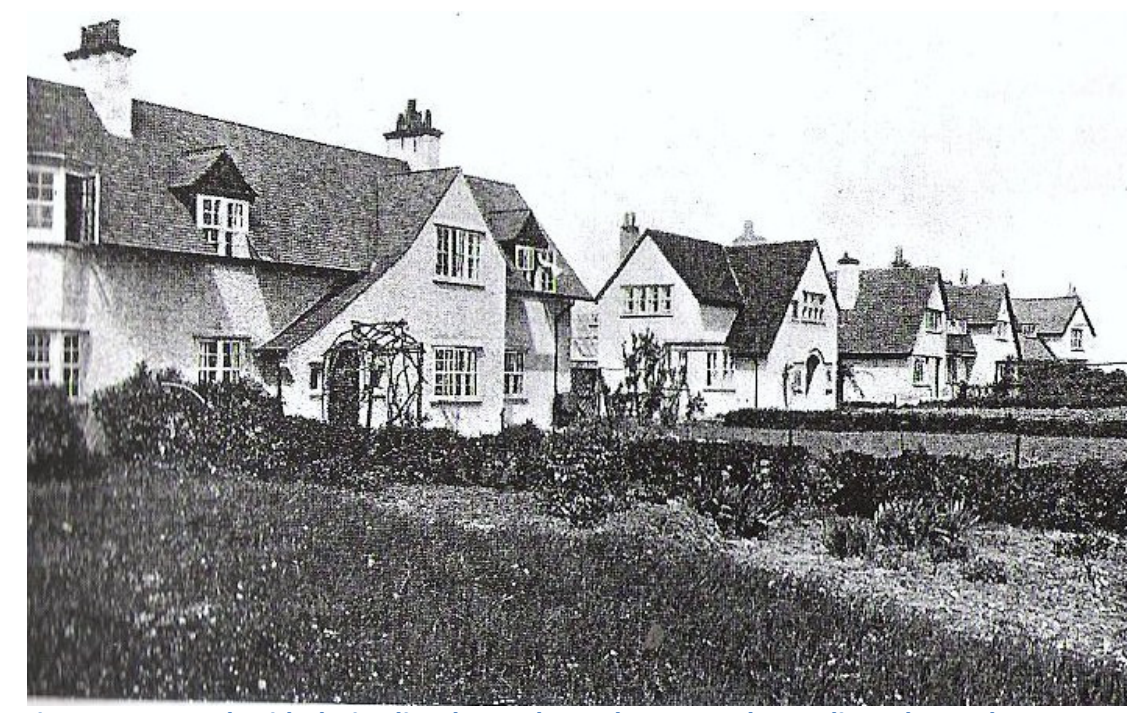

Fig. 4.13 Casas da cidade-jardim de Letchworth, mostradas no livro de Purdom. 


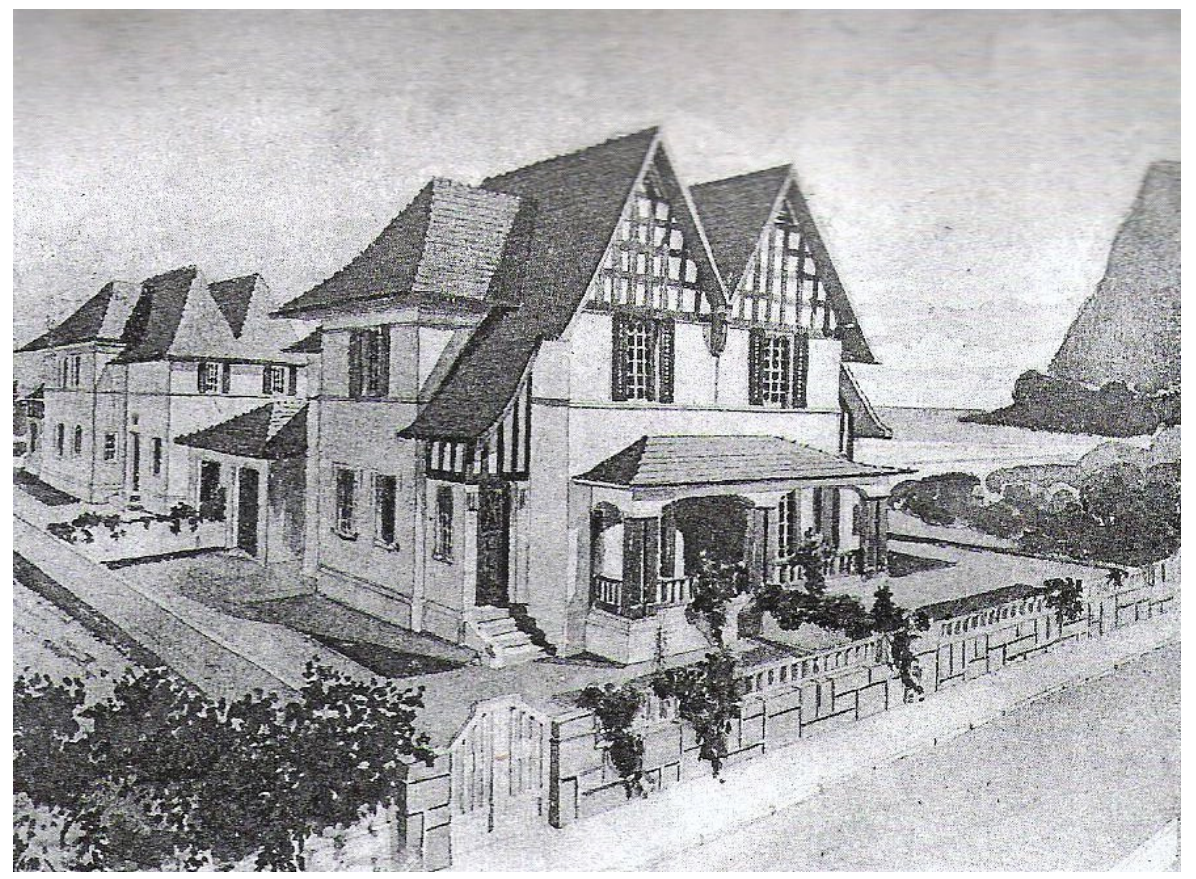

Fig. 4.14 Ilustração da revista $A$ Casa, (1924, n. 4, p.13)

$\mathrm{Na}$ Lagoa Rodrigo de Freitas, em Ipanema, seriam implantadas algumas casas geminadas. Entre as características que remetem aos cottages mencionados, a integração entre salas de jantar e estar, grandes telhados com águas-furtadas, madeira nas empenas e a pequena varanda para a qual se abre o estar. ( $A C A S A$, 1924, n. 4, p.13)

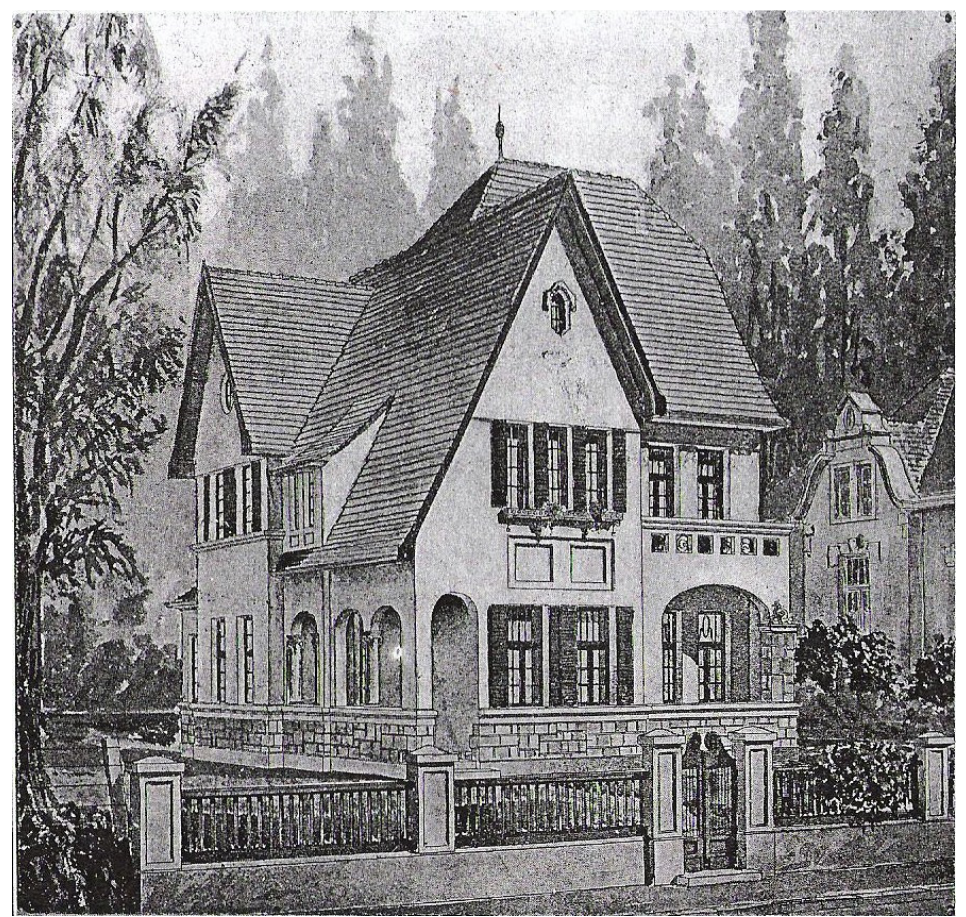

Fig. 4.15 llustração da revista $A$ Casa, 1924, n. 4, p.18. 
Outro projeto ( $A C A S A, 1924$, n. 4, p.18) tem a base das paredes em pedra e um terraço e varandas que marcam a integração exterior-interior. A casa situa-se no centro do lote, em meio ao jardim. A interação de formas simples, resultando em telhados bastante inclinados remete à arquitetura inglesa de Barry Parker e Baillie Scott.

Em um anúncio de venda de casas em Copacabana, Ipanema e Leblon, são mostrados alguns cottages, chamados aqui de bangalôs ( $A C A S A, 1924$, n. 4, p.29). Apesar de projetadas e construídas em conjunto, cada casa individualiza-se e tem sua "personalidade".

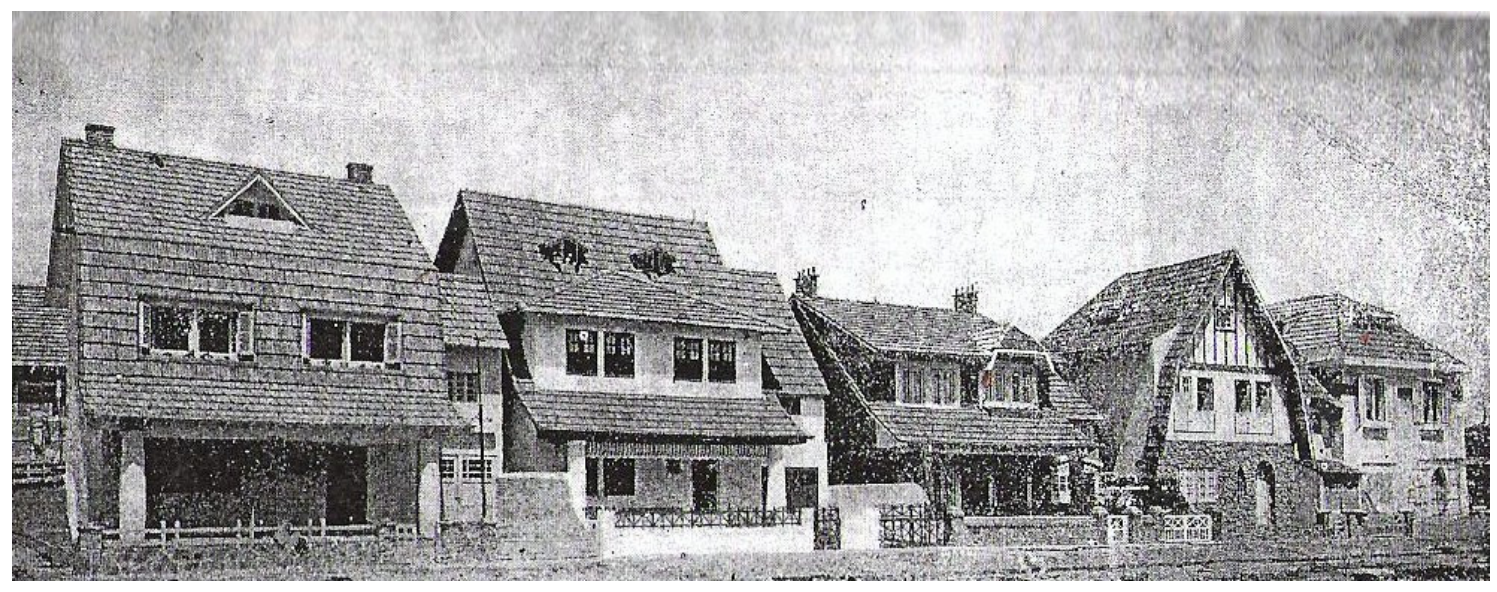

Fig. 4.16 Bangalôs em Copacabana, (A CASA, 1924, n. 4, p.29)

Por toda a revista vêem-se pequenas ilustrações de casas, sem qualquer referência. Como na página 28 (1924, n. 4), em que é mostrada uma casa que remete ao Old English de Norman Shaw, o arquiteto inglês do século XIX e à arquitetura Tudor. É mostrada uma composição pinturesca, com um arco de acesso e paredes com pedras no térreo e madeira no segundo pavimento.

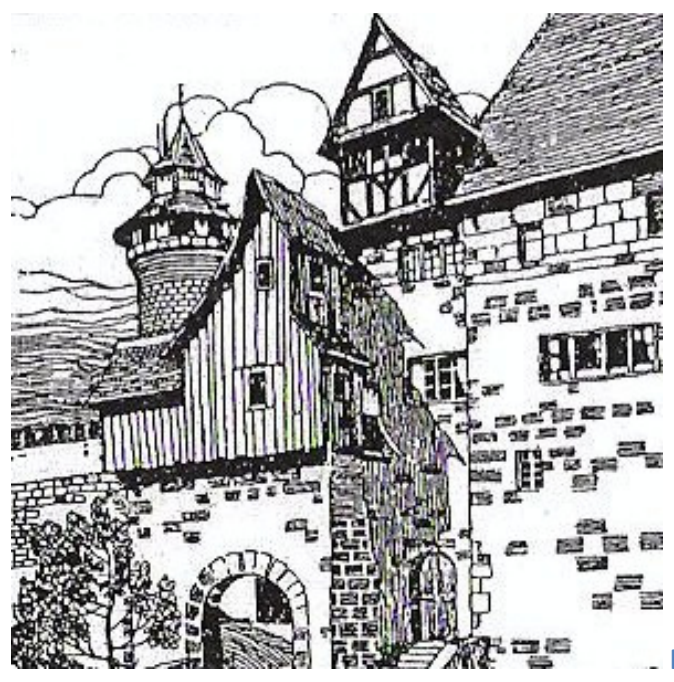

- Fig. 4.17 Composição pinturesca sem referências. 
Na página 17, de $A$ Casa (1924, n. 8) aparecem dois outros pequenos cottages $^{10}$ geminados, com as pequenas varandas de acesso e o embasamento em pedra.

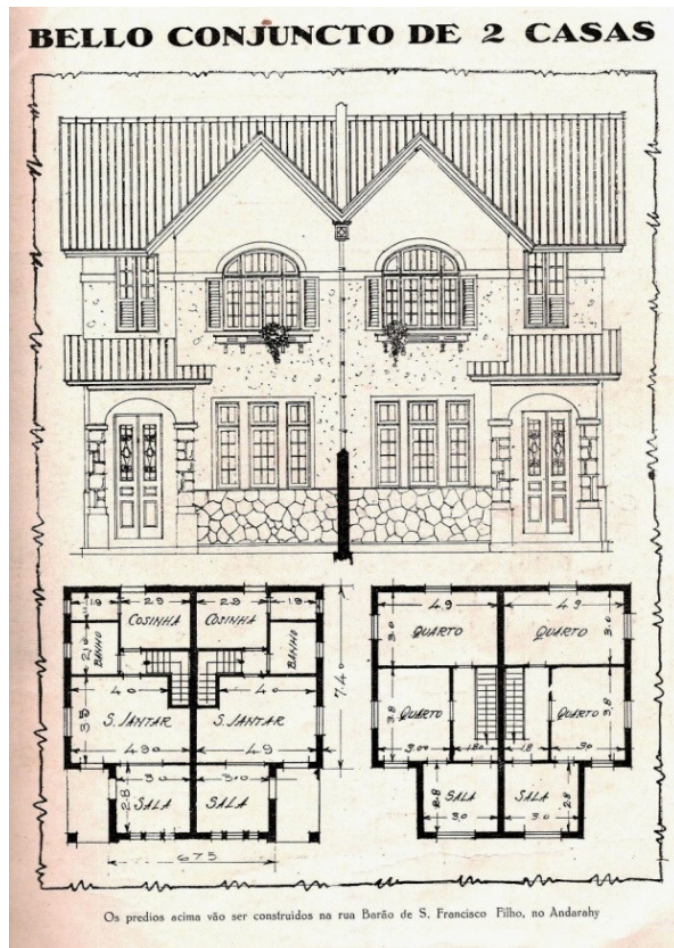

Fig. 4.18 Casas geminadas

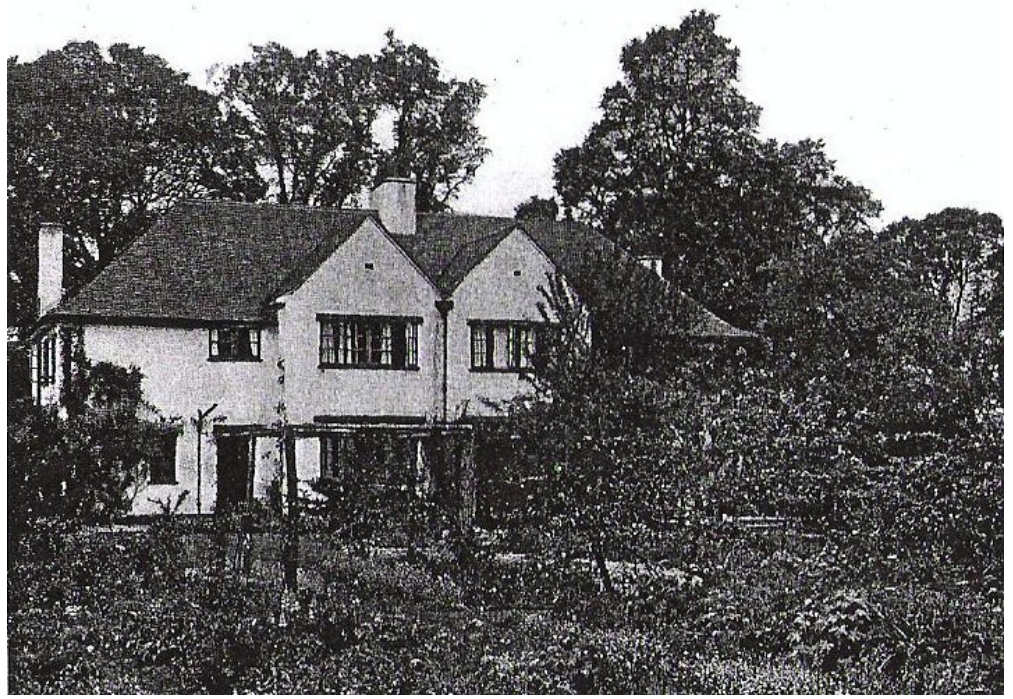

Fig. 4.19 Casas em Letchworth, composição semelhante às anteriores.

10 Atualmente, um cottage é visto como uma habitação no campo ou em um subúrbio. Na GrãBretanha, o termo tende a referir-se a uma habitação no campo ou em uma vila, de "um pavimento e meio", onde no pavimento superior, tem-se que avançar pelos beirais para olhar pelas janelas, que geralmente estão localizadas em um sótão. Isto significa que, muitas vezes, o madeiramento do telhado penetra no espaço interno do segundo pavimento, e freqüentemente, especialmente em reformas, as partes mais importantes do madeiramento, como vigas, terças e pilares podem ficar expostas, realçando as características do cottage. Em vários outros locais, o termo "cottage" designa uma pequena habitação aconchegante, mas em outros lugares, como no Canadá, o termo não faz nenhuma referência ao tamanho da habitação (http://en.wikipedia.org/wiki/Cottage) 
Outro pequeno cottage ${ }^{11}$ é apresentado em anúncio da Companhia Immobiliaria Nacional do Rio de Janeiro (A CASA, 1925, n.9, p.2). Mas, este é térreo, como raramente se encontra na Inglaterra, e remete ao bangalô americano. Este tipo de casa térrea se tornará muito comum no Brasil, popularizado como habitação de baixa renda.

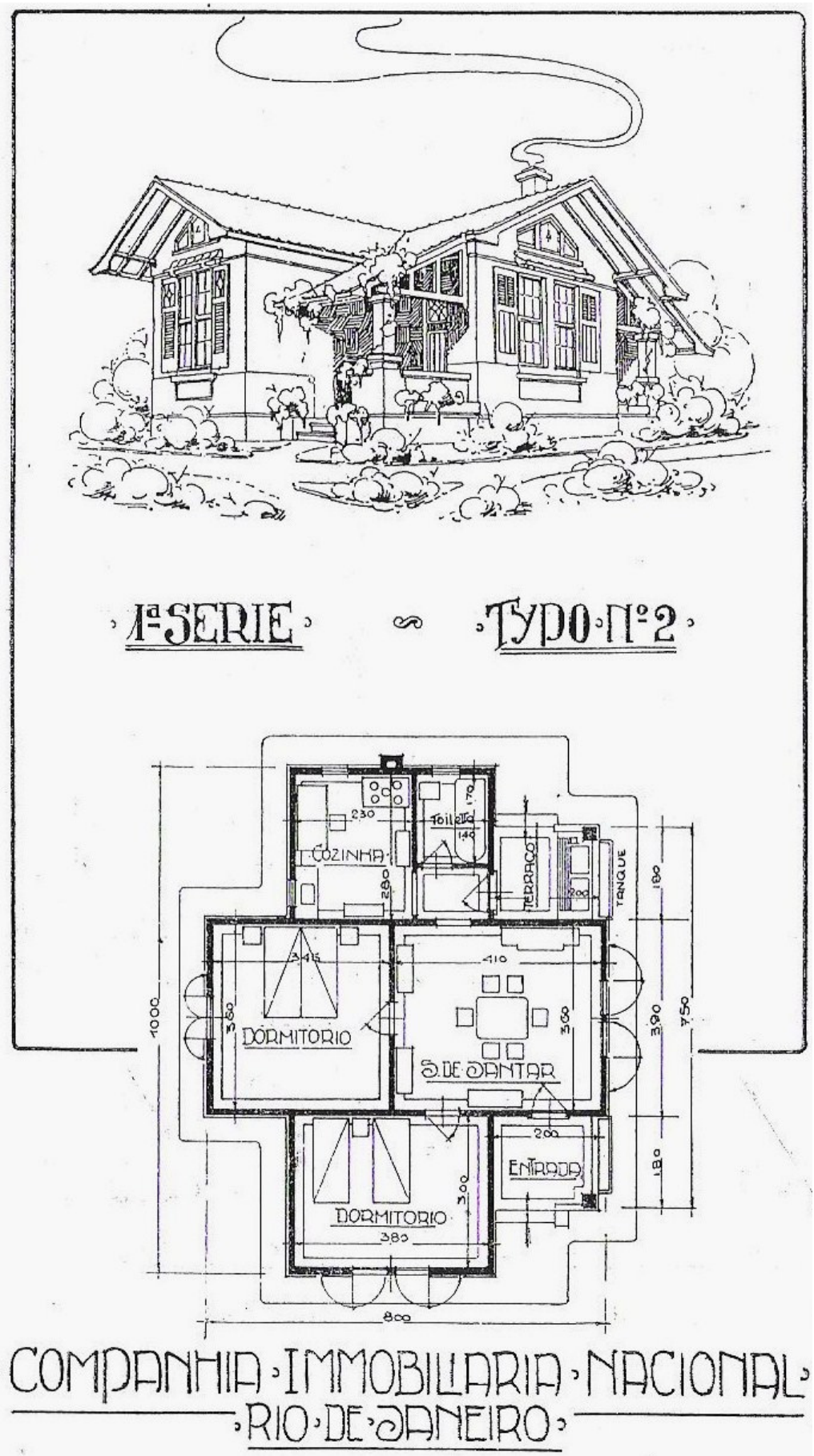

Fig. 4.20 Cottage

\footnotetext{
${ }^{11}$ A casa apresenta área aproximada de $68,78 \mathrm{~m} 2$ (consideradas todas as paredes com espessura de 25 $\mathrm{cm}$, já que são todas provavelmente estruturais).
} 
Não se cogita neste caso em se ter economia nos custos através de um volume único e de um telhado com apenas duas águas. O desenho pinturesco acaba prevalecendo e a contenção nos custos se dará por outros meios, como a concentração das instalações hidráulicas.

Nestas pequenas casas, não há perda de espaço com corredores internos e os dormitórios têm acesso através da sala. $\mathrm{O}$ banheiro fica afastado, junto à cozinha, racionalizando assim as instalações hidráulicas. Esta solução é quase sempre adotada; uma maior separação entre setores social, íntimo e de serviço apenas será encontrada nos sobrados, em que os dormitórios situam-se no pavimento superior. Porém, mesmo nestes, existem, muitas vezes, um dormitório no térreo, que se mescla à área social.

A austeridade de uma casa, da qual se vê a foto na página 12 de $A$ Casa (1924, n. 8), remete ao Arts and Crafts em sua atmosfera gótica. Trabalho em madeira na varanda; uma chaminé que se destaca dos demais volumes da casa; as paredes do segundo pavimento em madeira e a base do térreo em tijolos aparentes são algumas características. A sobriedade da casa acaba por ser suavizada pela natureza circundante, ainda que seja uma natureza domesticada, contida em um lote urbano e demarcada pela pequena cerca em madeira. Uma pequena porção da natureza também é trazida às janelas através das floreiras. A varanda ajuda na transição interior-exterior. Apesar de a estética remeter ao Arts and Crafts e ao Gótico, é uma forma moderna de morar, com inovações tecnológicas e novos materiais que asseguram o conforto, como é o caso da persiana externa de enrolar ${ }^{12}$, que aparece em apenas uma janela frontal, provavelmente devido a seu alto custo na época.

\footnotetext{
${ }^{12}$ A veneziana externa de enrolar é uma inovação eminentemente européia. Desde o final do século XIX, são conhecidos exemplos da aplicação de um novo tipo de resguardo externo de janelas. Trata-se de uma espécie de esteira bastante robusta, constituída por réguas de madeira justapostas e articuladas entre si por meio de grampos metálicos, e podendo ser levantada ou abaixada através de um cadarço associado a um eixo encaixado por trás da verga. Em seu deslocamento vertical a esteira é guiada por trilhos de perfil metálico que atuam ao mesmo tempo como caixilho. Inicialmente restrita aos movimentos verticais contidos dentro da moldura das janelas, essas esteiras evoluem para um sistema de abertura mais complexo, combinando o deslocamento vertical com a projeção da base para o exterior, a exemplo dos toldos. Muito difundidos na Franca a na Itália, sobretudo nas primeiras décadas deste século, aí ficaram conhecidas como store ou volet rouiant e persiana avvolgibile (toldo e persiana de enrolar), respectivamente. Praticamente desconhecido nos países anglo-saxônicos e nórdicos o sistema alcançou enorme difusão no Brasil, sendo inicialmente chamado apenas de veneziana e mais tarde de persiana externa de enrolar. (www.persianascoelho.com.br/HISTORIAPERSIANA.htm)
} 
Bello predio de alvenaria e madeira

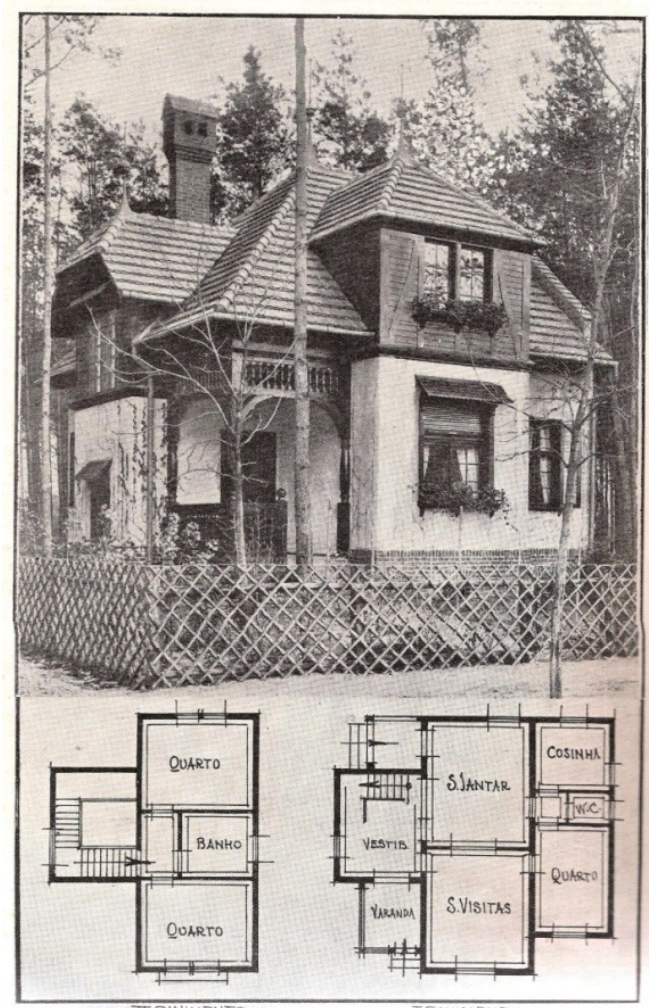

Fig. 4.21

Pequeno predio moderno

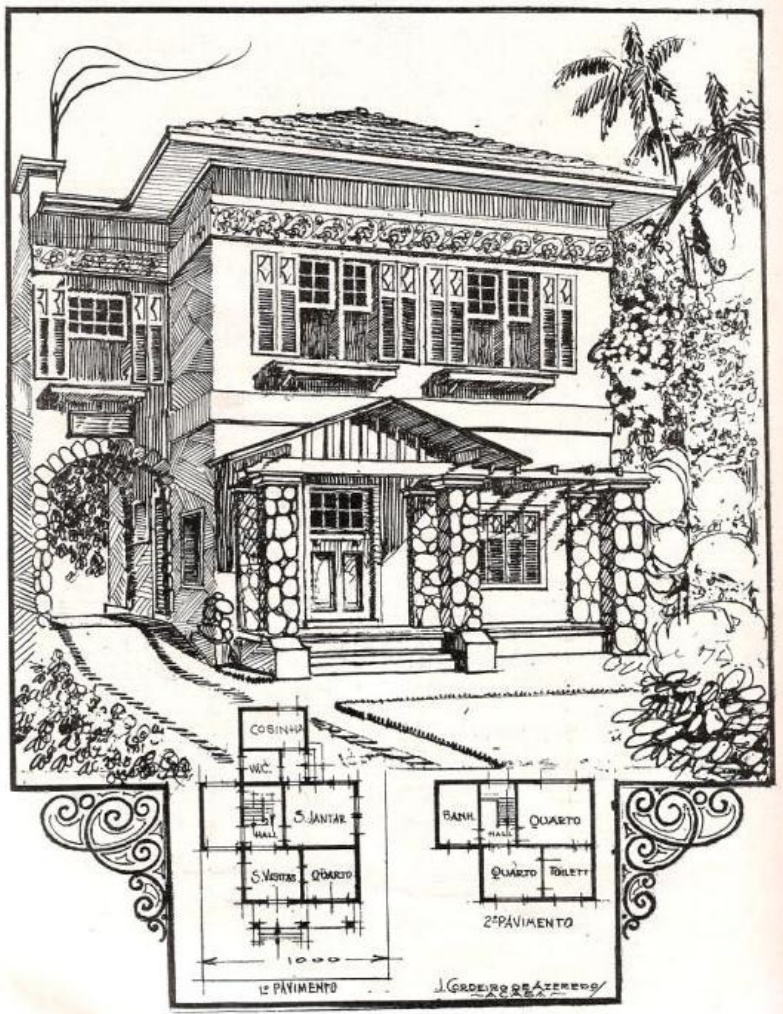

Fig. 4.22 Bangalô (A Casa, n.8, p.16) 
Outra ilustração ( $A$ Casa, 1924, n. 8, p.16) mostra um bangalô, com sua característica varanda de acesso - com telhado em duas águas e os pilares em pedra. Pérgulas, muito comuns nos jardins, frisos decorativos - neocolonais talvez -, e uma chaminé completam a casa, que se abre para um jardim exuberante. Já aparece o abrigo para o automóvel, uma inovação presente em poucas residências ainda.

Em artigo em A Casa (1925, n. 16, p. 11-12), salienta-se que a carência de habitações no Rio e em São Paulo acentuava-se. "A procura de pequenas casas para habitação tende, portanto, a augmentar tremendamente, desde que as mesmas possam ser vendidas em condições accessíveis aos que têm rendimento mensal de menos de dois contos (...). É necessário que o custo das casas seja reduzido." As principais causas do encarecimento da construção seriam, entre outras: “(...) falta absoluta de standardisação, ausência de organisação na obra, exigências demasiadas dos códigos de construcção (...), péssima divisão em lotes das zonas de moradia, vendose habitualmente terrenos de pouca frente, com 50 e mais metros de fundos!" Quanto à standardisação, deveria-se "diminuir o serviço feito na obra, substituindo-o pelo feito na officina", deveria-se "standardisar systematicamente as esquadrias, em suas dimensões e typos." Havia muita discussão a respeito da racionalização dos processos construtivos, como acontecia na Escola Politécnica, à época.

No número 62 de A Casa, (1929, página 32-3), fala-se sobre o desperdício de espaços, em artigo sobre a preocupação com projetos econômicos. Salienta-se que nas "casas com dois pavimentos, o banheiro do sobrado deve assentar sobre a cozinha, para reduzir o custo dos encanamentos". A economia deveria abranger a disposição dos cômodos da casa e a sua dimensão. Para exemplificar, são mostrados dois projetos de casas, reproduzidas da revista americana House Beautiful. Faz-se uma analogia entre o aproveitamento do espaço em uma casa e o rendimento das máquinas. A eficiência do traçado da planta deveria ser determinada dividindo-se a área dos aposentos principais pela área absoluta da casa. Tal percentagem deveria obedecer a um número mínimo. Na pesquisa sobre o Jardim América, os projetos de sobrados encontrados quase sempre fazem coincidir as paredes do pavimento térreo e do superior, outro exemplo de racionalização.

No número 35 ( $A C A S A, 1927$, p. 13), é mostrada uma casa que pertenceria a José Marianno Filho, com uma vaga inspiração no Neocolonial ${ }^{13}$, perceptível nas colunas da pérgula, na moldura da janela e no detalhe em forma de meia lua presente nas

\footnotetext{
${ }^{13}$ Alguns estilemas do Neocolonial são: varandas sustentadas por colunas toscanas, telhados com largos beirais, feitos de telhas-canal e tendo, nos vértices, uma telha em forma de pluma virada para cima, rótulas, azulejos recobrindo as paredes das varandas, frontões com pináculos. (BRUAND, 1997, p. 53).
} 
muretas. A planta baixa já está resolvida com o isolamento dos setores íntimo, social e de serviço, apesar de se constituir em uma casa térrea de pequenas dimensões.

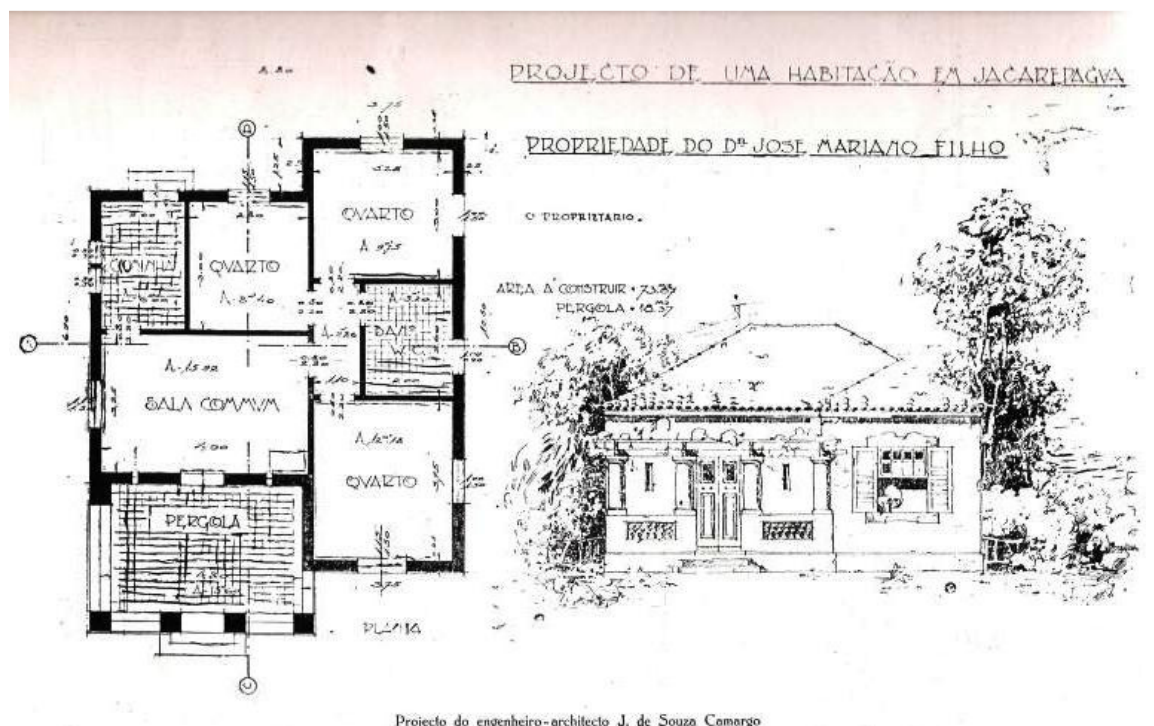

Fig. 4.23

Antes deste, já haviam sido mostrados outros projetos neocoloniais. Entre os primeiros estão aqueles apresentados no número 9 da revista ( $A C A S A, 1925$ p. 17-8) do arquiteto Ângelo Bruhns ${ }^{14}$. Com grande área, seriam considerados uma "casa nobre ou palacete". Confirmam a hipótese de que o Neocolonial foi inicialmente uma linguagem utilizada em grandes edifícios, residenciais ou não, por arquitetos conhecidos e que seria depois apropriada pela classe média.

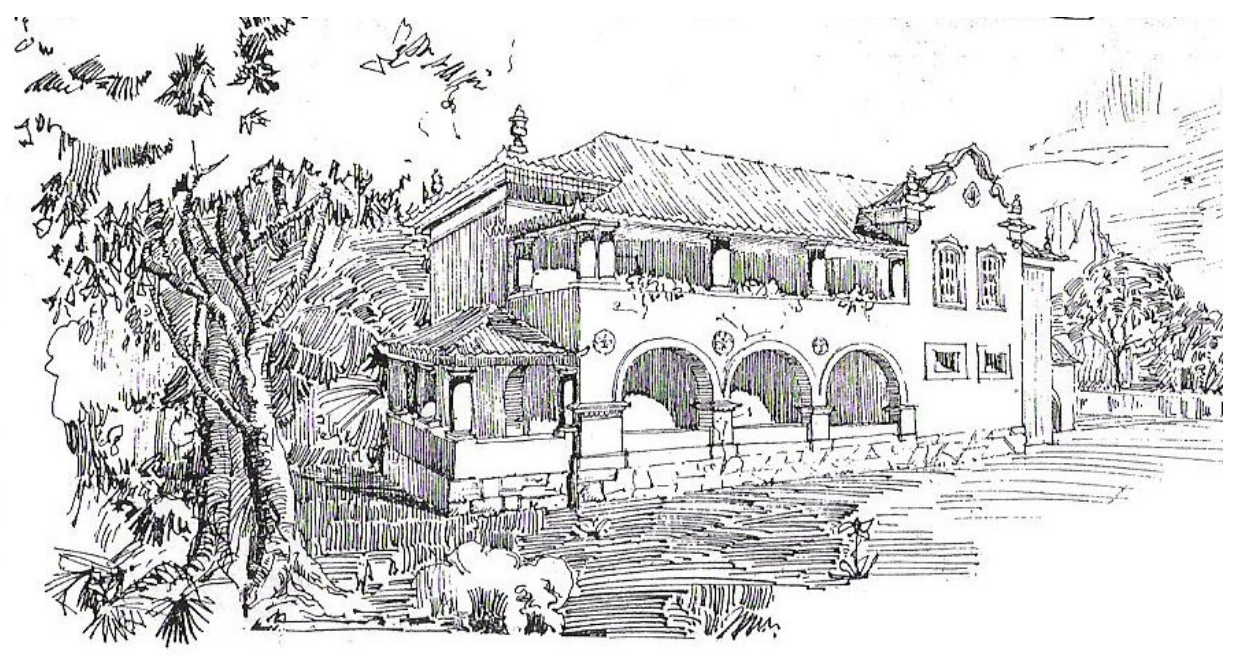

\footnotetext{
${ }^{14}$ Ângelo Bruhns foi um arquiteto bastante atuante no Rio de Janeiro, um dos mais conhecidos representantes da arquitetura neocolonial. Em 1923, recebeu o 'Prêmio Heitor de Mello'. Projetou edifícios como o antigo Instituto de Educação (atual Instituto Superior de Educação do Estado do Rio de Janeiro), construído entre 1927 e 1930, em parceria com o arquiteto José Cortez.
} 

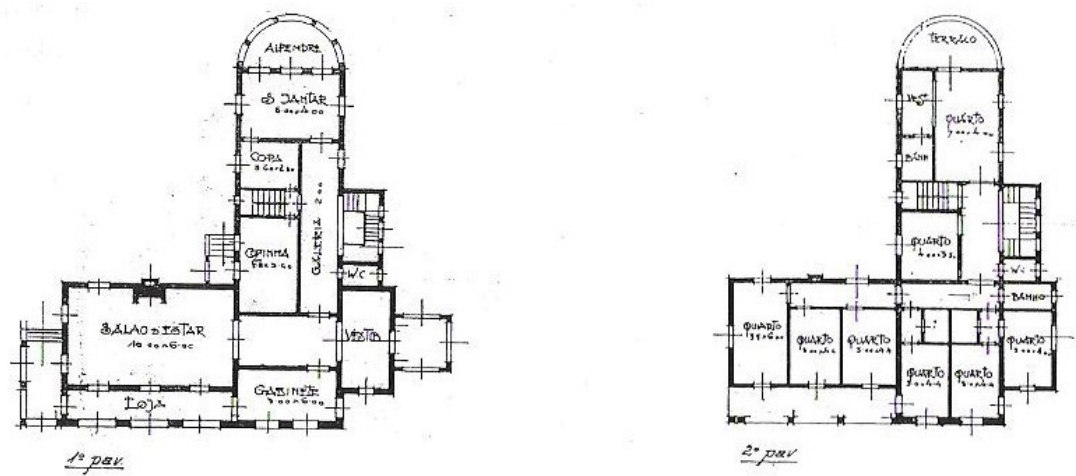

Como coloca Lemos (1989, p.179) “(...) o neocolonial expressou-se entre nós a partir da vertente 'erudita' formulada por arquitetos categorizados (...). Desta vertente elitista decorreu toda a produção popular receptadora sem indagações maiores dos modelos ricos levantados nos bairros da alta burguesia".

No concurso de $A$ Casa, cujo resultado foi publicado no número 16 (1925, p. 5): "Comquanto houvesse sido facultado aos architectos a escolha do estylo, os projectos, em sua maioria, apresentaram as fachadas em estylo colonial, problema aliás difficil de resolver, por isso que se tratava de casas de um só pavimento." O primeiro e segundo lugares no concurso foram obtidos por projetos com características do Neocolonial. Apesar de supostamente incógnitos, dois arquitetos dividiram os cinco primeiros prêmios do concurso: J. de Souza Camargo e Carlos Raposo.

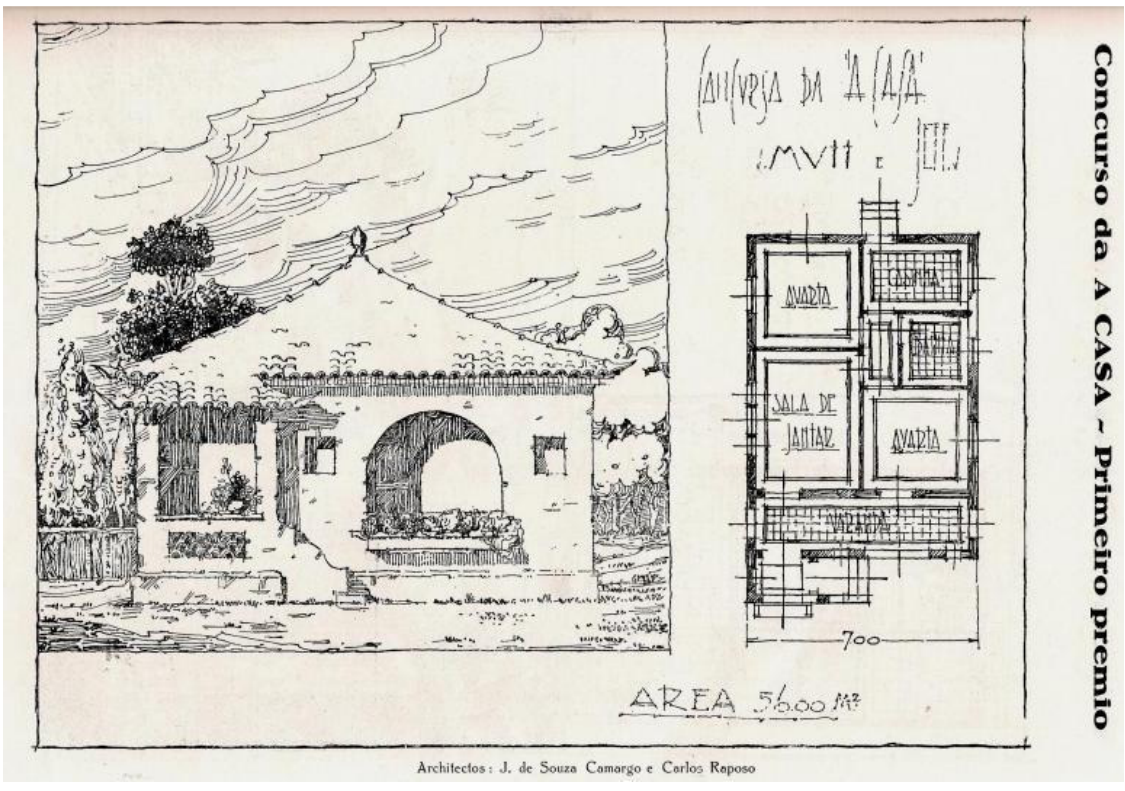


Para o Neocolonial, a procura pela arquitetura vernácula era fundamental, assim, era importante "viajar pelo Brasil, nas suas cidades do interior mineiro, bahiano e pernambucano para descobrir as preciosidades. (...) renovar a façanha do garimpeiro em busca das pedras preciosas da arte desconhecida." Ou: "No dia em que colligarmos o que nos resta da architectura da metade do século XVIII e XIX, para estabelecer um confronto com os exemplares europeus, ver-se-há que muitos destes particulares architectonicos, (vírgula no original) honrariam as velhas civilisações." Esta comparação de nossa arquitetura com a européia está bem de acordo com o espírito nacionalista da época, logo após a comemoração do centenário da independência, em 1922. Este é um artigo sobre Congonhas do Campo ( $A$ CASA, 1925, n. 16, p. 7). São apresentados "magníficos detalhes, perdidos no Arraial de 'Congonhas do Campo'”.

No número 56 de $A$ Casa (1928, p.10), é anunciado o livro "Estylo Colonial Brasileiro Composições Architectônicas de Motivos Originaes" de Felisberto Ranzini ${ }^{15}$, de 1927 , com detalhes arquitetônicos retirados de igrejas e outros edifícios do período colonial, para que fossem utilizados em exemplares da arquitetura Neocolonial. O livro - que se tornaria muito conhecido, com os detalhes copiados à exaustão - era vendido na redação da revista.

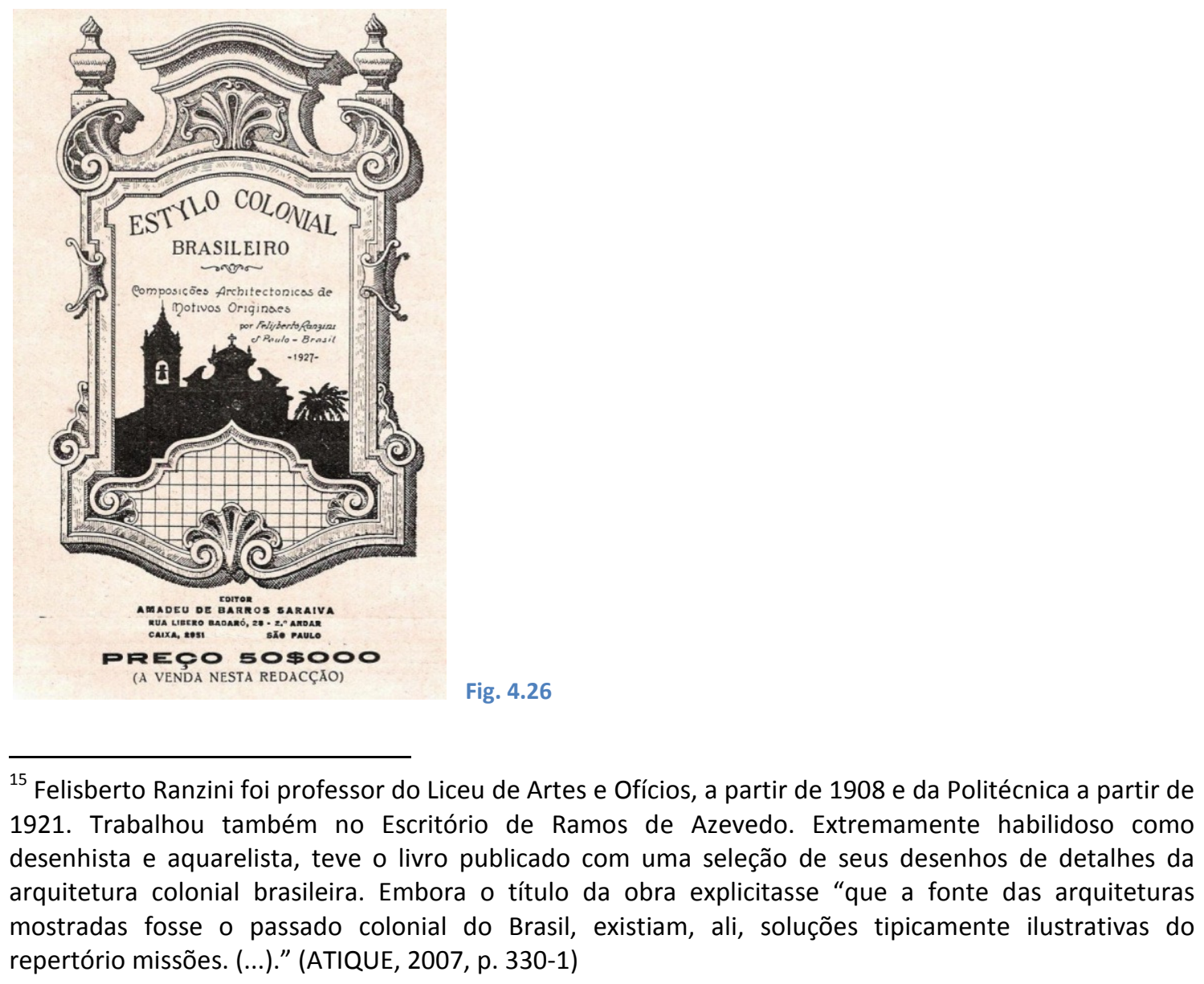


Já na capa da revista no número 35 ( $A C A S A, 1927)$, aparece uma perspectiva do arquiteto Moacyr Fraga que representaria uma casa no "estylo hispano-mouro". Seria um dos primeiros projetos no estilo Missões ${ }^{16}$ publicados pela revista.

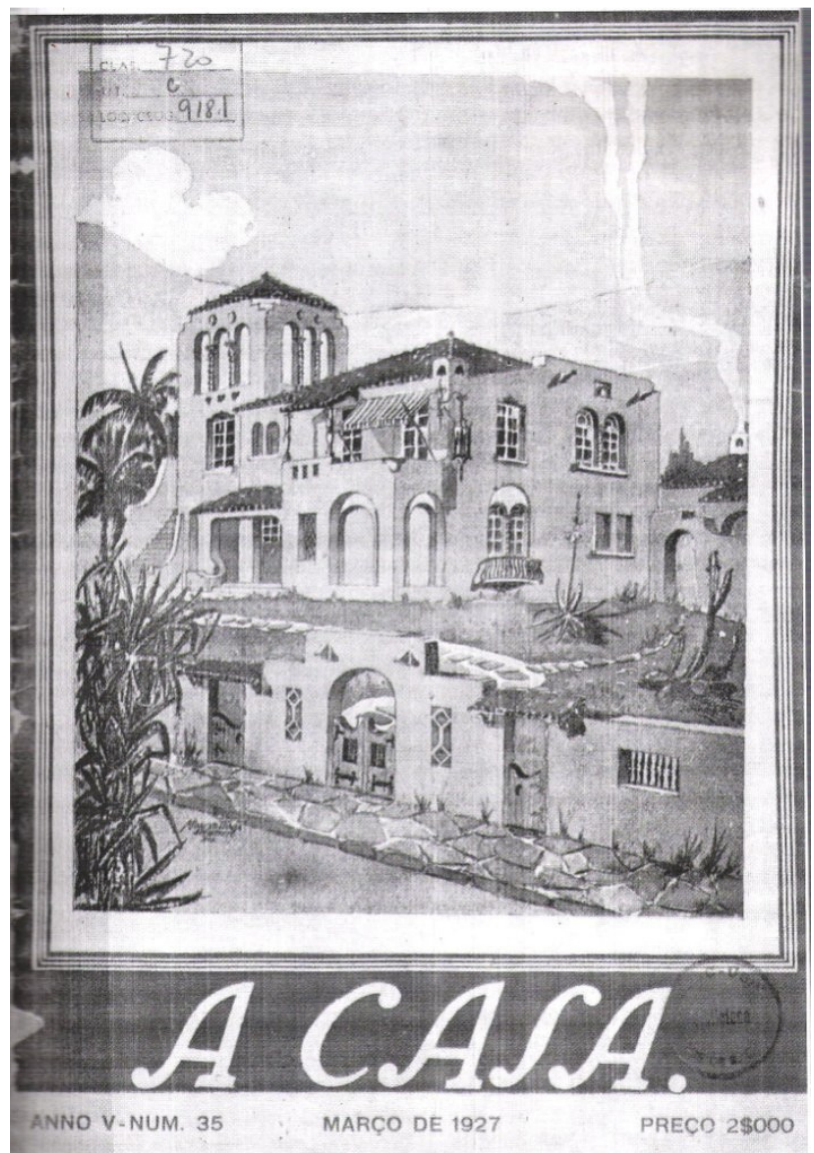

Em artigo no mesmo número, à página 16, o arquiteto explica que "a fusão do estylo hespanhol com o mouro, transportado para a América, nos proporcionou um producto harmonioso, artístico, sóbrio, e de estylo architectonico simples e agradável, chamado

\footnotetext{
${ }^{16}$ A arquitetura Missões originou-se no sul da Califórnia. Passou a ser conhecida como Mission Style, nos Estados Unidos.

Algumas características do "estilo missões" praticado em São Paulo são: o torreão circular, coberto por telhado cônico, marcando a caixa de escadas. Telhado em várias águas coberto com telhas capa - e canal. À frente, telhado em duas águas coberto por telhas "paulistinhas" transversalmente dispostas. Outros estilemas freqüentes eram pequenos corpos em balanço nos andares superiores, balcões no pavimento superior com colunas salomônicas ou torneadas; alpendres com arcos plenos, abatidos ou goticizantes, às vezes emoldurados por tijolos ou pedras. Gradis de ferros trabalhado, em portas e janelas e nos guarda-corpos dos balcões; revestimento rústico das fachadas com reboco grosso em relevo, geralmente na cor branca - para evocação das marcas deixadas pelas brochas das constantes caiações nos prédios que inspiraram tais construções -; painéis de azulejos. (D'ALAMBERT, 2003, p.1967)
} 
estylo colonial mexicano." Atacando o Neocolonial, que seria uma "salada", ele faz a apologia do estilo Missões:

Hoje em dia, felizmente, os architectos já principiam a abandonar os velhos moldes e se entregam com efficência às composições hispano-missões, parecendo chegada a vez da derrocada das antiquadas construcções feitas sem escopo artístico, que mais visam só interesses sórdidos de proprietários usurários, e de constructores sem a menor noção de estylo, (...).Urge, portanto, dar destino à verdadeira architectura, relegando para o plano inferior que the compete, o que em geral e impropriamente designamos por estylo colonial brasileiro e que com muito mais acerto deveríamos classificar como estylo mestre de obras, inimigo acérrimo do bom gosto, que accumula erros sobre erros nos frontaes para gáudio dos apreciadores de saladas (itálicos do autor), perpetuado até nossos dias. (A CASA, 1927, n. 35, p. 18)

Neste número não se encontram referências nominais a bangalôs, mas sua inspiração ainda pode ser constatada em projetos que dividem espaço com os neocoloniais e os filiados à estética Missões.

Aparecem artigos sobre arquitetura antiga, como "Fragmentos de Architectura architectura ogival", chamada pelo autor de Gótico primitivo (A CASA, 1927, n. 35, p. 23).

Os anúncios crescem em número. Aparecem os de grandes construtoras; máquinas para construção, cálculo e desenho, e permanecem os de eletrodomésticos e materiais de construção.

Neste número começa a ser publicado um maior número de fotos dos projetos: "No intuito de apresentar aos nossos leitores a mais variada collaboração, estamos publicando, conforme tiveram occasião de vêr no número passado, photographias de fachadas e de interiores de prédios construídos nesta Capital. Além da variedade, a photographia tem a vantagem de mostrar certos acabamentos da construcção, que, em geral, a não ser em detalhes, nos projectos é quase impossível indicar." ( $A$ CASA, 1928 , n. 56, p. 15).

Aparecem várias fotos, como de um dos primeiros projetos publicados do arquiteto Edgar P. Vianna ${ }^{17}$, que apareceria muitas outras vezes nas páginas da revista. $O$

\footnotetext{
17 Edgar Pinheiro Vianna, arquiteto brasileiro que estudou nos Estados Unidos, na University of Pennsylvania, formando-se em 1919. Foi bastante atuante no Rio de Janeiro, empregando geralmente o estilo Missões. Promoveu eventos arquitetônicos em alguns lugares do país e fez parte das sociedades
} 
projeto em questão teria ganhado o primeiro prêmio no concurso de fachadas de 1926, promovido pela prefeitura do Rio de Janeiro. Trata-se de uma fachada em estilo Missões, segundo a revista. As fotos do interior mostram mulheres em poses lânguidas, à semelhança de atrizes de cinema.

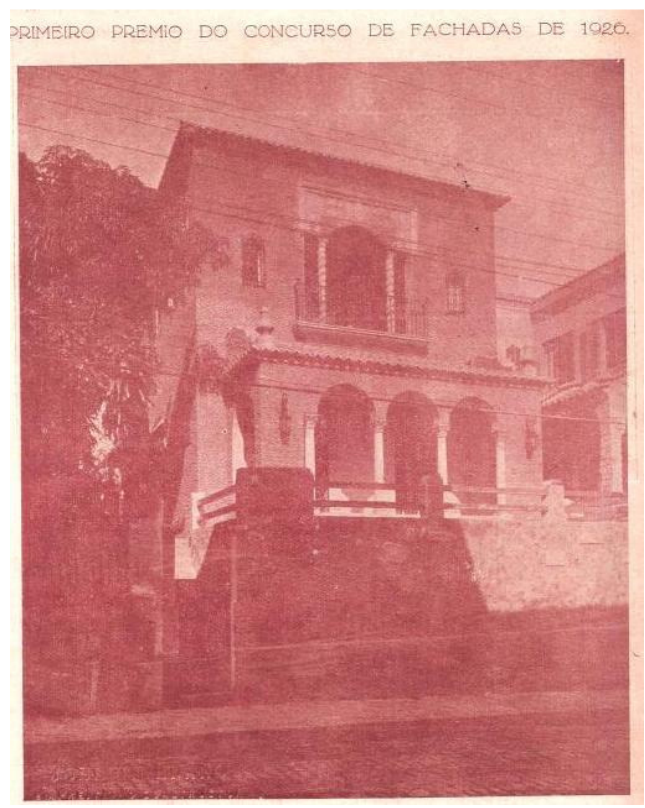

Fig. 4.28

Outra curiosidade do número 56 é a "pequena residência em arte moderna", no Andaraí, do arquiteto J. Cordeiro de Azeredo, em que se vêem platibandas e beirais, sem telhado aparente.

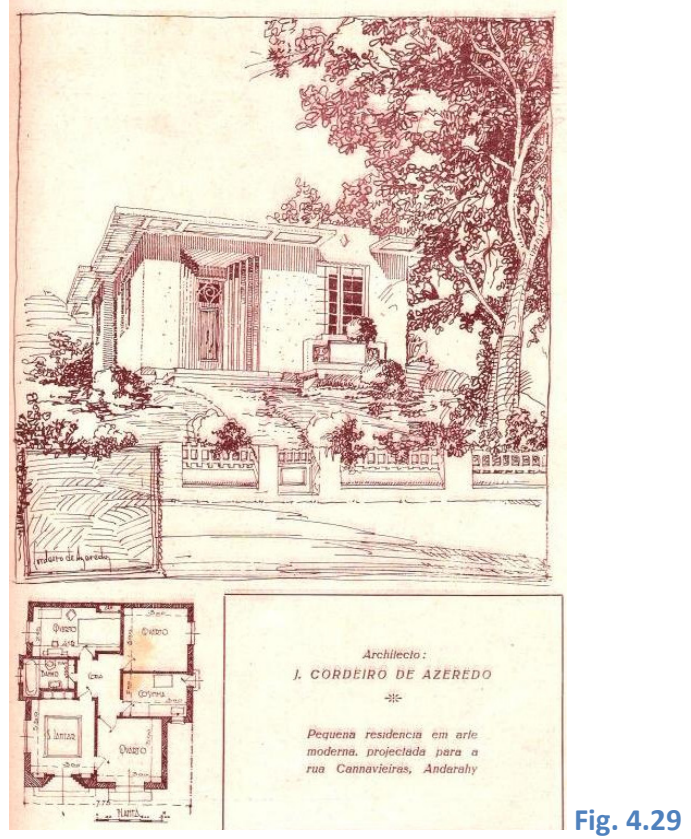

de classe dos arquitetos do Rio de Janeiro. Sobre o arquiteto Edgar Vianna, ver ATIQUE, 2007, p.246265. 
Neste número, também uma residência, utilizando o repertório do Arts and Crafts. $\mathrm{O}$ exagero no tratamento das fachadas e os pilares em pedra na varanda, nesta casa situada em pequeno lote urbano, tornam a composição "pesada" e desarmônica. E a sensação de repouso e conforto, que os cottages costumam passar, perde-se. À época, nos Estados Unidos, também podem ser encontradas casas com características próximas, como as que se vêem no número especial da House and Garden, de $1925^{18}$.

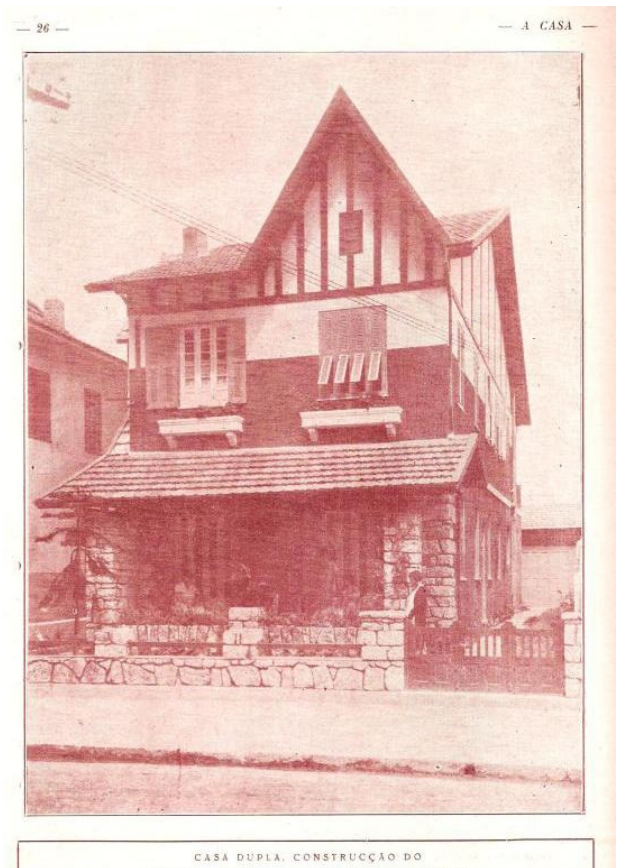

Fig. 4.30 Rio de Janeiro (1928)

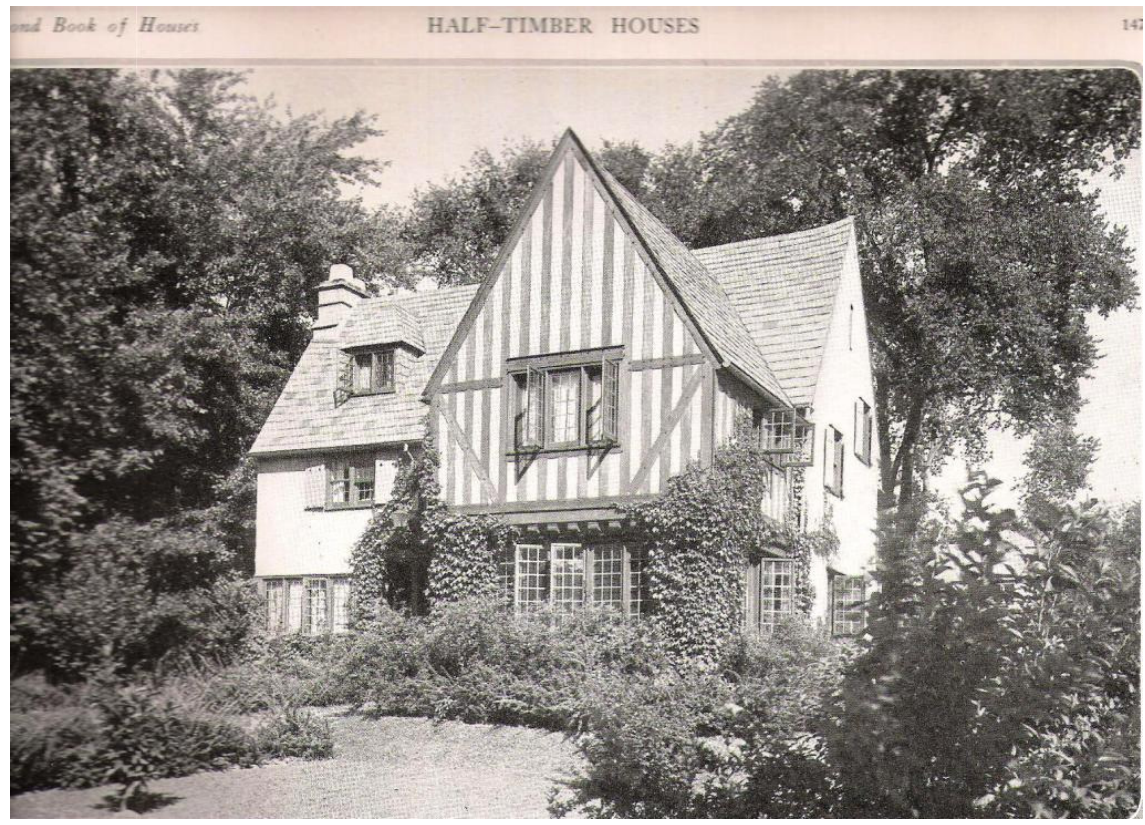

Fig. 4.31 Casa com half-timber nos Estados Unidos (1925)

${ }^{18}$ Também pertencente ao acervo da Biblioteca Central da Politécnica. 
No número 61 (A CASA, 1929, p. 8) outra casa com as características do movimento inglês: bay windows, chaminé, água furtada ${ }^{19}$, floreiras nas janelas e revestimento de pedra nos pilares da varanda. Mas, desta vez, a discrição e a harmonia foram obtidas com o projeto.

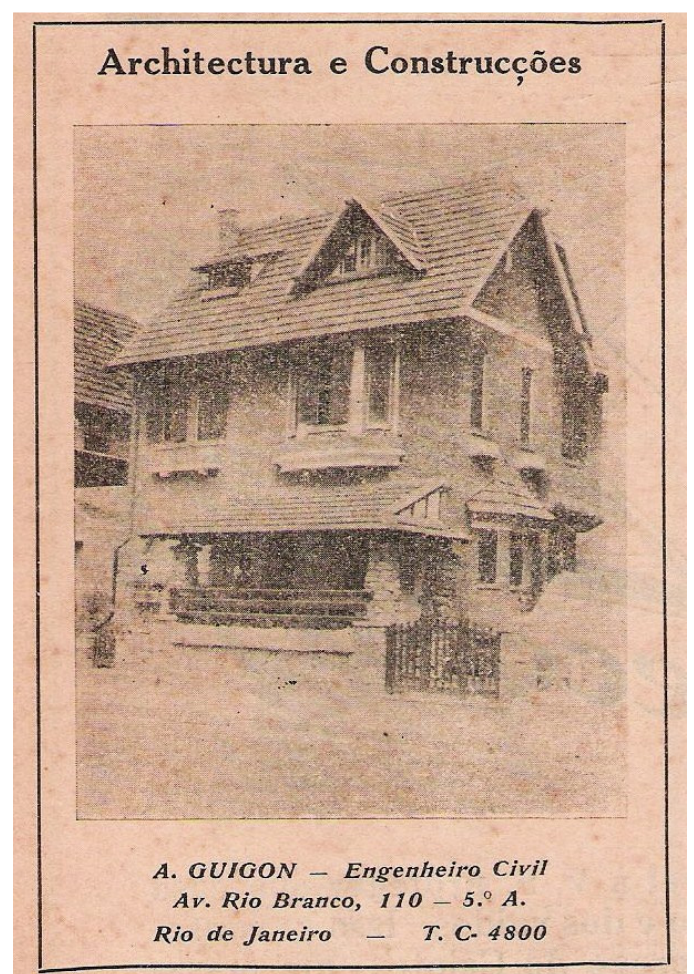

Um projeto filiado ao Neocolonial, do que seria considerado um palacete. Uma pérgula e uma varanda na sala de jantar favorecem a utilização dos fundos do terreno como uma área de permanência junto aos jardins, algo ainda raro nos projetos. O espaço flui entre as salas e em direção ao exterior, integrando a casa ao seu entorno. A cozinha encontra-se em outra ala. Projeto de F. Faro Filho (da E.N.B.A).

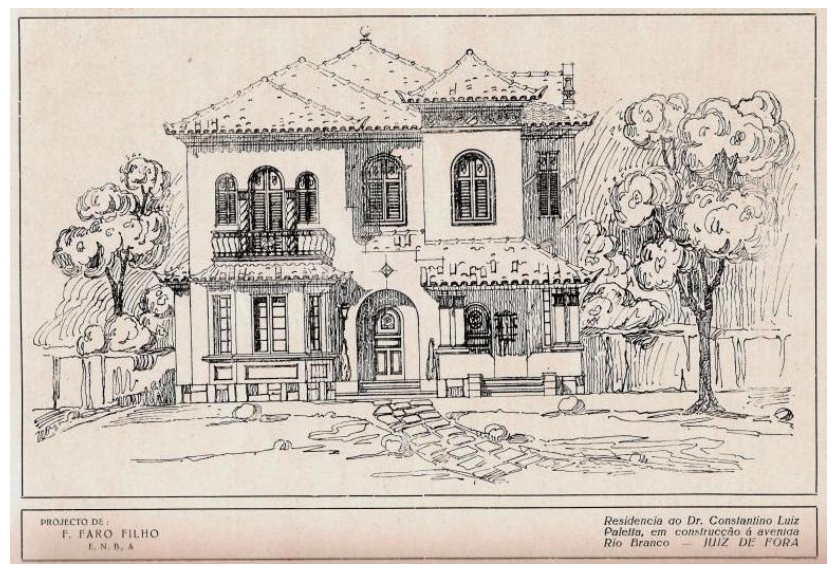
19 Janela de sótão coberta por duas águas, que emerge de uma água de telhado.
(http://pt.wiktionary.org) 
Fig. 4.33 e Fig. 4.34 Projeto Neocolonial de F. Faro Filho

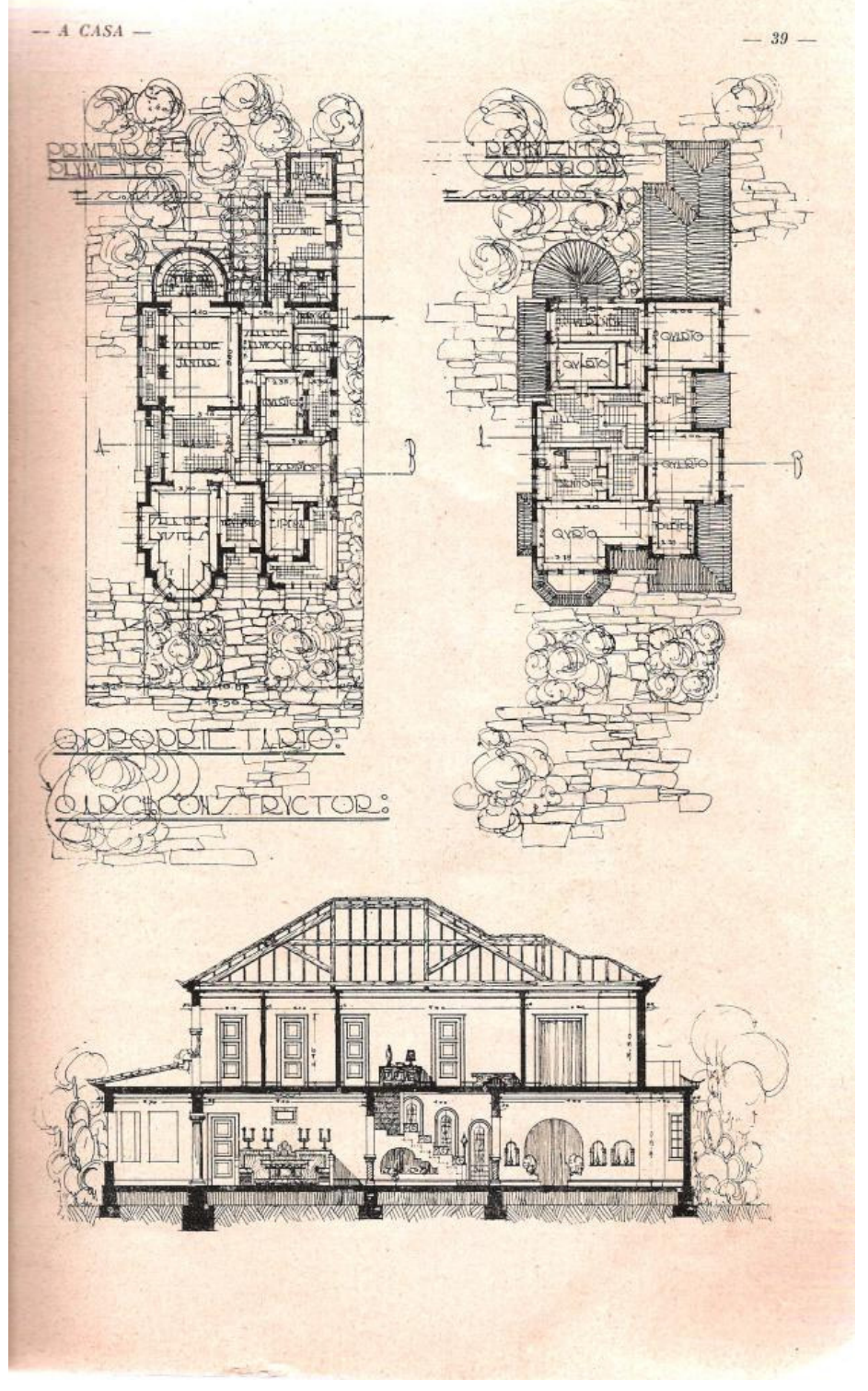

E um posto de abastecimento neocolonial.

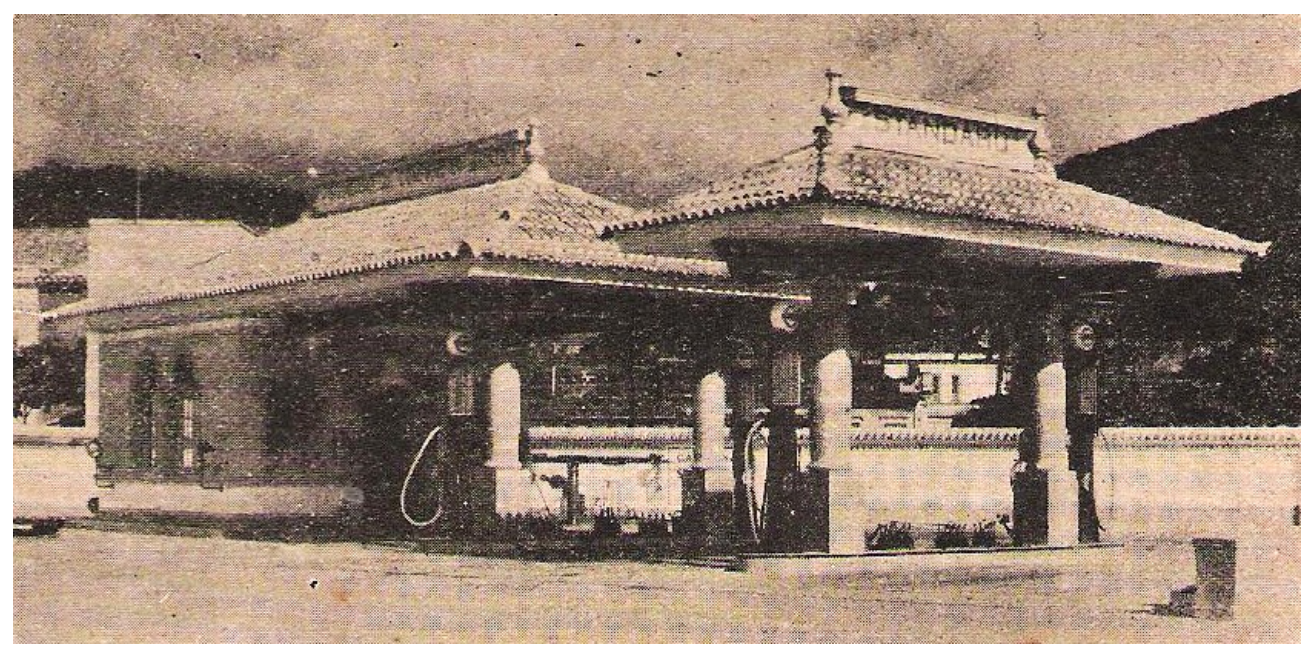


Mas os pequenos cottages estão sempre presentes. Como o que acompanha artigo sobre a casa da pequena família, assinado pelo arquiteto J. Cordeiro de Azeredo ( $A$ CASA, 1929, n.62, p. 27): "Falemos sobre a casa de hoje. A fachada deve ser revestida com cimento branco imitação de pedra e o embasamento formado de pedra apparelhada". A planta apresenta pequenas inovações: o serviço está incorporado ao corpo da casa. À época, costumava-se colocá-lo nos fundos como edícula. O banheiro continua afastado dos dormitórios, próximo à copa.

O interior é descrito em detalhes: a pintura das paredes seria feita a óleo em uma imitação de damasco na cor azul. A parede, dividida em painéis com molduras de madeira dourada. Assoalho de parquet. Portas esmaltadas em cor clara. Os dormitórios seriam tratados de forma mais simples, em uma cor clara. A área social é mais elaborada.

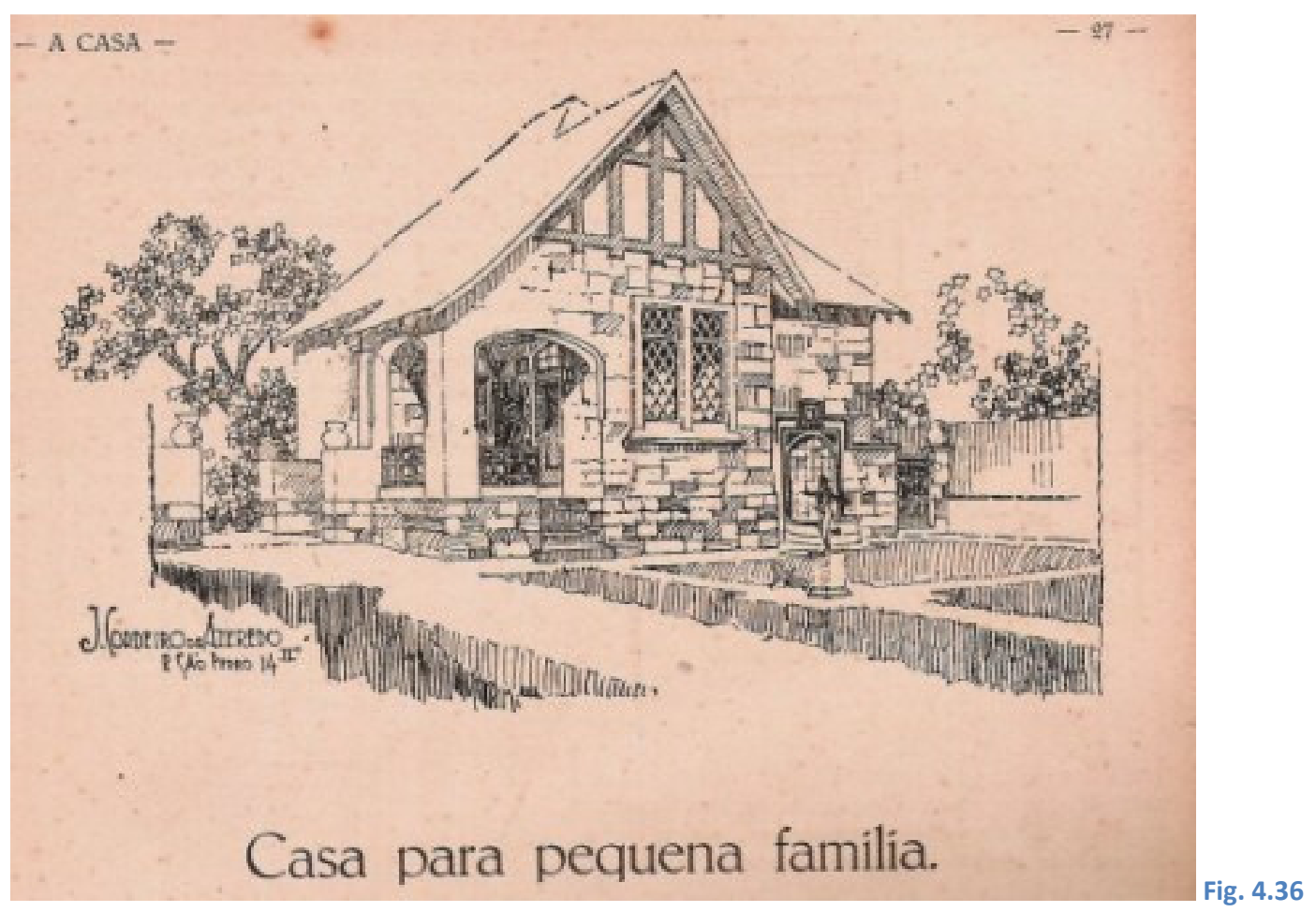

Outro cottage, do arquiteto F. Faro Filho, apresenta madeira na fachada principal, bay window, embasamento em pedra nas paredes, pequenas janelas estreitas e um austero ar gótico.

Também se aproxima da linguagem utilizada nas casas de Letchworth. 


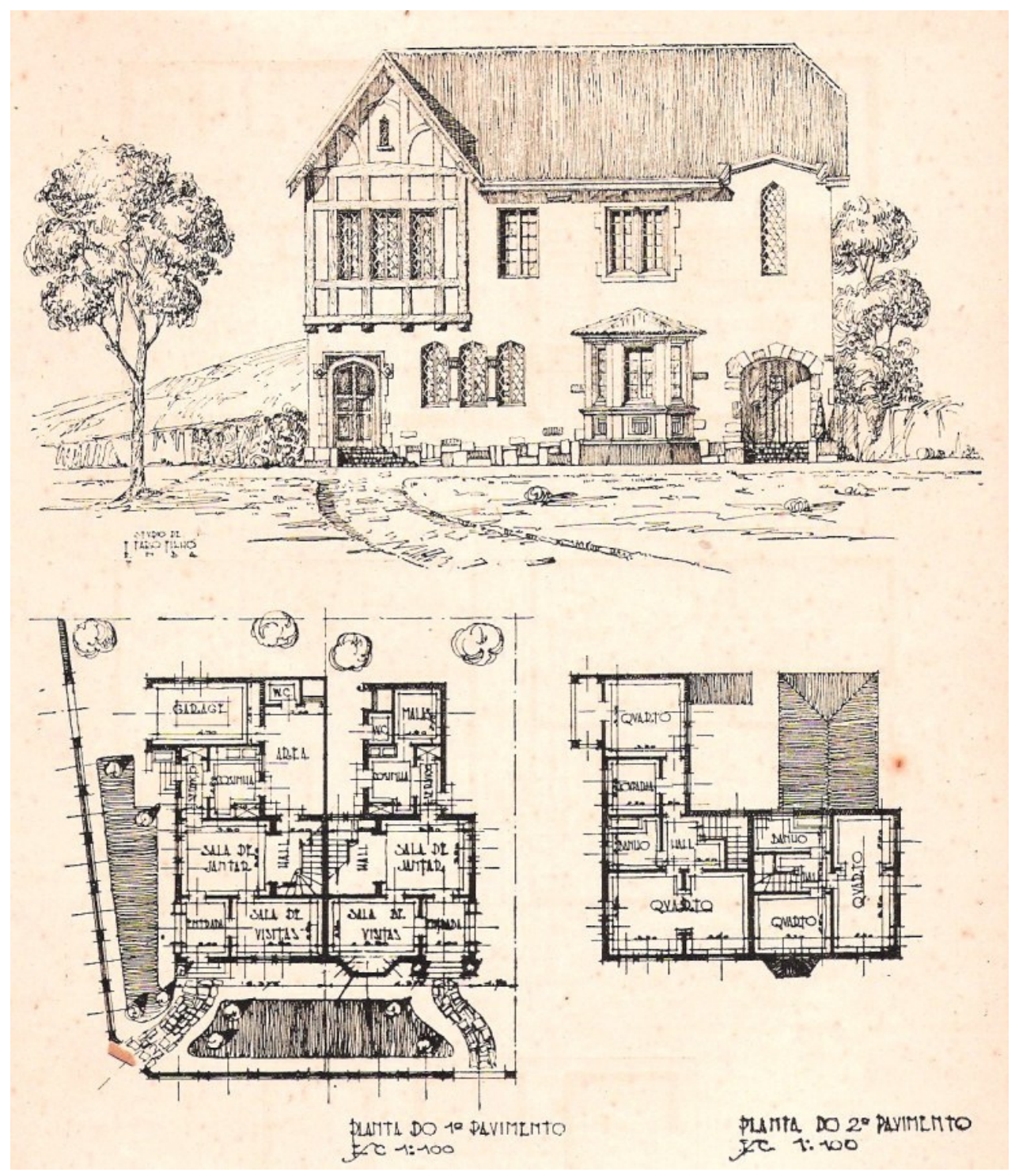

Fig. 4.37 Cottage do arquiteto F. Faro Filho

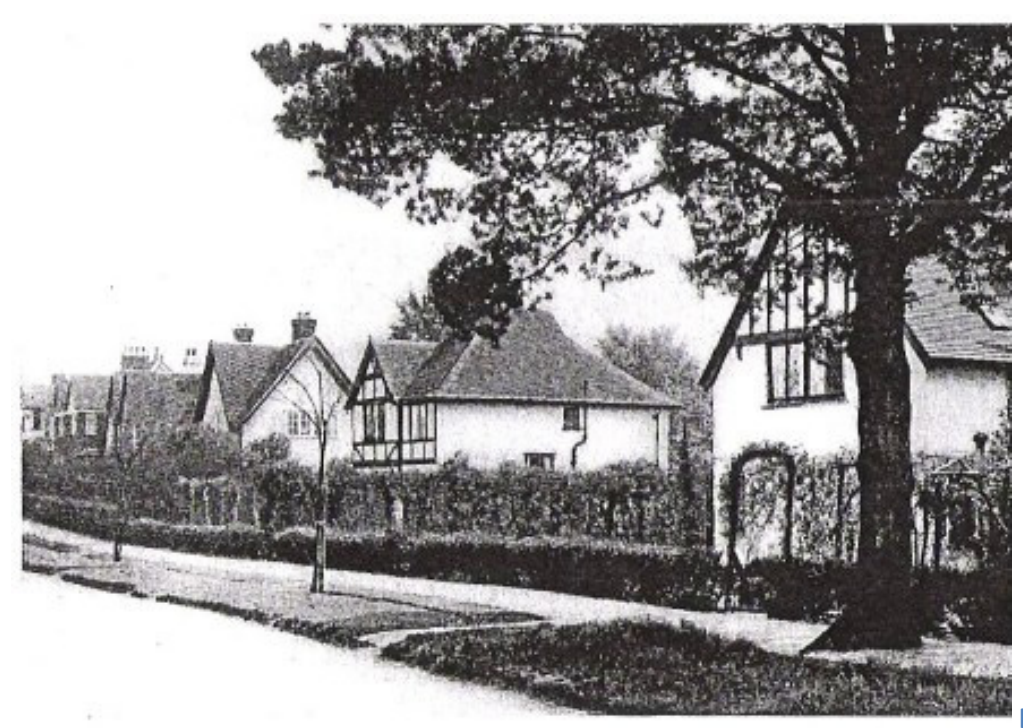

Fig. 4.38 Casas de Letchworth. 
Outra construção, assemelhando-se a um bangalô, aparece em A Casa (1929, n.63, p. 13): um sobrado em que os volumes verticais são equilibrados pelas varandas do pavimento térreo e o acesso se dá por uma abertura em arco, abaixo de um conjunto de esquadrias no pavimento superior, constituindo-se em detalhe marcante. A simetria deste volume vertical é quebrada pelos comprimentos diferentes das varandas. Planta com setores íntimo, social e de serviços separados. Projeto de Ricardo Wriedt, que aparece constantemente na revista.

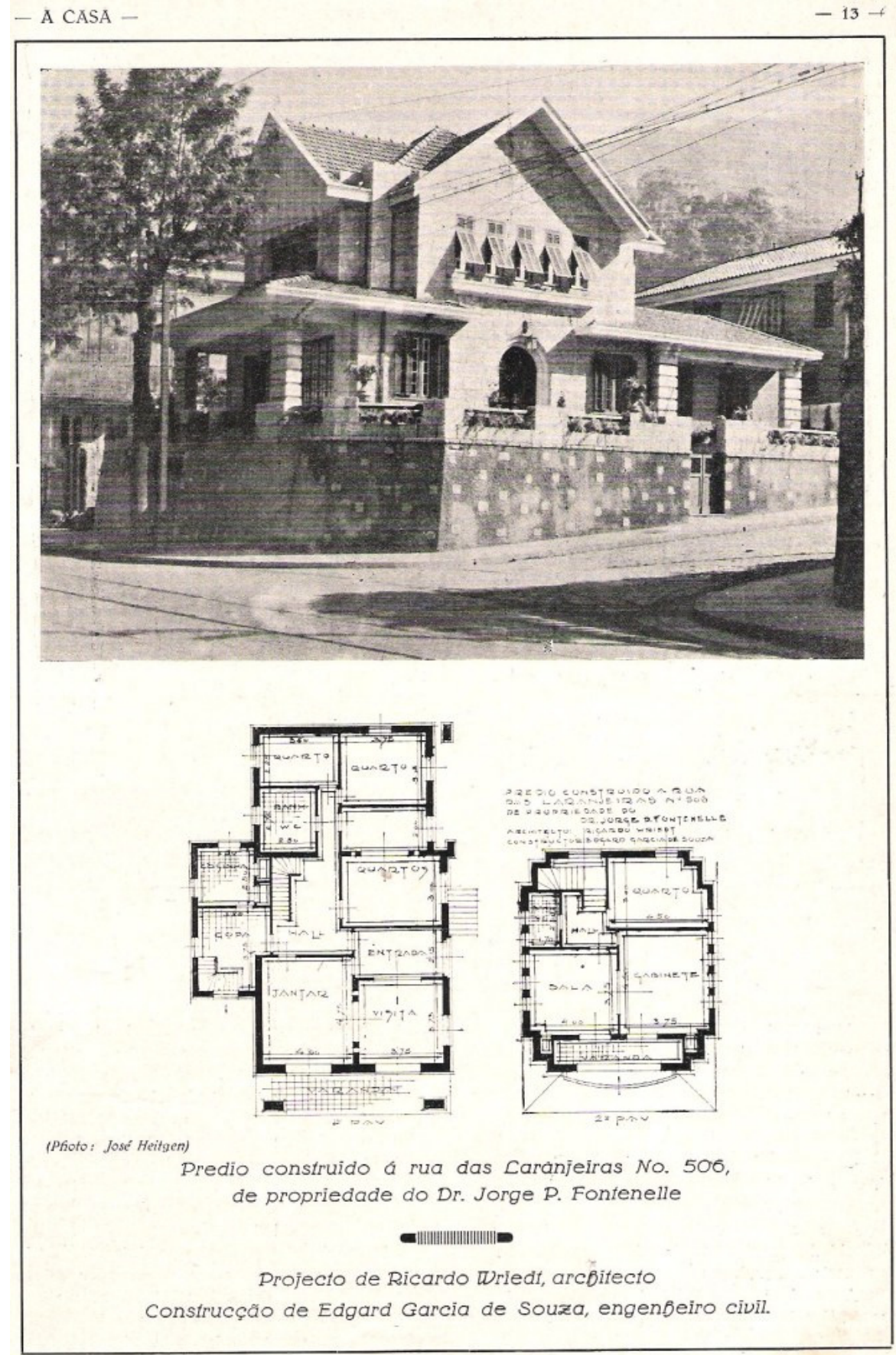

Fig. 4.39 Bangalô 
À época, habitar uma casa moderna poderia significar ter todos os confortos que as inovações técnicas poderiam assegurar, mas, externamente, buscar inspiração nos estilos passados. É este o caso aqui mostrado. Abaixo de uma ilustração de uma casa em pedra, com elementos da arquitetura medieval, de J.Cordeiro de Azeredo, fala-se na casa moderna, em artigo do mesmo arquiteto.

Coloca-se que "a revolução na arquitetura se faz naturalmente, devido às condições que offerecem os novos materiaes (...). Póde-se dar ao edifício a forma mais extravagante, pois que a engenharia equilibral-o-á. (...) A exposição de Artes Decorativas em Paris marcou um real successo, confirmando a victoria do espírito modernista". (A CASA, 1929, n.63, p. 14-6).

No mesmo número da revista (p. 20, 21, 31, 35, 36) aparecem fotos de "diversos typos de palacetes, projectados e construídos pelo Cav. José Sacchetti", arquiteto de São Paulo, que também aparece nas páginas da Revista do Mackenzie na mesma época, anunciando os mesmos palacetes austeros, alguns mais contidos, em composição clássica; outros, de volumetria mais movimentada, mas sempre com detalhes da mais variada procedência - neoclássicos, góticos, bizantinos.

Com os palacetes de José Sacchetti, as grandes casas, que eram raramente vistas nas páginas de $A$ Casa, começam a aparecer com mais freqüência.

\section{Diversos}

typos de

palacetes
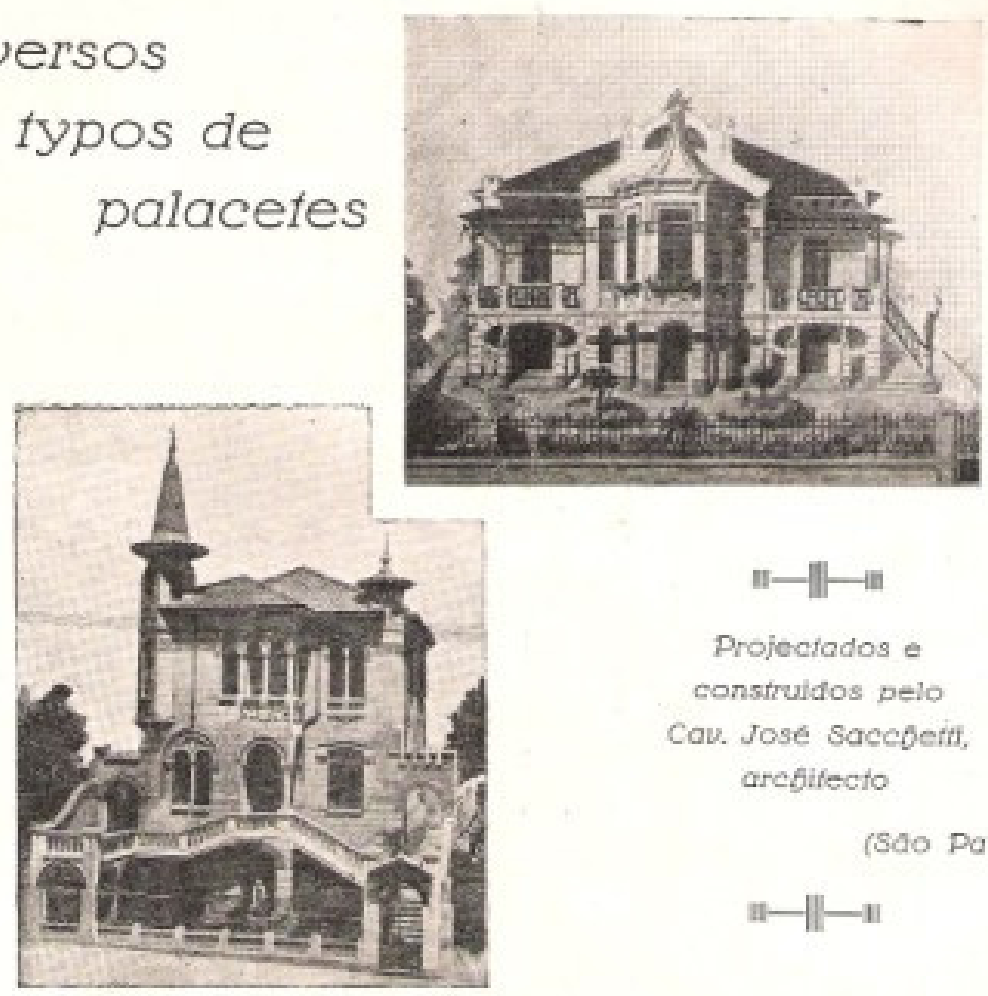

Projectados e

construidos pelo

Cav. Jose saccberit,

arefilecto

(Scio paulo)

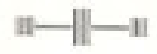


Ainda uma referência a bangalôs em $A$ Casa (1929, n.63, p. 32), na verdade um pequeno cottage térreo com dois dormitórios.

E ainda outra casa, de inspiração inglesa, no número 65 ( $A C A S A, 1929$, p.18), com pedras no primeiro pavimento e madeira aplicada à empena.

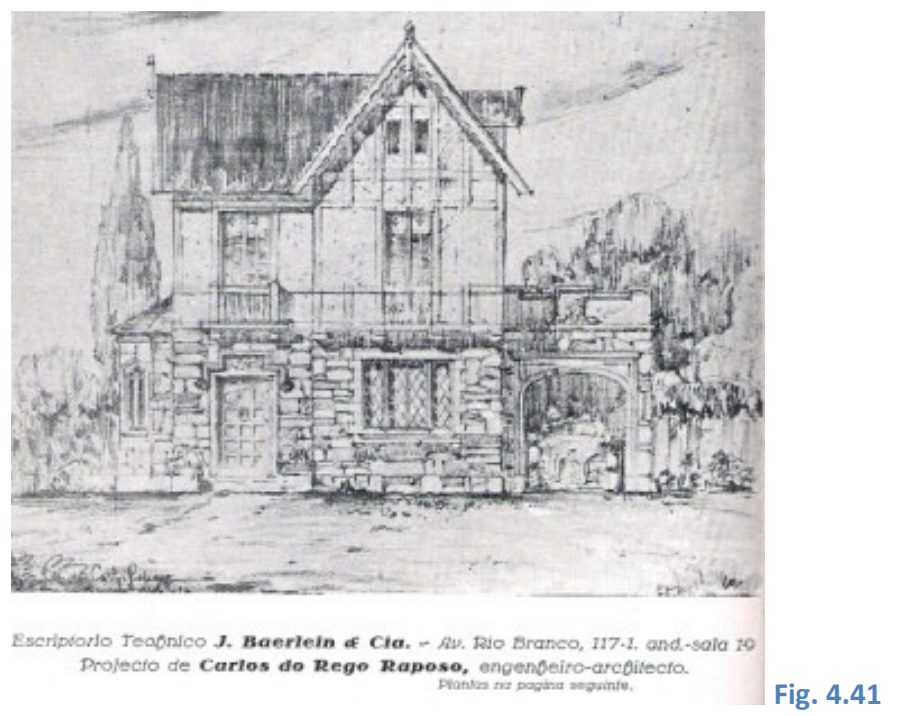

Em A Casa, n.65, (1929, p.38-9), aparece uma casa nas mesmas linhas, em que "a fachada do projecto offerece linhas de gothico inglez um tanto pittorescas, para quebrar a sobriedade do estilo, uma vez que se trata de residência particular. 0 'Tudor', encarado desta forma, é muito apreciado nos Estados Unidos." As características do estilo Tudor inglês são realmente visíveis neste projeto e no número especial da House and Garden: telhados bastante inclinados, grandes chaminés e a madeira escura formando desenhos nas fachadas claras. Na revista americana, ele é referido como um cottage inglês.

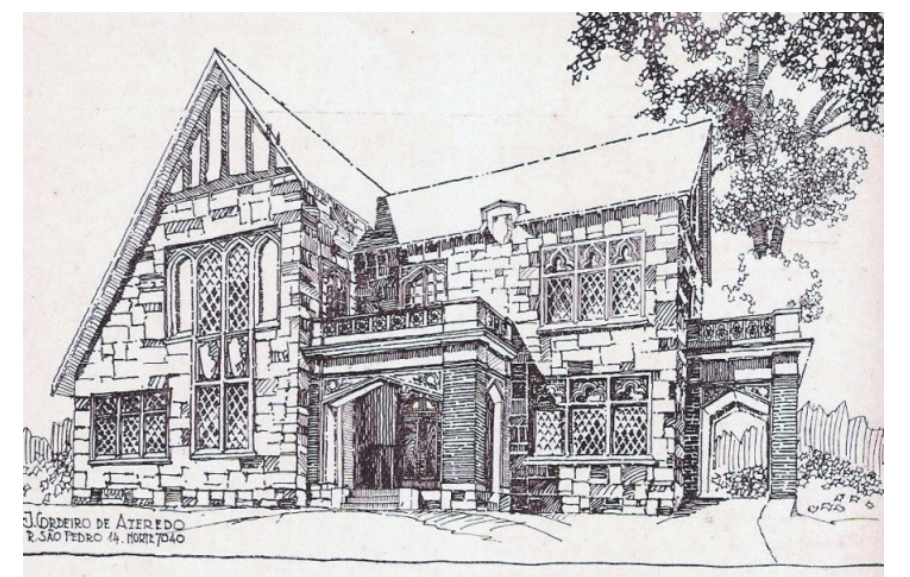

\section{Residencia senhorial. \\ I. Cordeiro de Azeredo - Architecto.}




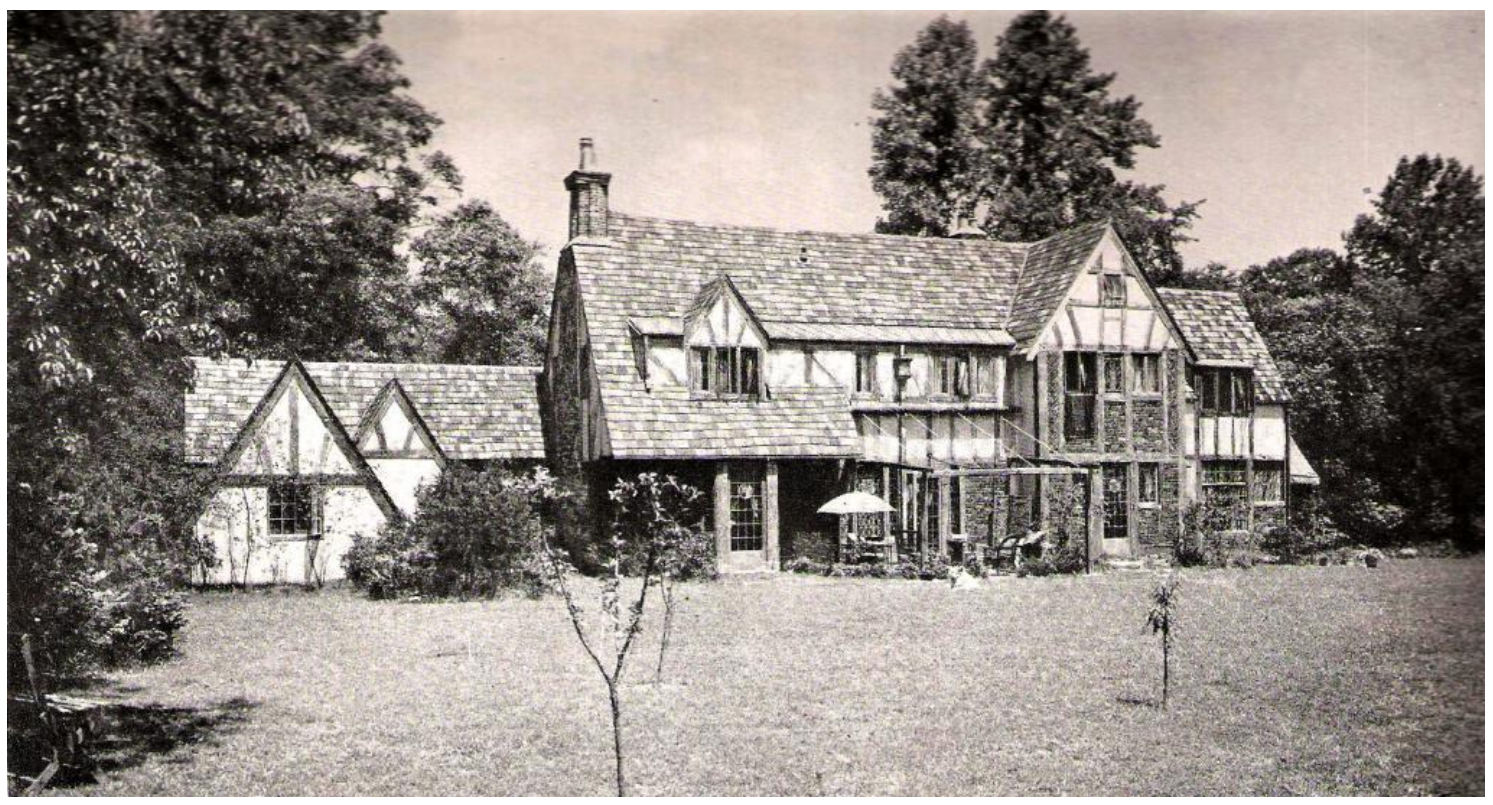

Fig. 4.43 Casas americanas seguindo a mesma estética (1925)

E na capa do número 67 (A CASA, 1929), aparecem mais cottages, onde a identificação com o Arts and Crafts já não é tão imediata. A individualização das casas é garantida por pequena variação de detalhes e cores diferentes. A aproximação com a natureza exuberante do Rio de Janeiro destaca o conjunto.

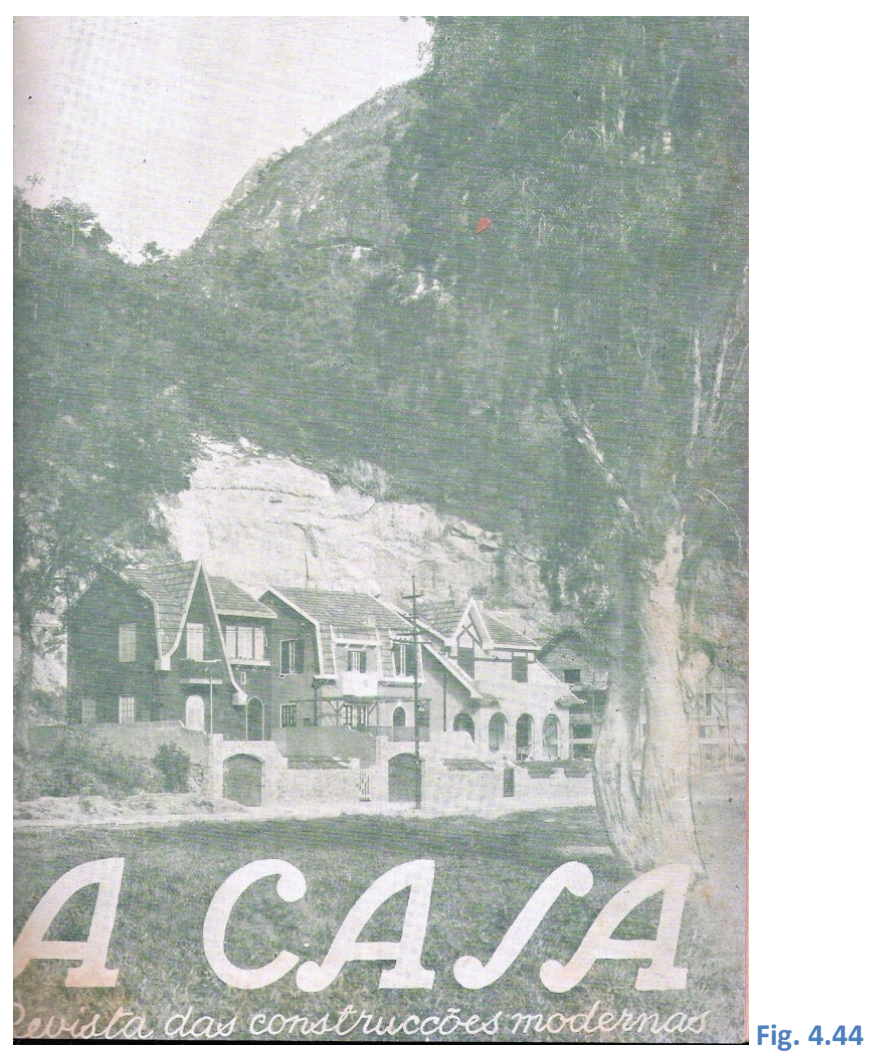


No número 70 de $A$ Casa (1930, p. 20-21), os cottages anteriores seriam denominados "projectos em estylo Normando", neste caso da autoria de Pers \& Ferlié.

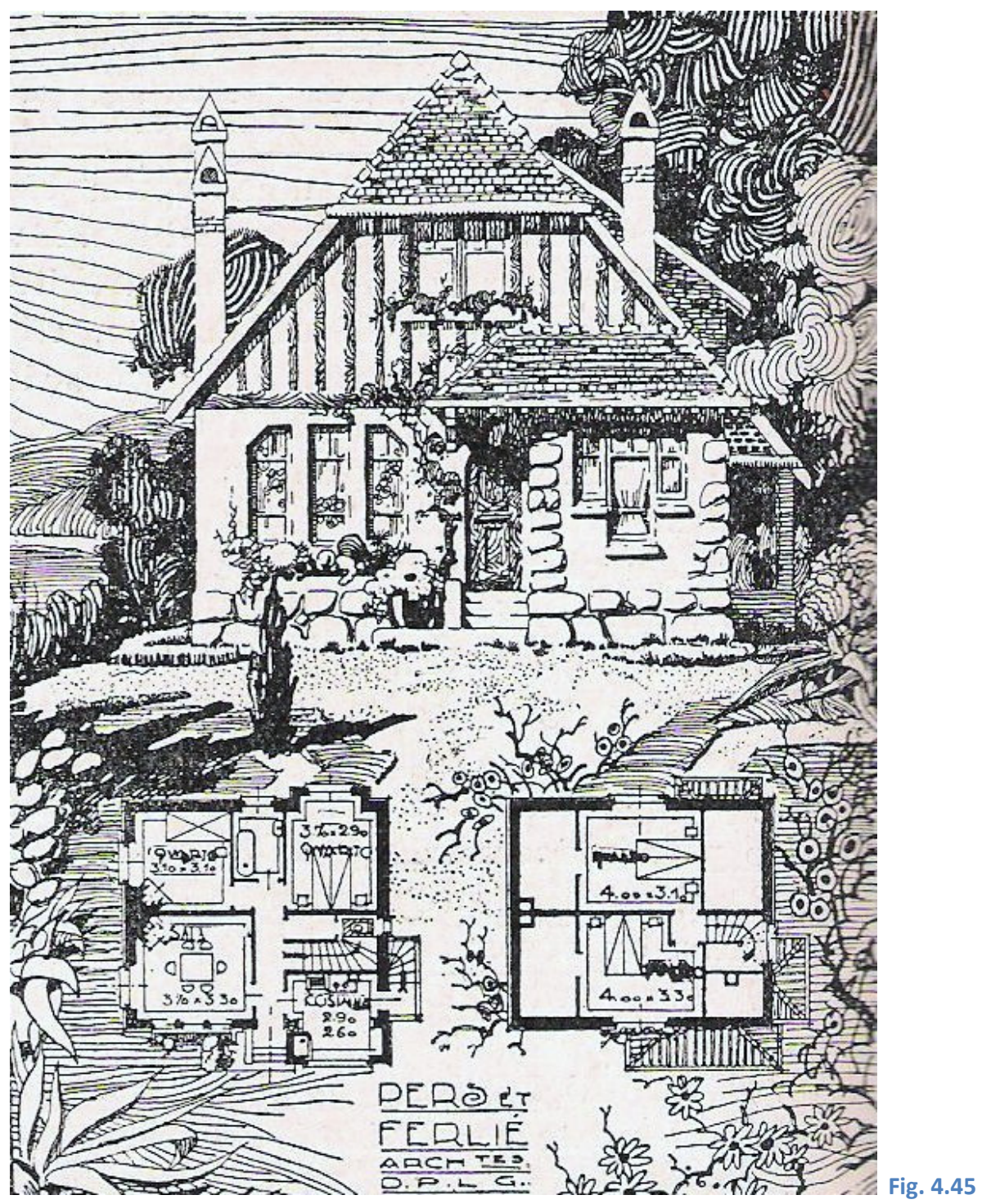

Um "solar em estylo missões" está no número 66 ( $A$ Casa, 1929, p.17): "O aspecto externo é assaz pittoresco e original, pois não lembra de modo algum essas casas a que freqüentemente estamos habituados a vêr. Accresce salientar ainda que o autor do projecto, o architecto Edgar Pinheiro Vianna, comquanto nas linhas geraes do ediifício tenha seguido a graciosa silhueta do Estylo Missões, não é todavia um escravo obediente da fórma typica. Porque, se na região em que nasceu o estylo todos os elementos se justificam plenamente, já em outro paiz esses mesmos elementos chocam pela discordância do meio." Apesar de o arquiteto utilizar alguns 
elementos formais do missões, como a torre, os arcos e a própria disposição dos volumes, os detalhes remetem ao Neocolonial.

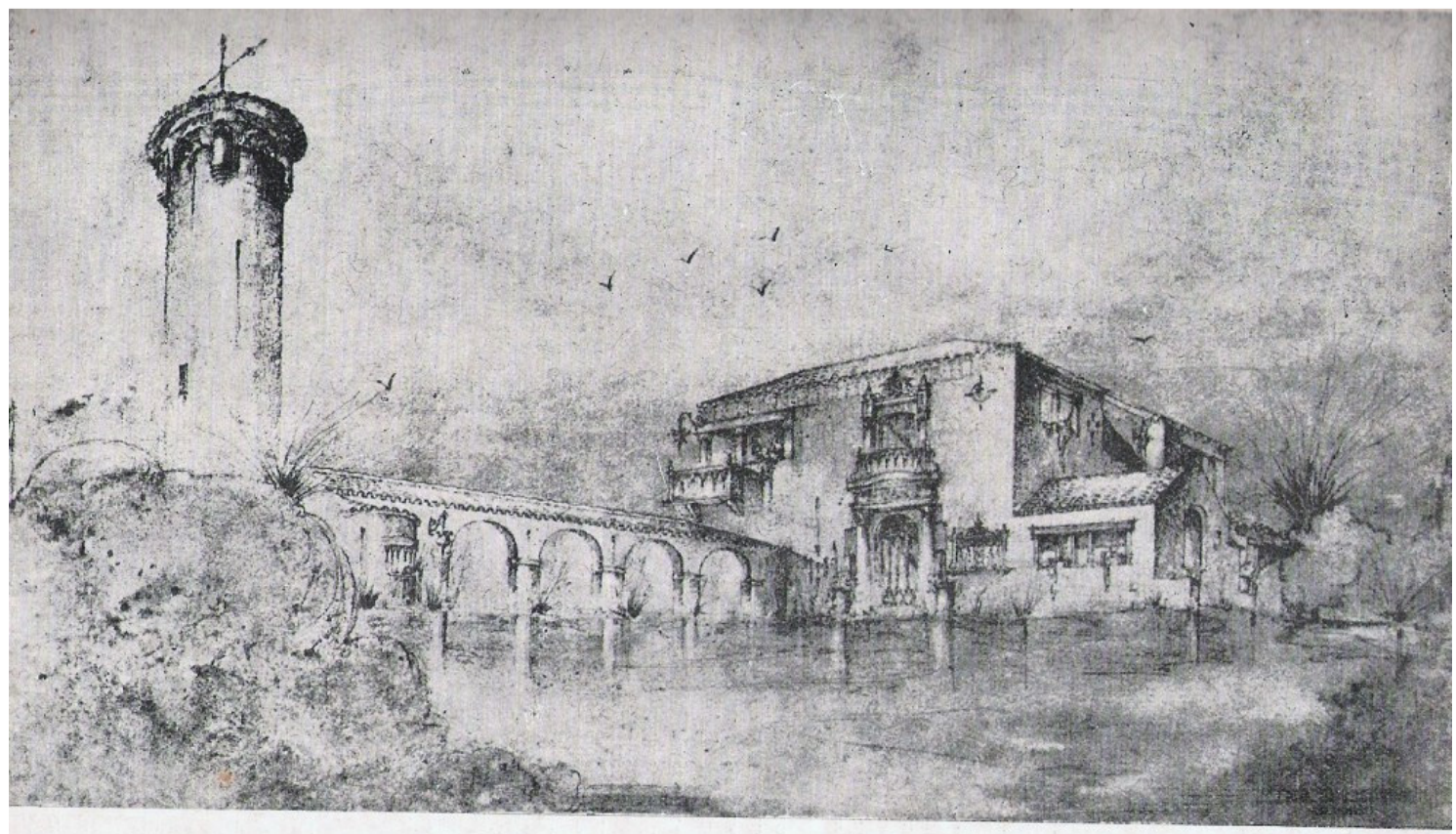

Projecto do Solar para a exma familia do Dr. Gonçalo Vasconcellos, em Campos - E. do Rio. Edgar pinbeiro Vianna -. Arcbitécto

Fig. 4.46

A casa espanhola era descrita no número 70 de $A$ Casa (fev.1930, p. 24-25), mencionando as primitivas casas construídas pelos colonizadores espanhóis, com suas grossas paredes de adobe. Vários detalhes são sugeridos: texturas nas paredes; cores para as paredes, esquadrias e em outros detalhes. A cor deveria ser usada, também, para se criar um contraste entre as diferentes casas, valorizando sua individualidade.

De resto, por toda a revista, existe a ênfase na valorização do detalhe e na individualização de cada casa. Os leitores são incentivados a usar os projetos apresentados como uma espécie de guia, o que não impediria a sua própria manifestação, fosse nos pequenos detalhes da decoração ou no acabamento interno e externo.

Neocolonial é o projeto publicado no número 67 (ACASA, 1929, p. 21), com um grande portal de uma igreja barroca aplicada a uma residência média. Esta fachada principal é simétrica, tripartida, assemelhando-se mesmo a uma igreja. 


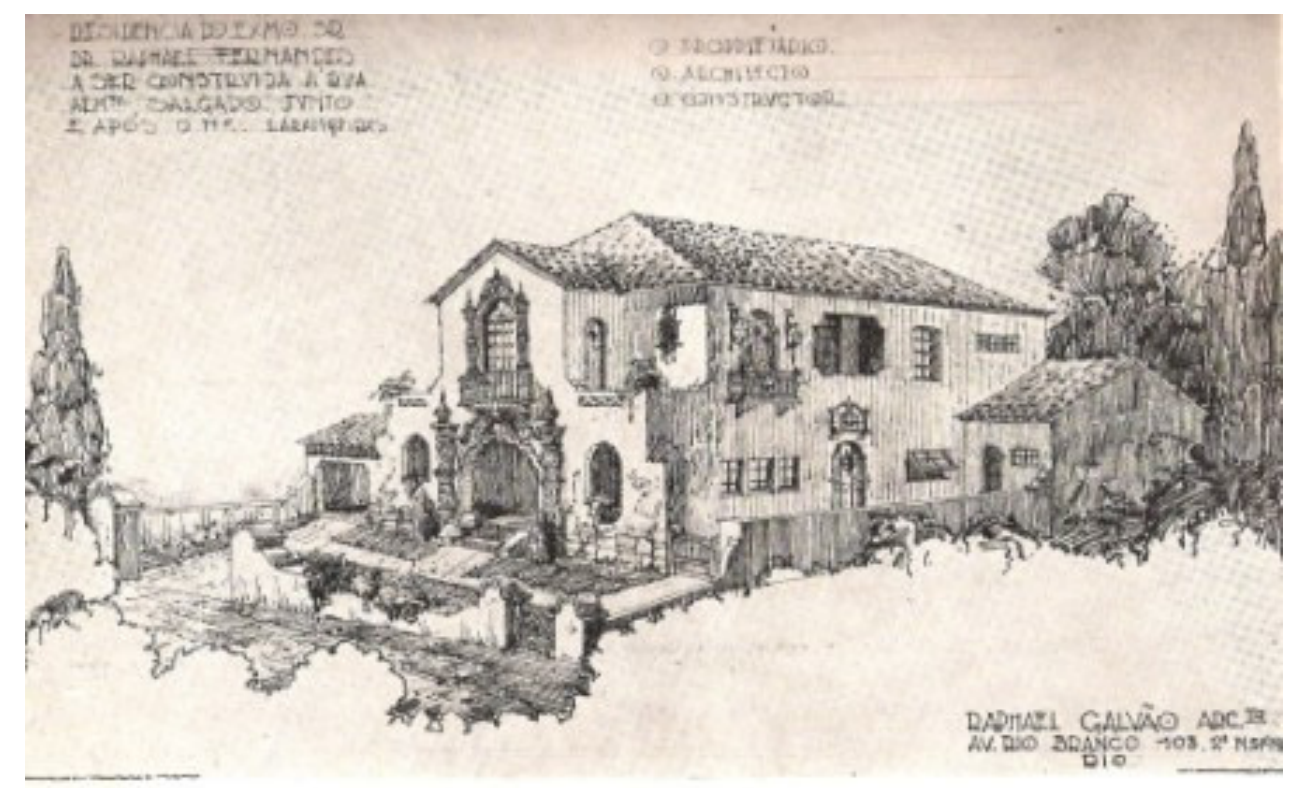

No número 70 de $A$ Casa (1930, p. 20-1), explicam-se os vários estilos que se apresentavam nas páginas da revista: Colonial - nesse estylo encontravam-se freqüentemente pátios, circundados por pórticos ou colunatas - que seria 0 Neocolonial; Espanhol - que teria muita influência nas casas modernas americanas, principalmente na Flórida e na Califórnia - apresentaria portas, balaustradas e grades de ferro batido, telhados em telha capa e canal e galerias e pátios com arcos e colunatas - o Missões.

\subsection{Os Bungalows}

Os bangalôs são mencionados muitas vezes, com a palavra ainda sem tradução: bungallows. Apesar da difícil definição formal deste tipo de habitação, que não se configura como um estilo, com estilemas próprios, os bangalôs são descritos neste item, em separado, para que se possa perceber o que era concebido, na época, com tal denominação.

Segundo o anúncio dos engenheiros Freire e Sodré, eles seriam uma verdadeira tentação: uma estranha figura masculina vestida com uma capa preta oferece um bangalô a uma jovem. 


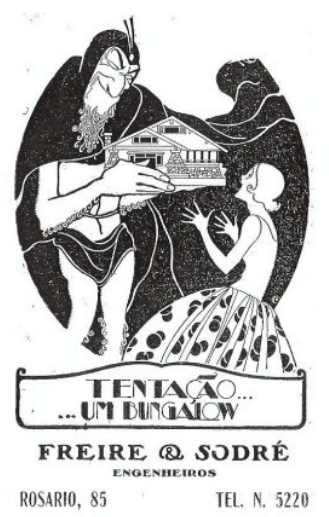

Fig. 4.48

São vistos como uma casa pequena, para um público de pouco poder aquisitivo, geralmente vendido em várias prestações.

$\mathrm{O}$ arquiteto J.Cordeiro de Azevedo anuncia seu trabalho, dizendo que faz projetos para "Bungalows, (...) Cottages, Casas Nobres, etc." Na mesma página, o arquiteto Ricardo Wriedt diz que faz plantas e projetos para "palacetes, Bungalows, etc." Tais palacetes ou casas nobres, de autoria de arquitetos conhecidos, inicialmente não são encontrados nas páginas de $A$ Casa. Estes não se destinavam ao público a que a revista falava. (A Casa, n. 8, dez. de 1924, p. 34)

Isto está claro na seguinte colocação: "No Rio, como em São Paulo, o estylo americano com todos os seus requintes de conforto, foi introduzido, garantindo a victoria do typo 'bungalow' para a pequena moradia. Nas residências mais abastadas, em que o architecto pode com mais liberdade estylisar a construçção, o 'colonial' venceu, e lindos edifícios podem ser hoje observados." ( $A C A S A, 1925$, p. 11). Mais uma vez, o Neocolonial é identificado com grandes casas, de arquitetos conhecidos, feitos para clientes abastados. No final da década é que, com maior freqüência, o Neocolonial será apropriado pela classe média.

O bangalô, como mencionado no artigo anterior, é associado a um estilo americano de morar, moderno, baseado em uma imagem burguesa do mundo - na separação e privatização dos ambientes.

Nos países da América Latina, e no caso específico desta pesquisa, em São Paulo, a introdução do bangalô ocorre quando acontece a mudança para uma economia de mercado e gostos, estilos e padrões de vida burgueses - através do consumo de bens 
- são assimilados. Os subúrbios completam o cenário ${ }^{20}$. É a emergência de uma economia e de uma cultura globalizadas.

O movimento Arts and Crafts atingiu na América sua maior popularidade, de forma mais pragmática, sem a carga ideológica da Inglaterra. E o maior símbolo desta democratização do movimento foi o bangalô. Os bondes tornaram possíveis os novos subúrbios de classe média e o bangalô encontrou ali seu lugar. Uma nova arquitetura doméstica. Ou variações sobre o tema "lar".

“'Desenho democrático' o termo usado nos EUA, em torno de 1900 para se designar objetos simples, feitos para um público amplo poderia ser estendido ao fenômeno do bangalô e, guardadas as proporções, ser aplicado ao que a revista $A$ Casa significou no Brasil. Em ambos, democratização significa "acessível à classe média". Tal conjuntura só foi possível graças ao crescimento da classe média no Brasil e ao incremento na propriedade individual da casa, que pode ser constatado pela quantidade de anúncios de casas e terrenos, vendidos em prestações, na própria revista $A$ Casa. Eram loteamentos localizados nos subúrbios, que só poderiam existir graças aos novos meios de transporte público, que eram mencionados nos anúncios.

Como aquele do bangalô - que também se assemelha a um cottage - no bairro do Andaraí, construído pela Companhia de Immoveis e Construcções e que poderia ser pago em até quinze anos. Fazendo um paralelo com a descrição de Gustav Stickley sobre um cottage-bungalow, na The Craftsman: "o aspecto simples, firme e democrático do cottage, que sugere verdadeiro conforto interno e vida saudável; ao mesmo tempo (...) as varandas arejadas, as amplas salas de estar, lareiras agradáveis. (...). As linhas longas e baixas do telhado, os grandes beirais, a localização dos principais cômodos no térreo, colocaria as casas na categoria do bangalô". (STICKLEY, 1988, p. 121-122). Só que na versão brasileira, as varandas arejadas se limitam àquela pequena, que protege a porta de entrada; as amplas salas de estar e jantar são duas pequenas saletas conjugadas; a lareira agradável, apenas uma chaminé decorativa e as linhas baixas do telhado, apenas as da pequena varanda.

Mas, neste caso, talvez a descrição das características físicas não seja a mais importante. Seu significado, sim, que é o de uma pequena habitação, localizada no centro do terreno, com o pequeno jardim frontal e a horta nos fundos. Seu banheiro e os serviços localizam-se no corpo da casa. Existe água encanada, luz elétrica - talvez

\footnotetext{
${ }^{20}$ Sobre a circulação das idéias relacionadas a estas formas modernas de vida, ver KING, 1995, p. 259263.
} 
não em um primeiro momento, mas acabará por alcançar o loteamento. E, como diz o texto que acompanha o anúncio: “(...) pois foi sempre o ideal dos desherdados da fortuna, livrarem-se dos senhorios e possuírem o seu lar."
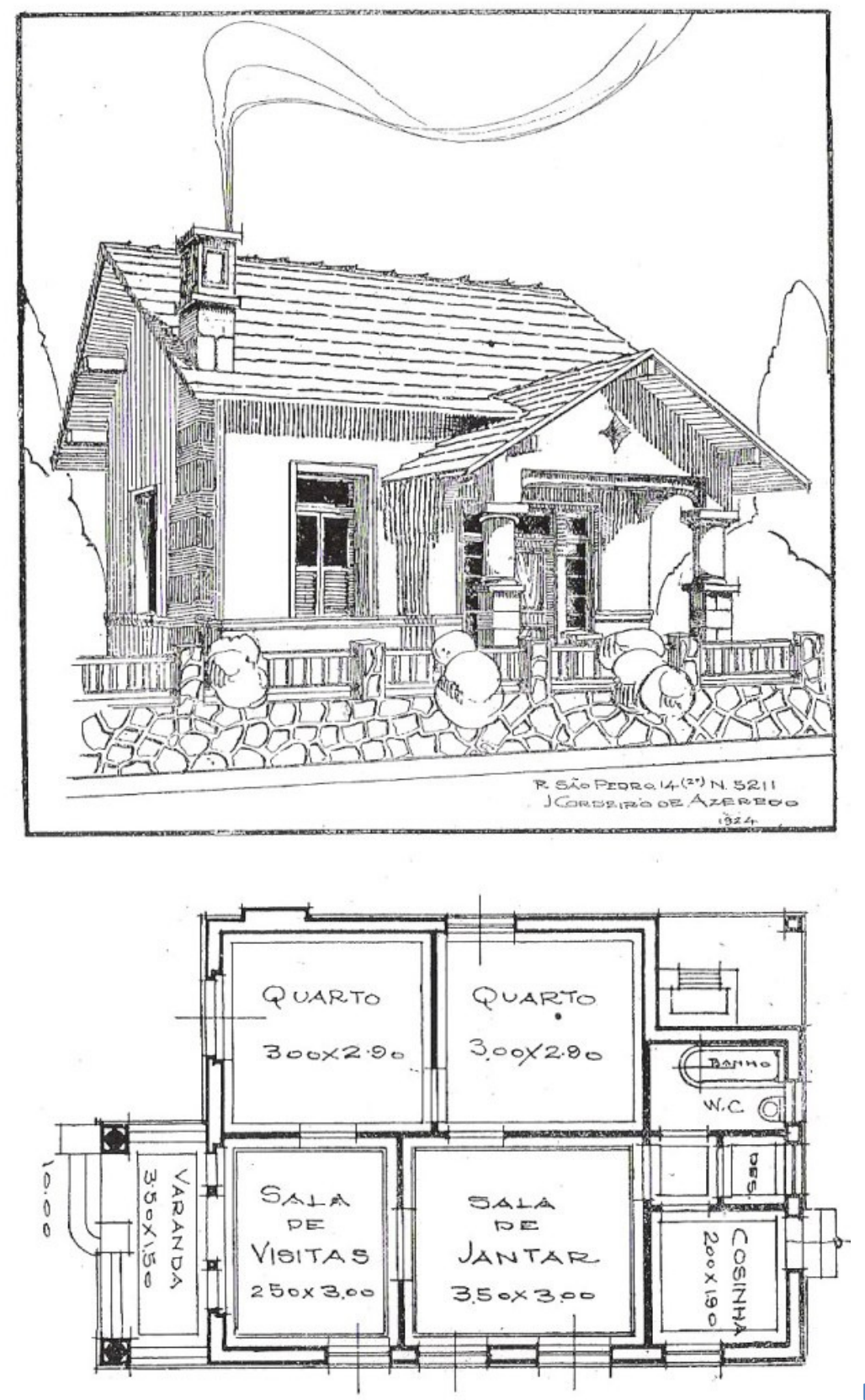

Fig. 4.49

Em um balanço sobre os sete anos de existência da revista, comparam-se os que vivem em casas ou apartamentos de aluguel a nômades, sem ambição e vencidos na vida. As nações mais estáveis seriam aquelas em que a maioria da população possuía casa própria. E fala-se sobre a aquisição de uma casa "num arrabalde ou subúrbio. (...) Mas, seja qual fôr o processo, a casa deve ser tão adequada aos hábitos do morador como o vestuário que Ihe assenta no corpo. Mais do que um logar para viver, 
a casa é além de tudo o continente de sua personalidade e da de sua família." ( $A$ CASA, 1930, n.69, p.5) E o significado de se possuir uma residência fixa era manter distância dos pobres que perambulavam pela cidade em busca de emprego e moradia. A instituição de hábitos moralizados, costumes regrados significava expor a todas as classes sociais o modelo de organização familiar a seguir, com os papéis sociais higienizados. A idéia da família nuclear, reservada, voltada para si mesma, neste ambiente aconchegante deveria seduzir o trabalhador (RAGO, 1997, p.61)

Em A Casa: "causa verdadeiro prazer ver-se na Allemanha, nas casas dos operários, o gosto predominante nos arranjos internos, que é o exacto sentimento do lar. Nellas não se nota uma parede sem um quadro artístico, um soalho nu, nem uma janella desguarnecida de cortinas. (...) A belleza e o conforto de um lar estão também no mobiliário sóbrio e elegante, na maestria de sua collocação e na escolha de quadros, tapetes, cortinas e vasos."

A casa surge como um espaço para o disciplinamento dos extratos mais baixos da sociedade. "Esperava-se que a dimensão do consumo cumprisse as funções que a dimensão da produção não tinha condições de cumprir - ensinar novos hábitos de ordenação, saber viver de forma rotineira, regular, moderada, higiênica." (CARVALHO, 2008, p. 315).

A maioria dos bangalôs mostrados era pequena ou de tamanho médio. O de autoria do arquiteto J.Cordeiro de Azeredo constitui-se em exceção, com oito quartos no pavimento superior. Este arquiteto está sempre presente nas páginas da revista. $(A$ CASA, 1924, n. 8).

\section{Bungalow para terreno de grande frente}

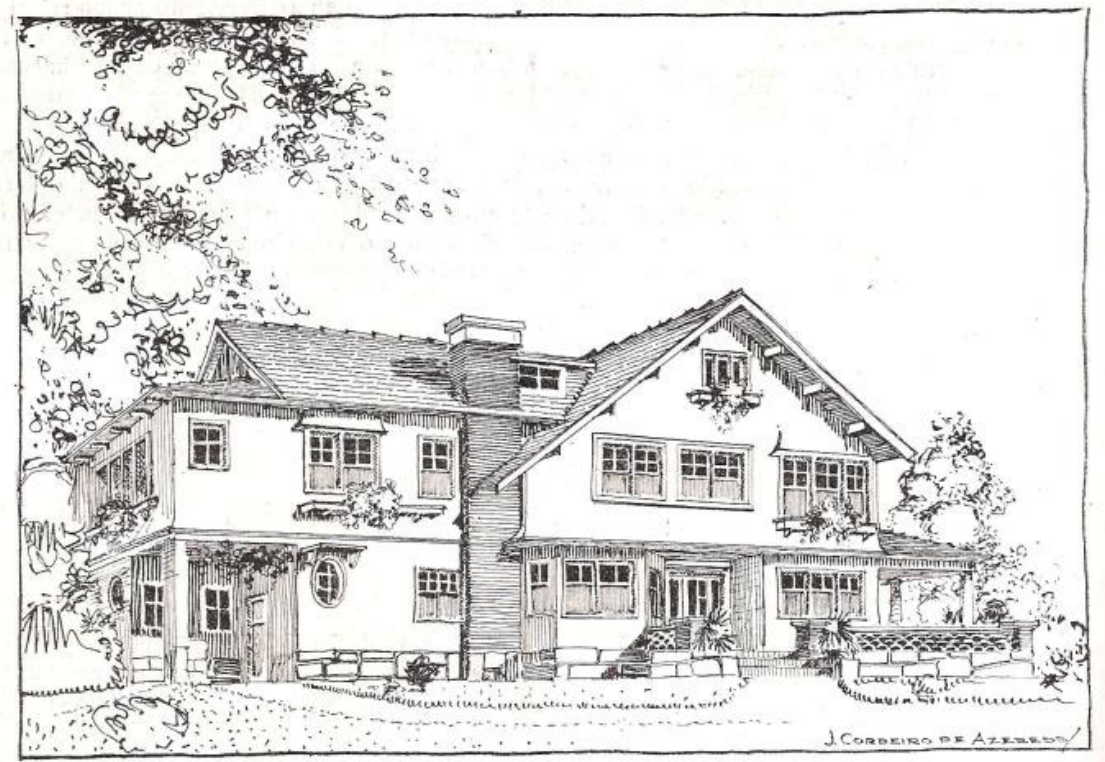




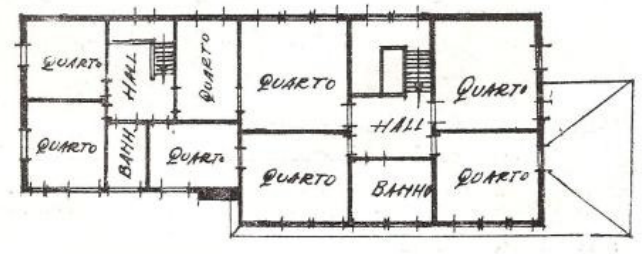

20 PAYIMEYTO

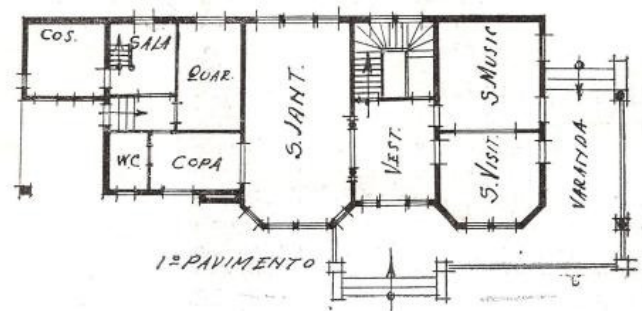

Existiam mesmo os bungalowettes, "o bungalow mínimo, é a casa dos noivos por excelência, (...) um sobrado mignon e gracioso (...) em summa, a casa ideal para recém-casados." com não mais que cinco metros de largura.

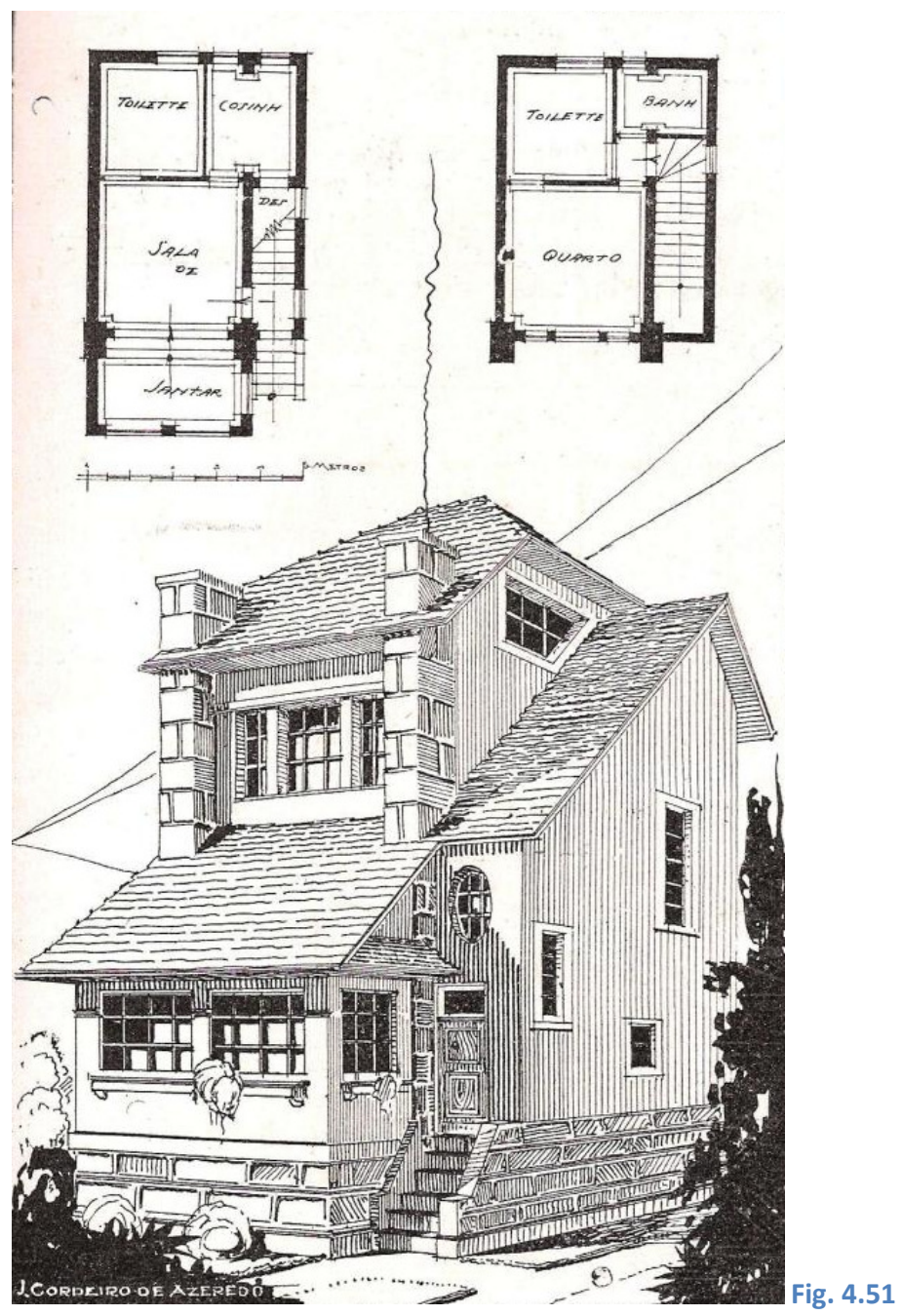


"Bungalowette é casa econômica por excelência, a casa de dimensões mínimas, como convém nesta época em que a construcção está a preços excessivos. (...) representa uma casas de dois quartos pequenos; apresenta todas as comodidades de uma casa moderna para pequena família." Projeto de J. Cordeiro de Azevedo. O Bungalowette, na verdade, seria um pequeno cottage.

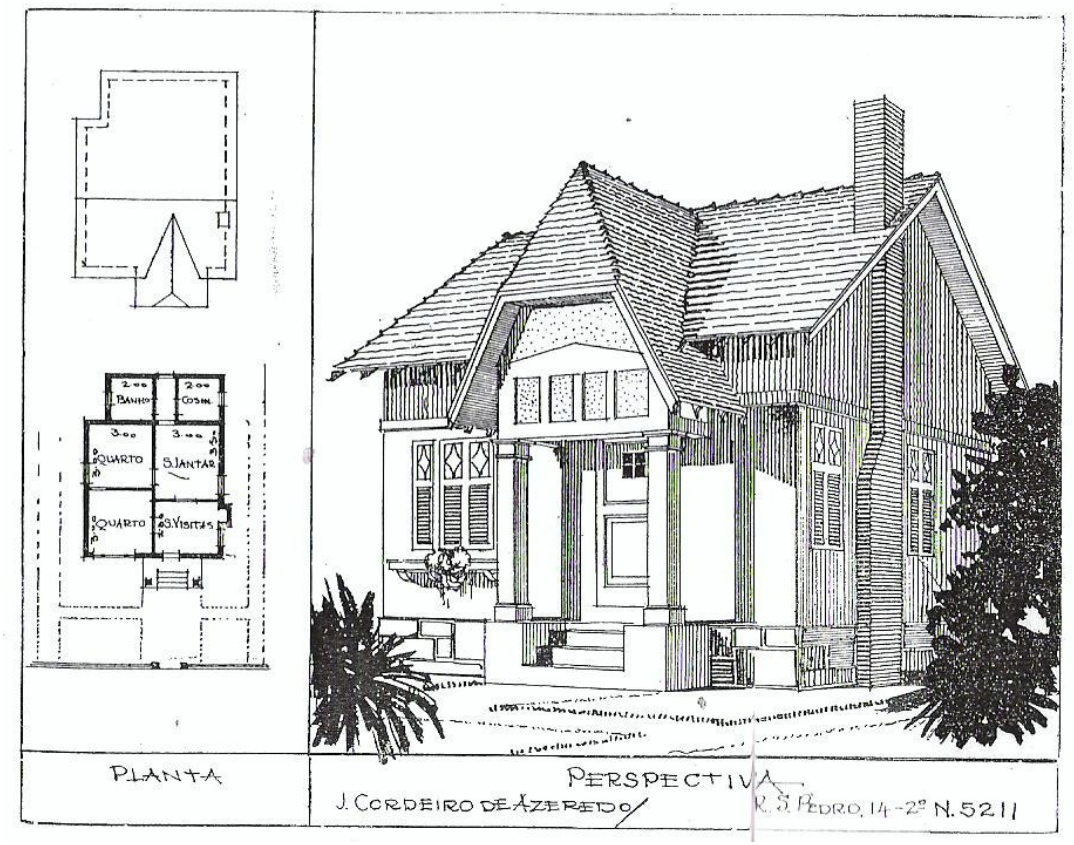

Outro bangalô é mostrado em $A$ Casa (1925, n. 9, p. 21) para um bairro central, Copacabana. Tem área maior, trata-se de um sobrado com cinco dormitórios no pavimento superior e área social no térreo com sala de jantar e estar integradas. $O$ abrigo para o automóvel está presente. Um grande telhado cobre a varanda, que ocupa toda a fachada frontal.

\section{BUNGALOW PARA COPACABANA}

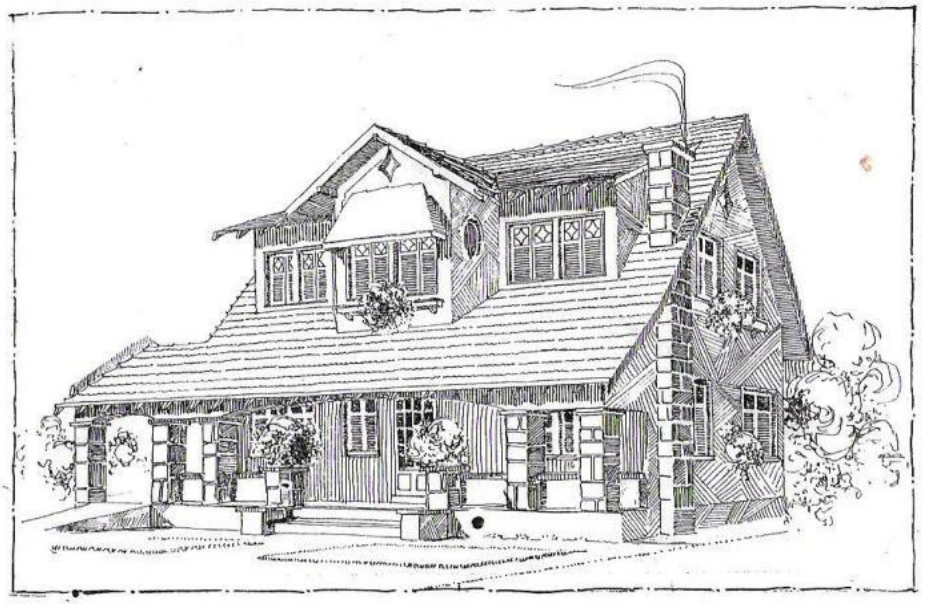




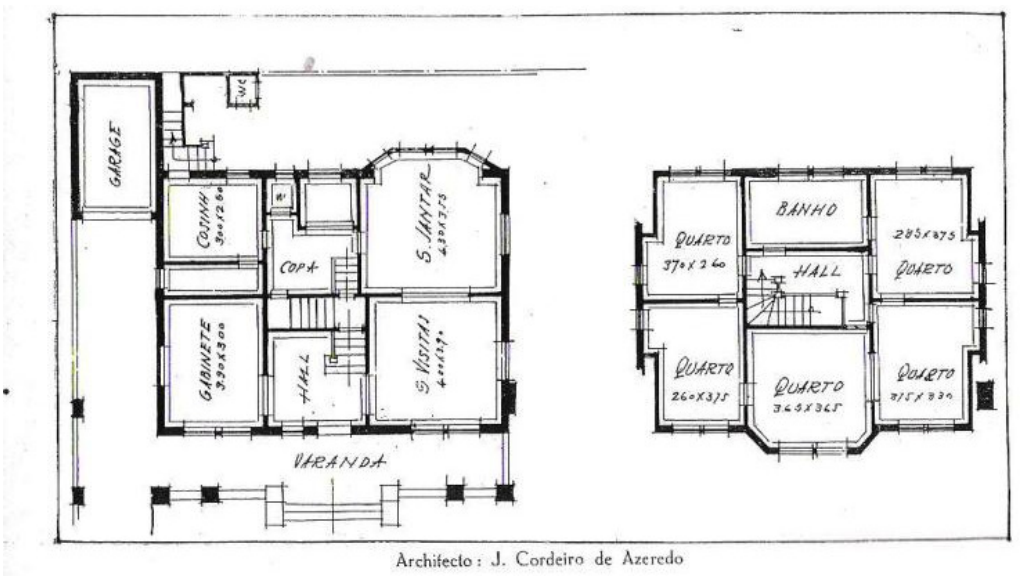

Fig. 4.54

A integração entre estar e jantar é vista em muitas casas mostradas na revista. No bangalô californiano, uma das características mais marcantes era a planta aberta. A sala de estar informal, ligada por um arco à sala de jantar, tornara-se o centro da vida familiar. Ela não se originou com o bangalô, mas ao menos desenvolveu ali todo seu potencial.

No número 56 (A CASA, 1928), aparecem ainda duas referências a bangalôs: na página 14, uma pequena casa a qual foram adicionadas algumas características deste tipo de habitação à fachada. Tentou-se mesmo executar uma bay window; e uma simulação de half timbering na empena. Outra, na página 20 é um "bungalow americano em estylo Missões", cuja referência ao estilo se resume a pequenos detalhes como o arco da entrada e um pequeno ornamento sobre a janela, além do reboco mais grosso, formando uma textura.

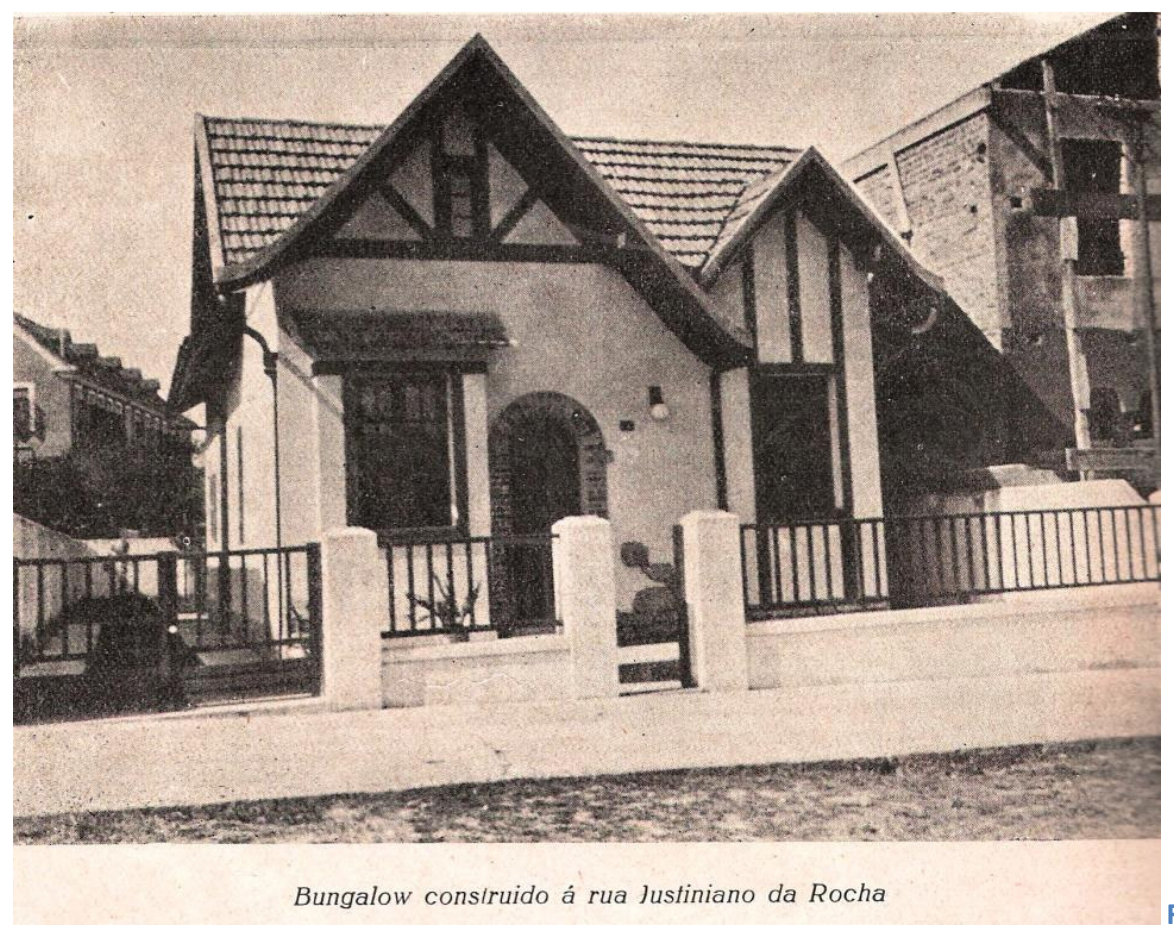



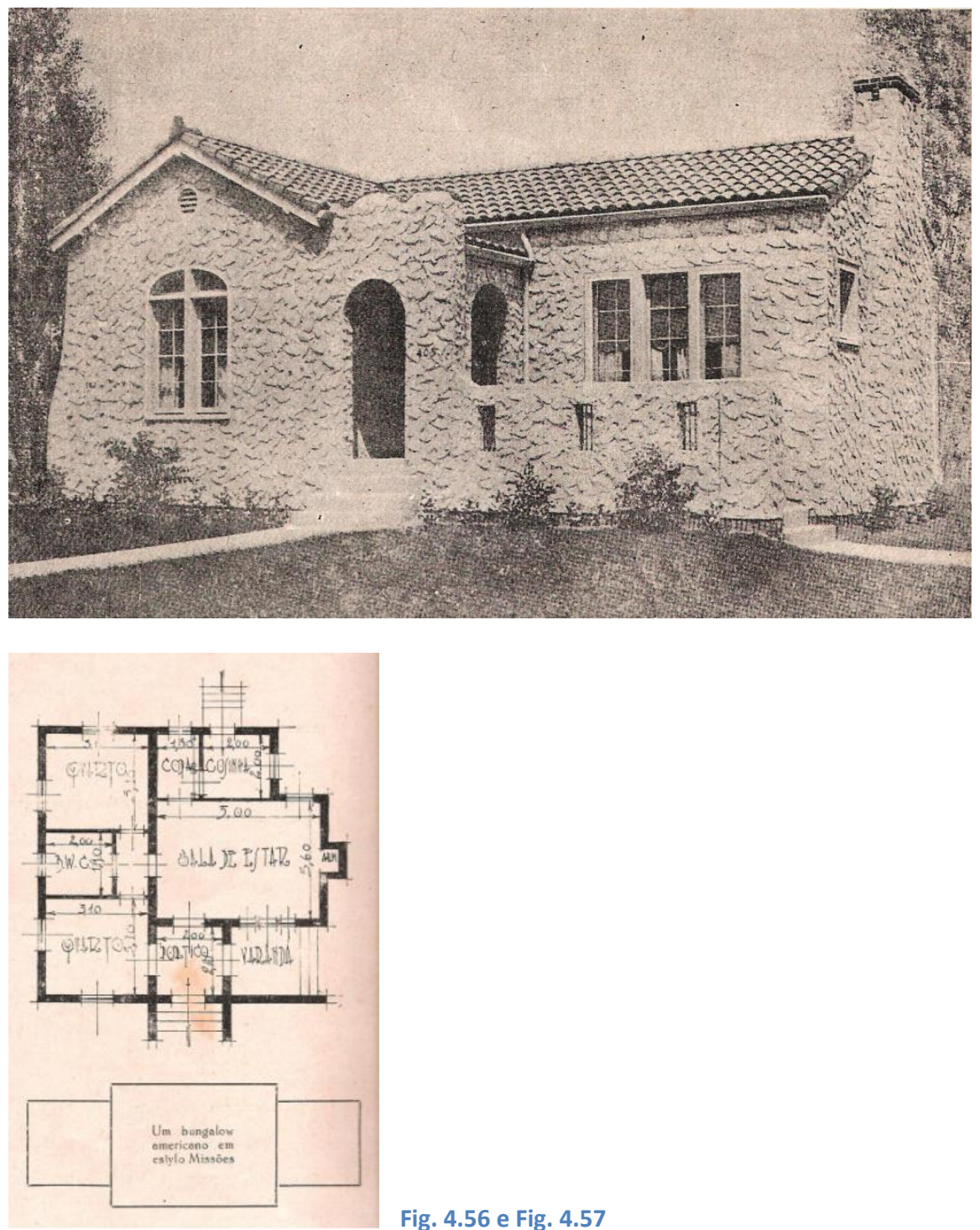

Fig. 4.56 e Fig. 4.57

\subsection{0 interior doméstico}

Nos periódicos de arquitetura, nos EUA, no início do século $X X$, quase não se discutia a casa de classe média. Esta lacuna seria preenchida pelas revistas de decoração da casa, que vinham de encontro a um grande interesse das mulheres de classe média por informações e conselhos. Revistas como House Beautiful, Ladie's Home Journal a de maior circulação - através das quais os ideais do Arts and Crafts migraram das casas da elite para aquelas da classe média. O Arts and Crafts torna-se um estilo de vida associado à classe média.

Estas revistas tinham um visual elaborado, porém difundindo a filosofia da 'vida simples', no âmbito da domesticidade. O movimento pela simplificação da vida estava 
basicamente ligado à classe média. $\mathrm{E}$ o bangalô, como já foi dito, torna-se o símbolo deste movimento, sua habitação característica.

Somando-se às revistas, os livros com modelos de projetos tornam-se uma verdadeira indústria. Como no Brasil onde, além dos álbuns de bungalows importados anunciados em várias revistas, existem aqueles livros de modelo publicados pelos arquitetos. Um deles era "Casas Modernas", que seria publicado pelos engenheiros Cápua e Rossi, mencionado na "Página de Architectura" da "Revista de Engenharia do Mackenzie (dez. 1928, n.40)

Prova de que as idéias difundidas por estas revistas americanas circulavam também no Brasil é o anúncio de $A$ Casa (1929, n.68, p. 5), sobre a revista Ladies' Home Journal, mencionada como a maior revista americana, com 250 páginas. A revista brasileira representava a americana e as assinaturas poderiam ser obtidas escrevendo-se para a redação no Rio de Janeiro. Existem muitos paralelos entre os assuntos tratados pelas revistas nos EUA e por A Casa, como a casa de classe média, a que não era reservado muito espaço nas revistas técnicas de arquitetura existentes. No Brasil, revistas mais antigas, como A Revista Feminina apresentavam alguns conselhos sobre a casa, principalmente em relação à decoração, mas faziam parte de uma miscelânea de assuntos, como as atuais revistas femininas.

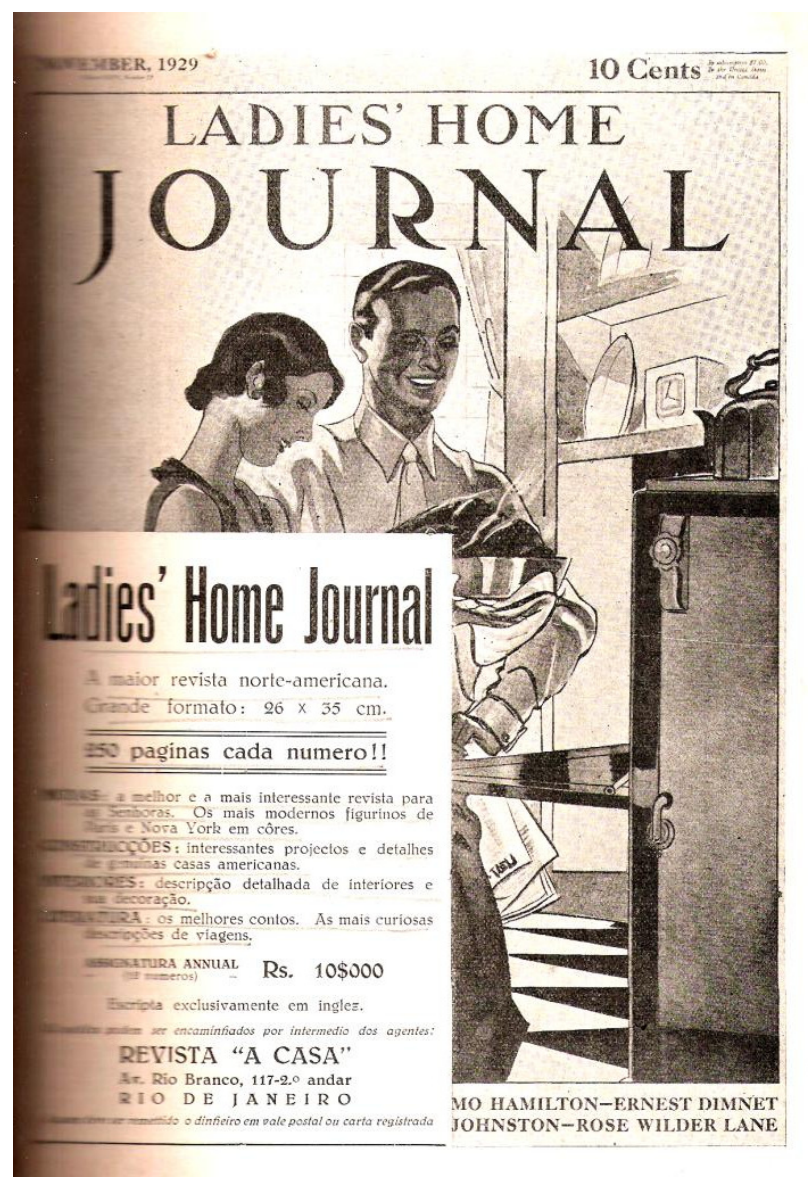


Porém a simplificação dos interiores, que se vê nas casas americanas da época, só seria obtida gradualmente aqui no Brasil. Fotos que aparecem nas páginas da revista A Casa mostram casas com decoração elaborada - papéis de parede, tapetes, estofados - mas não tão excessiva quanto na década anterior, em que havia uma profusão de quadros pelas paredes. Mas, estes ainda não poderiam ser definidos como um interior "limpo".

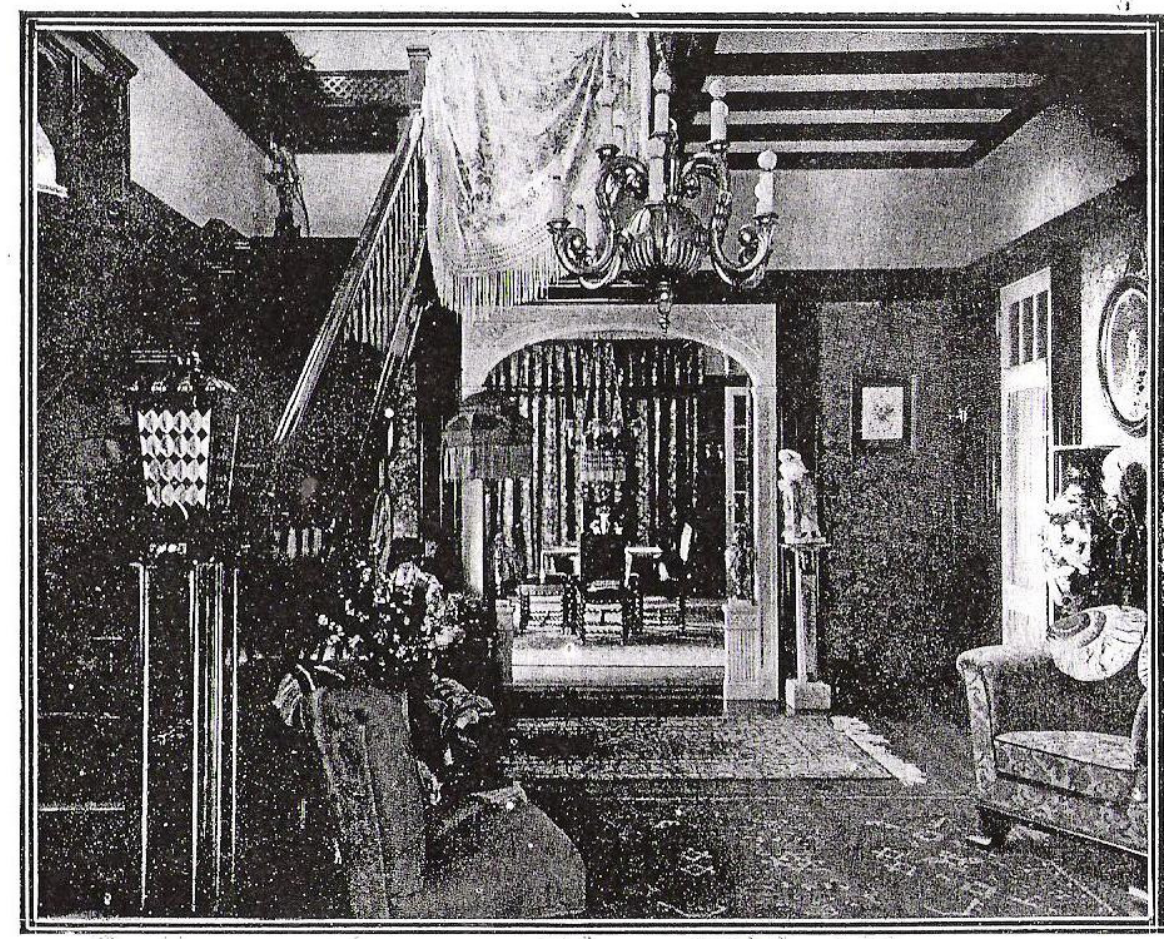

Fig. 4.59 e Fig. 4.60 Interiores mostrados na revista.

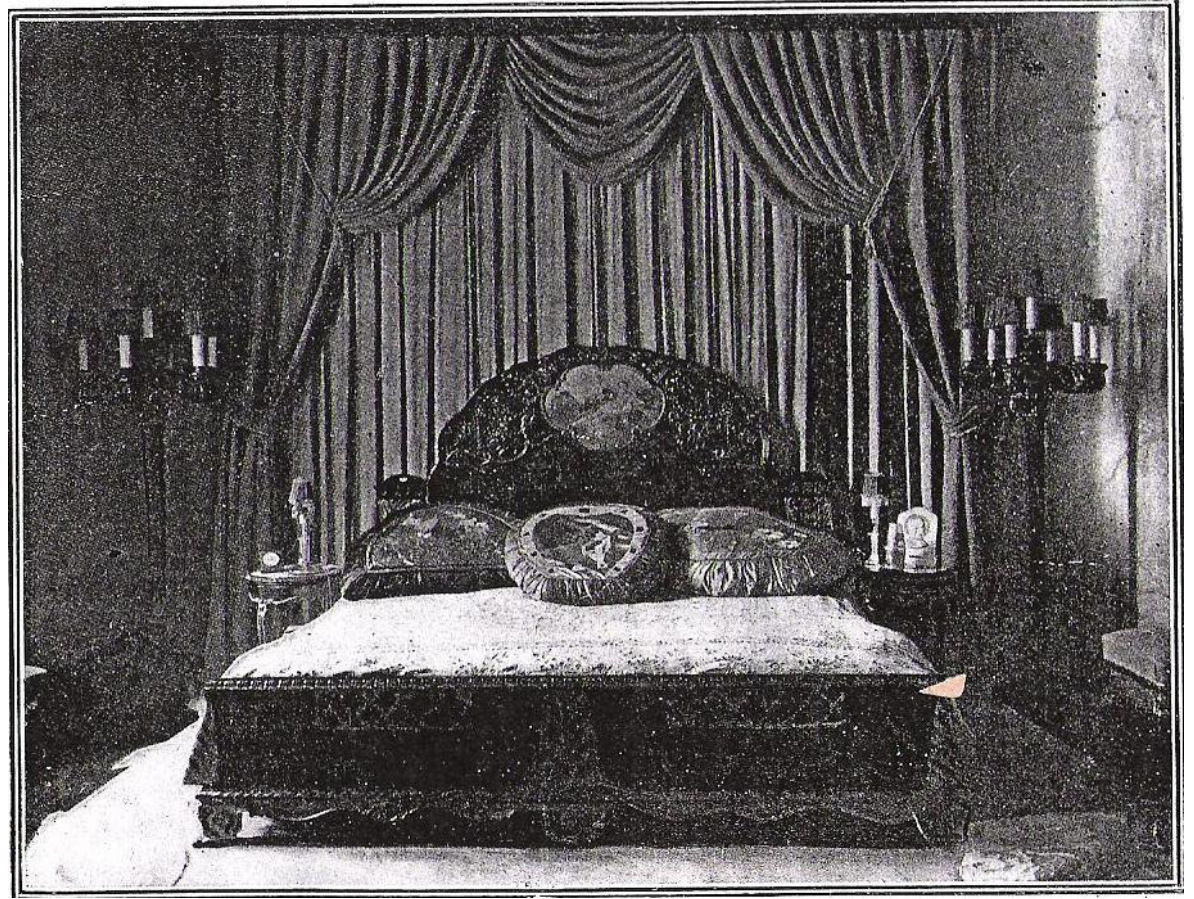


Alguns desenhos de interiores mostrados no número 4 da revista ( $A C A S A, 1924$, p.24-26), remetem aos projetos do arquiteto Barry Parker. Pé direito baixo, vigas de madeira aparentes no teto, simplicidade e requinte no desenho. Lambris de madeira e faixas horizontais nas paredes, que unificam os ambientes. A escada e o ambiente em torno da lareira são valorizados. Esta é mais simples e menor que aquelas desenvolvidas pelo arquiteto inglês, porém não menos sofisticada. Toda a mobília é fixa, inclusive os bancos encaixados sob a janela. Não é mencionado o autor do projeto, nem do artigo. Mas, não se tratava de um modelo já adotado aqui. A simplicidade e o despojamento da decoração somente apareceriam aos poucos. Os comentários ao texto dizem que o intuito era o de orientar os leitores no que de moderno, confortável e agradável se estava criando para o lar. Os desenhos representariam "o máximo de conforto, alliado ao bom gosto (...)". Mais uma vez falando da participação da mulher na elaboração da decoração, diz-se que: "A coadjuvação das Exmas. Snras. é nesta tarefa de um valor indiscriptível, pois, uma mão feminina sabe sempre que, uma almofada bordada ou pintada com arte, uma cortina escolhida com acerto, o tom da cor de um tapete, um vaso de flores distinctamente collocado em seu devido logar, são de uma importância capital no conjunto a formar. Compete a todos collaborar efficazmente e proporcionar a nossa família todo o bem estar e alegria para o interior do nosso lar, tornando-o assim, sempre e inconfundivelmente, o lugar mais desejado." Tais comentários não se relacionam com as ilustrações mostradas, que não apresentam, por exemplo, cortinas.

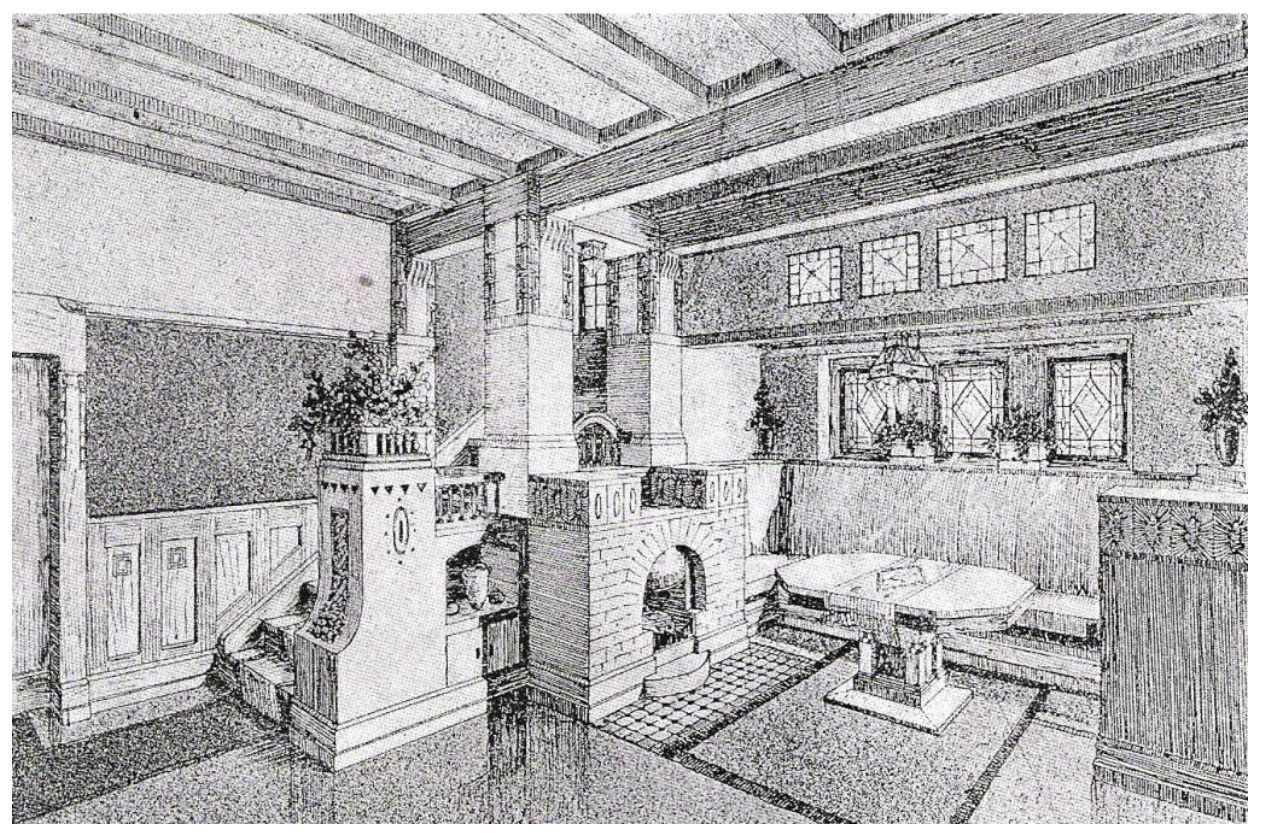

Fig. 4.61.e Fig. 4.62 Interiores mostrados na revista $A$ Casa. 

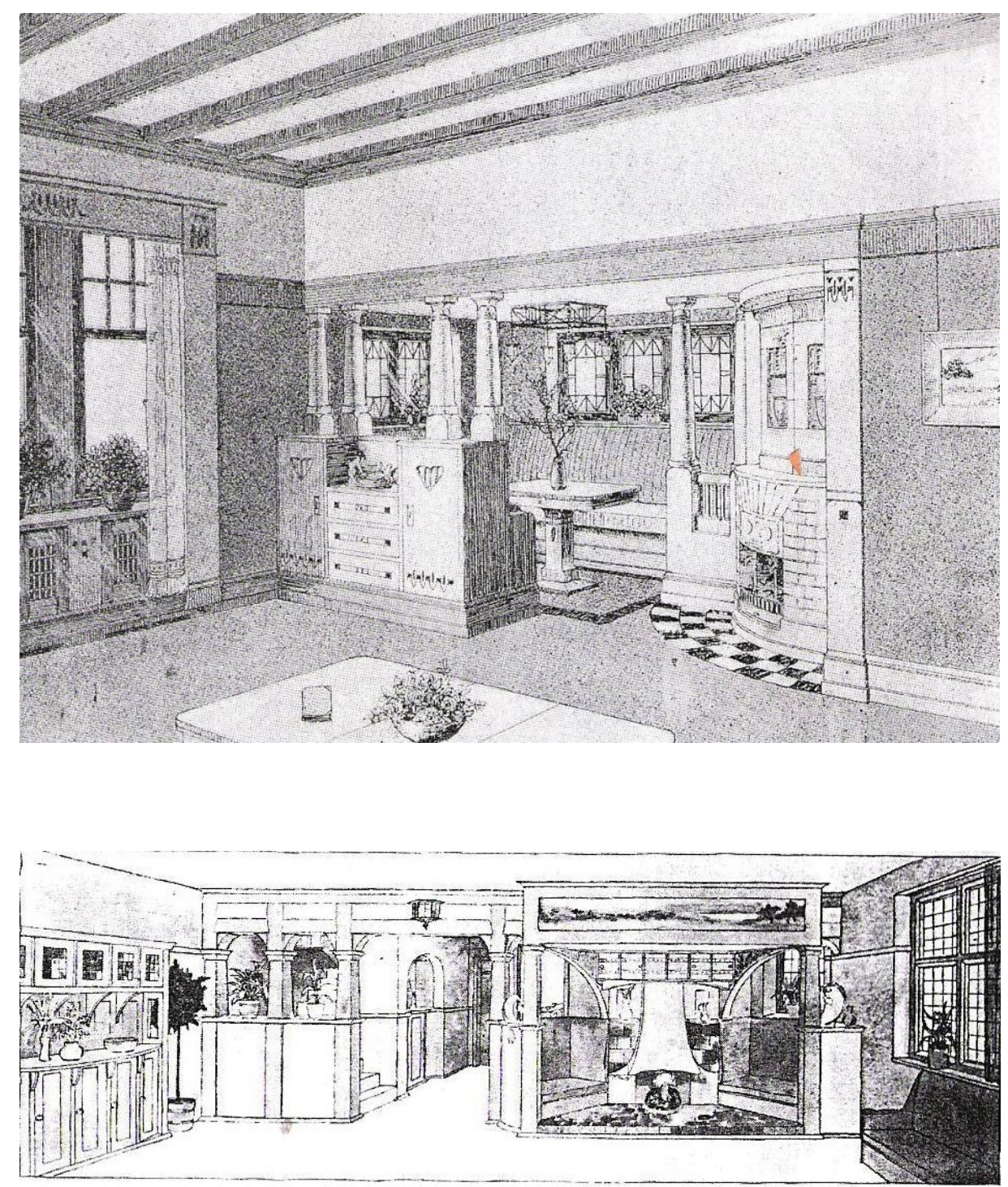

Fig. 4.63 Interior de casa inglesa de Barry Parker

A última ilustração mostra um interior clássico, imponente, com pé direito alto, poucos móveis, e certa frieza que não se encontra nos aconchegantes ambientes anteriores.

Outro interior é mostrado em anúncio de $A$ Casa (1924, n. 8, p. 35), com poucos móveis e uma figura feminina que se esmera na decoração, colocando vasos de flores sobre os móveis. Na mesa aparecem toalhas, que se supõe sejam também um trabalho da dona da casa. O anúncio também diz que são produzidos "dormitórios completos embutidos, estylo moderno", provavelmente uma novidade para a época no Brasil. 


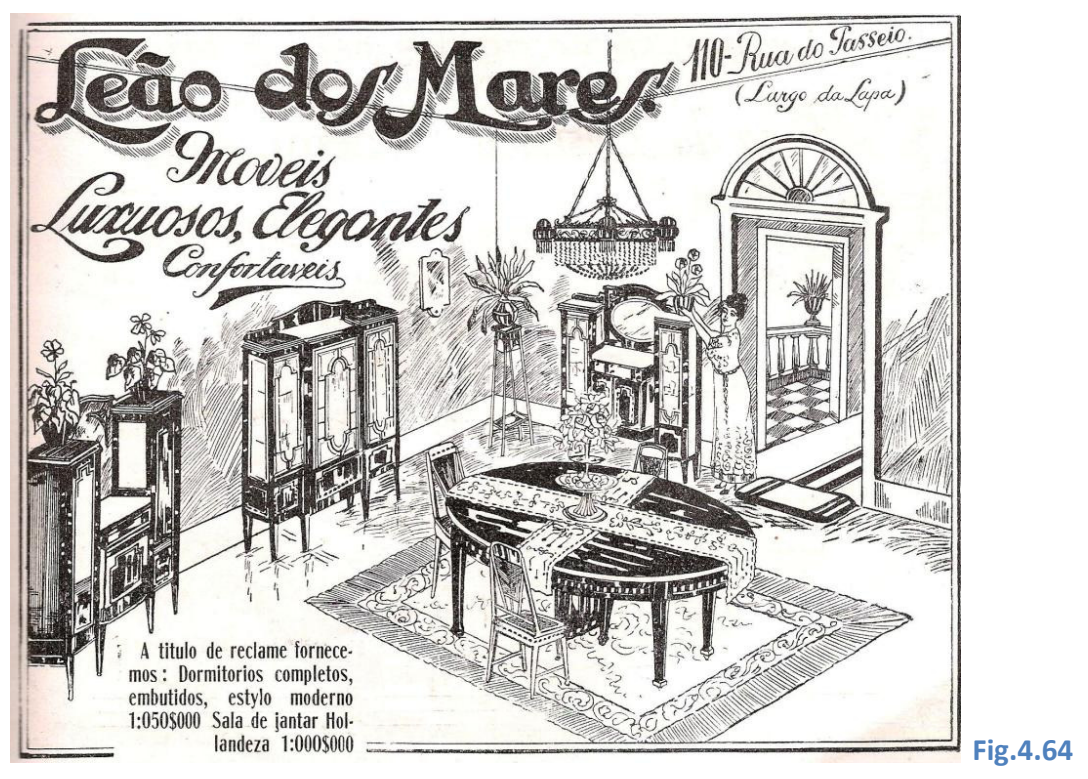

Em outro número é mostrado um interior com pé direito bastante alto, em uma época em que começa a haver redução em suas dimensões. A decoração, bem mais sóbria e limpa, resume-se praticamente aos forros com diferentes desenhos, feitos em "celotex", um material isolante anunciado em várias revistas da época. ( $A$ Casa, 1928, n.56, p. 35).

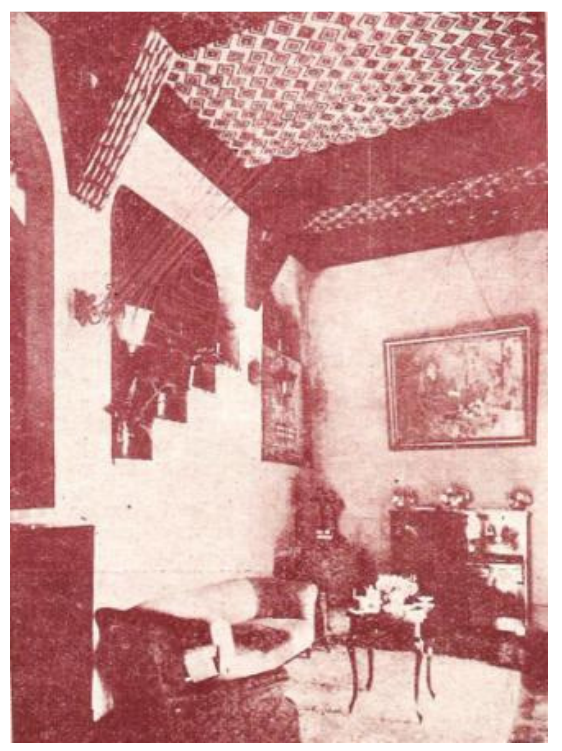

Fig.4.65 Interior com forros de "celotex"

E este anúncio de vidros também mostra uma decoração bastante simples. Nas paredes, apenas um quadro e na janela uma cortina leve que parece ter sido feita pela dona da casa. Completam a decoração muitas flores, porta retratos, almofadas, tudo muito individualizado, personalizado, relativo à família. Remetendo à esfera pessoal, cultivado. A casa como moldura da vida familiar. Com o conforto dos novos móveis estofados. ( $A$ Casa, n.35, março de 1927, capa interna) 


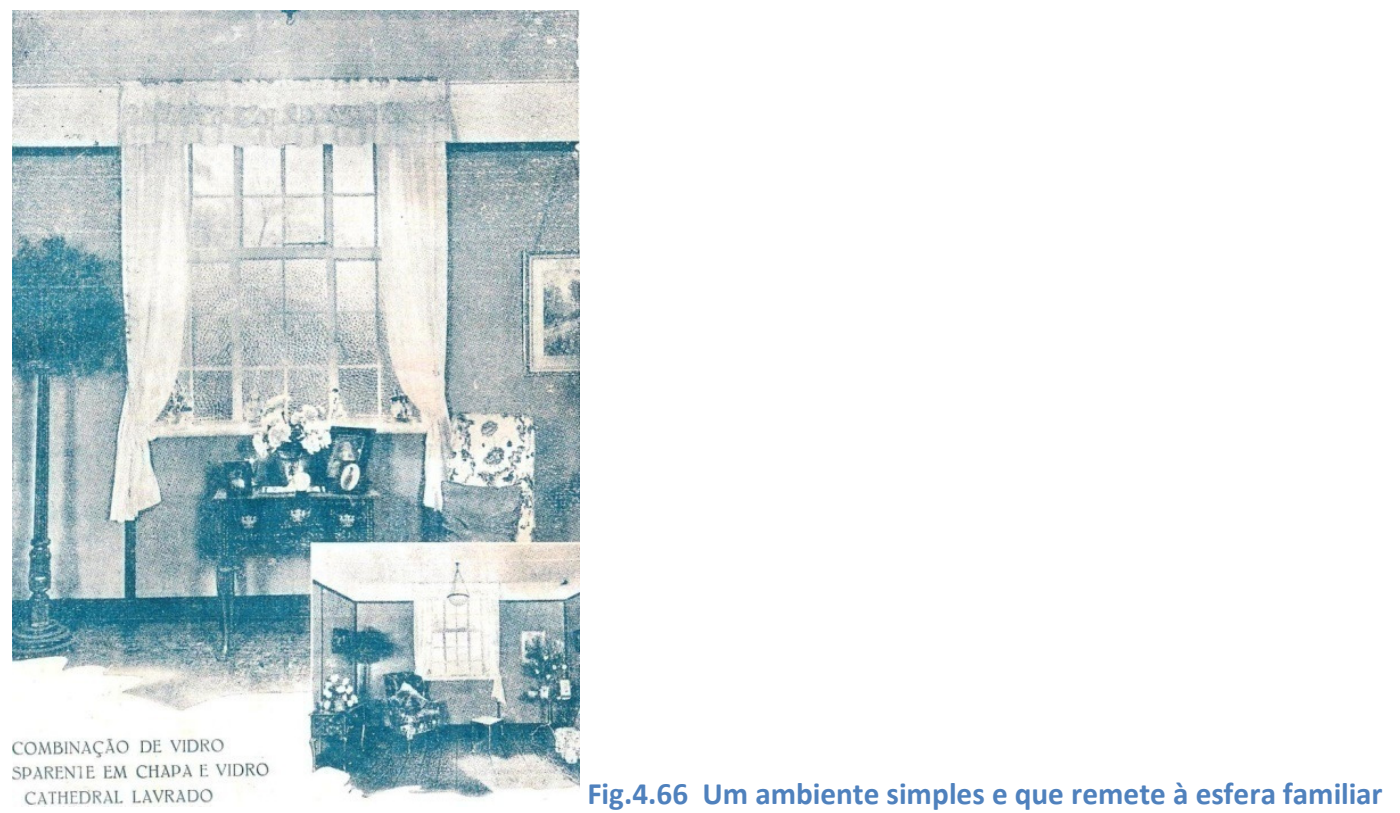

No número 61 de $A$ Casa (maio de 1929, p. 27), um ambiente bem mais austero e simples, onde todos os móveis têm desenho similar, com detalhes em madeira retorcida, características do Neocolonial associadas à decoração. Esta, além dos móveis se resume aos tapetes e lambris na parede. Projeto do arquiteto Edgar Vianna, que provavelmente projetou também os móveis. As esquadrias obedecem todas ao mesmo desenho.

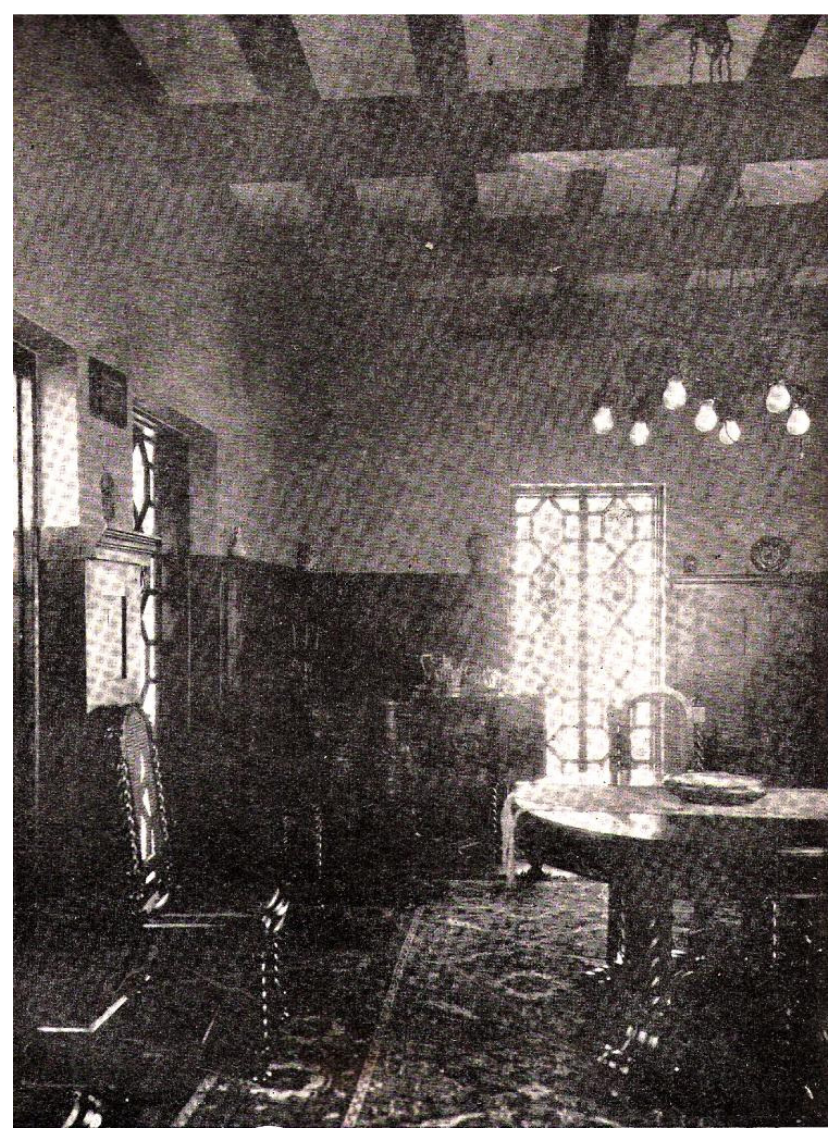

Fig.4.67 Projeto do arquiteto Edgar Vianna 


\subsection{Cozinhas}

Nos Estados Unidos, a racionalização do trabalho doméstico aconteceu de forma marcante ${ }^{21}$. A idéia de se economizar o tempo da dona de casa através do planejamento e organização das atividades levou à utilização dos termos economia doméstica, engenharia doméstica e gestão científica do lar. Na cozinha, a racionalização atingiu seu ápice, através do desenho e do acabamento das superfícies de trabalho e da presença dos eletrodomésticos.

Em artigo sobre a casa americana ( $A$ Casa, nov. 1929, n.67, p. 43-44) - apenas do final da década, 1929 - é apontada a falta de empregados domésticos como uma das razões para a criação de múltiplas invenções na casa americana. Esta teria sido o resultado de uma longa série de pesquisas sobre as necessidades sociais e econômicas e teria se tornado extremamente confortável.

$\mathrm{Na}$ sua elaboração, seriam obedecidas fórmulas matemáticas. Haveria uma modulação nas dimensões dos cômodos para que houvesse o melhor aproveitamento dos materiais.

As salas de jantar e estar seriam separadas por portas envidraçadas, para que pudessem ser integradas, formando um grande salão.

Haveria vários eletrodomésticos na casa, inclusive máquinas para lavar e secar roupas. Para garantir o conforto, aquecimento central.

A cozinha teria sido objeto de vários estudos, que determinaram os tempos e movimentos necessários aos diversos trabalhos ali desenvolvidos. Haveria vários aparelhos elétricos, inclusive uma máquina para lavar louças, locais para a preparação dos alimentos e armários. O fogão seria elétrico ou a gás. ( $A$ Casa, nov. 1929, n.67, p. 43-44)

No Brasil, o processo de racionalização das cozinhas aconteceu de modo diverso dos EUA. Aqui, a cozinha na década de 1920 ainda permanecia como o local de trabalho essencialmente da empregada doméstica. ${ }^{22}$

Enquanto nas revistas americanas de arquitetura e decoração, as cozinhas estão sempre presentes e têm o mesmo peso de outros ambientes, nas revistas paulistanas raramente aparecem.

\footnotetext{
${ }^{21}$ Buscava-se a racionalização não apenas pela escassez de empregados, mas, pela própria resistência à sua presença no ambiente doméstico, como foi dito no capítulo 2 .

${ }^{22}$ Sobre a racionalização do trabalho doméstico nos EUA, ver CARVALHO, 2008, p. 247-257.
} 
No número especial da revista americana House \& Garden (1925, p.18), encontra-se esta ilustração de uma cozinha, conjugada a uma copa, onde já aparecem a geladeira elétrica, o fogão a gás, armários planejados, superfícies de trabalho, um dispositivo para a lavagem das louças e eletrodomésticos, como a torradeira. A presença da eletricidade na casa pode ser percebida pela quantidade de tomadas elétricas na cozinha: cinco. Existe a preocupação com a decoração através das cores e dos acabamentos - no caso, o dos armários é laca. A equiparação deste ambiente aos demais está clara neste trecho do artigo: "Esta cozinha é como o resto da casa, muito elegante."

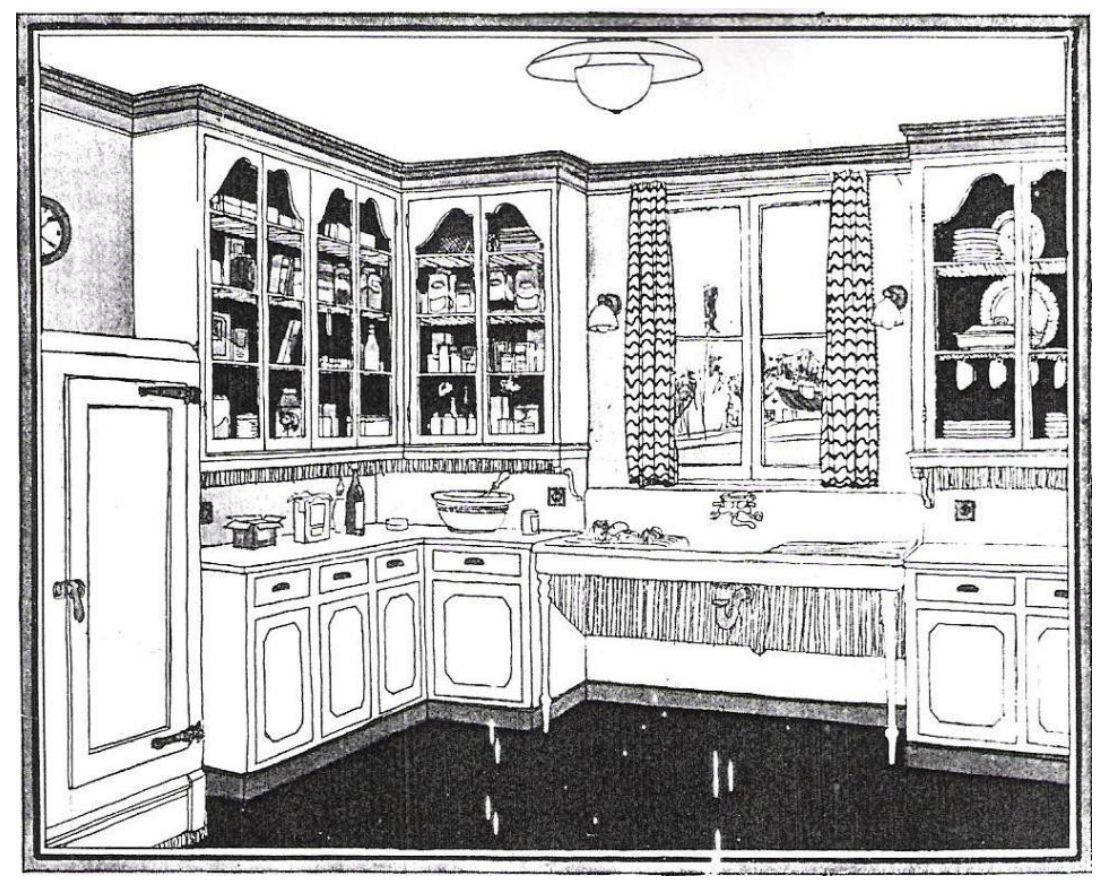

Fig. 4.68 Cozinha americana

Em São Paulo, a busca da eficiência na utilização do espaço da cozinha terá outra origem: a preocupação com a higiene no preparo dos alimentos.

A proliferação de epidemias fez com que os médicos e o poder público associassem o modo de vida da população pobre à falta de higiene, à promiscuidade, à doença e à desordem.

"O medo da contaminação aprofundou as diferenças que já existiam entre patrões e empregados e colocou a casa no centro das discussões sobre a saúde pública". Por isso, em São Paulo as modificações na vida doméstica aconteceram de maneira diferente dos Estados Unidos. "Em vez de engenheiros e arquitetos, foram os médicos que tomaram a dianteira nas propostas de modernização da casa". (CARVALHO, 2008, p. 250) 
"O consultório médico, um dos espaços de trabalho masculino mais respeitados dessa sociedade, vai fornecer os parâmetros materiais dessa nova cozinha para uma clientela privilegiada que tinha acesso aos seus serviços, mas também para um público mais amplo, que podia se familiarizar com o ambiente asséptico e mecanizado pelas fotografias de seus interiores divulgadas nas revistas." (CARVALHO, 2008, p. 257) Os consultórios médicos aparecerão em vários números de $A$ Cigarra entre os anos de 1917 e 1930.

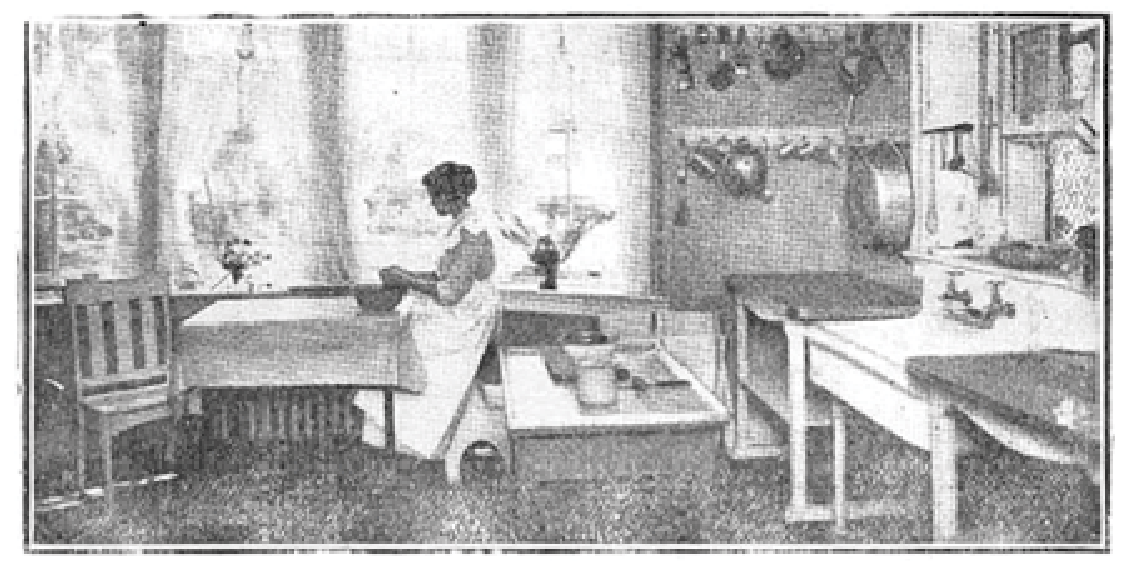

Fig. 4.69 “A Cozinha Moderna”, Revista Feminina, 1918.

Outro fator de modernização das cozinhas paulistanas foi a introdução de novas tecnologias. Apesar de a cozinha não aparecer nas páginas de $A$ Casa como um ambiente que mereceria especial atenção, ela está presente nos anúncios de fogões:

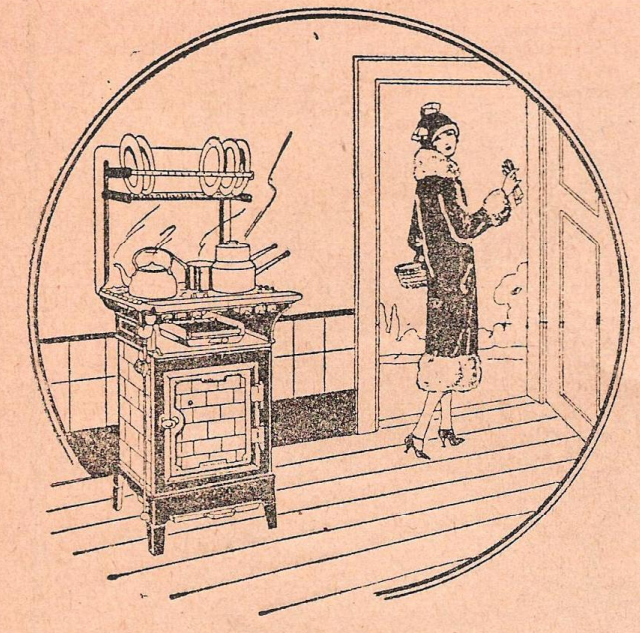

Fogões a gaz

\section{"Regulo"}

O "PEGLLO" é um dispositivo pelo qual, de antemão, se dá ao forno uma determinada temperatura, que não será ultrapassada, evitando assim o aquecimento do forno além da temperatura que elle. deve ter.

Para isso se conseguir, é necessario fazer girar um disco graduado e collocar defronte d'um indicador, o numero correspondente á temperatura que se deseja dar ao forno. Isto feito, tem-se a certeza de que essa temperatura não será excedida e será mantida constante, pois o "REGULO" se encarrega de controlar a entrada de gaz, diminuindo-a á medida que o aquecimento se fôr produzindo.

\section{"New - World"}

Fig. 4.70 
Além da questão econômica para a aquisição das novas tecnologias, havia a questão da resistência às modificações por parte das empregadas domésticas e mesmo das donas de casa. Uma das maneiras de vencer esta resistência era a publicidade. Esta, além de divulgar os novos produtos, deveria deixar subentendidos os valores de modernidade e de racionalidade relacionados a eles. Nunca é mostrada a figura da empregada doméstica manipulando o novo artefato. Quando não se mostra a própria dona de casa, bem vestida, cozinhando, mostra-se a figura de um cozinheiro profissional, sempre uma figura masculina que remete aos modernos restaurantes. Relaciona-se a cozinha doméstica a um espaço profissional como aquele de preparo dos alimentos em restaurantes.

Além disto, em São Paulo, a modernização da cozinha incluiu o jogo de interesses de mercado de grandes empresas como a Light e a The São Paulo Gas Company. De lugar desprezado da casa, relegado ao porão ou à edícula, a cozinha transforma-se em um local planejado, higiênico, pronto para as novas tecnologias. "As empresas de energia procuravam fomentar o consumo de gás e eletricidade (além dos equipamentos correspondentes) apelando para um desejo difuso de modernização das elites urbanas. Apesar do limite do consumo de gás, ele teve um grande impacto no desenvolvimento de uma nova casa (principalmente a cozinha). (...)" (SILVA, 2006, p.90)

A modernização definitiva acontecerá apenas a partir de 1930, com a valorização dos princípios de simplificação do trabalho na indústria e no lar entre nós. A geladeira elétrica seria introduzida a partir de $1927 .^{23}$

Esta é uma das primeiras cozinhas onde já se percebe certo planejamento na colocação do fogão, das superfícies de trabalho e da pia. Aparece apenas em 1930 na revista $A$ Casa (n.71, p.29)

\footnotetext{
${ }^{23}$ Sobre a modernização da cozinha após 1930, ver HOMEM, Maria Cecília Naclério o princípio da racionalidade e a gênese da cozinha moderna. In: Revista do Programa de Pós-graduação em Arquitetura e Urbanismo da FAUUSP. São Paulo: n.13 junho de 2003, p.124-153.
} 


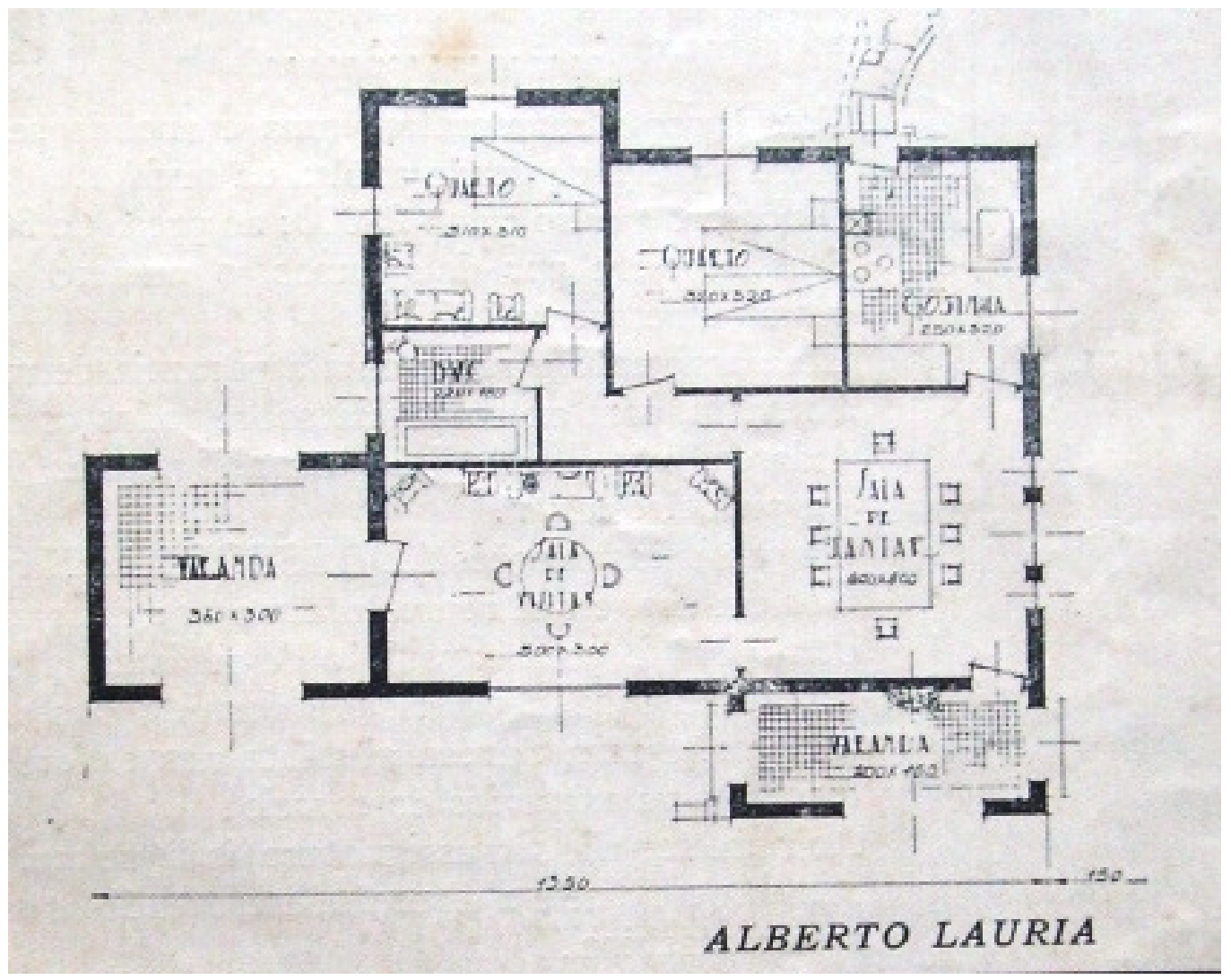

Fig. 4.71 


\section{CAPÍTULO 5}

\section{A ARQUITETURA EM SÃO PAULO NO PERÍODO}

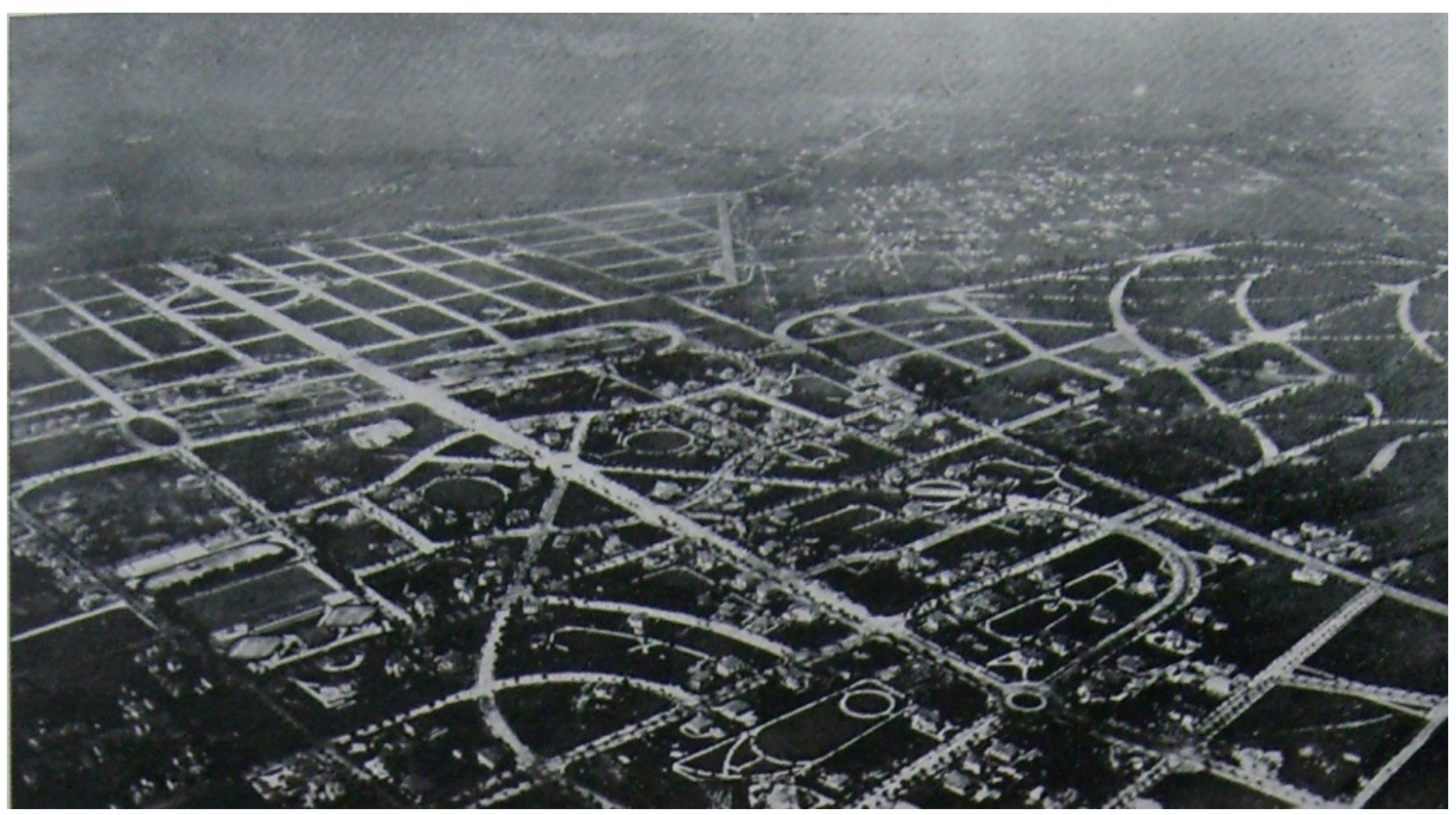

Fig. 5. 1 Jardim América, anos 1920.

\subsection{A Companhia City ${ }^{1}$ e o Jardim América}

Mas os milionários abandonaram a avenida Paulista. Seguindo a expansão da cidade, desceram com ela o Sul da colina, para bairros sossegados de ruas sinuosas. Suas residências de inspiração californiana, em cimento misturado à mica e com sacadas de ferro fundido, deixam-se entrever no fundo de jardins abertos nos pequenos bosques rústicos onde se implantam esses loteamentos ${ }^{2}$.

\footnotetext{
${ }^{1}$ A Companhia City de Desenvolvimento é a única titular do direito de uso e propriedade das marcas compostas por CITY e CIA CITY. (nota da Companhia City).

2 LÉVI-STRAUSS, Claude Tristes Trópicos. São Paulo: Companhia das Letras, 1999, p.94 apud ATIQUE, 2007, p. 402.
} 
O episódio que Claude Lévi-Strauss ${ }^{3}$ relata acontece provavelmente nos anos 1930 , pois ele se refere ao estilo Missões na arquitetura e sobre o abandono da Avenida Paulista pela elite ${ }^{4}$. O início do bairro remonta à segunda metade dos anos 1910 . As residências maiores e mais refinadas, ligadas à estética Missões, somente aparecerão nos anos 1930.

Em 1915, o notável architecto Raymond Unwin, membro do Instituto Real dos Architectos Britannicos, preparou a planta original de arruamento e desenvolvimento do subúrbio jardim. A seguir, o Snr. Barry Parker, outro architecto igualmente de reconhecida competência e nomeada, era chamado a collaborar no grande emprehendimento, tendo, então, occasião de introduzir importantes e diversos melhoramentos no plano geral. (The City of São Paulo Improvements \& Freehold Land Co., Ltd.,1923, texto de apresentação)

Sobre seu plano para o Jardim América, Parker diz que "em minha primeira visita ao 'Jardim América', percebi que sua capacidade de atrair moradores teria que ser criada (grifo de Parker). Quero dizer com isto que o fracasso ou o sucesso dependiam em grande parte do desenho, planejamento, administração e do tipo de casa (...). Projetado da forma habitual, encorajando a construção da costumeira casa brasileira, este empreendimento não resistiria". (PARKER, 1919, p. 3).

O desenho de Parker, em relação ao anterior de Unwin, realizado em abril ou maio de 1917, altera o traçado das ruas, porém é mantida sua estrutura básica, aumentando ainda o número de jardins internos às quadras e definindo a divisão em lotes. (ANDRADE, 1998, p. 247)

\footnotetext{
${ }^{3}$ O filósofo francês lecionou na USP de 1935 a 1938.

${ }^{4}$ A crise de 1929 alteraria o perfil da Avenida Paulista, quando vários empresários do café foram obrigados a vender seus imóveis. A última das grandes mansões da Paulista foi construída em 1935. Ramos de Azevedo a projetara nove anos antes para sua filha. E, em 1936, foi promulgada uma lei autorizando a construção de edifícios residenciais e instalações comerciais na avenida. Já havia pressões, há alguns anos, pela permissão da sua verticalização. A partir de então, vários moradores mudam-se para outros bairros e iniciam-se as transformações que mudaram seu perfil original. Simbolicamente, a morte de Francisco Matarazzo, em 1937, seu primeiro e um dos mais ilustres moradores marca o fim da primeira fase de ocupação da avenida. (D'ALESSIO, 2002, p.53).
} 


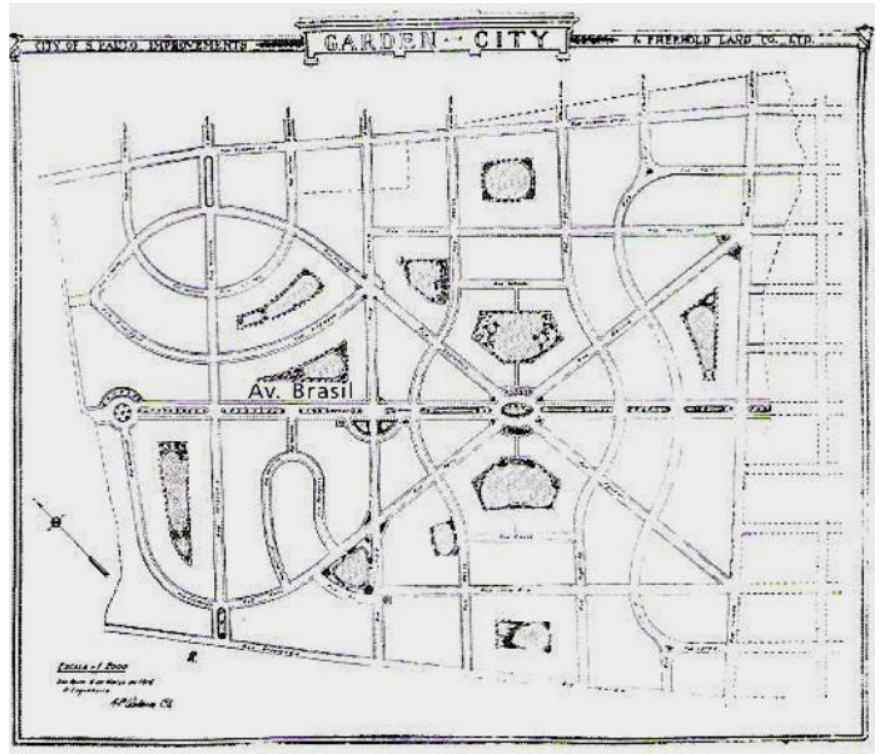

Fig. 5. 2 Plano de Unwin para o Jardim América.

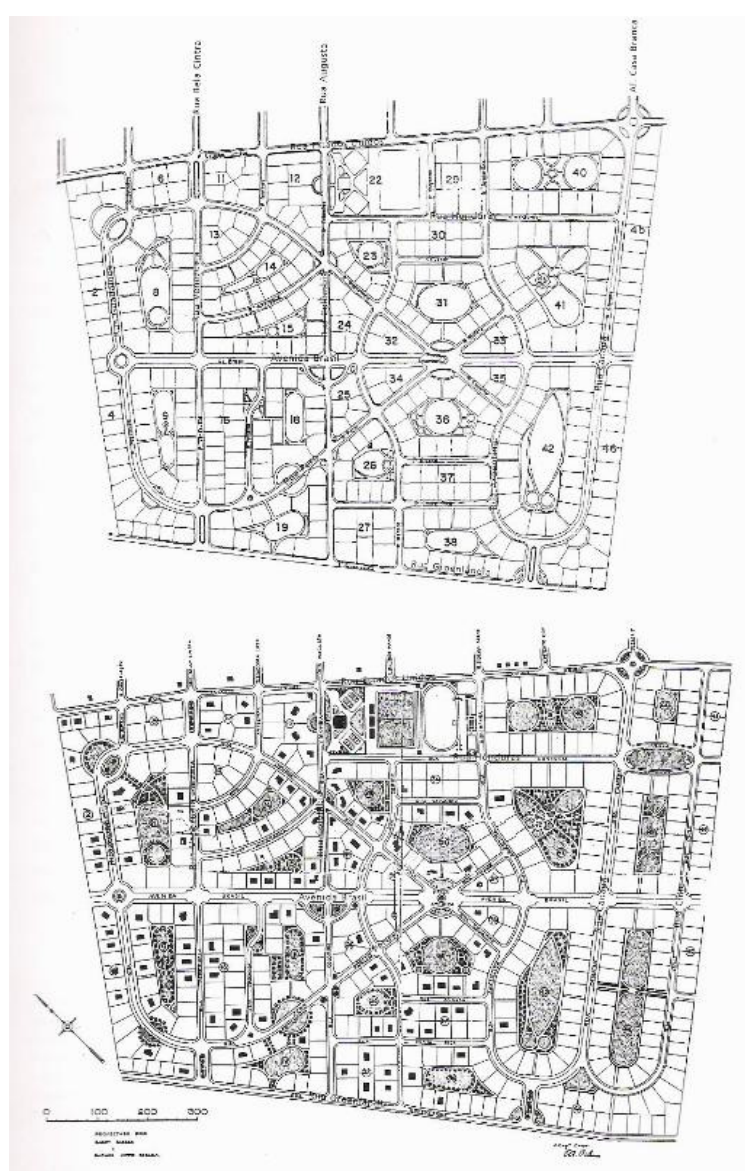

Fig. 5. 3 Planos de Barry Parker para o Jardim América, antes e depois da ampliação realizada com a aquisição de novas terras.

O Jardim América foi implantado em terrenos planos pertencentes à planície de inundação do Rio Pinheiros. Os motivos para se traçarem ruas curvas foram outros e 
não os usuais, de adaptação à topografia. O usual, em tal situação, seria o "tabuleiro de xadrez".

Porém, a necessidade de "criar-se atração", como dissera Parker, prevaleceu, através de um traçado interessante, misto de composição clássica e pinturesca. As ruas curvas adicionam certa variedade ao desenho, calcado em eixos ortogonais e diagonais, de inspiração barroca. Seria possível perceber a totalidade deste desenho clássico, quase simétrico, "quebrado" pelas ruas curvas. Provavelmente pesou neste traçado a racionalização da área a ser utilizada com o sistema viário e o melhor parcelamento dos lotes. Tais ruas curvas criariam vistas interessantes e recantos que tornaram o bairro um refúgio na cidade.

O aterramento da várzea em que se constituía o Jardim America foi realizado de acordo com as recomendações de Barry Parker: um sistema de drenagem com galerias em ambas as laterais das ruas.

Casas localizadas no centro do lote e cercadas por jardins já existiam na cidade, como pode ser visto, por exemplo, nas fotos dos palacetes da Avenida Paulista. Mas, eram algumas casas, em algumas ruas e avenidas. No entanto, todo um bairro planejado desta forma, em que havia toda uma permeabilidade visual (ANDRADE, 1998, p. 248), possibilitada ainda pela limitação na altura dos muros laterais - dois metros - era uma novidade no conjunto da cidade. Uma nova forma de morar, associada às cidadesjardins inglesas e aos subúrbios anglo-americanos do século XIX e início do XX.

Mas, a formação desta paisagem levou alguns anos, após o início da implantação do bairro. As fotos das primeiras casas mostram ainda muitas ruas sem asfalto, guias e calçadas por fazer e cercas de arame no fechamento frontal dos lotes; gramados e jardins ainda por executar, em grande parte do loteamento.

Nas "Cláusulas das servidões para o uso dos terrenos" (ANDRADE, 1998, p. 247) que regulamentavam as construções no Jardim América, provavelmente elaboradas por Barry Parker, são especificados os recuos para a implantação em todas as laterais da casa, isolando-a no centro do lote. Os recuos de frente e de fundos não são especificados. Os laterais seriam de 4 metros para casas térreas, 6 metros para sobrados e 8 metros para casas de três pavimentos. Para casas térreas, a área mínima seria de $130 \mathrm{~m}^{2}$ e máxima de $1 / 5$ da área do terreno. Para sobrados, a área mínima seria de $80 \mathrm{~m}^{2}$ e máxima de $1 / 7$ da área do terreno. O uso também era regulamentado, exclusivamente residencial ${ }^{5}$.

\footnotetext{
${ }^{5}$ O Código Sanitário de 1918 influenciou de modo decisivo a implantação e a volumetria das residências deste período. Introduziu noções de higiene nas habitações, ao reconhecer os benefícios propiciados
} 
A Companhia City divulgava o zoneamento de funções - chamado de zoning - como uma das atrações do loteamento, como diz o anúncio da Revista de Engenharia do Mackenzie (maio 1929, n. 50), denominado "Urbanismo em São Paulo": "Nos bairros ideados e construídos pela Companhia City com a mais ampla liberalidade e rigorosamente de accôrdo com a technica e normas do Urbanismo Moderno V. Sra. terá de antemão o conhecimento exacto e a garantia do que será construído ao lado do seu terreno."

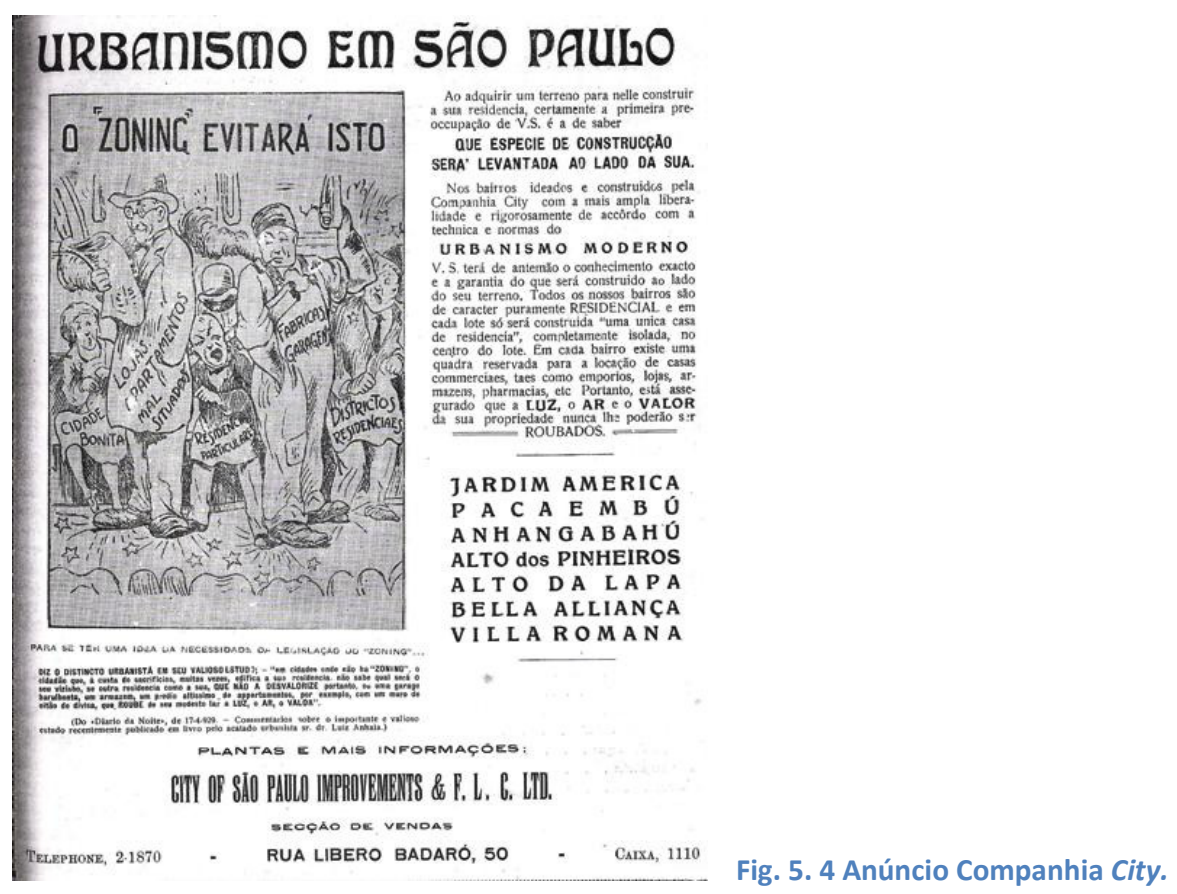

Em 1923, a City publica um álbum de fotografias com as casas até então construídas, que seriam mais de cem. A primeira casa fora construída em 1916. Houve certo retardo nas obras e construções até o final da guerra, em 1918. O texto de apresentação do álbum diz:

As grandes avenidas bem arborisadas, extensos gramados em diversos formatos para recreação do público (...) dão ao jardim

pela ação bactericida do sol. Eram recomendados cuidados especiais quanto à implantação das edificações no terreno e à orientação das janelas. Esta orientação evitaria também a incidência direta dos ventos úmidos que ocorriam na capital paulista em certas épocas do ano. Os afastamentos dos limites do lote permitiriam uma insolação mínima diária.

As prescrições do código foram tão importantes, que muitas foram endossadas depois pelo Código de Obras de São Paulo, (lei $n^{\circ} 3.427$ de 1929). Promulgado como Código Arthur Saboya em 1934, estabeleceu um novo padrão para as edificações residenciais paulistanas, pois definiu recuos mínimos frontais, laterais e de fundo a serem atendidos pelas construções particulares. Estas novas condições de afastamento entre as edificações em busca de salubridade sugerem certa influência dos critérios de implantação trazidos pelos loteamentos da Companhia City. 
América uma aparência sugestiva e peculiar às residências dos Anglo-Saxões do outro lado do Atlântico. É verdadeiramente pitoresco e encantador o local e o único jardim do gênero existente no Brasil. (The City of São Paulo Improvements \& Freehold Land Co., Ltd.,1923, texto de apresentação).

Tais fotos constituem-se em importante documentação, uma amostragem dos modelos de residências burguesas na cidade de São Paulo à época, neste loteamento que seria considerado um paradigma da forma de se morar moderna e sofisticada. No álbum, são mencionados os autores dos projetos, profissionais muitas vezes esquecidos pela historiografia.

"Após quasi sete annos de consciencioso e constante trabalho, o Jardim América conta hoje com mais de uma centena de palacetes e 'bungalows'”, diz ainda a apresentação do álbum. Os bangalôs eram casas com menos de $200 \mathrm{~m}^{2}$ situadas em lotes de mais de $1000 \mathrm{~m}^{2}$. Assemelhavam-se a pequenas chácaras. Assim, não era difícil obedecer aos recuos exigidos pela companhia. Os palacetes eram sobrados maiores, porém, nada comparáveis, em termos de área construída e de requinte, aos palacetes do início do século localizados em Higienópolis e na Avenida Paulista.

No início, o Jardim América constituiu-se em um bairro de classe média. $O$ fato de a companhia vender os terrenos a prazo e também conceder financiamentos para a construção tornou o loteamento acessível às camadas médias, compostas de profissionais liberais, funcionários de grandes empresas e comerciantes, entre outros. Estendiam-se, assim, a outras camadas sociais as possibilidades, antes restritas à elite, de morar em um bairro diferenciado. Um novo padrão de vida urbana difundia-se. A arquitetura do Jardim América representa padrões de moradia da classe média que se expandia e comprava sua casa própria no novo bairro, que se tornará símbolo de elegância.

E a Companhia City tinha plena consciência deste fato: "Mostram ellas claramente o que se tem feito em matéria de residências em São Paulo e o que poderá ainda ser feito. Em summa, o Jardim América sobre constituir uma grande novidade para o Brasil serve de exemplo aos que desejarem, futuramente, formar um bairro estrictamente de residências". (The City of São Paulo Improvements \& Freehold Land Co., Ltd.,1923, texto de apresentação).

O padrão dos loteamentos da Companhia City foi tão bem recebido que empreendimentos de outras empresas incorporaram características dos seus bairrosjardins. O mais evidente é o Jardim Europa, implantado em 1921. E nos dias de hoje, ainda existe grande confusão quanto aos loteamentos que foram executados pela City. 
Como relatado por funcionários da companhia a esta pesquisadora, existem muitas consultas sobre normas de loteamentos que os compradores imaginam terem sido feitos pela companhia, e na verdade não o são. Hoje, ainda, morar em um loteamento da empresa é sinal de "morar bem".

Era bucólico o bairro; os pouco automóveis que o percorriam pertenciam aos moradores ou a eventuais visitantes. As redes de eletricidade eram subterrâneas, reforçando tal sensação. Parker já se mostrara contrário às redes de energia aéreas: "Todos lamentam a forma como as necessidades modernas desfiguram nossos caminhos, enchendo-os com fios e cabos de telégrafo, telefone, luz elétrica e bondes e com os suportes que os sustentam." (PARKER, 1919, p.4)

As formas de sociabilidade eram totalmente diferentes daquelas das cidades- jardins. O espírito de comunidade que pautava o desenho urbano de Unwin e Parker não era esperado no Jardim América. Como assinala Andrade (1998, p.248), as fotos da época, das ruas e praças, mostram poucos usuários, praticamente apena as babás e os filhos dos moradores. Como as fotos da Avenida Paulista na mesma época. O fato dos moradores do Jardim América não haverem se interessado em custear a manutenção dos jardins internos às quadras, de certa forma permitindo que fossem retalhados em novos lotes, praticamente em seus "quintais", mostra o desinteresse pela utilização da área. Foi uma alteração radical da paisagem, a que aconteceu quando os novos terrenos foram colocados à venda. A permeabilidade visual mencionada antes ficou comprometida, principalmente se considerarmos que os terrenos do centro das quadras eram menores que os demais, assim as novas casas seriam construídas mais próximas umas às outras.

A planta encontrada no arquivo da Companhia City mostra o desmembramento de um dos jardins internos em vários lotes - neste caso, como o jardim era pequeno, quase toda a área foi vendida aos proprietários para ampliação de seus lotes.

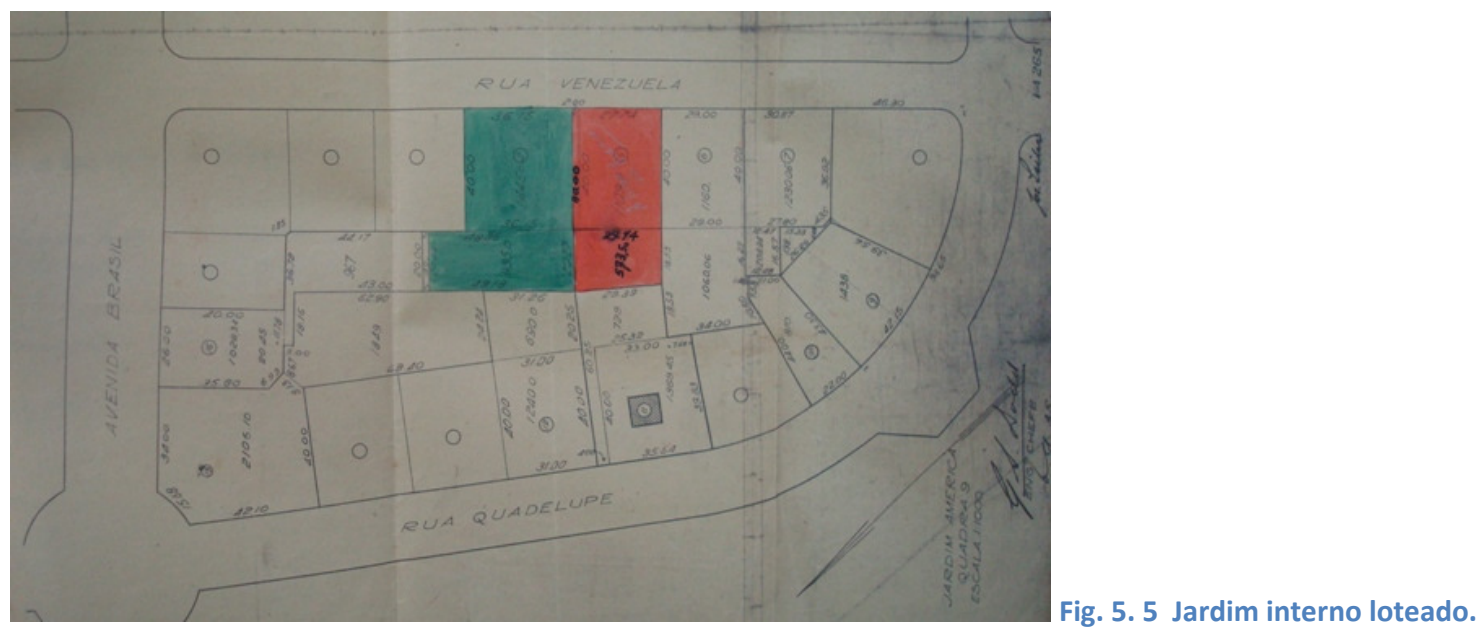


A partir do lançamento do Jardim América, para que a empresa obtivesse sucesso na venda dos terrenos de um loteamento situado em área sem grandes atrativos, com a situação econômica desfavorável em plena guerra, várias estratégias foram utilizadas. Publicou anúncios em vários órgãos de imprensa, em várias línguas, criou folhetos de propaganda e construiu casas em pontos estratégicos do bairro, a cargo de Barry Parker e de outros arquitetos contratados pela companhia, como Royden McLellan Harding - canadense -, W. Fillinger, George Saville Dodd e W.B.F. Williamson ingleses. Estes arquitetos eram também responsáveis pela análise dos projetos para a verificação do cumprimento dos regulamentos da companhia.

Foi muito bom que houvesse recursos financeiros disponíveis para a construção de casas quando cheguei a São Paulo, e assim pude projetar e ver construídas nove casas, Mr. Williamson, uma casa e Mr. Harding, duas outras. (...) permitiu-me 'dar uma pista' e uma demonstração visual do que eu pensava ser o tipo de casa que melhor cumpria os objetivos que se tinha em mente para aproveitar todas as oportunidades que o plano oferecia. (PARKER, 25/1/1919, p.10-11)

A casa de Williamson, apresentada no álbum "Jardim América", tem semelhanças com outros projetos do Arts and Crafts inglês, como as casas de Voysey, na volumetria movimentada, na composição da entrada - com um arco levando ao recesso onde se encontra a porta e a pequena abertura circular ao lado. De resto, as esquadrias são do tipo utilizado por Parker nos projetos brasileiros e as áreas sociais voltam-se para os fundos do terreno.

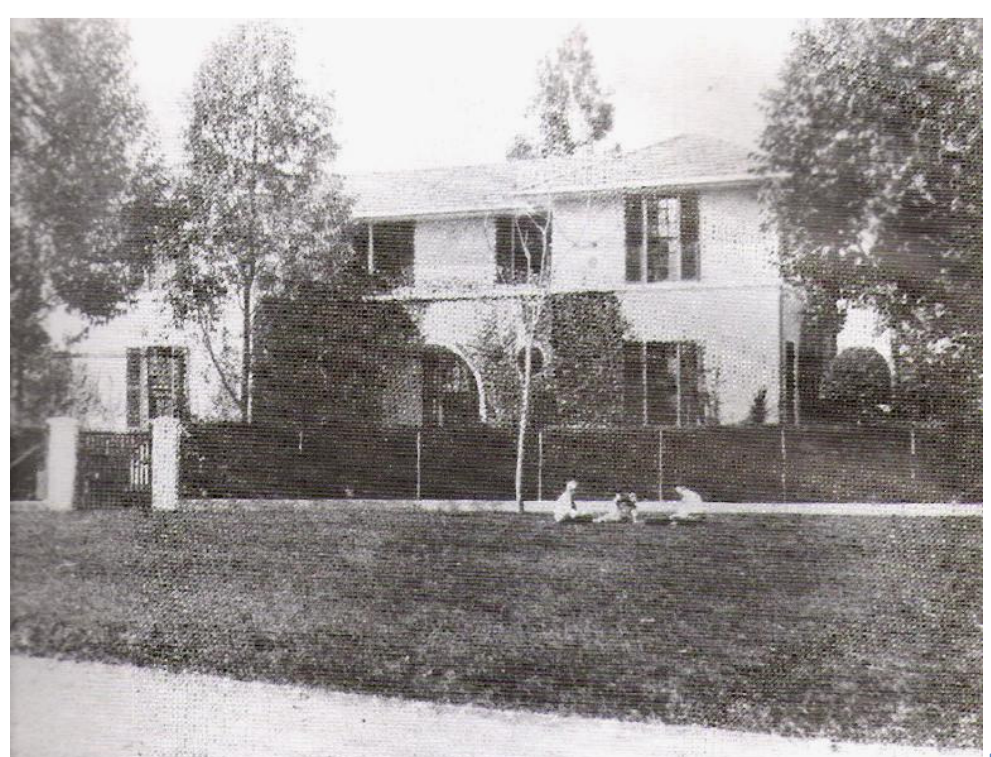

Fig. 5. 6 Casa de Williamson. 
Sobre o efeito causado por estas "casas da City", Parker diz ainda no relatório final: "Com certeza é verdade que a venda de tanta terra foi o resultado direto da construção de doze casas no loteamento (...)." (PARKER, 25/1/1919, p. 16)

As casas de Parker e destes outros arquitetos foram, com exceção da primeira de 1916, as únicas até 1920. A partir deste ano, identificam-se projetos de outros arquitetos, engenheiros e construtores.

Os anúncios dos loteamentos da Companhia City foram muitos e continuaram sendo publicados ao longo dos anos. Na revista Architectura e Construcções (agosto 1929, n.1), aparece um anúncio do Jardim América e Anhangabaú, enaltecendo as qualidades de ambos. A Avenida Nove de Julho estava sendo aberta e ainda tinha 0 nome provisório de Avenida Anhangabaú.

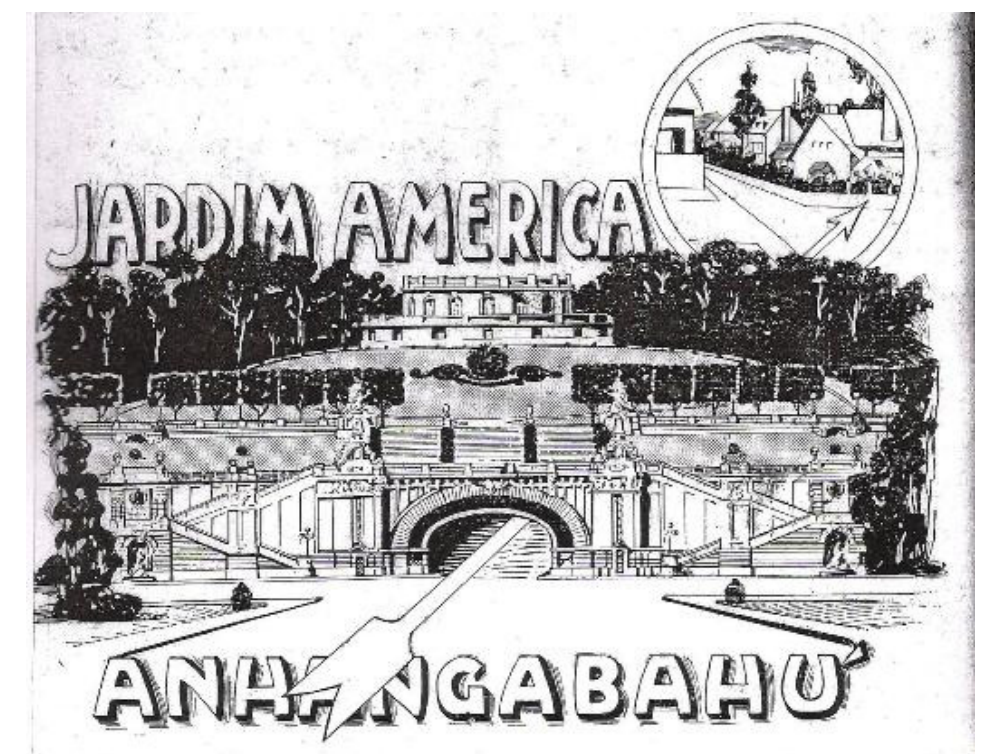

Duas esplendidas realidades

Duas opportunidades magnificas

Fig. 5. 7 Anúncio Companhia City.

No número 10 (maio 1930) da revista Architectura e Construcções, um anúncio do loteamento do Pacaembu, onde a Companhia City convida a visitar a casa mobiliada que teria sido construída no "pittoresco bairro do Pacaembu". Ao menos duas casas foram construídas pela City no Pacaembu como estratégia de vendas. Esta, na Rua Bragança, e outra na Rua Bahia, que aparece na Revista de Engenharia do Mackenzie (1928, n.40) 


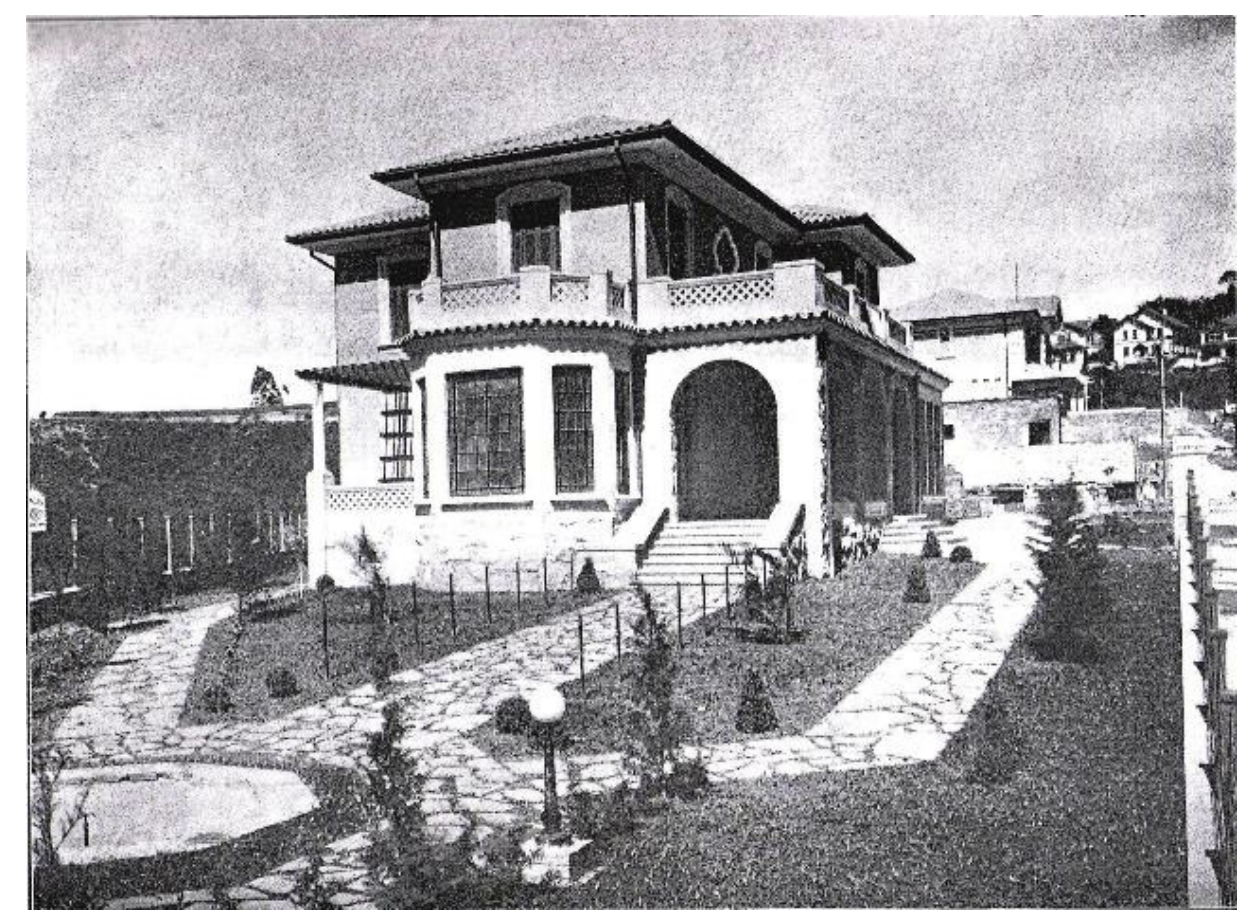

Fig. 5. 8 Casa da Companhia City no Pacaembu.

Ela tem algumas características do Neocolonial, como os grandes beirais, condutores e calhas aparentes, elementos vazados no guarda corpo e detalhes em pedra.

Sintomática da importância do Jardim América e dos demais loteamentos da City é a excursão que fazia parte das atividades do Primeiro Congresso de Habitação, que aconteceu em São Paulo entre 23 e 30 de Maio de 1931, organizado pelo Instituto de Engenharia. Tal excursão percorreu vários loteamentos residenciais realizados pela companhia, entre eles o Pacaembu, o Jardim América e o Alto da Lapa, com o próprio engenheiro chefe da Companhia, George S. Dodd, esclarecendo dúvidas sobre as obras.

Em anúncio da City na revista Architectura e Construcções (julho 1930, n.12) diz-se que, após o encerramento do IV Congresso Pan-Americano de Arquitetos, realizado no Rio de Janeiro, quase todos os congressistas teriam vindo a São Paulo em visita oficial. No programa da viagem, uma visita aos bairros do Jardim América e do Pacaembu. A notícia publicada na revista carioca Kosmos e reproduzida no anúncio da City, diz: "As cidades jardins da Companhia City de S. Paulo com o seu admirável Jardim América e o extraordinário Pacaembu são simplesmente maravilhosas." 


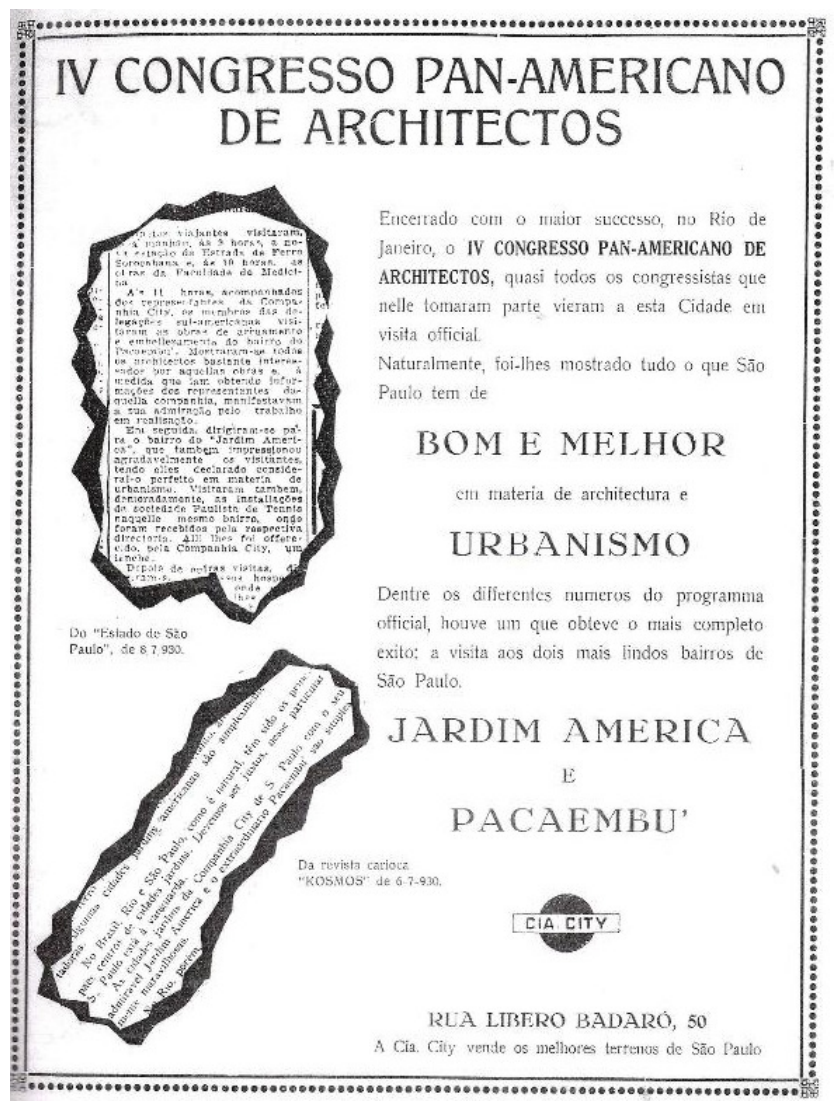

Fig. 5. 9 Anúncio da Companhia City.

Na revista Architectura no Brasil (junho-julho 1926, n. 29, p. 173-182), em um artigo intitulado "As recentes creações urbanas em São Paulo", o engenheiro civil Amadeu de Barros Saraiva, defende o zoneamento funcional, através da especialização dos bairros. Criticando o crescimento da cidade de São Paulo, o autor a compara a uma colcha de retalhos. Porém, na abertura dos novos bairros, uma nova mentalidade teria predominado, as idéias modernas de cidade-jardim "vulgarisadas depois da abertura do bairro-jardim América" teriam configurado um conjunto urbano que constituiria "um dos encantos de São Paulo" (p.177).

No artigo, é mencionada a impressionante valorização dos terrenos do Jardim América. O preço inicial de venda teria sido de $5 \$$ (cinco mil réis) o metro quadrado e, decorridos dez anos, o valor seria de $60 \$$ a $70 \$$ (sessenta a setenta mil réis). $O$ artigo descreve ainda o Jardim Europa (que não foi executado pela Companhia City), o Pacaembu, o Alto da Lapa. E segue o autor, pedindo mudanças na legislação para o "embellezamento gradual dos nossos núcleos urbanos".

Sobre a valorização dos terrenos do Jardim América, Parker já dissera em seu relatório final: "O preço de venda da terra no Jardim América praticamente dobrou enquanto estive em São Paulo (...) (PARKER, 25/1/1919, p. 14) 


\subsection{Barry Parker: as casas paulistanas}

O arquiteto permaneceu em São Paulo por dois anos, de fevereiro de 1917 a janeiro de 1919. Parker entendeu bem a política da Companhia City e a ela se ajustou, contribuindo para seu aprimoramento. Como ele diz no relatório final que escreve aos diretores da companhia, já de volta à Inglaterra.

(...) poderia olhar para trás e me sentir completamente satisfeito com meu trabalho. Ao analisar a satisfação que senti, descobri que foi, em grande parte, o resultado do fato de ter concordado com vocês, com seu diretor (Mr. Gurd) nas diretrizes pretendidas e propostas para os empreendimentos em suas propriedades. (PARKER, 25/1/1919, p. 2)

Sabia que os objetivos da companhia em São Paulo diferiam totalmente das propostas para Letchworth. Conseguiu, no entanto, em um loteamento para a burguesia, com grandes perspectivas de lucro para a companhia, desenvolver suas idéias sobre urbanismo e sobre a construção da paisagem. Desenhou e ajudou na concretização dos loteamentos do Jardim América, Anhangabaú, Pacaembu e Alto da Lapa. Isto envolveu diferentes projetos, adaptados a diferentes topografias, e sugestões de alterações na legislação municipal para que se tornasse factível seu plano para o Pacaembu. Atuou também para a prefeitura de São Paulo, na remodelação do Parque da Avenida Paulista, atual Parque Siqueira Campos.

Parker em seu primeiro relatório sobre o Pacaembu (PARKER, 1917), dirigido a Mr. Gurd, o diretor da Companhia City à época, deixa claro não abrir mão dos princípios aplicados em seus projetos ingleses. $\mathrm{Na}$ página 3, referindo-se ao traçado do Pacaembu, Parker diz que "as condições do sítio e as necessidades reais devem determinar o desenho".

Outro ponto discutido por ele neste relatório: “(...) deve ser feito, antes de tudo, um lugar agradável para se viver; não deve ser feito um local para impressionar o visitante com simetrias arquitetônicas". No Pacaembu, as casas teriam duas entradas e todas as fachadas seriam tratadas da mesma forma, sem "fundos", sem edículas, todos os cômodos, inclusive os de serviço, estariam contidos no mesmo volume. As garagens poderiam ser alojadas no espaço sob os terraços, para que não ocupassem mais área. O porão - a única palavra em português no texto - seria executado devido ao desnível no terreno. Ali se localizariam áreas de estar, além dos serviços. Parker, em seus projetos ingleses, colocava todos os ambientes sob o mesmo telhado, sem edículas de serviço e outros tipos de construção, que ele acreditava acabariam desfigurando as vistas e elevando o custo da construção. 
Para o Pacaembu, a criação de vistas, devido à topografia acidentada, também era mencionada. Estas vistas, somadas à arborização, seriam um convite às caminhadas pelas ruas do loteamento.

Parker procura, em suas casas de São Paulo, assimilar o modo de morar local, em uma perspectiva regionalista. Ele observa que "os hábitos e a vida da família brasileira são muito diferentes dos nossos; o projeto de uma casa brasileira é diferente" ${ }^{6}$. A esse "modo local" soma-se a tradição portuguesa que ele conhecera pouco antes, quando projetara o Centro Cívico do Porto: "restaurar e dar continuidade às velhas tradições portuguesas, sentindo que nelas repousam os melhores fundamentos sobre os quais construir um verdadeiro estilo brasileiro." (PARKER, 1920, p. 48 apud ANDRADE, 1998, p. 338).

Discurso muito parecido com o de Ricardo Severo, em defesa do Neocolonial. Não foi encontrada nenhuma referência a um encontro entre ambos, Parker e Severo, mas é muito provável que tenha acontecido. Ambos defendiam uma visão regionalista da arquitetura e o resgate de tradições passadas, mas incorporadas em novas maneiras de morar. No entanto, o olhar de Severo se voltava à cópia das formas existentes no passado, o que não acontecia a Parker e nem a outro praticante do Neocolonial Victor Dubugras. Este e o arquiteto inglês procuravam no passado a essência da arquitetura vernácula, assim, ela não se constituía em um peso a ser incorporado à arquitetura do presente, como tantas vezes ocorreu no Neocolonial.

Parker diz ainda:

(...) a idéia portuguesa é fazer uma casa o mais arejada possível. Em uma casa portuguesa a parede é freqüentemente reduzida ao mínimo absoluto ditado por exigências estruturais - isto é, as janelas são feitas tão numerosas e amplas quanto possível, assim, quando todas estão abertas, cada sala é, para fins práticos, um terraço (loggia). Entretanto, o terraço é, de fato, muito raro em Portugal. Na Itália, pelo contrário, ele comparece em quase todas as casas. A prática portuguesa parece a mais lógica, para ela é muito mais sensato construir uma sala a qual pode ser convertida em um terraço, do que dividir o espaço útil em dois, metade sala e a outra metade terraço, como fazem os italianos. (PARKER, 1920, p. 48 apud ANDRADE, 1998, p. 338)

\footnotetext{
${ }^{6}$ PARKER, Richard Barry Two years in Brazil. In: Garden cities and town planning. Vol. IX, $\mathrm{n}^{\circ} 8$, Agosto, $\mathrm{p}$. 143-151 apud ANDRADE, 1998, p. 337.
} 

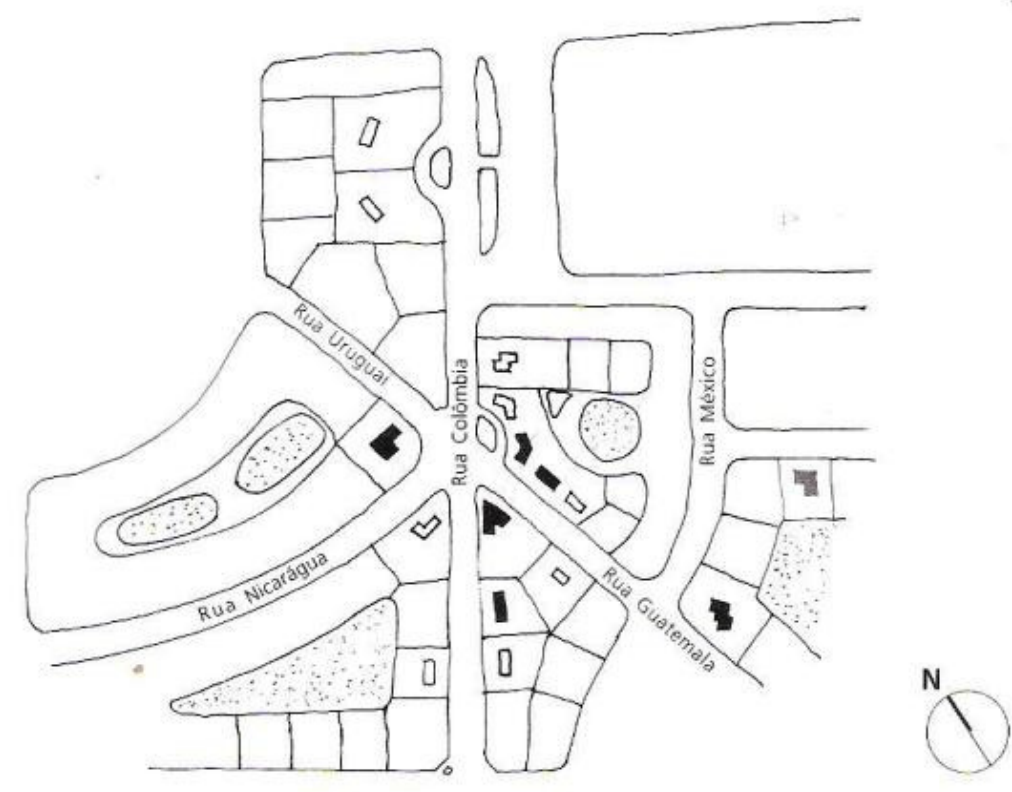

Fig. 5. 10 Localização das casas de Barry Parker no Jardim América.

Nas casas que fará no Jardim América, Parker tentará incorporar estas tradições portuguesas, inclusive as "salas-varandas", procurando inspiração no que ele acreditava serem as raízes de nossa arquitetura, assim como na Inglaterra o Arts and Crafts buscara resgatar a essência do Gótico.

Os projetos de Parker e Unwin eram um continuum, dos detalhes do mobiliário ao desenho das vias e praças. No Jardim América, desenho urbano e desenho arquitetônico mais uma vez dialogam, e são ambos racionais. Surgem do "nada". O sítio era plano e não havia topografia acidentada que forçasse as ruas a se adaptarem. Condição muito mais difícil para se iniciar um projeto do que as colinas do Pacaembu, onde o próprio local "dita" ao arquiteto o desenho.

No Jardim América, o traçado urbano era a única atração. Ele deveria seduzir.

Não havia desníveis, vistas dramáticas a serem aproveitadas ou vastas áreas de vegetação que guiassem o projeto. ${ }^{7}$ Havia grandes espaços planos, e este é talvez o mais difícil dos condicionantes.

\footnotetext{
${ }^{7}$ Como a área onde foi implantado o Jardim América era a várzea de inundação do Rio Pinheiros, a vegetação constituía-se de espécies hidrófilas, com muitas gramíneas. Trata-se de vegetação de porte baixo e estrutura bastante variável e sua característica é suportar inundações periódicas por estar situada nas baixadas que margeiam os rios.
} 
Como adaptar um projeto a um entorno que era quase uma "tabula rasa"? Como fazer com que a casa parecesse ter brotado da terra? Poderia haver um diálogo apenas entre as ruas e casas. Assim, as casas seguiriam os alinhamentos. Aquelas localizadas em meio de quadra tinham as maiores dimensões paralelas à rua, liberando o espaço dos fundos para o lazer.

"Como estas casas de duas frentes teriam fachadas frontais largas, com agenciamentos de serviço entre elas, assim, tais casas teriam suas maiores dimensões paralelas às ruas e aos jardins semi-públicos, e seus lados menores faceando as outras casas, o objetivo era aumentar a largura média dos lotes (...). (PARKER, 25/1/1919, p. 7-8) Este comentário de Parker deixa claro que o traçado das ruas, das casas e dos lotes foi pensado em conjunto. A idéia da unidade no desenho é aqui colocada em prática, cada uma das partes - casas, lotes, ruas, - deve "ceder" um tanto, para que haja harmonia no todo.

Este "diálogo" também seria utilizado no loteamento Alto da Lapa, onde certo número de casas tipo cottage para operários seriam planejadas antes da definição do sistema viário. Este procedimento levaria a definir-se "de modo articulado a arquitetura das casas e o traçado das vias" (ANDRADE, 1998, p. 276). Era uma característica da arquitetura de Barry Parker e de Raymond Unwin - o projeto articulava-se nas diversas escalas, do planejamento à arquitetura e ao design.

No Jardim América, talvez Parker tenha pensado em longas fachadas, interrompidas apenas por jardins.

Sobre este ponto, Parker já dissera, referindo-se a lotes de pouca largura resultando em casas estreitas, que: "O principal defeito das casas isoladas em filas em lotes comparativamente estreitos (...) é que as janelas laterais de cada casa olham diretamente para os lados das outras casas. (PARKER, 15/03/1919, p.6), ou ainda: “(...) favorecer a construcção de casas que poderão ter commodos com mais vista sobre as ruas e jardins e menos para a faixa de terreno necessariamente estreita entre as casas. Tal condição é, sob todo o ponto de vista, obviamente benéfica". (PARKER, $15 / 01 / 1919$, p. 2 , documento traduzido para o português). Aumentava a privacidade para os moradores das casas.

Ele procura valorizar não apenas a fachada frontal, mas manter certa equivalência com as demais. Ali, a idéia da casa com duas frentes seria executada: uma para a rua e outra para os jardins semi-públicos internos às quadras.

Meu maior temor para o futuro do Jardim América vinha da possibilidade de os proprietários quererem fazer um "show", para 
impressionar os que passam, como resultado, as casas dariam as costas aos jardins semi-públicos e estes seriam gradualmente rodeados por edículas - garagens, banheiros de empregados, lavanderias -, galinheiros, depósitos, lixeiras, etc. (...) A maneira de se evitar isto seria fazer cada casa com duas frentes, isto é, que cada casa tenha uma frente voltada para a rua e uma frente voltada para 0 jardim e localizar todos os agenciamentos de serviço entre as casas.(PARKER, 25/1/1919, p. 6-7)

As casas, principalmente aquelas localizadas no meio das quadras, apresentavam entradas laterais de serviço.

Eu gostaria de ter feito do Jardim América um subúrbio sem cercas, mas eu descobri que a opinião pública no Brasil não estava pronta para isto, tendo sido o preconceito muito forte para mim. (PARKER, 25/1/1919, p.13-4).

Parker dispõe janelas em várias paredes de um mesmo cômodo, em várias direções, para se desfrutar as vistas e transformá-lo em uma varanda: grandes aberturas verticais com venezianas e vidros recortados. Além deste tipo de janelas, Parker utiliza as bay windows, de seu repertório inglês. E para receber o sol, que na Inglaterra é tão precioso.

Parker dizia, como já foi assinalado no primeiro capítulo desta dissertação (p. 87), que "somando-se à procura intuitiva pela simetria, existe um instinto por uniformidade, onde é lógica e natural."

(...) Entre todos os avisos que daria ao projetista de pequenas casas, viria um, contra o esforço consciente de se fazer algo pinturesco. Deixemos o exterior ser o resultado e a expressão de um arranjo interno bem estudado. (...) talvez os mais importantes fatores para o sucesso ou fracasso artístico no desenho de pequenas casas seja a relação entre sólidos e vazios, entre o espaço das janelas e o das paredes e na proporção e distribuição destes. (PARKER, 1986, p. 42)

Os exteriores das casas inglesas de Parker são normalmente muito simples, despretensiosos, até desapontadores, mas escondem interiores bastante interessantes.

Ainda como foi dito no primeiro capítulo desta dissertação (p.87), "Parker se interessava pelo uso da simetria nos edifícios", não a simetria clássica, mas antes uma conciliação de ambas as linguagens, clássica e pinturesca, como Voysey fizera antes. Isto pode ser observado nas casas do Jardim América, com fachadas aparentemente simétricas, tornadas assimétricas por uma janela a mais em um dos lados da fachada 
principal. Ou nas plantas borboleta, que olhadas de frente são composições simétricas, mas de outro ângulo parecem ter certa variedade. Como na casa da Rua México, esquina com a Rua Guatemala, em que ele se utiliza deste tipo de planta, mas agora em uma casa térrea.

As casas de São Paulo foram feitas para serem vendidas e, segundo Parker, "todas as que foram postas à venda, foram vendidas em poucas semanas, com bons lucros e, de fato, uma por quase o dobro do que custou." (PARKER, 25/1/1919, p.11)

Ainda na Inglaterra, Parker escrevera: “(...) Os problemas que se apresentam ao projetista de casas construídas para serem alugadas ou vendidas são bem diferentes. Isto é, não se deve atribuir-Ihes individualidade, mas apresentar um exterior totalmente discreto. (...) A ajuda de uma simetria natural é mais do que nunca bem vinda para ajudar ao projetista". (PARKER, 1986) Este é o caso das casas paulistanas.

"Os melhores edifícios sempre parecem ter tido uma concepção completa. Sua planta e suas elevações parecerem inseparáveis (...)." (PARKER, 1986, p. 44).

Nas casas do Jardim América, a racionalidade da planta é a mesma das elevações. Racionalidade observada, por exemplo, nas áreas de circulação e nos banheiros. Os corredores são reduzidos ao mínimo. Para Parker, o correto planejamento destes espaços era muito importante. Deveriam ser evitados, na medida do possível, e sua área incorporada aos cômodos. Os banheiros destas casas paulistanas são pequenos, se comparados aos das casas projetadas aqui por outros arquitetos, e sempre retangulares, o que torna mais fácil a distribuição das várias peças.

Os banheiros e dormitórios dos empregados têm dimensões próximas às dos demais, o que também não se fazia aqui à época.

A ventilação cruzada deveria ser considerada através do posicionamento das aberturas, previstas também para iluminar o espaço onde as pessoas iriam ler, conversar, desenhar, comer. O sol deveria penetrar a casa pelas várias aberturas.

As casas paulistanas térreas, de meio de quadra, são resolvidas de maneira mais próxima a dos cottages que ele fazia na Inglaterra, geralmente a partir de um retângulo.

Estas casas têm as salas de jantar e de visitas integradas. A área de serviço reduzida ao mínimo e localizada no corpo principal da casa. A janela dos dormitórios de empregados - com a mesma dimensão das demais - voltada para a fachada frontal ou lateral. 
Outra característica muito presente nestas plantas era o acesso principal protegido por pequeno recesso na fachada, conduzindo quase em linha reta, perpendicular ao eixo da rua, à varanda dos fundos, quando esta existia.

Uma das casas térreas é a da Rua Guatemala, nomeada por Andrade (1998, fig.4.06) como Casa Gurd I, pequena, com o formato de um retângulo. As dimensões aproximadas são $17.50 \mathrm{~m} \times 9.00 \mathrm{~m}$, resultando em área de $157,50 \mathrm{~m}^{2}$. Área próxima à das casas térreas projetadas por alguns arquitetos brasileiros no Jardim América e pouco superior à área mínima exigida $-130 \mathrm{~m}^{2}$.

O espaço é totalmente aproveitado. Parker prevê dois dormitórios, um grande banheiro (ao contrário das outras casas), área social com estar e jantar integrados, com uma lareira. Um pequeno hall de distribuição interna também dá acesso à varanda - chamada de loggia. A planta é bem resolvida, as paredes seguem alguns eixos estruturais, apesar de o espaço interno haver sido um tanto sacrificado pela distribuição uniforme das esquadrias na fachada principal. Existem alguns recuos nas paredes para o encaixe de armários e outros móveis.

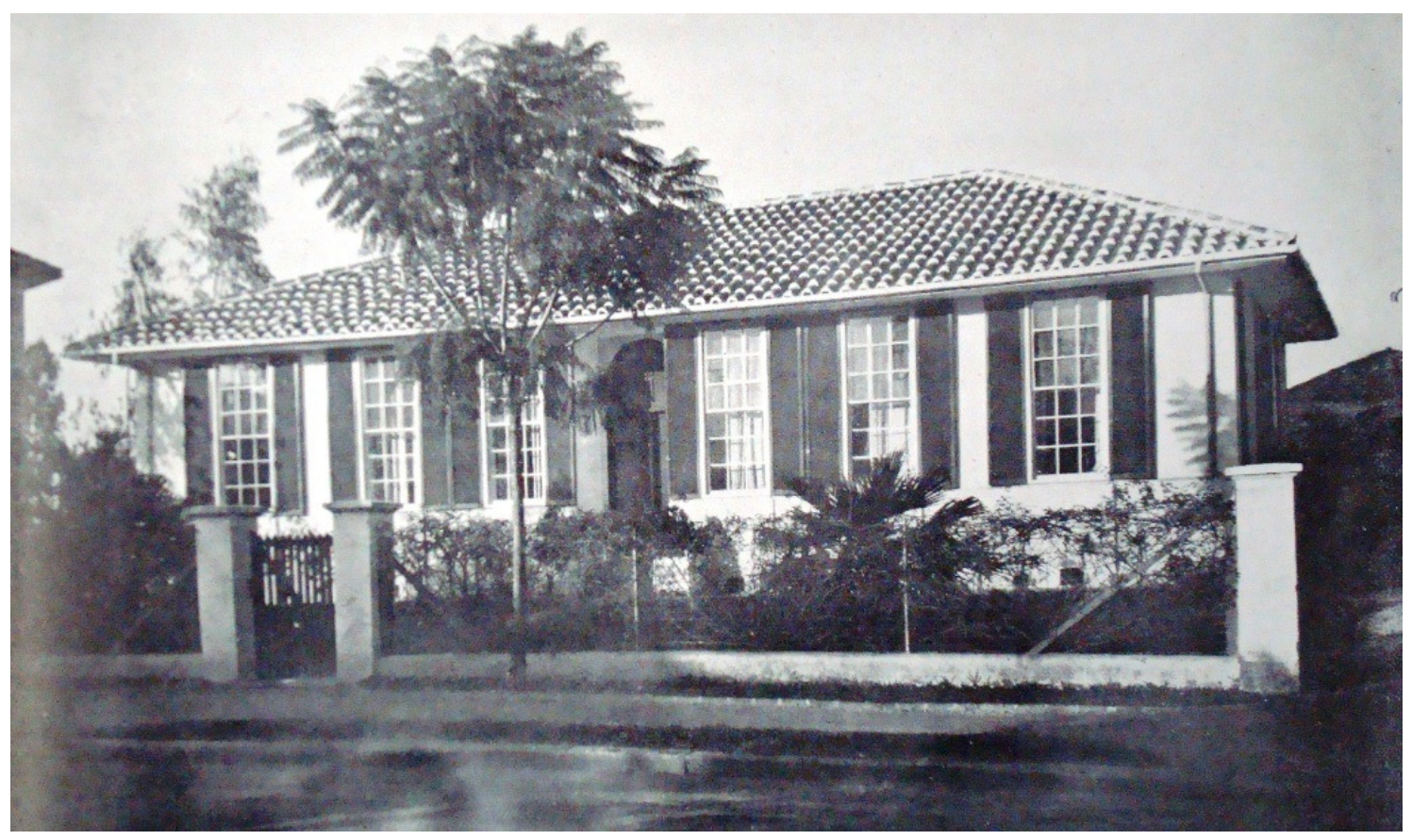

Fig. 5. 11 e Fig. 5. 12 Casa Gurd I. 


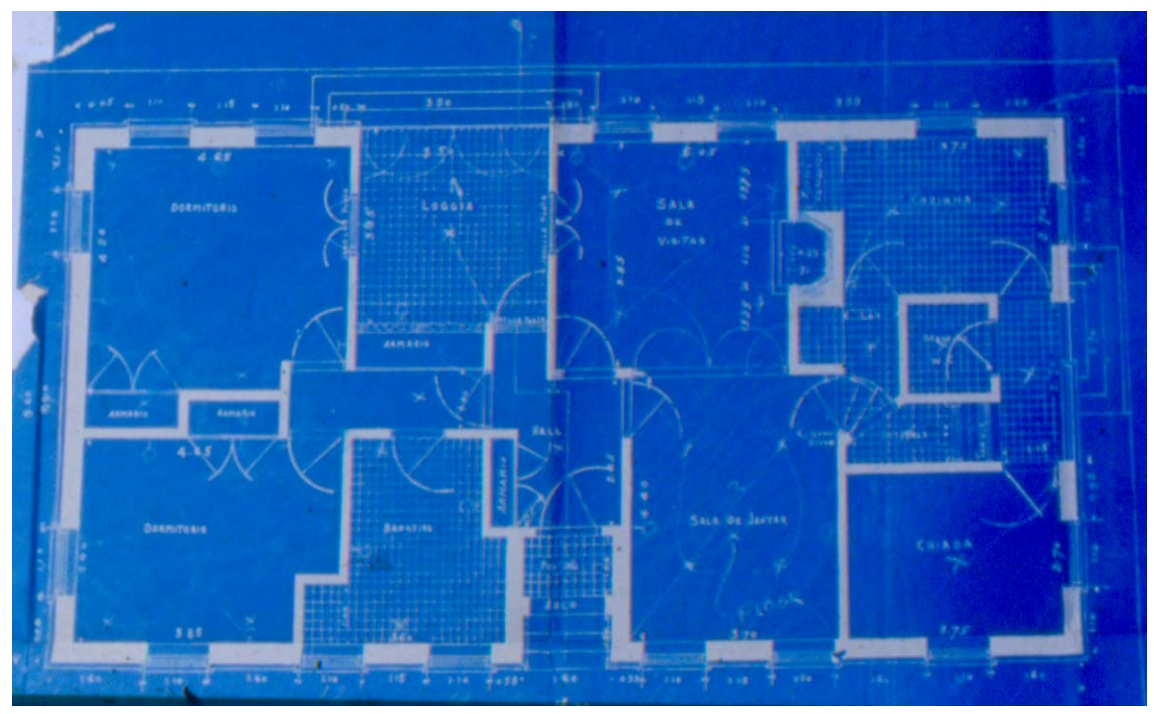

Outra casa térrea é a da Rua Colômbia, chamada por Andrade (1998, fig. 4.10) de Casa Castro. A planta é similar à da casa anterior. Apenas o espaço ocupado pela varanda aqui se torna um escritório. Não existe acesso para os fundos da casa a partir do setor social, pois ela se encontra em uma quadra sem jardins internos. O recesso da porta de entrada torna-se aqui uma pequena varanda com colunas.

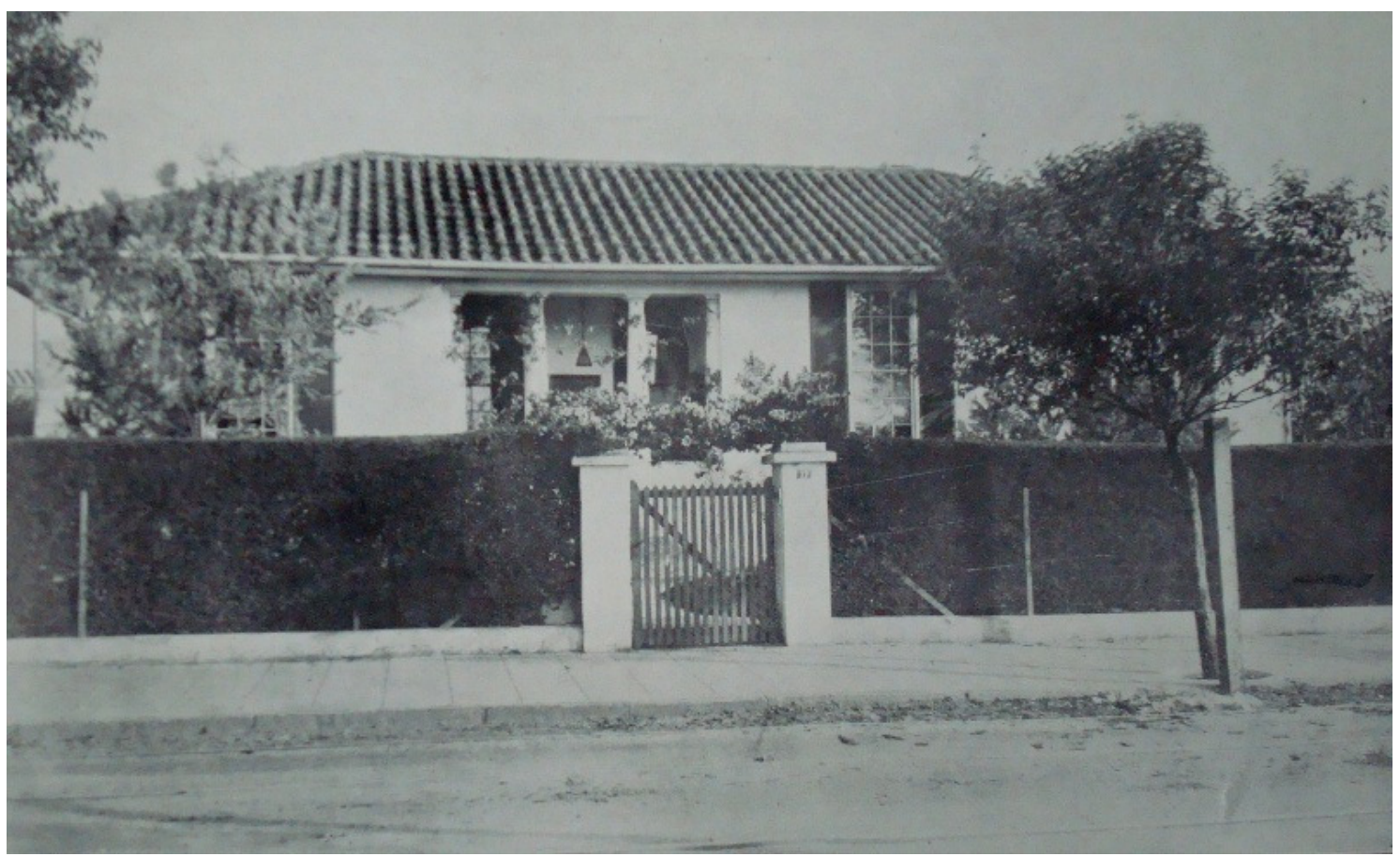

Fig. 5. 13 Casa Castro 


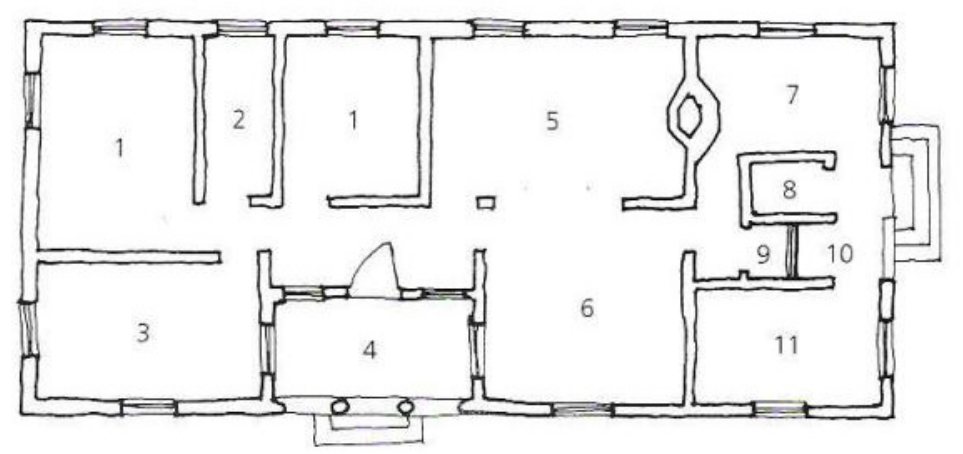

Pavimento Térreo

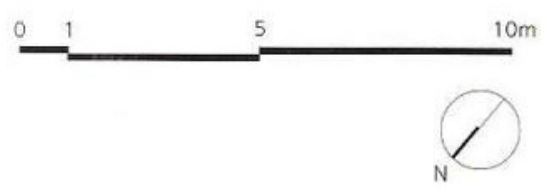

1. Dormitório, 2. Banheiro, 3. Escritório, 4. Terraço, 5. Sala de Visitas, 6. Sala de Jantar,

7. Cozinha, 8. W. C., 9. Despensa, 10. Tanque, 11. Quarto de Empregada.

Fig. 5. 14 Casa Castro, planta baixa

A casa de Charles Miller na Rua México, esquina com Rua Guatemala, com dois pavimentos, seria um dos "palacetes" mencionados no álbum Jardim América. Nestes sobrados, Parker desenvolve plantas com os três setores independentes e o vestíbulo faz a articulação.

A casa tem um hall com pé direito duplo e no pavimento superior, uma bela galeria, como nas melhores casas do Arts and Crafts. Uma clarabóia ilumina ambos. O terraço no pavimento superior quebra a simetria exterior. Também externamente, detalhes como frisos próximos às janelas e embasamento em pedra.

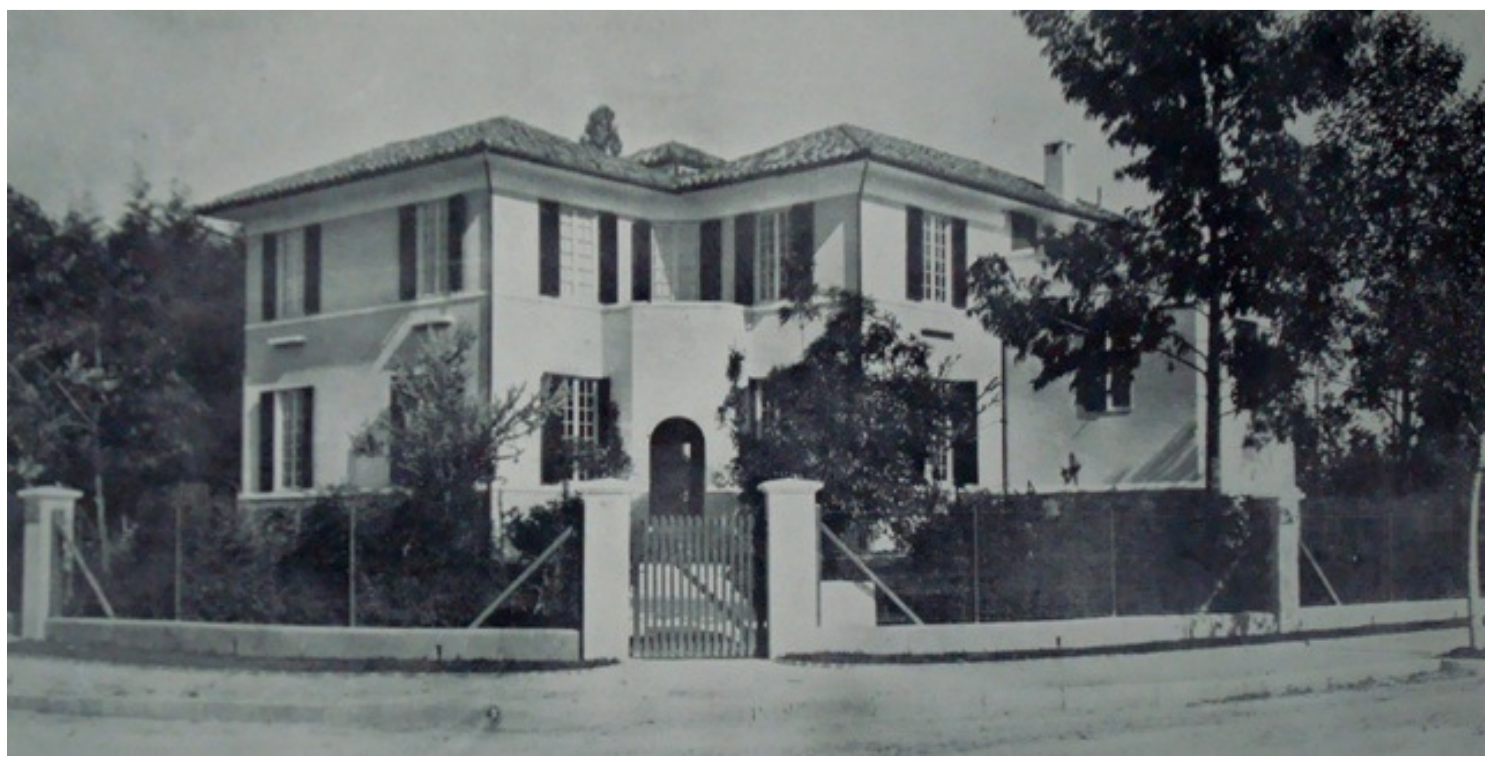

Fig. 5. 15 Casa Miller. 


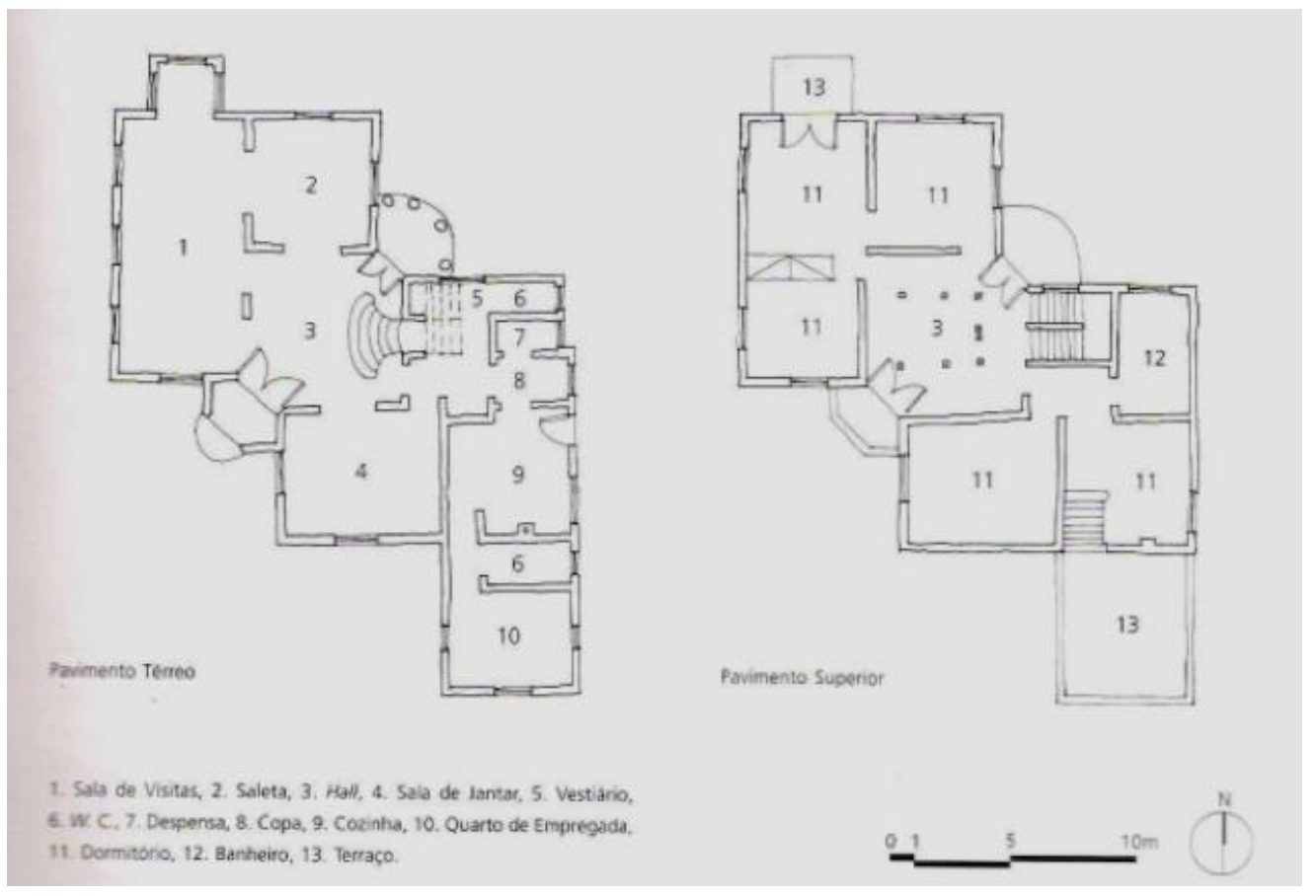

Fig. 5. 16 Casa Miller, plantas baixas.
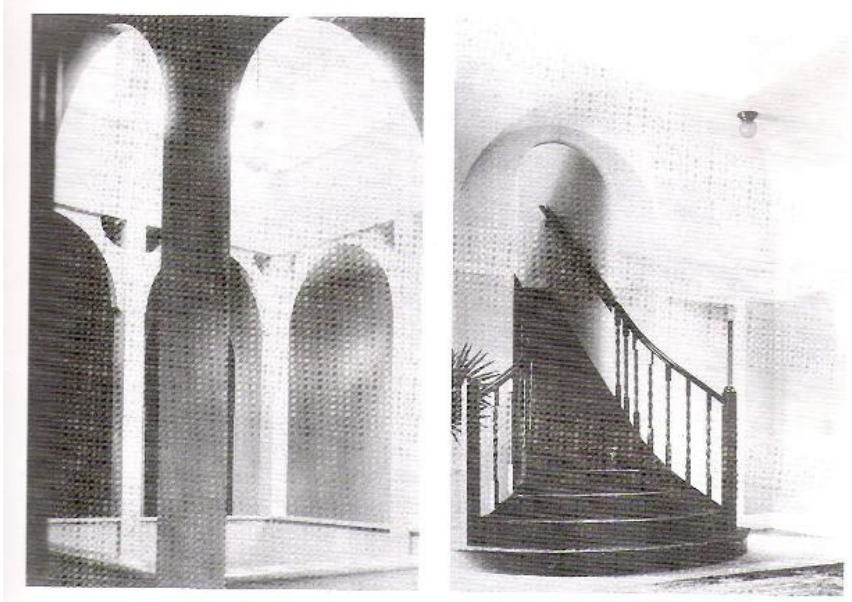

Fig. 5. 17 Casa Miller, clarabóia e escada.

Na casa da Rua México, Parker parece livre ao desenvolver a planimetria, mas não chega a explorar bem as possibilidades, pois o setor íntimo está dividido entre as duas alas da casa. As salas de jantar e visitas constituem um espaço único, porém sua utilização é prejudicada pela sua forma e pelas portas de acesso. O que parece ser o espaço de uma bay window não está bem resolvido. Em linha reta vai-se da entrada principal ao terraço e ao jardim, solução utilizada por ele nas outras casas paulistanas situadas em quadras que possuem jardins internos, mas também em um projeto inglês para Letchworth. 


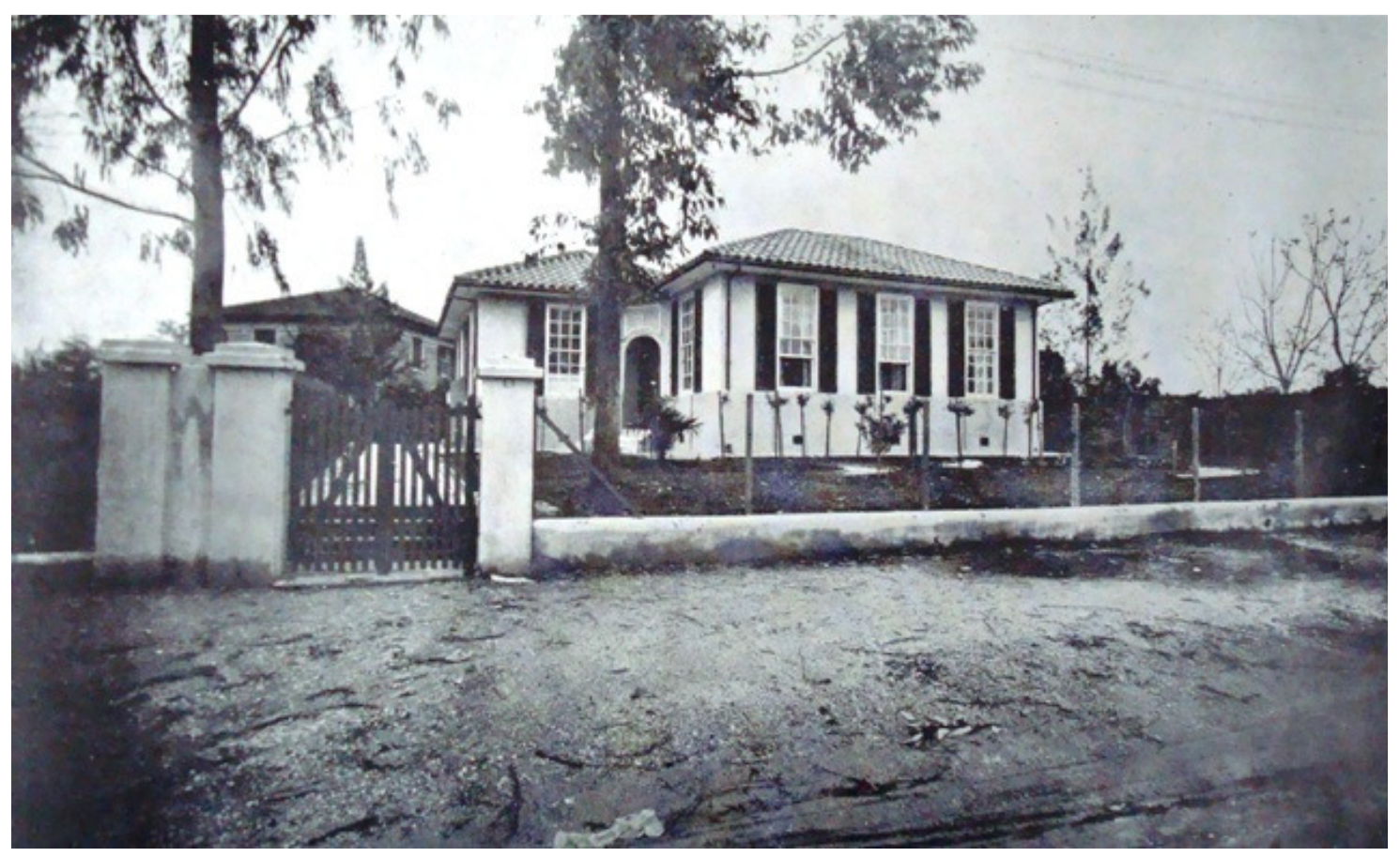

Fig. 5. 17 Casa na Rua México.

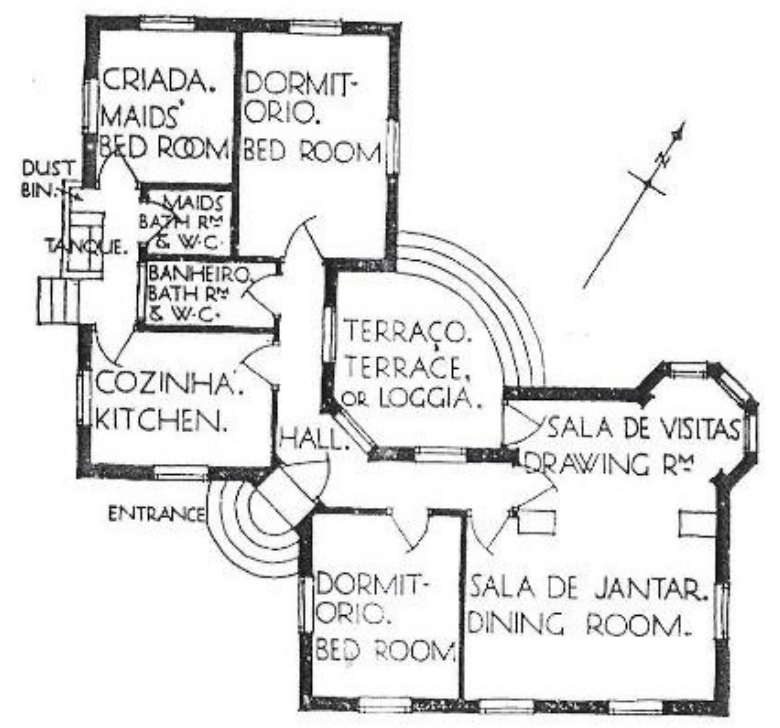

Fig. 5. 18 Casa na Rua México, planta baixa

Outra casa com planta borboleta é o sobrado denominado Casa Gurd II por Andrade (1998, fig. 4.25). O desenho desta casa e das outras situadas no circus ${ }^{8}$ articulam-se ao desenho das ruas. A planta do pavimento superior é resolvida com os dormitórios voltados aos jardins internos e um grande terraço no cruzamento das duas alas. No

\footnotetext{
${ }^{8}$ O circus é o espaço circular onde se cruzam as ruas Nicarágua, Colômbia, Uruguai e Guatemala.
} 
primeiro pavimento, a área social é mais compartimentada que a das casas térreas, como no palacete burguês paulistano.

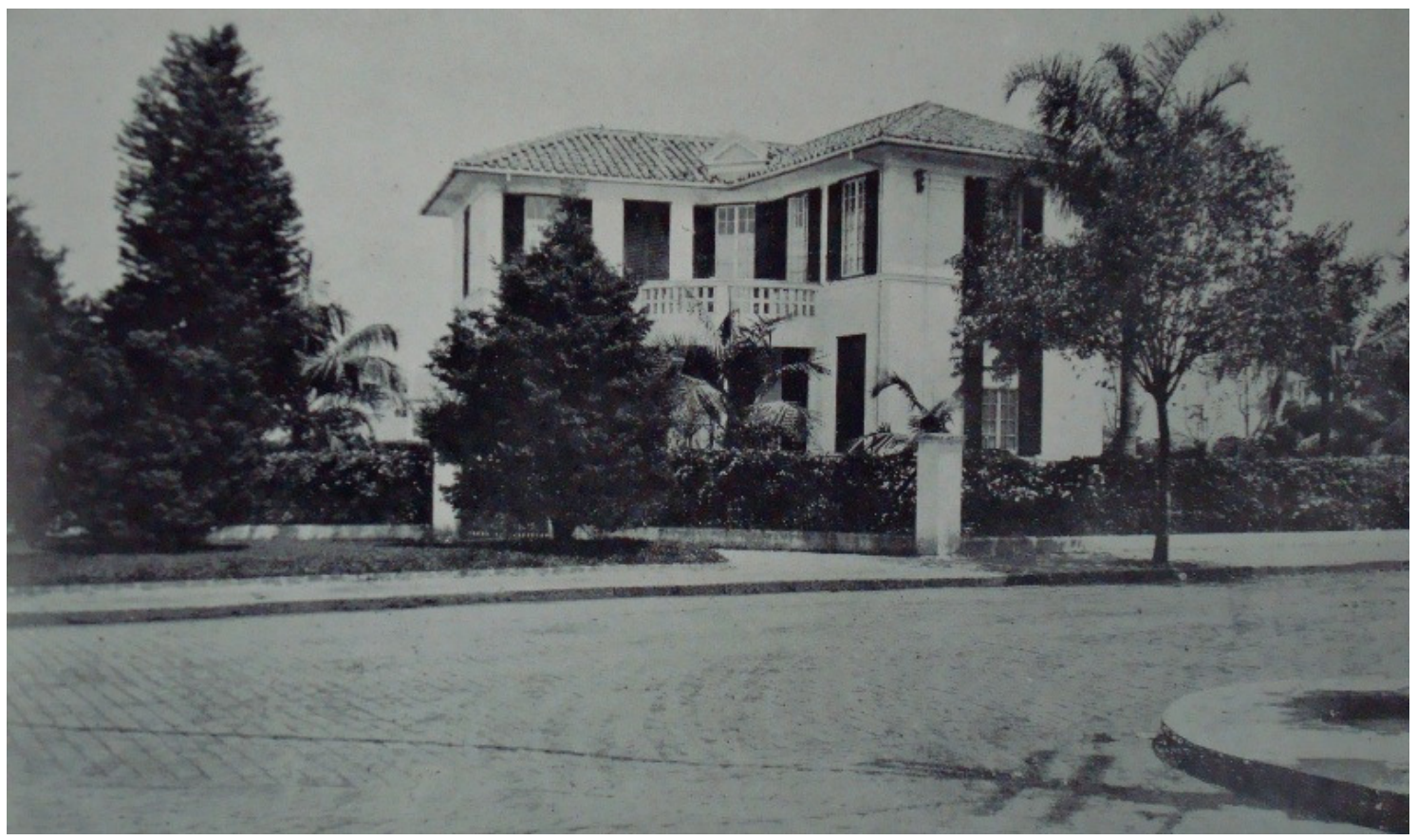

Fig. 5. 2019 Casa Gurd II.
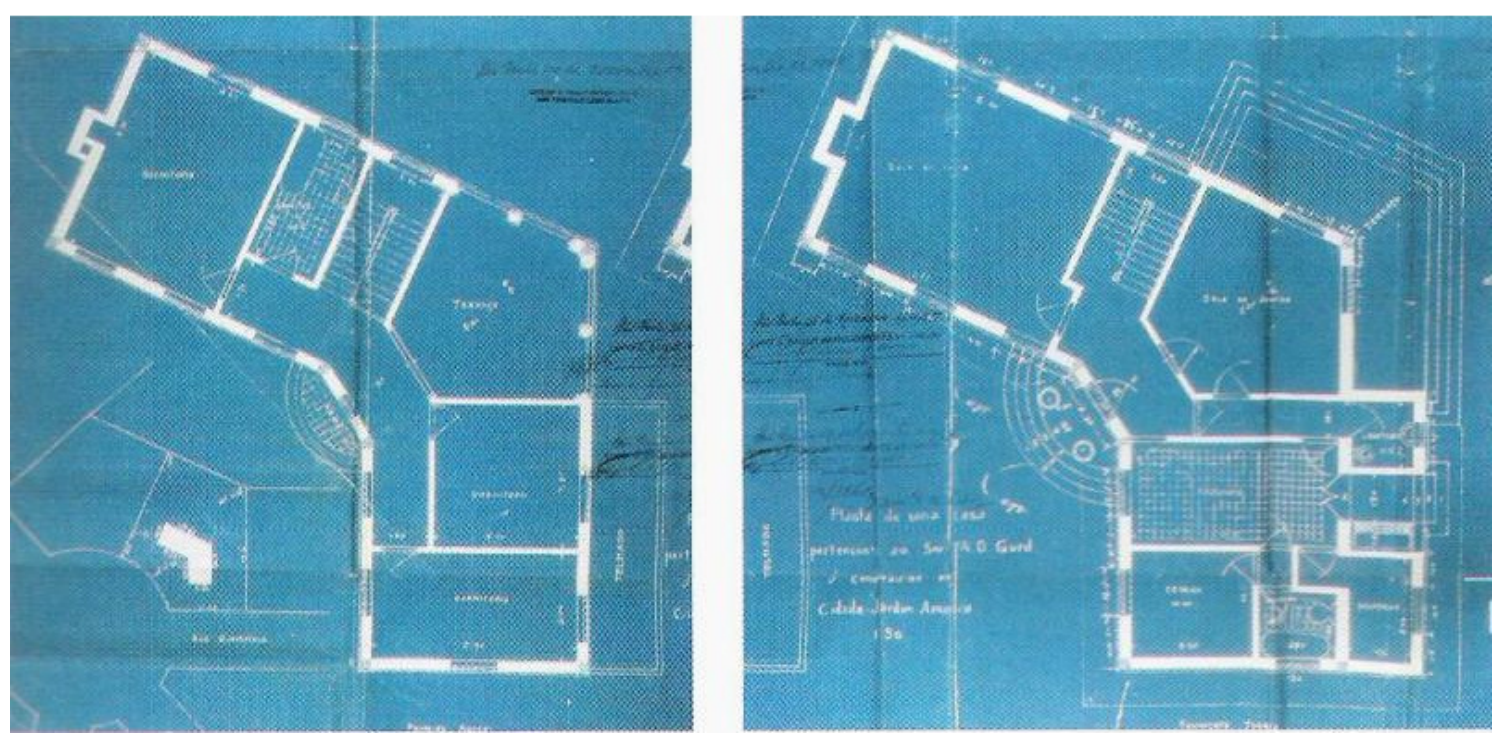

Fig. 5. 20 Casa Gurd II.

Outra residência localizada no circus é aquela da esquina da Rua Colômbia com a Rua Uruguai, que apresenta no pavimento térreo uma loggia, com as colunas características. Localiza-se em outra quadra que possui jardim interno. 


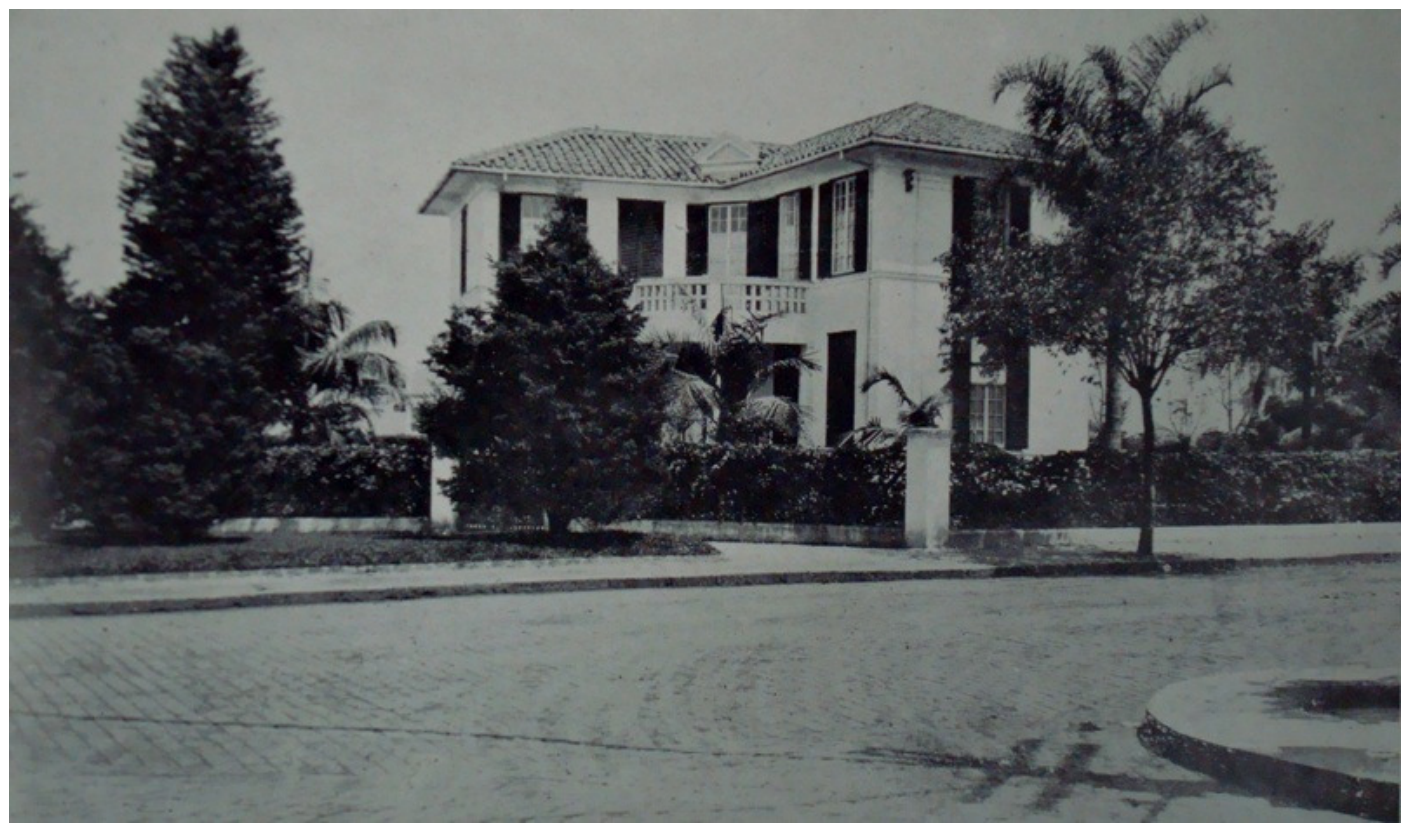

Fig.5.22 Casa da Rua Colômbia com Rua Uruguai

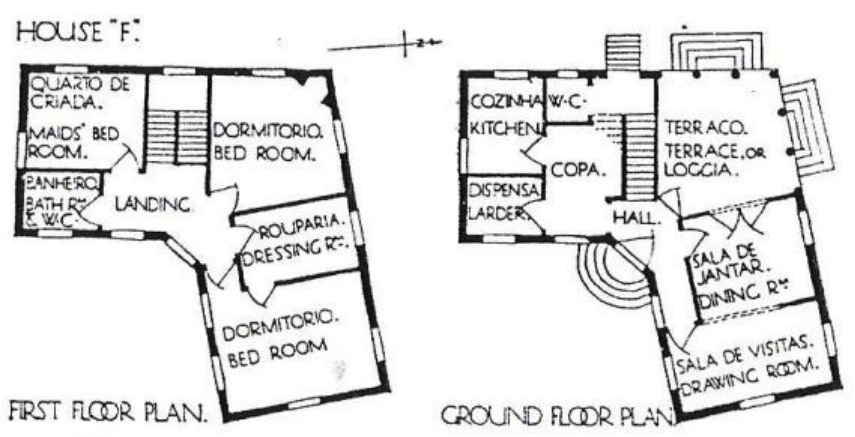

HOLSE AT IARDIM M.MERICA, SAS PAULL, BRAZIL. BARRY PARKER, F.R.I.B.A., ARCHITECT.

Fig.5.23 Casa da Rua Colômbia com Rua Uruguai, plantas baixas.

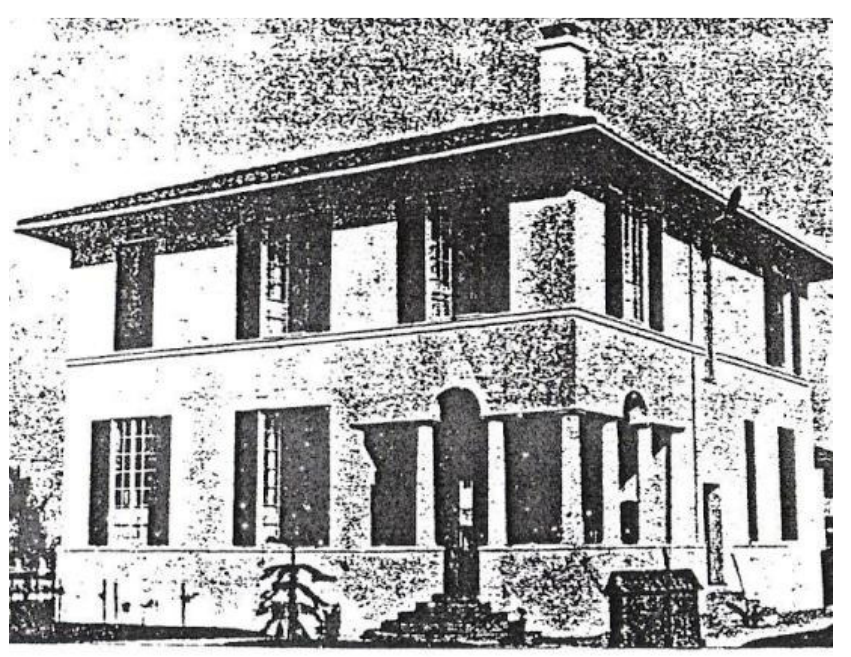

Fig.5.24 Casa da Rua Colômbia com Rua Uruguai, vista posterior. 
E também no circus, a casa Von Puttkammer, localizada em um lote triangular, seguindo seus contornos. Externamente, é talvez a mais expressiva das casas de Parker no Jardim América. Como nos outros sobrados do arquiteto, a preocupação com o aspecto construtivo está presente no fato de todas as paredes do andar superior coincidirem com as do térreo. Parker consegue resolver este aspecto sem, no entanto, prejudicar a divisão interna.
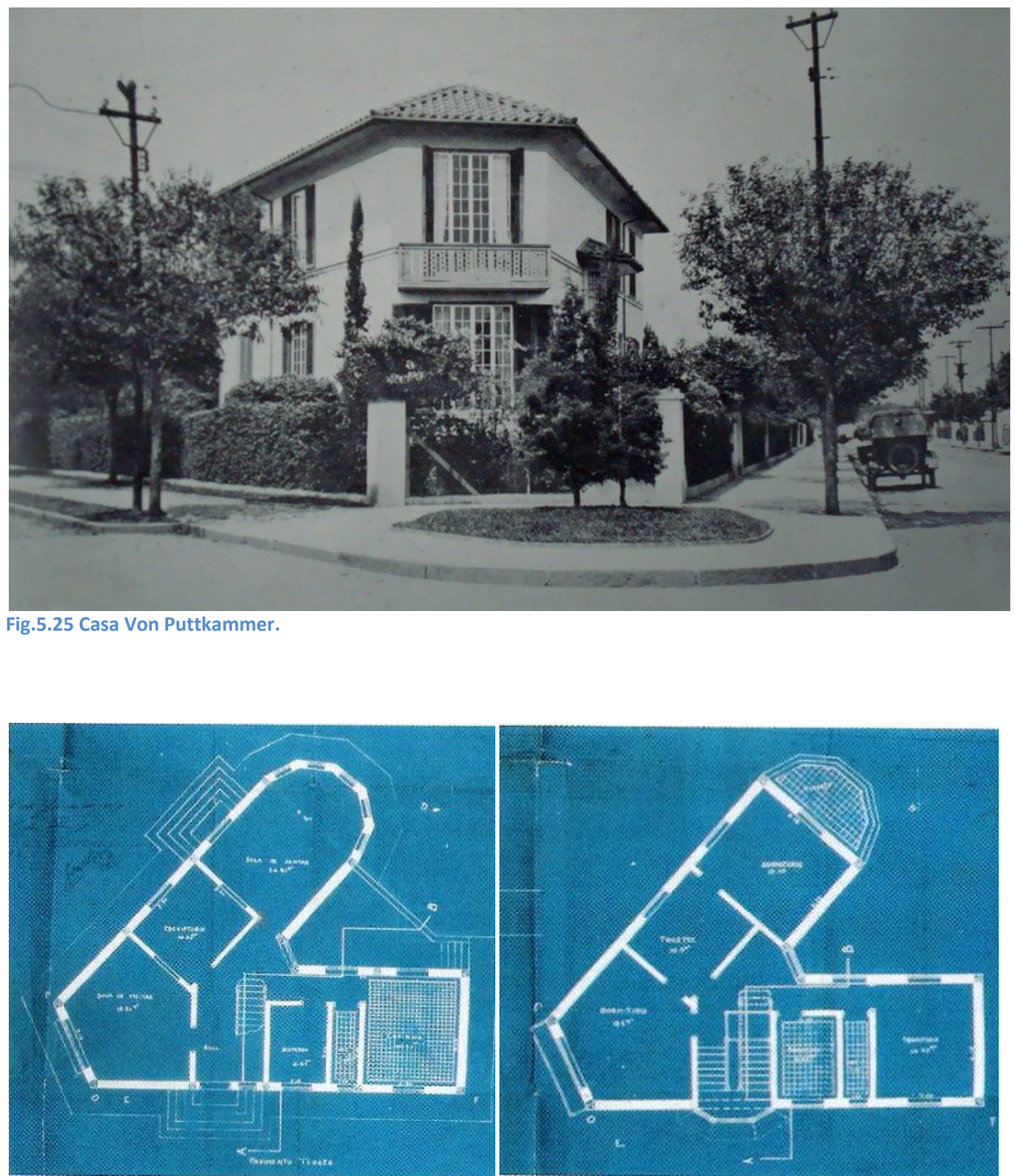

Fig.5.26 Casa Von Puttkammer, plantas baixas. 
E a casa situada na esquina da Rua Colômbia com Avenida Brasil, da qual não foi localizado o projeto. Segue o mesmo arranjo dos sobrados localizados no circus. Destacam-se o grande terraço, localizado entre as duas alas da casa, e o embasamento em pedra.

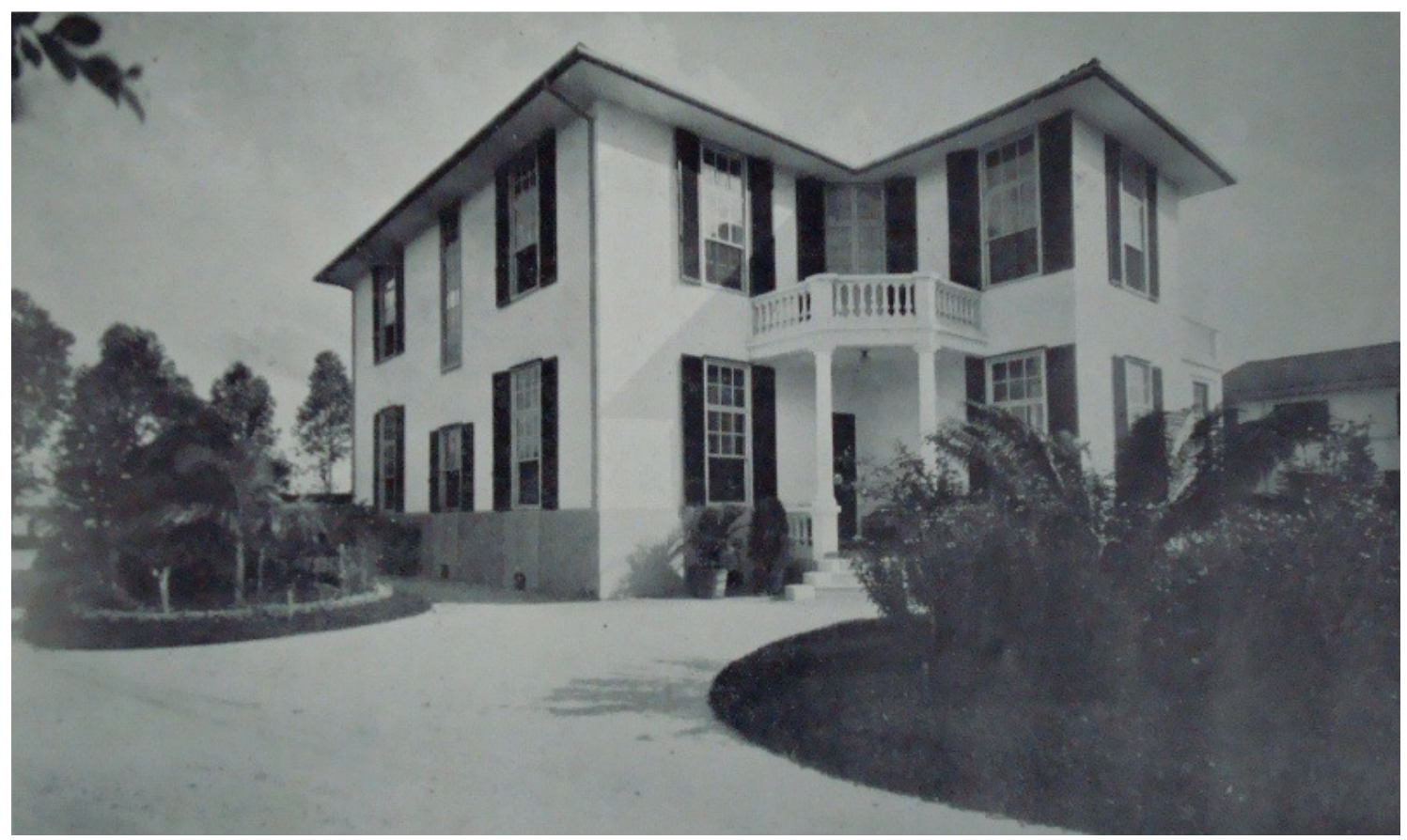

Fig.5.27 Casa na Rua Colômbia com Avenida Brasil

A Casa Manuel (ANDRADE, 1998, fig.4.13) é um sobrado localizado em meio de quadra, na Rua Salvador, com formato em L. Localizado na Rua Salvador, Parker aproveita as melhores vistas, a partir da casa, em direção aos jardins internos e localiza as salas de jantar e de visitas. No pavimento superior, não é tão feliz na localização dos dormitórios. Aproveita o centro da planta para a colocação dos serviços e da escada.

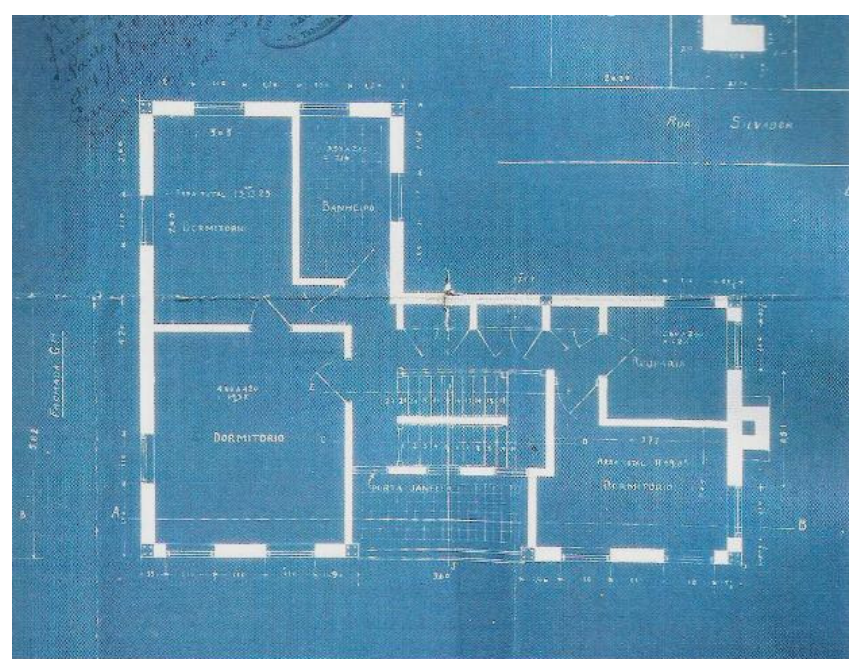


Fig.5.28-a e Fig.5.28-b Casa Manuel, plantas baixas.
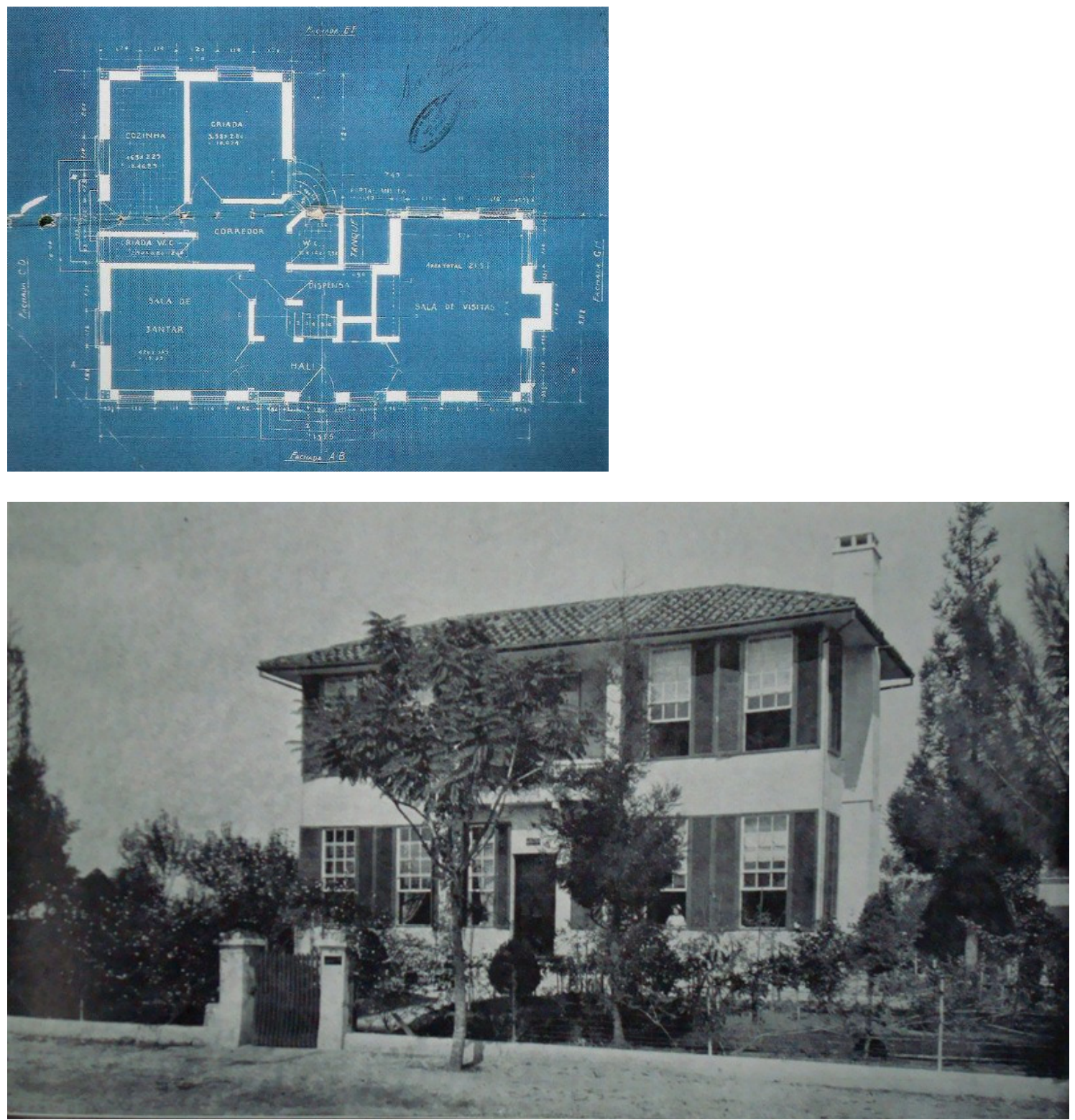

Fig.5.29 Casa Manuel.

Não era muito comum, em São Paulo à época, a utilização dos fundos dos lotes para jardins voltados ao lazer. Esta área ainda era vista como local para hortas, pomares, criações e dependências de serviço. Entre as exceções, alguns projetos de Victor Dubugras. Somente a partir da década de 1930, tal prática aparecerá de forma mais constante.

Várias residências projetadas por Parker localizavam-se nas esquinas do circus. É uma das poucas áreas do bairro que aparecem com ruas asfaltadas, jardins e calçadas no álbum Jardim América. Era a "porta de entrada" para o bairro. Esta região e seu entorno foram primeiro ocupados. 
Estas casas do circus são as mais interessantes, surpreendentes, dramáticas, seguindo o velho modelo da butterfly plant, tantas vezes utilizado pelos arquitetos do Arts and Crafts, dando boas vindas aos que chegam ao novo bairro.

\subsection{Neocolonial}

Certo sentimento de integração americana, o pan-americanismo da época, está presente até mesmo na denominação do bairro, "Jardim América", e nos nomes das ruas: Colômbia, México, Cuba. Deste contexto, de integração entre os países americanos, faz parte o movimento Neocolonial. Um conjunto de movimentos semelhantes acontece nas Américas, nas primeiras décadas do século $X X$, com discursos regionalistas - um espírito de revalorização da cultura e do passado locais, em cada país. Contrapunham-se às características de internacionalismo do modo de vida urbano e industrial. As antigas formas da arquitetura colonial serviriam de inspiração para a arquitetura do presente, mas atendendo a novos programas, novos modos de vida, através das novas tecnologias da construção.

O lançamento do Neocolonial deu-se em São Paulo. A conferência de Ricardo Severo na Sociedade de Cultura Artística aconteceu em 1914. Sua residência "Numa de Oliveira", uma das primeiras casas do movimento, localizada na Avenida Paulista, foi construída entre 1916 e 1917. Tudo acontece ao mesmo tempo em que o Jardim América é lançado. Muitos eventos próximos no tempo e no espaço.

Em outra conferência, de $1916^{9}$, Severo cita o projeto de Barry Parker, para a reforma do Centro Cívico do Porto, como um dos exemplos contemporâneos da "prova de como pode fazer-se a arte tradicional, modernizando-a na sua aplicação à civilização da atualidade". O arquiteto inglês colocara em seu relatório sobre o projeto alguns conceitos que poderiam ser considerados, segundo Severo, "dogmas tradicionalistas do urbanismo moderno". Parker teria sido capaz de construir um "tipo ultramoderno de centro cívico na mais completa harmonia com o meio tradicional do velho burgo portuense"

Em busca das raízes da arquitetura brasileira, que serviria de modelo para os exemplares do novo estilo, Ricardo Severo contratou os serviços de José Wasth Rodrigues para fazer um levantamento das edificações da arquitetura colonial

\footnotetext{
${ }^{9}$ SEVERO, Ricardo A Arte Tradicional no Brasil. Revista do Brasil. São Paulo, ano II, vol.4 , jan.-abr.1917 apud SILVA, 2005, p.138
} 
brasileira, principalmente de seus ornamentos e demais elementos constitutivos, pensando na elaboração de um Dicionário da Arte e da Arquitetura Colonial do Brasil, obra nunca publicada. Rodrigues a publicaria, décadas depois, sob o nome de Documentário Arquitetônico Relativo à Antiga Construção Civil no Brasil.

Outra busca de nosso passado foi patrocinada por José Marianno Filho ${ }^{10}$ : as viagens de estudos da arquitetura tradicional do Brasil em 1924, da qual fizeram parte Lúcio Costa, Nestor Egydio de Figueiredo e Nereo Sampaio.

José Marianno defendia a tese de que os estilos provenientes de outros países enfraqueceram a expressão da "raça brasileira".

Teve presença constante na imprensa, polemizando e defendendo a causa da "arquitetura tradicional brasileira".

Tão grave é a causa das arquiteturas raciais dos povos americanos deante dos perigos de desnacionalização dos estilos sem pátria, que a tese considerada de maior importância do IV Congresso PanAmericano de Arquitetos aqui reunida em 1930 versava sobre "A orientação espiritual da arquitetura americana (continental)". De sua discussão resultou a seguinte indicação: "que cada nação americana procure viver dentro da respectiva tradição nacional arquitetônica". (MARIANNO FILHO, 1943, p. 12)

José Marianno falara na sessão de encerramento do Primeiro Congresso de Habitação que se realizara em São Paulo em 1931. Sobre o problema arquitetônico nacional, ele diz que "a chave do problema está na mão do sociólogo. Fenômeno geográfico por excelência, a arquitetura é, em sua essência, uma expressão de meio." (MARIANO FILHO, 1943, p. 58)

Falando sobre hibridações arquitetônicas, ele diz que: "Houve até quem se lembrasse de casar o estilo gótico com o marajoara. Incapazes de apreender o sentido da arquitetura viviam esses cidadãos a escarafunchar as revistas americanas em busca de inspiração." (MARIANO FILHO, 1943, p. 101)

\footnotetext{
10 José Marianno Filho é considerado o mecenas da "Arquitetura Neocolonial Brasileira". No entanto, ele abominava tal denominação, preferia "arquitetura tradicional brasileira". Pernambucano que residiu no Rio de janeiro desde cedo, onde se formou em medicina, mas nunca chegou a clinicar. Conviveu com poetas, escritores e artistas do Rio de Janeiro e, entre outras atividades, tornou-se crítico de artes e de arquitetura. Foi também diretor da escola Nacional de Belas Artes entre 1926 e 1927.
} 
Marianno cita o arquiteto português Raul Lino, que teria se referido com desprezo à arquitetura brasileira de fundo tradicional. (MARIANO FILHO, 1943, p. 32).

Raul Lino constituiu-se em um divulgador dos princípios do Arts and Crafts em Portugal, com seu "Movimento da Casa Portuguesa".

Este movimento também procurava a individualização da casa, através do respeito à maneira de viver do morador. O papel do lar como abrigo dos perigos do mundo exterior está perfeitamente em sintonia tanto com o movimento Arts and Crafts quanto com a arquitetura da época no Brasil, como foi visto freqüentemente na análise da revista $A$ Casa no capítulo anterior.

Aparece, inclusive, um artigo assinado por Raul Lino em A Casa (n.7, nov. 1924, p.1011), em que o arquiteto diz que não se pode conceber o aspecto externo de uma casa antes de se ter uma planta bem estudada e definitiva, que, por sua vez, depende de sua localização - do terreno -, além dos gostos e do modo de viver do proprietário. $A$ questão das condições climáticas e da paisagem a ser desfrutada - isto na localização das aberturas - também deveria ser considerada. $O$ aspecto técnico também deveria ser considerado. E, finalmente, ele levanta a questão da "casa de estar", onde se reuniria a família e se receberiam os amigos. Assim, deveria ser o centro da moradia, o local para "recrear-se com occupações espirituaes". As mesmas concepções em relação a moradia que se encontram no movimento inglês e também no Brasil nos anos 1920.

Raul Lino, segundo Paulo Santos, esteve no Brasil nos anos 1930, quando conheceu Ricardo Severo. (SILVA, 2005, p. 159).

Maria Lúcia Bressan Pinheiro (2006, p.5), referindo-se ao Neocolonial e a Ricardo Severo, diz que “(...) transferia para solo brasileiro o programa nacionalista do movimento denominado 'Casa Portuguesa', que, por sua vez, tinha suas raízes na tendência regionalista inglesa conhecida como Arts \& Crafts, que muito contribuiu para o surgimento da arquitetura moderna, no início do século XX".

A propósito das aproximações Neocolonial - "Movimento Casa Portuguesa"- Arts and Crafts, assunto ainda por investigar melhor, cabe aqui repetir uma citação de Voysey, ao lado dos discursos de Ricardo Severo e José Marianno:

Por que (...) deveria a Inglaterra virar as costas a seu próprio território e fingir que nasceu tão híbrida que não pode ter uma verdadeira arquitetura nacional? Ela não tem um clima nacional? As suas condições geológicas e geográficas são as mesmas de todos os outros países? Não há diferenças entre homens ingleses e homens 
italianos? (...) Por que, então, nós tentamos insistentemente imitar os modos estrangeiros? (VOYSEY, 1911, p.60 apud DAVEY, 1995, p.97)

\subsection{Além de Barry Parker, as "outras arquiteturas do Jardim América".}

$\mathrm{Na}$ arquitetura, o Art Nouveau já morrera. Construtores licenciados faziam modestas moradias enfeitadinhas (...). Procura-se restaurar, sem sucesso, o estilo colonial mal imitado. (...) Há casas mexicanas desambientadas, um ou outro edifício oriental como o do Pátio do Colégio onde está a Secretaria da Agricultura, e algumas residências sírias na Avenida Paulista. Mas interessantes eram agora as residências "bungalow" com "bow windows" e confortáveis mobílias "chippendale", cômodas poltronas de couro, tapetes grossos, paredes e tetos lisos, um quadro e uns pratos na parede. $\mathrm{Na}$ arquitetura sobressaíam-se Dubugras, Przyrembel, Warschawski, Ademar de Morais, Dácio de Morais. O francês Le Corbusier escandaliza, nas suas conferências, trazendo teorias e idéias novas sobre arquitetura e urbanismo. Vai surgir a nova arquitetura brasileira, autonomisada do barroco, embora influenciada pelos modelos coloniais. (AMERICANO, Oscar Panorama Lítero-Artístico-Cultural. In: AMERICANO, Oscar São Paulo Nesse Tempo, s.d.) ${ }^{11}$

Agora em dezembro de 1935, acabei de construir a casa térrea em que vou morar na Rua Ceará. O terreno comprado da Companhia City saiu à base de 100 mil réis o metro quadrado, e a construção a 500 mil réis o metro quadrado. O operário percebeu entre 20 a 25 mil réis por dia. (...) Ali por 1929 o presidente Washington Luís comprou por 200 contos uma casa em frente ao Clube Atlético Paulistano, no Jardim América, para morar quando deixar o Govêrno da República. (AMERICANO, Preços de Imóveis e Construções (1935). In: op. cit.)

A crônica de Oscar Americano traça um panorama interessante da arquitetura paulistana dos anos 1920, sua indefinição, com casas de inspiração colonial, missioneiras e outros tipos de influência; e os bangalôs - cuja importância é ressaltada - com suas janelas e mobília de inspiração inglesa. Outra menção interessante em

\footnotetext{
${ }^{11}$ Crônica sem data, mas como Americano fala do centenário da Independência e em seu livro, logo após, aparece uma crônica sobre a Semana de Arte Moderna, provavelmente é de 1922.
} 
sua crônica é à nova noção de conforto - discutida no capítulo 4 -, representada pelas "cômodas poltronas de couro", pelos tapetes grossos e por uma decoração mais simples, mas mais elaborada.

Quanto ao quadro de profissionais, Americano fala dos arquitetos mais conhecidos um deles, Adhemar de Moraes, totalmente ignorado pela historiografia - mas menciona também a atuação dos construtores licenciados. Estes profissionais não diplomados podiam obter licença para trabalho provando sua experiência profissional, e na época sua atuação era muito significativa. ${ }^{12}$

Americano anuncia ainda a "nova" arquitetura tradicional brasileira.

$\mathrm{Na}$ segunda crônica, Americano conta que vai morar em um loteamento da Companhia City- o Pacaembu - e que o ex-presidente Washington Luís escolhera para morar, após sua saída do governo, o bairro do Jardim América.

Washington Luís comprou a casa em 1929, ainda segundo Americano, uma fase em que as residências maiores passam a predominar, pois a ocupação do bairro se alterou quanto ao perfil das residências, a partir provavelmente da metade da década de 1920.

As arquiteturas do Jardim América ${ }^{13}$ são muitas, se considerarmos seu aspecto externo, mas se outro aspecto for levado em consideração, elas constituem uma unidade: são uma nova forma de morar - moderna -, da qual o bangalô foi um dos modelos e os subúrbios, o cenário. Um novo estilo de vida assimilado pela classe média.

Casas simplificadas. Bangalôs ou sobrados bem iluminados, por várias janelas, abertos aos jardins sempre presentes, pois houve uma libertação dos limites do terreno.

Os sobrados ainda eram chamados de palacetes, mas menores e mais simples em relação àqueles das elites paulistanas, que ainda se localizavam na Avenida Paulista.

Porque este não era um bairro da elite, ao menos em seus primeiros tempos. A classe média encontrou ali seu recanto, financiado pela própria Companhia City. O cenário perfeito para o "lar", para o cultivo de uma nova domesticidade. Conforto e beleza, para viver um novo tipo de vida.

\footnotetext{
${ }^{12}$ Este assunto foi tratado no capítulo 3.

${ }^{13}$ Esta parte da pesquisa, sobre a arquitetura do Jardim América, tornou-se possível graças às pesquisas anteriores de Andrade e Wolff. Foram cruzadas informações entre o álbum Jardim América - do qual existe um exemplar na Biblioteca da Câmara de São Paulo - e os projetos encontrados nos arquivos da Companhia City - localizados através dos códigos que estão no livro de Wolff.
} 
Inúmeros álbuns de bangalôs, vendidos nas livrarias, e as revistas auxiliavam as futuras moradoras a escolher a casa ideal, para a família, agora muito menor. E os arquitetos deveriam atender as exigências dos clientes.

A sala de estar, ligada por um arco à sala de jantar, substitui a antiga e enclausurada sala de visitas. E nos dias quentes, a varanda atua também como ambiente de estar. O próprio jardim tem equipamentos para favorecer a permanência, constituindo-se em outro ambiente para a família se reunir. $\mathrm{Na}$ copa, são feitas as refeições mais informais, que predominam. Talvez esta nova configuração, com espaços para a reunião da família, tenha feito destas, casas "mais alegres" e cheias de vida.

Estas casas menores tornaram-se possíveis porque várias atividades começaram a ser executadas fora da casa, como o pão e a preparação de outros tipos de alimentos. Começa a ser utilizado o fogão a gás, e, no final da década, a geladeira. Com a diminuição do número de empregados domésticos, são necessárias casas menores e mais simples de serem mantidas.

\subsection{Os arquitetos do Jardim América}

Como foi dito no capítulo 3, no final dos anos 1920, havia em São Paulo dois grupos de arquitetos diplomados, com atuação política: o da Divisão de Arquitetura do Instituto de Engenharia, liderado por Alexandre Albuquerque e formado predominantemente por politécnicos, e aquele do IPA (Instituto Paulista de Arquitetos), de composição mais heterogênea, com grande número de egressos do Mackenzie e sob orientação de Stockler das Neves.

Entre os temas em discussão na época, o do predomínio dos politécnicos em determinadas áreas do mercado de trabalho. Comparando-se os engenheirosarquitetos da Politécnica e os do Mackenzie, os politécnicos obtinham as obras de vulto, públicas ou privadas, e os cargos públicos, estando sempre em maior evidência que os mackenzistas

Analisando-se a relação de projetos executados por oriundos da Politécnica no Jardim America, em Wolff (2000, p.278-282), encontraram-se 18 formandos da Politécnica ${ }^{14}$, tanto do curso de engenheiro-arquiteto quanto do curso de engenheiro civil. Destes, 13

\footnotetext{
${ }^{14}$ Considera-se aqui a equipe como autor único.
} 
fizeram apenas 1 projeto; 3 fizeram 2 projetos; 1 fez 5 projetos e 1 fez 7 projetos, em um total de 31 projetos.

Quanto aos mackenzistas ${ }^{15}$, 10 autorias de projetos, mas em um total de 51 projetos. Alguns com vários projetos, até nove. Deve ser ressaltado que a pesquisa de Wolff refere-se ao período que vai do início do Jardim América até a década de 1940.

Em nossa pesquisa, cujo universo é bem menor, tanto quanto ao período quanto à amostragem, percebemos que houve um predomínio de profissionais ligados ao Mackenzie, tanto de formandos, quanto de profissionais com algum tipo de relação com a Universidade, sobre a qual tenha sido encontrada alguma indicação, nem sempre explicitada.

A escolha dos arquitetos para análise foi feita com base no álbum Jardim America. A escolha recaiu sobre arquitetos, com certo número de projetos, que nos pareceram mais representativos da arquitetura ali praticada. Também foram levadas em consideração outras informações sobre estes profissionais, que mostravam sua importância no cenário da arquitetura paulistana dos anos 1920. Não se pensou em analisar profissionais ligados a determinada escola, Mackenzie ou Politécnica.

E acabamos por escolher seis arquitetos: Adhemar de Moraes, apesar de não haver sido obtida informação sobre a formação do arquiteto, sabe-se que ele era ligado à Universidade Mackenzie; Renato Aguiar, Olavo Caiuby e Alfredo Ernesto Becker eram egressos do Mackenzie - Caiuby foi, inclusive, presidente do Instituto Paulista de Arquitetos em 1933 -; Dácio Aguiar de Moraes, que se formou em Stuttgart, mas era próximo a Christiano das Neves, diretor do curso de engenheiro-arquiteto do Mackenzie, juntos polemizaram sobre a arquitetura moderna e defenderam os valores da arquitetura tradicional apoiados por José Mariano Filho; e, por último, Álvaro Carlos de Arruda Botelho, do qual não se sabe a formação.

Alguns, como Adhemar de Moraes e Olavo Caiuby, com vários projetos.

Encontraram-se alguns projetos de autoria de egressos da Politécnica, mas que não apareciam no álbum Jardim América - publicado em 1923. Destes profissionais da Politécnica, talvez os mais importantes sejam Augusto de Toledo, cujo único projeto é posterior à publicação do álbum, e Mário Whately que aparece no álbum com um projeto, atribuído a Victor Dubugras.

Acho que, desta forma, pode-se concluir que houve um predomínio dos arquitetos formados ou ligados ao Mackenzie, ao menos no início da ocupação do Jardim

${ }^{15}$ Wolff considera apenas aqueles formados no curso de arquitetura. 
América. Acreditamos que, com as obras mais significativas e os cargos públicos nas mãos dos politécnicos, os mackenzistas souberam reconhecer e explorar este novo mercado que surgia - a arquitetura de classe média, no caso, do Jardim América. A atividade profissional envolvia o projeto e a construção, pois como já foi dito no capítulo 3 o projeto não tinha valor de venda, estando vinculado à execução da obra.

Mesmo se considerarmos a ocupação do Jardim América até a década de 1940, como fez Wolff, apesar da presença de um maior número de profissionais formados na Politécnica, o fato de cada um deles ter executado poucos projetos mostra que, provavelmente, trabalhar para esta nova clientela de classe média constituía uma atividade esporádica dentro do seu universo profissional, ao contrário dos egressos do Mackenzie, onde a atuação neste mercado representava uma percentagem maior do trabalho.

Já era uma atuação profissional consolidada, que logicamente não se alteraria, mesmo após o significativo engajamento de engenheiros e arquitetos, tanto do IPA quanto do Instituto de Engenharia, na Revolução de 1932. Após a revolução, houve certa união da classe, inclusive com a incorporação dos mackenzistas ao Instituto de Engenharia $^{16}$ e o progressivo desaparecimento do IPA. Esta categoria profissional mais unida, em São Paulo, possibilitou um avanço na luta pela regulamentação profissional a nível federal.

A seguir descreve-se a atuação profissional dos arquitetos escolhidos.

\subsubsection{Adhemar Queiroz de Moraes}

Não foram encontradas informações sobre a formação profissional de Adhemar de Moraes; assinava seus projetos como engenheiro-construtor. Consta como sócio do Instituto de Engenharia (Revista do Instituto de Engenharia, 1926, n. 31). Porém este fato não significa que ele tivesse formação acadêmica, pois havia sócios que não eram diplomados, como Victor Dubugras.

Wolff (2001, p. 278) menciona que ele teria participado do Primeiro Congresso de Habitação realizado em São Paulo em 1931.

\footnotetext{
${ }^{16}$ Assunto já tratado no capítulo 3.
} 
Sobre o arquiteto, existem apenas informações esparsas, como a de que seria "fortemente ligado" à Universidade Mackenzie" ${ }^{17}$. Ainda sobre Adhemar de Moraes, sabe-se que teria participado do júri do $1^{\circ}$ Salão Paulista de Arte Fotográfica - de âmbito nacional - em $1942 .^{18}$

Sua importância à época ainda é atestada pelo fato de existir uma rua com seu nome em São Paulo, a Rua Dr. Adhemar Queiroz de Moraes. Ainda mostrando sua projeção nos anos 1920, no número 13 (agosto 1930, p. 2) da revista Architectura e Construcções, Adhemar de Moraes é retratado na "Galeria dos nossos Engenheiros e Architectos"19. Além do fato de ele aparecer na crônica de Oscar Americano, colocada no início deste capítulo, como um dos arquitetos de destaque na cena paulistana da época, ao lado de Dubugras, Przyrembel, Warschawski e Dácio de Morais.

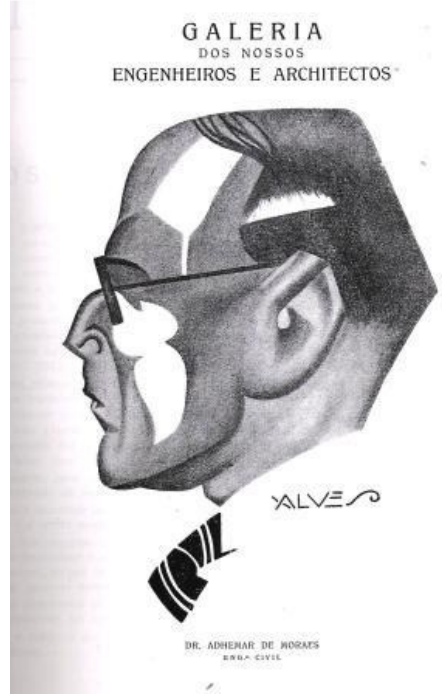

Fig.5.30 Caricatura do arquiteto

Adhemar de Moraes aparece no álbum da Companhia City com 11 fotos de casas de sua autoria. Além destas, ele projetou outras, e algumas tiveram seus projetos localizados no arquivo da Companhia City.

Ele faz pequenos cottages e bangalôs no Jardim América, ainda na época de formação do bairro, quando as casas maiores dividiam espaço com estas menores. Como era o costume, além do projeto ele executava as obras. É um dos arquitetos com maior número de casas no álbum.

\footnotetext{
${ }^{17}$ Informação obtida na biografia de João Pandiá Calógeras no site: www.mackenzie.br/fileadmin/Editora/Revista_Mackenzie/pdfs/m34/pgs_de_8_a15.qxd.pdf 18 o Salão teve apoio da prefeitura municipal e foi realizado na Galeria Prestes Maia. (www.fotoclub.art.br)

${ }^{19}$ A cada número era publicada uma caricatura de um profissional bastante conhecido.
} 
A casa mais interessante de sua autoria é a da Rua Equador, que aparece no álbum Jardim América. Uma espécie de grade, provavelmente metálica, serviria de apoio às plantas na varanda, que assim se transforma em um espaço de transição entre o interior e o exterior da casa, que se prolonga até o caramanchão do jardim. Os limites do terreno são demarcados por uma cerca viva. No acesso à casa, existe um arco. Esta varanda transforma totalmente o caráter da casa. Outros pequenos detalhes são as janelas guilhotina do lado direito da fachada, correspondendo ao setor íntimo, os vitrôs que iluminam a escada e aquele que forma um conjunto com a porta de entrada, todas mostrando as diferentes funções de cada parte da casa.

O viver de forma mais simples e em contato com a natureza transforma-se aqui em uma residência unifamiliar isolada em um lote no subúrbio, em meio a um jardim doméstico. Cenário perfeito para se viver em torno da família, distante dos barulhos, da poluição e das multidões.

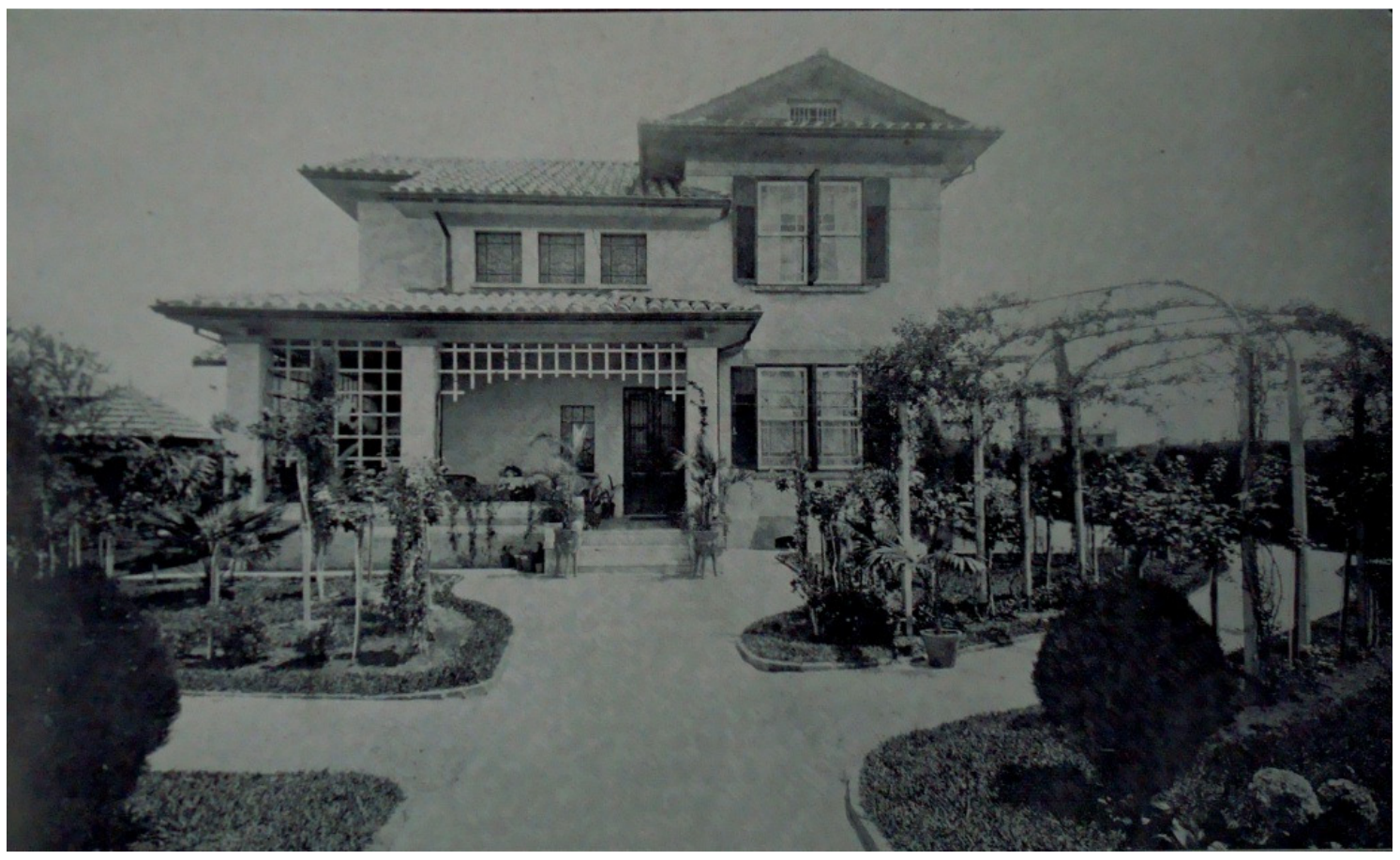

Fig.5.31 Casa na Rua Equador

A partir das pastas com os processos referentes a cada lote do Jardim América - e dos demais loteamentos - que a City guarda em seu acervo é possível saber como se dava a aprovação dos projetos junto à companhia. Além do projeto em si, através dos memoriais, é possível determinar os sistemas construtivos e os materiais utilizados. Eles eram bastante detalhados pois funcionavam como uma espécie de contrato de empreita junto ao cliente. 
Em um dos processos em nome de Adhemar de Morais - uma casa a ser construída na Rua Guadalupe, n.8, código 02.04.326.259 ${ }^{20}$-, no dia 12 de abril de 1923, um funcionário da Companhia City encaminha a planta da casa ao Departamento de Engenharia, para o Sr. George Saville Dodd - engenheiro chefe da companhia -, para que seja calculada sua área e seu valor. Isto era necessário para determinar o valor do financiamento a ser concedido pela City para a construção. Dodd anota a lápis na própria carta as informações solicitadas, logo no dia seguinte. Da carta, ainda consta a informação de que a obra era do "Doutor Adhemar Q. de Moraes" e que, mesmo não tendo recebido as especificações, haviam sido informados de que o acabamento seria de primeira ordem. Provavelmente, o profissional já era bastante conhecido pela Companhia City e dispensava maiores formalidades. Em carta de 5 de maio de 1923, endereçada a outro funcionário da City, Adhemar de Moraes reponde a questionamento anterior sobre as datas das parcelas do financiamento a ser concedido pela City - três parcelas de 9 contos de réis e uma de 8 . As parcelas eram amarradas ao término de determinada etapa, sendo que a primeira apenas seria paga após a conclusão da alvenaria. Não foi encontrado o projeto desta casa no arquivo da companhia.

Existem outras três casas na Rua Guadalupe, da autoria de Adhemar de Moraes:

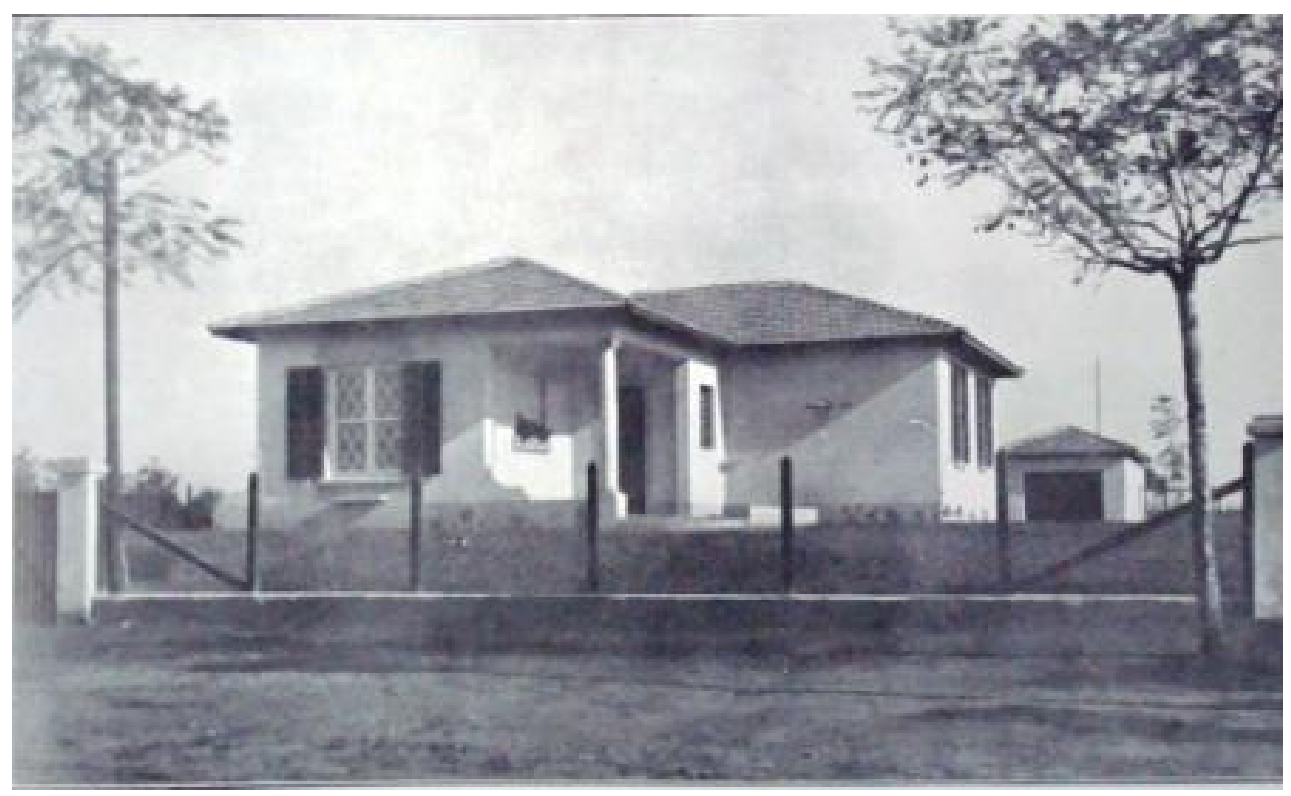

Fig.5.32 Casa na Rua Guadalupe

Este pequeno cottage, com dois volumes e uma pequena varanda já possui garagem para automóveis, ainda não muito comum à época.

\footnotetext{
${ }^{20}$ Estes códigos da Companhia City indicam: quadra, no caso 2; lote, 4; classificado na pasta de venda 326; e colocado na caixa de arquivo 259.
} 
As outras casas da Rua Guadalupe são construções simétricas, também térreas, telhados pouco inclinados e assemelham-se a bangalôs.

A primeira tem varanda frontal, com duas colunas cilíndricas marcando o acesso e pequenas floreiras. Os detalhes resumem-se aos desenhos dos vidros das esquadrias. Estas casas ainda tinham porão, considerando-se a localização do loteamento, na planície de inundação do Rio Pinheiros.

Esta casa, apesar de constar no álbum como sendo na Rua Guadalupe, provavelmente é a casa encontrada no arquivo da companhia com o código 08.04.232.256, que se situava na Rua Venezuela, n. 12.

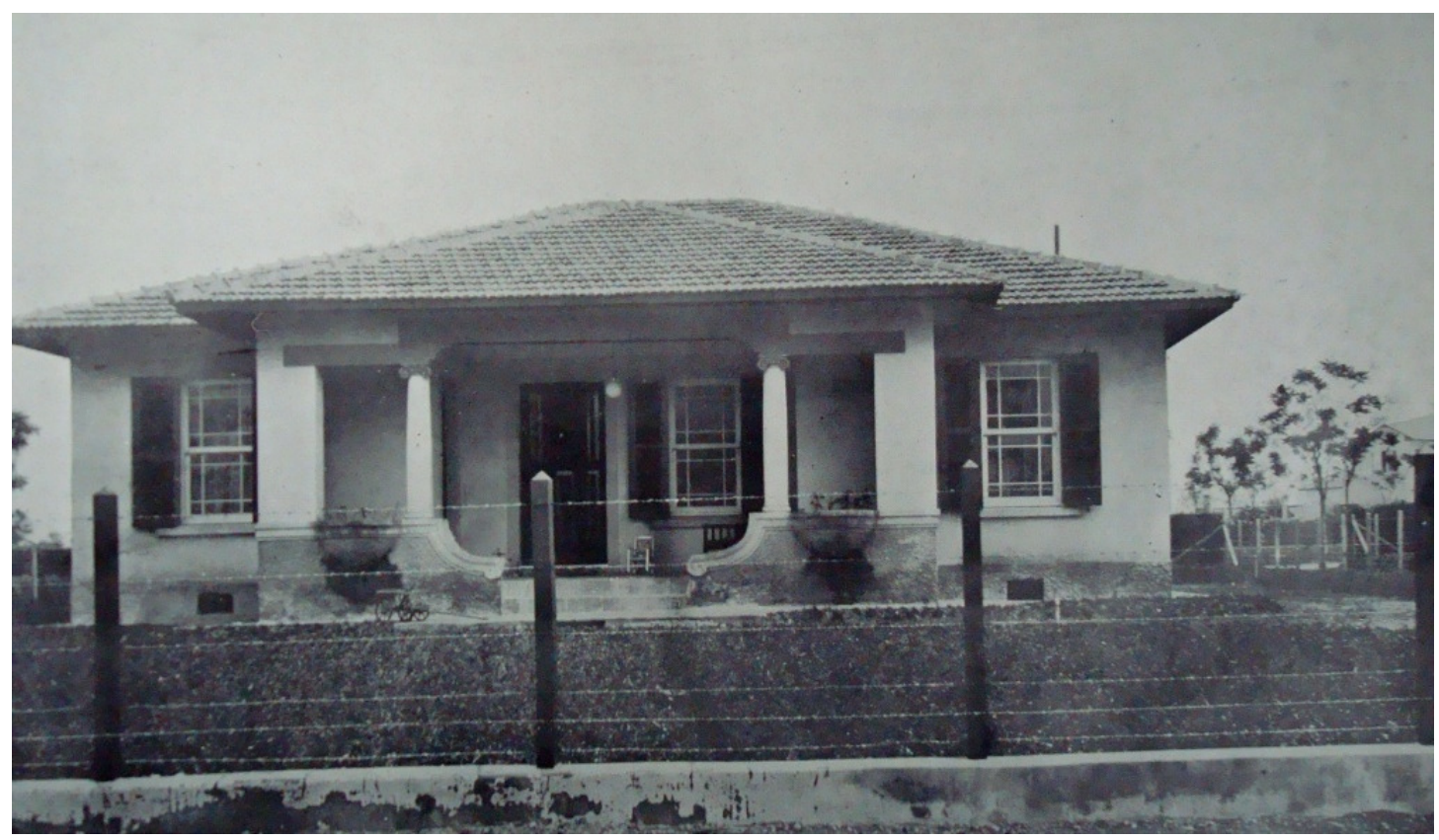

Fig.5.33 Casa na Rua Guadalupe ou Rua Venezuela

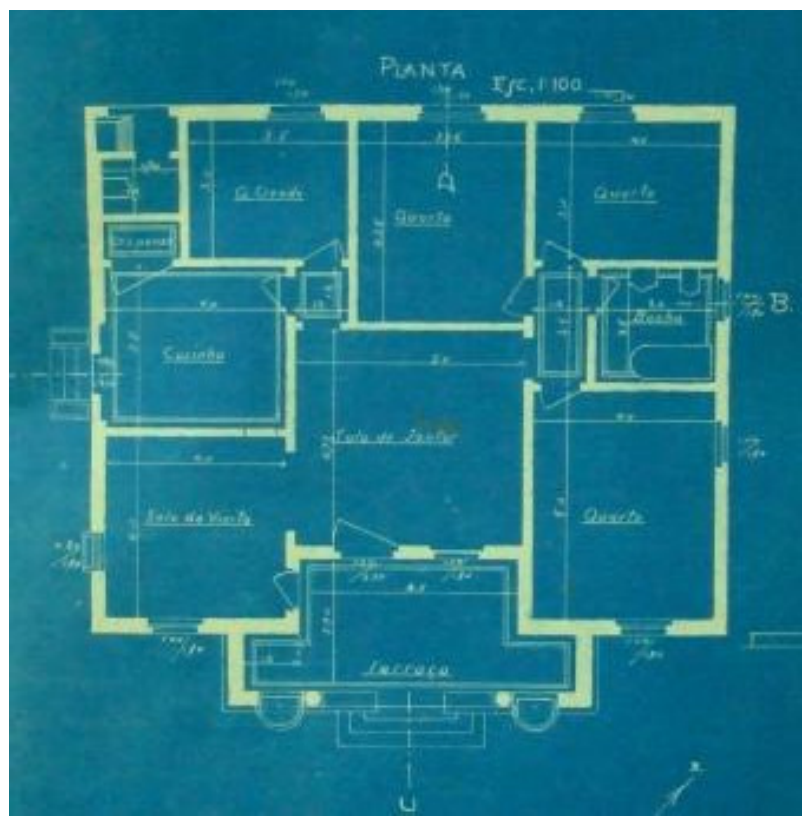

Fig.5.34 Casa na Rua Venezuela, n.12 
Esta outra casa na Rua Guadalupe, com área maior, tem uma pequena pérgula na entrada, com pilares em madeira, como os bangalôs americanos.

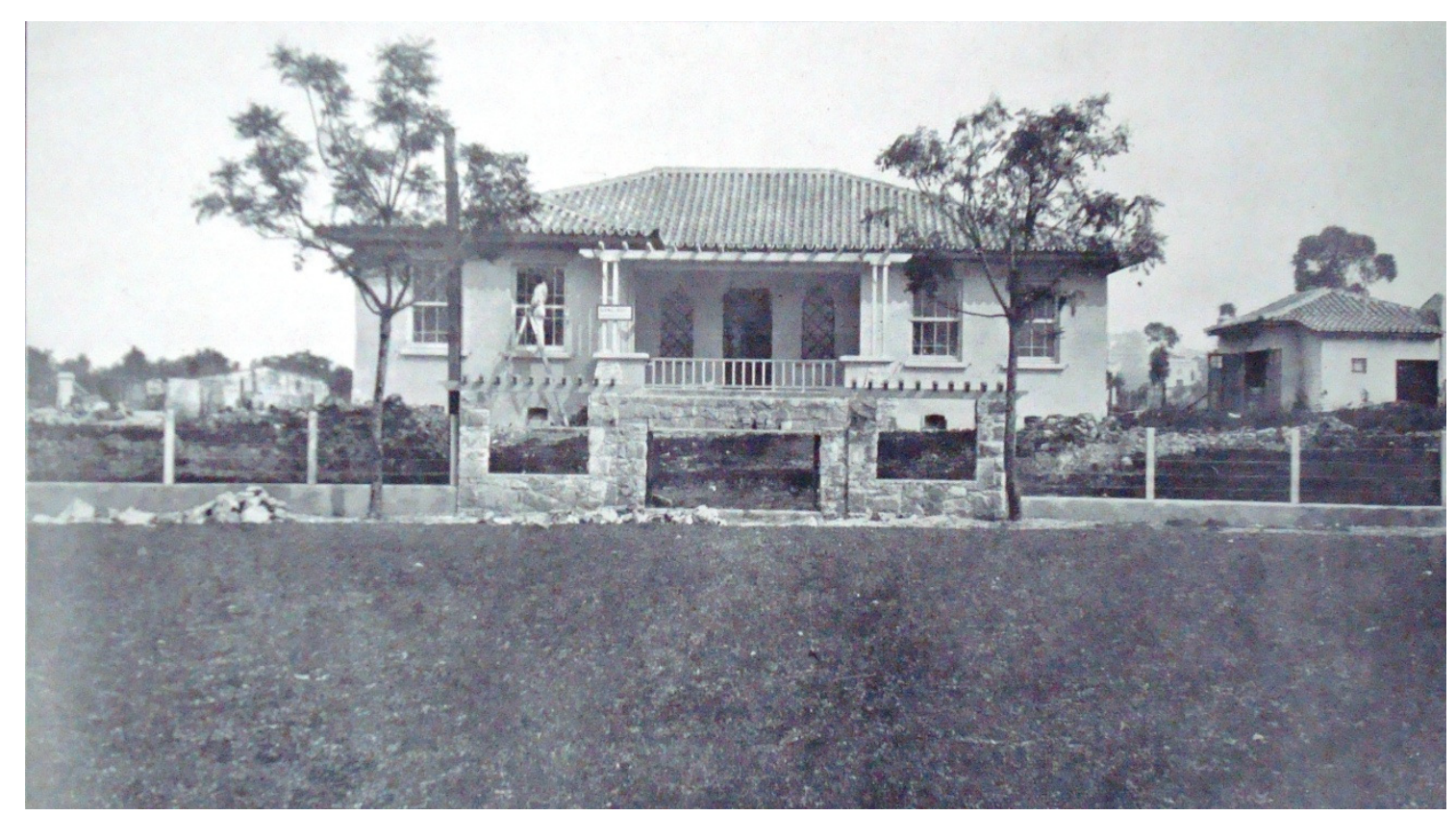

Fig. 5.35 Casa na Rua Guadalupe

Na mesma linha, outra casa na Rua Venezuela, n. 28 (código 09.04.250.256), um projeto mais elaborado, com tijolos aparentes nas floreiras e em parte das paredes. Nas demais, pintura clara, telhado mais elaborado e com pouca inclinação e o acesso marcado por pérgula com vegetação: um pequeno bangalô. $O$ arquiteto consegue um equilíbrio entre cheios e vazios.

A horizontalidade da casa, que denota aconchego e repouso, é "quebrada" pelos volumes com telhado em duas águas e pelos pilares da pérgula, conferindo certo ritmo à fachada. Apesar do tratamento pinturesco dado à fachada e da profusão de pequenos detalhes, ele se harmonizam, inclusive com as janelas em pequenos panos de vidro e com o jardim em que existe outra pérgula.

A casa tem aproximadamente $164 \mathrm{~m}^{2}$ de área, com apenas um dormitório e um pequeno quarto de vestir - "toilete"- com o banheiro integrado. O setor de serviço está todo contido no corpo da casa (área de serviço, quarto e banheiro de empregados). $\mathrm{Na}$ cozinha ainda há previsão do fogão a lenha. A chaminé em tijolinhos faz uma bonita composição na fachada lateral com as duas esquadrias da cozinha e um arco também em tijolos aparentes. Uma pequena pérgula com flores também nesta fachada. 


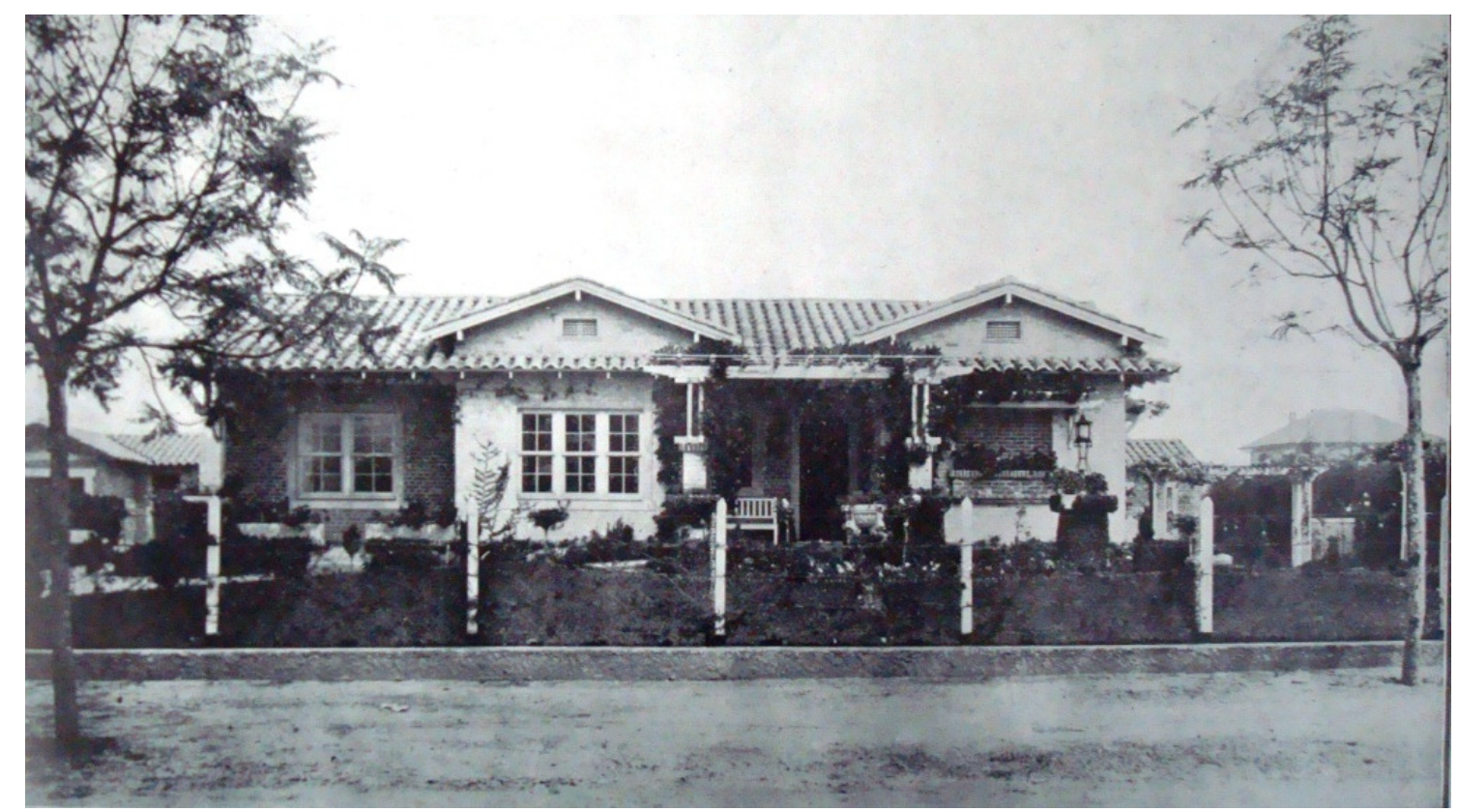

Fig. 5.36 Casa na Rua Venezuela, n.28

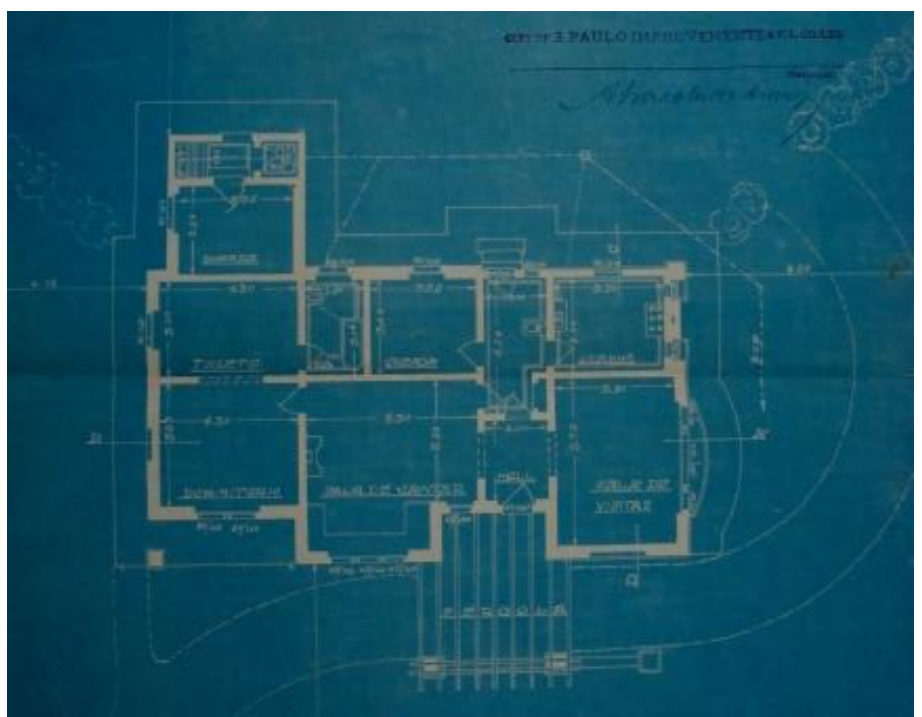

Fig. 5.37 Casa na Rua Venezuela, n.28, planta baixa

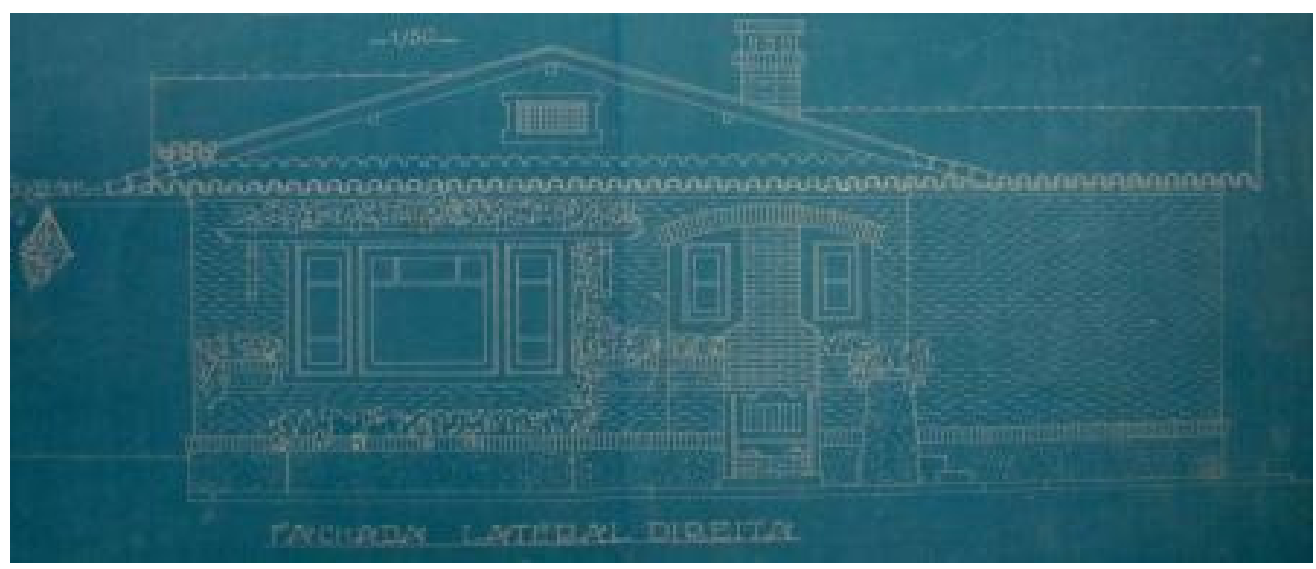

Fig. 5.38 Casa na Rua Venezuela, n.28-fachada lateral 
Em 25 de maio de 1925, é passada a escritura de um terreno, comprado por Adhemar de Moraes (código 30.02.060.249), sendo a aprovação do projeto de abril de 1921, na Rua São Salvador esquina com Rua México. Novamente, o setor de serviços está contido no corpo da habitação, mas esta planta é melhor resolvida. Tem apenas $153 m^{2}$ e praticamente não é perdido espaço com circulações internas como na anterior. Com três dormitórios e um banheiro, a área íntima tem circulação independente. No desenho da fachada, a composição típica do bangalô, varanda com telhado em duas águas, detalhes em tijolinhos. A varanda foi deslocada para a direita na construção, mudando a concepção do projeto, que perdeu todo o equilíbrio da composição.

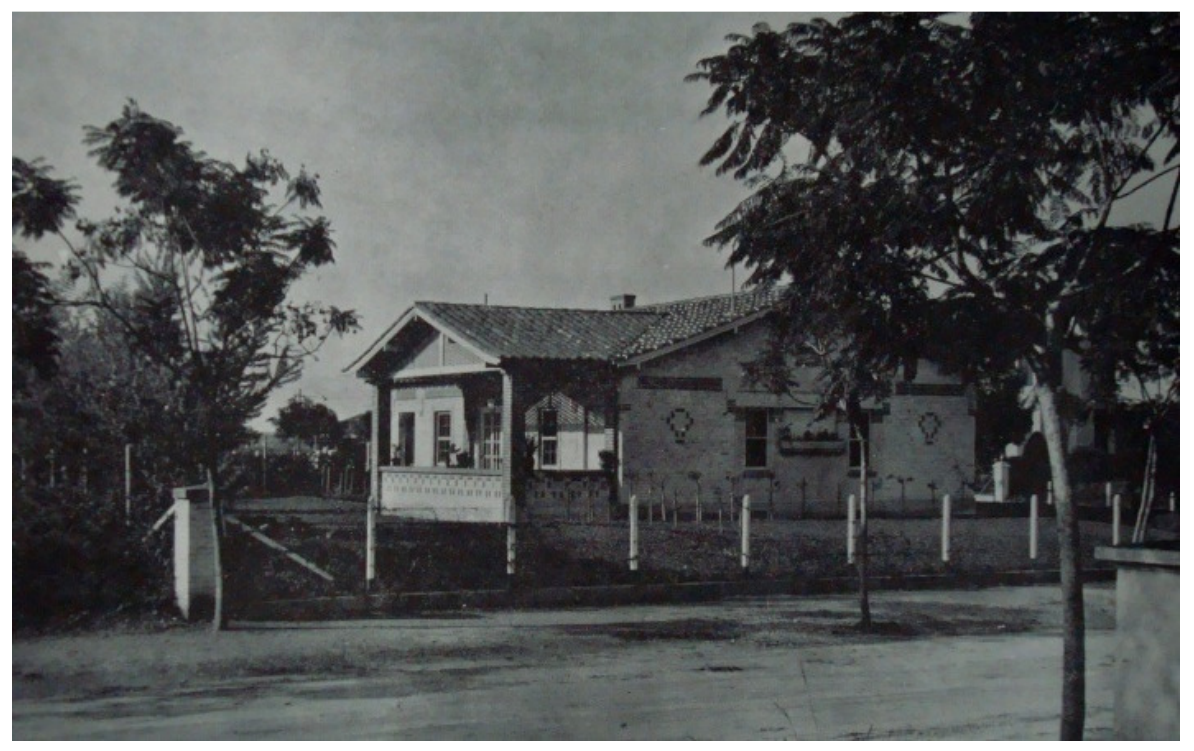

Fig. 5.39 Casa na Rua São Salvador, esquina com Rua México.

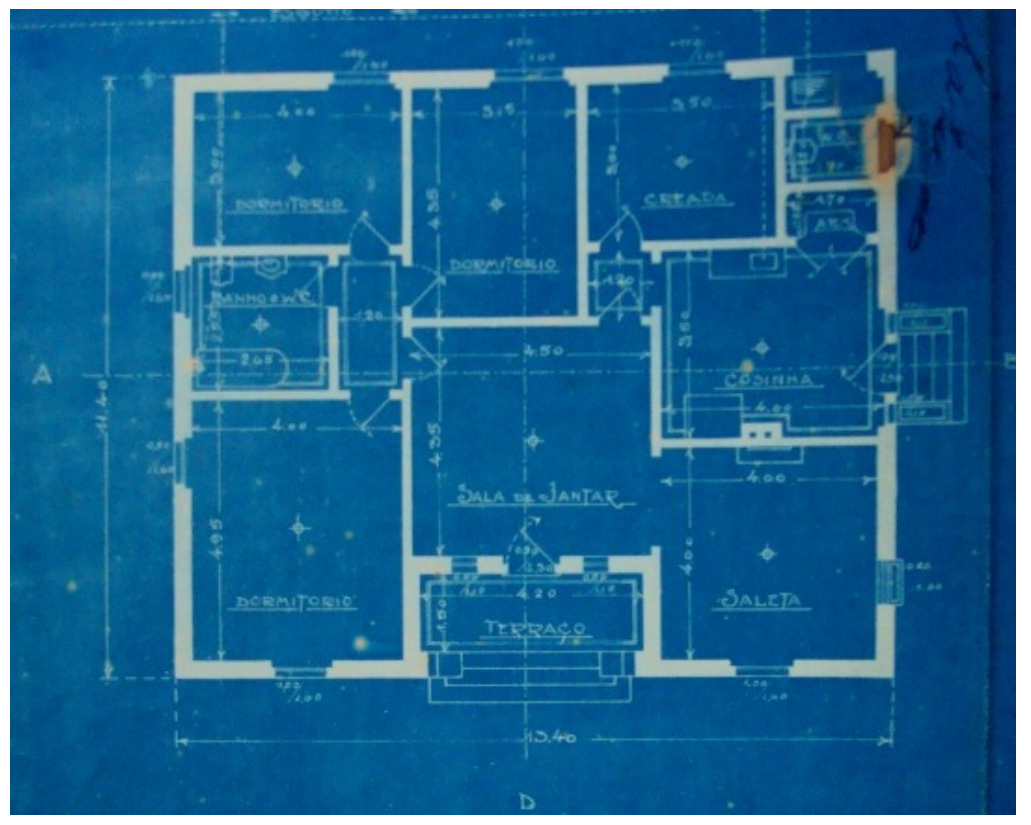


Fig. 5.40 e Fig. 5.41 Casa na Rua São Salvador, esquina com Rua México, planta baixa e fachada frontal.

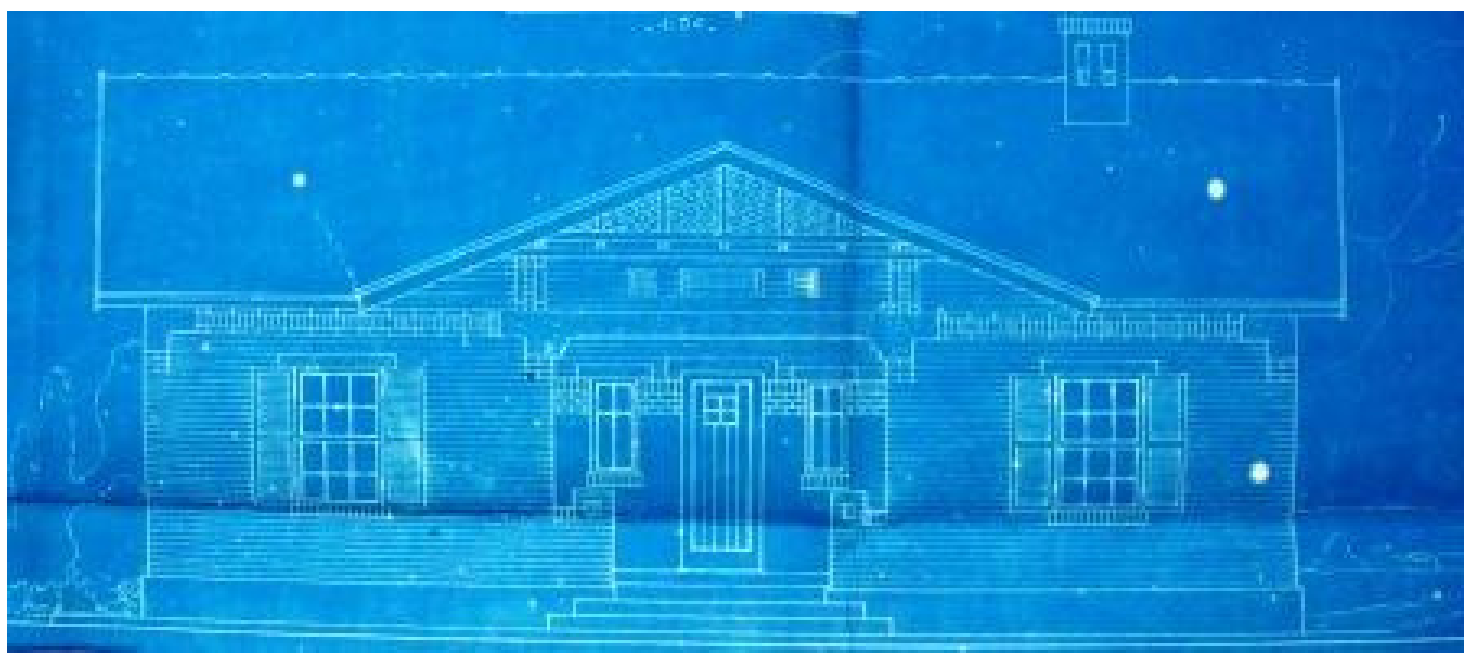

A implantação desta casa nos permite ter uma idéia da área que era ocupada por estas pequenas casas e dos recuos que acabavam resultando. Restavam grandes áreas do terreno vazias, que acabavam ocupadas por jardins na frente e nas laterais e nos fundos, pomares, hortas, construções de serviço e, às vezes, as garagens. Uma casa de $153 \mathrm{~m}^{2}$ está colocada em terreno de aproximadamente $1200 \mathrm{~m}^{2}$ e apresenta recuo frontal de $10 \mathrm{~m}$, de fundos de $13,60 \mathrm{~m}$ e laterais de $10,00 \mathrm{~m}$ e 11,30m. Nas "Cláusulas das servidões para o uso dos terrenos" (ANDRADE, 1998, p. 247) no Jardim América, os recuos de frente e fundos exigidos estão em aberto e os laterais, seriam de $4 \mathrm{~m}$ para casas térreas e a área mínima de $130 \mathrm{~m}^{2}$.

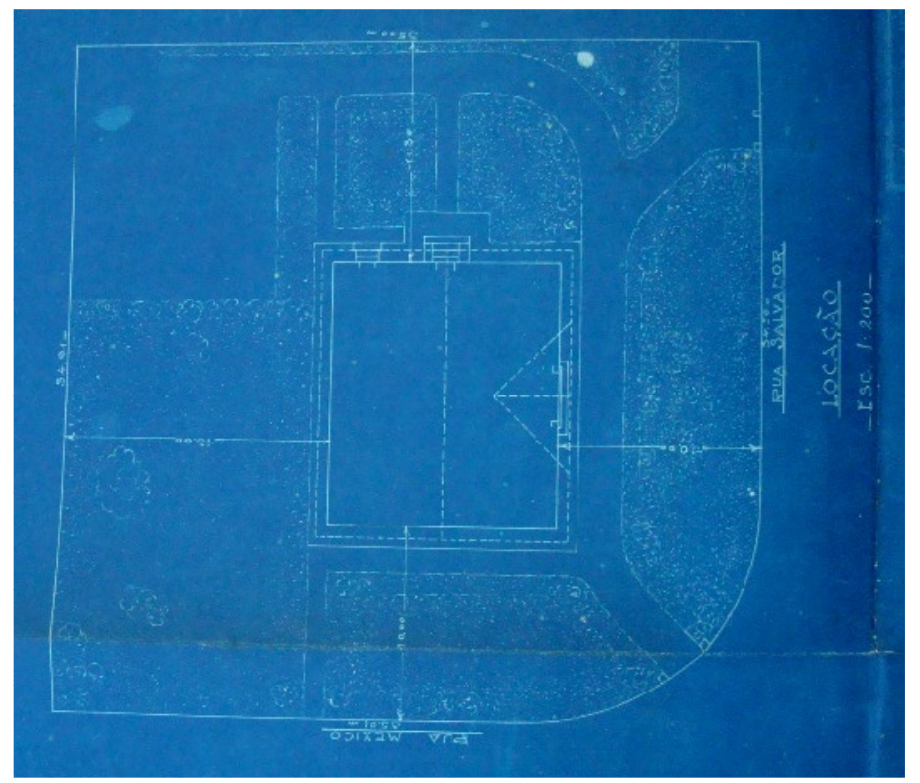

Fig. 5.42 Casa na Rua São Salvador, esquina com Rua México, implantação. 
Outra casa nos mesmo moldes é mostrada no álbum da City, e foi encontrada nos arquivos (código 16.10.175.254). Situava-se à Rua Venezuela, n. 37. A casa totaliza $200 \mathrm{~m}^{2}, 160 \mathrm{~m}^{2}$ no corpo principal e $40 \mathrm{~m}^{2}$ nas dependências de serviço.

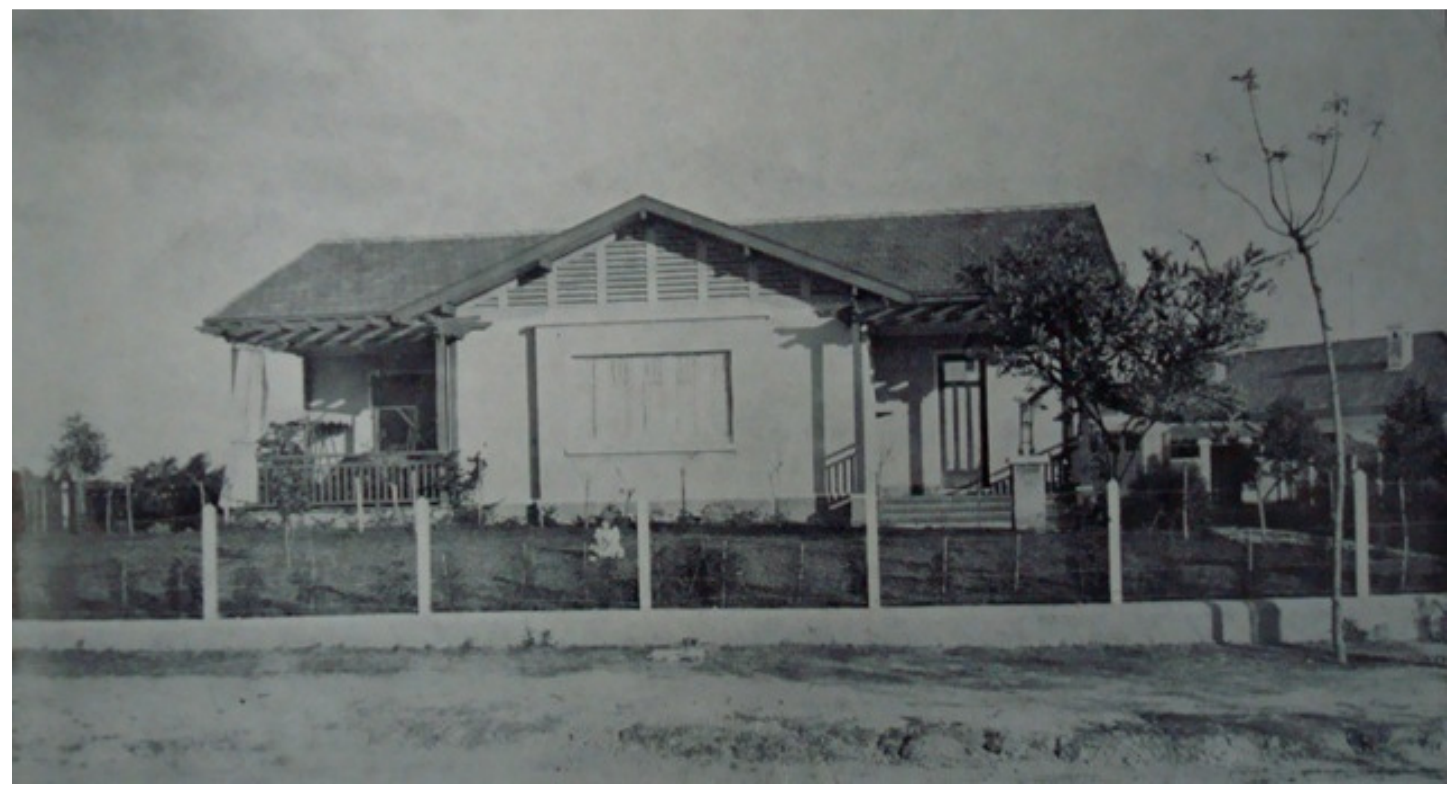

Fig. 5.43 Casa na Rua Venezuela, n.37.

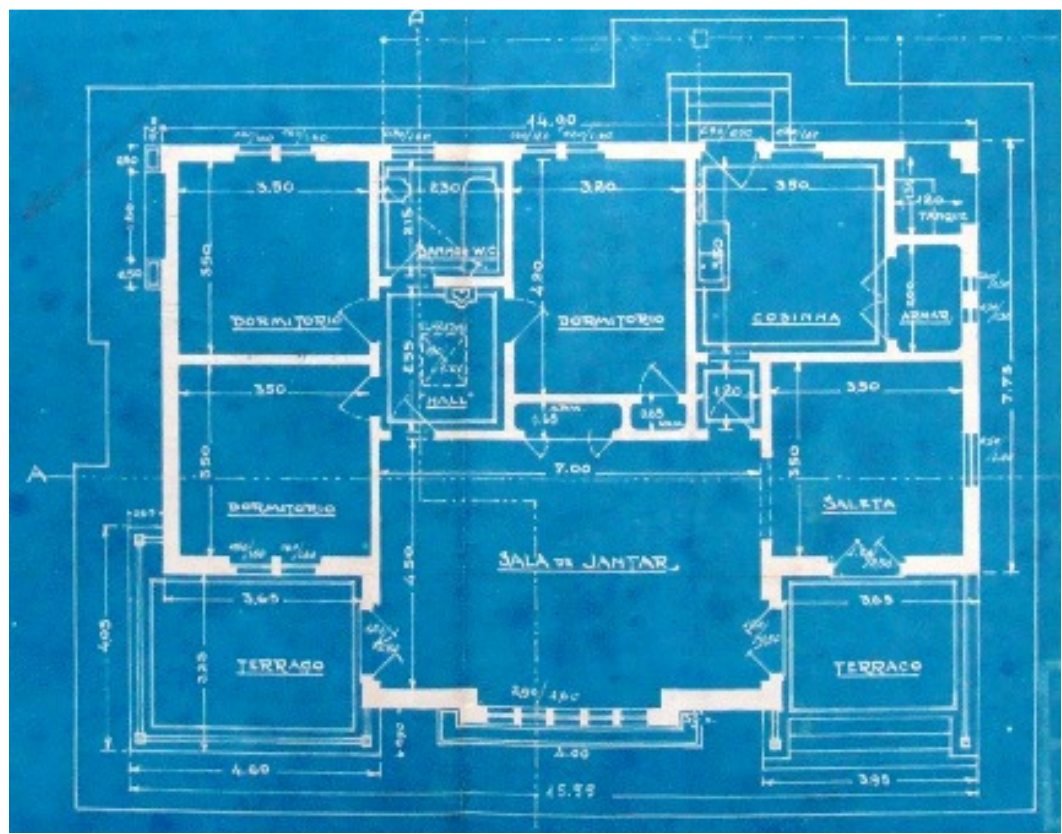

Fig. 5.44 Casa na Rua Venezuela, n.37, planta baixa.

E ainda uma pequena casa na Rua Venezuela, um pequeno cottage sem nenhum detalhe especial, da qual não foi encontrado o projeto nos arquivos da City. 


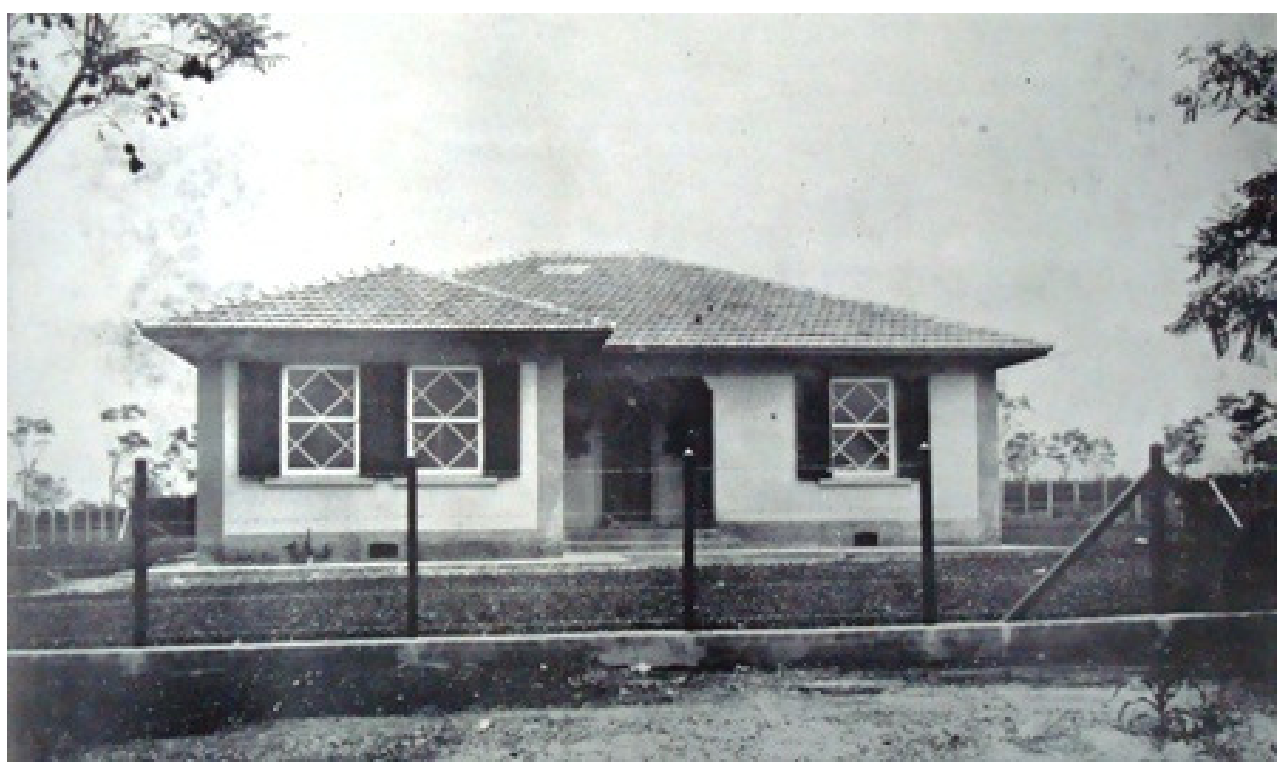

Fig. 5.45 Cottage na Rua Venezuela.

Mas, existem projetos que não foram bem resolvidos pelo arquiteto, como o sobrado da Rua Argentina. A varanda está deslocada na composição, uma chaminé também mal colocada e alguns pequenos detalhes neocoloniais que parecem ter sido acrescentados já na obra.

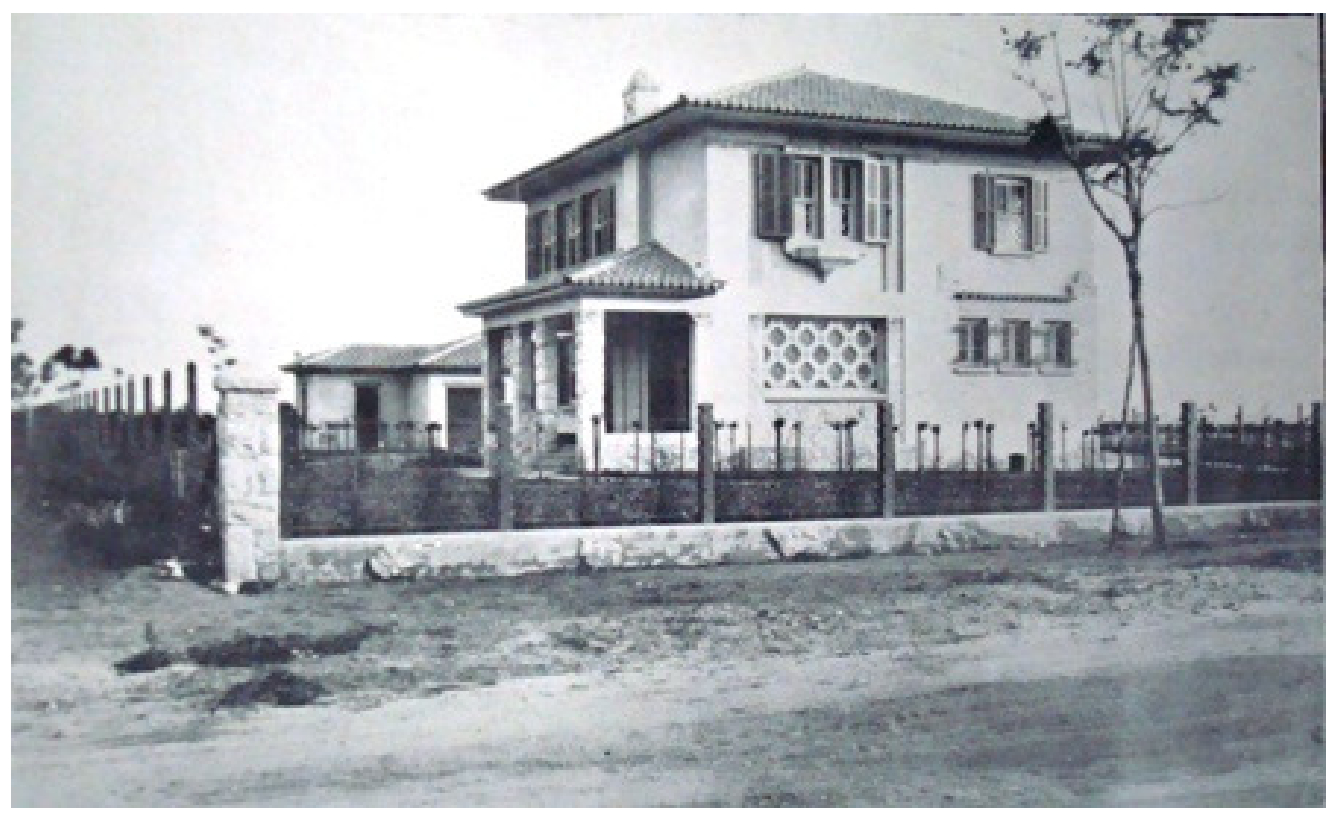

Fig. 5.46 Sobrado na Rua Argentina.

E a casa totalmente clássica, situada na esquina da Rua Groenlândia com a Rua México, que consta como sendo de Adhemar de Moraes no álbum da City, mas Wolff (2001, p. 206-7) a atribui a George S. Dodd. Realmente, a composição simétrica, 
contida em um volume cúbico, com tijolos aparentes e um grande telhado em quatro águas segue a mesma linha dos demais projetos de Dodd, destoando completamente da produção de Adhemar de Moraes.

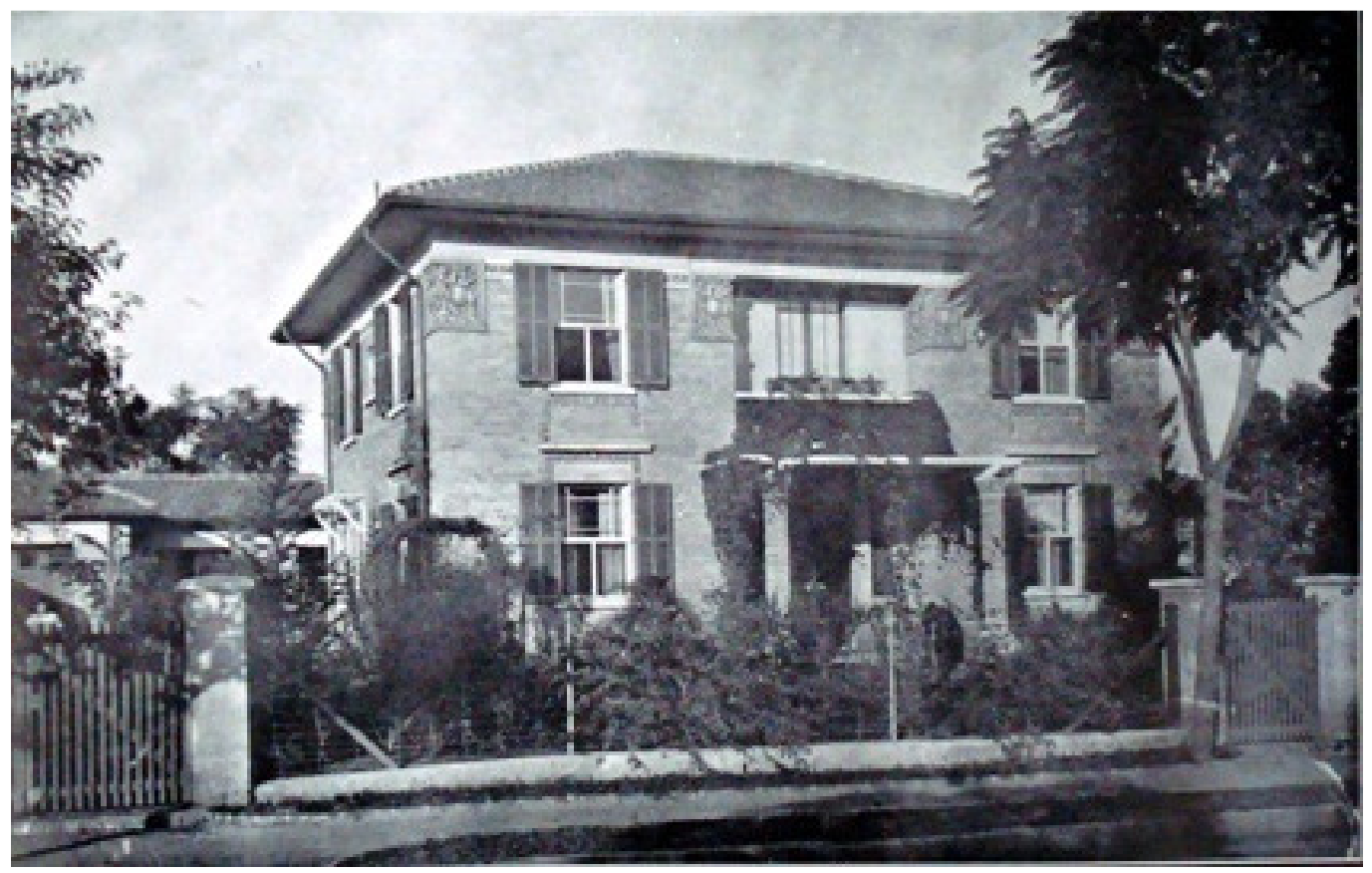

Fig. 5.47 Sobrado na esquina da Rua Groenlândia com a Rua México.

Outro sobrado que não consta no álbum da City é o da Rua Venezuela, esquina com a Rua Guadalupe, com área total de $203,10 \mathrm{~m}^{2}$ (código 06.04.281.257). Segundo a documentação encontrada, o acabamento seria "bom" e o total do empréstimo concedido pela City seria de setenta contos de réis. No térreo, as salas de jantar e de visitas constituem um único ambiente, provavelmente separadas por um arco. Nestas casas do Jardim América, é comum a integração dos ambientes sociais e raras as salas compartimentadas, que teriam como função apenas a recepção dos visitantes. Havia um grande ambiente de estar, às vezes com uma lareira, onde a família provavelmente se reunia, em torno da mesa ou no ambiente mobiliado com poltronas e sofás. Era, provavelmente, o local mais movimentado da casa. O estar normalmente se abria para a varanda ou terraço, onde as pessoas se reuniam quando o tempo estava agradável.

Este sobrado tem tijolos aparentes no andar superior e varanda em arcos abatidos. Pequenos detalhes colocados nos cantos das paredes, provavelmente pré-moldados, em alto relevo. Tais detalhes seriam muito comuns no Neocolonial. Nesta fachada são colocadas cotas de altura e é possível verificar o pé direito, $3.00 \mathrm{~m}^{21}$.

\footnotetext{
${ }^{21}$ Adotado pelo Código Sanitário de 1918.
} 

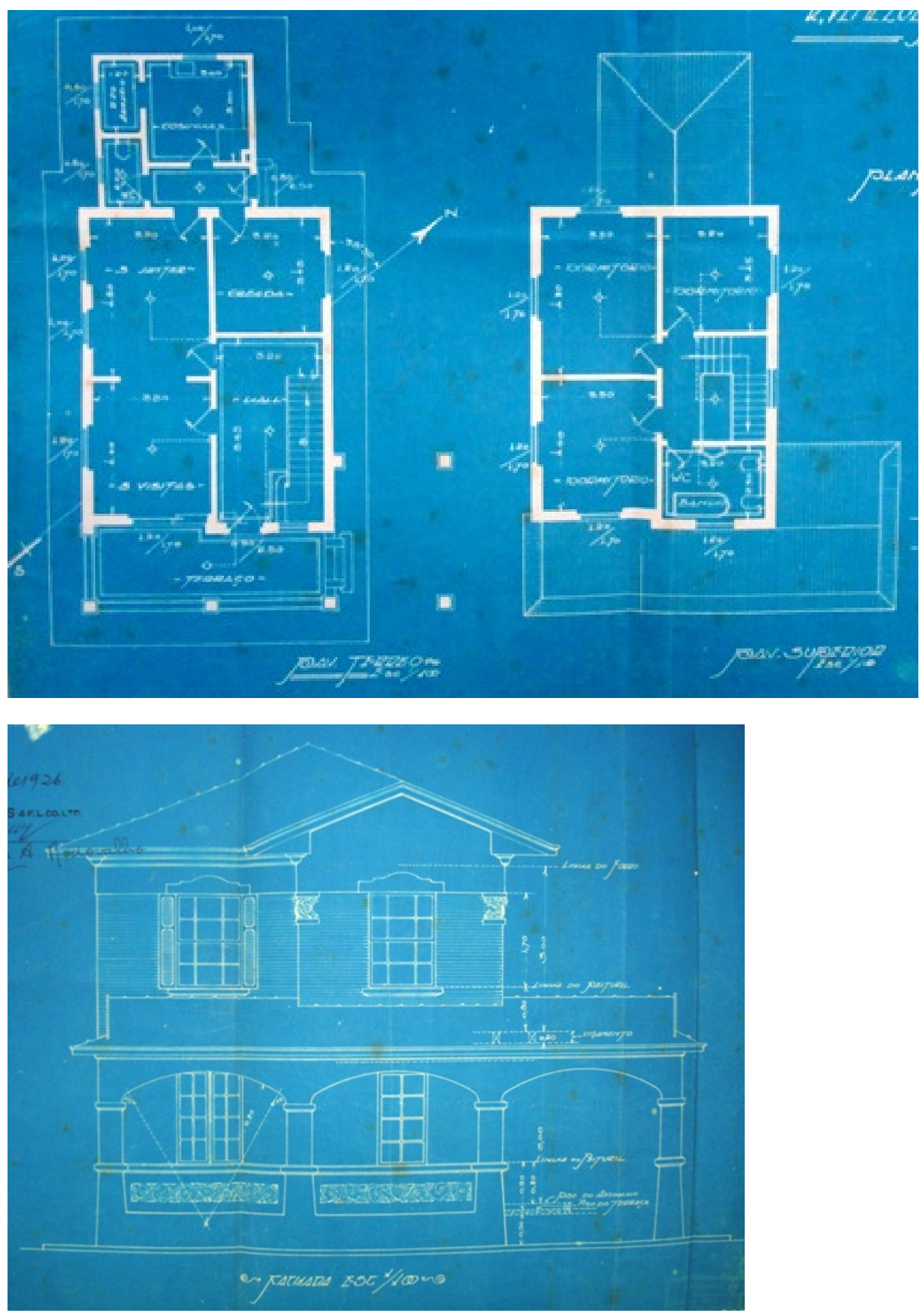

Fig. 5.48 E Fig. 5.49 Sobrado na esquina da Rua Venezuela com Rua Guadalupe, plantas baixas e fachada frontal.

No numero 39 da Revista de Engenharia do Mackenzie (agosto 1926), aparece reportagem sobre a arquitetura de Adhemar de Moraes, contendo fachada e dois 
interiores de uma residência à Rua Conselheiro Brotero, 129. A revista não foi encontrada.

$\mathrm{Na}$ "Página de Arquitetura" (março de 1927, n.41) da Revista de Engenharia do Mackenzie, aparece um projeto Neocolonial do arquiteto. A casa localizava-se na esquina das ruas Haddock Lobo com Alameda Franca, a meio caminho entre o Jardim América e a Avenida Paulista, ainda um reduto de grandes casarões à época.

A composição é bastante equilibrada entre cheios e vazios, com um volume central no térreo, encimado por uma varanda com acesso por um dos dormitórios do segundo pavimento.

É uma grande casa, com dois banheiros no pavimento superior, ainda incomum na época, e uma pequena varanda, denominada loggia, com acesso pelo banheiro e fechada por rótulas. No térreo, quase o programa de um palacete, com estar e jantar integrados, escritório, quarto de costura, copa e sala de almoço.
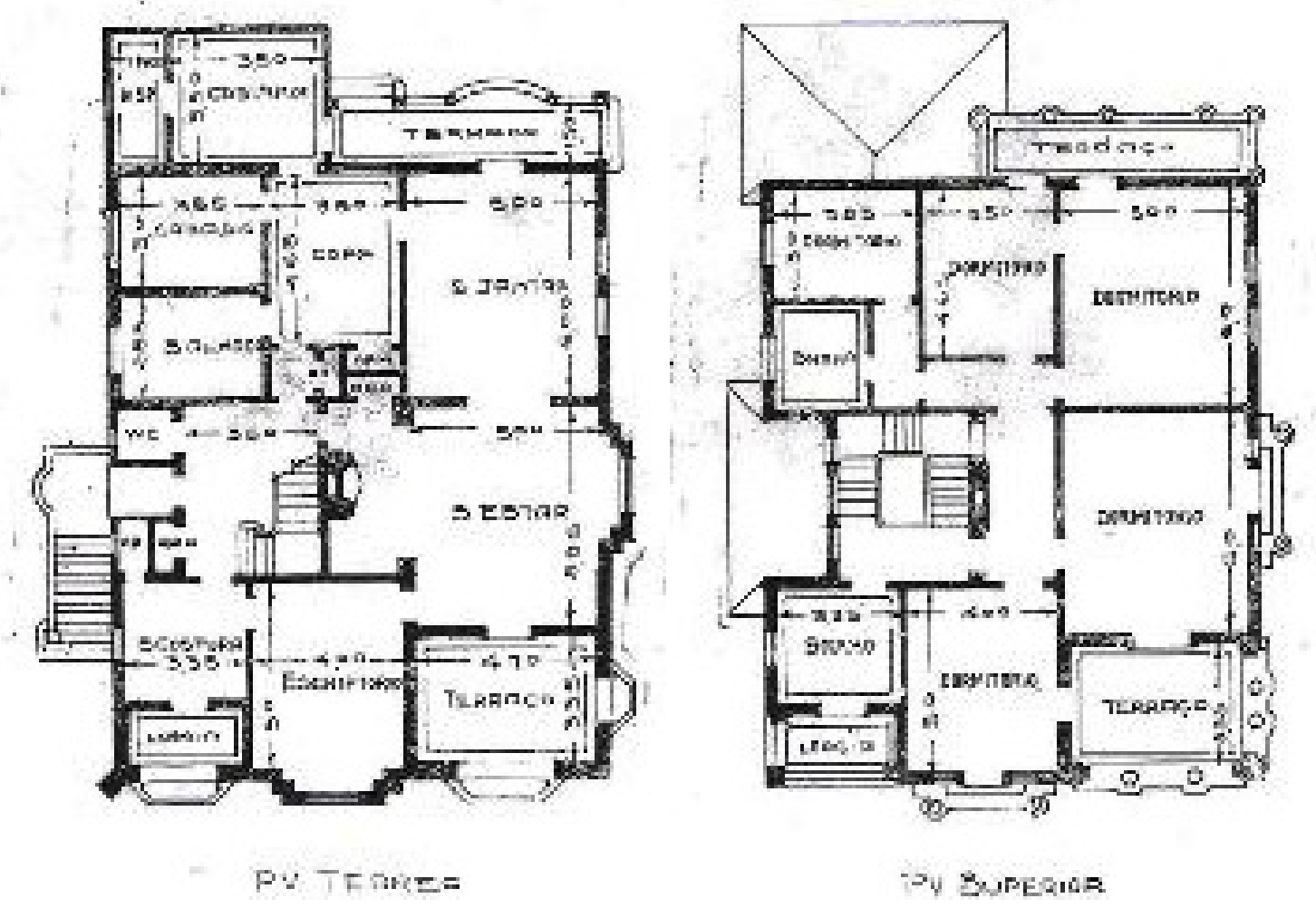

Adhenar de Mornes

Engenteiro Constructor.

Fig. 5.50 Sobrado na Rua Haddock Lobo, plantas baixas. 


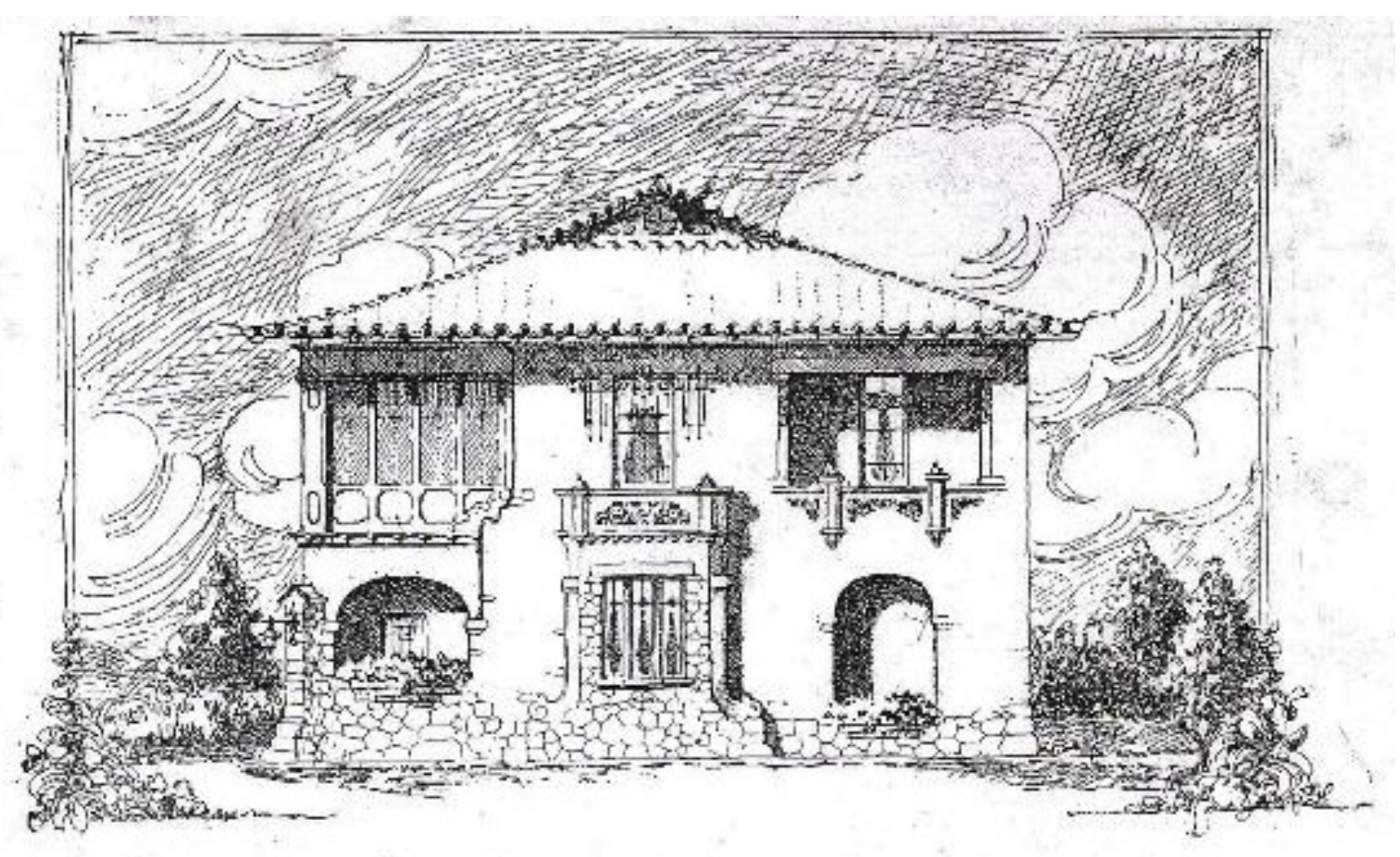

Fig. 5.51 Sobrado na Rua Haddock Lobo, fachada frontal.

No número 13 (agosto 1930, p. 2) da revista Architectura e Construcções, o mesmo onde Adhemar de Moraes aparece na "Galeria dos nossos Engenheiros e Architectos", é mostrado projeto de sua autoria de um jazigo, com frontão neocolonial e colunas retorcidas. O Neocolonial definitivamente estava presente em São Paulo.

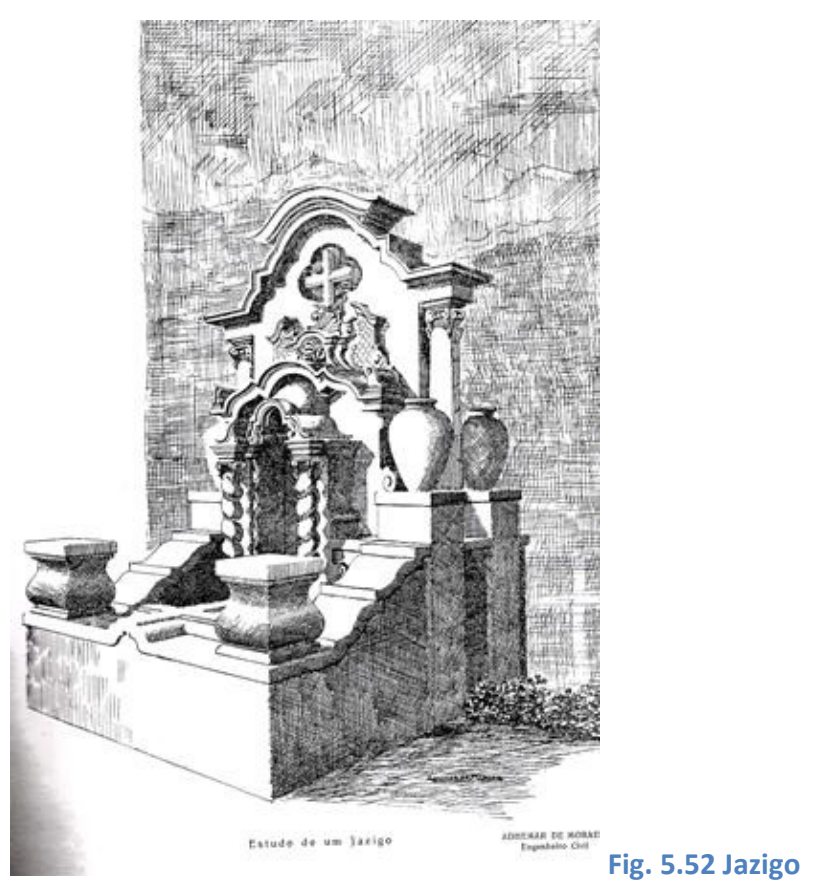




\subsubsection{Renato Ribeiro de Aguiar}

Renato Aguiar formou-se no Curso de Arquitetura da Escola de Engenharia Mackenzie, em 1922. Também construía, pois seu anúncio na Revista de Engenharia do Mackenzie (n.42, p.52) o apresentava como engenheiro-arquiteto e construtor.

No álbum da Companhia City ele comparece com cinco projetos ${ }^{22}$. Um deles, de outubro de 1921, à Rua Panamá, n.6, foi localizado no arquivo da companhia (código 16.17.081.250). Apesar do memorial construtivo estar datilografado em papel timbrado de "Aguiar \& Diciatteo Architectos", a legenda da foto no álbum aponta como autor Renato Aguiar, confirmando ser ele o sócio de Diciatteo.

A casa tem dois pavimentos. No térreo, as salas de jantar e de visitas são separadas apenas por abertura com colunas. Há também uma pequena saleta que provavelmente serviria para receber visitas. Existe uma grande pérgula na fachada frontal, que foi diminuída na construção e acrescida de uma pequena varanda no acesso principal. No pavimento superior, além do banheiro principal, existe um W.C. Trata-se de uma composição clássica, simétrica, a que foram acrescentados o volume da sala de jantar à direita e a pérgula do lado esquerdo. $O$ fechamento frontal do terreno já é mais elaborado.

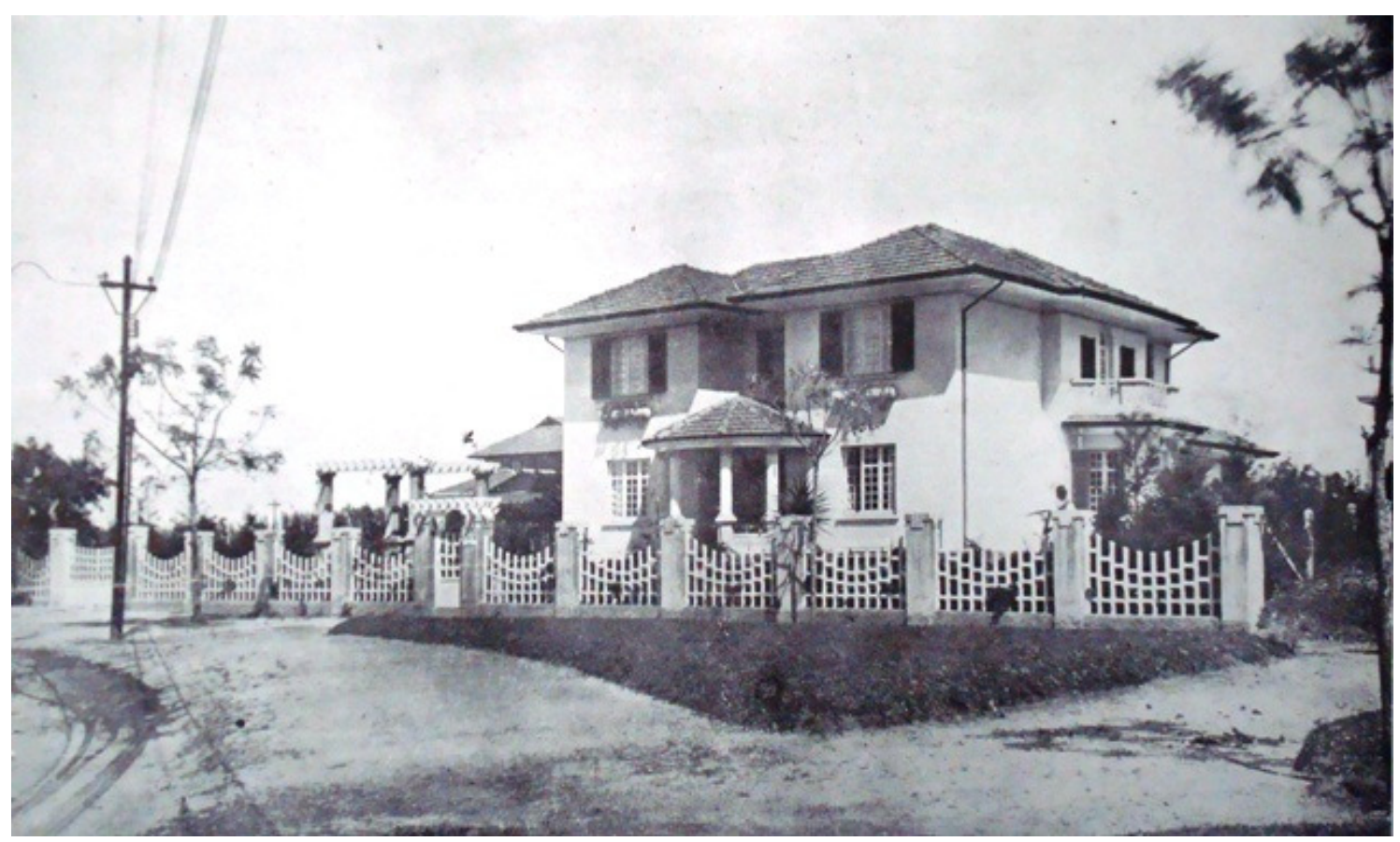

Fig. 5.53 Casa na Rua Panamá.

\footnotetext{
${ }^{22}$ WOLFF, 2001, p. 282. Consta ainda que ele teria projetado mais duas residências no Jardim América, uma no período 1935-40, na Praça Lucaias, e outra no período 1940-45, na Rua Chile.
} 


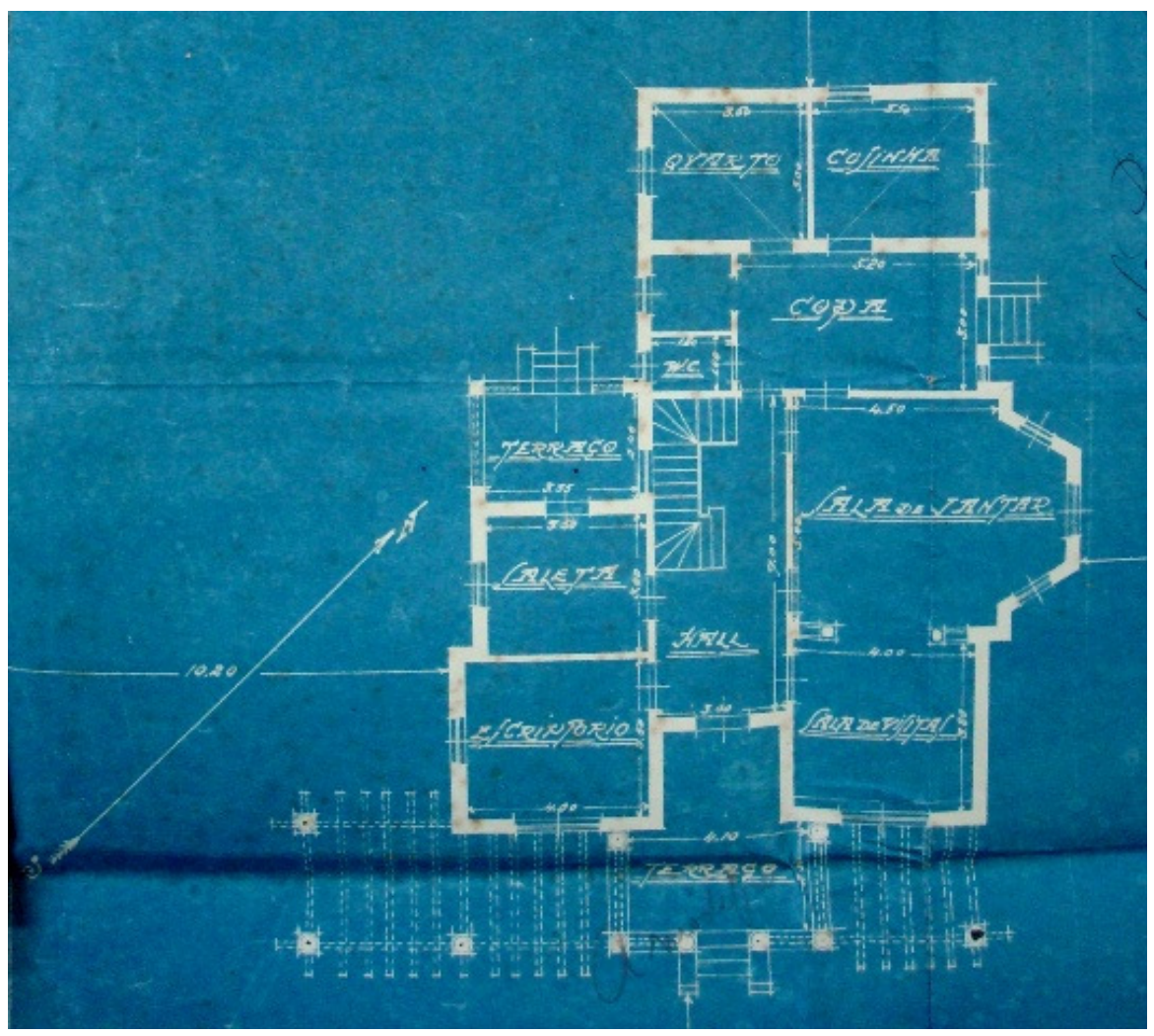

Fig. 5.54 Casa na Rua Panamá, planta baixa do térreo.

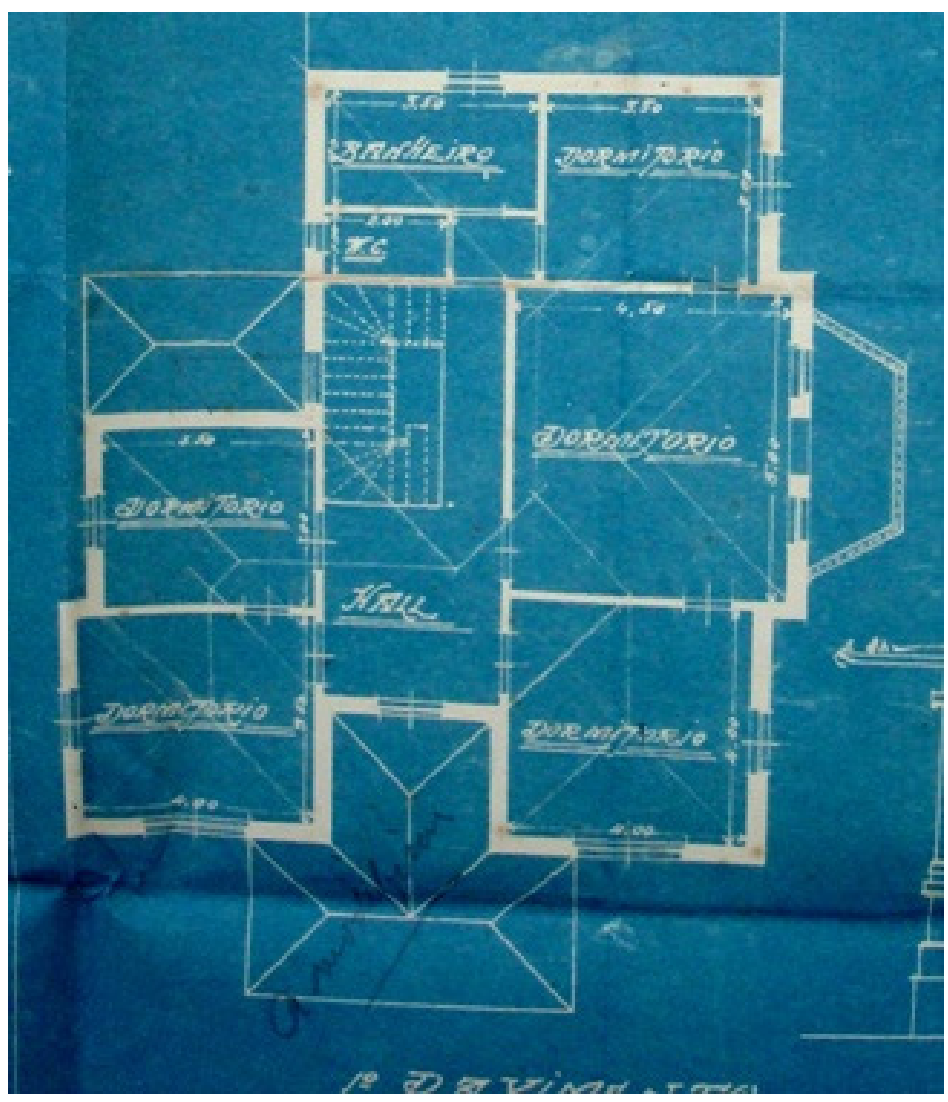

Fig. 5.55 Casa na Rua Panamá, planta baixa do pavimento superior. 
Outra casa do arquiteto, que aparece no álbum Jardim América como sendo da autoria de Aguiar e Diciatteo, situada na Rua Venezuela, tem grandes volumes como os da arquitetura Arts and Crafts, de concepção purista. O grande telhado é interrompido e dá lugar à pérgula na fachada frontal. Nesta vertente do Arts and Crafts, as aberturas são praticamente os únicos detalhes nas fachadas. Mas aqui, o tratamento pinturesco dado às paredes e a atenção aos detalhes estão mais próximos dos bangalôs americanos. O tijolo aparente utilizado no segundo pavimento - comum na arquitetura paulistana da época e também utilizado pelos arquitetos do Arts and Crafts-acaba por valorizar os detalhes e as superfícies, em detrimento daquelas formas mais simples. Os volumes que se destacam na fachada principal, que seriam pequenas águasfurtadas $^{23}$ em uma casa de Voysey ou de Barry Parker, tem aqui dimensões exageradas.

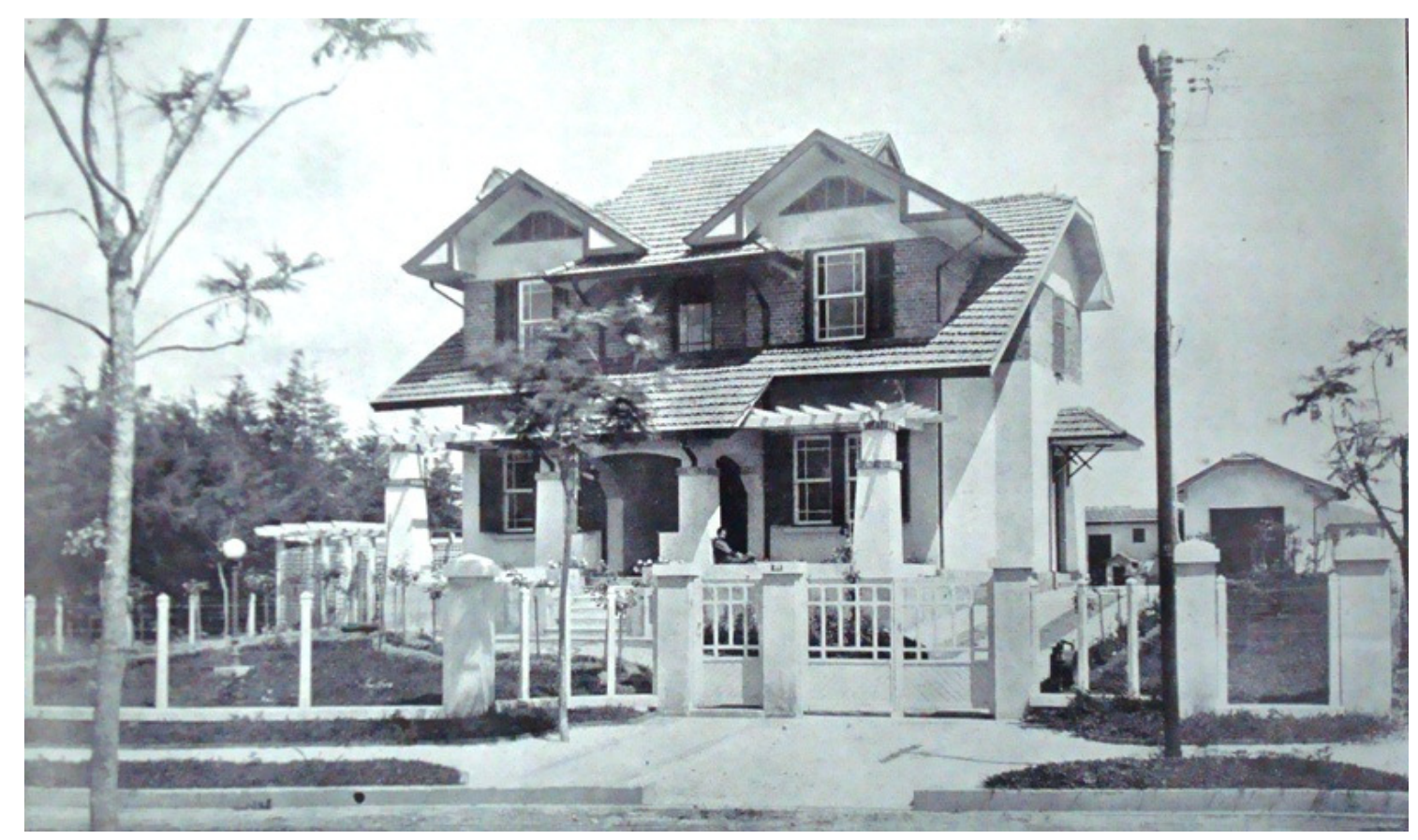

Fig. 5.56 Casa na Rua Venezuela

Outro sobrado, um cottage, também na Rua Venezuela - com autoria atribuída a Renato Aguiar \& Co. -, tem quase toda a superfície coberta por tijolos aparentes. Um tipo de casa bastante comum em São Paulo à época, com detalhes como a pérgula e a cobertura da varanda.

\footnotetext{
23 Janela de sótão coberta por duas águas, que emerge de uma água de telhado (http://pt.wiktionary.org/wiki/\%C3\%A1gua-furtada)
} 


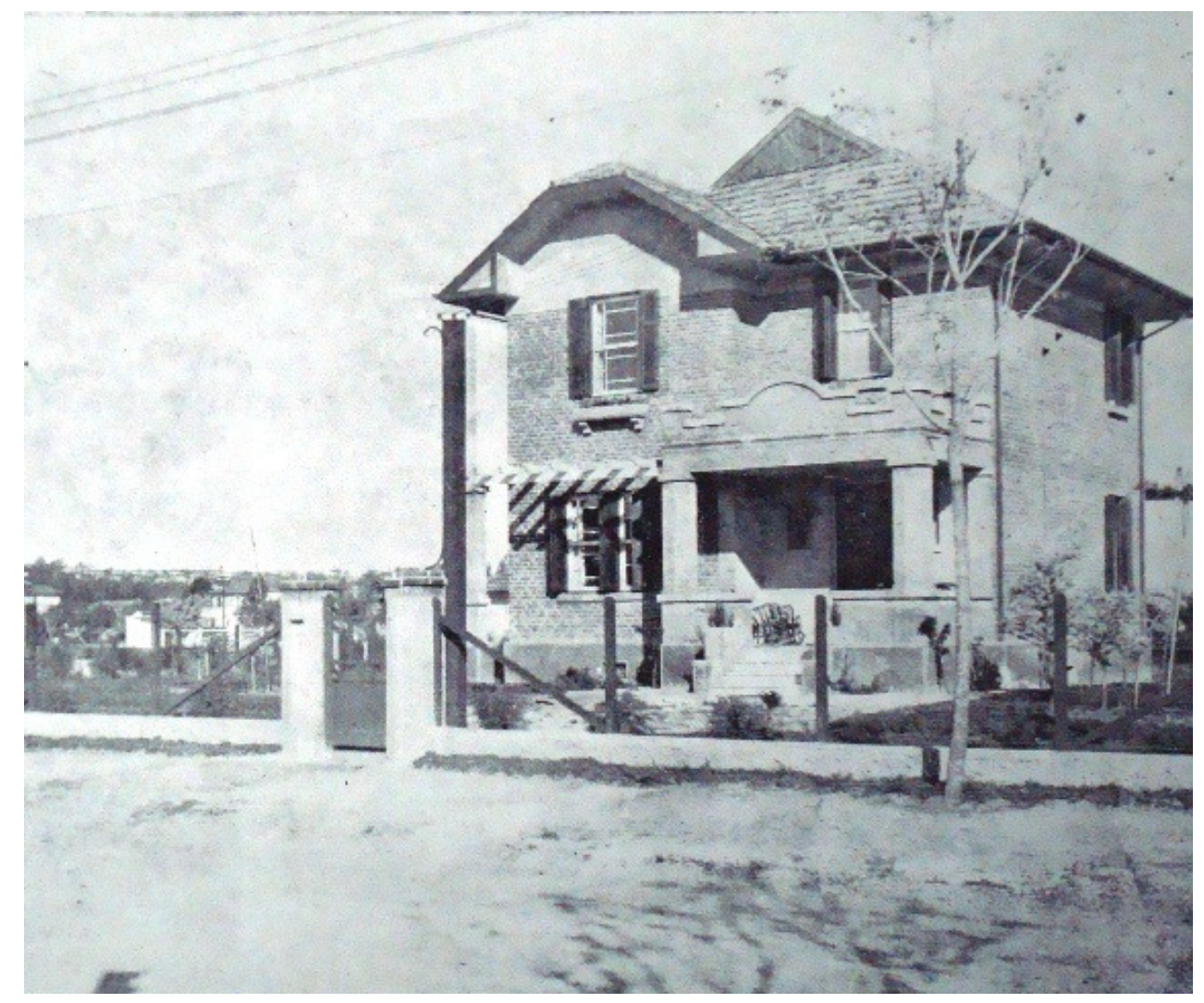

Fig. 5.57 Outro sobrado na Rua Venezuela.

Duas casas térreas completam a colaboração de Renato Aguiar ao álbum da City, ambas com volumes e telhados recortados. A primeira seria um pequeno cottage, com uma estranha colunata na varanda, localizado na Rua Venezuela.

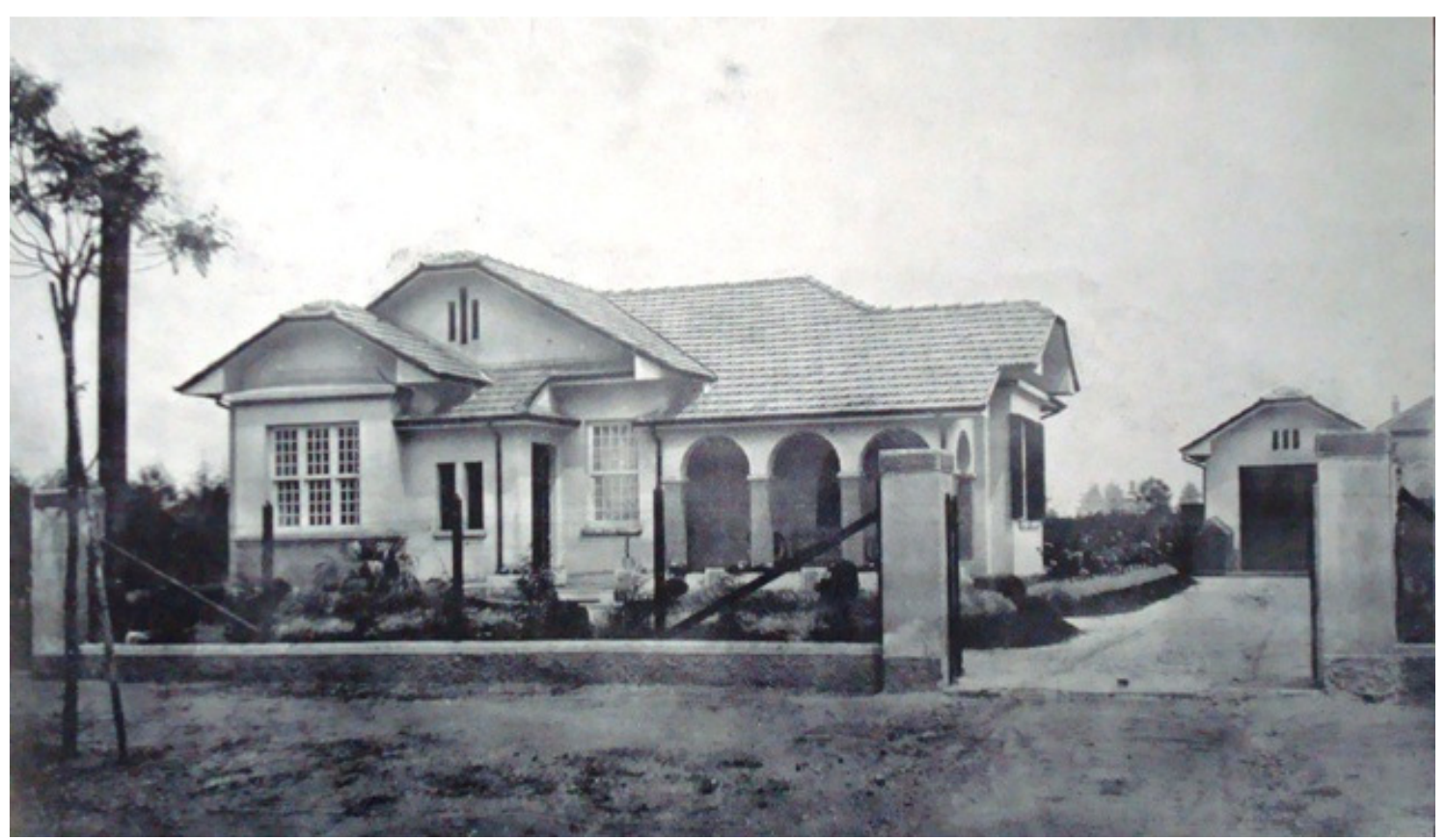

Fig. 5.58 Casa na Rua Venezuela. 
A segunda, na Rua Argentina, tem um pequeno frontão clássico e outros detalhes que desequilibram este pequeno cottage.

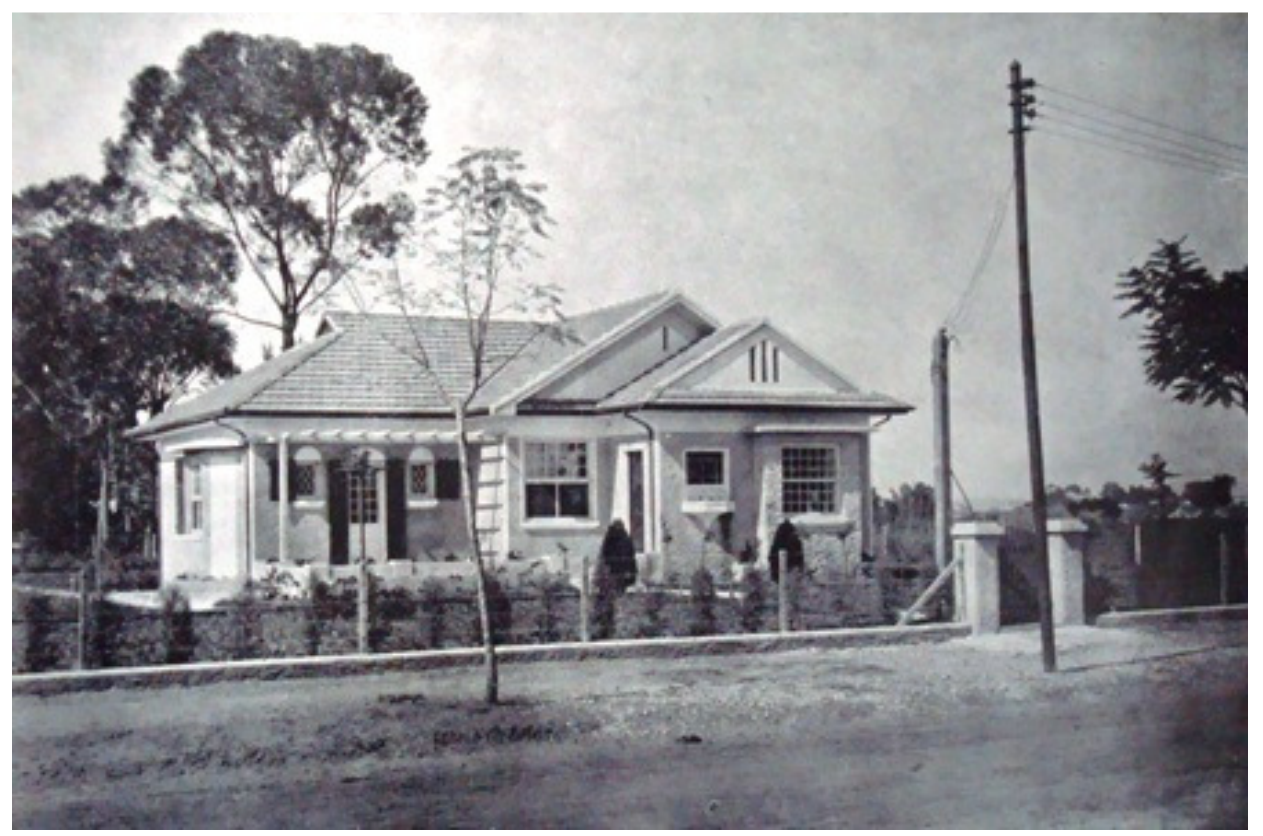

Fig. 5.59 Casa na Rua Argentina.

Em todas estas casas, Renato Aguiar sempre cria um espaço de transição para o jardim, como pérgulas, varandas, volumes da casa que se prolongam em direção ao espaço externo, sempre para a fruição deste novo espaço, o entorno da casa, um espaço bem cuidado antes só encontrado nos palacetes da elite

$\mathrm{Na}$ Revista de Engenharia do Mackenzie (maio 1927, n.42, p.30-1), foi publicado o projeto de um palacete da autoria de Renato Aguiar, que seria construído no Jardim América, na Rua Groenlândia, n.40, em estilo Neocolonial. Uma composição aditiva, assimétrica, que, apesar dos grandes volumes verticais com frontões, evita a monumentalidade. O escritório e jantar são integrados, com um pequeno recanto com várias aberturas abrindo-se para um terraço. A casa, um sobrado em meio a jardins, pomar e local para criações, parece uma pequena chácara.

A mesma casa aparece no número seguinte da revista (julho 1927, n.43, p. 30-31), em artigo com o título "Detalhes de um Palacete a ser construído no Jardim América". O projeto, bastante minucioso refere-se às fachadas, especificando a execução de detalhes neocoloniais, como o raio de abertura a ser utilizado na confecção dos arcos. 


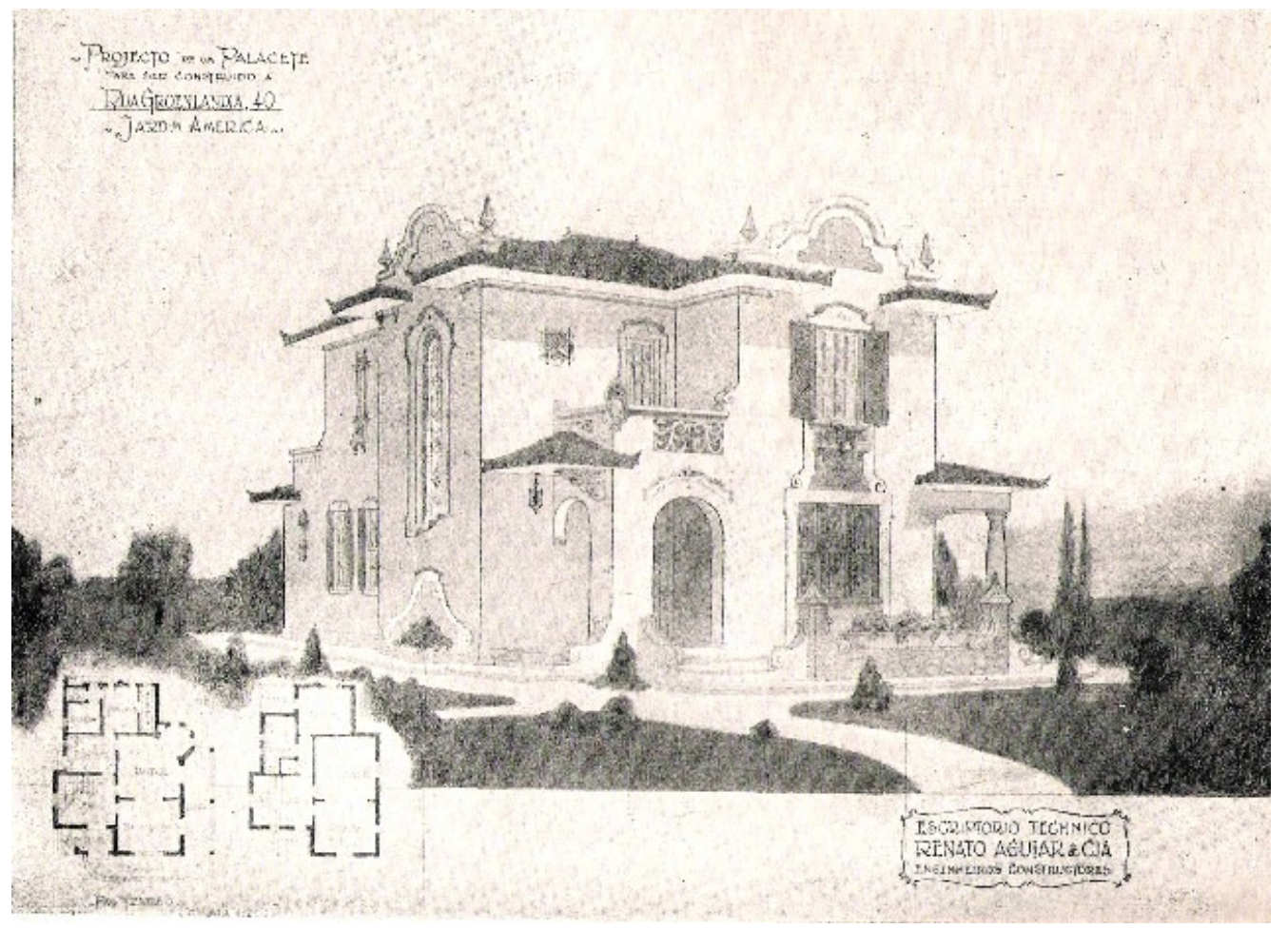

Fig. 5.60 "Palacete" no Jardim América.

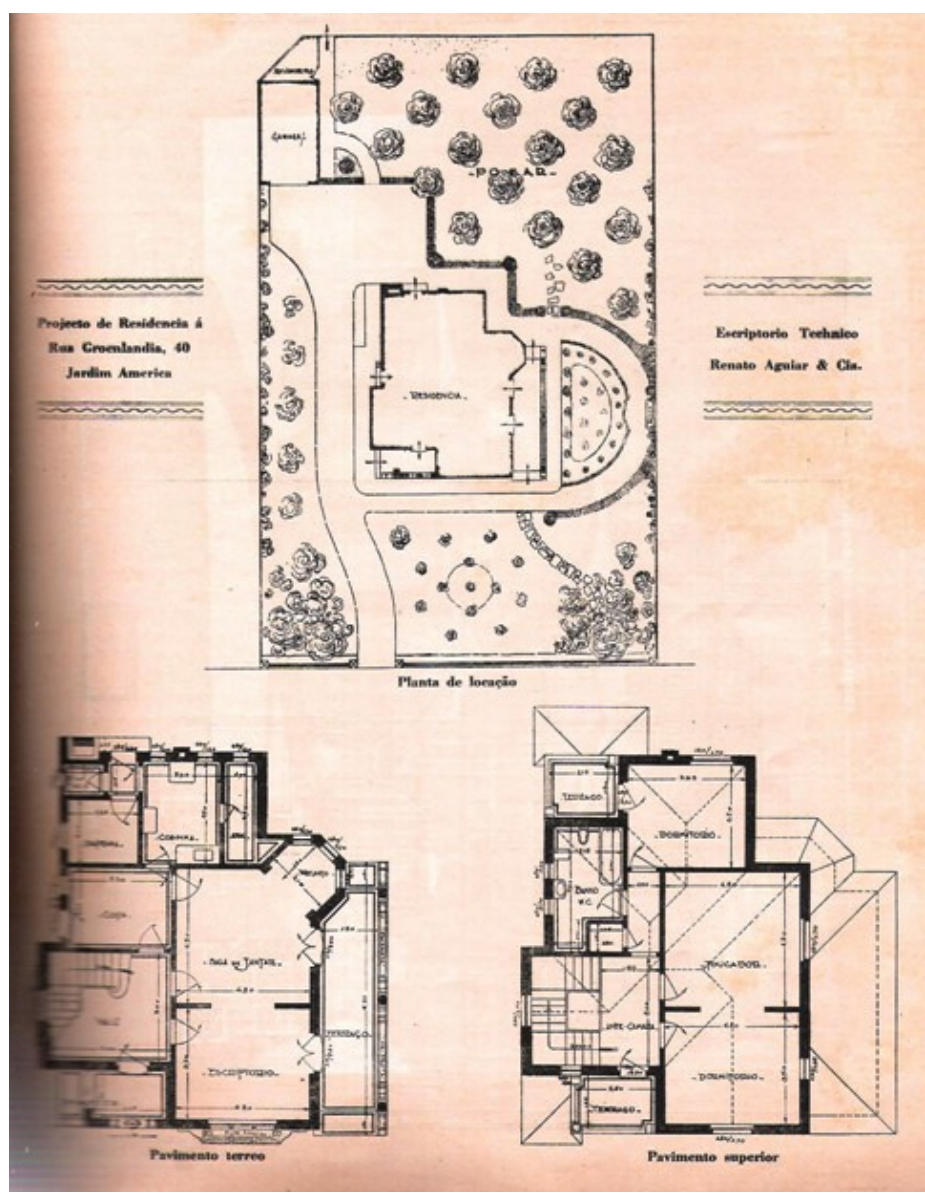

Fig. 5.61 "Palacete" no Jardim América, plantas baixas e implantação. 


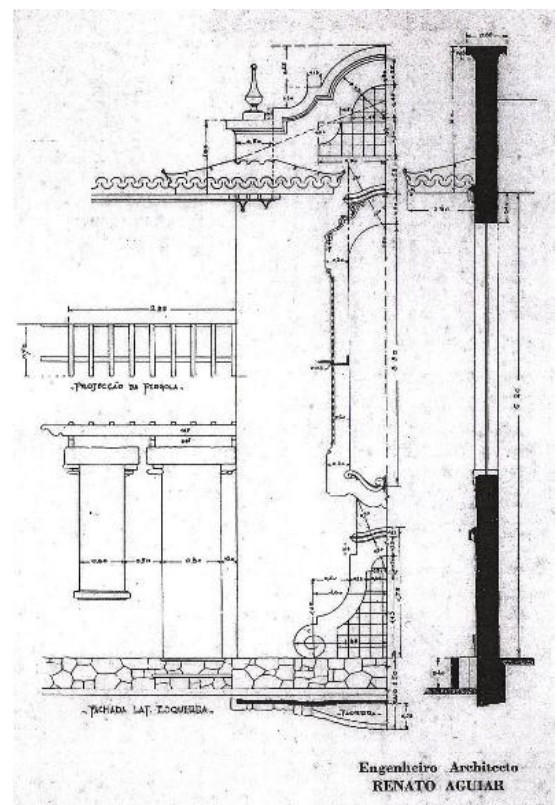

Fig. 5.62 "Palacete" no Jardim América, detalhes construtivos.

Aqui, Renato Aguiar mostra mais domínio do projeto e um equilíbrio que não existia em suas casas anteriores, que aparecem no álbum Jardim América. A planta está muito bem resolvida, apesar das paredes do térreo e do pavimento superior coincidirem. Parece haver diálogo entre planta e distribuição dos volumes.

Provavelmente aconteceu um amadurecimento desde seus primeiros projetos em parceria com Diciatteo, quando ele acabara de se formar. Nesta época - 1927 -, sua firma já se chamava Renato Aguiar \& Cia. Apesar de certo exagero na quantidade de detalhes utilizados, principalmente na casa apresentada no número 44 da Revista de Engenharia do Mackenzie (Set. 1927, p. 21-22, "Página de Arquitetura"), "um palacete" na Rua Guadalupe, também no Jardim América, tais detalhes seguem a mesma linguagem, a do Neocolonial, e se harmonizam com o todo.

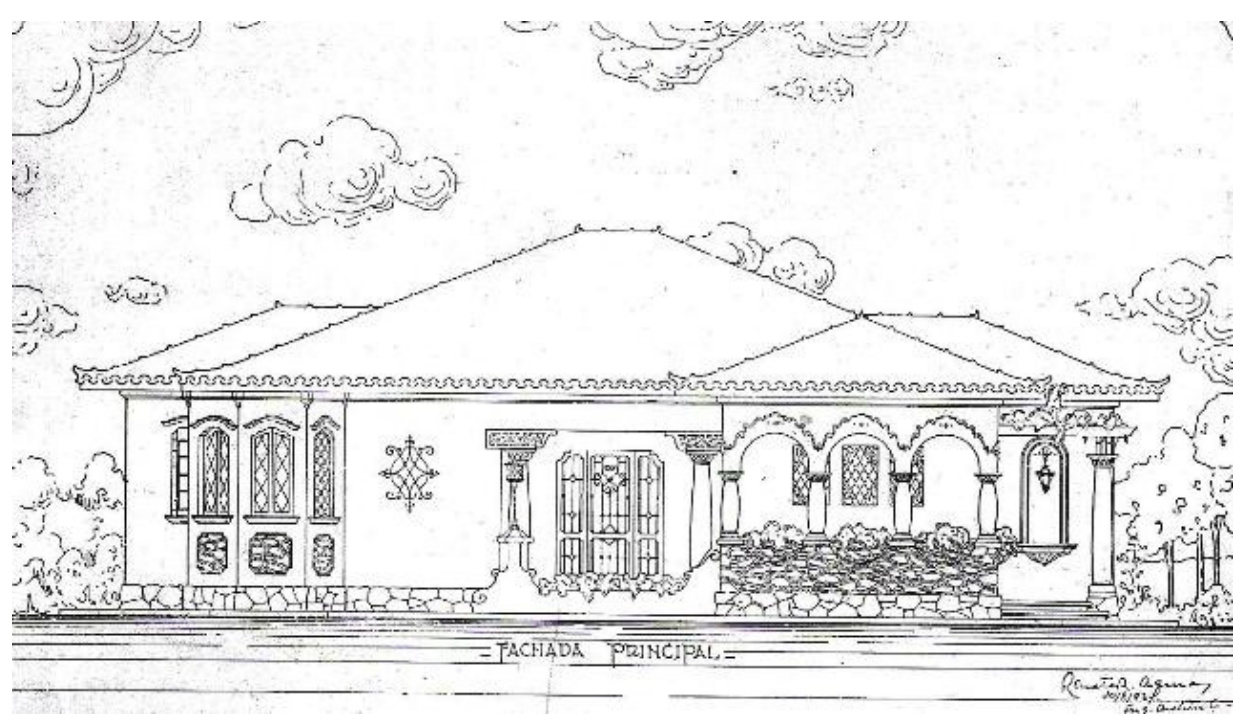


Fig. 5.63 e Fig. 5.64 "Palacete” no Jardim América, Rua Guadalupe, fachada principal e planta baixa.

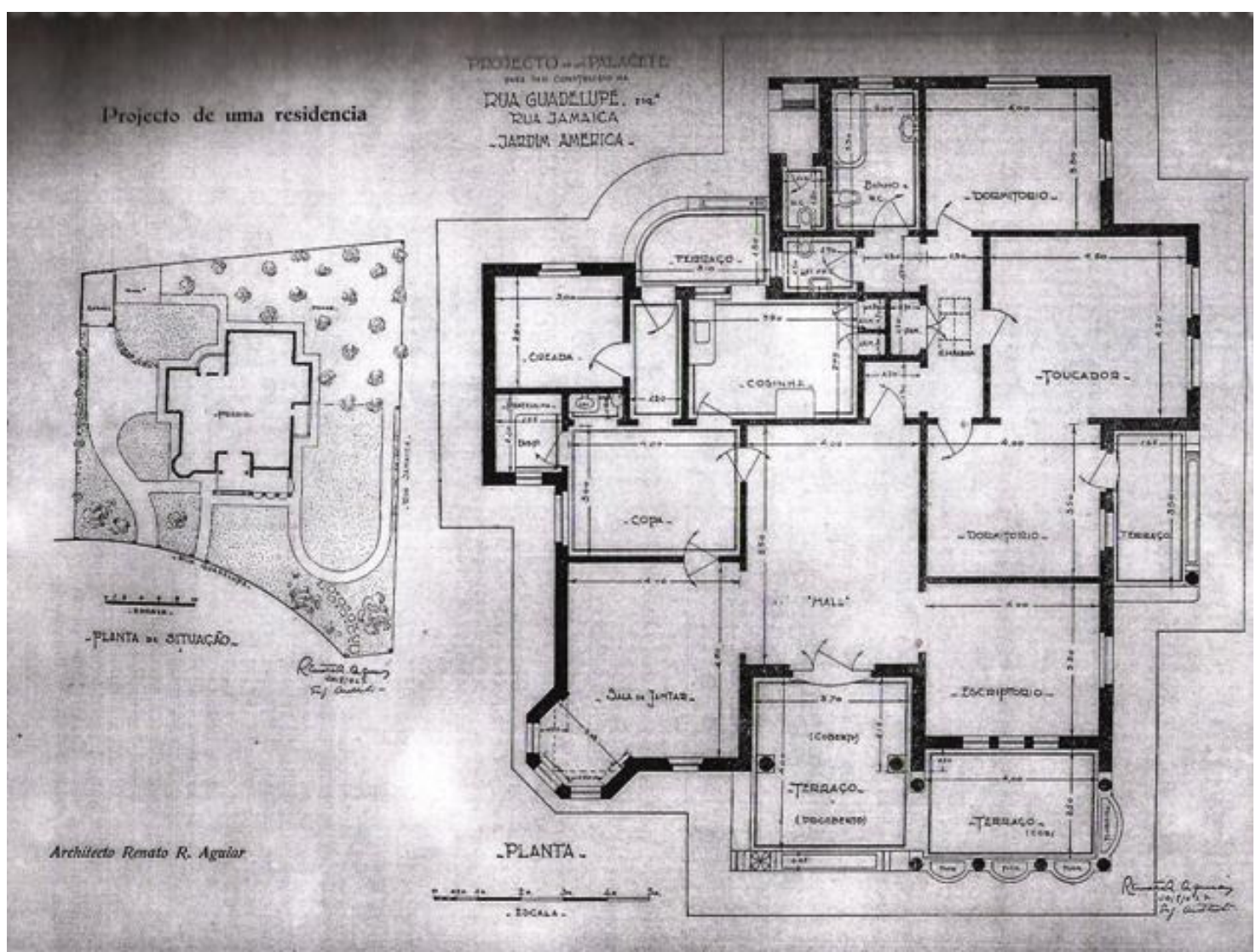

\subsubsection{Olavo Soares Caiuby}

Olavo Caiuby ${ }^{24}$ formou-se na Escola de Engenharia do Mackenzie. Seu anúncio na Revista de Engenharia do Mackenzie o apresentava como engenheiro civil e arquiteto, com escritório à Rua Líbero Badaró.

Caiuby aparece como "colaborador efetivo" da revista Architectura e Construç̧ões, ao menos desde o seu $2^{\circ}$ número (setembro de 1929). No ano de 1933, era presidente do Instituto Paulista de Arquitetos - IPA. (FICHER, 2005, P. 235).

O arquiteto tem cinco casas publicadas no álbum Jardim América e outros seis projetos seus foram encontrados nos arquivos da Companhia City.

Olavo Caiuby também atuava como empreiteiro, como atesta a carta de um proprietário dirigida à Companhia City - anexada ao projeto de código 02.01.278.257 -,

\footnotetext{
${ }^{24}$ No número 52-3 da Revista de Engenharia do Mackenzie (junho 1930), com alunos e ex-alunos do Mackenzie, aparecem dois projetos de Olavo Caiuby, confirmando este fato.
} 
datada de 4 de agosto de 1922, dizendo que fora contratado para executar a obra de ampliação da casa que estaria sendo construída à Rua Estados Unidos, n. 25. Provavelmente, esta ampliação justificaria um novo financiamento a ser concedido pela companhia. O projeto original era também do arquiteto - de março de 1922. O valor desta segunda empreitada era de 3 contos e 300 mil réis.

No memorial de construção pode-se ter uma descrição dos materiais e técnicas utilizadas. Externamente, alvenaria aparente, com embasamento e faixa junto ao beiral pintados; cobertura com telhas marselhesas; lajes de concreto com espessura de 10 $\mathrm{cm}$ apenas no banheiro do pavimento superior, como era usual à época.

Quanto aos pisos, seriam utilizados ladrilhos "nacionais finos" no hall e no banheiro; e "nacionais de cimento" na cozinha, passagem e terraço. Os demais ambientes receberiam assoalho de peroba - tábuas de 8 a $9 \mathrm{~cm}$ sobre vigotas embutidas no concreto do piso. No segundo pavimento, seriam utilizadas também as tábuas de peroba sobre vigas da mesma madeira $(17 \times 7 \mathrm{~cm})$. Sobre a sala de jantar e escritório, tais vigas ficariam aparentes, assim sua parte inferior seria aparelhada ${ }^{25}$.

As esquadrias seriam de madeira, e entre o estar e jantar haveria uma porta envidraçada de quatro folhas. Lemos (1989, p. 186), comentando as casas de classe média da época, observa que: "Suas plantas sempre possuíam o hall de distribuição e necessariamente a 'sala de visitas' em separado da sala de jantar por uma larga porta toda envidraçada com cristais lapidados."

A escada também seria executada em madeira.

Sob uma parede do banheiro do pavimento superior, seria utilizada uma viga metálica - que aparece também em vários outros projetos pesquisados. Alambert (2003, p.92), em sua tese sobre a arquitetura residencial paulistana no entre-guerras, mostra que as vigas metálicas eram comumente usadas para vencer vãos entre paredes, sustentando as lajes de concreto armado do pavimento superior e da cobertura. Eventualmente, o concreto armado era também utilizado para a fabricação de elementos de composição de fachada como os frisos e outros detalhes.

No banheiro do pavimento superior haveria água quente e fria, armazenada em caixas d'água.

A pintura dos banheiros e cozinha seria feita com tinta a óleo.

\footnotetext{
${ }^{25}$ As vigas aparentes de madeira estavam sempre presentes nos ambientes térreos de Barry Parker e Voysey.
} 
A transmissão de energia entre a casa e o alinhamento da rua seria subterrânea (provavelmente exigência da Companhia City). Já havia rede de abastecimento de gás, pois consta um medidor para este fim no memorial.

Localizada no centro de um terreno de $27,31 \mathrm{~m}$ de frente por $29,01 \mathrm{~m}$ de fundos, a casa apresenta recuos laterais, de $8,93 \mathrm{~m}$.

A planta do pavimento superior era a usual, acrescida de uma espécie de roupeiro, que ainda não era comum nas casas de classe média.

$\mathrm{Na}$ foto da casa é possível ver a ampliação mencionada - que se constituía de um quarto e uma despensa - que não aparece na planta original. Esta adição permitiu a execução de um terraço no pavimento superior.

Influências de Dubugras, além do tijolo aparente, são as três pequenas esquadrias que acompanham a subida da escada. Existe correspondência entre os volumes da casa e sua planta. Parecem ter sido pensados conjuntamente, como no efeito do grande telhado que desce do segundo pavimento e cobre a varanda, aparecendo na fachada principal e sendo aproveitado para a colocação da escada. Uma sensação geral de espontaneidade é reforçada pela falta de hierarquia entre as fachadas e pelo tratamento pinturesco dado a elas. Detalhes como a madeira da empena e a diferenciação entre térreo e pavimento superior lembram os cottages de Barry Parker para Letchworth.

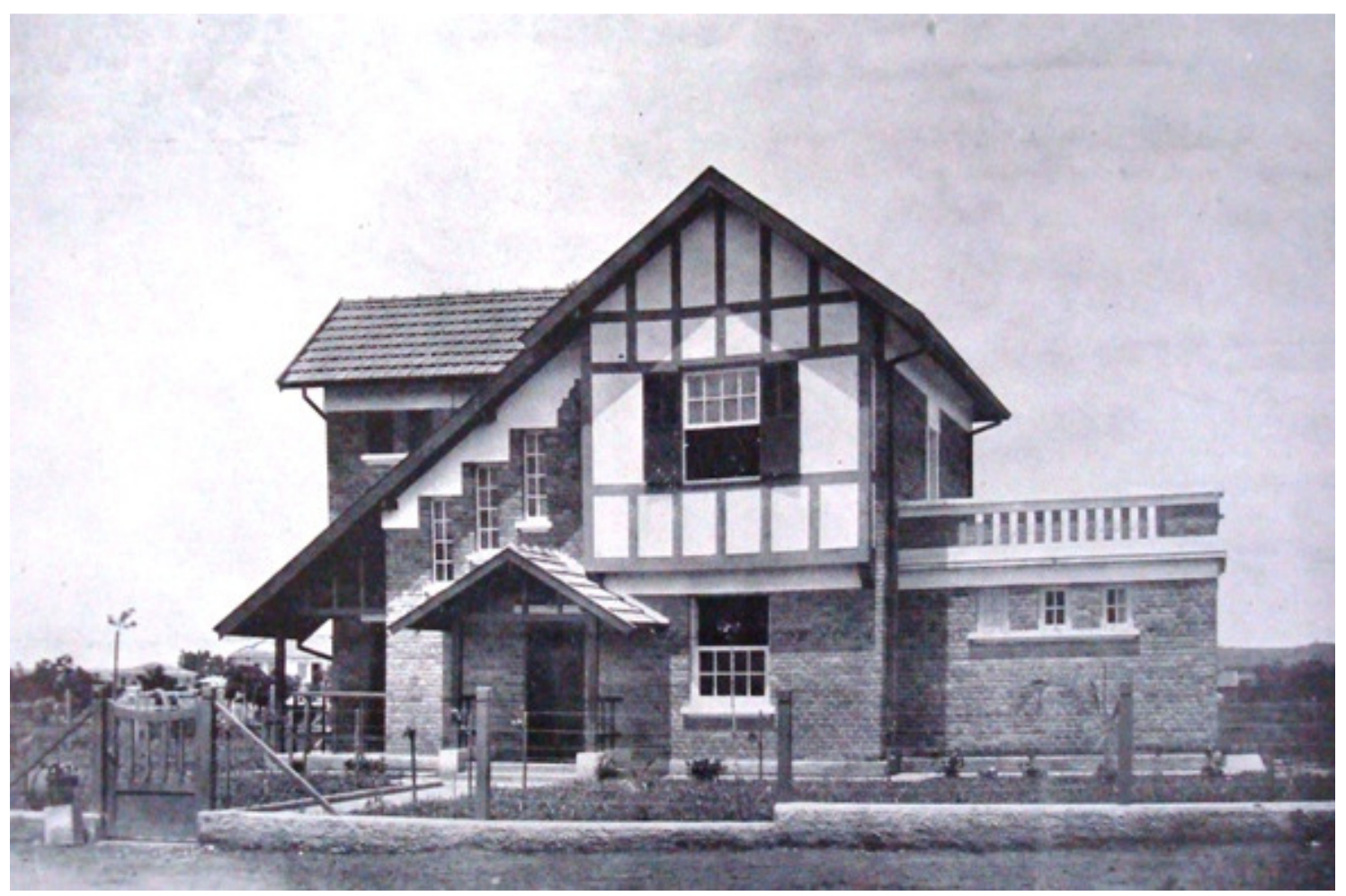

Fig. 5.65 Casa na Rua Estados Unidos. 


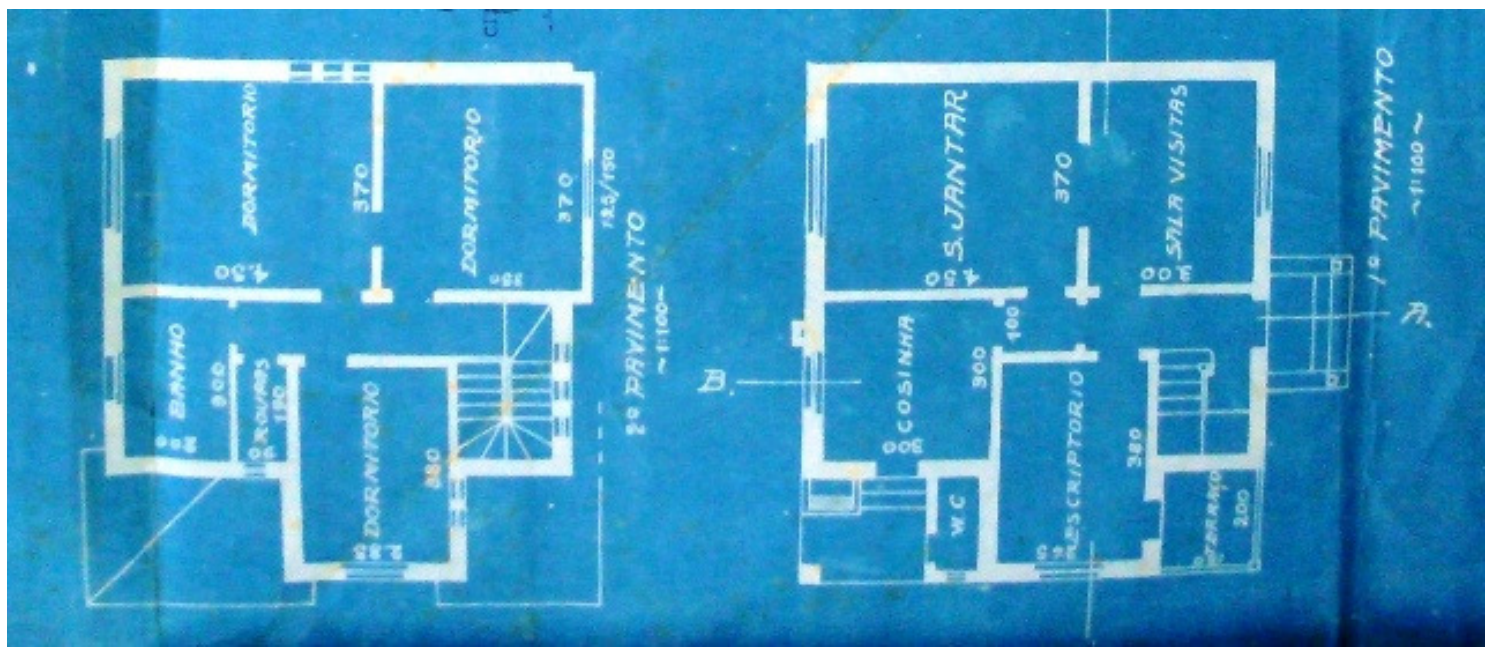

Fig. 5. 66 Casa na Rua Estados Unidos, plantas baixas.

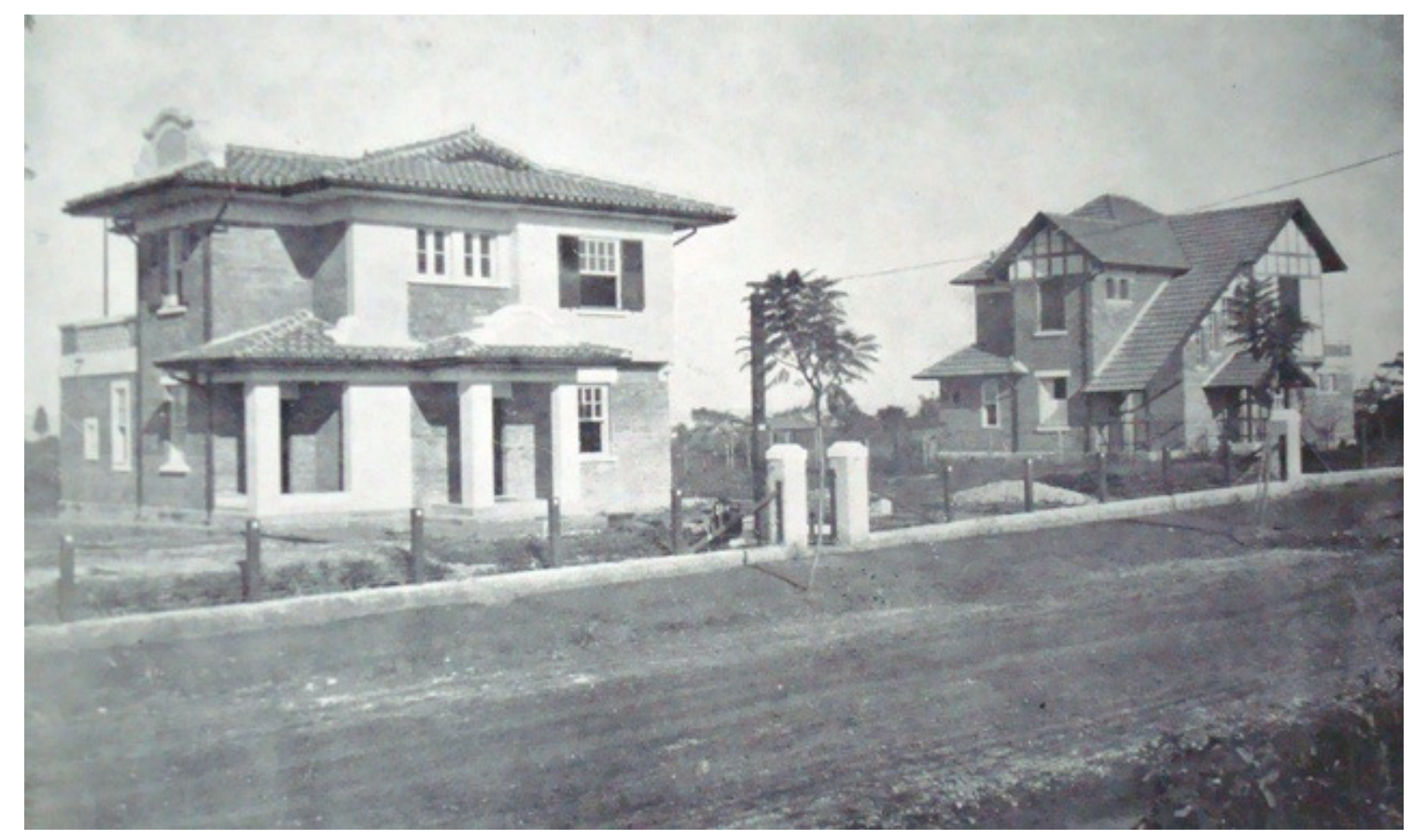

Fig. 5.67 Casas do arquiteto na Rua Estados Unidos.

Outro sobrado da autoria de Olavo Caiuby aparece no álbum publicado pela Companhia City, ao lado da casa anterior, fotografada de outro ângulo. Uma concepção totalmente diversa do projeto anterior, lembrando o Neocolonial praticado por Dubugras, no contraste existente na fachada entre pintura e tijolos aparentes, no telhado com grandes beirais e nos discretos detalhes neocoloniais - frontão e guardacorpo da sacada. 
Outra casa, na Rua Guadalupe, tem composição simétrica com detalhes também neocoloniais.

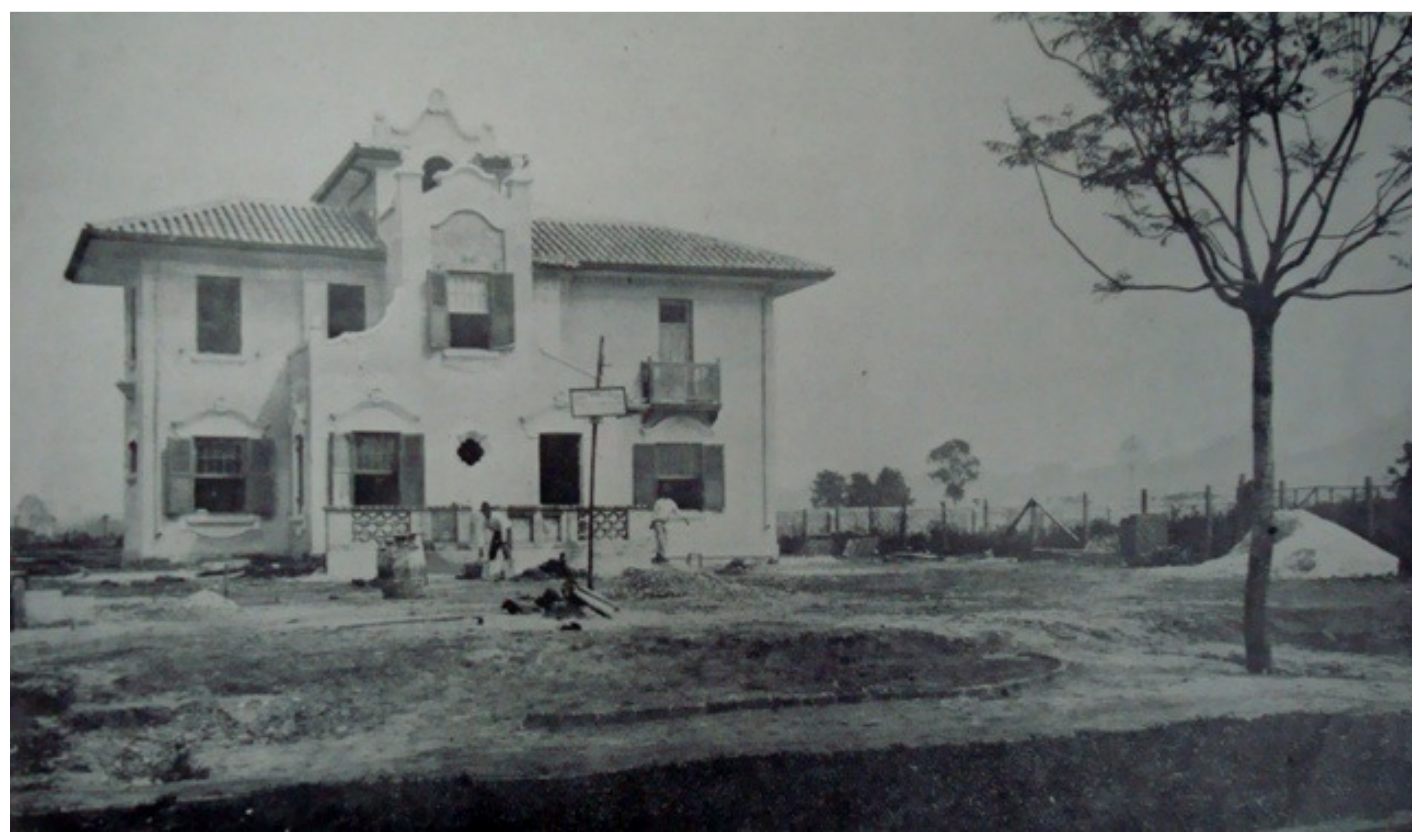

Fig. 5.68 Casa na Rua Guadalupe

Outro sobrado neocolonial foi encontrado nos arquivos da Companhia City ${ }^{26}$ (código 08.02.272.257), de abril de 1929, posterior à publicação do álbum Jardim América, localizado na Rua Venezuela, n.10. Além do projeto, existe o memorial descritivo. ${ }^{27}$

Aparecem detalhes neocoloniais como o frontão, a faixa contínua sobre as janelas e os relevos decorativos pré-moldados executados em cimento. A casa tem um programa próximo de um palacete, com vários cômodos na área social e no serviço inclui até uma adega. Existem circulações verticais independentes até o patamar da escada. $O$ arquiteto tem sempre a preocupação com pequenos detalhes, como os vários armários na circulação do pavimento superior. Nos fundos, como era ainda comum, várias dependências, horta e locais para criações.

Na planta baixa do térreo, existem indicações de vigas metálicas sob as paredes do pavimento superior, com as respectivas dimensões. No memorial, aparece menção a lajes de concreto, mas não é especificada a localização.

\footnotetext{
${ }^{26}$ O projeto é de 1928, como consta na planta e também aparece o autor do desenho, algo que não havia sido observado ainda nos projetos.

${ }^{27} \mathrm{O}$ memorial descritivo provavelmente tinha duas funções. Era uma espécie de contrato com o cliente para a construção da casa - o memorial mencionado encontra-se até mesmo carimbado por um tabelião -, onde eram apresentados até preços aproximados dos pisos a serem utilizados. Também serviria para que, juntamente com a planta, a Companhia City determinasse o valor do financiamento a ser concedido ao proprietário do terreno para a construção.
} 


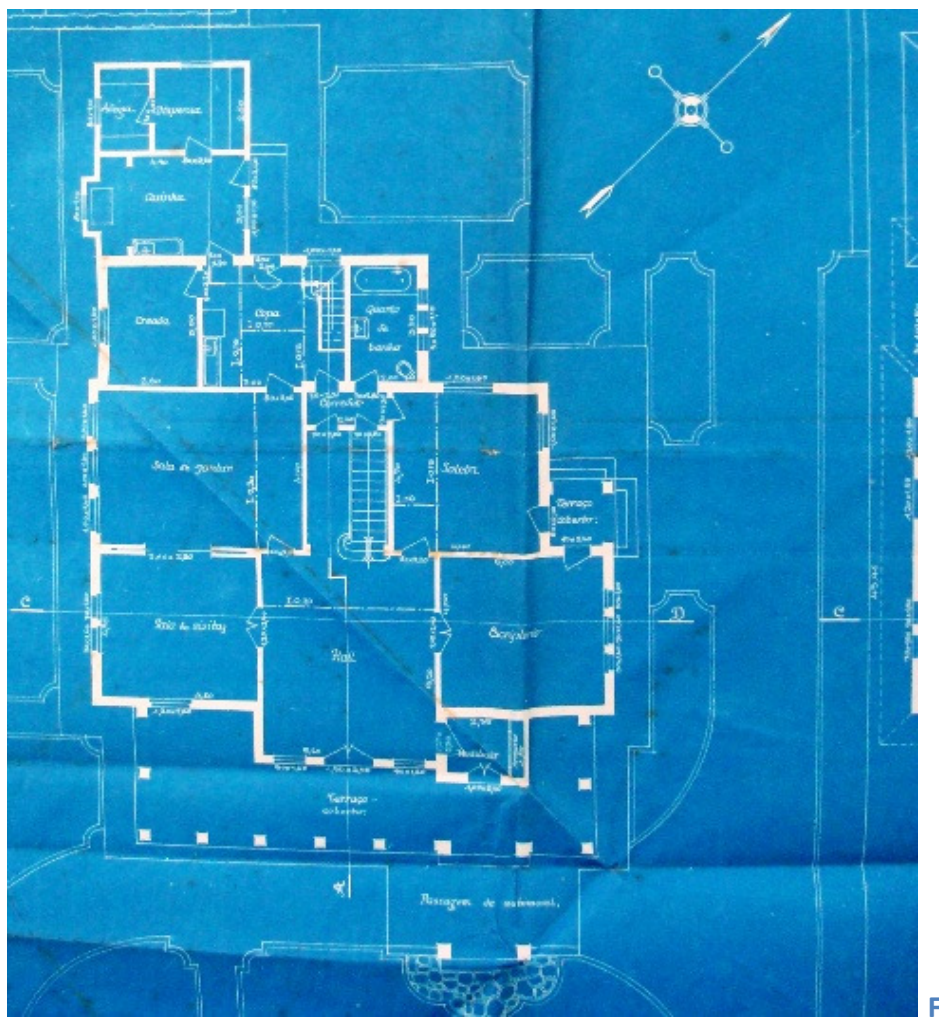

Fig. 5.69 Casa na Rua Venezuela - térreo

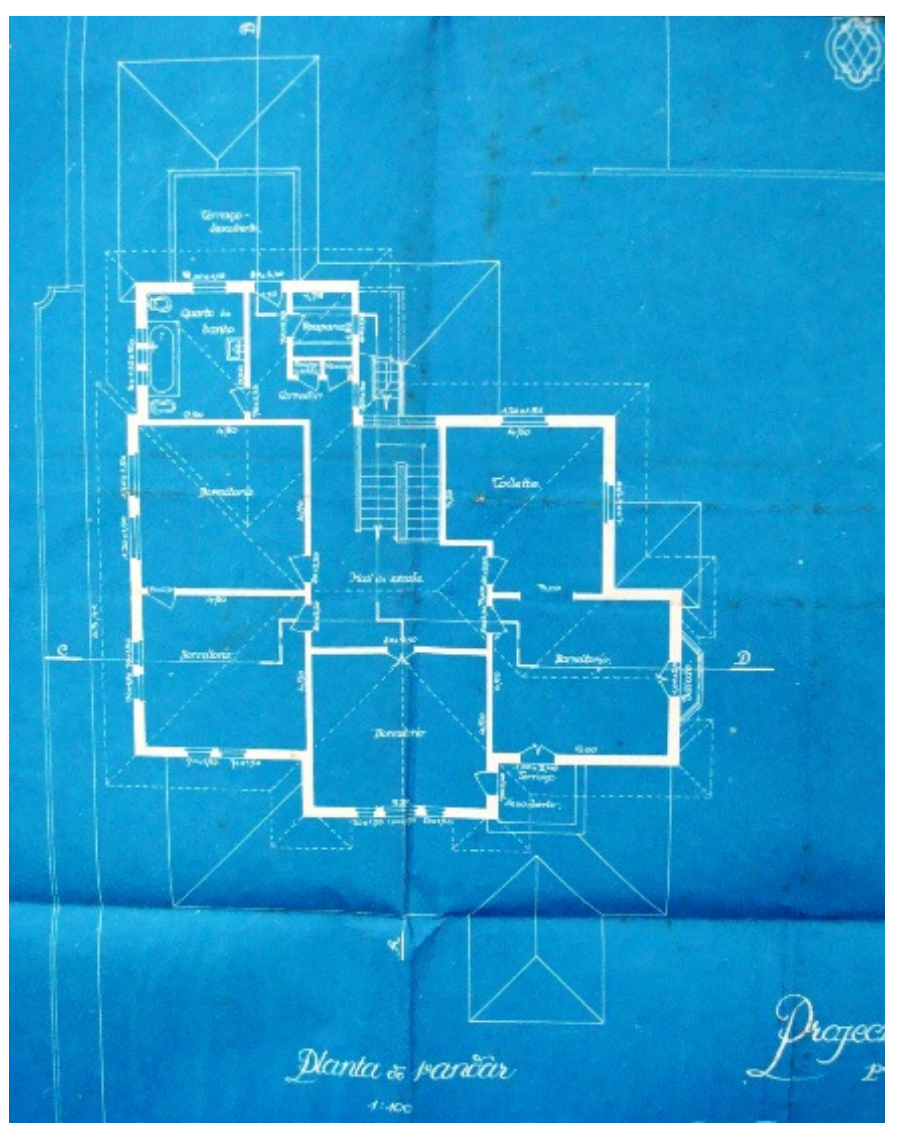

Fig. 5.70 Casa na Rua Venezuela - pavimento superior.

318 I C a pítulo 5 


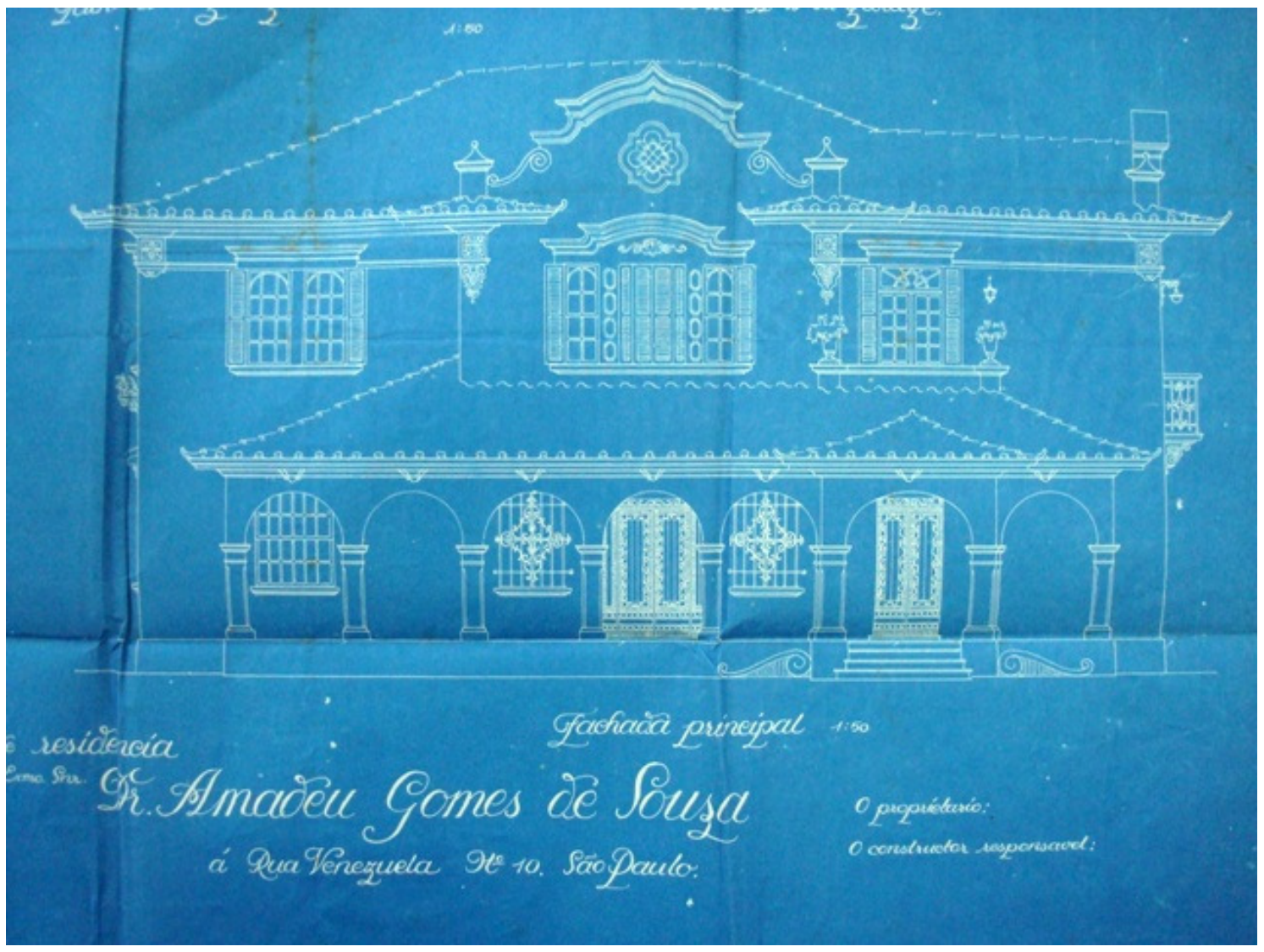

Fig. 5.71 Casa na Rua Venezuela - fachada principal.

Caiuby sempre resolve bem seus projetos. Nas casas menores, todo o programa está contido sob um único telhado, inclusive a área de serviço - que se resume a um pequeno espaço com um tanque - e o quarto para os empregados.

O projeto datado de setembro de 1923 (código 18.04.072.250), situado na Rua Colômbia, 22 refere-se a uma pequena casa térrea com dois dormitórios, um "toillette"28 e um banheiro. O setor íntimo tem circulação independente entre seus cômodos. Os três setores da casa, social, íntimo e de serviço, estão separados e a circulação entre eles é feita através do hall. O setor social tem três cômodos integrados, através de grandes aberturas, e no hall há uma lareira. Um terraço frontal provavelmente era utilizado como prolongamento destas áreas de estar da família. $\mathrm{Na}$

\footnotetext{
${ }^{28}$ Aparece em muitas casas do Jardim América, principalmente nas maiores, o cômodo chamado "toilette", anexo ao dormitório principal. Na cultura européia do século XIX, era um local ligado ao universo feminino, de permanência prolongada e preservada da mulher. Nestes espaços, onde havia escrivaninhas, poltronas, cômodas, guarda-roupas e penteadeiras, a dona de casa na cultura burguesa dedicava-se a escrever cartas, dar ordens a empregados graduados, vestir-se e arrumar-se. (WOLFF, 2000, p.157).
} 
cozinha, existe ainda a previsão para fogão a lenha e outro ambiente que funcionaria como uma pequena copa ${ }^{29}$, tendo também uma pia para lavagem de louça.

A planta é assimétrica. Este pequeno e descontraído bangalô completa-se com a alvenaria em tijolos aparentes, enquadrados pela alvenaria pintada, a varanda de acesso, uma pequena chaminé e as jardineiras nas janelas. Um "lar alegre e luminoso", cheio de pequenos detalhes pinturescos e delicados.

E cercado pela vegetação, como mostra o belo desenho de Olavo Caiuby - seus projetos são sempre representados em meio à vegetação, reforçando o clima campestre.

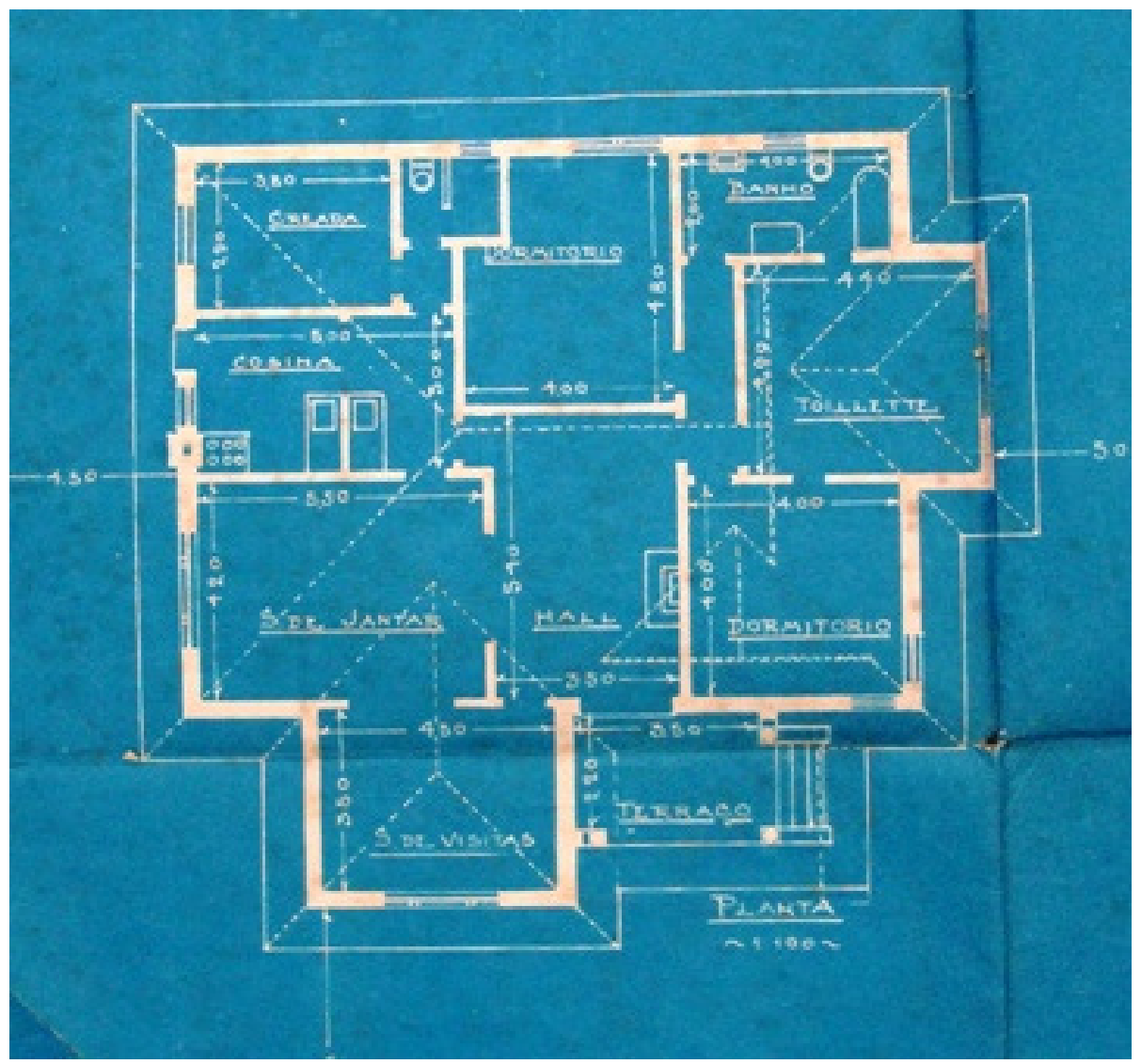

Fig. 5.72 Casa na Rua Colômbia - planta baixa-térreo.

\footnotetext{
${ }^{29}$ A introdução da copa nas casas de classe média paulistana aconteceu nos anos 1920, passando a funcionar como um espaço de convivência doméstica; o local onde a família se reunia de maneira informal para fazer as refeições do dia, substituindo as funções de estar da antiga varanda. Situada junto à cozinha, a copa configurava-se nestas casas como um cômodo de transição entre a zona social(salas de estar e jantar) e a de serviço (cozinha, dependências de serviço, quarto da criada e o quintal). (D'ALAMBERT, 2003, p. 99).
} 


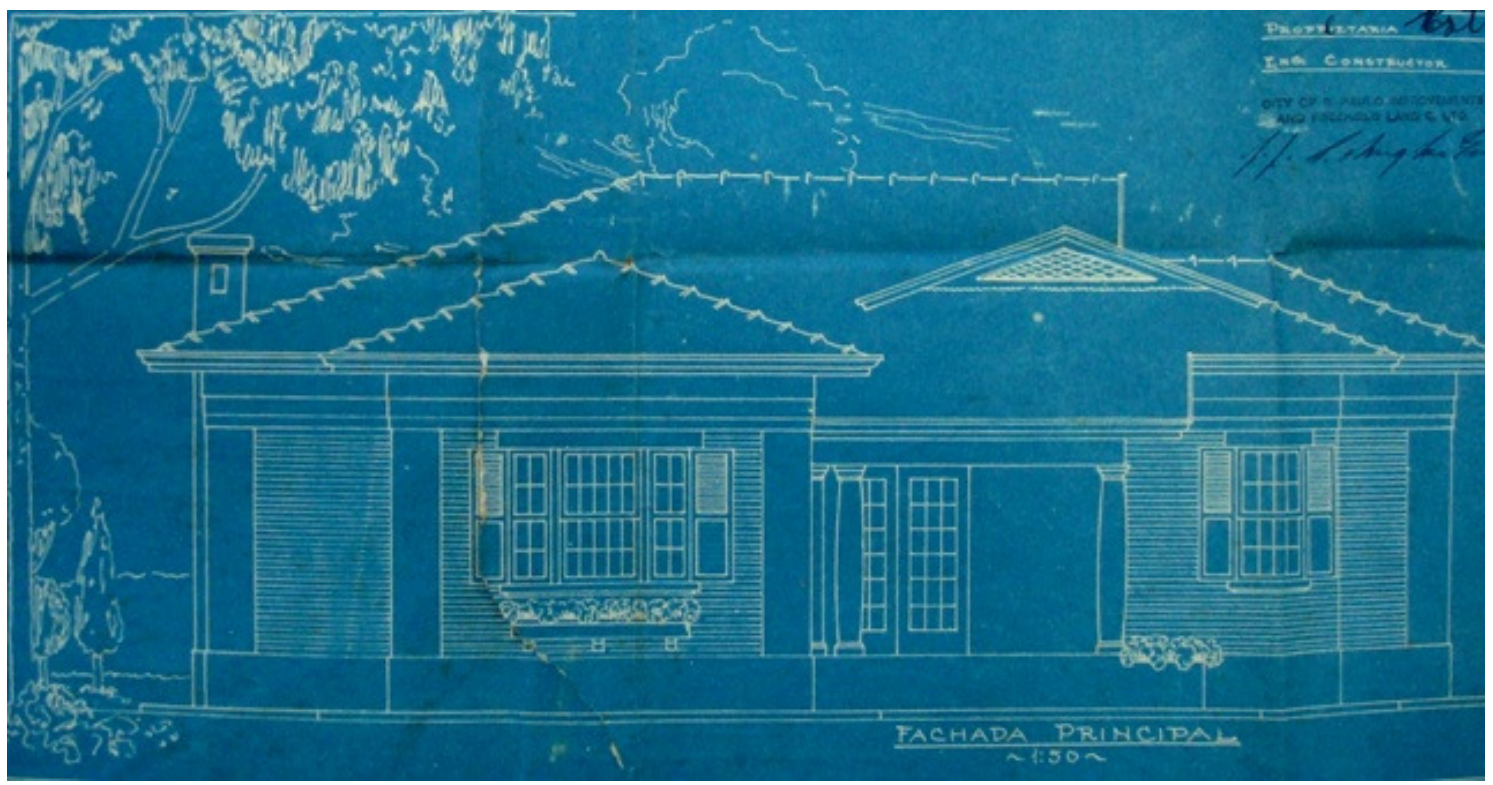

Fig. 5.73 Casa na Rua Colômbia - fachada.

Outra casa (código 18.12.191.254), de janeiro de 1924 na Rua Panamá, n.11, não aparece no álbum Jardim América, semelhante a esta, no programa e no aspecto externo. A planta não é assimétrica como a anterior, e está quase totalmente contida em um quadrado, compensada pela movimentação do telhado.

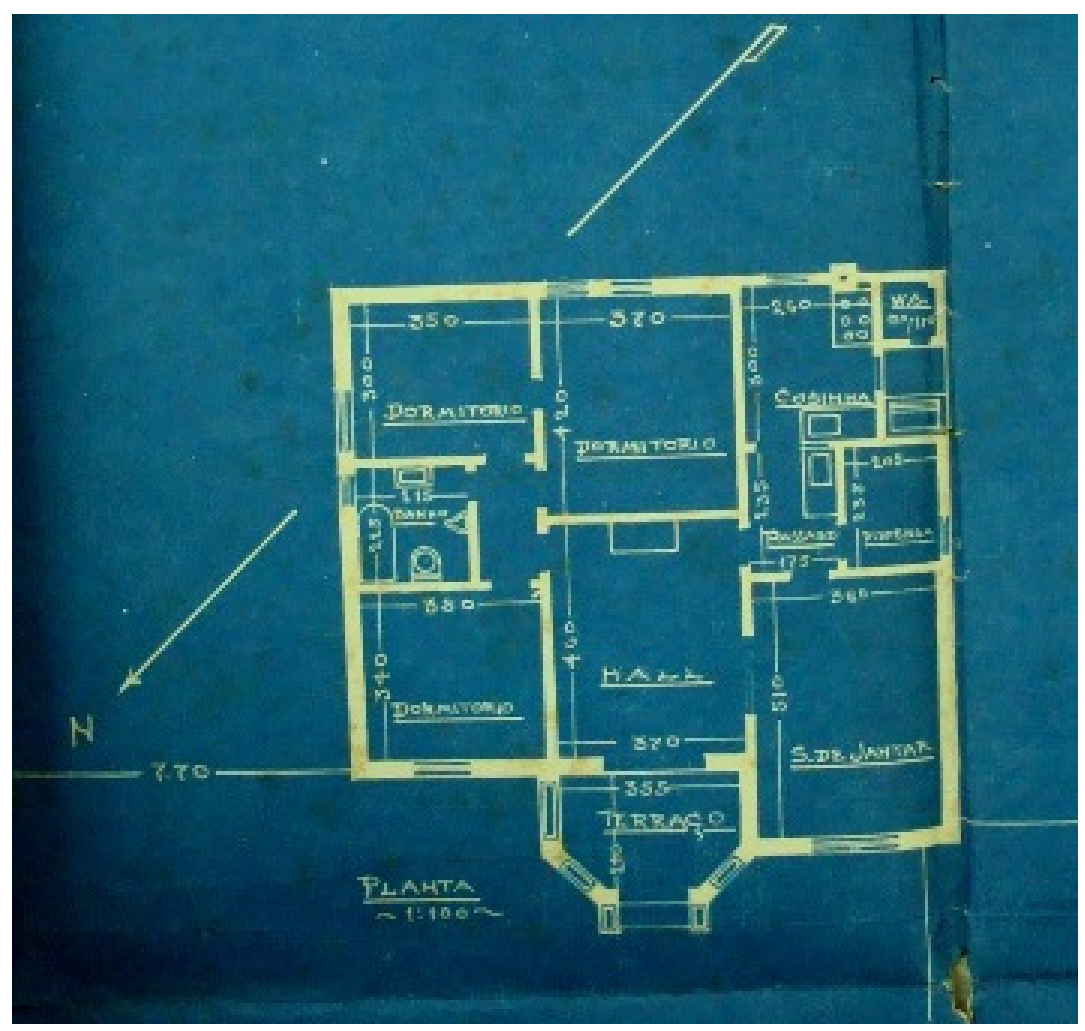

Fig. 5.74 Casa na Rua Panamá - planta baixa-térreo. 
E, ainda de Caiuby, outro bangalô com planta similar (código 15.13.374.261), de setembro de 1924, à Rua Nicarágua, n.4. Detalhes verticais - em alvenaria pintada se contrapõem à horizontalidade da casa. Que aparece também na Revista de Engenharia do Mackenzie (março 1927, n.41), na "Página de Arquitetura", como uma "Residência para casal no Jardim América", com planta baixa e foto.

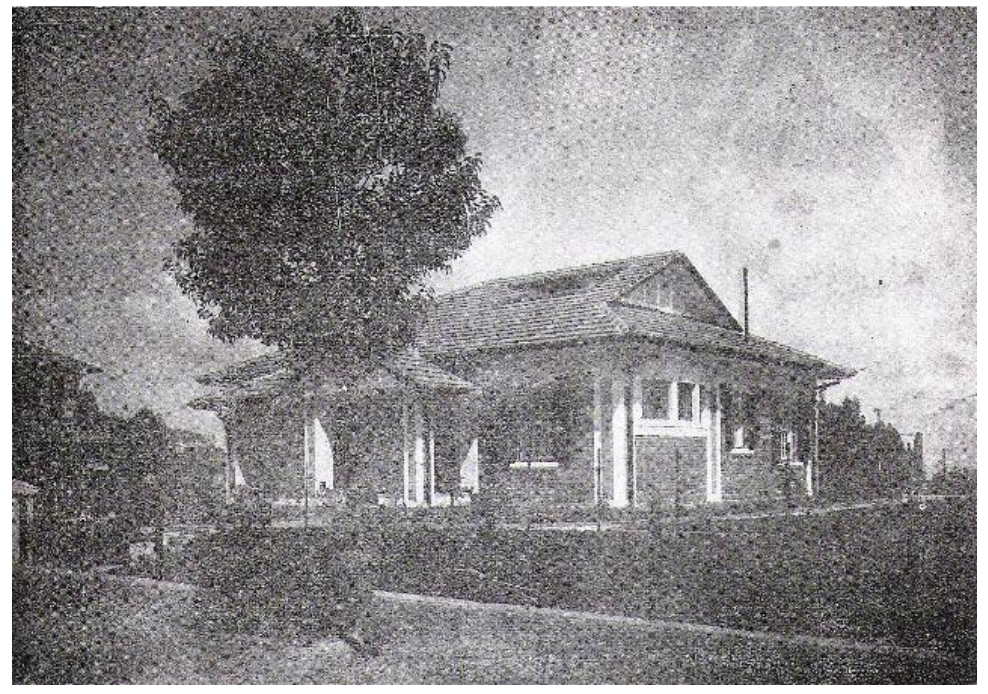

Fig. 5.75 Casa na Rua Nicarágua.

Outra casa com a mesma linguagem aparece no álbum da City, na Rua Estados Unidos.

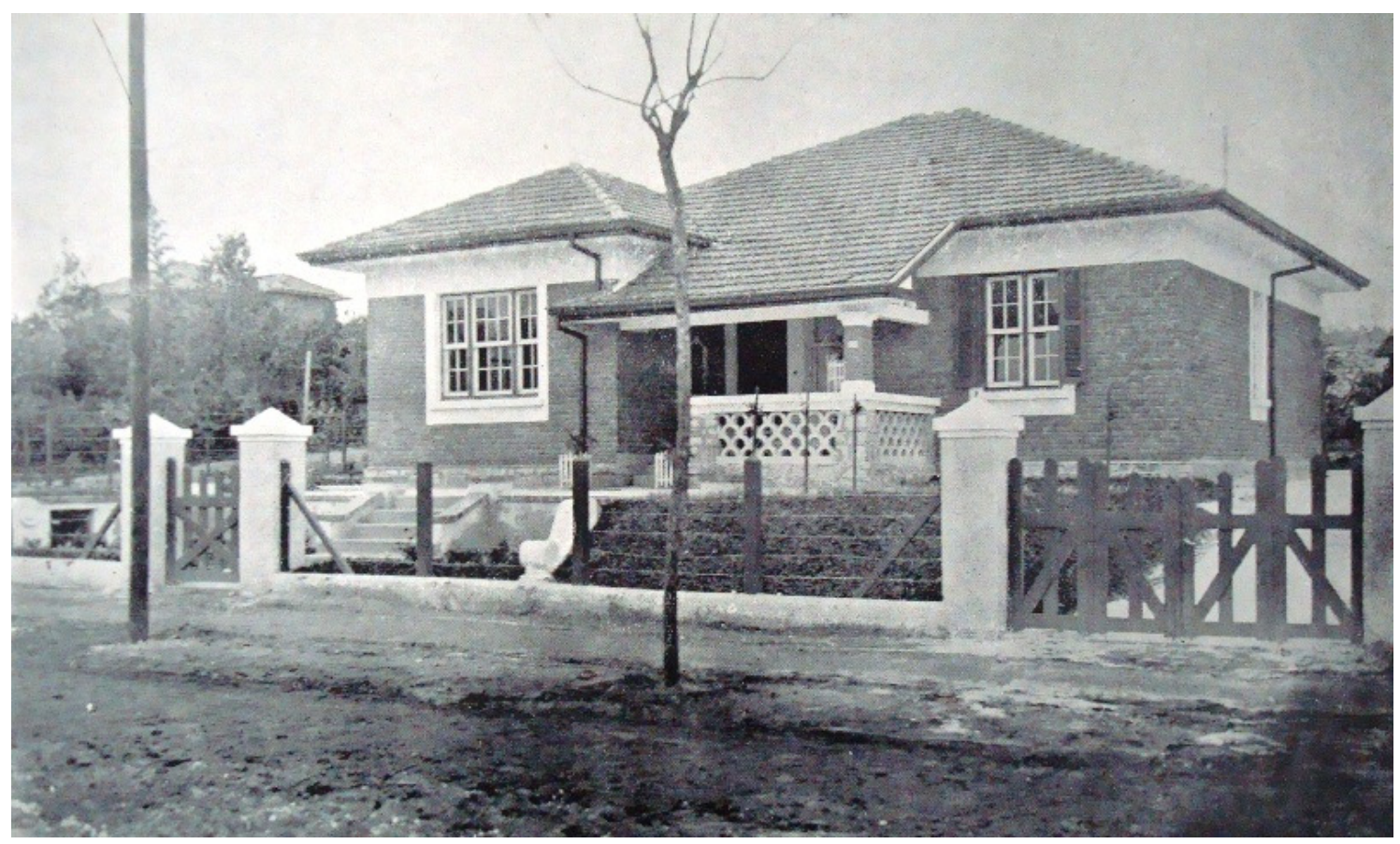

Fig. 5.76 Casa na Rua Estados Unidos. 
$\mathrm{Na}$ Revista de Engenharia do Mackenzie (dezembro 1928, n, 49), na "Página de Arquitetura", é mostrado um projeto de Olavo Caiuby, na Rua Peru, n.3, no Jardim América, também encontrado nos arquivos da Companhia City (código 36.03.059.249), datado de maio de 1927. Falta certa leveza a casa, Neocolonial; os arcos da varanda no térreo e outros detalhes em número excessivo desviam nossa atenção de outros elementos, como a bela chaminé que na fachada lateral direita faz contraponto ao frontão no lado esquerdo da fachada frontal. É importante notar que à medida que as casas do Jardim América vão crescendo em área e se sofisticando, o próprio fechamento frontal do terreno torna-se mais elaborado. Ao invés dos portões de madeira e das cercas de arame farpado das primeiras casas, vemos pilaretes de alvenaria com pináculos e grades e portões de ferro com desenhos.

A planta baixa do térreo tem arranjo similar a dos bangalôs anteriores. A sala de estar tem as funções de hall e estar, com uma lareira. Na cozinha e na grande copa, espaços para armazenamento. O que seria um espaço para um piano na sala de visitas, transformou-se em outra varanda na construção. No pavimento superior, os três dormitórios e banheiro usuais, apenas acrescentada uma pequena copa.

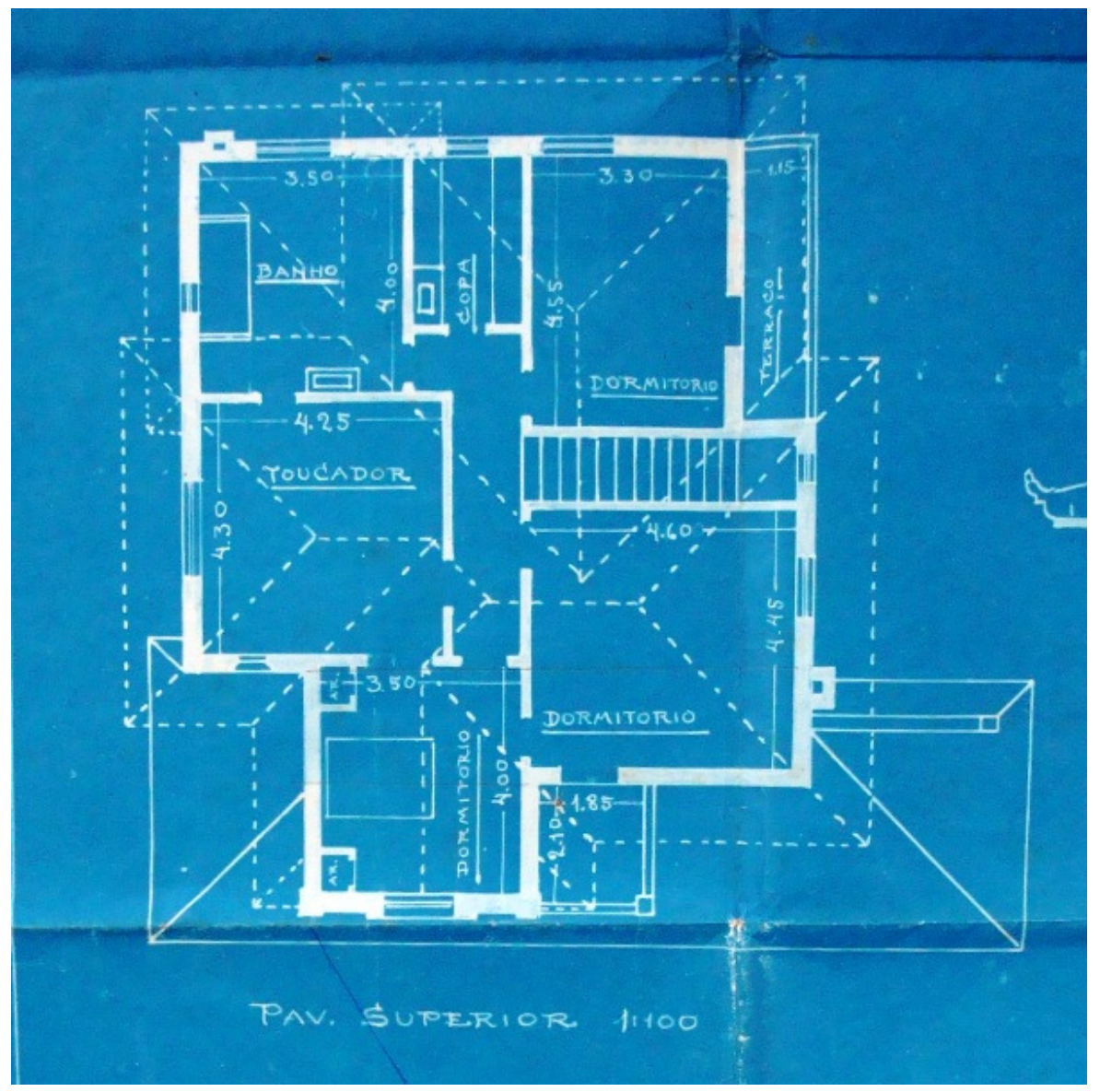

Fig. 5.77 Casa na Rua Peru, planta baixa - pavimento superior. 


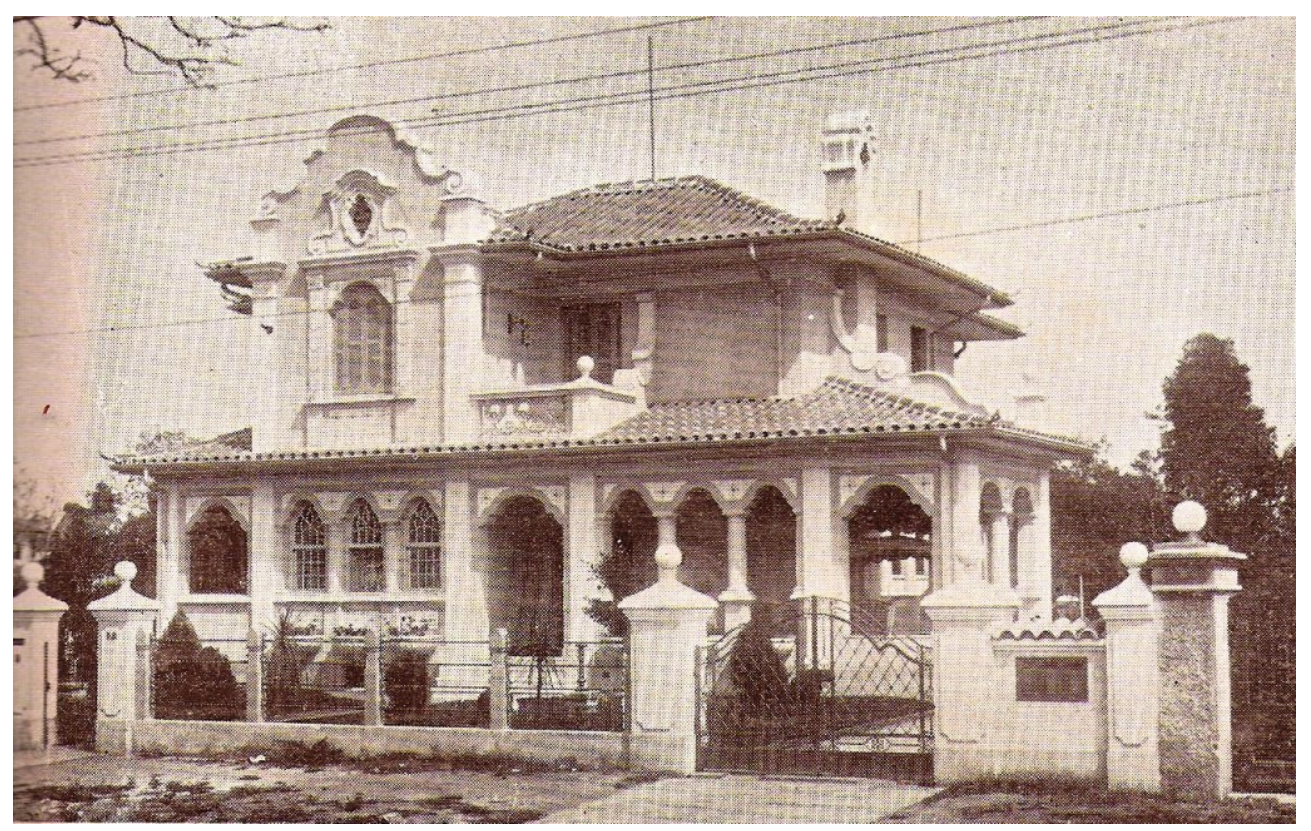

Fig. 5.78 Casa na Rua Peru.

Também de Caiuby é o projeto com código 38.07.350.260, do arquivo da Companhia City, de outubro de 1929, na Rua Argentina, 32. Trata-se de uma grande casa clássica, simétrica, mas com detalhes inusitados, como arcos que parecem góticos, cunhais de pedra e detalhes decorativos em alto relevo, do repertório do Neocolonial.

Já era final da década de 1920, e o Jardim América estava se transformando, as pequenas casas dos primeiros tempos dando lugar aos "palacetes" da época, como esta casa.

As vigas metálicas permitem grandes vãos nos salões do pavimento térreo, integrados por meio de grandes aberturas ao hall com lareira. Completa a área social um grande terraço frontal. Estas casas, com grandes salas integradas, abertas para o jardim, se tornariam comuns em fase posterior de ocupação do Jardim América, nos anos 1930, vinculadas muitas vezes ao estilo Missões. No setor de serviço, existe uma grande copa e uma cozinha racional e planejada, com fogão a gás, prateleiras, pia com duas cubas - além daquela da copa - mesa e um armário embutido. Percebe-se a preocupação com a seqüência das tarefas a serem executadas na cozinha. Isto confirma o que foi dito sobre as cozinhas paulistanas - que sofreriam transformações a partir do final dos anos 1920 -, no capítulo 4 desta dissertação. E na copa, já aparece a geladeira, ainda chamada pelo nome da marca: "Frigidaire". No pavimento superior, a presença de dois banheiros caracteriza-se como uma inovação, além dos armários embutidos nos dormitórios. 


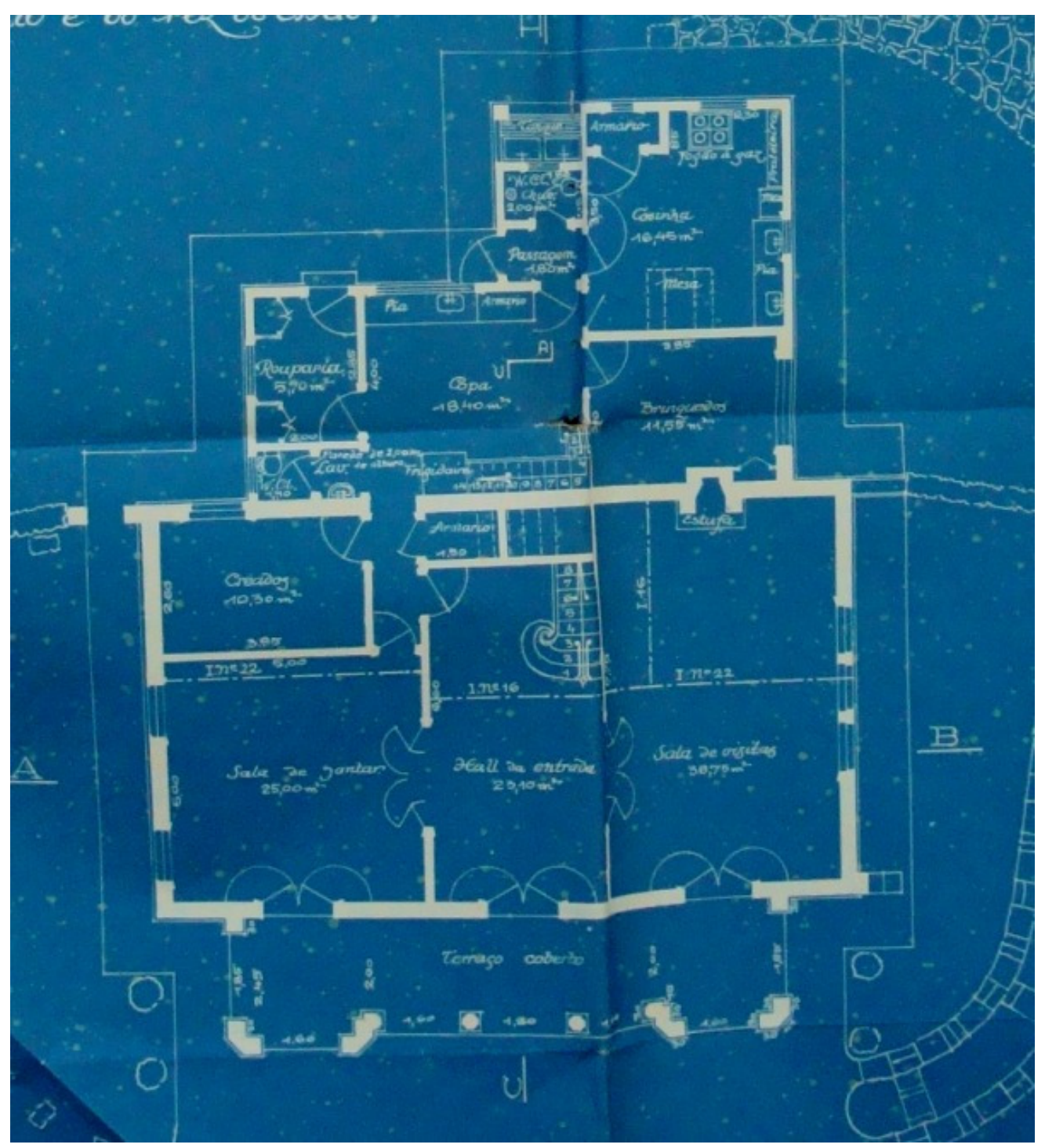

Fig. 5.79 Casa na Rua Argentina- planta baixa - pavimento térreo.

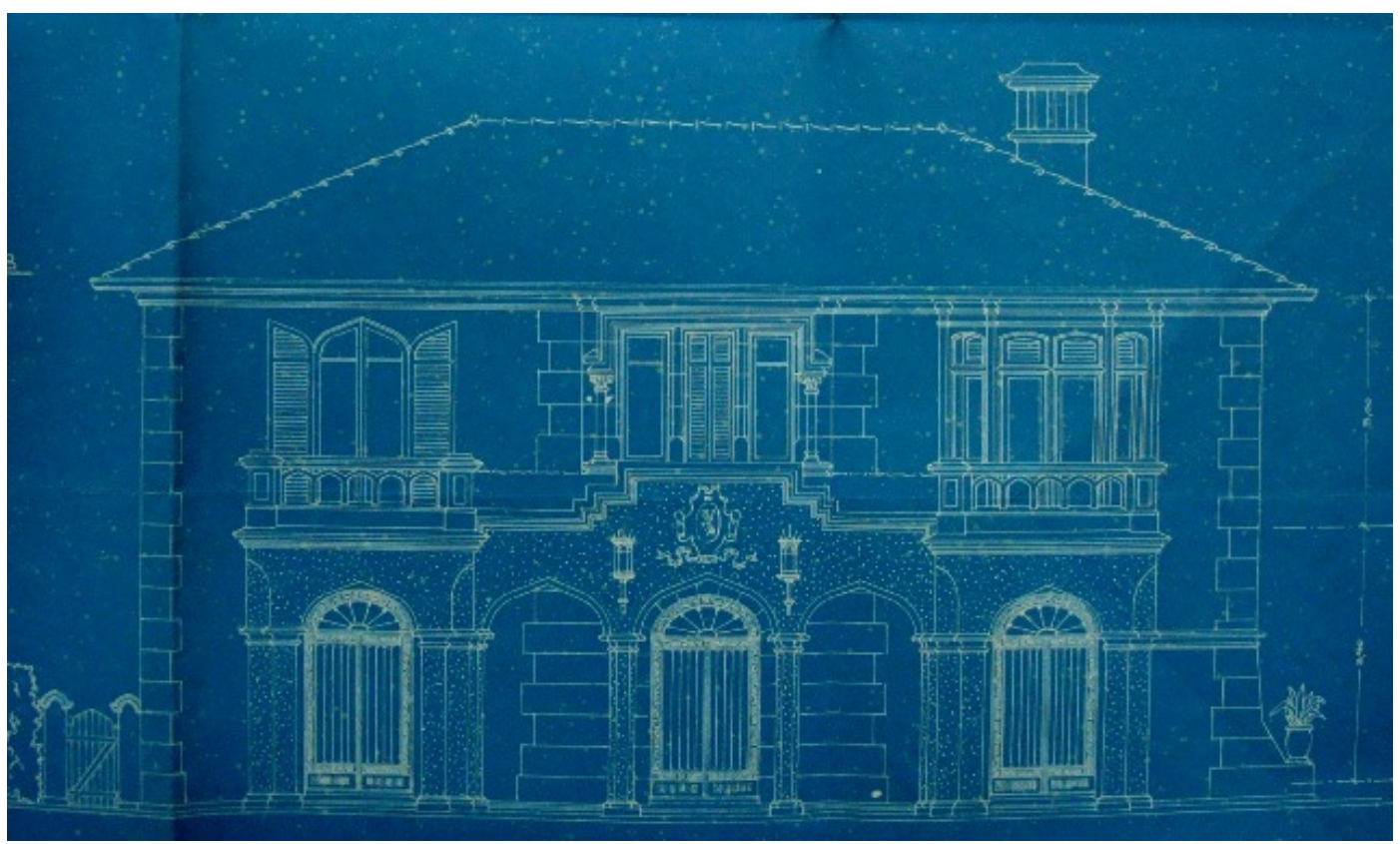




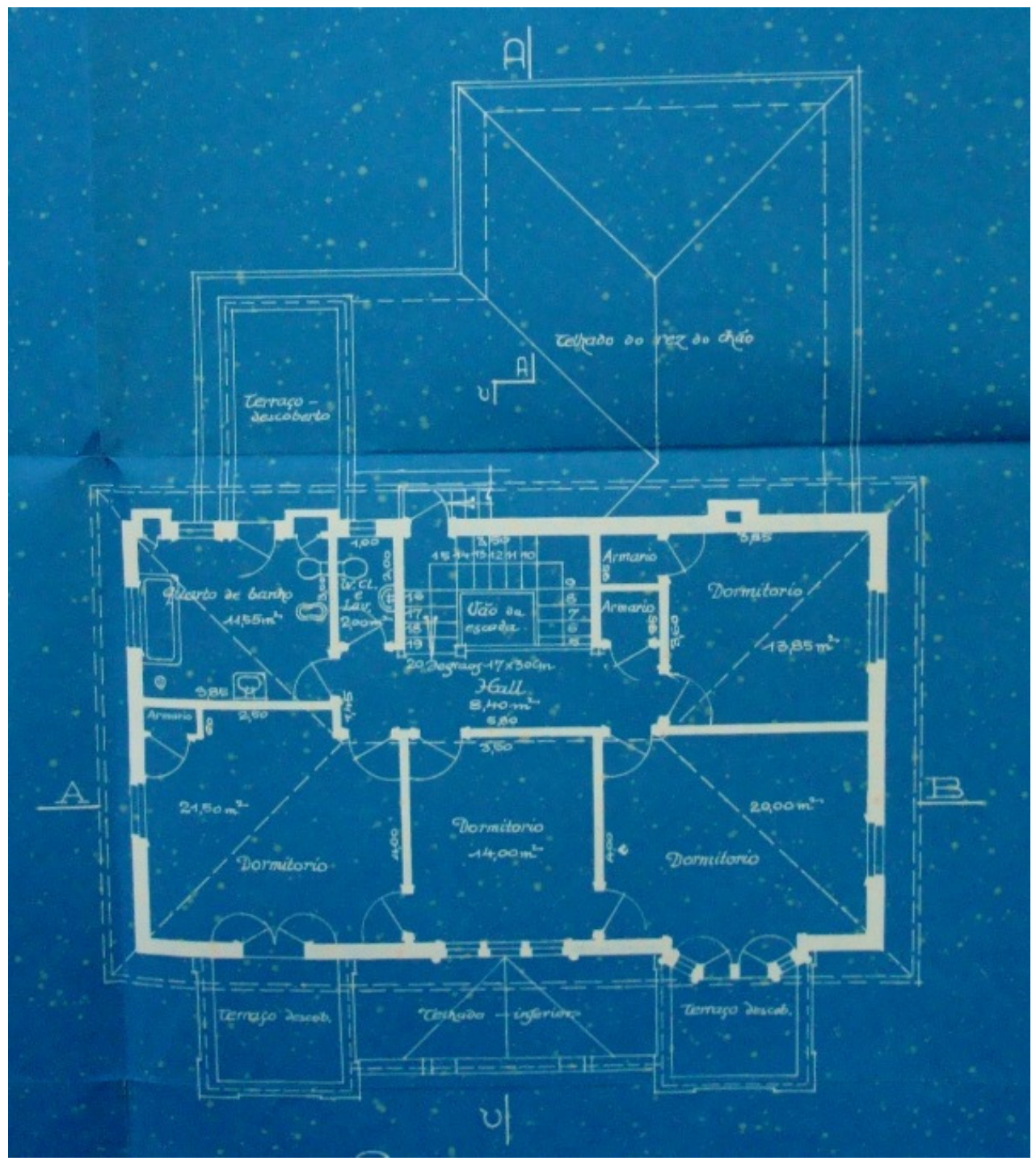

Fig. 5.81 Casa na Rua Argentina - planta baixa - pavimento superior.

No número 52-3 da Revista de Engenharia do Mackenzie (junho 1930), a "Página de Arquitetura" era dedicada aos alunos e ex-alunos do Mackenzie, mostrando seus projetos.

São apresentadas duas fotos de obras de Olavo Caiuby. Uma delas é uma grande casa no estilo Neocolonial, à Rua Tupy. Esta casa situada em um lote de tamanho menor do que aqueles dos loteamentos da Companhia City, e com as construções vizinhas quase encostadas às divisas, mostra como o efeito das grandes casas neocoloniais é bem diverso quando localizadas no centro de um grande terreno. Além desta, é mostrada na revista outra casa, destinada a um diretor de banco, clássica com grandes porões e platibandas com detalhes neoclássicos. O arquiteto da época deveria dominar o repertório de vários estilos, para atender seus vários clientes. 


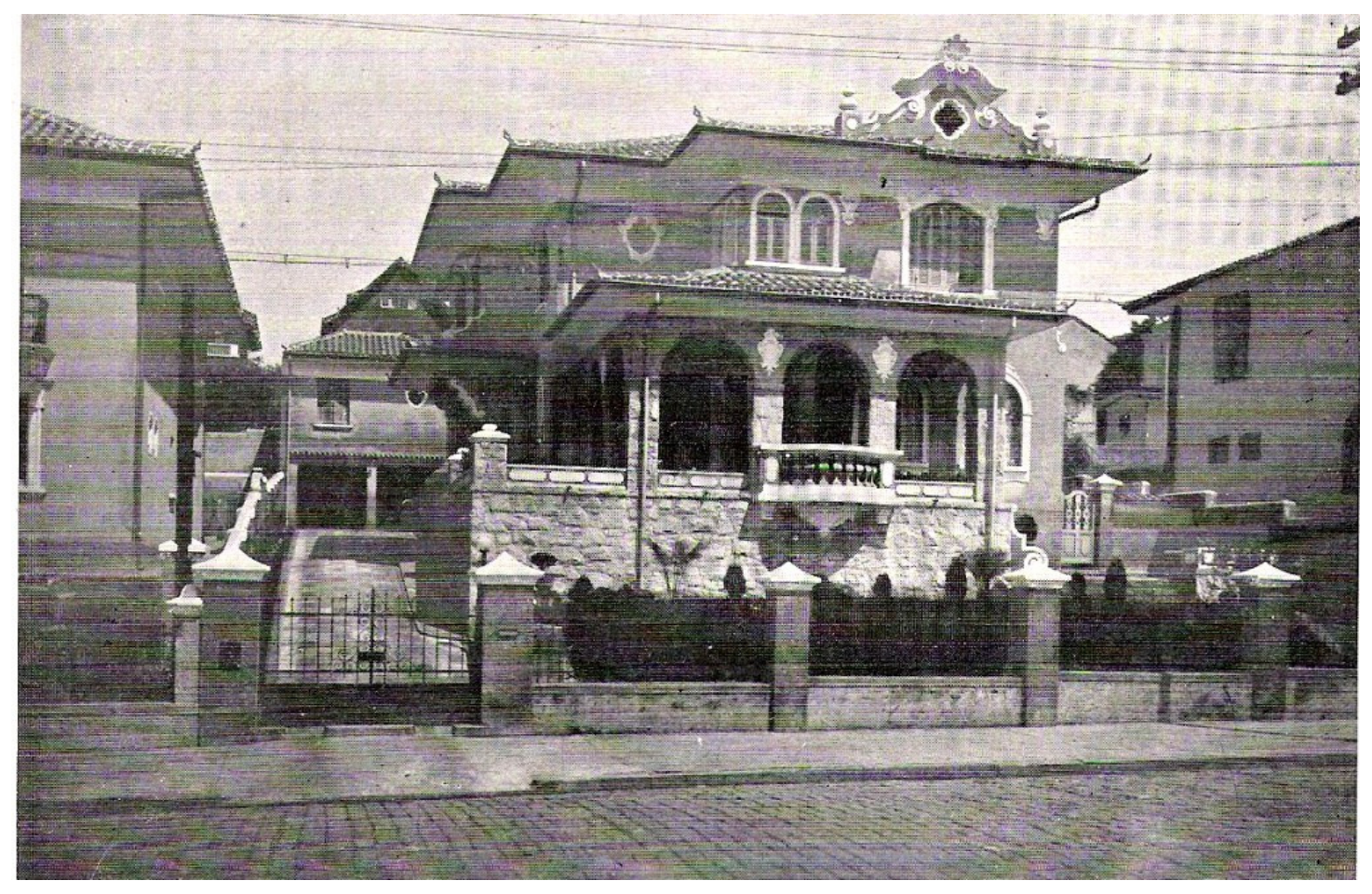

Fig. 5.82 Casa na Rua Tupi.

Um projeto atribuído a Caiuby por Wolff (2001, p. 279) na Rua lucatã, encontrado nos arquivos da companhia (08.22.716.271) que seria de 1935 ou 1936, mostra um sobrado híbrido, com características do Neocolonial e do Missões.

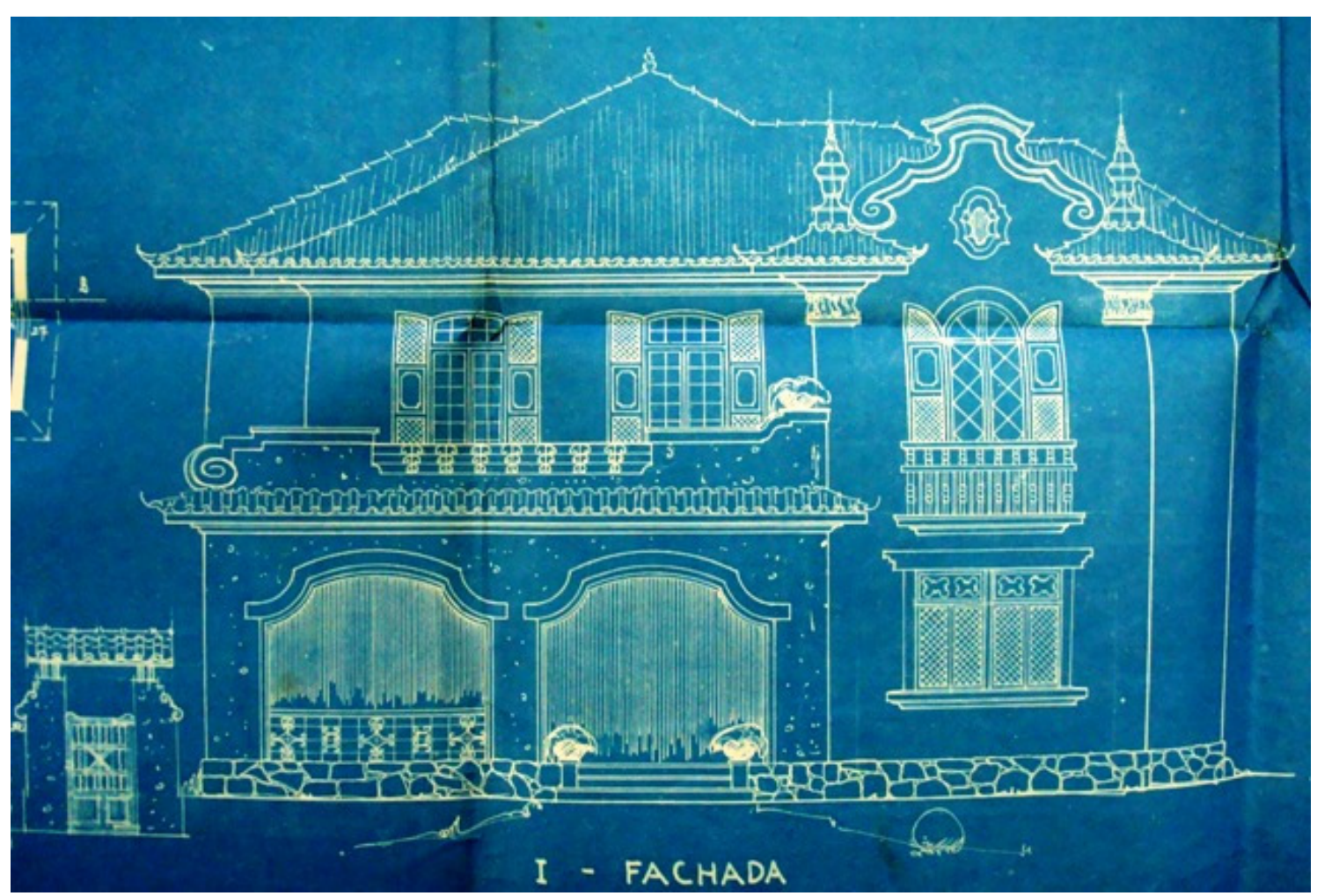

Fig. 5.83 Casa na Rua lucatã 
Na Revista Acrópole, número 7 (novembro 1938, p.33-7), Caiuby publicou uma casa que teria projetado para o Jardim América, na Rua Nicarágua, de linhas sóbrias, telhado aparente, um volume cilíndrico que se destaca, a linguagem geométrica despojada que caracterizou muitas residências na segunda metade dos anos 1930, segundo Wolff (2001, p.242-3). No número 12 da Revista Acrópole, (abril 1939, p. 1723), na Praça Califórnia, outro projeto de Caiuby, nos mesmos moldes.

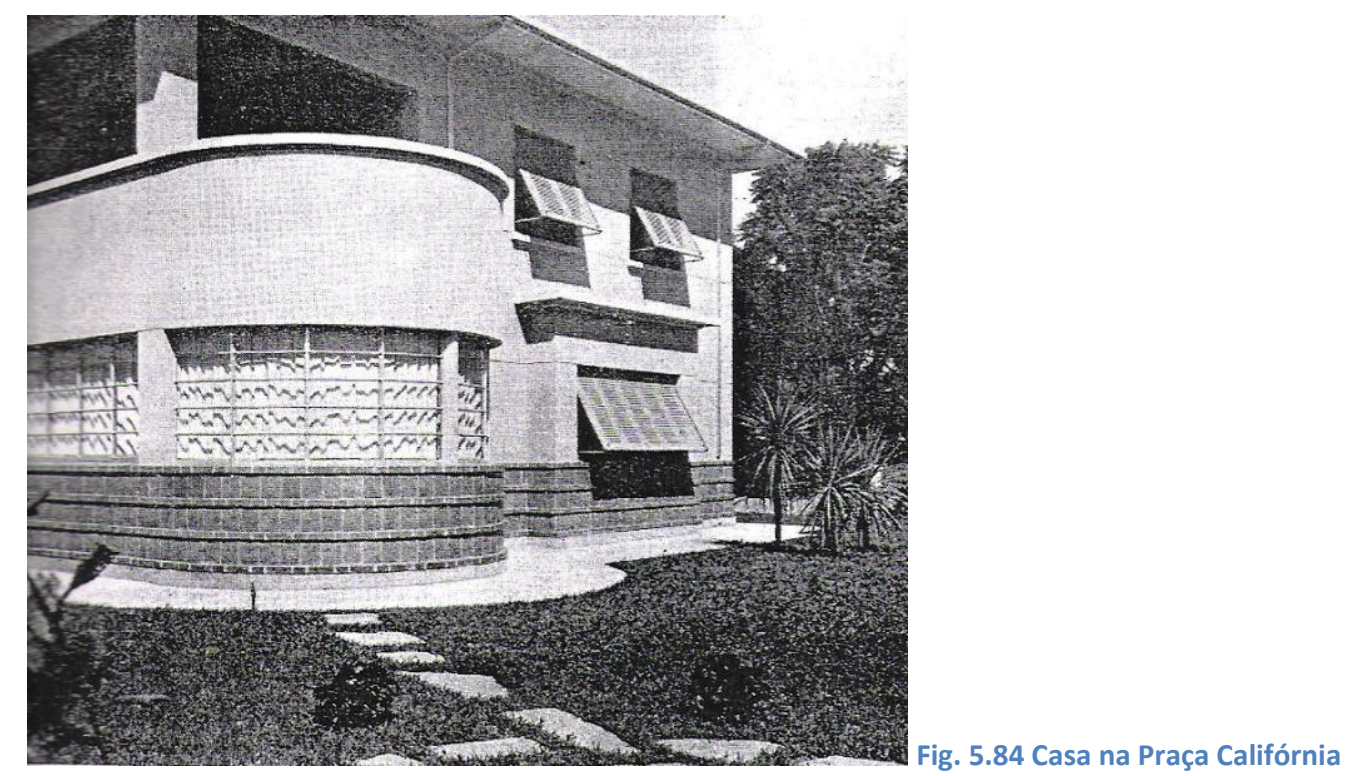

O arquiteto seguiu as "modas", os "estilos" que surgiram, provavelmente a pedido dos clientes. Uma atitude perfeitamente compatível com a época em que começou a exercer a profissão. Projetava-se utilizando-se da linguagem mais adequada à determinada situação. Olavo Caiuby, dentro deste quadro, soube utilizar bem o repertório à sua disposição, sempre apresentando qualidade em seu trabalho, estabelecendo pequenas modificações sucessivas em seus projetos, que mostravam alterações progressivas na maneira de se viver.

\subsection{4 Álvaro Carlos de Arruda Botelho}

Segundo seu anúncio, o arquiteto faria "estudos, projetos, empreitadas, administração de obras - estruturas metálicas e cimento armado". A firma denominada Álvaro Botelho \& Cia. teria engenheiros, arquitetos e construtores. Mas, não é especificada a formação do arquiteto, indicando que talvez ele não fosse diplomado. Porém, o fato de 
ele pertencer à família tradicional e abastada contradiz tal afirmação. Não foi encontrada nenhuma outra informação a este respeito. Estava registrado no CREASP, com o número 95. Porém, havia profissionais diplomados e não diplomados - os "licenciados" - inscritos no CREA. ${ }^{30}$

Neste número da Revista de Engenharia do Mackenzie (n. 46, março de 1928), o anúncio do arquiteto Álvaro Botelho ${ }^{31}$ apresenta um projeto Neocolonial. Este é bem característico da obra do arquiteto. Uma bela composição de volumetria e telhados movimentados, com grandes beirais e detalhes neocoloniais como a chaminé, rótulas e portais. As rótulas fecham uma varanda no pavimento superior, provavelmente como proteção para uma melhor utilização do ambiente. É o resgate de um elemento da nossa arquitetura colonial, com finalidade prática, não se configurando apenas como um detalhe decorativo. Uma maneira positiva de se reviver a arquitetura vernácula.

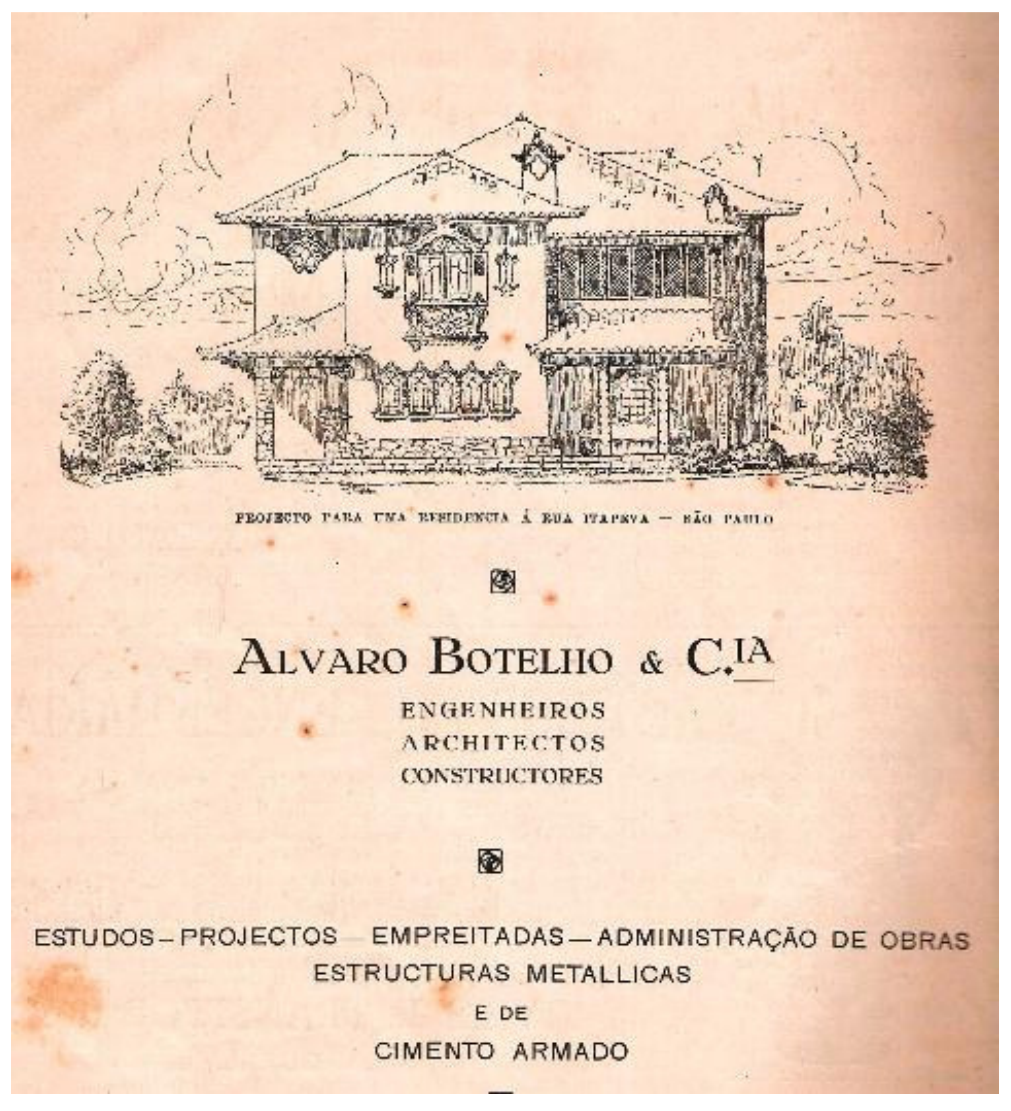

Fig. 5.85 Anúncio de Álvaro Botelho

\footnotetext{
${ }^{30}$ Os profissionais não diplomados que contassem cinco anos de exercício da profissão de engenheiro, arquiteto ou agrimensor, no território do Estado, poderiam receber o título de licença (Lei Estadual $\mathrm{n}$. 2.022, de 27 de dezembro de 1924, conhecida como Lei Alexandre Albuquerque). (FICHER, 2005, p.17980)

${ }^{31}$ Segundo Wolff (2001, p. 280), Álvaro Botelho teria participado do Primeiro Congresso de Habitação. Teria projetado mais duas casas no Jardim América, uma na Rua Chile no período 1935-40 e outra na Rua Estados Unidos, entre 1923 e 1930.
} 
Apesar dos vários detalhes, estes se harmonizam e se equilibram, assim como os vários volumes da casa. A impressão geral é de espontaneidade, adequada à arquitetura residencial, e não a de monumentalidade, como acontecia muitas vezes com o Neocolonial. Neste sentido, o Neocolonial de Álvaro Botelho lembraria o de Victor Dubugras.

Álvaro Botelho constava como sócio do Instituto de Engenharia (Revista do Instituto de Engenharia, 1926, n. 31).

No número 18, vol. IV (provavelmente janeiro 1923, p.171) do Boletim do Instituto de Engenharia aparece uma casa Neocolonial de Álvaro Botelho, com um portal na porta de acesso, volutas nas platibandas, bicas à moda chinesa no telhado e uma pequena janela ogival com rótulas no térreo. A autoria desta casa é atribuída, no álbum Jardim América, a Adhemar de Morais. ${ }^{32}$

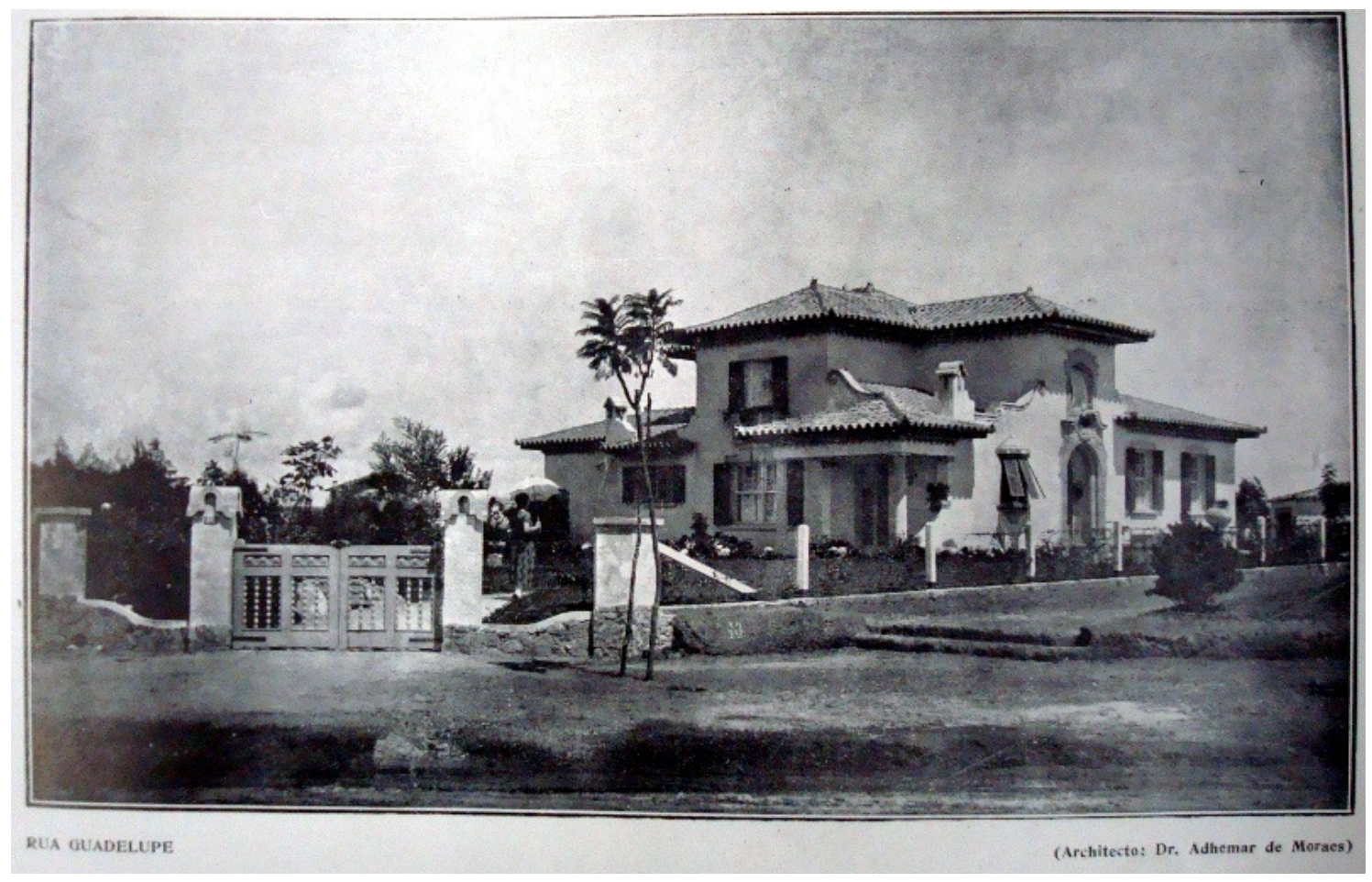

Fig. 5.86 Casa no Jardim América

\footnotetext{
32 Provavelmente Álvaro Botelho comprou o terreno da Companhia City e Adhemar de Moraes - que atuava como empreiteiro - construiu a casa - com um financiamento da companhia, no valor de 20 contos de réis. O memorial descritivo foi datilografado em papel timbrado de Adhemar de Moraes, mas se refere ao proprietário como sendo Álvaro Botelho. A casa foi depois modificada pelo próprio Álvaro entre os desenhos consta parte da planta com indicações de paredes a demolir e a construir.

Devido à reforma que foi feita - para a qual Botelho conseguiu em 1922 um financiamento adicional da City no valor de 17 contos de réis - ele consta como autor no Boletim do Instituto de Engenharia. Álvaro Botelho venderia a casa em 1924. Ele provavelmente era jovem à época, pois se casou no intervalo entre a compra do terreno e a venda da casa.
} 


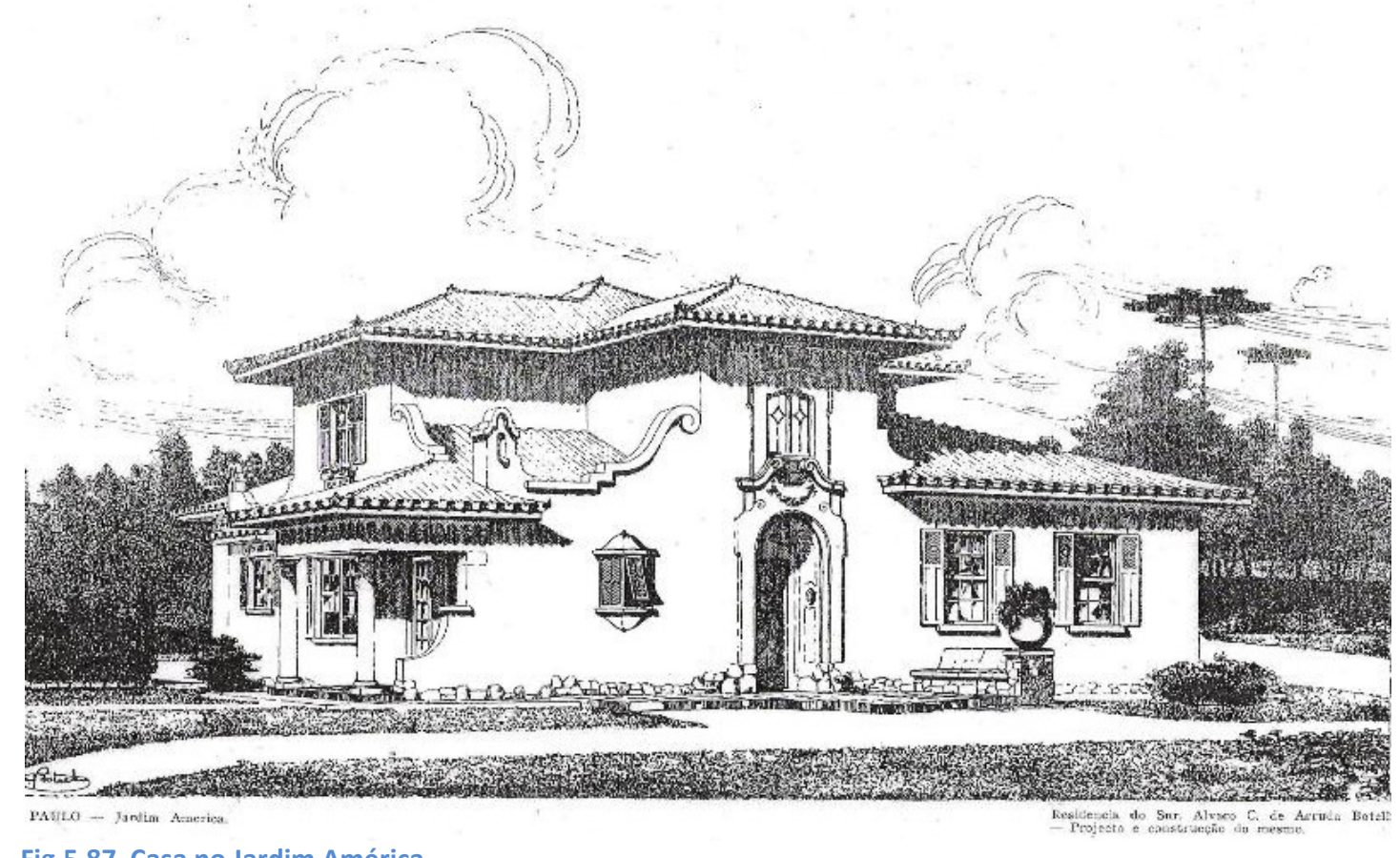

Fig.5.87 Casa no Jardim América

No número 25 do Boletim do Instituto de Engenharia (mar. 1924), o arquiteto, em um anúncio de página inteira de seus serviços como arquiteto, reproduz considerações do arquiteto português Raul Lino:

(...) a nossa habitação é a moldura em que se enquadra uma boa parte da nossa vida espiritual e o melhor da nossa vida familiar. Ela não é só abrigo das intempéries que o fustigam, é também refúgio para o espírito após a luta diária que o assola. Se se goza de boa saúde, a casa é capaz de reclectir e aumentar o nosso bem-estar. (...) Quando construímos uma casa de novo, para que nos seja tam querida logo desde os primeiros mezes em que a habitamos é preciso que pela sua disposição ela corresponda perfeitamente à nossa maneira de viver.

Esta citação ${ }^{33}$ mostra que Botelho estava familiarizado com o arquiteto Raul Lino e sua busca pela arquitetura vernácula e pela essência do modo de vida português - e sintonizado com o movimento Arts and Crafts. Para Lino, como também para o movimento inglês, o lar seria a moldura para a vida ideal, um novo tipo de vida familiar. Foram encontrados dois projetos de residências da autoria de Álvaro Botelho nos arquivos da Companhia City: Um deles é o projeto com o código 51.09.467.263, à Rua Estados Unidos, n.139, de janeiro de 1929. O sobrado tem revestimento em tijolinhos,

\footnotetext{
33 Esta mesma citação aparece na revista $A$ Casa (n.7, nov. 1924, p.10-11), como foi mencionado ao se discutir o Neocolonial.
} 
que contrasta com a área pintada das paredes. A planta do pavimento térreo tem área social integrada (sala de visitas com lareira, jantar e hall), complementada pelo pequeno terraço.

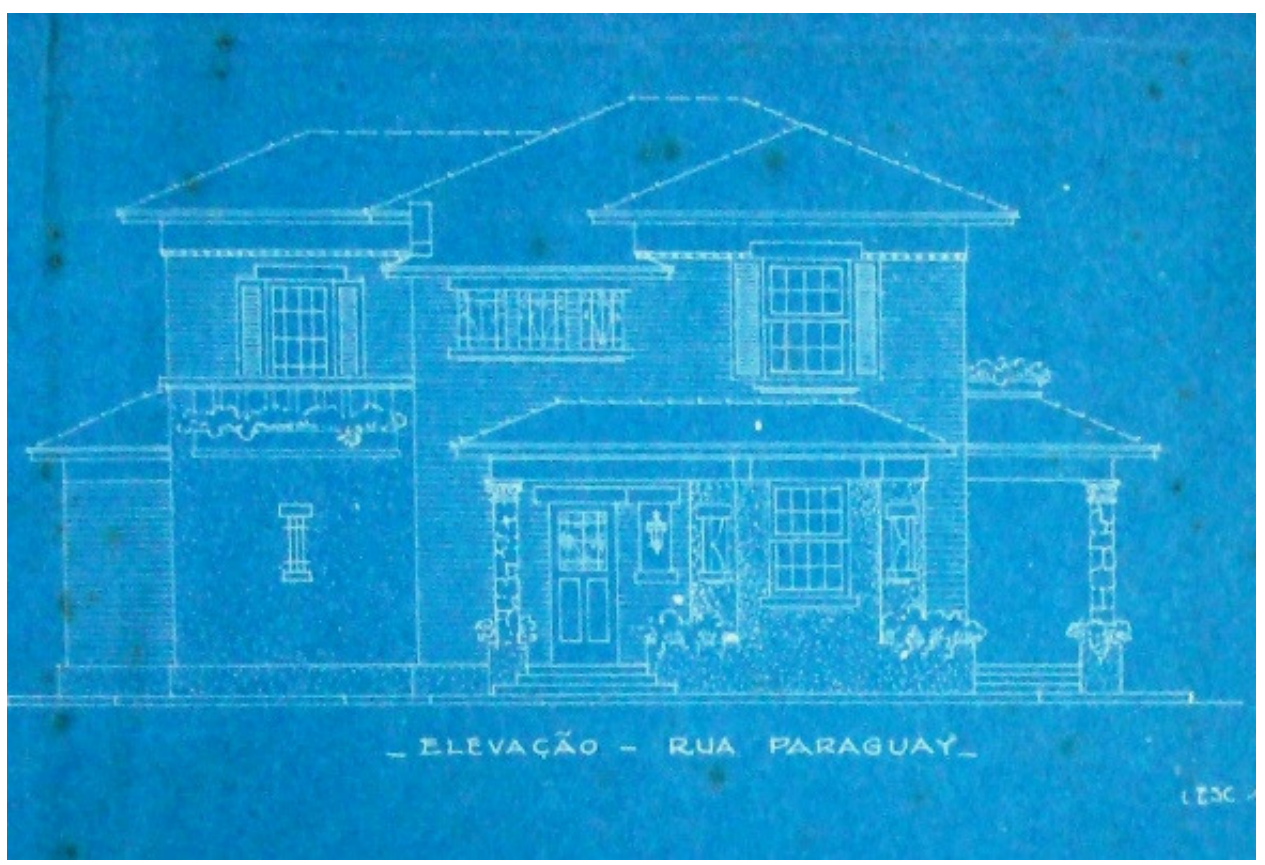

Fig.5.88 e Fig.5.89 Casa na Rua Estados Unidos.

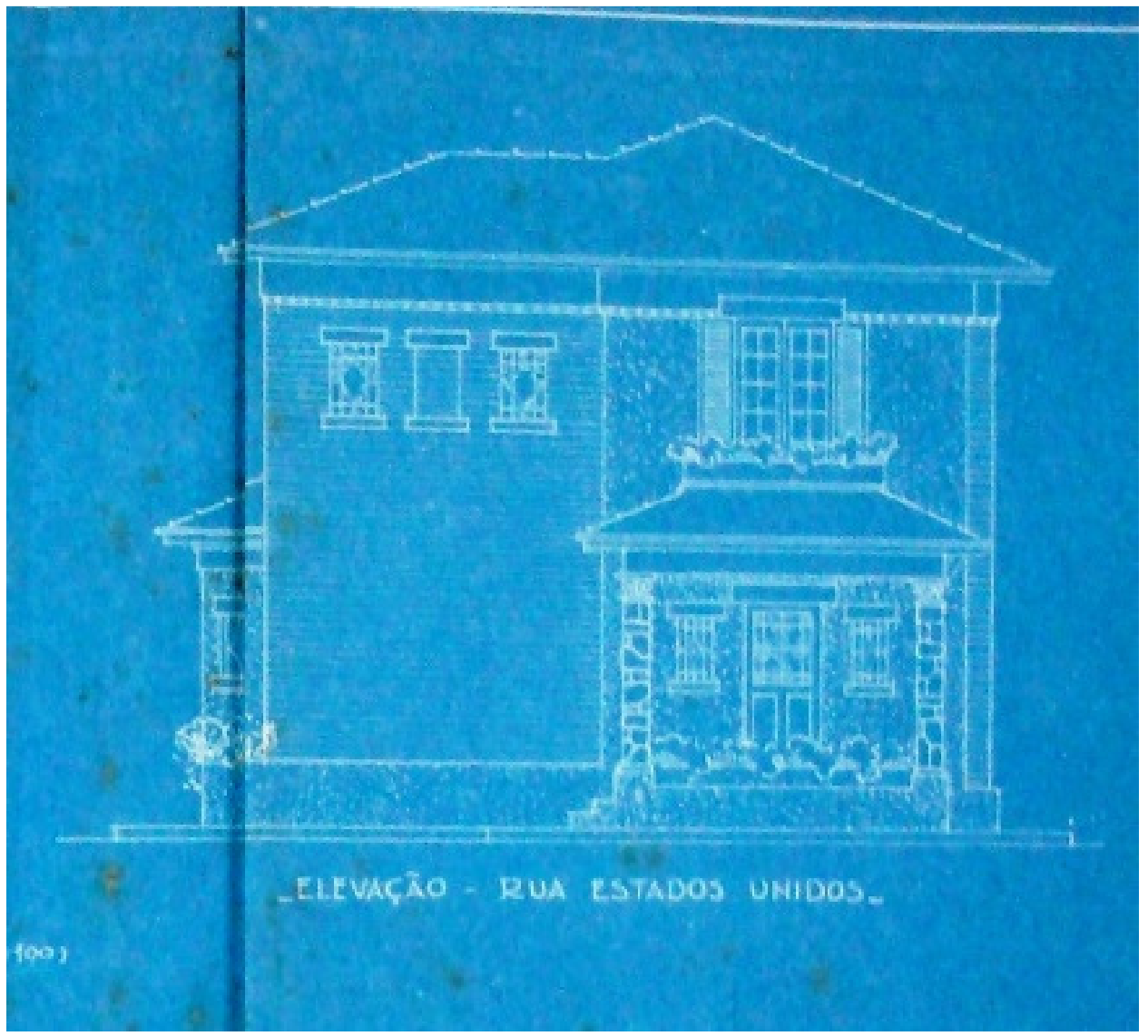




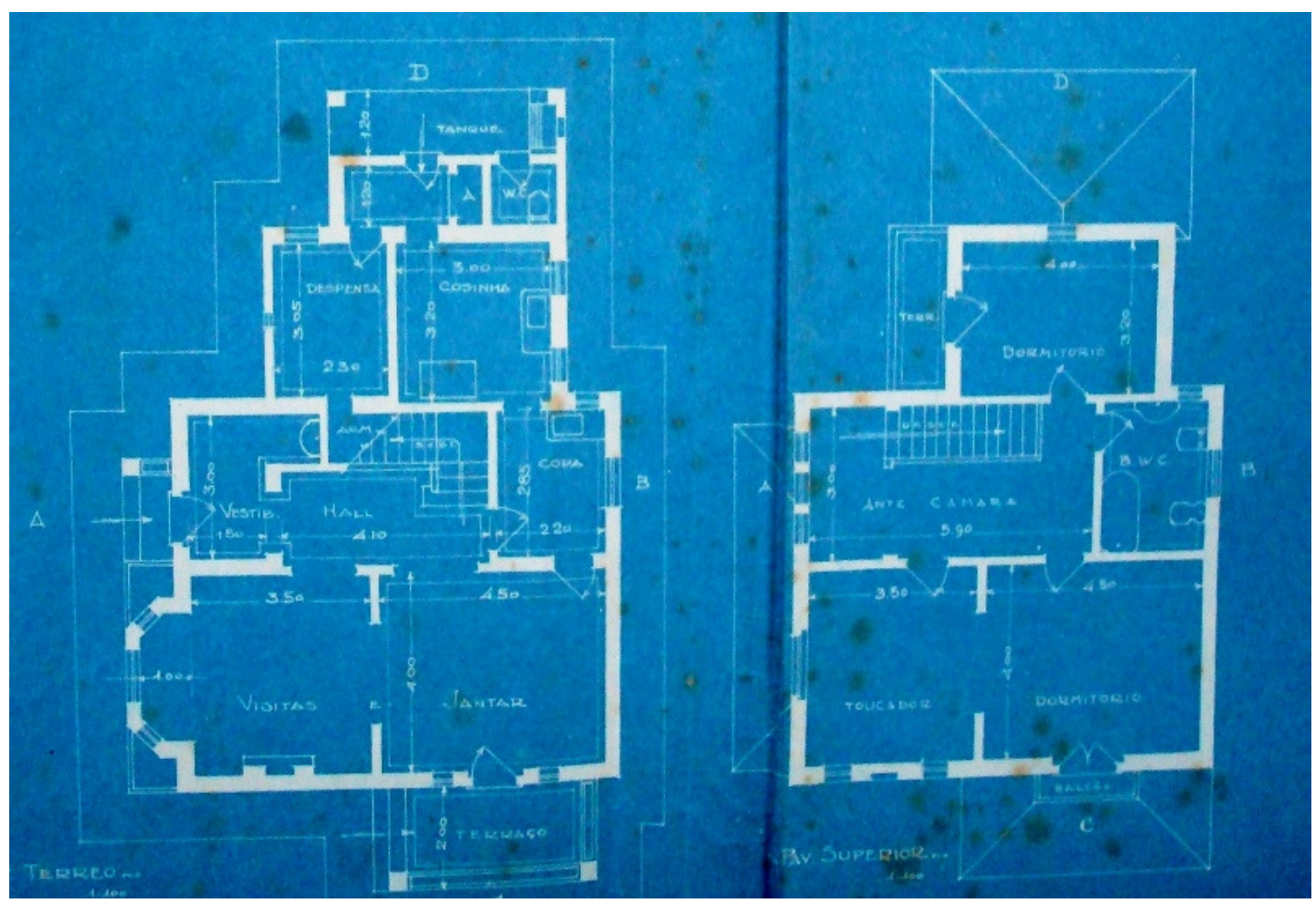

Fig.5.90 Casa na Rua Estados Unidos.

O tijolinho, a faixa em alto relevo na altura das janelas, e as floreiras lembram Dubugras. Porém, Álvaro Botelho foi além de "ser influenciado por Dubugras e projetar casas para a classe média".

Ele trabalha com maestria suas composições assimétricas, variadas, distribuindo bem os volumes, sempre em equilíbrio, com uma liberdade e segurança que não se encontra em muitos destes arquitetos dos anos 1920.

Dava atenção aos detalhes em oposição à totalidade do edifício, fazendo com que dialogassem. Estes pequenos detalhes lembram o Arts and Crafts - como nesta casa, em que ele compõe o volume que se destaca da sala de jantar com a pequena varanda de acesso - porém as características que o filiam ao movimento vão muito além. Cada parte da casa mostra sua função através dos volumes e tipos de esquadrias. E ele trabalha todas as fachadas, dá importância a todas, sem hierarquias, em um tratamento pinturesco em que uma elevação passa a outra naturalmente.

Ele se filia ao Neocolonial, utilizando as soluções regionalistas, sem copiar simplesmente os modelos da arquitetura tradicional. Procurando utilizar elementos com outras finalidades, que não a meramente decorativa. É o caso das rótulas, dos grandes beirais que protegem paredes e esquadrias, dos balcões com floreiras que aproximam o entorno da casa. E seu Neocolonial tem o caráter de arquitetura residencial, evitando a monumentalidade, sempre com certa "descontração". Ele 
continuará utilizando a estética Neocolonial e não se encontraram projetos no estilo Missões do arquiteto.

E uma última característica que o liga ao movimento inglês: o requinte no uso dos materiais. Da prancheta do arquiteto saiu um dos mais belos e requintados exemplos da arquitetura art déco em São Paulo, localizado no centro da cidade: o edifício projetado em 1935 e inaugurado em 1938 para ser a sede do antigo Banco de São Paulo, hoje ocupado pela Secretaria da Juventude, Esporte e Lazer.

Neste edifício, a fachada é revestida com granito e o piso do térreo com mosaico romano. Uma de suas imponentes portas de ferro é decorada com figuras de bronze fundido. Acredita-se que tenha sido concebida pelo artesão Cezar Urgaretti, um dos envolvidos na construção das esquadrias do edifício ${ }^{34}$. Este refinamento artístico dos elementos decorativos está presente também nos vitrais e nas luminárias de alabastro, no relógio cercado de esculturas, nas madeiras e couros trabalhados pelo Liceu de Artes e Ofícios.

No Boletim do Instituto de Engenharia (abr.1931, n.70, p.147), é mostrada outra bela residência neocolonial de Álvaro Botelho, com poucos detalhes do estilo, mas bem distribuídos pela composição, novamente uma varanda fechada por uma espécie de rótula. Seu Neocolonial não apresenta os frontões da arquitetura religiosa, mas sempre a proteção de grandes beirais.

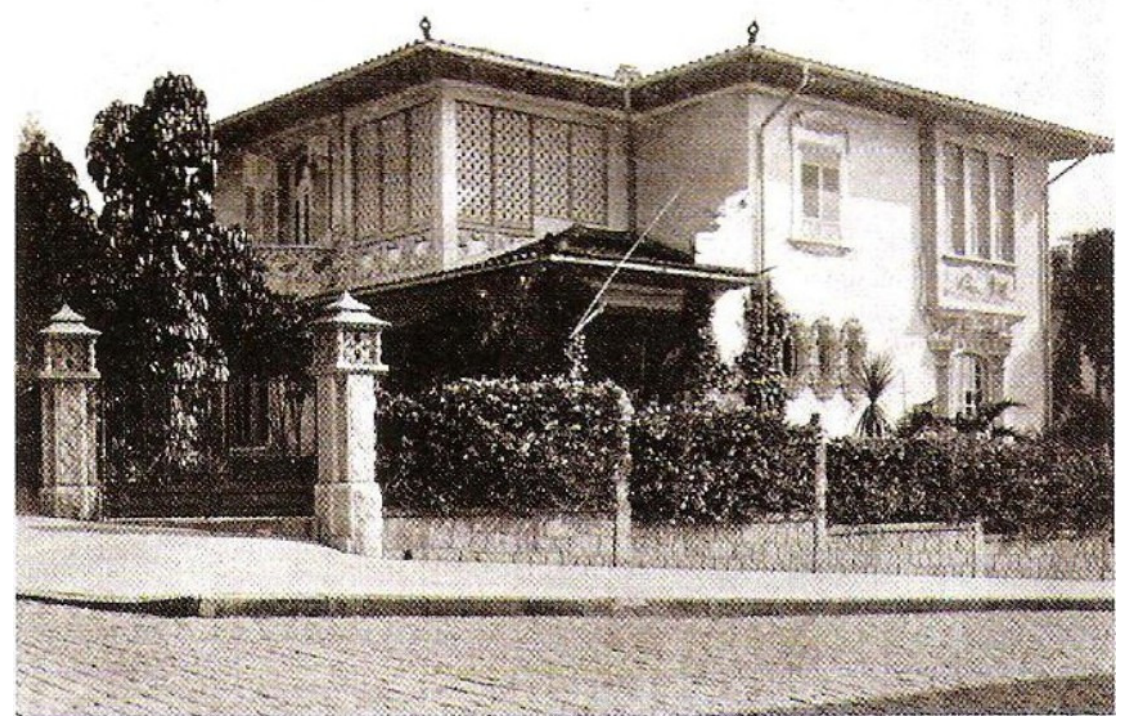

Fig. 5.91 Residência Necolonial

${ }^{34}$ Sites http://veja.abril.com.br/vejasp/010206/misterios.html e http://www.preservasp.org.br/fórum, 
Esta é provavelmente a residência mostrada por Lemos (1989, p. 179) quando ele se refere ao arquiteto e diz que ele "nos anos 30 e seguintes fez, como o maior requinte, a arquitetura art déco".

Outro projeto do Jardim América é o que tem o código 45.05.821.277, à Rua Chile. Em carta à Companhia City, de 3 de julho de 1936, a proprietária avisa que o construtor da casa seria o engenheiro Sílvio Pinto Freire, assim Botelho seria apenas o autor do projeto, como consta na planta. Talvez o arquiteto estivesse apenas fazendo projetos, como começava a acontecer na época. O aspecto mais interessante da planta é o pátio, um espaço meio aberto, meio fechado com, o que parece ser, uma sucessão de arcos e uma espécie de jardim de inverno.
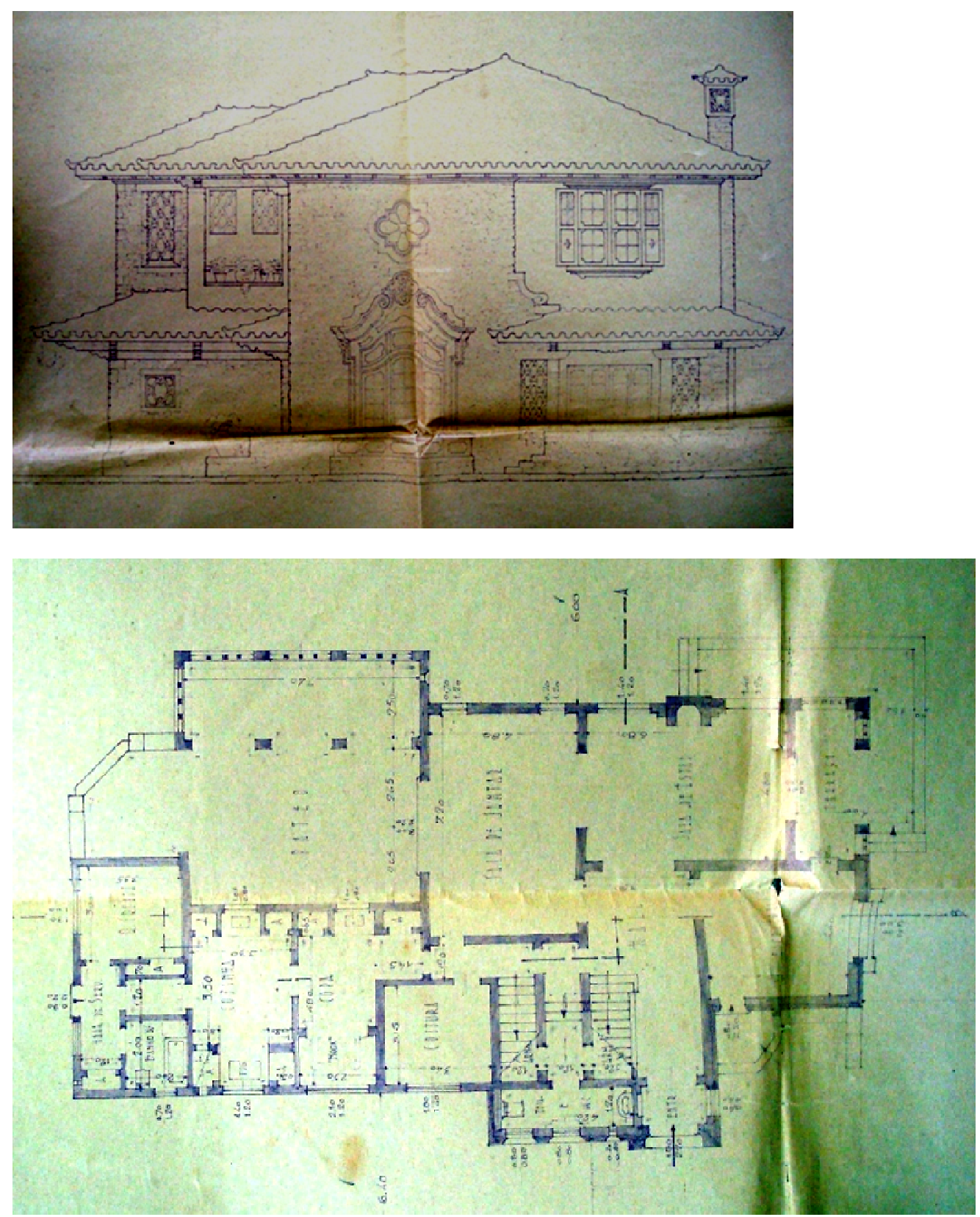

Fig. 5.92 e Fig. 5.93 Casa na Rua Chile, fachada frontal e planta baixa. 
No número 8 da Revista Acrópole (dez. 1938, p.48-52), Álvaro Botelho aparece com outra residência neocolonial ${ }^{35}$, outra composição equilibrada, localizada na Rua Padre João Manoel. Os detalhes neocoloniais são: embasamento em pedra, as meias luas no guarda corpo da sacada, grandes beirais com cachorros de madeira no telhado recortado e o balcão e a porta envolvidos por um grande portal. Nesta casa, transparece o interesse pelos detalhes por parte do arquiteto. Pérgulas, floreiras em varias janelas, bancos. Tudo com um desenho muito requintado.

Na planta, com um programa que já evoluiu desde os anos 1920, as salas de estar e jantar continuam integradas, e agora voltam-se para o jardim lateral e dos fundos, onde além da pérgula, existe uma fonte, influência do estilo Missões. Os fundos da casa agora se tornaram um espaço de fruição dos jardins, para onde se abrem quase todos os dormitórios.

No andar térreo, apenas o escritório e os serviços voltam-se para a rua. São os espaços que se conectam a cidade. O restante da casa deve ser reservado à família e aos amigos e, assim, suas aberturas se voltarão para "dentro" do terreno, protegidas dos olhares curiosos dos transeuntes, e desfrutando da vegetação que envolve a casa. A cidade só será vista pelos moradores quando estes saírem à rua.

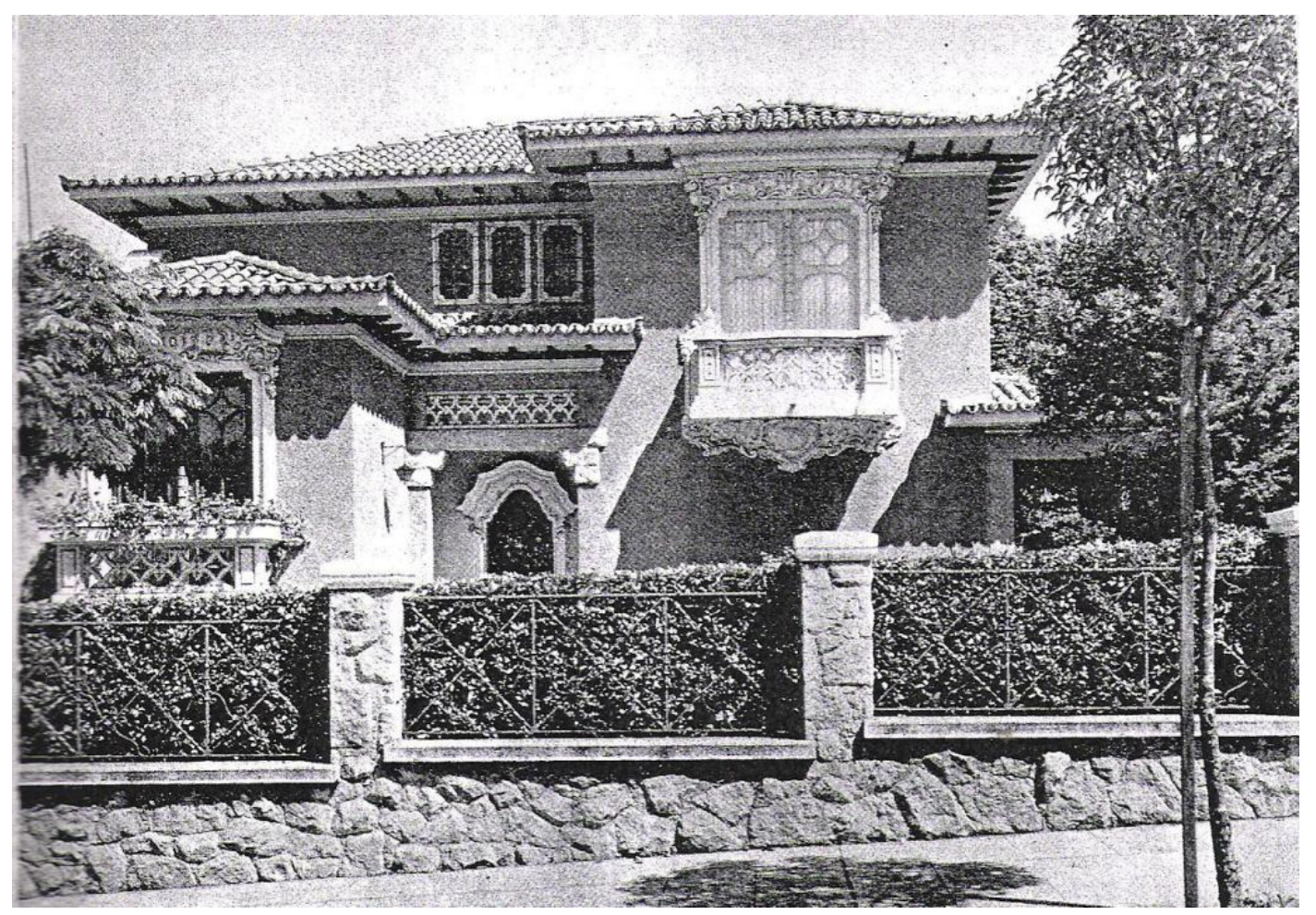

Fig. 5.94 e Fig. 5.95 Casa na Rua Padre João Manoel

\footnotetext{
35 Esta casa foi construída pela Sociedade Construtora e de Imóveis, pois se encontra no álbum publicado pela construtora em 1940, o que reforça a hipótese de que Álvaro Botelho estava apenas projetando e não construindo nesta época.
} 


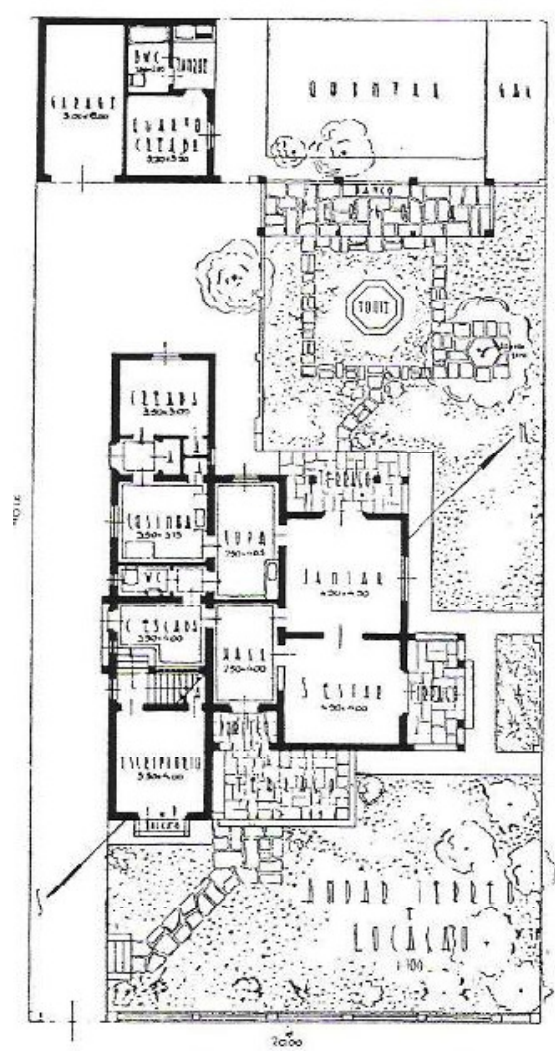

\subsubsection{Dácio Aguiar de Moraes}

Dácio de Moraes formou-se em Stuttgart, em 1898. (Ficher, 2005, p.131). Ele aparece na "Galeria dos arquitetos e engenheiros" da revista Architectura e Construcções no número 3 (outubro de 1929, p.14). Era um colaborador habitual da revista, como atestam os vários textos de sua autoria encontrados.

GALERIA

ARCHITECTOS E ENGENHEIROS

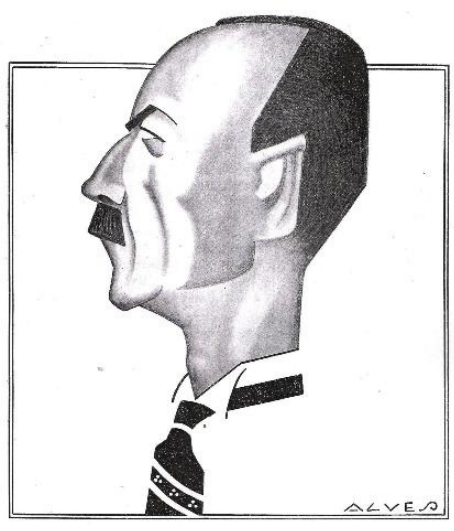

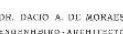

Fig. 5.96 Caricatura do arquiteto. 
No mesmo número em que é mostrado na galeria, ele assina um artigo denominado "O traço do architecto". Segundo ele:

(...) sempre, na realisação prática de todo e qualquer problema de arquitetura (...) (de) forma artística e em perfeita correspondência com a sua finalidade e mais recursos technicos (...) aparecerá sempre, como na sua assignatura, o traço e a personalidade do architecto. (...) A regra 'tudo o que é technicamente bom, também é bello' não passa também de um outro Dogma, resultante da natural obediência à legitimidade e perfeita funç̧ão dos materiaes.(p.15)

A identidade de um artista realmente só apparece e manifesta-se na totalidade da sua obra pela integração dos seus detalhes e particularidades. Como, aliás e de regra, toda a obra artística e verdadeira guarda nos seus menores detalhes a sua unidade indissolúvel, também resulta caracterisar-se o seu aspecto de conjuncto como um organismo integrado, pela harmonia sempre reflexa dos seus detalhes. (p.16)

Neste trecho pode-se dizer que, de certa forma, está a concepção da arquitetura da época: a solução de qualquer problema, de forma artística, de acordo com sua finalidade e recursos técnicos. Esta "forma artística" poderia ter várias feições, o arquiteto dominava várias linguagens. Mas, apesar disto, a arquitetura ainda era vista como unidade, como obra de arte, onde deveria haver correspondência entre o todo e os detalhes, em perfeita harmonia.

Dácio de Moraes polemizou com Gregori Warchavchik nas páginas de O Correio Paulistano nos anos de 1928 e 1929. Moraes, adepto do Neocolonial, começou a polêmica com uma série de artigos em que apontava os equívocos de uma arquitetura internacional. Warchavchik, em contrapartida, defendia sua "Architectura Nova", que praticava em São Paulo.

Gregório Warchavchik tem sido compreendido pelo público que acorre em massa curiosa à casa estranha e sóbria da rua Itápolis. Talvez porque duas fitas excelentes que passam no écran paulista Ihe dão razão. Basta olhar para os interiores apresentados por Greta Garbo em Mulher Singular e Joan Crawford em Donzelas de Hoje, para qualquer indivíduo, por mais curto, compreender que uma arte da casa atual, intransigente, lógica, unida nos demais diferentes detalhes, reivindica para si o lugar de vitória no mundo transformado de hoje. 
Mário de Andrade anunciou mais ou menos isso num artigo de massuda erudição. Dentro em pouco só haverá casas modernas em São Paulo e a obra pessoal de Warchavchik se perderá confundida entre os tijolos de bananada arquitetônica que passarão a fazer o Sr. Dácio de Moraes - que já se anuncia dadá - e o peso pesado da engenharia copista, o Sr. Christiano das Neves! $!^{36}$

Uma grande controvérsia criada no ambiente paulistano, dividindo arquitetos, artistas e críticos num acirrado debate via imprensa. De um lado: Rino Levi, Warchavchik, Mário de Andrade, Oswaldo de Andrade, defendendo e promovendo a nova arquitetura, de outro, Christiano Stockler das Neves, Dácio de Moraes, que defendiam os valores da arquitetura tradicional e foram apoiados por José Mariano Filho.

No número 13 (agosto 1930, p. 11-2) da revista Architectura e Construcções, outro artigo de Moraes, "Architectura e Sciencia", onde ele coloca arquitetura e ciência em pólos opostos que seriam conciliados pelo arquiteto.

Na Revista de Engenharia do Mackenzie (out. 1930, n.54, p.182-3), seguindo com a polêmica, ele escreve artigo denominado "Architectura Constructivista (Objetivismo Funcional)" sobre o “(...) antagonismo existente entre a Architectura e a Sciência. E assim consideramos a Architectura como uma expressão artística de synthese, subjectiva e emocional, em contraposição às características da Sciência, essencialmente analytica, objectiva e atomista." Ele continua sua crítica à "escola ultra-objectiva moderna." A arquitetura moderna consideraria apenas os aspectos funcionais e não passaria de uma realização puramente material e objetiva, o que, segundo Dácio de Moraes, seria coerente com a autodenominada máquina de habitar. Continua, dizendo que esta nova orientação teria sua maior repercussão na Rússia pós-revolução, com seu materialismo e "aspecto objectivista". Esta associação da arquitetura moderna com o comunismo também é observada no discurso de José Marianno Filho.

A discussão de Dácio de Moraes continua, quando ele diz que um aeroplano deverá ter a forma que ofereça a menor resistência à pressão do ar e consiga sua máxima eficiência. Assim, dar tal forma a um edifício seria um absurdo. Na arquitetura todos os elementos deveriam ter suas formas definidas em "funcção estática (na falta de outro termo) em relação ao seu respectivo trabalho de resistência (sempre de equilíbrio estático)". Haveria conseqüências de "ordem constructiva e esthetica, quando entram

\footnotetext{
${ }^{36}$ ANDRADE, Oswald A casa modernista, o pior crítico do mundo e outras considerações. Publicado no Diário da Noite, São Paulo em julho de 1930. Republicado na Arte em Revista n.4, São Paulo, em agosto de 1980. Em www.vitruvius.com.br/documento/arquitetos/oswald01.asp.
} 
em jogo razões de estática ou resistência dos materiaes, como expressões reaes, de effeito seguro e eternamente moderno".

$\mathrm{O}$ arquiteto teve ao menos duas firmas de arquitetura. Uma dela teria sido, segundo anúncio no número 48 da Revista de Engenharia do Mackenzie (set. 1928), a Dácio de Moraes Ltda - Engenheiros e Arquitetos, que faria projetos, orçamentos e construções, por empreitada ou por administração. Antes disso, em 1918, formara uma sociedade com Guilherme Ernesto Winter, engenheiro-arquiteto e engenheiro civil formado pela Escola Politécnica em 1907.

Um projeto de Dácio de Moraes foi escolhido o melhor no $3^{\circ}$ grupo (projeto de edificações geminadas com apenas uma parede em comum) do Concurso de Casas Proletárias promovido pela administração municipal de Washington Luís, em agosto de 1916.

Foram encontrados dois projetos do arquiteto nos arquivos da Companhia City, ambos de 1926.

O projeto com o código 12.08.261.257, à Rua Antilhas, n.1, é de fevereiro de 1926. Dácio de Moraes assina como engenheiro-arquiteto. Um pequeno cottage, com alguns detalhes neocoloniais como as colunas jônicas, os vasos, as jardineiras, os alto relevos e a faixa na altura das janelas. No térreo, alguns ambientes compartimentados.

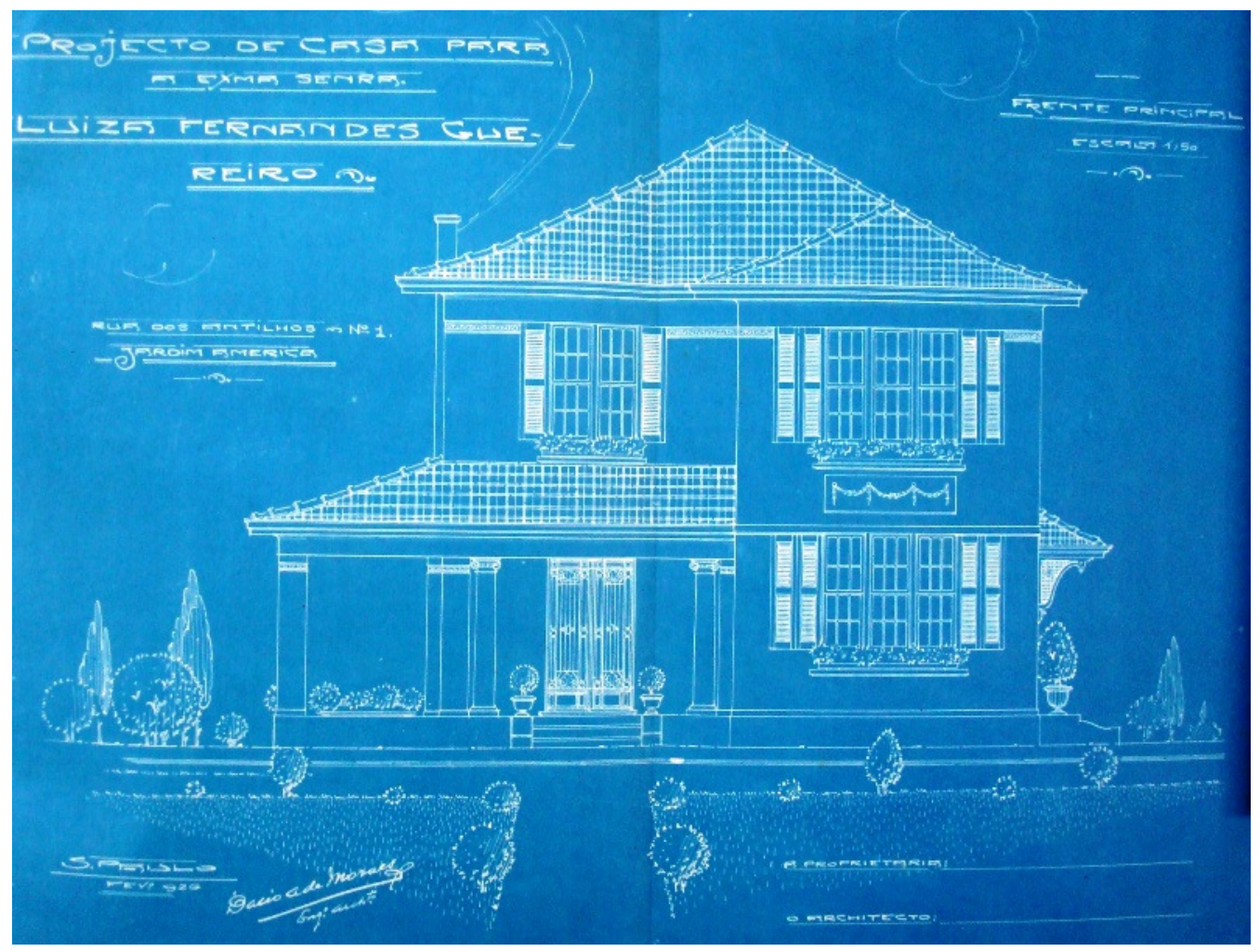

Fig. 5.97 Casa na Rua Antilhas, fachada frontal. 


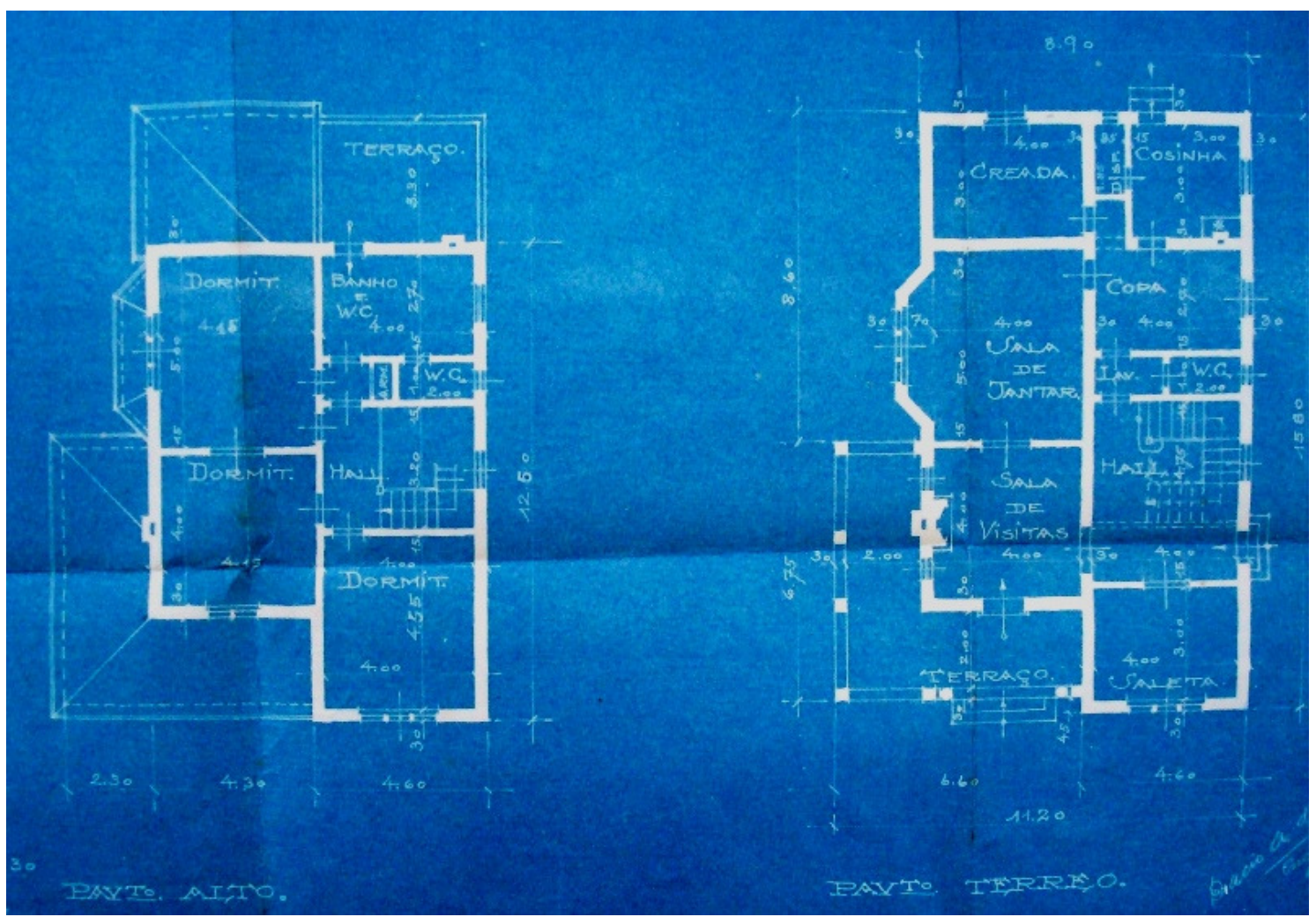

Fig. 5.98 Casa na Rua Antilhas, plantas baixas.

E existe ainda o projeto de código 16.16.094.257, de maio de 1926, à Rua Panamá. Similar ao anterior, apenas a volumetria é mais recortada. A área total é de $184 \mathrm{~m}^{2}$.

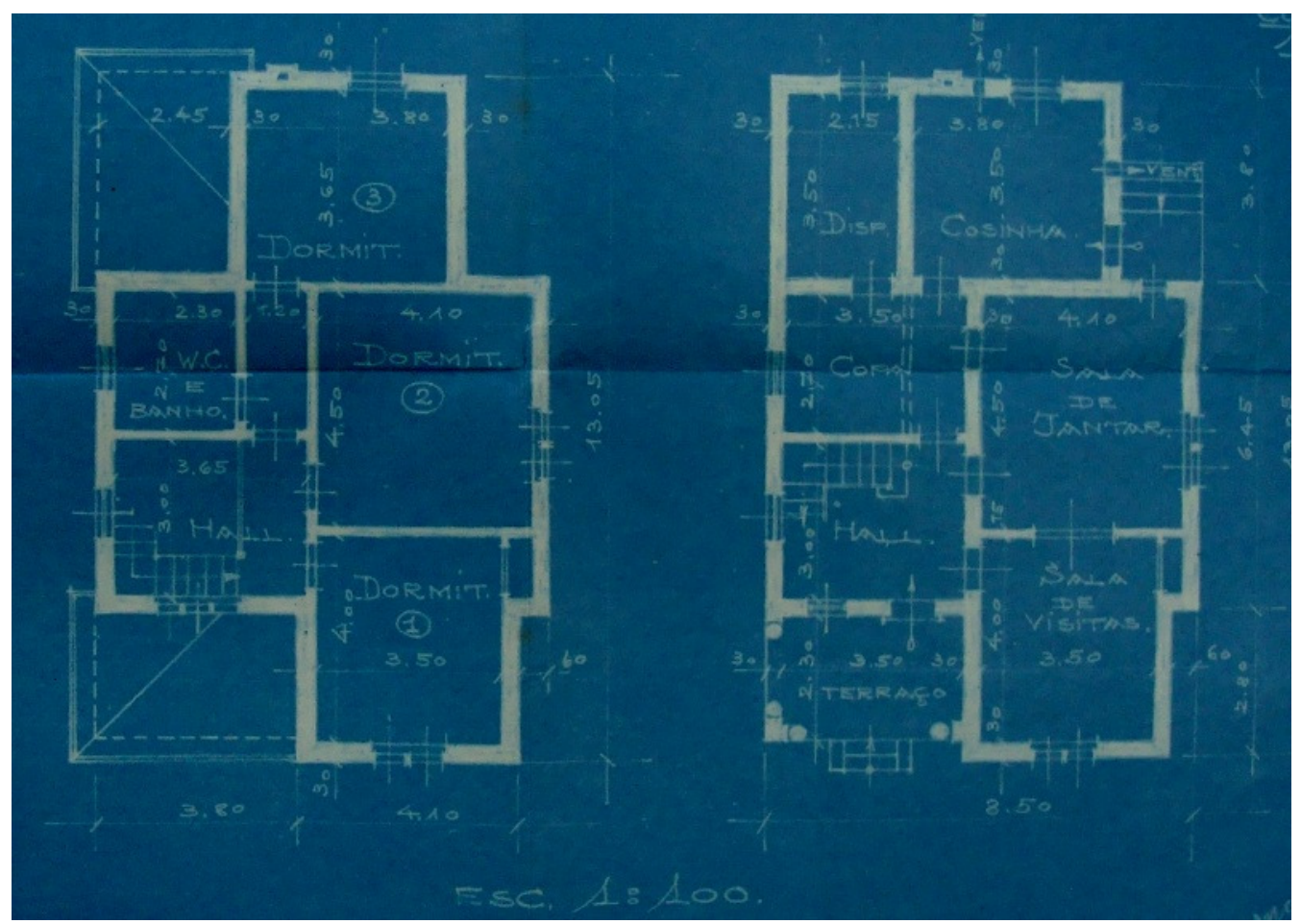

Fig. 5.99 Casa na Rua Panamá, plantas baixas. 


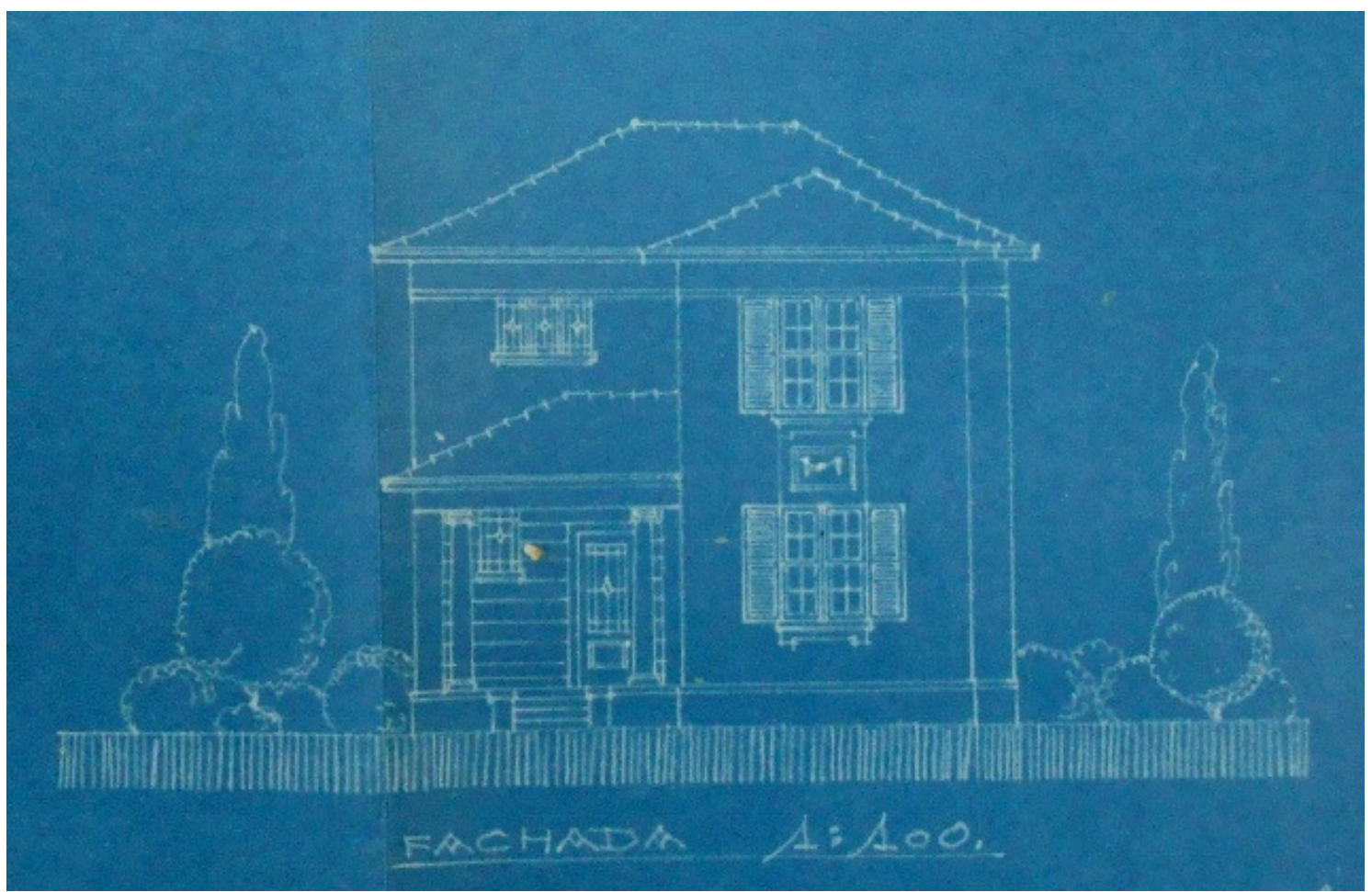

Fig. 5.100 Casa na Rua Panamá, fachada principal.

Dácio de Moraes constava como sócio do Instituto de Engenharia à época (Revista do Instituto de Engenharia, 1926, n. 31).

No número 2 (set. 1929) da revista Architectura e Construcções, é mostrado outro projeto de Dácio de Moraes na capa, localizado na Rua Brigadeiro Luiz Antônio, n.361. Apresenta o mesmo tipo de volumetria do projeto de fevereiro de 1926, encontrado no arquivo da City. As plantas e os interiores são mostrados nas páginas 18 a 24. A casa tem apenas alguns detalhes neocoloniais, como as bicas chinesas no telhado, os cachorros nos beirais e os portais nas aberturas. O programa é extenso, o que corresponderia na época a um "palacete". A planta, dividida em três módulos iguais, tanto no térreo quanto no pavimento superior, demonstra preocupação com a racionalização da estrutura, mesmo em detrimento do espaço. O segundo pavimento já possui dois banheiros, algo ainda incomum na época.

Os interiores têm grande número de objetos, tapetes, almofadas e forrações - cortinas, papéis de parede, capas para sofá -, principalmente a sala de visitas. Mostram, no entanto, a preocupação com a unidade na decoração e o caráter de cada espaço. $\mathrm{Na}$ cidade de São Paulo já estava estabelecido, nesta época, o uso dos estofados, tapeçarias, cortinas, capas e almofadas para criar um clima de aconchego e elegância, acrescido do uso de papéis de parede com estampas. O abajur completava esta idéia de conforto, através da luz suave e pontual. (CARVALHO, 2008, p. 177) 
A sala de jantar é mais solene, com móveis em tons escuros de linhas sóbrias. Na sala de visitas, um piano e sofás providos de almofadas para aumentar o conforto. $\mathrm{O}$ hall provavelmente funcionava como uma sala de estar, pois é um ambiente mais despojado, em tons mais claros, com poltronas mais confortáveis e uma lareira. A partir deste espaço tinha-se acesso a todos os setores da casa, social, íntimo e de serviço, separados entre si.

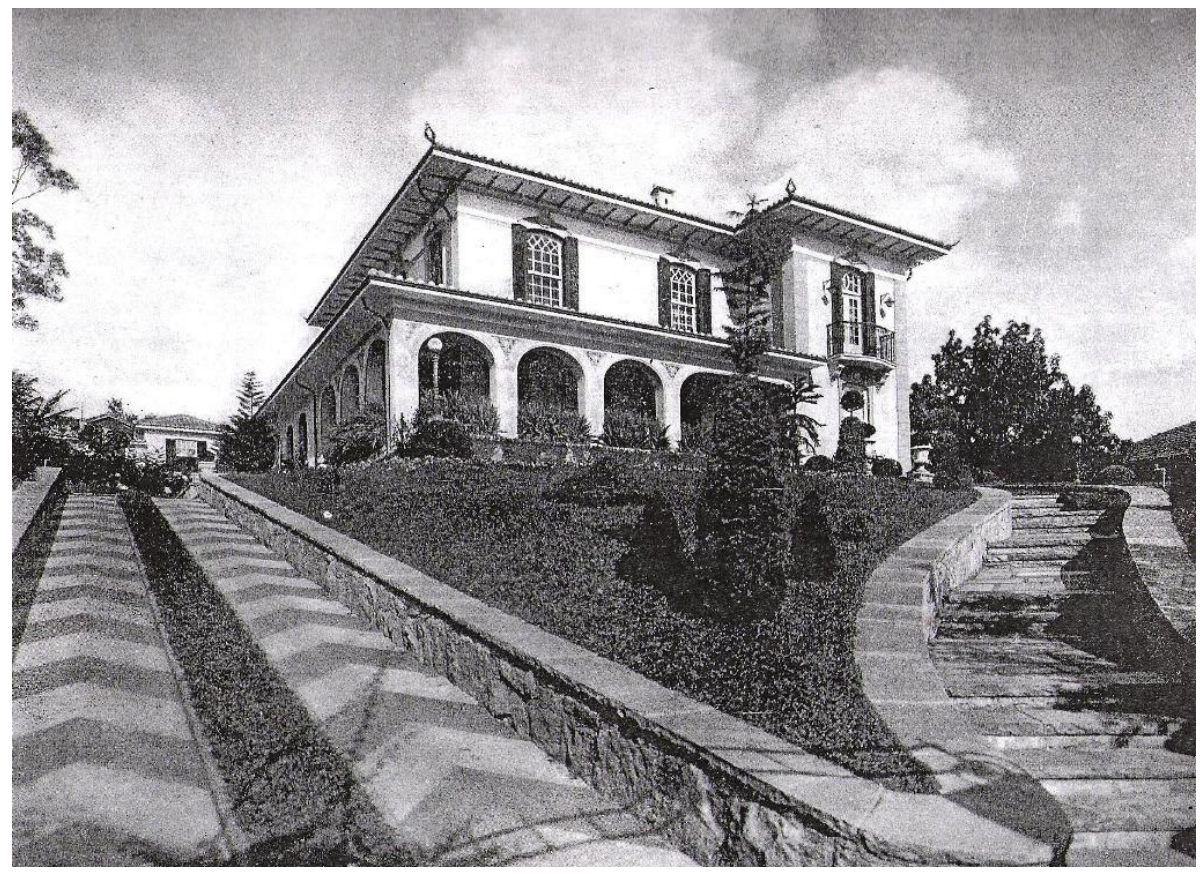

Fig. 5.101 Casa na Rua Brigadeiro Luiz Antônio.

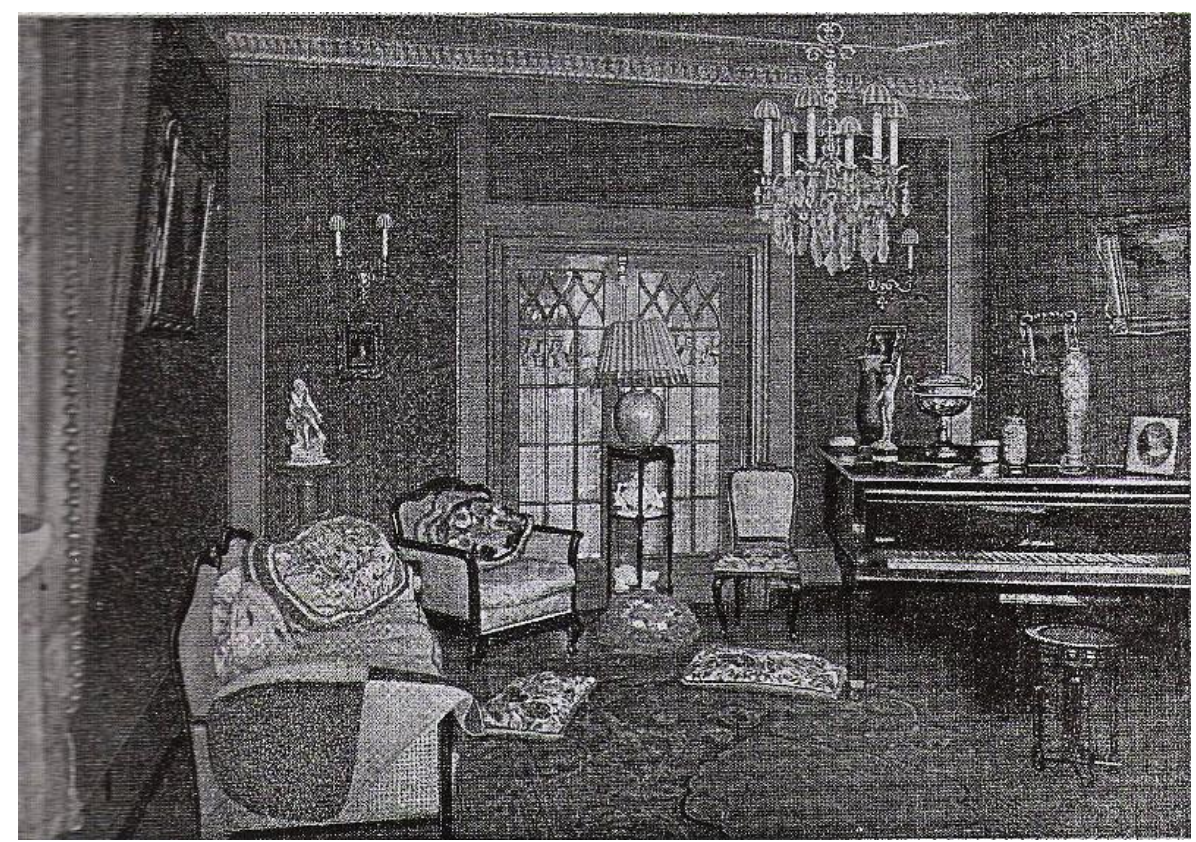

Fig. 5.102 Casa na Rua Brigadeiro Luiz Antônio, sala de visitas. 


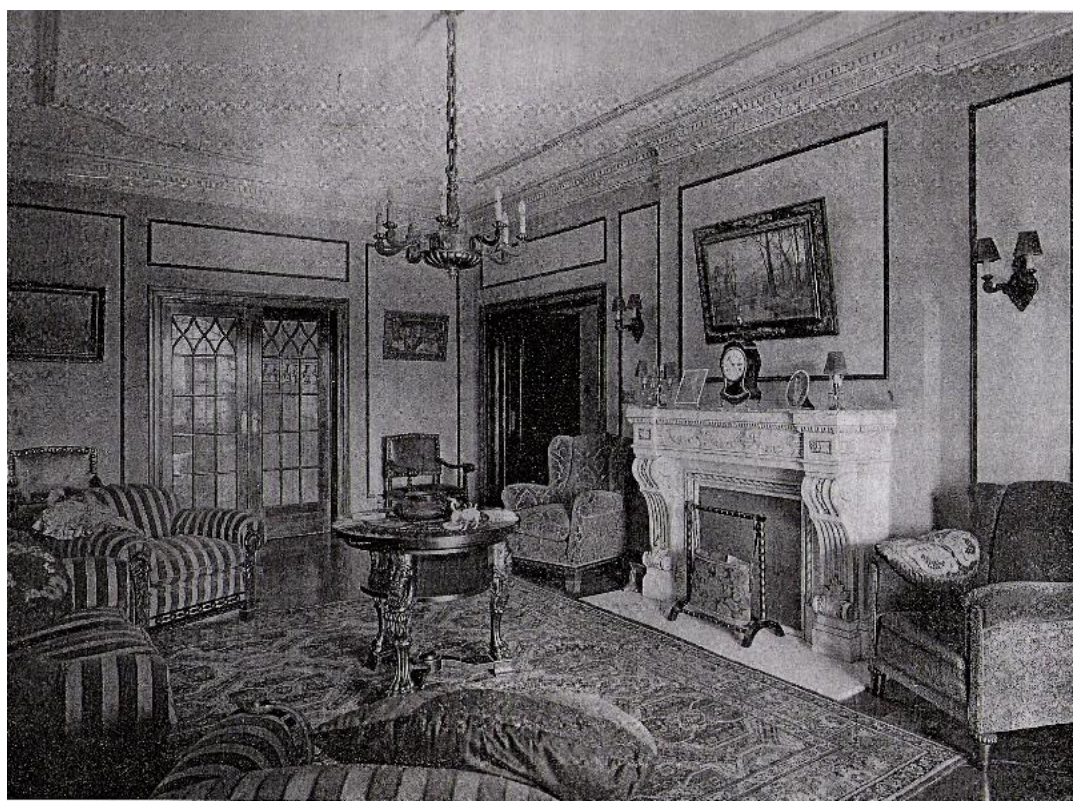

Fig. 5.103 Casa na Rua Brigadeiro Luiz Antônio, hall.

D'Alambert (2003, p. 92-5) em sua pesquisa encontrou apenas um caso de estrutura autônoma de concreto armado - a residência Armando Álvares Penteado, de 1931, da autoria de Dácio de Moraes, localizada na Rua Ceará em Higienópolis. As estruturas eram usualmente mistas: alvenaria estrutural, vigas metálicas e lajes de concreto armado $^{37}$. Do projeto de Dácio ${ }^{38}$ constam, além das plantas de detalhamento estrutural, toda a memória de cálculo realizado para o dimensionamento das vigas, pilares e lajes de concreto armado da construção. E ainda, no memorial, a descrição detalhada da impermeabilização a ser executada na laje de cobertura.

Outra obra de autoria do arquiteto foi o Edifício Saldanha Marinho no Largo de São Francisco, erguido nos anos 1930, para funcionar como sede do Automóvel Clube da cidade. Foi adquirido ainda em obras pela Companhia Paulista de Estradas de Ferro.

As obras do Grande Hotel São Pedro, primeiro estabelecimento hoteleiro da nova Estância de Águas de São Pedro, foram confiadas ao Arquiteto Luiz Camerlingo e a Dácio de Moraes. O hotel em estilo art déco foi inaugurado em 25 de julho de $1940^{39}$

Dácio de Moraes participou ainda do conselho fiscal do IAB-SP, na diretoria de Rino Levi, em 1954.

\footnotetext{
${ }^{37}$ Este tipo de estrutura foi a que se encontrou em nossa pesquisa, praticamente em todos os projetos onde havia menção a este aspecto.

${ }^{38}$ Processo n 42.716/31, no Arquivo Histórico Municipal Washington Luís. In: D’Alambert (2003, p. 92 e 95)

39 Informação no site www.portaldeaguas.com.br/portal/
} 


\subsubsection{Alfredo Ernesto Becker}

Outro arquiteto analisado nesta pesquisa, Alfredo Ernesto Becker, era egresso do Mackenzie. (ATIQUE, 2007, p.399) Teria participado do Primeiro Congresso de Habitação. (Wolff, 2001, p. 279).

$\mathrm{Na}$ Revista de Engenharia do Mackenzie, na "Página de Arquitetura" (março 1928, n.46), é mostrado um projeto neocolonial com grandes frontões, dos engenheirosarquitetos Luiz Espinheira e Alfredo Ernesto Becker: um palacete à Avenida Higienópolis.

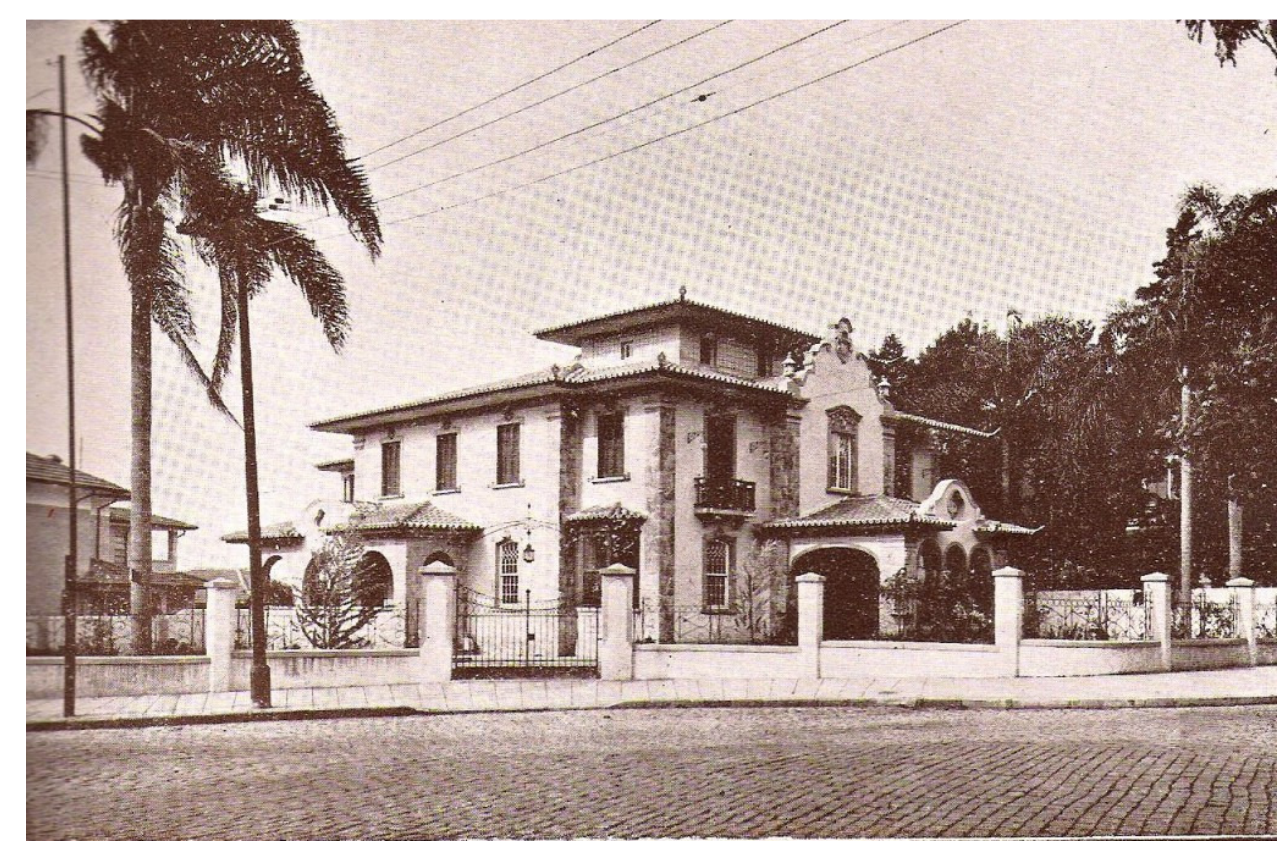

Fig. 5.104 Palacete à Avenida Higienópolis.

No número 47 da Revista de Engenharia do Mackenzie, aparecem dois outros projetos da dupla de arquitetos, um deles com alguns elementos do Neocolonial, localiza-se na Alameda Barros.

Já o segundo projeto é outra grande casa, na Rua José Getúlio, assimétrica e mais interessante: o térreo possui uma varanda de acesso com arco e jardineiras, lembrando o Arts and Crafts, e um volume lateral em semicírculo. No pavimento superior, a faixa na altura das janelas e o guarda corpo lembram-nos o Neocolonial. A localização da casa, elevada em relação à rua, permite a visão do jardim, bastante elaborado. A integração exterior-interior é permitida através da varanda do térreo e do balcão do pavimento superior. 


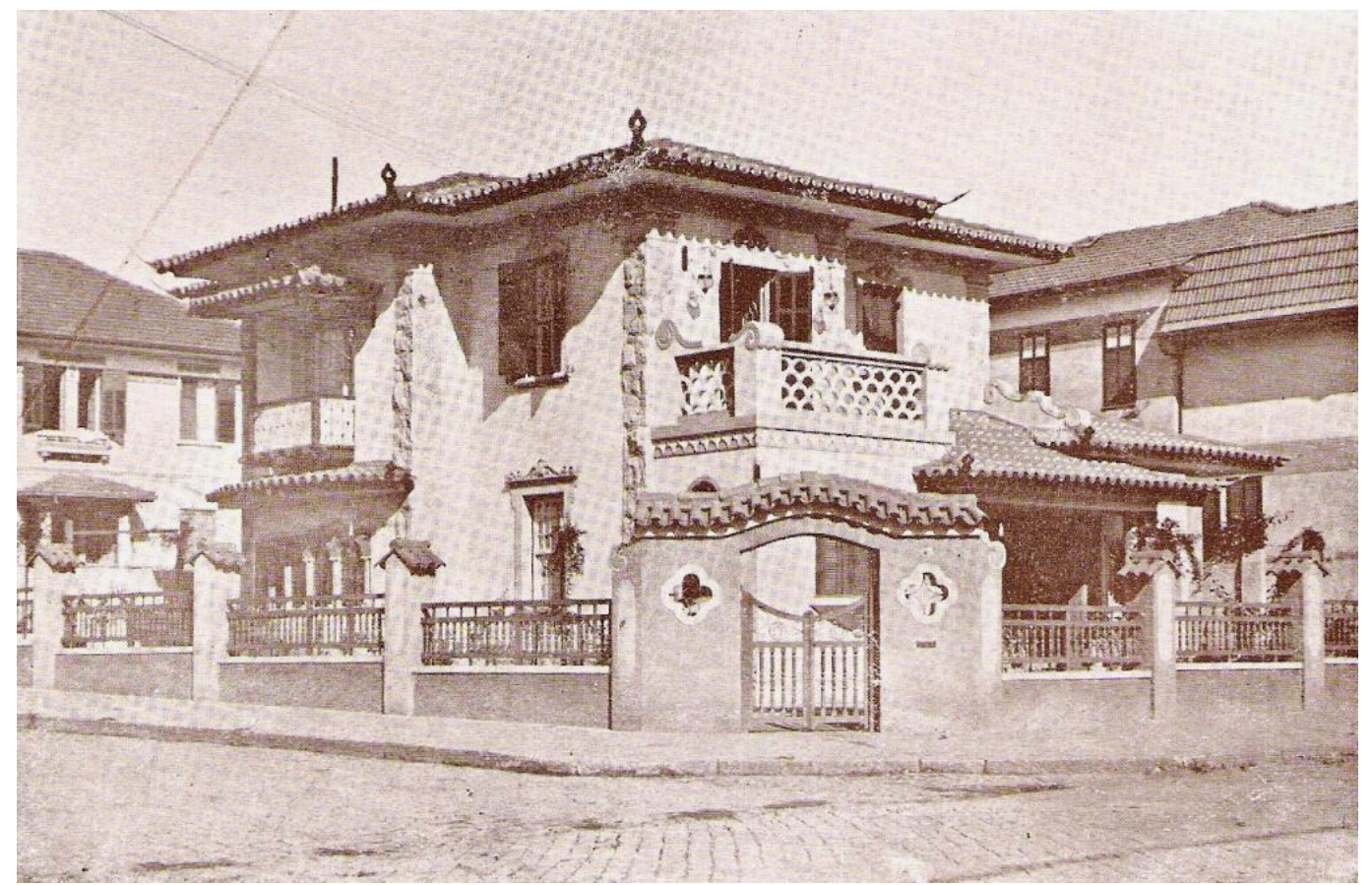

Fig. 5.105 Casa na Alameda Barros.

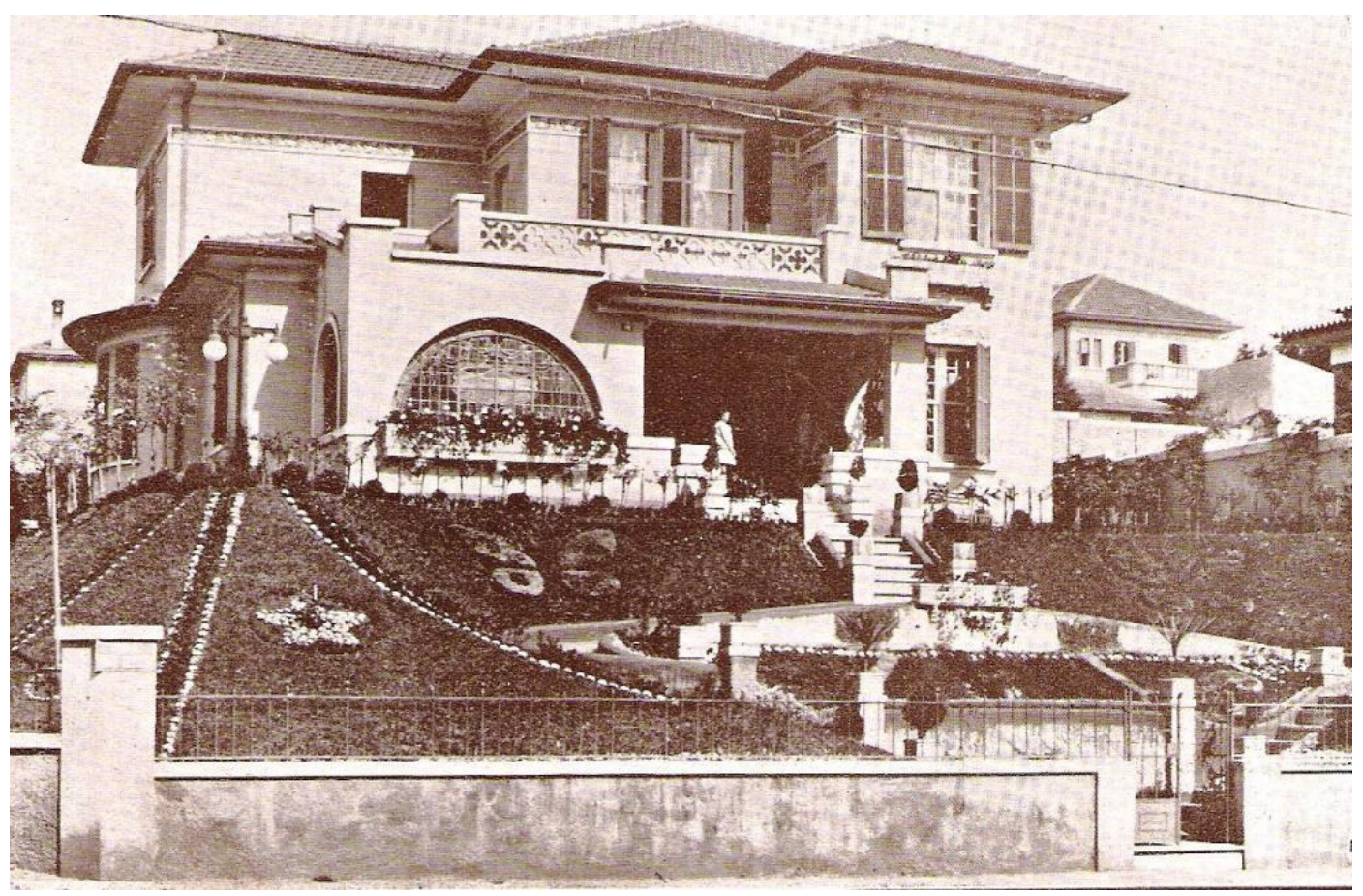

Fig. 5.106 Casa na Rua José Getúlio.

$\mathrm{Na}$ Revista de Engenharia do Mackenzie (setembro 1929, n.51) na "Página de Arquitetura", encontra-se outra casa da autoria de Espinheira \& Becker, que remete aos piores momentos do Arts and Crafts. O Old English de Norman Shaw, sem nenhum senso de equilíbrio e de proporção. O pinturesco levado ao extremo em uma profusão de detalhes: tijolo aparente, pedra, half timbering, esquadrias de vários tipos, 
uma chaminé fora de lugar. No telhado, uma composição estranha, uma grande "água furtada".

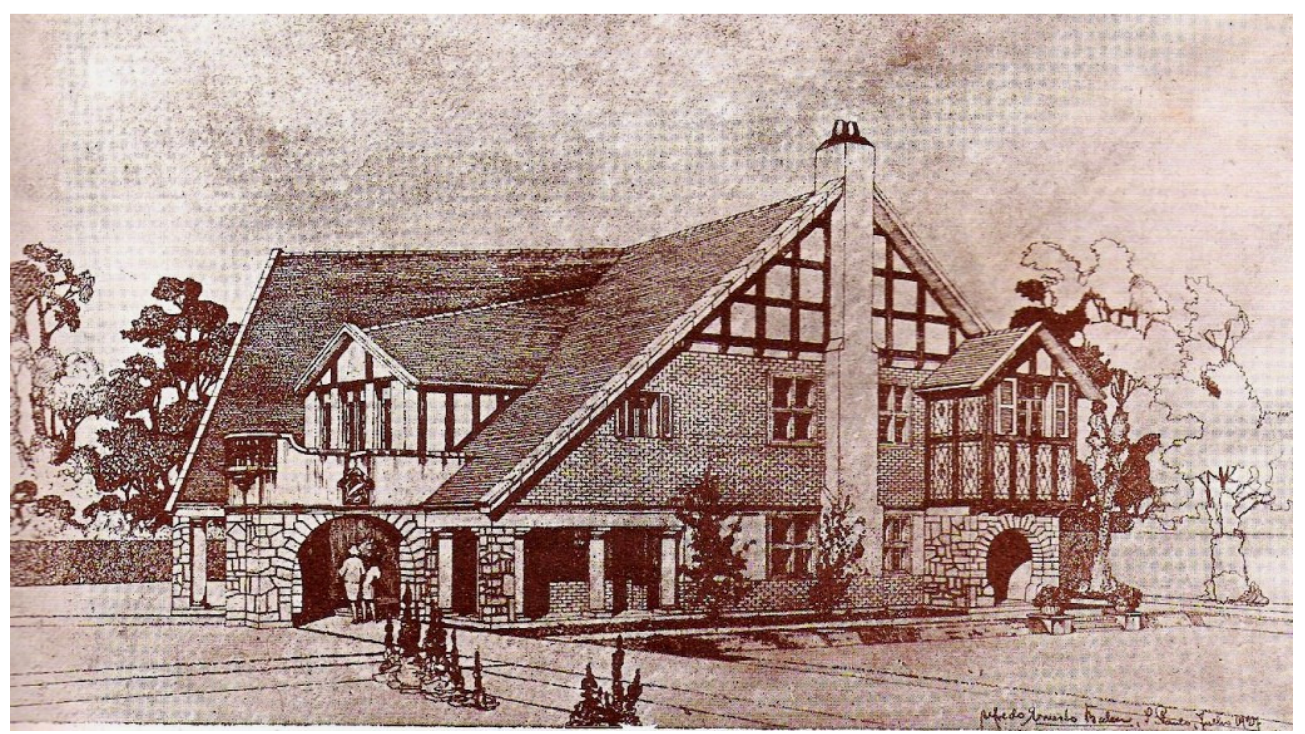

Fig. 5.107 Casa no Jardim América.

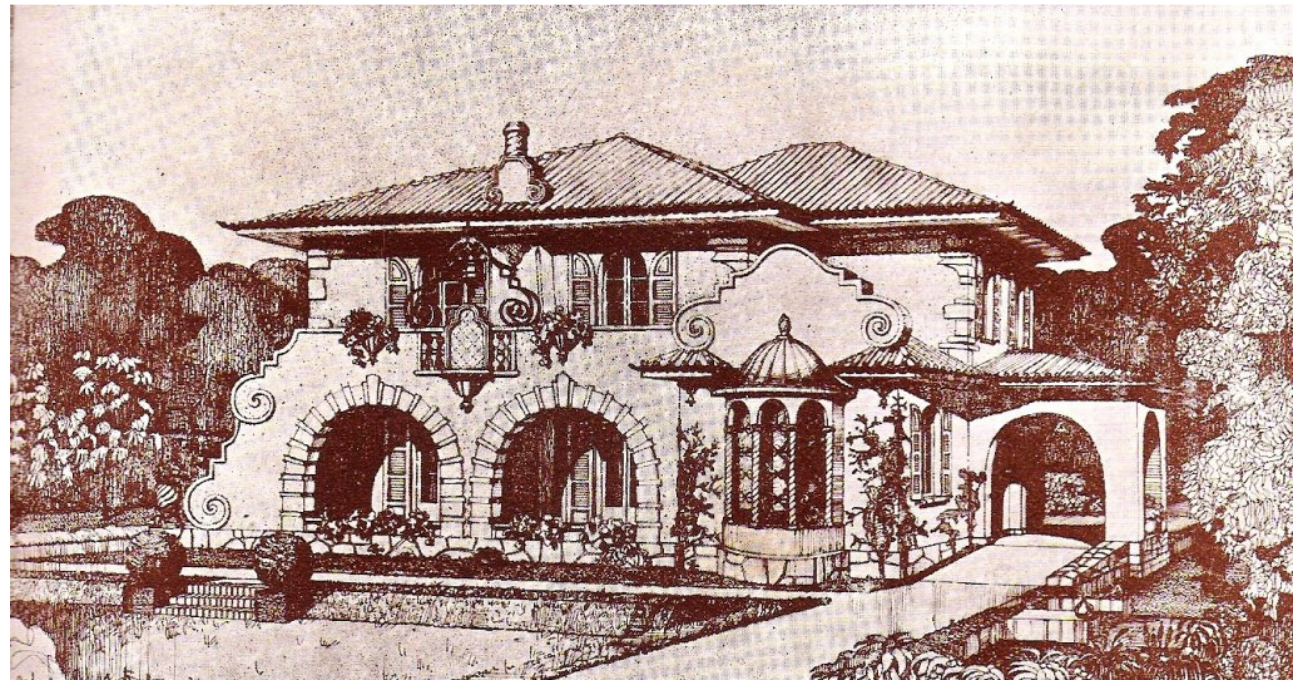

Fig. 5.108 Casa no Jardim América.

$\mathrm{Na}$ mesma página, existe outro projeto dos mesmos autores, híbrido, com características do Missões e do Neocolonial. O fechamento da varanda, que apresenta um volume com colunas no lado direito, "pesa" na composição, desviando a atenção do corpo da casa. Ambos os projetos são para o Jardim América.

Becker teria outro projeto para uma casa no Jardim América, encontrado no arquivo da Companhia City, código. 04.12.223.256, de 1925, na Rua Venezuela. É uma grande casa, com planta interessante: o hall de grandes dimensões tem uma parede curva, 
mas o aproveitamento do espaço é prejudicado pelas colunas colocadas próximas à lareira. A volumetria é bem proporcionada, o aspecto geral é interessante, porém existe ainda a profusão de detalhes e acabamentos.

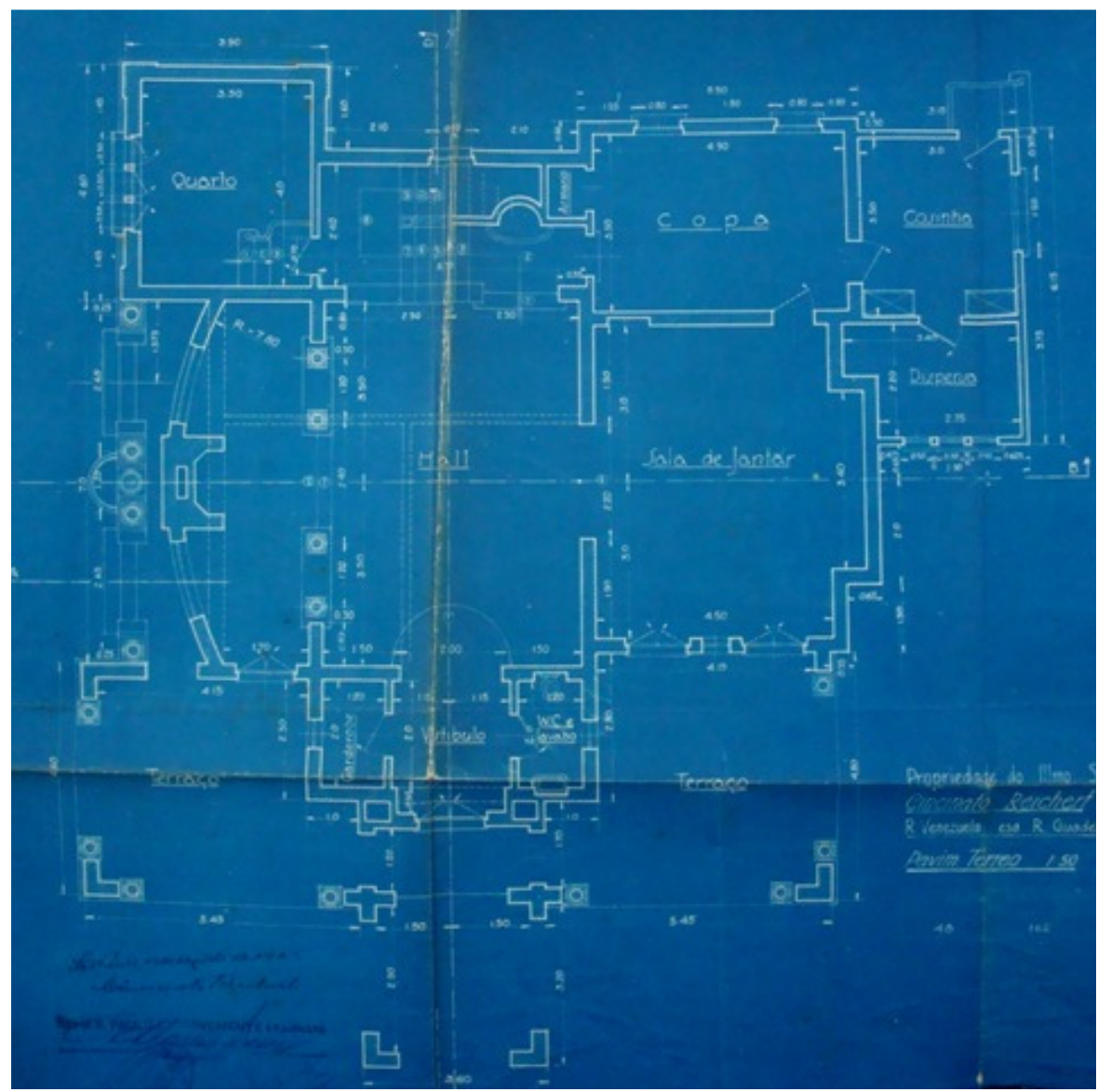

Fig. 5.109 e Fig. 5.110 Casa no Jardim América, planta baixa do térreo e fachada frontal.

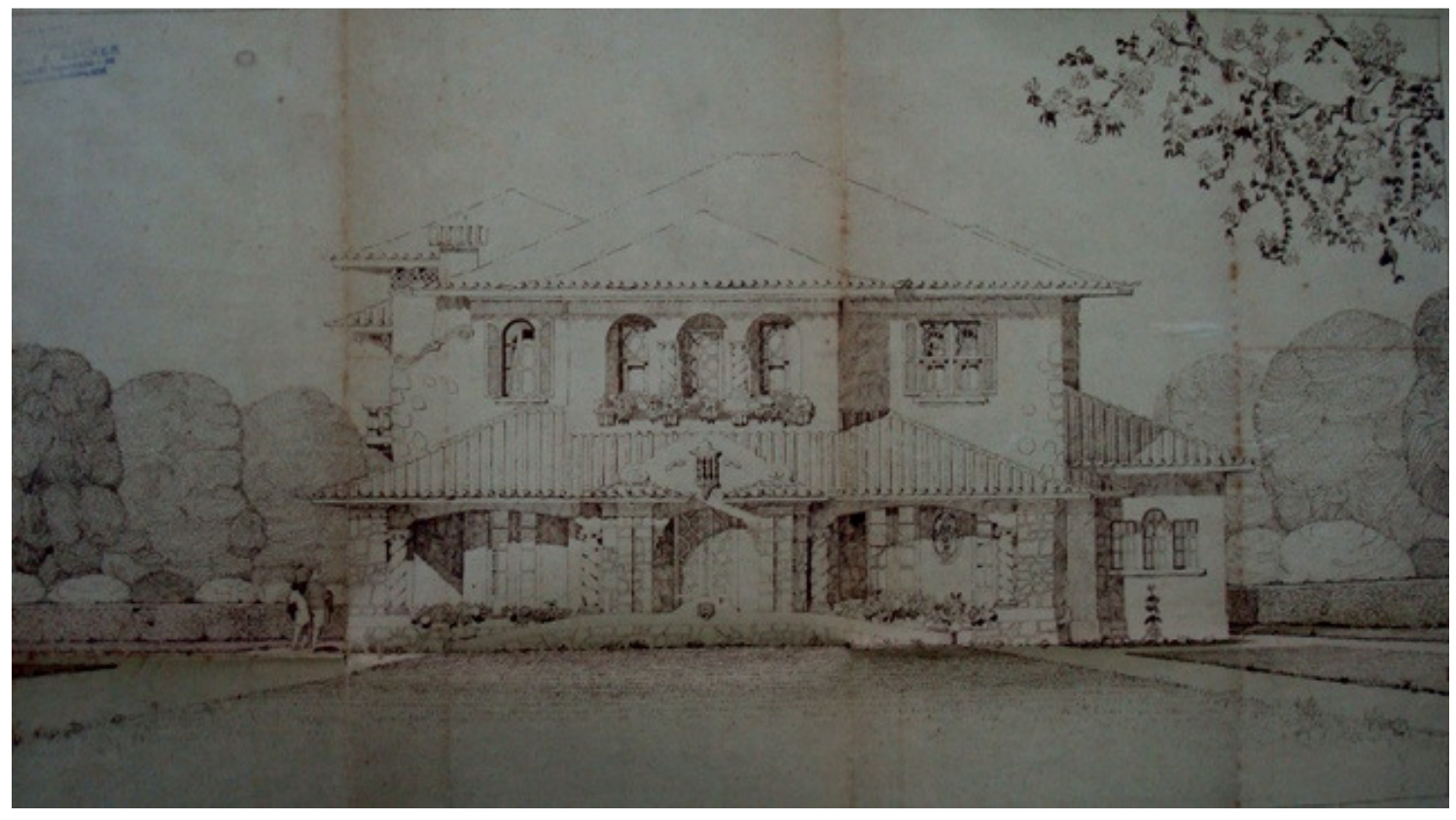


Becker, mais tarde, seria consultor técnico da Revista Acrópole, como consta no primeiro número da revista, de maio de 1938. Neste mesmo número (p. 34-7), seria publicado um artigo de sua autoria sobre a arquitetura monumental européia, uma critica à arquitetura moderna:

Em que consistem no entanto, a importância e o valor estético dessas obras? A resposta a esta pergunta pode ser resumida na definição que se segue: Volta às antigas e indestructíveis concepções de belleza, particulares às raças brancas e que há milhares de annos já encontrado às suas sedimentações mais perfeitas, mais cristallinas e mais syntheticas, nos estylos "clássico-grego" e clássico gregoromano". Este retorno, contudo, não significa submissão servil ou mera reedição de realizações antigas, pelo contrário prova o resurgimento indomável de archetypos, que as nevroses artísticas do "Art Nouveau", do "Futurismo" e do "Utilitarismo à la Corbusier", tinham conseguido "recalcar" para as mais fundas espheras do subconsciente.

No segundo número da revista, Becker escreve um artigo intitulado "ProtoRenascença Florentino", onde diz que "o verdadeiro architecto-criador, quando em suas obras revive as concepções do passado, se esforça por dar-lhe este cunho tão necessário quanto humano: a evolução". E exemplifica com um projeto de sua autoria, uma residência em estilo "florentino", no Jardim América.

Becker também teria participado do conselho fiscal do IAB-SP na diretoria de Rino Levi, em 1954. 


\section{CONSIDERAÇÕES FINAIS}

O conhecimento e a satisfação das necessidades individuais do morador são fundamentais no Arts and Crafts, inglês e americano, é uma de suas premissas. Mesmo quando um alcance maior junto ao público é conseguido, como no fenômeno do bangalô americano, e certa massificação é esperada, a individualidade é sempre incentivada, mesmo que o morador tenha se inspirado em um livro de modelos ou em uma revista voltada ao grande público. Ele é convidado a deixar sua marca em sua casa, mesmo nos pequenos detalhes. A casa deve expressar sua personalidade, onde ele poderá ter uma vida plena, verdadeira.

De certa forma, Purdom aqui resume o movimento Arts and Crafts na arquitetura

Não é apenas nos detalhes da construção que haverá toques pessoais, mas na atmosfera que impregna a casa, seu aspecto real. Quando uma casa é ocupada por aqueles que pensaram e se importaram com sua construção, e que dela cuidam como coisa sua, esta terá uma aparência muito diferente daquela de uma casa alugada, habitada por pessoas que Ihe são indiferentes, ou mesmo que a detestam. Uma casa que alegra seus proprietários e àqueles que nela se abrigam, tem um ar de júbilo, tanto quanto uma casa que não é cuidada mostra os sinais da ruína. É estranho que sem seres humanos para nela viver, que dela tenham orgulho e nela sintam prazer, uma casa logo envelhecerá. Uma casa é como o corpo humano, necessita de uma alma. Se for deixada vazia por muito tempo, torna-se desanimada e melancólica. (PURDOM, 1913, p. 767)

Aqui, a metáfora "cidade - organismo" é transformada em "casa-organismo". Purdom Ihe imputa uma alma. Não sem razão, pois se uma das questões colocadas pelo movimento era uma nova integração do homem à natureza - esta busca romântica da volta ao berço de onde fôramos separados pela própria evolução humana -, esta integração exige uma mediação, que será feita através da moradia. Da fria casa do início do XIX, ela passa a ser um organismo - com órgãos, funções -, que deve funcionar com perfeição, através das partes interdependentes. Uma simbiose se estabelecerá entre o homem e a casa, por isso a necessidade de sua individualização, da marca de seu morador aplicada a ela. E outra simbiose acontecerá entre casa e 
natureza. O continuum tantas vezes mencionado envolve homem-casa-natureza. Esta era a filosofia.

Havia também tentativas de comunhão homem-natureza, como no movimento de simplificação da vida, mas era geralmente uma natureza já transformada, domada para nosso deleite.

O alegado fim do Arts and Crafts na verdade foi uma transformação, em direção às cidades-jardins pré-guerra ou às filas de cottages dos subúrbios Arts and Crafts ingleses e americanos. Houve a massificação, mas também a democratização do movimento, a filosofia mantida, em grande parte, na arquitetura de Letchworth. Democratização também no movimento americano, sintetizado no bangalô. Ambos, arquitetura das cidades-jardins, bangalôs, ganharam o mundo e vieram ressoar aqui.

Mas, os ecos do Arts and Crafts deram-se em vários momentos e começaram ainda no Novecentos. Victor Dubugras recria, em seu pequeno cottage em São Paulo, a marcante realização de Philip Webb e William Morris, a Red House. Fundamental seria a utilização da técnica do tijolo aparente - que seria para sempre assimilada pela arquitetura brasileira - e também a concepção geral do projeto: uma casa para ser olhada por vários ângulos, todos diferentes. Uma liberdade no projetar, equilibrada pelo ar austero. E uma simplicidade desconcertante. Provavelmente, não era a casa que se esperava que um arquiteto construísse para si em 1896, no Brasil. Dubugras influenciaria, através de suas obras; ele foi uma das referências para a arquitetura que a classe média criaria para morar. Foi principalmente esta arquitetura de classe média que foi analisada nesta pesquisa.

Também as referências ao trabalho e à filosofia de William Morris e principalmente de John Ruskin estão sempre muito presentes. A filosofia ruskiniana, mesmo quando não explicitada, é perceptível, por exemplo, no discurso de Ricardo Severo e Ramos de Azevedo sobre o Liceu - fundado sobre a concepção de trabalho de Ruskin. Ou em um projeto de vila operária - em Niterói, publicado também em revista paulistana inspirado por Port Sunlight e outras experiências inglesas e americanas. Porém, apesar do discurso em favor do trabalho humano que acompanha este projeto específico, por trás da idéia da construção de vilas estava a questão da segregação do operário e da imposição de regras morais rígidas e do modo burguês de vida.

Além de Dubugras, o ambiente da Politécnica, de forma geral, no início do século XX, teve influência do movimento inglês. Através do próprio Dubugras que lecionava ali, de outros professores - muitos estrangeiros -, de revistas importadas e das viagens dos politécnicos. 
Em várias fontes, quando é citado o trabalho destes arquitetos paulistanos do início do século, utilizam-se denominações como "Queen Anne", "cottages ingleses", "bangalôs" e outras, que acabam por remeter ao Arts and Crafts. Acreditamos que foi, principalmente, o movimento ainda impregnado de referências historicistas que se viu aqui no Brasil, nos primeiros anos do século. Mas com exceções, vide a Vila Gama Jr. de Augusto de Toledo e Pujol Júnior, que mostra que a evolução purista do movimento inglês aqui ecoou. E continuou influenciando as novas gerações de arquitetos ${ }^{40}$.

O livro encontrado na Biblioteca Central da Politécnica sobre Letchworth é de 1913 e é um balanço dos seus dez anos e, no âmbito desta pesquisa, serve como exemplo do que estava disponível na biblioteca da instituição. São referências eruditas, livros e revistas dirigidas ao público especializado. E este ambiente da Escola Politécnica também exercerá influência através do trabalho de seus alunos e professores.

A Politécnica do início do século, segundo Reis Filho, seguia uma corrente, onde estavam presentes o "racionalismo", a "verdade dos materiais", a "exposição da estrutura", enfim, a "arquitetura de base construtiva". Nada mais é, acredito, que a materialização dos princípios do Arts and Crafts. Além da própria arquitetura a provar isto, os termos utilizados neste discurso dos arquitetos politécnicos eram claros: "harmonia do membramento"; "bela simplicidade"; "paz acolhedora"; "alegria tranqüila de casas de morada"; "disposições constructivas e natureza dos materiaes francamente accusadas"; "maneira de construir tão honesta e racional." 41

A vertente purista do Arts and Crafts, materializada nas cidades-jardins, também foi incorporada pela arquitetura dos anos 1920, inclusive a partir do "livro de modelos" em que se constituía a revista $A$ Casa. Já não se trata de influência erudita, como a anterior. Isto não impede que arquitetos de renome, como o próprio Raul Lino, apareçam nas páginas da revista.

Porém, na revista $A$ Casa, não são encontrados apenas aqueles cottages reduzidos às suas formas mais limpas, mas também composições pinturescas, pertencentes ao Arts and Crafts na fase inicial do movimento na arquitetura. É o caso das casas que parecem ter sido inspiradas diretamente por Norman Shaw. A variedade levada ao extremo e perdendo todo o sentido da racionalidade.

\footnotetext{
${ }^{40}$ Este período não foi pesquisado em fontes primárias, por estar fora do recorte temporal e mostrou-se assunto tão vasto que merece várias pesquisas próprias.

${ }^{41}$ Augusto de Toledo na Revista Politécnica (jan. 1905, n.2, p. 75-7), sobre a Vila Uchoa, de Dubugras, onde ele descreve a casa.
} 
Em A Casa, também são encontrados os bangalôs, herança do Arts and Crafts americano. A própria revista brasileira representava a mais popular revista americana de decoração voltada à classe média, a Ladies' Home Journal.

E havia, além das revistas americanas, os "álbuns de bungalows", anunciados em praticamente todas as revistas, técnicas ou não, do período.

A exposição das formas como o Arts and Crafts pode ter chegado ao Brasil é bastante esquemática e tal simplificação é utilizada apenas de forma didática, já que um caminho não exclui os demais. Um mesmo arquiteto poderia viajar ao exterior, assinar uma revista técnica nacional ou estrangeira, comprar um álbum de bangalôs.

Procuraram-se utilizar outros instrumentos, outras categorias analíticas nesta pesquisa. Análises mais consistentes do que simplesmente a categoria estilo, não adequada a um movimento que não se configura como tal.

Uma das categorias usadas foi o tipo de abordagem ao projeto, a clássica e a pinturesca, entendidas como níveis supra-estilísticos, que não possuem limites temporais ou físicos e que, em um contexto mais amplo, podem ser encaradas como duas maneiras diferentes de se olhar o mundo.

Ressalvas devem ser feitas a este critério, que não deve ser o único, pois nem sempre é possível classificar-se uma obra assim, de forma tão simples, e os próprios arquitetos do Arts and Crafts muitas vezes eram clássicos e pinturescos em um mesmo projeto. E quando Davey (1995) se utiliza deste artifício e faz uma divisão absoluta entre edifícios clássicos ou edifícios com formas vernáculas, desqualificando os primeiros (BURMAN, 1998, p.4-5), com certeza a análise da arquitetura torna-se esquemática.

Tentou-se ver a arquitetura sob uma perspectiva mais ampla, relacionada a fenômenos mais gerais de construção da cidade, como foi dito na introdução. Porque são inseparáveis, arquitetura e cidade, e os mesmos fatores culturais e sócioeconômicos estão presentes em ambas, talvez mais que a materialidade implícita no desenho arquitetônico e urbano. Procurou-se compreender as mudanças sociais, culturais e econômicas, que se davam na passagem do século XIX ao XX, e as idéias que circulavam entre os países. E situar qual o lugar da arquitetura neste contexto. Jamais conferindo-Ihe poder de, isoladamente, determinar comportamentos.

A maneira como a arquitetura tem sido analisada, como coloca Reis Filho (1997, p.30), "a partir de critérios estabelecidos para a elaboração de projetos em épocas posteriores. Com raras exceções este tem sido um procedimento regular entre os autores modernistas: negar valor à arquitetura das etapas anteriores e apagar sua 
memória, a partir de critérios que não estavam em uso na época em que tais arquiteturas foram criadas, mas foram adotados bem mais tarde. É um anacronismo, quando estes autores pretendem estudar as relações sociais e a cultura de uma época a partir de critérios estabelecidos socialmente em outra época, deixando de lado as condições históricas em que viveram os agentes envolvidos. (...) A implantação da arquitetura no lote urbano e a passagem da bidimensionalidade para a tridimensionalidade na arquitetura comum são categorias analíticas fundamentais para o estudo das obras dos séculos XIX e XX". (REIS FILHO, 1997, p. 30, 36)

Os estilos eram secundários. O mais importante era o atendimento das necessidades do homem da época e a utilização da técnica construtiva mais desenvolvida. O projeto decorria de novas maneiras de se viver, novas noções de conforto. Estas eram as questões relevantes.

A própria revista $A$ Casa apresentava muitos textos com esta nova filosofia de vida simples, mas confortável e moderna, irradiada de um novo tipo de casa, adaptada a uma nova cidade, quase uma metrópole que, como tal, precisava de "refúgios". Refúgios como os interiores burgueses analisados por Simmel no início do século XX, analisados juntamente com este novo cidadão, habitante da cidade, morador burguês da casa moderna. Assim, a denominação "livro de modelos" para a revista não foi utilizada de forma pejorativa, como se esta fosse mero livro de desenhos a serem seguidos.

Percebe-se uma tentativa de imposição de valores - não apenas para a classe média, mas também às classes trabalhadoras, imigrantes incluídos. Sanitizar, tornar científico, reformar, inclusive a família. Um instrumento moralizador, para a assimilação dos valores burgueses de consumo, de individualização. Para que o trabalhador internalizasse o ideal de vida em família, recolhida ao lar, com o aprendizado de hábitos regrados e comedidos. Faz parte deste quadro o ataque aos nômades, àqueles que viviam de pequenos trabalhos temporários e outros expedientes, e não conseguiam se fixar. E o apelo às mulheres para que se tornassem as "guardiãs" deste lar.

E o "subúrbio" dos pobres, a periferia, ou as vilas operárias, chamadas "cidades-jardim operárias".

Neste contexto, também, o ensino dos trabalhos manuais, inclusive nas escolas, nas aulas de artes inicialmente separadas por sexo, mais tarde unificadas. Na revista $A$ 
Cigarra $^{42}$, são constantemente mostradas exposições de trabalhos manuais feitos por mulheres, e havia mesmo a utilização do artesanato como forma de sustento para aquelas que se viam sozinhas.

Constitui-se na época uma nova forma de morar para a classe média, que sofrera uma expansão, acentuada nos anos 1920. Classe média que habitará, entre outros bairros, o Jardim América, em seu início. Havia dois tipos de casas ali, palacetes e bangalôs. Apesar de lhes ser negada qualidade por vários autores, representam uma arquitetura com grandes novidades. A começar pelo próprio loteamento, com características inteiramente novas, revolucionárias para a época na cidade, e a evolução na maneira de viver das famílias em casas menores, mais integradas, interna e externamente, com seus grandes jardins e seus espaços de fruição. Abertas para o jardim, mas fechadas à cidade, reclusas em seu subúrbio-jardim. Ainda hoje impressiona o isolamento que o Jardim América proporciona, visto agora através de fotos de satélite, a sensação de "oásis na metrópole" continua.

São, fundamentalmente, novas formas de se viver, baseadas em padrões burgueses, em ambientes privados, contrapostos ao espaço público das novas metrópoles.

Estas novas formas de vida, modernas, transitam entre os países no início do século XX e novas idéias são apropriadas nos diversos locais a que chegam. Esta circulação tornou-se possível, entre outros fatores, graças ao incremento do comércio internacional, que levou a vários tipos de trocas: comerciais, científicas, culturais, sociais.

Nos diversos países, no caso do Brasil iniciando-se nos anos 1910 com o Neocolonial, acontece uma reação contra a internacionalização e descaracterização da cultura local, resultantes da adoção deste novo modo de vida, industrial e urbano. Estas reações são todas regionalistas, e a casa torna-se o seu símbolo, ajuda a constituir uma identidade nacional. A inspiração para esta nova casa viria da arquitetura vernácula, ou apenas de uma tradição inventada ${ }^{43}$, um passado manipulado para instituir, reforçar ou forjar identidades nacionais.

As primeiras reações haviam acontecido na Inglaterra, o primeiro país a se industrializar, e eram uma das bandeiras do movimento Arts and Crafts.

\footnotetext{
${ }^{42}$ A revista A Cigarra era uma revista de variedades dos anos 1920, revolucionária em certos aspectos, como a utilização de fotografias mostrando pessoas nas ruas, casas e outros temas.

${ }^{43}$ Conceito elaborado pelo historiador Eric Hobsbawn e mencionado no capítulo 2, p.120.
} 
O Neocolonial ${ }^{44}$ faz parte deste contexto dos movimentos regionalistas mencionados. Pode ser constatado mesmo no discurso dos líderes do movimento, como no capítulo $5^{45}$, onde são aproximadas as falas de Voysey, José Marianno Filho e Ricardo Severo. Sempre é utilizado o conceito de raça, meio, em discursos nacionalistas. Mas, este assunto só foi tratado de maneira superficial, e necessita ser melhor analisado. De qualquer forma, é relevante mencionar ainda uma vez que, dos arquitetos dos anos 1920 pesquisados, aquele que, a nosso ver, melhor incorporou o ideal do Arts and Crafts foi justamente um adepto do Neocolonial, Álvaro Botelho. Das duas formas de regionalismo apontadas por Reis Filho, ele seguiu o caminho que é o mesmo de Dubugras, da inspiração, não da cópia, dos modelos da arquitetura vernácula e da utilização das características antigas de forma não gratuita, mas sintonizada com as novas formas de vida.

O regionalismo apresentaria duas orientações. A formalista, de sentido nacionalista e conservador, que no Brasil podemos identificar com a "arquitetura tradicionalista", com o Neocolonial, de retomada das formas do passado que eram recombinadas em novos modelos. Outra linha seguida pelo regionalismo é a da busca dos processos construtivos e materiais mais adequados a determinadas regiões e apenas inspiração nas formas existentes (REIS FILHO, 1997, p.74) Este é o regionalismo de Philip Webb, de Victor Dubugras.

Regionalismo ligado à preservação das tradições culturais, à integração com a natureza e à sua preservação - no respeito à topografia, ao clima -, lições que ainda precisamos aprender.

E todos os dias, em nossas cidades "contemporâneas", vemos como é urgente aprender a se adaptar. À natureza, a uma nova forma de vida. De certa maneira, esta é a antiga lição dos Crafts.

\footnotetext{
44 O Neocolonial, no final da década de 1920, começará a ser apropriado pela classe média - será mostrado nas revistas paulistanas dedicadas a engenheiros e arquitetos, ao lado de projetos pinturescos Mas, o "Estilo Colonial Brasileiro" continuaria a dividir espaço com cottages e bangalôs. Estes, acreditamos, nunca perderam realmente seu lugar, como pode ser observado em números posteriores da revista $A$ Casa e da revista Acrópole, entre outras. Estes tipos característicos, cottages, bangalôs e grandes casas de composição pinturesca ainda são hoje adotados e podem ser vistos em nossas cidades. Sua utilização é resgatada de tempos em tempos, e pode ser vista nas casas de telhados pouco inclinados e "tijolinhos à vista" ou nas casas pinturescas, com profusão de detalhes. E, atualmente, a idéia de se integrar os ambientes sociais está novamente em voga. Nas regiões mais quentes do nosso país, a própria varanda torna-se o ambiente de maior permanência e se sofistica com um sem número de comodidades.

${ }^{45}$ Páginas 288 a 290.
} 
Hoje, o Arts and Crafts mostra-se cada vez mais atual. Em um mundo onde a preservação do ambiente e a valorização das várias culturas locais são cada vez mais discutidas, o movimento que nasceu na Inglaterra mostra-se um caminho possível.

Hoje vivemos uma época e um lugar bem diversos dos ingleses do século XIX. São contextos históricos bastante diferentes. Fazer do trabalho arte e centro de nossa vida, infelizmente, ainda é um luxo para poucos. Porém, a simples existência do ideal do "Artes e Ofícios" ainda questiona nossas condições de trabalho e de vida. 


\section{Anexo 1}

\section{Outros periódicos da época}

Quanto aos periódicos consultados, de engenharia e arquitetura, que se constituíam nos mais significativos à época, cabe ainda descrevê-los de forma sucinta e apresentar algumas matérias e projetos neles publicados que, apesar de não se referirem aos arquitetos mencionados anteriormente, ajudam a compor o quadro da arquitetura da época, que é, ao final, o objetivo desta pesquisa.

Em 1900, surgiu o Anuário da Escola Politécnica. Segue-se a Revista Politécnica, fundada pelo Grêmio Politécnico em novembro de 1904. (FICHER, 2005, p. 30).

Fora do âmbito acadêmico, a partir de junho de 1911, passa a circular a Revista de Engenharia, que durou apenas dois anos. A Revista de Engenharia do Mackenzie, organizada pelo Grêmio Horácio Lane, passa a ser publicada a partir de maio de 1915, e o Boletim do Instituto de Engenharia, a partir de outubro de 1917. (FICHER, 2005, p. 30-1).

\section{A Revista Politécnica}

A "Revista Polytechnica", bimestral, foi criada como órgão do Grêmio Politécnico, fundado e dirigido na época por Alexandre Albuquerque.

Já em janeiro de 1905 (p.75-7), em seu segundo número, apresentava um artigo de Augusto de Toledo, sobre a Vila Uchoa da autoria de Victor Dubugras ${ }^{46}$. A respeito da publicação de matérias sobre arquitetura, explica: "Daremos na 'Revista' uma notícia descriptiva das construcções que se forem executando nesta capital e que apresentem, pela architectura, pela execução alguma coisa de notável (...)" (p. 75).

Em março de 1905, a revista publicará uma reportagem sobre uma exposição com trabalhos de Victor Dubugras. Sempre ao lado de artigos técnicos, sobre cálculo ou sobre máquinas e equipamentos, aparecerão outros relacionados à arquitetura e discussões sobre urbanismo. Em relação à cidade, outros artigos tratavam de infraestrutura - pontes e estradas, abastecimento de água e outros temas.

\footnotetext{
${ }^{46}$ Artigo já descrito no capítulo 3, quando tratamos da arquitetura de Victor Dubugras.
} 
Ainda sobre arquitetura, um artigo apresenta o projeto que teria sido enviado por Victor Dubugras ao concurso para o edifício do Congresso Nacional do Brasil (maio 1907, n.15, p.113-121). Em 1908, no número 22 (julho-agosto, p. 186-192), aparece a Estação de Mayrink, um projeto revolucionário de Dubugras, em concreto armado. Em 1911, no número 33 (fev.-março, p. 91-145), é publicada a transcrição de uma conferência dada por Victor da Silva Freire no Grêmio Politécnico: "Melhoramentos de São Paulo". Freire era professor da Politécnica, além de diretor de Obras Públicas da prefeitura de São Paulo.

Outra conferência de Freire no Grêmio Politécnico, "A cidade salubre", aparece no número 48 (out.-nov. 1913, p. 319-355). Em 1926, (junho, n.81, p. 127-139), é publicado um artigo sobre estética, "Introducção ao estudo da Esthetica", de Anhaia Mello. Neste número, com exceção deste artigo, todos os outros versam sobre cálculo de estruturas, motores, tração elétrica e materiais. O artigo de Anhaia Mello constituise realmente em exceção, pois entre 1916 e 1917, a Revista Politécnica teve seu conteúdo alterado, concentrando-se nos assuntos técnicos e praticamente ignorando as antigas discussões sobre a arquitetura e a cidade. A mudança foi progressiva, mas no período citado a revista estava completamente modificada quanto à sua pauta.

Coincide com o que foi relatado sobre o período 1915-1930 no ambiente da Escola Politécnica, quando as pesquisas de caráter estético dos engenheiros-arquitetos teriam perdido importância e permanecido apenas as questões racionalistas no plano técnico.

Era noticiado na revista o recebimento de várias revistas européias, americanas (The American Architect, The Building Review - Sâo Francisco, The Architectural Forum), de outros países da América Latina e brasileiras (inclusive a Revista de Engenharia do Mackenzie).

\section{A Revista de Engenharia do Mackenzie}

Chamada Revista de Engenharia (publicada pelo Centro Acadêmico Horácio Lane da Escola de Engenharia do Mackenzie), o primeiro número aparece em maio de 1915. A revista era trimestral e era vendida também no Rio de Janeiro e em Belo Horizonte. 
Foi reformulada a partir de dezembro de $1926^{47}$. Mudanças no formato - aumentam suas dimensões -, e o número de anúncios cresce. O número de Agosto de $1926^{48}$ (Anno XI, n.39) já apresentava artigos sobre política, infra-estrutura, cálculos de estruturas, motores, materiais, e já uma página dedicada à arquitetura, com reportagem sobre "A architectura do dr. Adhemar de Moraes".

No número 40 (dez. 1926, n.40, p.22-5), tal sessão passa a ser denominada "Página de Arquitetura", apresentando um "elegante palacete de estylo medieval", obra de um escultor, com vaga inspiração medieval e assemelhando-se a uma escultura, não a um edifício. Apesar dos detalhes construtivos inusitados, o prédio obedeceria à higiene domiciliar e a mais rigorosa técnica; a insolação e a ventilação seriam adequadas.

Significativa sobre o conflito encontrado pelos arquitetos da época é a seguinte frase: “(...) os technicos (...) quando se encontram elles em face deste problema: convencer o cliente (...) que uma obra em taes e taes condições, não deve ser assim, assim (...) E como se não bastasse essa controvérsia, surgem ainda as esposas que, aliás, com muito feminismo, vão 'projectando' seu palacete, com pedaços de cem outros sonhados. (...) Que fazer? Conciliar as vontades recíprocas, adaptando, com essa solução, a technica e seu auto-sensum aos permissíveis caprichos dos clientes." O arquiteto deveria dominar um repertório de várias "estilos", que se adaptariam às soluções técnicas correntes, estas sim fora do âmbito de discussão dos clientes.

Neste mesmo número aparece o primeiro anúncio de geladeira elétrica - Frigidaire -, que ainda se assemelha a um armário, mostrando a modernização das cozinhas, através de novos equipamentos, assunto tratado no capítulo 4. Este outro anúncio foi publicado no n.46 (março 1928) da mesma revista e mostra outra marca do eletrodoméstico.

No número 45 (nov. 1927, p.40), são publicados dois sobrados geminados de Kosuta ${ }^{49}$ \& Santos. O aproveitamento do terreno em declive possibilitou a construção de uma garagem e acomodações para empregados, abaixo do nível do pavimento térreo, com acesso pela parte posterior da casa. Vagamente inspirada no estilo Missões, com arcos, gradis de ferro nas sacadas e colunas dividindo as janelas, a planta reflete um projeto racional e econômico. As paredes do segundo pavimento coincidem com as do térreo e todas as instalações hidráulicas estão concentradas.

\footnotetext{
47 Foi o primeiro número reformulado encontrado na EPBC, mas provavelmente a reformulação aconteceu no número de Agosto de 1926.

${ }^{48}$ Apesar de não ter sido encontrado, o conteúdo deste número pôde ser conferido no número 83 , da Revista Politécnica (junho de 1927), que apresentava o conteúdo de diversas revistas.

49 Francisco Kosuta era professor do Mackenzie e participou do IAB/SP, aparecendo em foto de 1946 (FICHER, 2005, p. 247) ao lado de outros arquitetos conhecidos, como Alfredo Ernesto Becker
} 


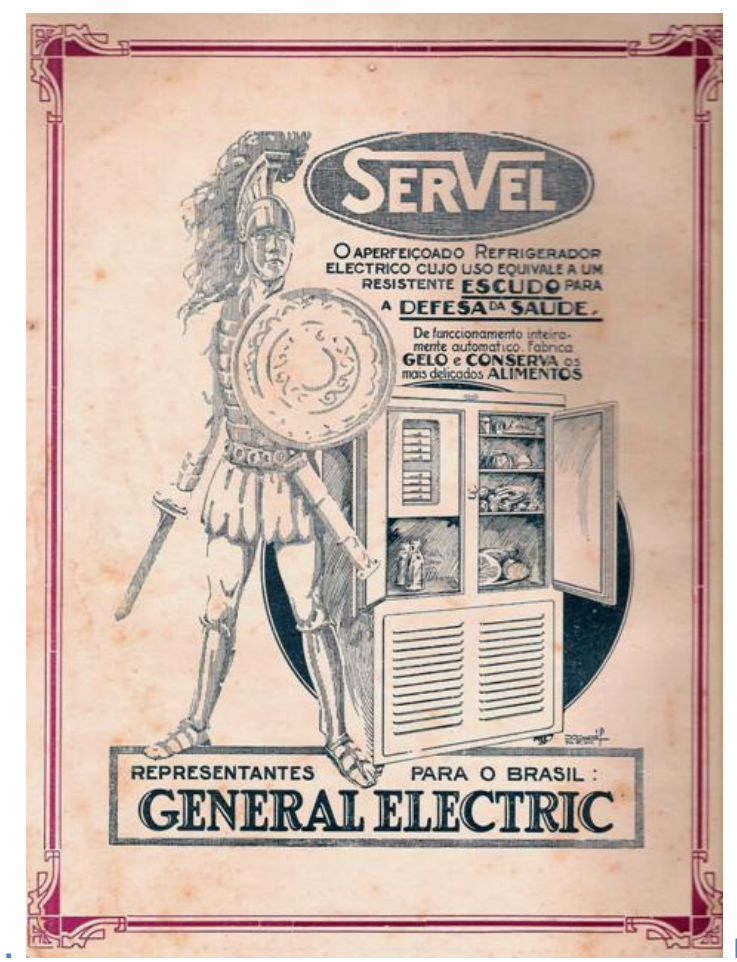

Fig. 5.111 Anúncio de refrigerador.

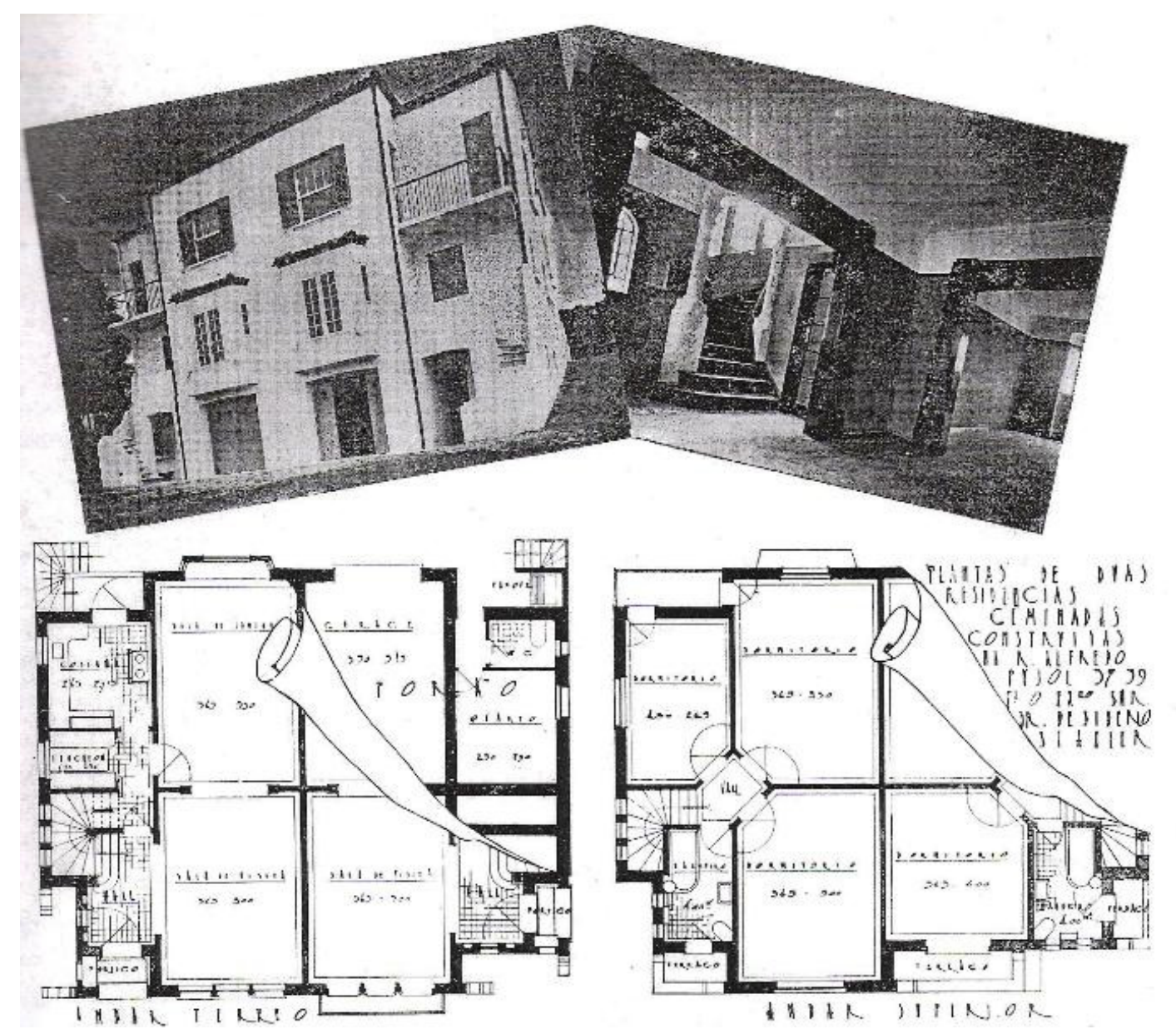

Fig. 5.112 Sobrados geminados. 
No número 48 (set. 1928, p. 20), aparece uma casa construída no Jardim América, na Rua Colômbia, de volumetria movimentada, detalhes neocoloniais, uma composição bastante interessante, equilibrada, do engenheiro Elias Machado ${ }^{50}$.

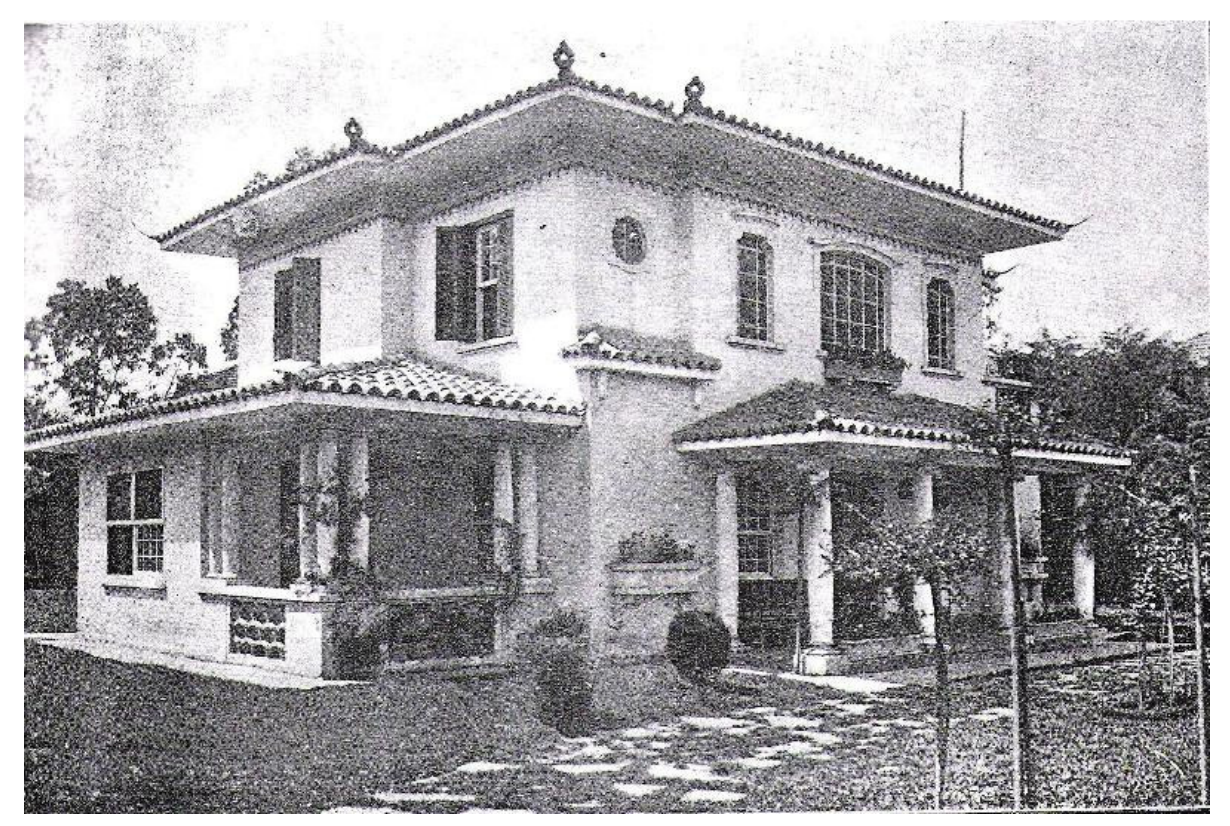

Fig. 5.113 Casa no Jardim América, arquiteto Elias Machado.

No mesmo número, é publicado um anúncio da Livraria EDANEE, sobre livros à venda, nacionais e importados. Entre estes, os "álbuns de Bungalows", com "sortimento variado dos melhores editores".

No número 49 (dez. 1928), é mostrada uma casa projetada e construída pela Companhia City no Pacaembu. Filia-se à fase do Arts and Crafts em que formas mais limpas estão sendo adotadas e apresenta poucos detalhes, como as varandas laterais e o madeiramento que aparece na fachada. Situa-se no topo de uma pequena elevação e o terraço, as salas e os dormitórios estão localizados de maneira a aproveitar a melhor vista. Este cottage austero foi construído pela Companhia City no início da ocupação do bairro, para atrair compradores, favorecido pela sua localização. Apareceu em várias revistas, em reportagens e anúncios da companhia. No térreo, existe um hall de grandes dimensões, uma espécie de houseplace, onde provavelmente se desenvolveria a "vida" da casa e que integra-se aos outros ambientes sociais, à varanda e ao terraço.

\footnotetext{
${ }^{50}$ O livro de Wolff (2001) não apresenta mais informações sobre o engenheiro, a não ser que o nome completo, Elias Machado de Almeida e a menção a outros três projetos seus no Jardim América, na década de 1930.
} 

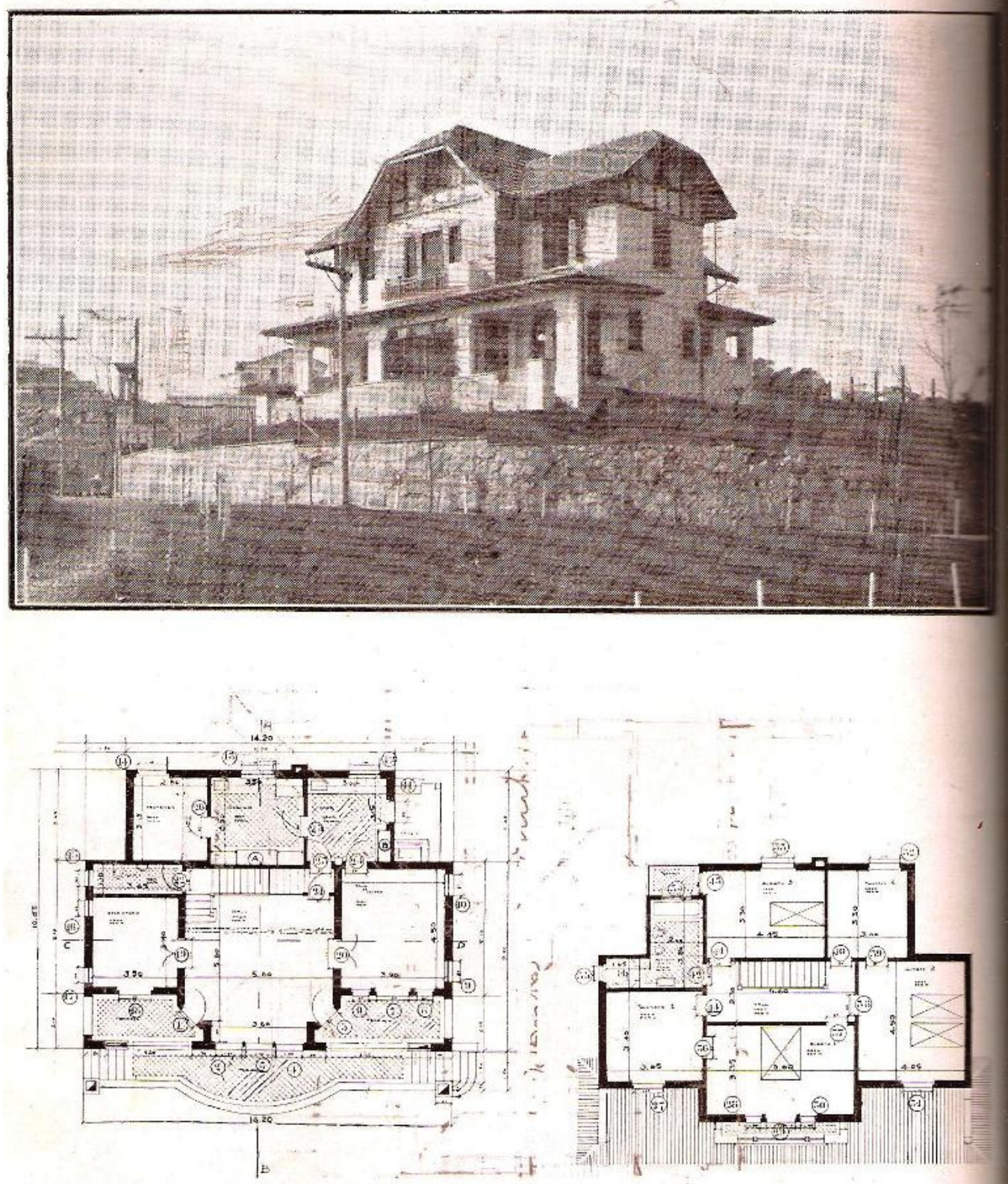

Is: $1: 50$

pavimento Terroo

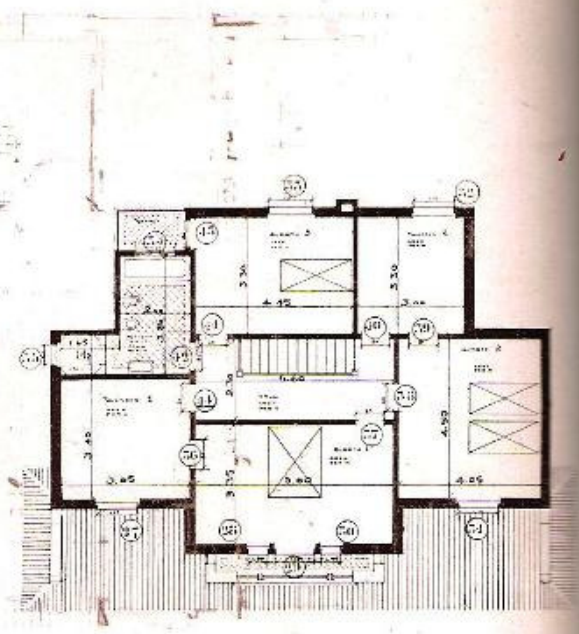

Pavimonto Suporior

Fig. 5.114 Casa construída pela Companhia City no Pacaembu.

No número 50 (maio 1929), na "Página de Arquitetura", é publicado um projeto dos engenheiros-arquitetos Pistoresi \& Comp., surpreendente para o ano de 1929 - época em que o Neocolonial e o Missões dividem a cena. Uma grande casa como as de Norman Shaw e seu Old English - com grandes telhados inclinados, volumes com várias alturas, recuados ou ressaltados, chaminés, leaded lights. Half timbering no pavimento superior. No térreo, o tijolo aparente. Não se sabe se o prédio foi construído ou não. Nenhuma informação foi obtida sobre os arquitetos. 


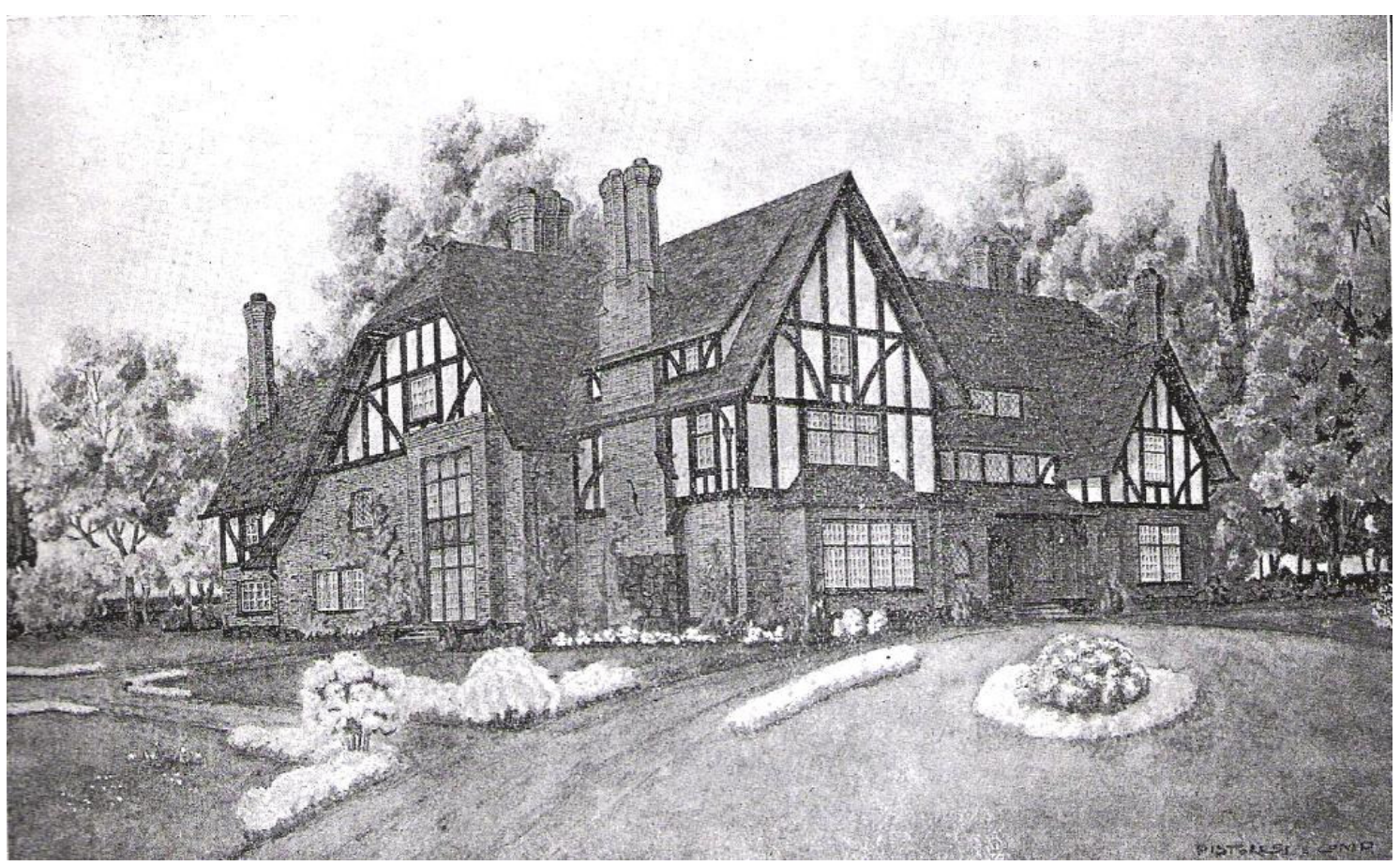

Fig. 5.115 Projeto dos engenheiros-arquitetos Pistoresi \& Comp.

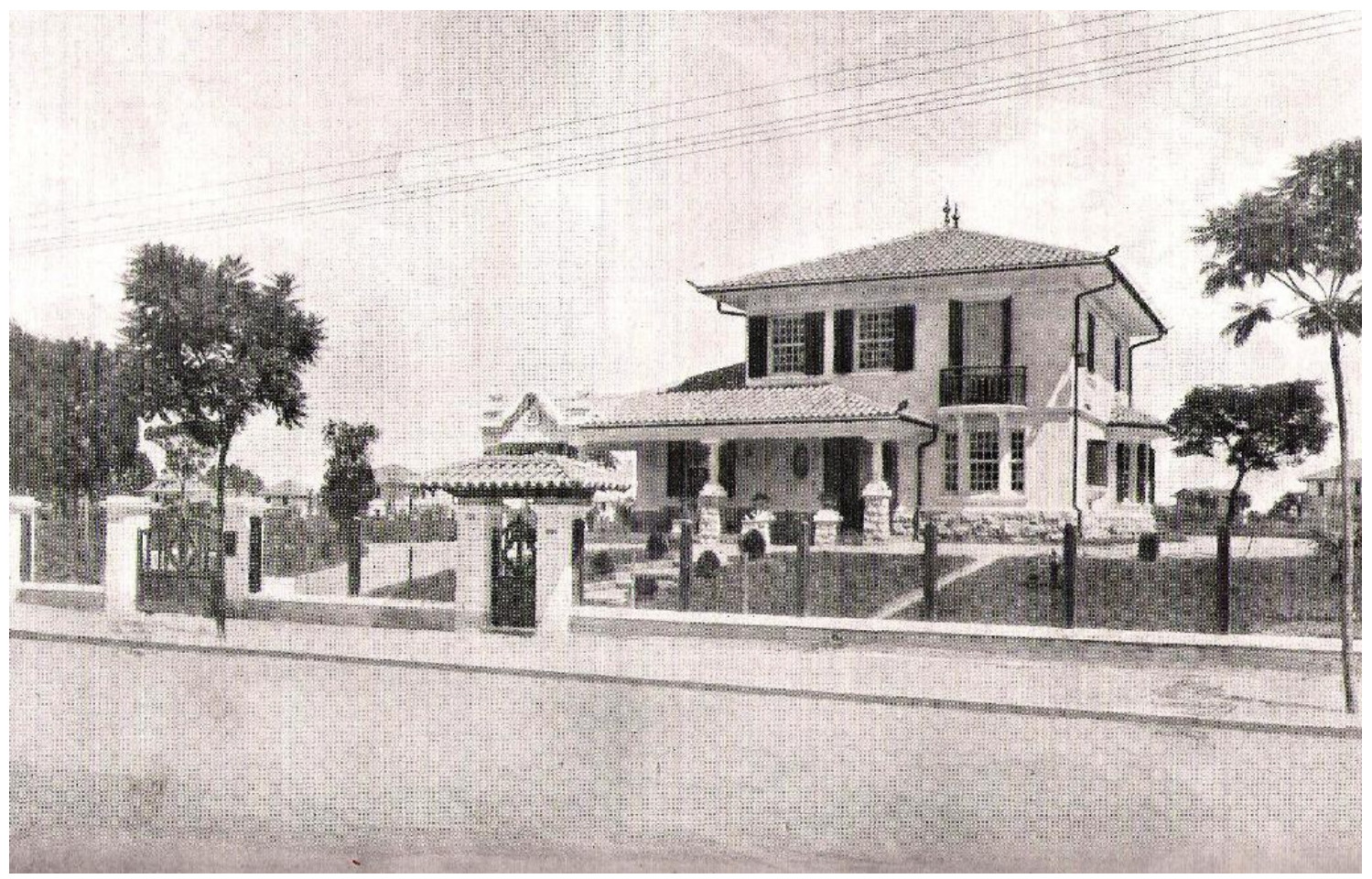

Fig. 5.116 Casa executada no Jardim América pela Sociedade Construtora e de Imóveis. 
O número $52-3$ (junho 1930) seria um número especial dedicado ao IV Congresso Pan-Americano de Arquitetura e apenas projetos de alunos e ex-alunos do Mackenzie seriam publicados.

Neste número, é mostrada uma casa executada pela "Sociedade Constructora e de Immoveis", com características neocoloniais - frontão na varanda, condutores de água fazendo parte da composição, base das paredes em pedra e telhados com as pontas levantadas. A casa consiste basicamente em um grande volume, a que foram adicionados a varanda e os detalhes neocoloniais. Esta casa localizava-se no Jardim América, na Rua Canadá, n. $30^{51}$, e percebe-se na foto a topografia praticamente plana do bairro. Fica bem clara também a "permeabilidade visual" a que se refere Andrade (1998, p. 248) e que seria comprometida com o retalhamento em lotes menores que os existentes - dos jardins internos.

Outra curiosidade publicada neste número (p.155) é a menção à "primeira formatura de uma representante do sexo feminino em um curso de engenharia". Zilda de Almeida Sampaio formou-se como engenheira - arquiteta naquele ano pela Escola de Engenharia do Mackenzie.

\section{A Revista Architectura e Construcções}

A revista - mensal - era editada em São Paulo e surgiu em agosto de 1929. Apresentava como colaboradores profissionais bastante conhecidos, como Francisco Prestes Maia. Tais profissionais eram egressos tanto da Politécnica - como Augusto de Toledo - quanto do Mackenzie - como Olavo Franco Caiuby e o próprio Christiano das Neves. O diretor fundador era o engenheiro Júlio Cápua.

Apresentava grande quantidade de anúncios, que incluíam materiais de construção, como areia, pedra, cimento, impermeabilizantes, madeiras; materiais de acabamento $^{52}$, como mármores, granitos, vernizes, louças sanitárias; e móveis e eletrodomésticos.

\footnotetext{
51 A casa foi construída pela Sociedade Construtora e de Imóveis e pertencia a um de seus diretores. A foto da casa aparece no álbum publicado pela empresa em 1928.

52 Entre estes anúncios de materiais de acabamento, havia os de vitrais - de Conrado Sorgenicht, que segundo Lemos (1989, p.186) foi o precursor da fabricação destes elementos tão presentes na arquitetura neocolonial.
} 
A única restrição era a não aceitação de anúncios entre o texto (set.1929). Isto era uma prática comum entre as revistas voltadas aos profissionais, como a Revista do Mackenzie e a Revista Architectura no Brasil. Diverso da revista A Casa, onde os anúncios e os artigos misturavam-se, como aliás se tornaria comum com o passar do tempo.

Havia uma seção chamada "Galeria dos nossos Architectos e Engenheiros", onde a cada número era publicada uma caricatura de um profissional bastante conhecido como Ricardo Severo, Christiano das Neves, a maior parte colaboradores da revista.

O leitor poderia solicitar um projeto personalizado, enviando um cupom com informações sobre o programa e a localização da casa. Os projetos seriam publicados na revista. Na página 26 do primeiro número (agosto 1929), são mostrados dois destes projetos. Aparece ainda um pequeno cottage sempre associado ao título da seção, como um logotipo. Em 1929, o "pequeno cottage" originado do Arts and Crafts ainda era visto como símbolo da casa familiar.

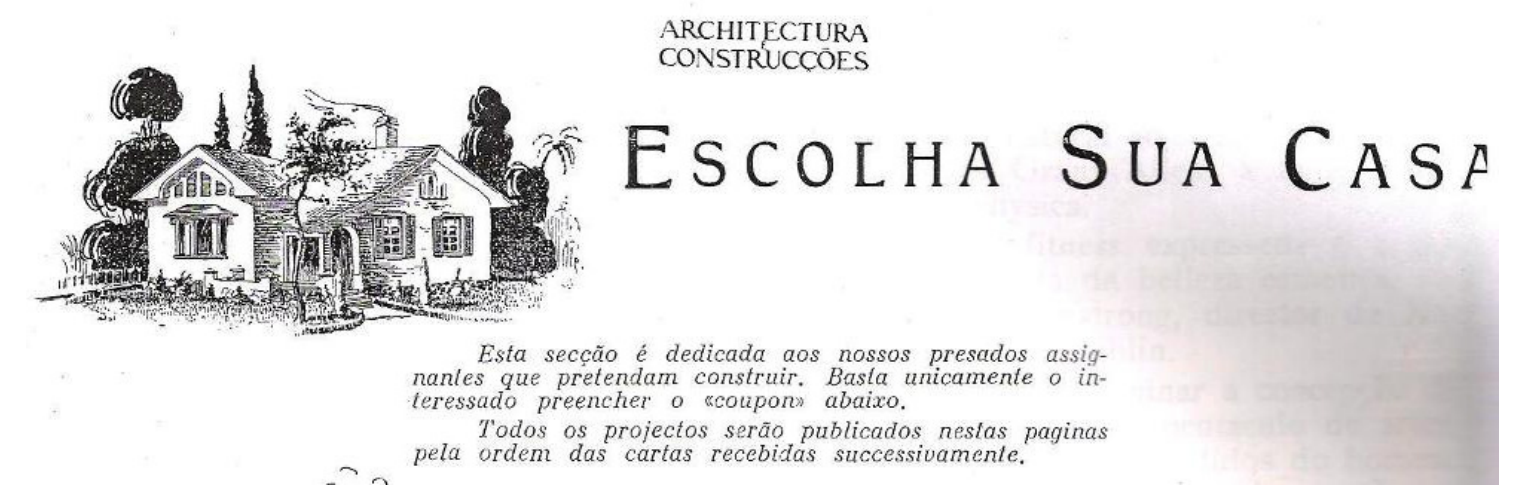

Fig. 5.117

No número 2 (set. 1929, p. 11-7), aparece um artigo da autoria de Christiano das Neves, com críticas contundentes à arquitetura moderna, como, aliás, ele publicava constantemente.

No mesmo número, anúncios de álbuns de Bungalows de vários tipos, na seção "Bibliographia", ao lado de livros técnicos e de outros, como os de Le Corbusier e Der Staedtebau (grafia da revista) de Stuebben (grafia da revista). (p.45)

No número 6 (jan. 1930, p. 15-18), reportagem sobre o IV Congresso Pan-Americano de Arquitetos que se realizaria no Rio de Janeiro em junho de 1930. Era divulgado o regulamento do congresso. 
E no número 12 da revista (julho de 1930, p. 3-7), aparece um artigo sobre o mesmo congresso, que já ocorrera no mês anterior. A força do tema regionalismo na arquitetura pode ser verificada na primeira tese discutida no congresso: "Regionalismo e internacionalismo na architectura contemporânea. A orientação espiritual da architectura na América." Um dos pontos discutidos dentro desta tese era de que a arquitetura das escolas públicas fosse inspirada nas tradições regionais, com o "intuito de despertar no espírito das crianças o sentimento da própria nacionalidade." $\mathrm{Na}$ tese sobre o ensino da arquitetura, aconselhava-se o estudo da composição arquitetônica, completados com conhecimentos artísticos, históricos, técnicos e científicos para se exercer a profissão. Outra tese - A VII -, em defesa do patrimônio artístico principalmente o arquitetônico das nações americanas, sugeria que fossem fundados museus de arte nacional pelos poderes públicos, para o estudo arqueológico da arquitetura e das demais artes. $O$ estudo da arquitetura vernácula era uma nova meta nos países americanos. O discurso de Ricardo Severo e de José Marianno Filho no Brasil repetia-se por quase toda a América. 


\section{Anexo 2}

\section{Sociedade Construtora e de Imóveis: uma importante construtora}

Importante também para compor o quadro da arquitetura paulistana dos anos 1920 é citar a Sociedade Construtora e de Imóveis, uma grande construtora paulistana, fundada naquela década, que executou obras não apenas na capital, mas por todo o interior e litoral. As obras incluíam estradas de rodagem e outras obras de infraestrutura, loteamentos, casas e outros tipos de edifícios.

Foram encontrados dois álbuns de fotos, editados como publicidade das obras da construtora, na biblioteca da FAUUSP. Um deles é de junho de 1928 e o outro de 1940, e está fora do período abarcado por esta pesquisa.

No álbum de 1928, diz-se que a construtora teria cinco anos de fundação e seria seu quarto ano de "vida social", assim provavelmente foi criada em 1923 e iniciou suas atividades em 1924.

Neste período, construiu 57 casas, no álbum denominadas "prédios residenciaes", e também "prédios para renda". Os prédios residenciais eram as casas construídas sob encomenda para os proprietários nelas morarem e os prédios para renda, imóveis para serem alugados - construídos isolados, geminados ou constituindo uma fila de casas. Estes imóveis são menos elaborados que aqueles feitos para moradia do proprietário, mas ainda existia a preocupação com o aspecto estético - a composição e os pequenos detalhes, o contraste entre os materiais. Percebe-se a qualidade da execução. Também têm área menor do que os primeiros.

Os autores dos projetos não são mencionados, o que faz sentido em uma época em que o projeto de arquitetura era considerado apenas uma etapa da construção, não tinha valor de venda e seu autor poderia ser qualquer dos projetistas empregados em uma firma construtora, como era o caso da Sociedade Construtora e de Imóveis ${ }^{53}$. Segundo a apresentação ao álbum, o escritório de engenharia de três dos sócios teria se incorporado à construtora. O total de sócios era seis, cinco com o mesmo sobrenome - Vidigal. Apresentando as obras, diz-se que: "Aqui, são casas residenciaes excellentes, construídas em optimos terrenos, não com desperdício, mas, também sem que o seu bom acabamento ficasse prejudicado por determinações

\footnotetext{
${ }^{53}$ Mas, pelo menos uma das casas do álbum era de um arquiteto conhecido à época, Álvaro Botelho.
} 
estrictas das condições financeiras dos proprietários; ali, encontram-se prédios que, pela exigüidade do terreno, ou devido à limitação do orçamento, fixado pelas condições e desejos dos proprietários, são apreciáveis apenas como demonstração do muito que, às vezes, se consegue dispondo de tão pouco;" (SOCIEDADE CONSTRUCTORA E DE IMMOVEIS, 1928, texto de apresentação).

Pela observação das fotos das casas, percebe-se que se destinavam à classe média, e sua localização confirma esta hipótese. Situadas na "Villa América", em "Hygienópolis", na "Villa Marianna", no "Paraizo", próximas ou localizadas nas ruas onde havia linhas de bonde, bairros urbanizados nos quinze anos anteriores aproximadamente, que se constituíam em bairros de classe média majoritariamente.

Os "prédios residenciaes" mostrados têm algumas características das casas do Jardim América. Localizadas em terrenos menores, mas todas locadas no centro do lote, refletindo as preocupações com a insolação das habitações presentes no Código Sanitário de 1918.

Grande parte das casas tem alvenaria de tijolos aparentes externamente, pequenas varandas no acesso principal, faixas decoradas - na verdade cintas de amarração da alvenaria - acima das esquadrias do pavimento superior, janelas com venezianas e vidros quadriculados e aparecem algumas bay windows.

São composições assimétricas em planta, principalmente na fachada principal, característica difícil de se repetir nas fachadas laterais, pois os terrenos eram compridos e estreitos, o tradicional parcelamento existente na cidade.

Poucas casas já apresentam características do Neocolonial, como os frontões e os grandes beirais com cachorros.

Pode-se dizer que as principais influências encontradas nestas casas provêm de Victor Dubugras - estes seriam os "sobrados de tijolinhos da classe média" (LEMOS, 1989, p. 184-5) -, dos bangalôs americanos - com varandas de acesso em duas águas e telhados de pouca inclinação - e dos cottages do Arts and Crafts.

Todas estas casas apresentam o fechamento frontal do terreno bastante elaborado, muros baixos com pilaretes e grades com desenhos. As garagens aparecem em muitas delas.

Alguns "prédios residenciaes": 


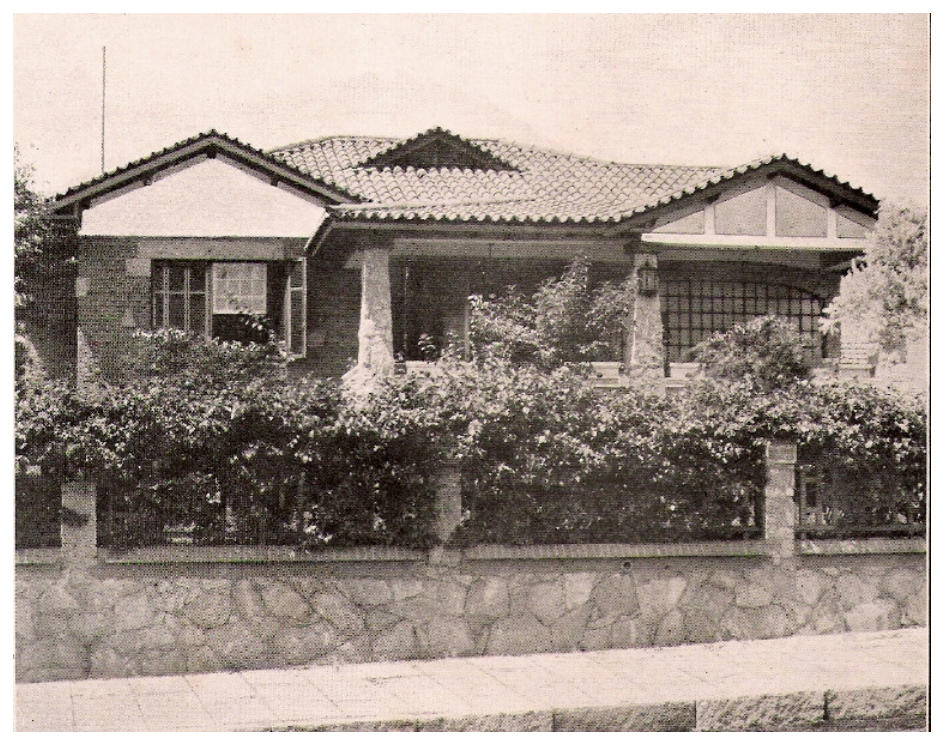

Fig. 5.118 Casa na Rua Cândido Espinheira, 63.

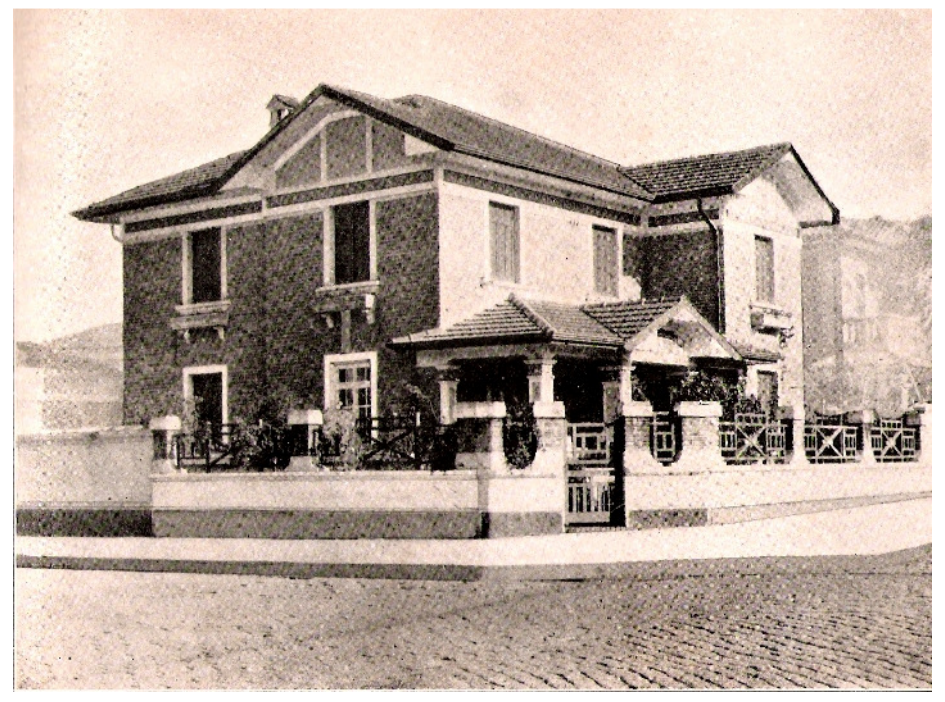

Fig. 5.119 Casa na Rua Conselheiro Brotero, 187.

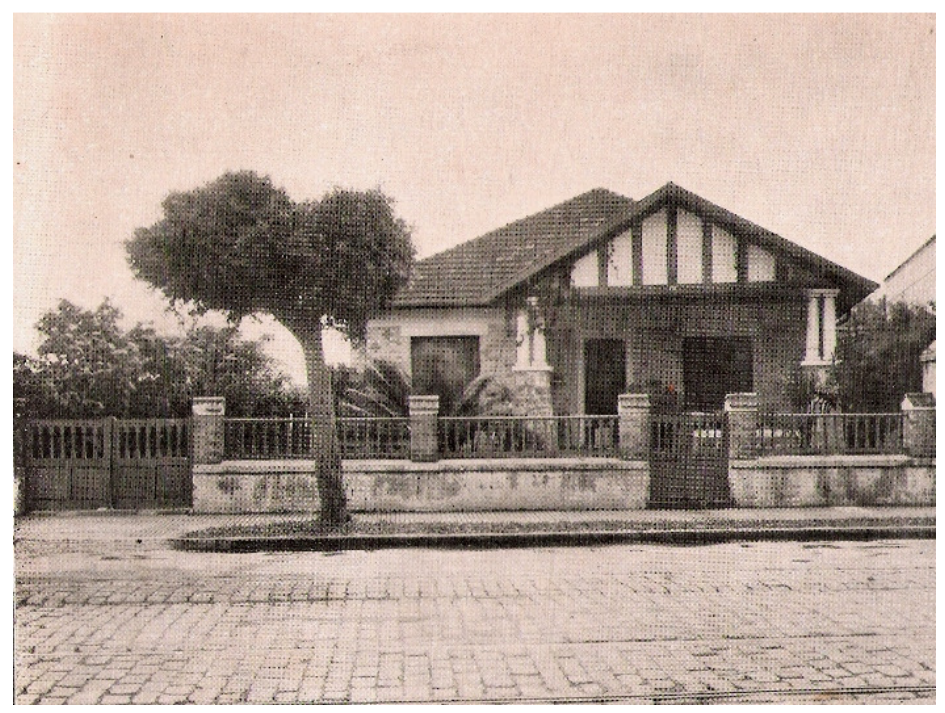

Fig. 5.120 Casa na Rua Conselheiro Nebias, 763, Santos.

370 I C a pítulo 5 

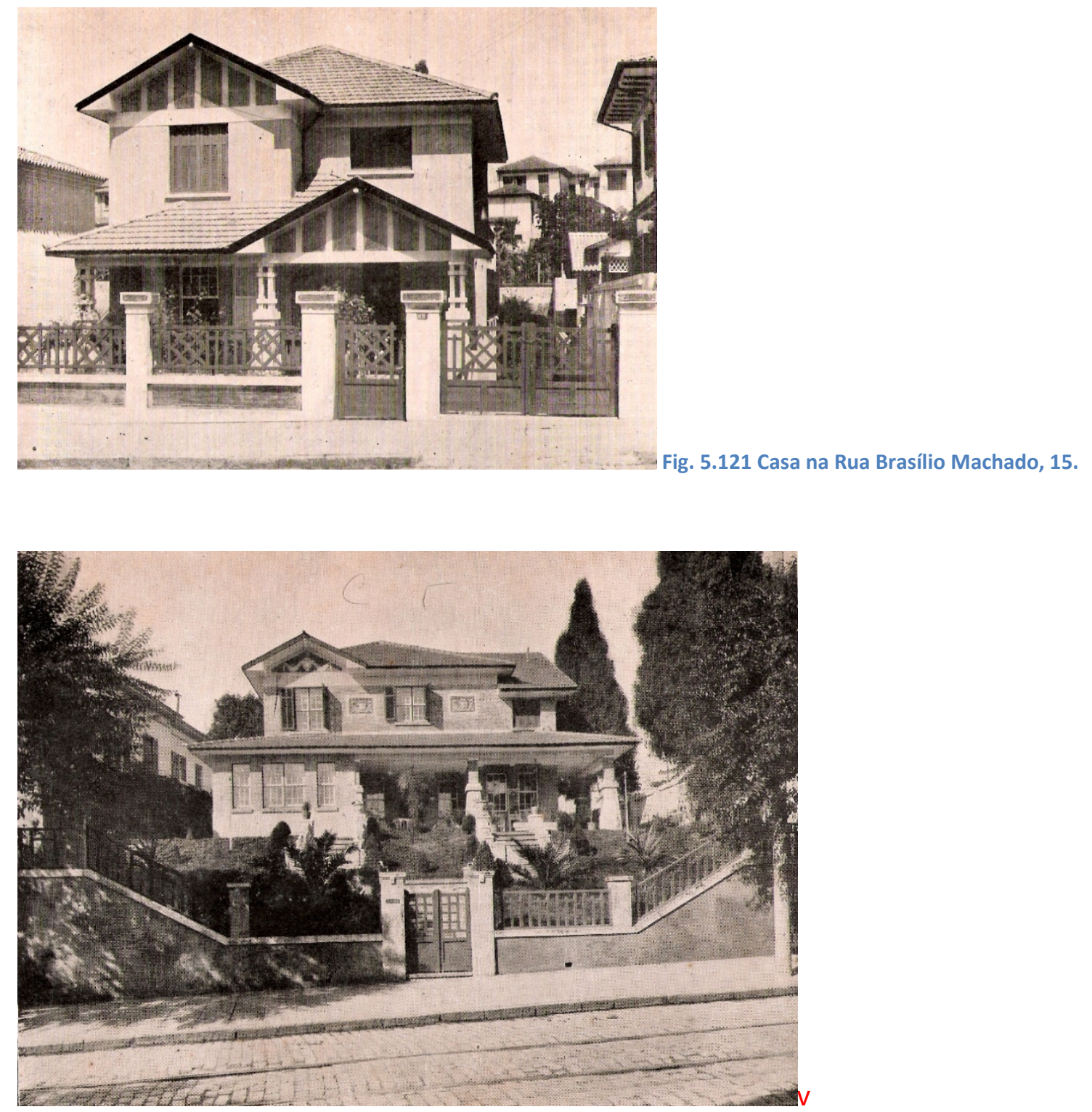

Fig. 5.122 Casa na Rua Vergueiro, n.153.

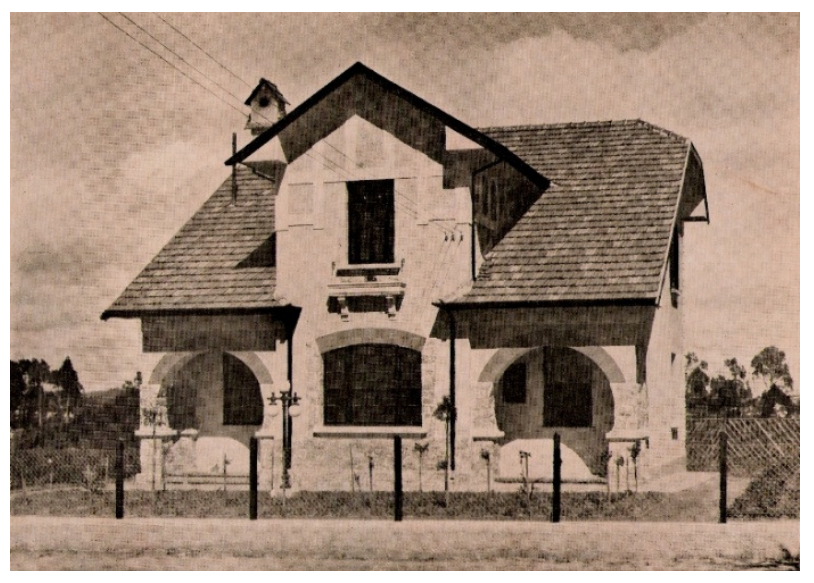

Fig. 5.123 Casa na Rua D. Hyppolita, 90. 


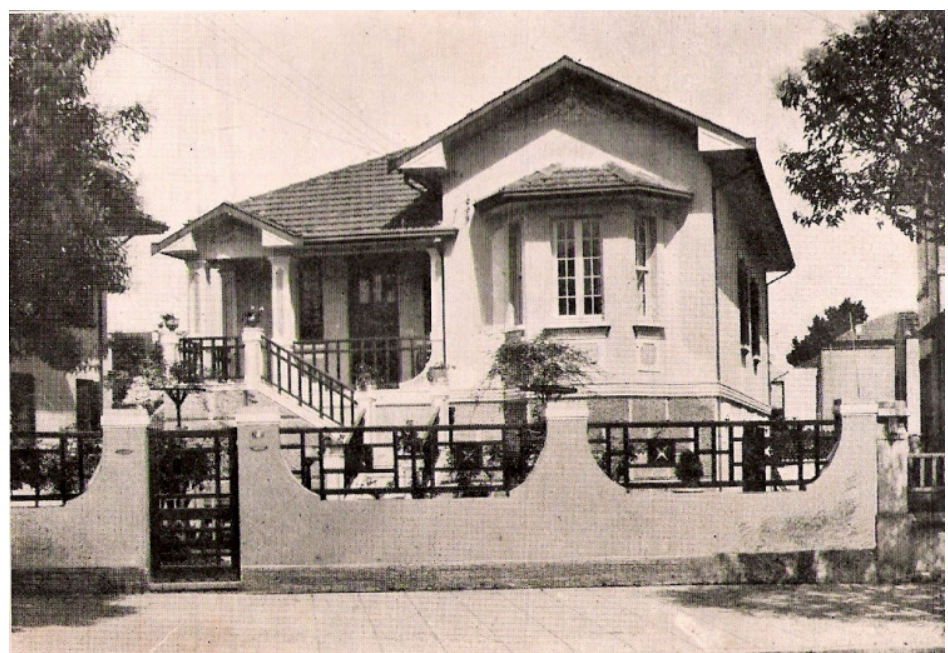

Fig. 5.124 Casa na Av. Angélica, 4.

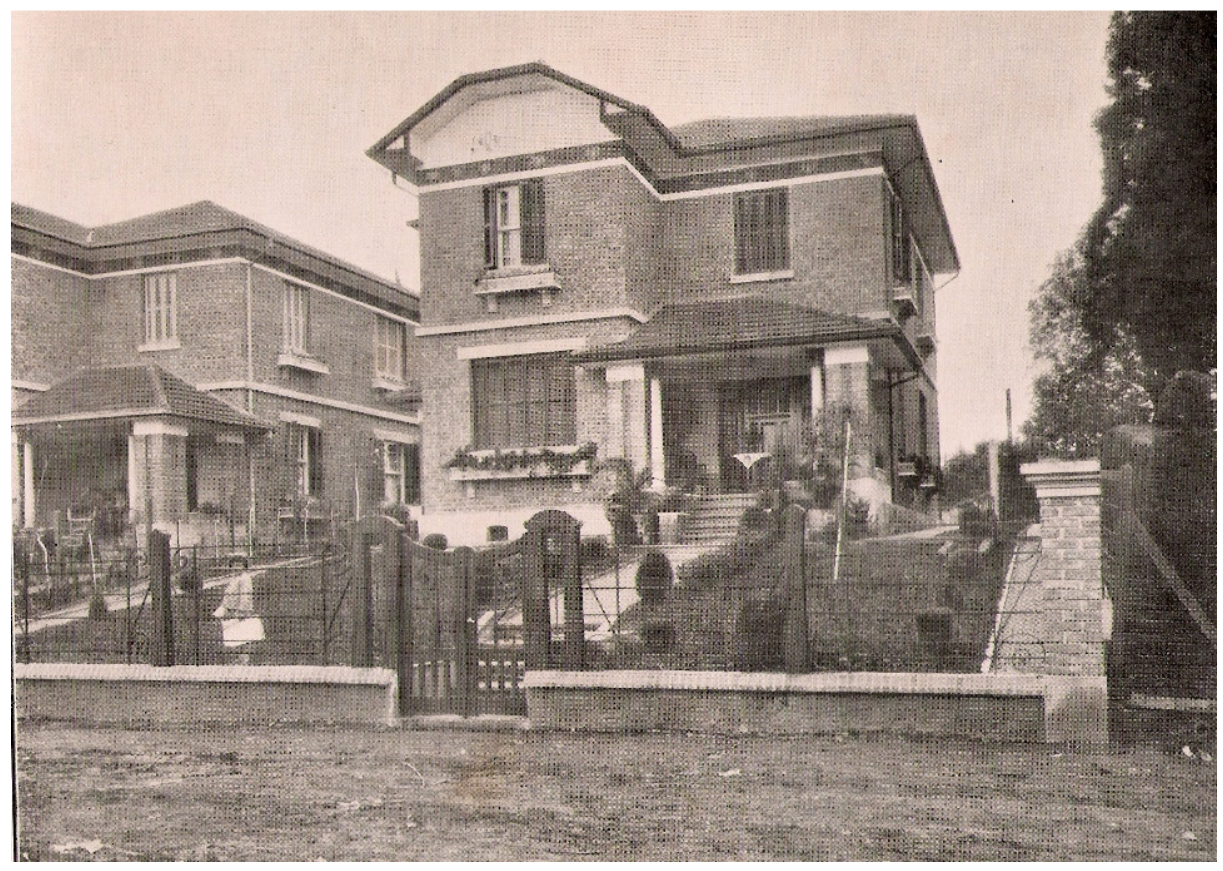

Fig. 5.125 Casa na Rua Caiuby, 18.

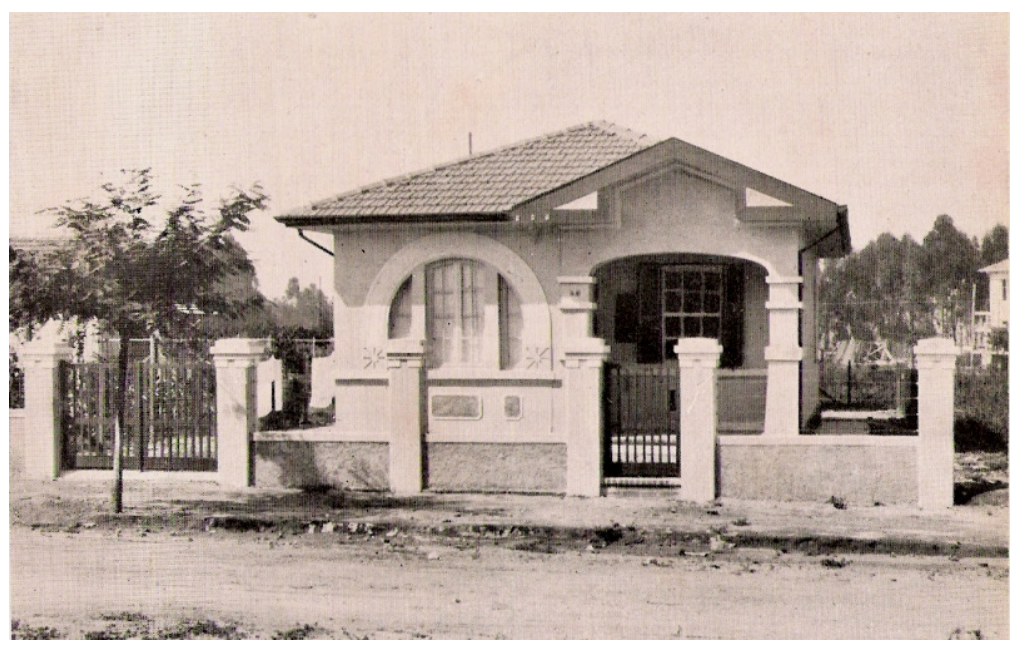

Fig. 5.126 Casa na Rua Jacupiranga, 1. 


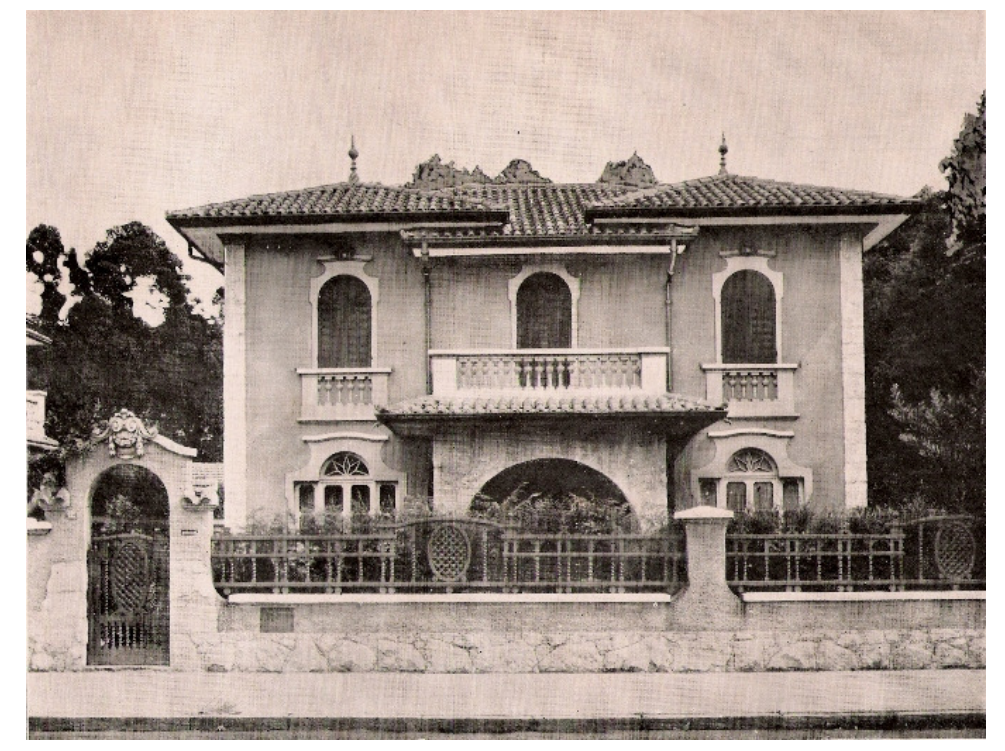

Fig. 5.127 Casa na Rua Carlos Sampaio, 12.

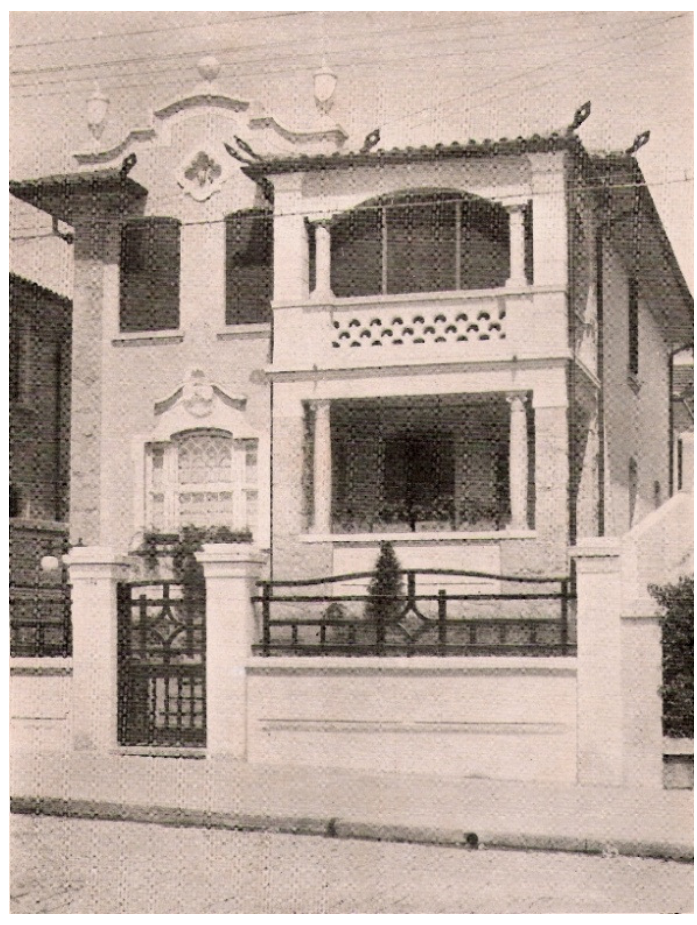

Fig. 5.128 Casa na Rua Brasílio Machado, 22.

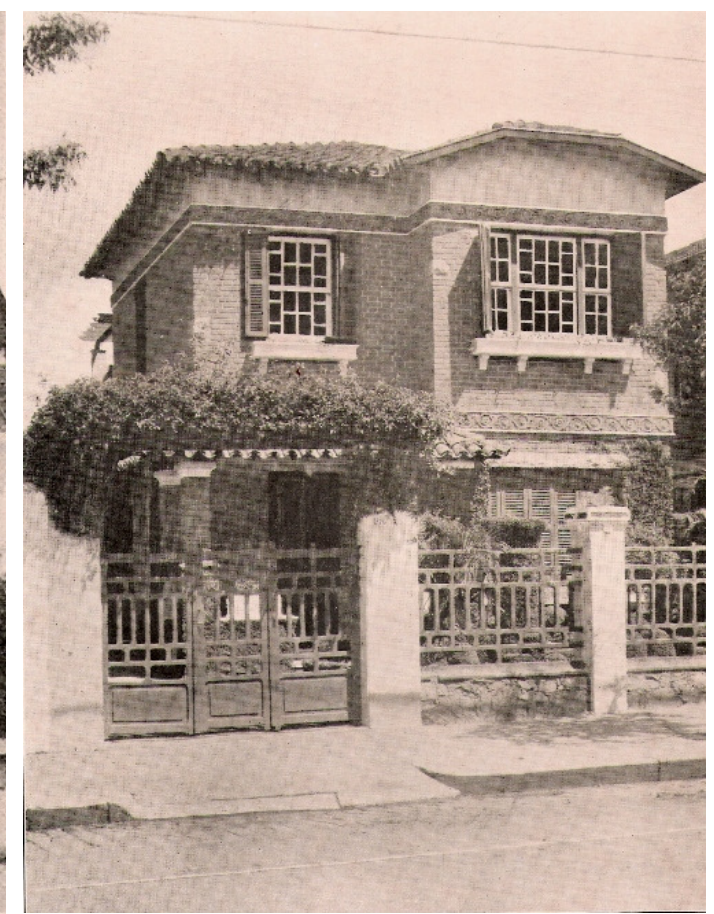

Fig. 5.129 Casa na Rua Augusta, 530. 


\section{Anexo 3}

Mapa do Jardim América - casas fotografadas para o álbum Jardim América.

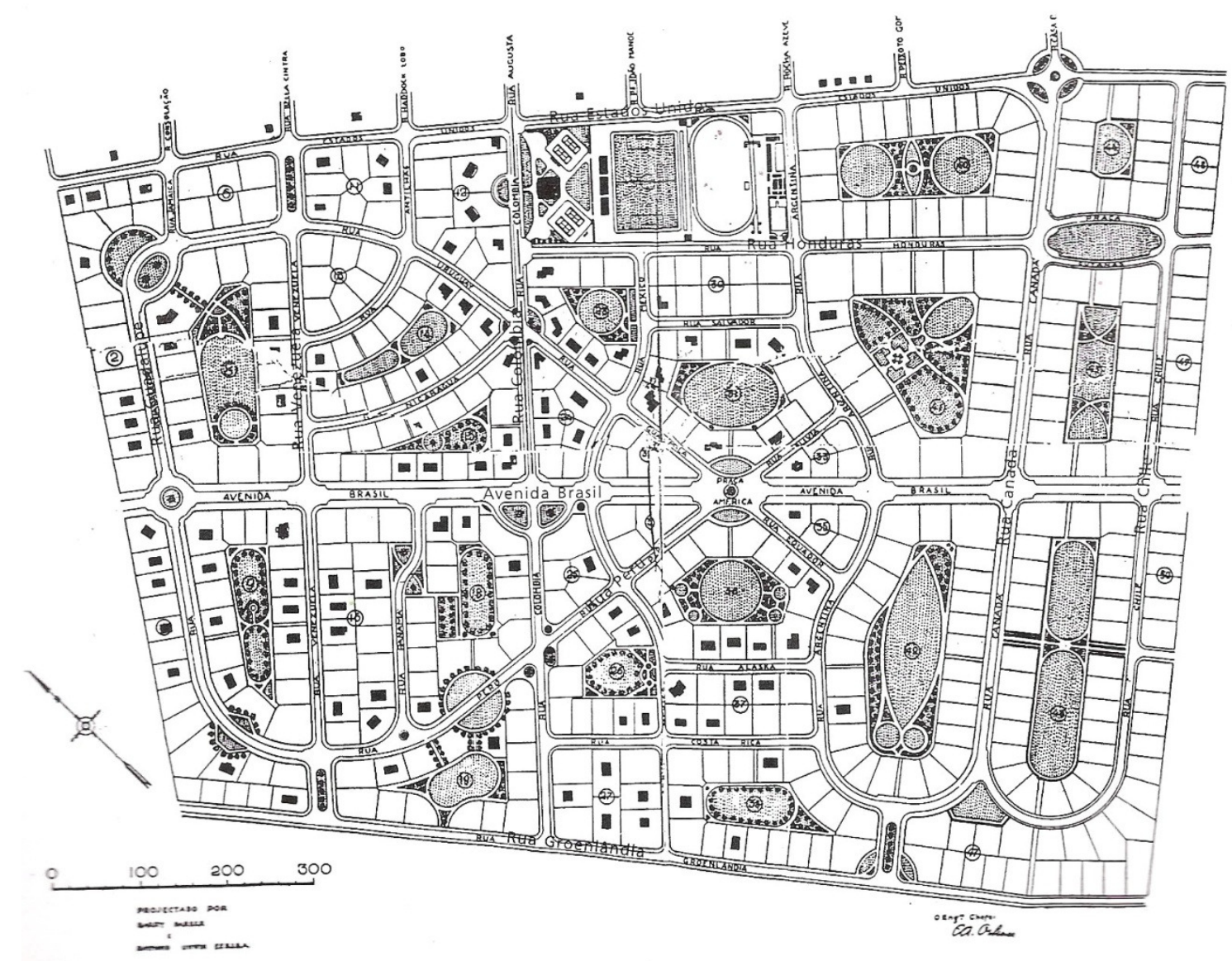

Fig. 5.130 Mapa do Jardim América. Marcadas em preto estão as casas fotografadas para o álbum Jardim América. 
Anexo 4

Mapa do Jardim América com os jardins internos já loteados.

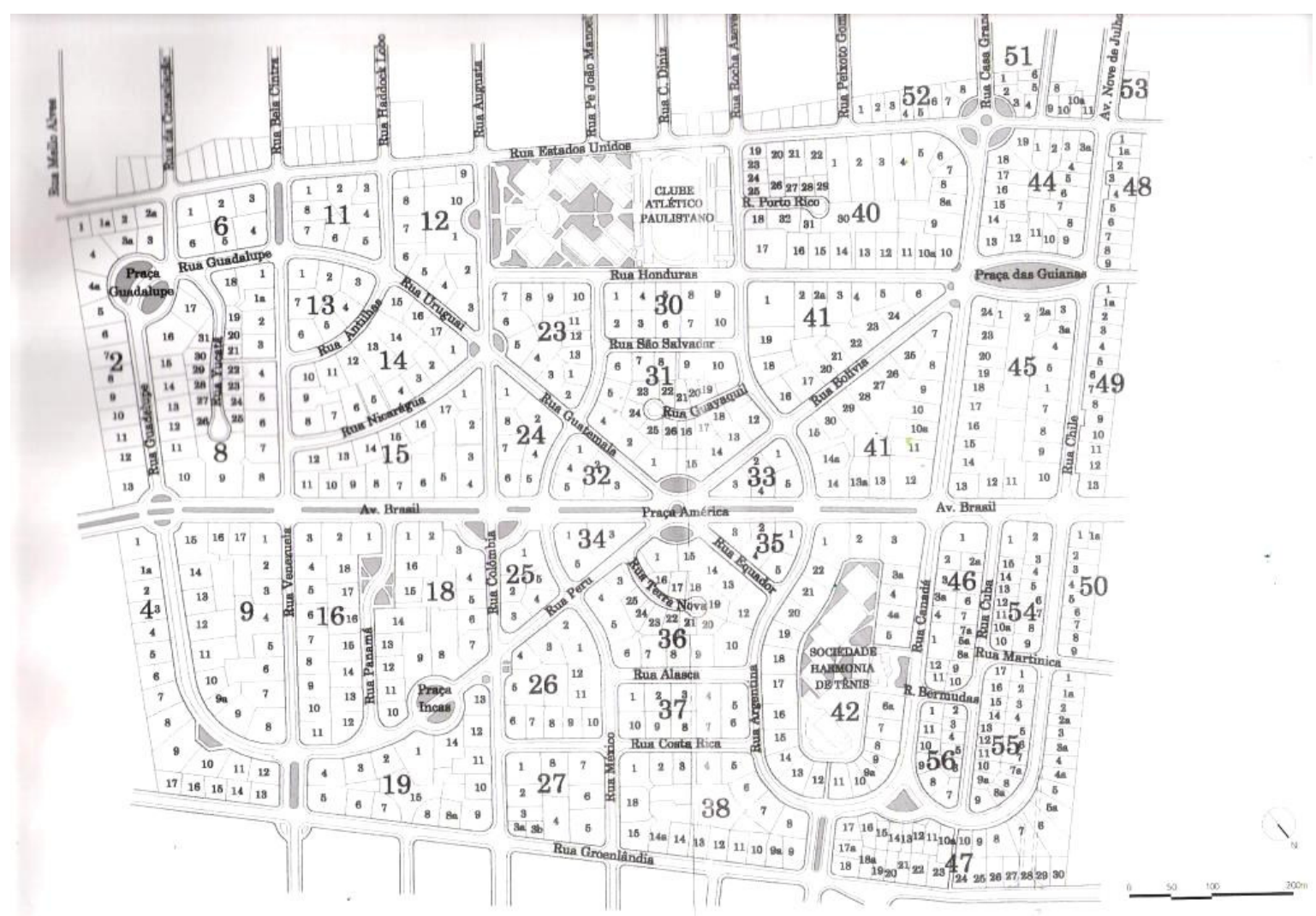

Fig. 5.131 Mapa do Jardim América. 


\section{Referências Bibliográficas}

\section{1- Fontes Primárias - Brasil}

\section{Livros}

AMERICANO, Jorge São Paulo Nesse Tempo (1915-1935). São Paulo: Melhoramentos, 19-? MARIANNO FILHO, José À Margem do Problema Arquitetônico Nacional Rio de Janeiro: s.n., 1943.

RODRIGUES, José Wasth Documentário Arquitetônico: relativo à Antiga Construção Civil no Brasil. São Paulo: Livraria Martins Editora, 1975

SEVERO, Ricardo 0 Liceu de Artes e Ofícios de São Paulo: histórico, estatutos regulamentos, programas, diplomas. São Paulo: Liceu de Artes e Ofícios, 1934.

\section{Documentos}

- 26 folhas manuscritas em inglês, assinadas por Barry Parker e datadas de 25-1-1919. Trata-se de um relatório de Parker aos diretores da Companhia City, fazendo um balanço de suas atividades durante sua estada em São Paulo, já de volta à Inglaterra.

- 11 folhas datilografadas com o título "Mr. Barry Parker's Report on Pacaembu, dated March 1st 1917". É o relatório sobre o Pacaembu enviado por Parker a Mr. Gurd, diretor da Companhia City no Brasil à época, datado de 1/3/1917.

- 4 folhas datilografadas em inglês e assinadas por Barry Parker, datadas de 15/01/1919. Na capa encontra-se o título: "Mr. Barry Parker's Report on Lapa, dated January, 15th 1919".

\section{Periódicos}

\section{Revista A Casa:}

- A Casa, n. 4, 1924

- A Casa, n. 8, dezembro de 1924

- A Casa, n. 9, janeiro de 1925,

- A Casa, n. 16, agosto de 1925 
- A Casa, n. 25, maio de 1926

- A Casa, n. 35, março de 1927

- A Casa, n.56, dezembro de 1928

- A Casa, n.61, maio de 1929

- A Casa, n.62, junho de 1929

- A Casa, n.63, julho de 1929

- A Casa, n.64, agosto de 1929

- A Casa, n.65, setembro de 1929

- A Casa, n.66, outubro de 1929

- A Casa, n.67, novembro de 1929

- A Casa, n.68, dezembro de 1929

- A Casa, n.69, janeiro de 1930

- A Casa n.70, fevereiro de 1930

\section{Boletim do Instituto de Engenharia}

- $\quad$ n.12, Julho 1921

- n.13, Outubro 1921

- n.25, Março 1924

- n.26, Outubro 1924

- $\quad$ n.27, Janeiro 1925

- n.29, Julho 1925

- n.31, Março 1926

\section{Revista Acrópole}

- n.1, Maio 1938

- $\quad$ n.2, Junho 1938

- n.7, Novembro 1938

- n.8, Dezembro 1938

- $\quad$ n.12, Abril 1939

\section{Revista Architectura e Construcções}

- n.1, Agosto 1929

- $\quad$ n.2, Setembro 1929

- $\quad$ n.3, Outubro 1929

- n.4, Novembro 1929

- n.5, Dezembro 1929

- n.6, Janeiro 1930 
- n.7, Fevereiro 1930

- n.8, Março 1930

- n.9, Abril 1930

- n.10, Maio 1930

- n.11, Junho 1930

- n.12, Julho 1930

- n.13, Agosto 1930

\section{Revista Architectura no Brasil}

- n.1, Outubro de 1921

- n.2, Novembro de 1921

- n.27, Fevereiro-Março 1926

- n.29, Junho-Julho 1926

\section{Revista de Engenharia do Mackenzie College}

- n.18, Abril 1919

- n.40, Dezembro 1926

- n.41, Março 1927

- $\quad$ n.42, Maio 1927

- n.44, Setembro de 1927

- n.45, Novembro de 1927

- n.46, Março 1928

- $\mathrm{n} .48$, Setembro 1928

- n.49, Dezembro 1928

- n.50, Maio 1929

- n.51, Setembro 1929

- n.52-53, Junho 1930

- n.54, Outubro 1930

\section{Revista Politécnica}

- n.2, Janeiro 1905 a n.82, Setembro 1926

\section{Álbuns de Construtoras}


Sociedade Constructora e de Immoveis: São Paulo, s.n., 1928.

Sociedade Constructora e de Immoveis: São Paulo, s.n., 1940.

THE CITY OF SÃO PAULO IMPROVEMENTS \& FREEHOLD LAND CO. Jardim América. São Paulo: s.n., 1923

\section{Álbuns de Modelos}

MUZI, Luiz Arquitetura e Construções. São Paulo: L. Muzi, 19-?.

\section{2- Fontes Primárias - Europa e Estados Unidos}

\section{Livros}

ANON. Men who build, N.45, Mr. Charles F. Annesley Voysey The Builder's Journal \& Architectural Review, Vol. IV, 9 de Setembro de 1896.

ANON. C.F.A. Voysey: the man and his work, The Architect \& Building News, CXVII (1927) P. 133-4, 219-21, 273-5, 314-6, 404-6.

ASHBEE, C. R. Memoirs, trabalho não publicado, Victoria and Albert Museum Library, 1938.

ASHBEE, C. R. Should We Stop Teaching Art, Londres: Batsford, 1911.

BLOMFIELD, Sir Reginald Richard Norman Shaw. London: Batsford, 1940

CRANE, Walter. Of the Revival of Design and Handicraft. In: Arts and Crafts Essays, por membros da Arts and Crafts Exhibition Society, Rivington Percival \&Co, Londres, 1893

DOWNING, Andrew Jackson Architecture of country houses. Nova York: Dover, 1969.

IMAGE, Selwyn. Introduction. In: RUSKIN, John The Seven Lamps of Architecture. Londres: J.M. Dent, 1907 (1849).

KIRK, Sheila. Philip Webb and traditional materials. In: BURMAN, Peter (ed.) Architecture 1900. Shaftesbury: Donhead, 1998, p. 145-55.

LETHABY W.R. Arts and the Function of Guilds, publicado primeiro no The Quest, Birmingham, 1896; reeditado em Lethaby, W.R. Form in Civilization, Oxford, 1957.

LETHABY, W.R Architecture: an Introduction to the History and Theory of the Art of Building, Londres: Thornton Butterworth, 1937 (1911).

LETHABY, W.R Architecture: Mysticism and Myth. Nova York: Dover, 2004 (1892)

LINO, Raul Casas portuguesas: alguns apontamentos sobre o arquitectar das casas simples. Lisboa: Valentim de Carvalho, 1933. 
MORRIS, May William Morris, Artist, Writer, Socialist. Oxford: s.n., 1935, Vol. III.

MORRIS, William Notícias de Lugar Nenhum ou uma Época de Tranqüilidade: um Romance Utópico. São Paulo: Fundação Perseu Abramo, 2002

MUTHESIUS, Hermann The English House Londres: BSP Professional Books, 1987 (1979). Primeiro publicado em alemão, Das englische Haus. Berlim: Wasmuth, 1904, 1905 (3 volumes)

PARKER, Barry Modern Country Homes in England: The Arts and Crafts Architecture of Barry Parker. Cambridge: Cambridge University Press, 1986, edição e prefácio por HAWKES, Dean. Publicado inicialmente como uma série de artigos na revista The Craftsman, de Nova York, entre abril de 1910 e março de 1912.

PURDOM, C.B. The Garden City: a study in the development of a modern town. Londres: J.M.Dent \& Sons, 1913.

RUSKIN, John The Seven Lamps of Architecture. Londres: J.M. Dent, 1907 (1849).

RUSKIN, John As Pedras de Veneza. São Paulo: Martins Fontes, 1992, original The Stones of Venice. Londres: Smith Elder, 1851.

RUSKIN, John A Natureza do Gótico capítulo de The Stones of Venice, 1853. Tradução no site www.eesc.sc.usp.br/babel.

STICKLEY, Gustav Craftsman Homes - More than 40 Plans for Building Classic Arts \& CraftsStyle Cottages, Cabins and Bungalows. Guilford. Connecticut: The Lyon Press, 2002. Publicado originalmente em 1909 pela The Craftsman Publishing Company.

WILSON, Henry L. The Bungalow Book: Floor Plans and Photos of 112 Houses, 1910. Mineola, N.Y.: Dover Publications, 2006. Reedição integral da quinta edição, de 1910.

UNWIN, Raymond Town Planning in Practice. Londres: s.n., 1911.

VOYSEY, C.F.A. Individuality, Londres: Chapman \&Hall, 1915.

VOYSEY, C.F.A. Reason as a Bases of Art, Londres: Elkin Mathews, 1906.

VOYSEY, C.F.A Ideas in Things, um de uma série de artigos no The Arts Connected With Building, Londres: Davidson, Raffles, Batsford, 1909. Os artigos foram uma série de conferências dadas à Carpenter's Company.

VOYSEY, C.F.A The English Home, The British Architect, Vol. LXXV, 1911.

\section{Periódicos}

MACARTNEY, Mervyn Edmund (ed.) Recent English Domestic Architecture: being a special issue of the Architectural Review. Londres: Offices of the Architectural Review, 1912

STICKLEY, Gustav (ed.) Craftsman Bungalows: 59 homes from "The Craftsman". Nova York: Dover Publications, 1998. Seleção de 36 artigos publicados entre dezembro de 1903 e agosto de 1916, no periódico The Craftsman, editado por Gustav Stickley.

THE CRAFTSMAN, n.5, Agosto 1912.

WRIGHT, Richardson (ed.) House \& Garden's Second Book of Houses. Nova York: Condé Nast Publications, 1925 


\section{3- Fontes Secundárias - Brasil}

\section{Teses, dissertações e artigos}

ANDRADE, Carlos Roberto Monteiro Barry Parker: um arquiteto inglês na cidade de São Paulo. Tese de Doutoramento não publicada. São Paulo: FAUUSP, 1998.

ATIQUE, Fernando Arquitetando a "Boa Vizinhança": a sociedade urbana do Brasil e a recepção do mundo norte-americano. Tese de Doutoramento. São Paulo: Faculdade de Arquitetura e Urbanismo, Universidade de São Paulo, 2007.

AYNSLEY, Jeremy. Graphic Change. Design Change: Magazines for the Domestic Interior, 1890-1930. Journal of Design History, Oxford, Vol. 18, n.1, p.43-59, 2005.

ALAMBERT, Clara Correia d' Manifestações da arquitetura residencial paulistana entre as Grandes Guerras. Tese de Doutoramento. São Paulo: Faculdade de Arquitetura e Urbanismo, Universidade de São Paulo, 2003.

BELLUZZO, Ana Maria de Moraes Artesanato, Arte e Indústria. Tese de Doutoramento. São Paulo: Faculdade de Arquitetura e Urbanismo, Universidade de São Paulo, 1988.

GONCALVES, Ana Maria do Carmo Rossi Obra de Ricardo Severo. Trabalho de Graduação Interdisciplinar. São Paulo: Faculdade de Arquitetura e Urbanismo, Universidade de São Paulo, 1977.

GONÇALVES, Marly de Menezes O desenho de arquitetura no tempo: estudo de caso: conteúdo gráfico de três arquitetos portugueses do século XX. Dissertação de Mestrado. São Paulo: Faculdade de Arquitetura e Urbanismo, Universidade de São Paulo, 2000

HOMEM, Maria Cecília Naclério. O princípio da racionalidade e a gênese da cozinha moderna. Revista do Programa de Pós-graduação em Arquitetura e Urbanismo da FAUUSP. São Paulo: n.13, junho de 2003, p.124-153.

MARTINS, Carlos Alberto F. Arquitetura e Estado no Brasil: elementos para uma investigação sobre a constituição do discurso moderno no Brasil; a obra de Lucio Costa 1924/1952. Dissertação de Mestrado. São Paulo: Faculdade de Filosofia, Letras e Ciências Humanas, Universidade de São Paulo, 1987.

MENEGUELLO, Cristina Da ruína ao edifício: Neogótico, reinterpretação e preservação do passado na Inglaterra vitoriana. Tese de Doutoramento. Campinas: Instituto de Filosofia e Ciências Humanas, Universidade Estadual de Campinas, 2000.

PINHEIRO, Maria Lúcia Bressan Origens da Noção de Preservação do Patrimônio Cultural no Brasil. Revista Risco, n. 3, fev.2006, p.5.

(www.arquitetura.eesc.usp.br/revista_risco/Risco3pdf/sumario_risco3.pdf)

PINHEIRO, Maria Lucia Bressan. Ricardo Severo e o "estilo tradicional brasileiro. Revista $D^{\prime}$ Art, n.3, p.22-28, dez. 1998.

PINHEIRO, Maria Lúcia Bressan e D'AGOSTINO, Mário Henrique Simão. A noção de pitoresco no debate cultural das primeiras décadas do século $X X$ no Brasil. In: COLÓQUIO DE HISTÓRIA DA ARTE (23: 2004 Rios de Janeiro). Rio de Janeiro: CBHA/UERJ/UFRJ, 2004, p. 339-351. 
PINHEIRO, Paulo Sérgio Classes Médias Urbanas: Formação, Natureza, Intervenção na Vida Política. In: FAUSTO, Boris (ed.) O Brasil Republicano, tomo III, $2^{\circ}$ volume. São Paulo: DIFEL, 1985.

RODRIGUES, Eduardo J. Estilo Missões: as fachadas na arquitetura paulistana. Dissertação de Mestrado. São Paulo: Faculdade de Arquitetura e Urbanismo, Universidade de São Paulo, 1986.

SILVA, Joanna Mello de Carvalho e Nacionalismo e Arquitetura em Ricardo Severo: Porto 1869-São Paulo 1940. Dissertação de mestrado, EESC, 2005

SILVA, João Luiz Máximo da As empresas de energia e o consumo doméstico de gás em São Paulo no início do século XX. Revista de História Econômica \& História de Empresas da Associação Brasileira de Pesquisadores em História Econômica (ABPHE). Ribeirão Preto: vol. IX. 2, 2006, p.73-9.

SILVA, João Luiz Máximo da. Transformações no espaço doméstico - o fogão a gás e a cozinha paulistana, 1870-1930. ANAIS DO MUSEU PAULISTA - HISTÓRIA E CULTURA MATERIAL. São Paulo: vol.15, n.2, julho-dezembro de 2007, p.197-200.

TOLEDO, Benedito Lima de Victor Dubugras e as atitudes de inovação em seu tempo, 2 vol. Tese de Livre Docência. São Paulo: Faculdade de Arquitetura e Urbanismo, Universidade de São Paulo, 1985.

\section{Livros}

BARBUY, Heloísa A Cidade-exposição: Comércio e Cosmopolitismo em São Paulo, 18601914. São Paulo: EDUSP, 2006.

BRUAND, Yves Arquitetura contemporânea no Brasil. São Paulo: Editora Perspectiva, 1997.

CARVALHO, Vânia Carneiro de Gênero e Artefato: o Sistema Doméstico na Perspectiva da Cultura Material - São Paulo, 1870-1920. São Paulo: EDUSP/FAPESP, 2008.

D’ALESSIO, Vito (org.) Avenida Paulista: A Síntese da Metrópole. São Paulo: Dialeto, 2002.

FICHER, Sylvia Os Arquitetos da Poli: Ensino e Profissão em São Paulo. São Paulo: EDUSP, 2005.

FREYRE, Gilberto Ingleses no Brasil: Aspectos da influência britânica sobre a vida, a paisagem e a cultura do Brasil. Rio de Janeiro: Topbooks: UniverCidade Editora, 2000

GRAHAM, Richard Grã-Bretanha e o início da modernização no Brasil. São Paulo: Editora Brasiliense, 1973.

HOMEM, Maria Cecília Naclério O Palacete Paulistano e Outras Formas Urbanas de Morar da Elite Cafeeira: 1867-1918. São Paulo: Martins Fontes, 1996.

LEMOS, Carlos A. C. Alvenaria Burguesa: Breve história da arquitetura residencial de tijolos em São Paulo a partir do ciclo econômico liderado pelo café. São Paulo, Nobel, 1989.

LEMOS, Carlos A. C. Ramos de Azevedo e seu escritório. São Paulo: Pini, 1993.

MORSE, Richard M. Formação Histórica de São Paulo (de Comunidade a Metrópole). São Paulo: Difusão Européia do Livro, 1970.

MOTTA, Flávio L. Contribuição ao Estudo do "Art Nouveau" no Brasil. São Paulo: s.n.,1957 
PADILHA, Márcia A Cidade como Espetáculo: Publicidade e Vida Urbana na São Paulo dos anos 20. São Paulo: Annablume, 2001.

PAIM, Gilberto A beleza sob suspeita: o ornamento em Ruskin, Lloyd Wright, Loss, Le Corbusier e outros. Rio de Janeiro: Jorge Zahar, 2000

PEREIRA, Margareth da Silva. The Rio de Janeiro Tramway Light and Power à la naissance de la ville moderne. In; Eletricité et électrification dans le monde. Paris: PUF, 1989, p. 379-399.

PEREIRA, Margareth da Silva. The Time of the Capitals: Rio de Janeiro e São Paulo: Words, Actors and Plans. In ALMANDOZ, A. (ed.). Planning Latin America's Capital Cities 18501950. Londres: Routledge, 2002, p.75-108.

PORTELA, Fernando (ed.) São Paulo 1860-1960: A Paisagem Humana. São Paulo: Albatroz e Terceiro Nome, 2004.

PUPPI, Marcelo Por uma História não Moderna da Arquitetura Brasileira: Questões de Historiografia. Campinas, SP: Pontes Editores, 1998.

RAGO, Luzia Margareth Do cabaré ao lar: a Utopia da Cidade Disciplinar - Brasil: 1890-1930. Rio de Janeiro: Paz e Terra, 1997 (1985).

REIS FILHO, Nestor Goulart Victor Dubugras: Precursor da Arquitetura Moderna na América Latina. São Paulo: EDUSP, 2005

REIS FILHO, Nestor Goulart Racionalismo e Proto-Modernismo na obra de Victor Dubugras. São Paulo: Fundação Bienal de São Paulo, 1997.

SAES, Decio Azevedo Marques de 0 Civilismo das Camadas Médias Urbanas na Primeira Republica Brasileira. Campinas: Unicamp, 1973

SEVCENKO, Nicolau. A Capital Irradiante: Técnica, Ritmos e Ritos do Rio. In: SEVCENKO, N.(org.). História da Vida Privada no Brasil, Vol.3: República: da Belle Époque à Era do Rádio, p.513-619. São Paulo: Companhia das Letras, 2001.

SEVCENKO, Nicolau Orfeu extático na metrópole: São Paulo, sociedade e cultura nos frementes anos 20. São Paulo, SP : Companhia das Letras, 2003

TOLEDO, Benedito Lima de Álbum iconográfico da Avenida Paulista. São Paulo: Editora Ex Libris e João Fortes Engenharia, 1987.

TOLEDO, Benedito Lima de Anhangabaú. São Paulo: FIESP, 1989.

WAIZBORT, L. As Aventuras de Georg Simmel. São Paulo: Editora 34, 2000.

WOLFF, Sílvia Ferreira Santos. Jardim América: O Primeiro Bairro-jardim de São Paulo e Sua Arquitetura. São Paulo: EDUSP, 2000.

\section{3- Fontes Secundárias - Europa, América Latina e Estados Unidos}

ALMANDOZ, Arturo Urbanization and Urbanism in Latin America: From Haussmann to CIAM. In: ALMANDOZ, Arturo (ed.). Planning Latin America's Capital Cities 1850-1950. Londres: Routledge, 2002, p. 13-44. 
AMARAL, Aracy (org.). Arquitectura Neocolonial: América Latina, Caribe, Estados Unidos. São Paulo: Memorial Fondo de Cultura Econômica, 1994.

ARGAN, Giulio Carlo. Arte Moderna. São Paulo: Cia das Letras, 1992

BANHAM, Reyner. Teoria e Projeto na Primeira Era da Máquina. São Paulo: Perspectiva, 1975

BENJAMIN, Walter. A obra de arte na era de sua reprodutibilidade técnica. In: BENJAMIN, Walter, Magia e técnica, arte e política. Ensaios sobre literatura e história da cultura. São Paulo: Editora Brasiliense, 1987

BENJAMIN, Walter. Experiência e Pobreza. In: BENJAMIN, Walter, op.cit. São Paulo: Editora Brasiliense, 1987.

BENJAMIN, Walter. Teorias do Fascismo Alemão. In: BENJAMIN, Walter, op.cit. São Paulo: Editora Brasiliense, 1987.

BORIS, Eileen Art and Labor: Ruskin, Morris, and the Craftsman Ideal in America. Filadélfia: Temple University Press, 1986.

BRANDON-JONES, John. Charles Francis Annesley Voysey (1857-1941). In: BURMAN, Peter (ed.) Architecture 1900. Shaftesbury: Donhead, 1998, p. 92-8.

BURMAN, Peter. An introductory perspective. In: BURMAN, Peter (ed.). Architecture 1900. York: Donhead, 1998

BURMAN, Peter. William Richard Lethaby and the Crafts. In: BURMAN, Peter (ed.) Architecture 1900. Shaftesbury: Donhead, 1998, p. 109-24)

COLQUHOUN, Alan. Critique of Regionalism. In: Canizaro, Vincent B. (ed.) Architectural regionalism: Collected Writings on Place, Identity, Modernity, and Tradition. Nova York: Princeton Architectural Press, 2007

CREESE, Walter L. The Search for Environment: the Garden City - before and after. Londres: The John Hopkins University Press, 1992 (1966).

CREESE, Walter L.(ed.) The Legacy of Raymond Unwin: A Human Pattern for Planning. Londres e Cambridge: The MIT Press, 1967. Inclui vários textos de Unwin e Parker, com introdução de Creese.

CRESPO, Raúl Arnaldo Gomez e COVA, Roberto Osvaldo Arquitectura Marplatense- EI Pintoresquismo. Resistencia: Editorial del Instituto Argentino de Investigaciones de Historia de la Arquitectura y del Urbanismo, 1982.

CUMMING, Elizabeth e KAPLAN, Wendy The Arts and Crafts Moviment. Londres: Thames and Hudson, 1991.

DAVEY, Peter J. Arts and Crafts Architecture. Londres: Phaidon Press Limited, 1995

DUNLOP, Beth e HOLLAMBY, Edward. Arts \& Crafts Houses I. Londres: Phaidon Press, 1999.

ELIA, Mario Manieri 1977 (1976). William Morris y la ideología de la arquitectura moderna Collección Punto y Línea. Barcelona, Gustavo Gili.

GEBHARD, David Charles F. A. Voysey: Architect, catálogo da exposição na The Art Galleries, University of California, Santa Barbara, 1970.

GORELIK, Adrián La Grilla y el Parque: Espacio público y cultura urbana en Buenos Aires, 1887-1936. Buenos Aires: Universidad Nacional de Quilmes, 1998.

GREENSTED, Mary An Anthology of the Arts and Crafts Movement: Writings by Ashbee, Lethaby, Gimson and their Contemporaries. Burlington e Londres: Lund Humphries, 2005. 
HARVEY, John The Master Builders: Architecture in the Middle Ages. Londres: Thames \& Hudson, 1971.

HITCHCOCK, Henry Russell Architecture: Nineteenth and Twentieth Centuries. New Haven: Yale University Press, 1987 (1958)

HITCHCOCK, Henry Russell Modern Architecture: Romanticism and Reintegration. Nova York: Da Capo Press, 1993 (1929)

HITCHMOUGH, Wendy C F A Voysey. Londres: Phaidon Press, 1995.

KAPLAN, Wendy. America: the Quest for Democratic Design. In: KAPLAN, Wendy (ed.) The Arts and Crafts Movement in Europe \& America: Design for the Modern World. Londres: Thames \& Hudson, 2004

KING, Anthony D. The Bungalow: The Production of a Global Culture. Nova York, Oxford: Oxford University Press, 1995.

KIRK, Sheila. Philip Webb and traditional materials. In: BURMAN, Peter (ed.) Architecture 1900. Shaftesbury: Donhead, 1998, p. 145-55.

$\mathrm{KOCH}$, Wilfried Dicionário dos Estilos Arquitetônicos. São Paulo: Martins Fontes, 2008

KREISMAN, Lawrence e MASON, Glenn The Arts and Crafts Movement in the Pacific Northwest. Portland: Timber Press, 2007

LANCASTER, Clay The American Bungalow: 1880-1930. Nova York: Abbeville Press, 1985.

MACCARTHY, Fiona William Morris: a Life for our Time. Londres: Faber and Faber, 1995

MANDER, Nicholas. Wightwick Manor and the creation of the House Beautiful in BURMAN, Peter (ed.). Architecture 1900. York: Donhead, 1998

MILLER, Mervyn The Art of Building a Home: the design continuum of Parker and Unwin. In: BURMAN, Peter, op. cit., p. 180-93.

MOSSER, Monique e TEYSSOT, Georges. The History of Garden Design: The Western Tradition from the Renaissance to the Present Day. Londres: Thames \& Hudson, 1991.

MUMFORD, Lewis A Cidade na História: suas origens, transformações e perspectivas. Belo Horizonte: Itatiaia, 1965

MUMFORD, Lewis A Cultura das Cidades. Belo Horizonte: Editora Itatiaia, 1961.

MUMFORD, Lewis (ed.) Roots of Contemporary American Architecture Nova York: Reinhold Publishing Corporation, 1952.

NAYLOR, Gillian The Arts and Crafts Moviment: a study of its sources, ideals and influence on design theory. Londres: Studio Vista,1971.

PEVSNER, Nikolaus. Os Pioneiros do Desenho Moderno: de William Morris a Walter Gropius. São Paulo, Martins Fontes, 2002 (1936),

PICCINATO, Giorgio La Costruzione dell'Urbanistica. Roma: Officina, 1977.

PONTE, Alessandra. Elettrico, igienico e eugenico-Patrick Gedes e a nova ordem doméstica. In: CALABI, Donatella (org) Architettura domestica in Gran Bretagna Milão: Electa Editrice, 1982.

POTES, Francisco R.e PAZ, Jaime G.; ARBOLEDA, Rodrigo U. Arquitecturas Neocoloniais: Cali, 1920-1950. Cali: CITCE, Universidad del Valle, 2000.

ROMERO, José Luiz. América Latina: as Cidades e as Idéias. Rio de Janeiro: Editora UFRJ, 2004. 
SCULLY JR., VINCENT J American Architecture and Urbanism Nova York: Praeger Publishers, s.d.

SCULLY JR., VINCENT J. The Shingle Style and the Stick Style: Architectural Theory and Design from Downing to the Origins of Wright. New Haven e Londres: Yale University Press, 1971 (1955)

SMITH, Mary Ann Gustav Stickley, the Craftsman. Mineola: Dover Publications, 1992 (1983)

SOLÀ-MORALES Rubió, Ignasi Eclecticismo y vanguardia. El caso de la Arquitectura Moderna en Catalunya. Barcelona: Gustavo Gili, 1980.

TAFURI, Manfredo e DAL CO, Francesco Modern architecture, 2 vols. Nova York: H. N. Abrams, 1979

TAUT, Bruno Costruire: la nuova edilizia abitativa. Bologna: Zanichelli, 1983 (1927)

WEISSMAN, Alan Introduction to the Dover Edition. In: Craftsman Bungalows: 59 homes from "The Craftsman". Nova York: Dover Publications, 1998.

ZUCCONI, Guido Dalla fase eroica alla standardizzazione: primi esiti dell'architettura domestica. In: CALABI, Donatella (org) Architettura domestica in Gran Bretagna Milão: Electa Editrice, 1982.

\section{DICIONÁRIOS}

THE MACMILLAN VISUAL DICTIONARY: MULTILINGUAL EDITION. Nova York: Macmillan, 1994

VISUAL ENCYCLOPEDIA Londres: Dorling Kindersley, 2005

WARE, Dora e BEATTY, Betty A Short Dictionary of Architecture. Londres: George Allen \& Unwin, 1952 (1943). 


\section{Créditos das Ilustrações}

\section{Capa}

- Desenho de Voysey, HITCHMOUGH, 1995, p.145

- Revista A Casa (n.8, dez. 1924, p.4)

\section{Capítulo 1}

- Fig.1.1 - DUNLOP; HOLLAMBY, s.n.p.

- Fig.1.2 e Fig.1.3 - MUTHESIUS, 1987, p. 16.

- Fig.1.4-MUTHESIUS, 1987, p. 23.

- Fig.1.5 e Fig. 1.6 - DAVEY, 1995, p.44.

- Fig.1.7 - DUNLOP; HOLLAMBY, 1999, s.n.p.

- Fig.1.8 - DUNLOP e HOLLAMBY, 1999, il. 22

- Fig.1.9-DAVEY, 1995, p. 67.

- Fig.1.10 - DAVEY, 1995, p. 162.

- Fig.1.11-DAVEY, 1995, p. 74

- Fig.1.12 - DAVEY, 1995, p. 75.

- Fig.1.13 e Fig.1.14 - DAVEY, 1995, p. 83.

- Fig.1.15 - HITCHMOUGH, 1995, p. 36

- Fig.1.16 - HITCHMOUGH, 1995, p.39

- Fig.1.17-HITCHMOUGH, 1995, p. 49

- Fig.1.18-HITCHMOUGH, 1995, p. 76

- Fig.1.19-HITCHMOUGH, 1995, p. 67

- Fig.1.20 - HITCHMOUGH, 1995, p. 70

- Fig.1.21 - HITCHMOUGH, 1995, p. 80.

- Fig.1.22 - HITCHMOUGH, 1995, p.88

- Fig.1.23- HITCHMOUGH, 1995, p.103

- Fig.1.24 - HITCHMOUGH, 1995, p. 82

- Fig.1.25-HITCHMOUGH, 1995, p. 108

- Fig.1.26-HITCHMOUGH, 1995, p. 96

- Fig.1.27 - HITCHMOUGH, 1995, p.111.

- Fig.1.28-HITCHMOUGH, 1995, p. 129

- Fig.1.29 - HITCHMOUGH, 1995, p. 155

- Fig.1.30 - DAVEY, 1995, p. 111

- Fig.1.31-DAVEY, 1995, p. 176.

- Fig.1.32-DAVEY, 1995, p. 177.

- Fig.1.33 - GREENSTED, 2005, fig.4 
- Fig.1.34 - DAVEY, 1995, p. 178.

- Fig.1.35 - CREESE, 1992, p. 274

- Fig.1.36 - The Craftsman

- Fig.1.37 - The Craftsman

- Fig.1.38 - The Craftsman

- Fig.1.39 - PARKER, 1986, p. 105

- Fig.1.40 - PARKER, 1986, p. 93

- Fig.1.41 - PARKER, 1986, p.40

- Fig.1.42 - PARKER, 1986, p.41

- Fig.1.43 e Fig.1.44 - The Craftsman

- Fig.1.45 e Fig.1.46 - PARKER, 1986, p. 90

- Fig.1.47 - PARKER, 1986, p. 105

- Fig.1.48 - PARKER, 1986, p. 104

- Fig.1.49 - CREESE, 1992, p. 293.

- Fig.1.50-PURDON, 1913, p. 63

- Fig.1.51- PURDON, 1913, p. 88

- Fig.1.52 - MACARTNEY, 1912, p.60

- Fig.1.53 - MACARTNEY, 1912, p.71

- Fig.1.54 - MACARTNEY, 1912, p.73

\section{Capítulo 2}

- $\quad$ Fig.2.1 - KREISMAN e MASON, 2007, p.182

- Fig.2.2 e Fig.2.3 - KREISMAN e MASON, 2007, p.274

- Fig. 2.4 - KREISMAN e MASON, 2007, p.273

- Fig.2.5 - STICKLEY, 2002, p. 127

- Fig.2.6.- STICKLEY, 2002, p. 110

- Fig.2.7 - STICKLEY, 1988, p. 78

- Fig.2.8 - STICKLEY, 1988, p. 78

- Fig.2.9 - STICKLEY, 2002, p. 10

- Fig.2.10 - STICKLEY, 2002, p.42

- Fig.2.11 - www.irvinggill.com

- Fig.2.12 - STICKLEY, 2002, p. 62

- Fig.2.13 - STICKLEY, 2002, p. 63

- Fig.2.14 e 2.15 - STICKLEY, 2002, p. 76

- Fig.2.16 - STICKLEY, 1998, p. 48

- Fig. 2.17 - KREISMAN e MASON, 2007, p. 161 
- $\quad$ Fig. 2.18 - KREISMAN e MASON, 2007, p. 129

- Fig. 2.19 - KAPLAN, 2004, p. 272.

- Fig. 2.20 - LANCASTER, 1985, p.36.

- Fig. 2.21 - KREISMAN e MASON, 2007, p.173

- Fig. 2.22 - KREISMAN e MASON, 2007, p.180

- Fig. 2.23 - KREISMAN e MASON, 2007, p.175

- Fig. 2.24 - STICKLEY, 1988, p. 22.

- Fig. 2.25 - WILSON, 2006, p. 14 e 30

- Fig. 2.26 - WILSON, 2006, p. 66

- Fig. 2.27 - WILSON, 2006, p. 36 e 37

- $\quad$ Fig. 2.28 - WILSON, 2006, p. 86

- Fig. 2.29 - KREISMAN e MASON, p. 162

- Fig. 2.30 - WILSON, 2006, p. 147 e 152

- Fig. 2.31 - KREISMAN e MASON, 2007, p. 221

- Fig. 2.32 - WILSON, 2006, p. 141

- Fig. 2.33 e Fig. 2.34 - KING, 1995, p. 167.

\section{Capítulo 3}

- Fig. 3.1 - BARBUY, 2006, p.76

- Fig. 3.2 - REIS FILHO, 1997, p. 41

- Fig. 3.3 - REIS FILHO, 2005, p.21

- Fig. 3.4 - REIS FILHO, 1997, p.141

- Fig. 3.5 - REIS FILHO, 1997, p.142

- Fig. 3.6 - REIS FILHO, 1997, p.153

- Fig. 3.7 - REIS FILHO, 1997, p.113

- Fig. 3.8 - D'ALESSIO, 2002, p.6-7

- Fig. 3.9 - http://www.itaucultural.org.br/

- Fig. 3.10 - REIS FILHO, 1997, p.194

- Fig. 3.11 - REIS FILHO, 1997, p.196

- Fig. 3.12 - REIS FILHO, 1997, p. 200

- Fig. 3.13 - REIS FILHO, 1997, p. 198

- Fig. 3.14 - "Acervo do Arquivo de Projetos e Bairros da Companhia City de Desenvolvimento", foto da autora

- Fig. 3.15 - Álbum Jardim América

- Fig. 3.16 - FICHER, 2005, p.87 
- Fig. 3.17 e Fig. 3.18 - "Acervo do Arquivo de Projetos e Bairros da Companhia City de Desenvolvimento", foto da autora

- Fig. 3.19 - FICHER, 2005, p.122, publicada na Revista de Engenharia, vol.2, n.1, p.27, 1912

- Fig. 3.20 - FICHER, 2005, p.121, publicada na Revista de Engenharia, vol.1, n.9, p.264, 1912

\section{Capítulo 4}

- Fig. 4.1-a - Revista A Casa (n.35, março de 1927, capa interna)

- Fig. 4.1-b - Revista A Casa (n. 9, jan. 1925, p. 41).

- Fig.4.2 - Revista A Casa (n.4, março 1924, p.6)

- Fig.4.3 - Revista A Casa (n. 8, dez. 1924, p.11)

- Fig.4 4 - Revista A Casa ( n.56, dezembro de 1928, p. 18 e 19)

- Fig.4.5 - Revista A Casa (n.68, dezembro de 1929, p. 7).

- Fig.4.6 - Revista A Casa (n. 16, agosto de 1925, p. 40)

- Fig.4.7-a - Revista A Casa (n. 8, dezembro de 1924, p. 4)

- Fig.4.7-b e Fig.4.7-c -- Revista A Casa (nov.1924, n.7, p.18).

- Fig.4. 8 - Revista A Casa (n.62, junho de 1929, página 5)

- Fig.4.9 - Revista A Casa (n. 9, janeiro de 1925, p. 5)

- Fig.4.10 - Revista A Casa (n. 9, janeiro de 1925, p. 44)

- Fig.4.11 - WRIGHT, 1925, p.36

- Fig. 4.12 - Álbum Sociedade Construtora e de Imóveis (1928), s.n.p.

- Fig.4. 13 - Purdon, 1913, p. 78

- Fig.4. 14 - Revista A Casa (n. 4, 1924, p.13)

- Fig.4. 15 - Revista A Casa (n. 4, 1924, p.18)

- Fig.4. 16- Revista A Casa, n. 4, 1924, p.29)

- Fig.4. 17 - Revista A Casa (n. 4, 1924, p.28)

- Fig.4. 18 - Revista A Casa (n. 8, dez. 1924, p. 17)

- Fig.4. 19 - Purdon, 1913, p. 80

- Fig.4. 20 - Revista A Casa (n. 9, janeiro de 1925, p. 2)

- Fig.4. 21 - Revista A Casa (n. 8, dezembro de 1924, p. 12)

- Fig.4. 22 - Revista A Casa (n. 8, dezembro de 1924, p. 16)

- Fig.4. 23 - Revista A Casa (n.35, março de 1927, p. 13)

- Fig. 4.24-a e Fig. 4.24-b - Revista A Casa (n. 9, janeiro de 1925, p. 18)

- Fig.4. 25 - Revista A Casa (n. 16, agosto de 1925, p. 15)

- Fig.4. 26 - Revista A Casa (n. 56, dez. 1928, p. 10)

- Fig.4. 27 - Revista A Casa (n. 35, março de 1927, capa) 
- Fig.4. 28 - Revista A Casa (n.56, dez. de 1928, p. 28)

- Fig.4. 29 - Revista A Casa (n.56, dez. 1928, p. 21)

- Fig.4. 30 - Revista A Casa (n.56, dez.1928, p. 26)

- Fig.4. 31 - WRIGHT, 1925, p. 147

- Fig.4. 32 - Revista A Casa (n.61, maio 1929, p. 8)

- Fig.4. 33 - Revista A Casa (n.56, dez. 1928, p. 38)

- Fig.4. 34 - Revista A Casa (n.56, dez. 1928, p. 39)

- Fig.4. 35 - Revista A Casa (n.62, junho 1929, p. 20)

- Fig.4. 36 - Revista A Casa (n.62, junho 1929, p. 27)

- Fig.4. 37 - Revista A Casa (n.62, junho 1929, p. 33)

- Fig.4. 38 - Purdon, p. 74

- Fig. 4.39 - Revista A Casa (n.63, julho de 1929, página 13)

- Fig.4. 40 - Revista A Casa (n.63, julho de 1929, página 20)

- Fig.4. 41 - Revista A Casa (n.65, setembro de 1929, p.18)

- Fig.4. 42 - Revista A Casa (n.65, setembro de 1929, p.38)

- Fig. 4.43 - WRIGHT, 1925, p. 150

- Fig. 4.44 - Revista A Casa (n.67, nov.1929, capa)

- Fig. 4.45 - Revista A Casa (n.70, fevereiro de 1930, p. 20)

- Fig. 4.46 - Revista A Casa (n.66, out. 1929, p.16)

- Fig. 4.47 - Revista A Casa (n.67, nov. 1929, p.22)

- Fig. 4.48 - Revista A Casa (n. 9, janeiro de 1925, p. 43).

- Fig. 4.49 - Revista A Casa (n. 4, 1924, p.33).

- Fig. 4.50-a e Fig. 4.50-b - Revista A Casa (n. 8, dez.1924, p.8)

- Fig. 4.51 - Revista A Casa (n. 8, dez.1924, p.9)

- Fig. 4.52 - Revista A Casa (n. 9, jan. 1925, p.11)

- Fig. 4.53 e Fig. 4.54 - Revista A Casa (n. 9, jan. 1925, p. 21).

- Fig. 4.55 - Revista A Casa (n.56, dez. 1928, p. 14)

- Fig. 4.56 e Fig 4.57 - Revista A Casa (n.56, dez. 1928, p. 20)

- Fig. 4.58 - Revista A Casa (n.68, dez.1929, p.5)

- Fig. 4.59 - Revista A Casa (n. 25, maio 1926, p. 23)

- Fig. 4.60 - Revista $A$ Casa (n. 25, maio 1926, p. 26)

- Fig. 4.61 - Revista A Casa (n. 4, 1924, p.24)

- Fig. 4.62 - Revista A Casa (n. 4, 1924, p.25)

- Fig. 4.63 - PARKER, 1986, p.75

- Fig. 4.64 - Revista A Casa (n. 8, dezembro de 1924, p. 35

- Fig. 4.65 - Revista A Casa (n.56, dezembro de 1928, p. 35

- Fig.4.66 - Revista A Casa (n.35, março de 1927, capa (interna)

- Fig.4.67 - Revista A Casa (n.61, maio de 1929, p. 29

- Fig. 4.68 - WRIGHT, 1925, p.18. 
- Fig. 4.69 - Revista Feminina, n.55, dezembro 1918, s.n.p

- Fig. 4.70 - Revista A Casa (n. 35, março de 1927, p. 3

- Fig. 4.71 - Revista A Casa (n.71, 1930, p.29)

\section{Capítulo 5}

- Fig. 5.1 - Revista Architectura no Brasil (n.29, junho-julho 1926, p.175).

- Fig. 5.2 - WOLFF, 2000, p.130

- Fig. 5.3 - WOLFF, 2000, p.131

- Fig. 5.4 - Revista de Engenharia do Mackenzie, (n. 50, maio de 1929, p.215)

- Fig. 5.5 - "Acervo do Arquivo de Projetos e Bairros da Companhia City de Desenvolvimento", foto da autora.

- Fig. 5.6 - WOLFF, 2000, p.215

- Fig. 5.7 - Revista Architectura e Construcções (n.1, agosto 1929, s.n.p.)

- Fig. 5.8 - Revista Architectura e Construcções (n.10, maio 1930, p.7)

- Fig. 5.9 - Revista Architectura e Construcções (n. 12, julho 1930, s.n.p.)

- Fig. 5.10 - WOLFF, 2000, p. 138

- Fig. 5.11 - Álbum Jardim América

- Fig. 5.12 - Andrade, 1998, fig. 4.09

- Fig. 5.13 - Álbum Jardim América

- Fig. 5.14 - Wolff, 2000, p. 180

- Fig. 5.15 - Álbum Jardim América

- Fig. 5.16 e Fig. 5.17 - WOLFF, 2000, p.161

- Fig. 5.18 - Álbum Jardim América

- Fig. 5.19 - Andrade, 1998, fig. 4.19

- Fig. 5.20 - Álbum Jardim América

- Fig. 5.21 - WOLFF, 2000, p.173

- Fig. 5.22 - Álbum Jardim América

- Fig. 5.23 e Fig. 5.24 - Andrade, 1998, fig. 4.22

- Fig. 5.25-Álbum Jardim América

- Fig. 5.26 - Wolff, 2000, p. 170

- Fig. 5.27- Álbum Jardim América

- Fig. 5.28-a e Fig.5.28-b - Wolff, 2000, p. 183

- Fig. 5.29- Álbum Jardim América

- Fig. 5.30 - Revista Architectura e Construcções (n. 13, agosto 1930, p. 2)

- Fig. 5. 31 - "Acervo do Arquivo de Projetos e Bairros da Companhia City de Desenvolvimento", foto da autora.

- Fig. 5.32 - Álbum Jardim América 
- Fig. 5.33 - Álbum Jardim América

- Fig. 5.34 - "Acervo do Arquivo de Projetos e Bairros da Companhia City de Desenvolvimento", foto da autora.

- Fig. 5.35 e Fig. 5.36- Álbum Jardim América

- Fig. 5.37 e Fig. 5.38 - "Acervo do Arquivo de Projetos e Bairros da Companhia City de Desenvolvimento", fotos da autora.

- Fig. 5.39 - Álbum Jardim América

- Fig. 5.40; Fig. 5.41 e Fig. 5.42 - "Acervo do Arquivo de Projetos e Bairros da Companhia City de Desenvolvimento", fotos da autora.

- Fig. 5.43 - Álbum Jardim América

- Fig. 5.44 - "Acervo do Arquivo de Projetos e Bairros da Companhia City de Desenvolvimento", foto da autora.

- Fig. 5.45; Fig. 5.46 e Fig. 5.47 - Álbum Jardim América

- Fig. 5.48 e Fig. 5.49 - "Acervo do Arquivo de Projetos e Bairros da Companhia City de Desenvolvimento", fotos da autora.

- Fig. 5.50 e Fig. 5.51 -. Revista de Engenharia do Mackenzie (n.41, p. 21)

- Fig. 5.52 - Revista Architectura e Construcções (agosto de 1930, n.13, p. 15)

- Fig. 5.53 - Álbum Jardim América

- Fig.5.54 e Fig. 5.55 - "Acervo do Arquivo de Projetos e Bairros da Companhia City de Desenvolvimento", fotos da autora.

- Fig. 5.56; Fig. 5.57; Fig. 5.58 e Fig. 5.59 - Álbum Jardim América

- Fig. 5.60 e Fig. 5.61 - Revista de Engenharia do Mackenzie (n.42, p. 30 e 31)

- Fig. 5.62 - Revista de Engenharia do Mackenzie (n.43, p. 31)

- Fig. 5.63 - Revista de Engenharia do Mackenzie (n.44, p. 22)

- Fig. 5.64 - Revista de Engenharia do Mackenzie (n.44, p. 21)

- Fig. 5.65 - Álbum Jardim América

- Fig. 5.66 - "Acervo do Arquivo de Projetos e Bairros da Companhia City de Desenvolvimento", foto da autora.

- Fig. 5.67 e Fig. 5.68 - Álbum Jardim América

- Fig. 5.69; Fig. 5.70; Fig. 5.71; Fig. 5.72; Fig. 5.73 e Fig. 5.74 - "Acervo do Arquivo de Projetos e Bairros da Companhia City de Desenvolvimento", fotos da autora.

- Fig. 5.75 - Revista de Engenharia do Mackenzie (março 1927, n.41, p.22),

- Fig. 5.76 - Álbum Jardim América

- Fig. 5.77 - "Acervo do Arquivo de Projetos e Bairros da Companhia City de Desenvolvimento", foto da autora.

- Fig. 5.78 - Revista de Engenharia do Mackenzie (dezembro 1928, n, 49)

- Fig. 5.79; Fig. 5.80 e Fig. 5.81 - "Acervo do Arquivo de Projetos e Bairros da Companhia City de Desenvolvimento", fotos da autora.

- Fig. 5.82 - Revista de Engenharia do Mackenzie (n.52-3, "Página de Arquitetura") 
- Fig. 5.83 - "Acervo do Arquivo de Projetos e Bairros da Companhia City de Desenvolvimento", foto da autora.

- Fig. 5.84 - Revista Acrópole (n.12, abril 1939, p. 18)

- Fig. 5.85 - Revista de Engenharia do Mackenzie (n.46, p.8)

- Fig. 5.86 - Álbum Jardim América

- Fig. 5.87 - Boletim do Instituto de Engenharia (n.18, vol. IV, p.171)

- Fig. 5.88, Fig. 5.89 e Fig. 5.90 - "Acervo do Arquivo de Projetos e Bairros da Companhia City de Desenvolvimento", fotos da autora.

- $\quad$ Fig. 5.91 - FICHER, 2005, p. 187

- Fig. 5.92 e Fig. 5.93 - "Acervo do Arquivo de Projetos e Bairros da Companhia City de Desenvolvimento", fotos da autora.

- Fig. 5.94 e Fig. 5.95 - Revista Acrópole (n.8, p. 48 e 49).

- Fig. 5.96 - Revista Architectura e Construcções (n.3, outubro 1929, p. 14)

- Fig. 5.97; Fig. 5.98; Fig. 5.99 e Fig. 5.100 - "Acervo do Arquivo de Projetos e Bairros da Companhia City de Desenvolvimento", fotos da autora.

- Fig. 5.101 - Revista Architectura e Construcções (n. 2,set.1929, p.19)

- Fig. 5.102 - Revista Architectura e Construcções (n. 2,set.1929, p.21)

- Fig. 5.103 - Revista Architectura e Construcções (n. 2, set.1929, p.24)

- Fig. 5.104 - Revista de Engenharia do Mackenzie (n.46, março 1928, "Página de Arquitetura").

- Fig. 5.105 e Fig. 5.106 - Revista de Engenharia do Mackenzie (n.47, março 1928, "Página de Arquitetura")

- Fig. 5.107 e Fig. 5.108 - Revista de Engenharia do Mackenzie (n.51, set. 1929, "Página de Arquitetura")

- Fig. 5.109 e Fig. 5.110 - "Acervo do Arquivo de Projetos e Bairros da Companhia City de Desenvolvimento", fotos da autora.

- Fig. 5.111 - Revista de Engenharia do Mackenzie.46 (n.46, março 1928)

- Fig. 5.112 - Revista de Engenharia do Mackenzie (n.45, nov. 1927, p.40)

- Fig. 5.113 - Revista de Engenharia do Mackenzie (n.48, set. 1928, p. 20),

- Fig. 5.114 - Revista de Engenharia do Mackenzie (n.49, dez. 1928)

- Fig. 5.115 - Revista de Engenharia do Mackenzie (n.50, maio 1929

- Fig. 5.116 - Revista de Engenharia do Mackenzie (n. 52-3, junho 1930)

- Fig. 5.117 - Revista Architectura e Construcções (n.1, agosto 1929,p. 26)

- Fig. 5.118 a Fig. 5.129 - Álbum Sociedade Constructora e de Immoveis, (1928, s.n.p.)

- Fig. 5.130 - WOLFF, 2000, p.131

- Fig. 5.131 - WOLFF, 2000, p.289 